\title{
WestVirginiaUniversity
}

THE RESEARCH REPOSITORY @ WVU

Graduate Theses, Dissertations, and Problem Reports

2018

\section{East or West? Understanding Strategic Alignment in the Post- Soviet Space}

John A. Mowchan

Follow this and additional works at: https://researchrepository.wvu.edu/etd

\section{Recommended Citation}

Mowchan, John A., "East or West? Understanding Strategic Alignment in the Post-Soviet Space" (2018). Graduate Theses, Dissertations, and Problem Reports. 6274.

https://researchrepository.wvu.edu/etd/6274

This Dissertation is protected by copyright and/or related rights. It has been brought to you by the The Research Repository @ WVU with permission from the rights-holder(s). You are free to use this Dissertation in any way that is permitted by the copyright and related rights legislation that applies to your use. For other uses you must obtain permission from the rights-holder(s) directly, unless additional rights are indicated by a Creative Commons license in the record and/ or on the work itself. This Dissertation has been accepted for inclusion in WVU Graduate Theses, Dissertations, and Problem Reports collection by an authorized administrator of The Research Repository @ WVU.

For more information, please contact researchrepository@mail.wvu.edu. 
East or West?

Understanding Strategic Alignment in the Post-Soviet Space

John A. Mowchan

Dissertation submitted to the Eberly College of Arts and Sciences

at West Virginia University

in partial fulfillment of the requirements

for the degree of

\author{
Doctor of Philosophy \\ in \\ Political Science
}

Joe D. Hagan, Ph.D., Chair

R. Scott Crichlow, Ph.D.

Erik Herron, Ph.D.

Boris Barkanov, Ph.D.

Robert Duval, Ph.D.

John D. Rockefeller IV School of Policy and Politics

Morgantown, West Virginia

2018

Key Words: Alignment, state identity, threat perceptions, foreign policy, ideas, beliefs, domestic politics, Azerbaijan, Georgia, Moldova, Ukraine, Russia, and the United States Copyright 2018 John A. Mowchan 


\section{Abstract \\ East or West? \\ Understanding Strategic Alignment in the Post-Soviet Space}

\section{John A. Mowchan}

This comparative foreign policy dissertation examines small state alignment in the postSoviet space. Specifically, I ask what explains change and continuity in the strategic alignment patterns of former Soviet states with the United States and Russian Federation since the end of the Cold War? To answer this question, I analyze the alignment trajectories of ruling governments in Azerbaijan, Georgia, Moldova, and Ukraine from 1995 to 2015. While neorealists expect these materially weak states to bandwagon with Russia because of threat or power considerations, the empirical reality does not consistently support these theoretical expectations. What has occurred is that at different times since the demise of the Soviet Union, ruling governments in Baku, Tbilisi, Chisinau, and Kiev have operated in a gray zone, sometimes pursing a closer alignment with either Moscow, Washington, or both.

By collecting data via elite interviews, a scenario-based experiment, and archival research of primary and secondary sources, this study takes a constructivist approach that employs qualitative and quantitative techniques to conclude three ideational factors - a political leader's ideas about the state's identity, his/her threat perceptions, and foreign policy orientation as conditioned by domestic politics - more so than the balance of threat or power, independently shape the alignment patterns of former Soviet states. This is not to say systemic and other unitlevel factors are of little consequence. On the contrary, these considerations help condition the preferences and actions of leading political elites in the ruling government moving them along a non-static continuum towards one of two forms of small state alignment: positive bandwagoning or great power bridging. It is through a multi-level analysis this study garners a more holistic understanding of the alignment tendencies of ruling governments in countries along Russia's geographical periphery since the end of the Cold War.

This research project advances our cumulative knowledge on small state alignment by developing a model that shows how and why ruling governments in former Soviet states will align with one regional great power over another. Using social identity and self-categorization theory as touchstones, this study looks beyond Stephen Walt's balance of threat theory to advance an ideational-based model where the predominate alignment preferences and strategies of political leaders in Russia's borderlands is best understood as positive bandwagoning or great power bridging. Knowledge from this research project responds directly to research priorities established by the United States Army. Additionally, this dissertation can assist academics and practitioners alike by improving their understanding of small state alignment leading to new research and viable policies that advance U.S. interests in the $21^{\text {st }}$ century. 


\section{To}

Nora, my mother in heaven and to John Sr., my father on earth, your love and encouragement have inspired me to reach for the stars in all I do; to my wife Rebecca, daughter Gabi, and son Zach, you are my love, my life, my everything. It is only because of you and your support that I am the husband and father I am today. 


\section{Table of Contents}

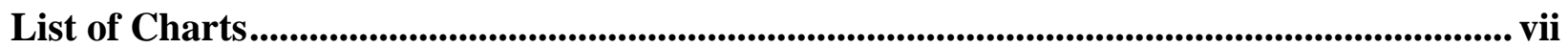

List of Figures........................................................................................................................................ viii

List of Tables ............................................................................................................................................ ix

Acronyms and Abbreviations ................................................................................................................ $x$

Acknowledgements ..........................................................................................................................

CHAPTER 1 - INTRODUCTION...................................................................................... 1

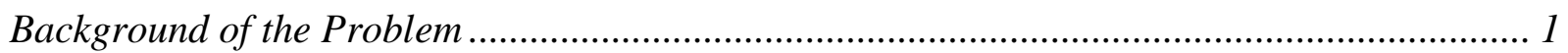

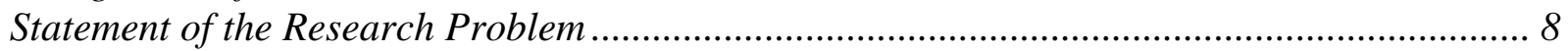

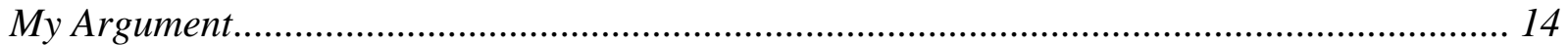

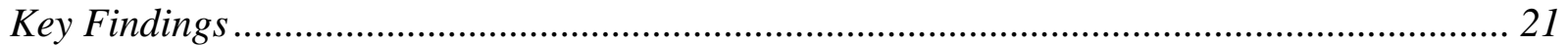

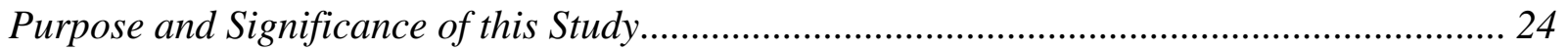

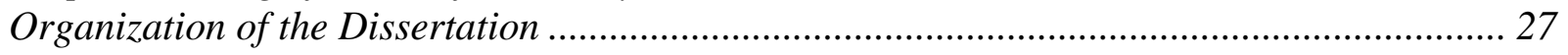

CHAPTER 2 - LITERATURE REVIEW .................................................................................... 30

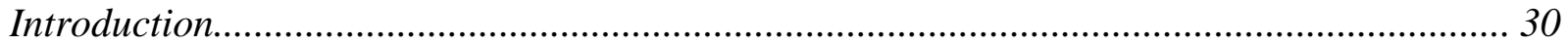

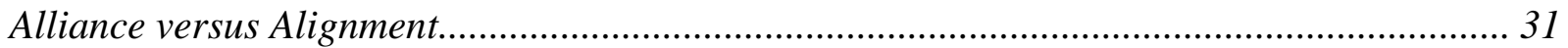

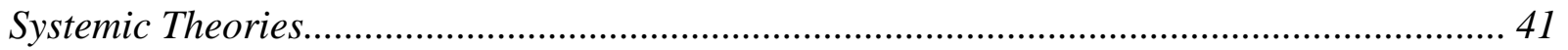

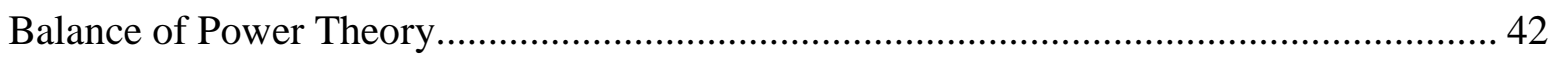

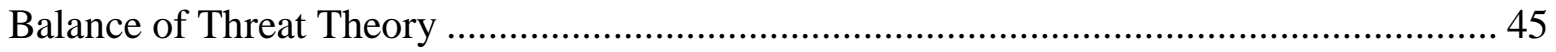

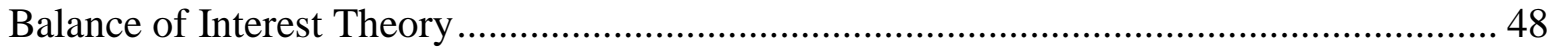

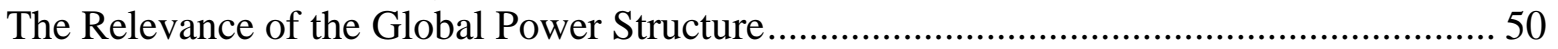

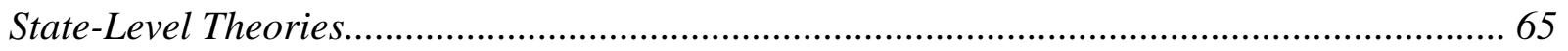

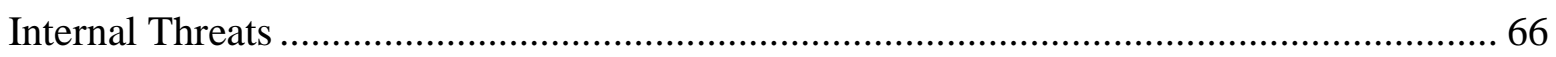

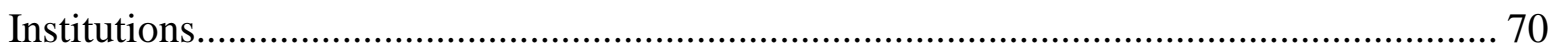

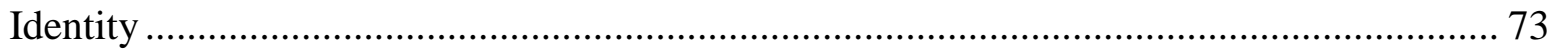

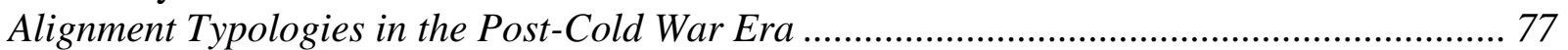

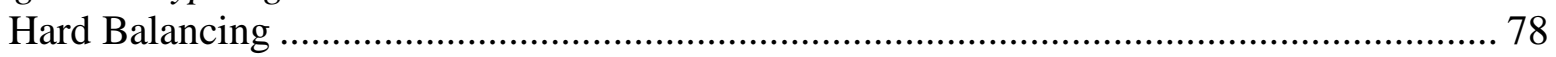

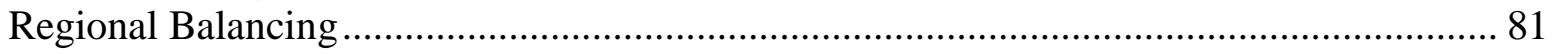

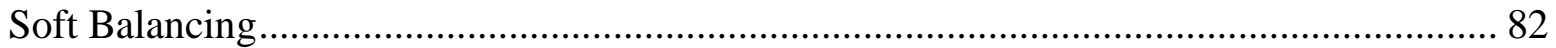

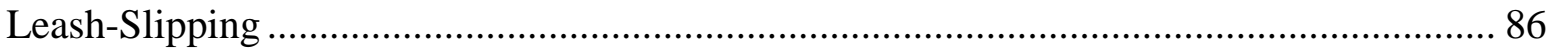

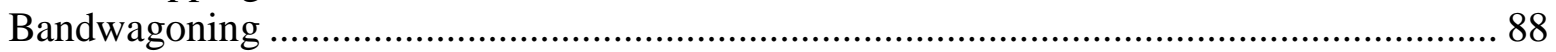

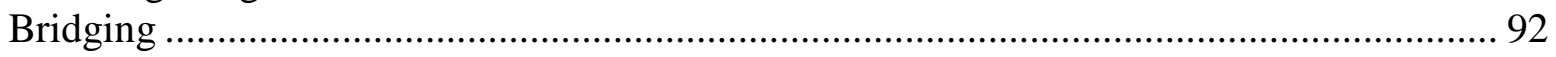

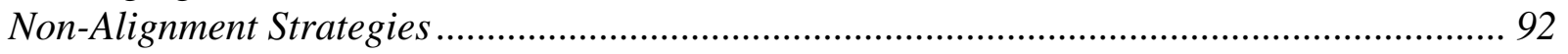

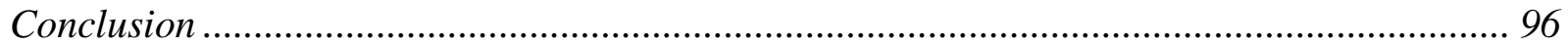

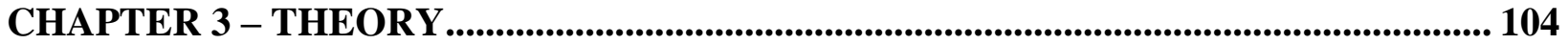

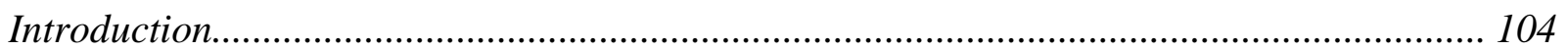

Social Identity Theory and Self-Categorization Theory …………..................................... 106

Small State Alignment: A New Conceptual Framework ..................................................... 111

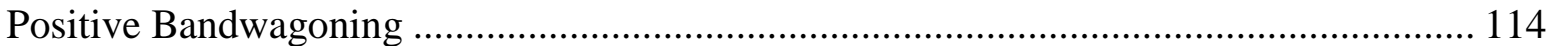

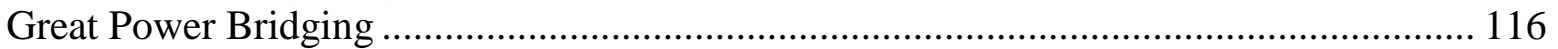

Determinants of Small State Alignment ……………......................................................... 117

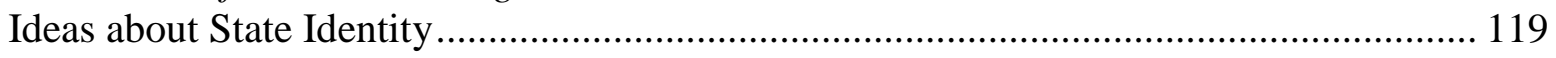




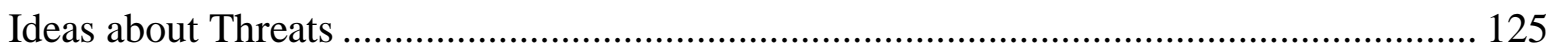

Foreign Policy Orientation and Domestic Politics............................................................. 129

Accounting for the Indirect Influence of the Independent Variables ..................................... 135

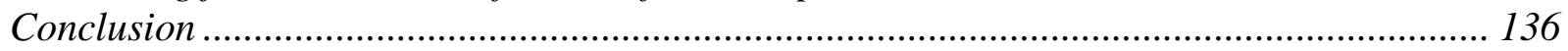

CHAPTER 4 - METHODS AND ANALYSIS.............................................................. 138

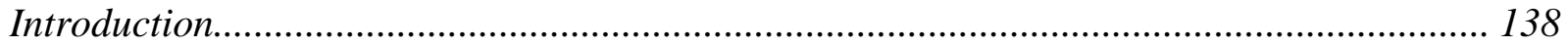

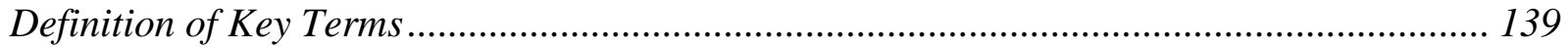

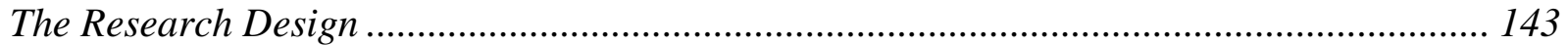

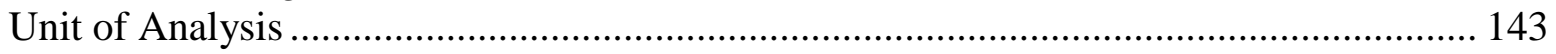

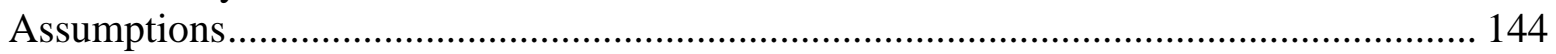

Qualitative and Quantitative Techniques................................................................... 145

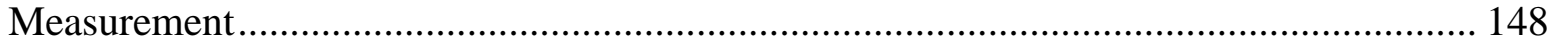

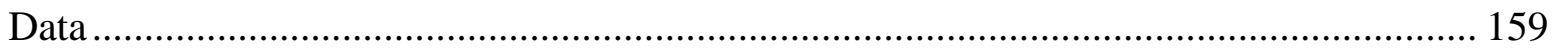

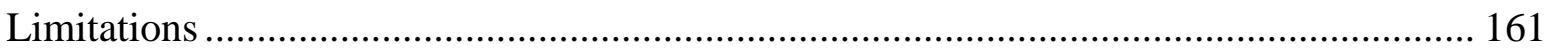

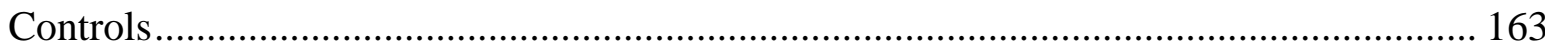

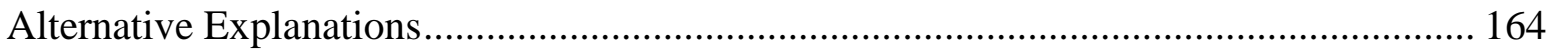

Case Selection - Testing Realist Expectations ………………………………………….... 164

Testing Realist Expectations on Alignment - Part 1 ....................................................... 167

Testing Realist Expectations on Alignment - Part 2 ……............................................... 172

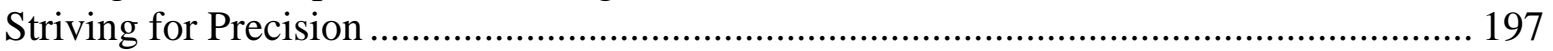

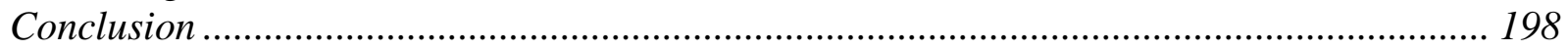

Chapter 5: State Identity and Small State Alignment ................................................................ 199

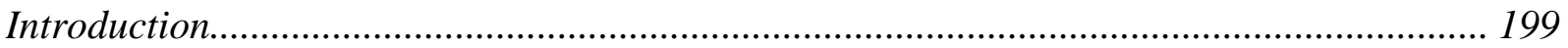

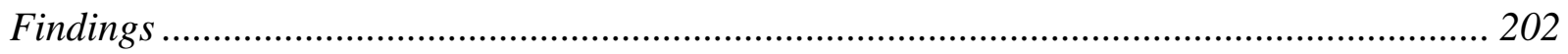

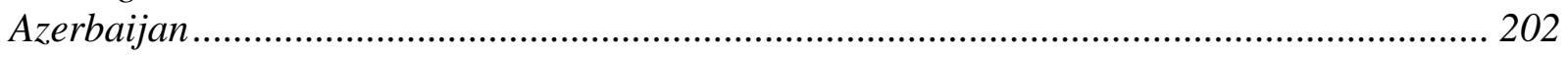

Heydar Aliyev's State Identity Narratives and Azerbaijan's Alignment............................. 206

Ilham Aliyev's State Identity Narratives and Azerbaijan's Alignment ............................... 213

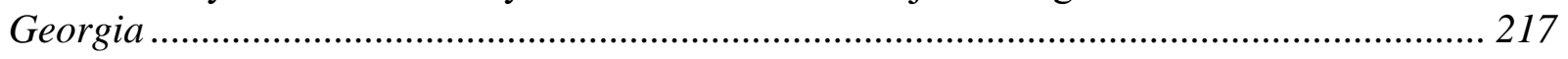

Eduard Shevardnadze's State Identity Narratives and Georgia's Alignment ..................... 220

Mikheil Saakashvili's State Identity Narratives and Georgia's Alignment........................ 225

Giorgi Margvelashvili's State Identity Narratives and Georgia's Alignment ................... 230

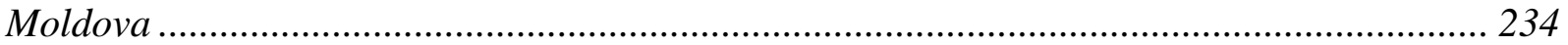

Petru Lucinschi's State Identity Narratives and Moldova's Alignment .............................. 236

Vladimir Voronin's State Identity Narratives and Moldova's Alignment......................... 239

Nicolae Timofti's State Identity Narratives and Moldova's Alignment............................ 246

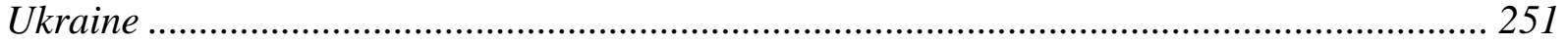

Leonid Kuchma's State Identity Narratives and Ukraine's Alignment ............................. 252

Viktor Yushchenko's State Identity Narratives and Ukraine's Alignment ........................ 257

Viktor Yanukovych's State Identity Narratives and Ukraine's Alignment .......................... 261

Petro Poroshenko's State Identity Narratives and Ukraine's Alignment.............................. 264

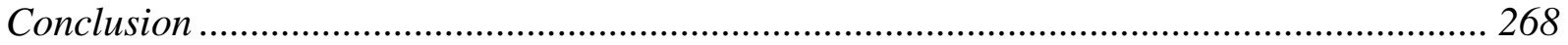

Chapter 6: Threat Perceptions and Small State Alignment .................................................... 271

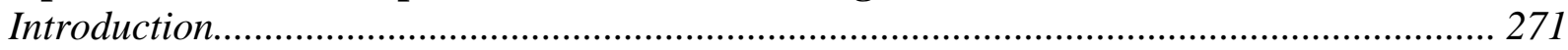

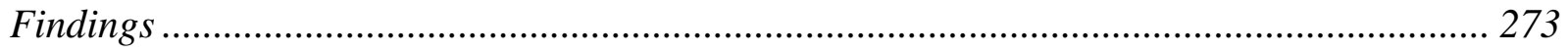

Azerbaijan: Findings and Analysis.............................................................................. 274 


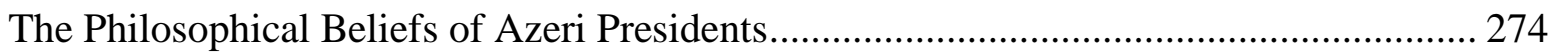

Azeri President Threat Perceptions and State Alignment ................................................. 276

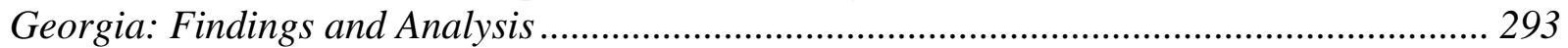

The Philosophical Beliefs of Georgian Presidents........................................................... 293

Georgian President Threat Perceptions and State Alignment ............................................ 297

Moldova: Findings and Discussion ......................................................................... 311

The Philosophical Beliefs of Moldovan Presidents .......................................................... 312

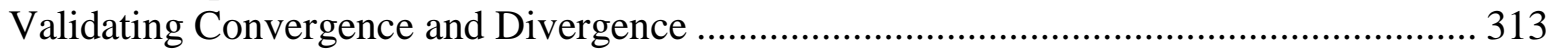

Moldovan President Threat Perceptions and State Alignment ........................................... 315

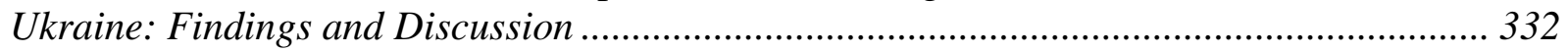

The Philosophical Beliefs of Ukrainian Presidents ......................................................... 333

Validating Convergence and Divergence …………..................................................... 334

Ukrainian President Threat Perceptions and State Alignment............................................. 336

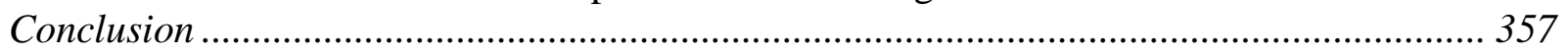

Chapter 7: Foreign Policy Orientation, Domestic Politics \& Small State Alignment ......... 359

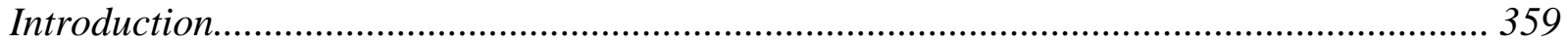

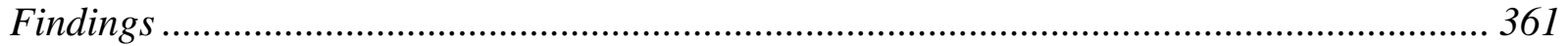

Azerbaijan: Findings and Discussion.......................................................................... 362

The Instrumental Beliefs of Azeri Presidents ................................................................... 362

Azeri President Alignment............................................................................................. 364

Georgia: Findings and Discussion ............................................................................ 373

The Instrumental Beliefs of Georgian Presidents ………….............................................. 374

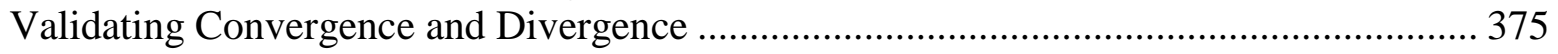

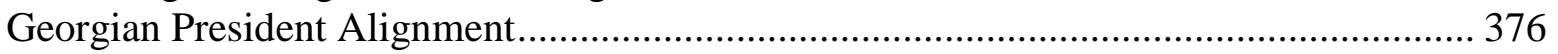

Moldova: Findings and Discussion ............................................................................... 393

The Instrumental Beliefs of Moldovan Presidents........................................................... 393

Validating Convergence and Divergence …………....................................................... 394

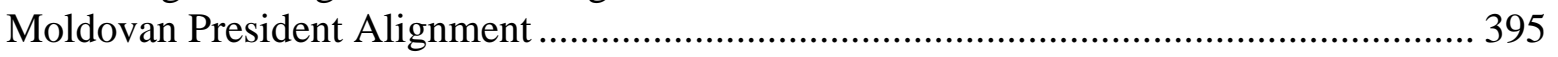

Ukraine: Findings and Discussion .............................................................................. 412

The Instrumental Beliefs of Ukrainian Presidents ........................................................... 413

Validating Convergence and Divergence ……………................................................ 414

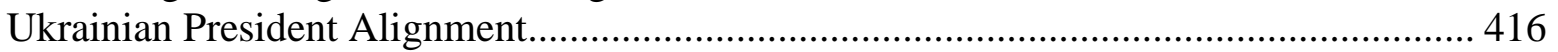

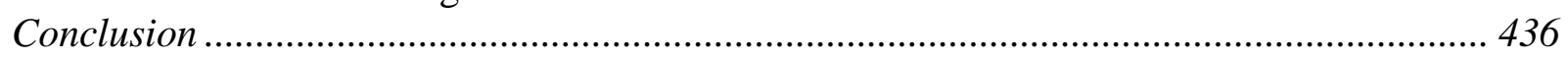

Chapter 8: Conclusion ............................................................................................................................. 439

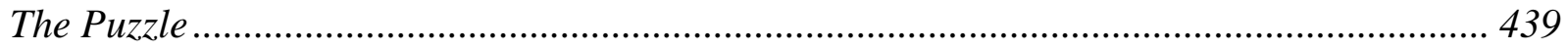

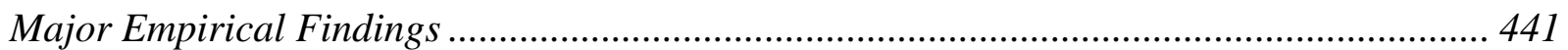

State Identity, Threat Perceptions, Foreign Policy Orientation and Alignment .................... 449

Implications for Theory and Methods............................................................................ 451

Implications for U.S. Policy......................................................................................... 453

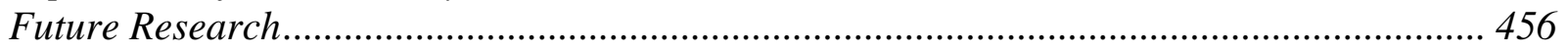

APPENDIX A - Scenario-Based Surveys ...................................................................................... 459

APPENDIX B - Interview Questions.................................................................................. 466

APPENDIX C - The Relevancy of Ideational Factors ............................................................... 469

Bibliography ..................................................................................................................................................... 478 
List of Charts

Chart 1: Belarus Military Exercises with the United States and Russia .......................... 174

Chart 2: Moldova Military Exercises with the United States and Russia ........................ 175

Chart 3: Ukraine Military Exercises with the United States and Russia ........................ 175

Chart 4: Armenia Military Exercises with the United States and Russia ........................ 176

Chart 5: Azerbaijan Military Exercises with the United States and Russia ..................... 176

Chart 6: Georgia Military Exercises with the United States and Russia.......................... 177

Chart 7: Estonia Military Exercises with the United States and Russia ......................... 177

Chart 8: Latvia Military Exercises with the United States and Russia ........................... 178

Chart 9: Lithuania Military Exercises with the United States and Russia ...................... 178

Chart 10: Kazakhstan Military Exercises with the United States and Russia................... 179

Chart 11: Kyrgyzstan Military Exercises with the United States and Russia................... 179

Chart 12: Tajikistan Military Exercises with the United States and Russia..................... 180

Chart 13: Uzbekistan Military Exercises with the United States and Russia ................... 180

Chart 14: U.S. and Russian Military Bases in Former Soviet State (1995-2015) ............. 182

Chart 15: Arms Purchases from the U.S. and Russia (in USD millions) .......................... 185

Chart 16: Total Head of State Visits to the U.S. and Russia (1991-2015)........................ 189

Chart 17: Heydar Aliyev's Alignment Preferences with the U.S. and Russia................... 208

Chart 18: Ilham Aliyev's Alignment Preferences with the U.S. and Russia ..................... 214

Chart 19: Eduard Shevardnadze's Alignment Preferences with the U.S. and Russia ...... 220

Chart 20: Mikheil Saakashvili's Alignment Preferences with the U.S. and Russia........... 226

Chart 21: Giorgi Margvelashvili's Alignment Preferences with the U.S. and Russia....... 231

Chart 22: Petru Lucinschi's Alignment Preferences with the U.S. and Russia ................. 236

Chart 23: Vladimir Voronin's Alignment Preferences with the U.S. and Russia............. 240

Chart 24: Nicolae Timofti's Alignment Preferences with the U.S. and Russia ................. 248

Chart 25: Leonid Kuchma's Alignment Preferences with the U.S. and Russia................ 253

Chart 26: Viktor Yushchenko's Alignment Preferences with the U.S. and Russia........... 259

Chart 27: Viktor Yanukovych's Alignment Preferences with the U.S. and Russia .......... 263

Chart 28: Petro Poroshenko's Alignment Preferences with the U.S. and Russia .............. 266

Chart 29: Ukraine Trade Trends (1996-2004; in 1000 USD) ........................................ 338 


\section{List of Figures}

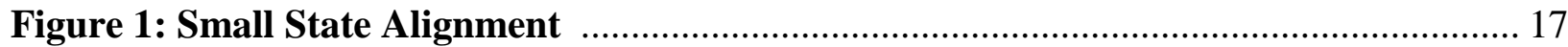




\section{List of Tables}

Table 1: Total Number of Military Commitments ....................................................... 168

Table 2: Total Number of UN Votes with the U.S. or Russia ......................................... 170

Table 3: By Year Voting Tendencies of Former Soviet States...................................... 171

Table 4: Average Number of Military Exercises Per Year ............................................. 174

Table 5: Head of State Visits to the U.S. and Russia ................................................... 188

Table 6: Visits by Other Government Leaders to the U.S. and Russia............................ 191

Table 7: Total Imports-Exports to and from the U.S. and Russia (in 1000 USD) ............. 191

Table 8: Bilateral Investment Treaties (1992-2015) ................................................ 193

Table 9: Tariff Rates on Russia and the United States .............................................. 195

Table 10: Summary of Small State Alignment in the Post-Soviet Space .......................... 197

Table 11: The Philosophical Beliefs of Azeri Presidents ............................................ 275

Table 12: The Philosophical Beliefs of Georgian Presidents ........................................... 294

Table 13: ANOVA Results - Georgian Presidents Philosophical Beliefs .......................... 295

Table 14: Georgia - Mean Comparisons of Tukey's HSD Test Results (P-1) .................. 296

Table 15: The Philosophical Beliefs of Moldovan Presidents ....................................... 312

Table 16: ANOVA Results - Moldovan Presidents Philosophical Beliefs ......................... 314

Table 17: Moldova - Mean Comparisons of Tukey's HSD Test Results (P-1) .................. 314

Table 18: The Philosophical Beliefs of Ukrainian Presidents ........................................ 334

Table 19: ANOVA Results - Ukrainian Presidents Philosophical Beliefs ......................... 334

Table 20: Ukraine - Mean Comparisons of Tukey's HSD Test Results (P-1) ................. 335

Table 21: Summary of Chapter Seven Findings ...................................................... 362

Table 22: The Instrumental Beliefs of Azeri Presidents................................................. 363

Table 23: The Instrumental Beliefs of Georgian Presidents .......................................... 374

Table 24: ANOVA Results - Georgian Presidents Instrumental Beliefs ......................... 375

Table 25: Mean Comparisons Tukey's HSD Test Results for Direction of Strategy (I-1). 375

Table 26: The Instrumental Beliefs of Moldovan Presidents........................................... 394

Table 27: ANOVA Results - Moldovan Presidents Instrumental Beliefs ........................ 395

Table 28: The Instrumental Beliefs of Ukrainian Presidents ......................................... 414

Table 29: ANOVA Results - Ukrainian Presidents Instrumental Beliefs ........................ 415

Table 30: Ukraine - Mean Comparisons of Tukey's HSD Test Results (I-1) ................... 415

Table 31: Support for "First Use" of Armed Force by the Balance of Power .................. 475

Table 32: Support for "First Use" of Armed Force by Opponent's State Identity ........... 476

Table 33: Support for "First Use" of Clandestine Assistance by Opponent's State.......... 476

Table 34: Support for "First Use" of Clandestine Assistance by the Balance of Power .... 477 


\section{Acronyms and Abbreviations}

AEI - Alliance for the European Integration

ANOVA - Analysis of Variance

APF - Azerbaijan Popular Front

BIT - Bilateral Investment Treaty

BTC - Baku-Tbilisi-Ceyhan

CAMEO - Conflict and Mediation Event Observations

CDPP - Christian Democratic People's Party

CIS - Commonwealth of Independent States

CRS - Congressional Research Service

CST - Collective Security Treaty

CSTO - Collective Security Treaty Organization

DA - Department of the Army

EEU - Eurasian Economic Union

EU - European Union

FPE - Foreign Policy Executive

PFCDM - Christian Democratic Popular Front of Moldova

GDP - Gross Domestic Product

GUAM - Organization for Democracy and Economic Development

GTEP - Georgia Train and Equip Program

HSD - Honest Significant Difference

ICEWS - Integrated Conflict Early Warning System

IR - International Relations

MAP - Membership Action Plan

MFN - Most-Favored Nation

MPs - Members of Parliament

MPF - Moldovan Popular Front

NAP - New Azerbaijan Party

NATO - North Atlantic Treaty Organization

OSCE - Organization for Security and Cooperation in Europe

PCRM - Party of Communists for the Republic of Moldova

PFP - Partnership for Peace Program

SCO - Shanghai Cooperation Organization

SCT - Social Categorization Theory

SIPRI - Stockholm International Peace Research Institute

SIT - Social Identity Theory

SOCAR - State Oil Company of Azerbaijan Republic

SSR - Soviet Socialist Republic

UN - United Nations

UNSC - United Nations Security Council

US - United States

USSR - Union of Socialist Soviet Republics

WTO - World Trade Organization 


\section{Acknowledgements}

The realization of this dissertation as a completed research project has only been made possible through the support, guidance, encouragement, and perseverance of so many people. The few short words on these pages will never truly convey how thankful and appreciative I am of all their efforts.

First and foremost, my greatest thanks go to my family. Thank you to my wife Rebecca, who has been there for me through the good, the bad, and the ugly. Rebecca's undying love, words of encouragement, and care of our children while I was gone makes her the world's best wife and mother; hands down! In the same breath, I must thank my wonderful children, Gabi and Zach for their understanding and support. They are so much smarter than me and I am blessed and humbled to be able to be called, by them, their dad.

My eternal thanks and appreciation also goes out to the members of my powerhouse committee. To begin, my utmost thanks to Joe Hagan, my chair, whose sage advice and patience have been instrumental to my success in this monumental endeavor. I have learned so much from him that it would take two lives to repay the debt of knowledge and insight he has given me since day one. Many thanks also go to Scott Crichlow for his undying support and direction over the last few years. It was Scott who moved me to more fully consider the relevance of cognitive factors in foreign policy. Most certainly, this project would not have been possible without the superb area expertise and guidance from Boris Barkanov and Erik Herron. It is from their experiences in the region that I am able to acquire new perspectives that allow me to see the trees through the forest. And last, but certainly not least, a huge thanks to Bob Duvall for all his assistance. It is through Bob's mentorship that I have come to appreciate the value of using quantitative techniques in my research. Although I still have much to learn, it is because of him I now see the political world in ways I could have never previously imagined.

I am also extremely grateful to so many more people in the John D. Rockefeller IV School of Policy and Politics at West Virginia University including Christina Fattore, Ph.D., David Hauser, Ph.D., Jason McDonald, Ph.D., Jeff Worsham, Ph.D., and Donna MacIsaac. Finally, I would be amiss if I did not thank individuals at the U.S. Army War College. Specifically, I want to thank Clay Chun, Ph.D., Joel Hillison, Ph.D., Jerome Sibayan, Ph.D., and Chris Bolan, Ph.D. for their support, encouragement, and willingness to always have my 'six' from day one. 
"In political, economic, and military terms, the European continent is again divided-with Russia to the east, NATO and the EU to the west, and the "lands in between" of Ukraine, Moldova, and the countries of the South Caucasus as the battleground." - Dmitry Trenin, Director of the Carnegie Moscow Center, 14 July 2014. ${ }^{1}$

\section{CHAPTER ONE - INTRODUCTION}

\section{Background of the Problem}

The dissolution of the Union of Soviet Socialist Republics (USSR) in December 1991 created a global shock to the international system that resulted in the creation of 15 newly-independent states (Map 1). This historic event also set in motion a series of positive and negative secondorder effects that would serve to reshape the crumbling bipolar world order. For many academics and practitioners, the end of Soviet totalitarianism was viewed as a positive development. Gone were the days of an East-West rivalry, which frequently walked the razor's edge of nuclear war and the end of humankind. In its place, there emerged what appeared to be a system dominated by the unparalleled military and economic power of the United States. This system promised to deliver a global collective good in terms of higher levels of peace, stability, and economic prosperity. From one perspective, the days of great power conflict were at an end leading Francis Fukuyama to conclude, "what we may be witnessing is not just the end of the Cold War, or the passing of a particular period of postwar history, but the end of history as such: that is, the end point of mankind's ideological evolution and the universalization of Western liberal democracy as the final form of human government."2

\footnotetext{
${ }^{1}$ Dmitri Trenin Dmitri. 2014. "The Ukraine Crisis and the Resumption of Great-Power Rivalry." Carnegie Moscow Center 9 (7), 9.

${ }^{2}$ Fukuyama, Francis. 1989. "The End of History?” The National Interest 16, 4.
} 
Beyond a marked decrease in the possibility of a large-scale armed conflict between the world's top superpowers, the demise of the 'evil empire" ${ }^{3}$ also served as a catalyst for a myriad of other positive developments. These included the reunification of East and West Germany, the spread of market-based capitalism and fledgling democracies throughout Eastern/Southeastern Europe, an increased emphasis on human rights and rule of law, and an end to U.S.-Soviet competition in the developing world, which had frequently manifested itself in a series of proxy wars. Clearly, from one perspective the breakup of the Soviet Union and "the end of the cold war... [was] ...a victory for all humanity."

Perhaps the most significant development, and of interest for this dissertation, was that for the very first time newly-elected political leaders in the countries and former Soviet republics behind the 'Iron Curtain' acquired a newfound ability to decide their respective country's domestic and foreign policies. In the domestic realm, presidents in the newly-independent states quickly enacted wide-scale institutional reforms designed to improve governance and bolster economic productivity. Such efforts were heralded by the international community leading Samuel Huntington and others, to conclude that the decisions by many former Soviet states to embrace the tenets of Western liberalism and capitalism represented the death knell for the communist ideology. As a result, their actions helped usher in what has become known as the third wave of democratization with ground zero centered in eastern and southeastern Europe. ${ }^{5}$ This project examines whether or not this wave of democratization also brought into being a new strategic alignment for former Soviet states.

\footnotetext{
${ }^{3}$ President Ronald Regan is attributed with calling the Soviet Union an 'evil empire.' See Regan, Ronald. 1983.

“"Evil Empire' Speech, 08 March 1983.” The Miller Center, University of Virginia. http://millercenter.org/president/ speeches/speech-3409. Accessed 01 May 2016.

${ }^{4}$ Bush, George H.W. 1991. "Address Before a Joint Session of the Congress on the State of the Union, 29 January 1991." The American Presidency Project. http://www.presidency.ucsb.edu/ws/?pid=19253. Accessed 01 July 2016. ${ }^{5}$ Huntington, Samuel P. 1991. “Democracy's Third Wave.” Journal of Democracy 2 (2): 12-34.
} 
Although domestic issues initially dominated the policy agenda for many of the post-Soviet states, developing an effective set of foreign policies that would help ensure the long-term security of the state quickly became a central point of discussion among ruling elites. First, on a theoretical level, the breakup of the Soviet Union did not bring an end to the anarchic international system filled with multiple regional great powers. Although the $\mathrm{West}^{6}$ had won the Cold War, no country—not even the United States—or international organization could assume the role of an omnipotent global hegemon capable of providing an enduring peaceful and stable world order. Whether it was a lack of political resolve, domestic political opposition, public opinion, or geography, U.S. power projection proved problematic in the post-Cold War era. Given this reality, a system of 'self-help' continued to flourish where states had to act in their best interests to ensure survival because there was still no higher governing body to intervene on their behalf in the event of war. ${ }^{7}$ As a result, the volatile, uncertain, complex, and ambiguous nature of the international system endured, creating a sense of vulnerability among many leading political leaders, especially those in the newly-independent states.

Second, the withdrawal of Soviet armed forces, intelligence officials, and gendarmerie personnel from the outer rim of the newly-established Russian Federation created a security vacuum that could not be filled by each countries' remaining organic military-security capabilities. Furthermore, material, technological, or budgetary shortfalls prevented ruling governments from building-up the country's armed forces as a way to deter armed attacks from neighboring countries. As a result, most former Soviet states found themselves in a precarious situation; vulnerable to external attack, but helpless to do anything about it on their own.

\footnotetext{
${ }^{6}$ In this dissertation, I broadly use the term 'West' to mean the United States and its European allies in NATO and the European Union.

${ }^{7}$ Waltz, Kenneth N. 1979. Theory of International Politics. Reading, MA: Addison-Wesley.
} 
This sense of vulnerability was amplified by the fact that even though the Russian Federation was but a fragment of the Soviet monolith in terms of military power, Moscow still retained a formidable nuclear arsenal and a conventional force capable of conducting limited, but sustained, regional military operations. ${ }^{8}$ Additionally, Russia's historical and often confrontational political and cultural ties with its former Soviet satellites created a sense of fear and uncertainty about the Kremlin's future intentions. ${ }^{9}$ Political elite concerns and the shadow of the future were confirmed as early as 1992 when President Boris Yeltsin, during a speech to senior generals of the Russian Armed Forces stated, "Russia always was and remains a great world power. Such is its geopolitical position and its potential." 10 From Yeltsin's words, it became clear that despite the country's diminished power position in the international system, Moscow would not yield to being anything less than a regional great power, capable of directly shaping the geostrategic events in Russia's historical sphere of influence in line with Kremlin interests.

These theoretical propositions and empirical realities served to shape what would become a new round of strategic competition between the United States and Russia for influence in countries occupying the post-Soviet space. Beginning in 1992, the United States via the Freedom Support Act and in concert with its European allies, began pouring millions of dollars into the former Soviet states to support a wide array of foreign policy objectives. By 2007, the United States had allocated over $\$ 28$ billion to countries in the Commonwealth of Independent States

\footnotetext{
${ }^{8}$ For an assessment on Russian military capabilities in the post-Cold War era, see Steve Millar and Dmitri Trenin as well as Marcel de Haas. Miller, Steven E. and Dmitri Trenin (eds.). 2004. The Russian Military: Power and Policy. Cambridge: MIT Press; Haas, de Marcel. 2011. "Russia’s Military Reform: Victory After 20 Years of Failure.” Netherlands Institute of International Relations, Clingendael Paper No. 5.

${ }^{9}$ One must certainly recognize that geopolitics is an important factor driving political elite threat perceptions in the newly independent states. John Vasquez argues that states in close geographical proximity are more likely to enter into war, while states that are located in distant corners of the world do not go to war as frequently. See Vasquez, John. 1995. "Why Do Neighbors Fight? Proximity, Interaction, or Territoriality." Journal of Peace Research 32 (3). ${ }^{10}$ Yeltsin, Boris. 1992. Cited in Ambrosio, Thomas. 2006. "The Geopolitics of Demographic Decay: HIV/AIDS and Russia's Great-Power Status.” Post-Soviet Affairs 22 (1), 4; emphasis added.
} 
(CIS) for humanitarian relief, internal security, anti-terrorism efforts, and the promotion of economic and democratic reforms. ${ }^{11}$ Robert Keohane captures the overarching objective of this effort noting, "the collapse of the Soviet Union in 1991 made the U.S. and liberal democratic states elsewhere believe that they could construct 'a new world order' more consistent with the values and practices of liberal domestic politics." ${ }^{\text {"2 }}$ By pursing such an approach, the West hoped that these actions would subsequently facilitate increased global stability and economic prosperity for all. However, Edward Mansfield and Jack Snyder remind us that there were also corresponding negative effects from the process of democratization. ${ }^{13}$ In this case, the efforts of liberal internationalists helped facilitate another round of great power competition in Russia's borderlands as Dmitry Trenin's quote at the beginning of this chapter so poignantly captures.

Initially, Moscow's response to the West's efforts were muted as Kremlin leaders mapped out foreign policies grounded in cooperation with the West. This strategic approach was advanced by the appointment of several key liberal Atlanticists ${ }^{14}$ including Foreign Minister Andrei Kozyrev and Deputy Prime Minister Egor Gaidar, who believed that integration into Euro-Atlantic structures and institutions would allow Russia to assume a "fitting place that has been predetermined for...[them] by history and geography." ${ }^{15}$ Initially, the former Cold War rivals

\footnotetext{
${ }^{11}$ Tarnoff, Curt. 2007. "US Assistance to the Former Soviet Union." Congressional Information Service, Library of Congress.

${ }^{12}$ Keohane, Robert O. 2012. "Twenty Years of Institutional Liberalism.” International Relations 26 (2), 129.

${ }^{13}$ Mansfield and Snyder find that democratization increased the war proneness of states. See Mansfield, Edward D., and Jack Snyder. 1995. "Democratization and the Danger of War." International Security 20 (1).

${ }^{14}$ Numerous academics and Russian area specialists have advanced different classifications of Russian foreign policy schools of thought. This study follows Ilya Prizel's conceptualization: Liberal Atlanticists, pragmatists, and fundamentalists. See Prizel, Ilya. 1998. National Identity and Foreign Policy: Nationalism and Leadership in Poland Russia and Ukraine. Cambridge: Cambridge University Press, 240. For similar categorizations, see Margot Light, John Lowenhardt, and Stephen White. 2003. "Russia and the Dual Expansion of Europe." In Gabriel Gorodestky (ed.) Russia between East and West: Russian Foreign Policy on the Threshold of the Twenty-First Century. London: Frank Cass; Richter, James. 1996. "Russian Foreign Policy and the Politics of National Identity." In Celeste A. Wallander (ed.) The Sources of Russian Foreign Policy After the Cold War. Boulder, CO: Westview. ${ }^{15}$ Abarinov, Vladimir and Vitalii Tretiakov. 1992. "The Union Left Russia With a Poor Foreign Policy Legacy." Nevavisimaia Gazeta, 01 April 1992. In Current Digest of the Post-Soviet Press (CDPDP) 44 (3), 4-6.
} 
made some progress on the security and economic fronts with Russia joining NATO's

Cooperation Council in 1991 and the Partnership for Peace (PFP) Program in 1994. In the economic sphere, in 1994 Russia and the European Union (EU) signed the Partnership and Cooperation Agreement (PCA) setting the stage for closer economic and political relations.

Despite this progress, by late 1995 the strategic situation changed dramatically when Russia's relations with the West transitioned from integration and cooperation to a new round of great power competition. ${ }^{16}$ Although there are a multitude of underlying factors driving Russia's foreign policy volte face, ${ }^{17}$ this study singles out two key events: NATO-EU eastward expansion and political opposition by former Soviet states to Kremlin demands in the CIS. Boris Yeltsin's September 1995 presidential edict on "The Establishment of the Strategic Course of the Russian Federation with Member States of the CIS" became a major turning point by which the nature of this new strategic competition would be defined in the years to come. According to Kathleen Mihalisko, this decree “crystallize[d] Russia's response to the prospect of NATO expansion and... [gave] credence to recent warnings from Yeltsin and his officials about the reemergence of two rival military blocs in Europe." 18

Residing in the shadow of an emerging new great power competition, the question for ruling elites in the newly-independent states turned to security choices and how best to ensure their

\footnotetext{
${ }^{16}$ Tsygankov, Andrei. 2006. Russia's Foreign Policy: Change and Continuity in National Identity. Rawman \& Littlefield Publishers.

${ }^{17}$ For example, Robert Freedman (1998) notes the emergence of a hardline factions in the Duma helped triggered Russia's shift in foreign policy with the West while Lilia Shevtsova points to the election of President Bill Clinton and a shift in U.S/Western attitudes towards the manner and rate of Russian reform. Freedman, Robert. 1998. "Primakov and the Middle East." The State of Russian Foreign Policy and U.S. Policy Toward Russia. The Heritage Lectures, no. 607, 16. http://s3.amazonaws.com/thf_media/1998/pdf/hl607.pdf. Accessed 14 August 2014; Shevtsova Lilia. 2010. Lonely Power: Why Russia has Failed to Become the West and the West is Weary of Russia. Washington D.C.: Carnegie Endowment for International Peace, 18-21.

${ }^{18}$ Mihalisko Kathleen. 1995. "Yeltsin's CIS Decree: An Instrument for Regaining Russia's Superpower Status.” The Jamestown Foundation, 06 October 1995. https://jamestown.org/program/yeltsins-cis-decree-an-instrument-forregaining-russias-superpower-status/. Accessed 02 January 2017; emphasis added.
} 
long-term survival. Kenneth Waltz notes that states can pursue one of two broad strategies: internal or external balancing. ${ }^{19}$ Internal balancing focuses on how a state can use its own domestic resources (population, budgetary allocations, technological innovations, industrial capacity, etc.) to build-up the country's organic military capabilities to improve its power position vis-à-vis other states. External balancing focuses on banding together with other likeminded states. The underlying logic here is that strength and security come from numbers.

While internal balancing may be a viable option for some states, this was not the case for the transitioning countries in Eastern Europe, the South Caucasus, and Central Asia. According to the International Monetary Fund (IMF), in the immediate aftermath of the Soviet Union's dissolution, the elimination of the Council for Mutual Economic Assistance and ensuing trade disruption generated a high degree of economic dislocation leading to plummeting gross domestic product (GDP) rates, rising unemployment, and high inflation during the early and mid-1990s in the newly-independent states. ${ }^{20}$ Clearly, these countries were in no position to devote precious resources for defense purposes at this time. Furthermore, even as economic conditions improved during the late 1990s and early 2000s, expending those scarce, albeit available resources may have not yielded the desired outcome. As Michael N. Barnett and Jack S. Levy remind us, "even if a country does have the necessary resources, extraction of them may provide short-term military security at the cost of weakening the long-term strength of the economy and therefore the long-term military potential and security of the state." 21

\footnotetext{
${ }^{19}$ For Waltz's discussions on internal and external balancing see Waltz, Kenneth N. 1979. Theory of International Politics. Reading, MA: Addison-Wesley, 168. See also Stevenson, David. 1996. Armaments and the Coming of War: Europe 1904 - 1914. New York: Oxford University Press and Kennedy, Paul. 1982. The Rise of the AngloGerman Naval Rivalry, 1860 - 1914. London: Allen \& Unwin.

${ }^{20}$ James Roaf et. al. 2014. "25 Years of Transition Post-Communist Europe and the IMF." The International Monetary Fund, Washington D.C., 3-5. https://www.imf.org/external/pubs/ft/reo/2014/eur/eng/pdf/erei_sr_ 102414.pdf. Accessed 01 November 2015.

${ }^{21}$ Barnett, Michael N. and Jack S. Levy. 1991. "Domestic Sources of Alliances and Alignments: The Case of Egypt, 1962 - 1973." International Organization 45 (3), 375. Barnett and Levy make this assertion based on the findings of
} 
A second option for former Soviet states was external balancing. Countries pursing this strategy seek to band with a more powerful country or group of countries. Typically, this is accomplished by joining a military alliance or signing a formal treaty of security or defense cooperation. By entering into these official arrangements, a state anticipates the collective actions of other like-minded countries will restore the power imbalance that can deter the present (or future) hostile actions of stronger states.

There are two key advantages with an external balancing strategy. First, external balancing costs less because collective security is spread across multiple countries. Second, external balancing via an alliance allows countries the strategic latitude to play on their inherent strengths. Whether it is geographical location, technological expertise, or access to resources, each member brings to the table a different set of capabilities that in one way or another can benefit the entire group. Of the two strategies, external balancing represents the best 'way ahead' for former Soviet states because ruling governments are afforded access to economic and military resources or political backing that may help them ensure the state's long-term survival.

\section{Statement of the Research Problem}

In sketching the broad contours of the alignment tendencies of former Soviet states, one can discern several distinct alignment patterns since the mid-1990s. On one hand, some countries like Armenia, Belarus, Kazakhstan, Kyrgyzstan, and Tajikistan have opted to develop closer foreign ties with their former imperial center quickly gaining membership in the Collective Security Treaty Organization (CSTO) by 1994. On the other hand, Estonia, Latvia, and Lithuania charted a different path, pursuing a Westward course by fostering strong military, economic, and

several other notable scholars. See Knorr, Klaus. 1970. Military Power and Potential. Lexington: D.C. Heath; Gilpin, Robert W. 1981. War and Change in World Politics. Cambridge: Cambridge University Press; Kennedy, Paul. 1987. The Rise and Fall of the Great Powers: Economic Change and Military Conflict from 1500 to 2000. New York: Random House. 
political ties with the United States and Western Europe. These efforts culminated in their accession into the North Atlantic Treaty Alliance (NATO) in 2004.

This divergence in state alignment in some ways reflect a wicked problem ${ }^{22}$ or puzzle that frames the general research question of this study: what are the key determinants of change and continuity in the strategic alignment patterns of former Soviet states? With the post-Soviet space becoming an epicenter for a new strategic competition between United States and the Russia Federation, contemporary theoretical explanations appear deficient to explain small state alignment. This empirical reality demands a fresh approach.

Any attempt to understand why, when, and how states will align is no doubt a complex scholarly endeavor. This challenge is made even more difficult when examining the alignment tendencies of countries in the post-Soviet space. Here, the independent theoretical propositions as espoused by realists are cast into doubt as they collide with the geostrategic realties and foreign policy autonomy of political elites across space and time; all of which, is wrapped in a veneer of strategic competition between the U.S. and the Russian Federation for influence in a multipolar world. From one perspective, understanding small state alignment in the post-Soviet space is like an attempt to solve "a riddle wrapped in a mystery inside an enigma." ${ }^{23}$ This dissertation seeks to address this challenge by positing the following primary research question:

\footnotetext{
${ }^{22}$ Horst Rittel and Melvin Webber delineate 10 characteristics of a wicked problem. Specifically, this study recognizes that when attempting to understand state alignment, there are no clear set of potential solutions, especially because all states will pursue a multi-vector foreign policy approach to world affairs. In concert with this characteristic, as will be detailed below, different scholars have advanced different theoretical approaches to explain state alignment and/or alliance formation. Second, variation in a state's alignment may be a byproduct of changes in resolution or the emergence of different underlying problems. Rittel, Horst WJ, and Melvin M. Webber. 1973.

"Dilemmas in a General Theory of Planning." Policy Sciences 4 (2), 161-167.

${ }^{23}$ I borrow the sage words of Sir Winston Churchill, who in 1939 describe Russian foreign policy in this manner. Cited in Hoffmann, Erik Peter and Frederic J. Fleron, eds. 1971. The Conduct of Soviet Foreign Policy. Transaction Publishers, 109.
} 
why do similarly placed, small states in the post-Soviet space opt to pursue a closer alignment with one regional great power over another?

Over the last 50 years, scholars have attempted to explain the alignment tendencies of states by employing a variety of different theoretical approaches. Although some of the dominant alignment theories that have pervaded the literature have been helpful in selected ways, they remain largely deficient for several key reasons. First, most alignment studies focus their analysis on the great powers, giving little attention to small states. Second, scholars have erroneously viewed alignment and alliance as the same political phenomenon making it difficult to truly understand the alignment outcomes of small states.

Third, many studies attempt to explain alignment and/or alliance formation my examining state actions prior to, during, or immediately after great power conflicts. Noticeably absent from the literature is an analysis of state alignment when great powers are engaged in strategic competition during the interwar years. Fourth, many scholars give emphasis to systemic drivers of state action because such an approach is parsimonious and easy to apply. This is particularly true when examining the alignment tendencies of former Soviet states. For example, Waltz asserts that in an anarchic system states seek to survive by balancing against power. Specifically, when a state occupies a lower power position in the international system, they will tend to align with other weaker states so that their aggregate power can balance against the most powerful state, thus helping ensure their collective survival.

With the demise of the Soviet Union, one can assume that the United States was, and has been, the most powerful country in the world. For some scholars viewing the global power structure in material terms, the passing of the 'Evil Empire' into the annals of history represented a decisive transition point moving the United States to the position as the most powerful country 
in the world. If this is true, then Waltz's neorealist argument appears to have some merit in explaining the alignment of Armenia, Belarus, and Kazakhstan with a weaker Russia by gaining formal membership in Russian-led CSTO and/or the Eurasian Economic Union (EEU). As Waltz notes, "secondary states, if they are free to choose, flock to the weaker side, for it is the stronger side that threatens them." ${ }^{24}$ However, Waltz's theoretical assertions appear deficient given the existence of contradictory empirical evidence. For example, the Baltics, Poland, and the Czech Republic have followed an alignment azimuth towards the United States and its Western European allies, eventually acquiring formal membership in NATO and the EU.

While Stephen Walt agrees with Waltz's balancing hypothesis, he argues states tend to balance not because of power considerations but because of the threat exhibited by a more powerful state. ${ }^{25}$ Given Russia's geographical proximity, aggregate power, continued possession of nuclear weapons, and Moscow's historical tendency to inject itself in the internal affairs of countries along its geographical periphery, one can argue the Russian Federation represents the greatest threat to former Soviet states. However, Walt's balance of threat theory, like Waltz's balance of power theory primarily applies to countries in the upper end of the international hierarchy. According to Walt, weak states owing to their geographical location and disregard by the most powerful states will kowtow, appease, and ultimately bandwagon with a threatening great power because they are unable to do little else. ${ }^{26}$ As Walt notes “ .... balancing may seem unwise because one's allies may not be able to provide assistance quickly enough...States that are close to a country with large offensive capabilities (and far from potential allies) may be forced to bandwagon because balancing alliances are simply not viable." ${ }^{27}$ If this is the case, then

\footnotetext{
${ }^{24}$ Waltz 1979, 127.

${ }^{25}$ Walt, Stephen M. 1987. The Origins of Alliances. Ithaca, NY: Cornell University Press, 73; 21.

${ }^{26}$ Ibid, 73.

${ }^{27}$ Ibid, 29.
} 
a majority of the newly-independent states should have bandwagoned with Russia since there was no great power to offer cart blanche immediate and enduring protection. While Belarus, Armenia, Kazakhstan did just that, the Baltics charted a Westward course that eventually resulted in their accession into Euro-Atlantic structures.

In contrast to systemic-level theories, some scholars have attempted to explain state alignment by focusing on domestic-level variables; however, on their own, they too suffer from a unique set of shortcomings leading to new set of anomalies. For example, Stephen David and Deborah Larson assert the necessity to consider the internal threats to a ruling government and how they shape alignment politics. ${ }^{28}$ In advancing his omnibalancing theory, David notes "the most powerful determinant of Third World alignment behavior is the rational calculation of Third World leaders as to which outside power is most likely to do what is necessary to keep them in power."29 David and Larson's focus on political elite decision-making does well to move away from system-based explanations on alignment; however, another puzzle emerges if one attempts to apply David's omnibalancing thesis to the post-Soviet space. Specifically, this approach does little to explain why the Baltic States, for example, with low or no internal threats decided to pursue NATO membership. Separately, while David's theory appears to garner some traction in Georgia with President Shevardnadze's decisions in the early 1990s to keep Russian military forces in the country and to sign the Collective Security Treaty (CST) to quell a raging civil war, why did President Saakashvili, facing the same domestic threat, opt to accept U.S. support under the Georgia Train and Equip Program (GTEP) and pursue a pro-West alignment trajectory?

\footnotetext{
${ }^{28}$ David, Stephen R. 1991. Choosing Sides: Alignment and Realignment in the Third World. Baltimore: The Johns Hopkins University Press; Larson, Deborah W. 1991. "Bandwagoning Images in American Foreign Policy: Myth or Reality.” In Robert Jervis and Jack Levy (eds.) Dominoes and Bandwagons: Strategic Beliefs and Great Power Competition in the Eurasian Rimland. New York: Oxford University Press.

${ }^{29}$ David 1991, 235.
} 
Finally, some scholars have opted to apply a constructivist framework to explain state alignment. In the post-Soviet space, Giorgi Gvalia and his colleagues argue political elite ideas about the state's identity and strategies are critical factors explaining the alignment trajectory of some former Soviet states. ${ }^{30}$ Although the external strategic environment is important, the beliefs and ideas of ruling political leaders are more important. By considering both, one can better understand that "while Azerbaijan and most of the other small post-Soviet states have pursued a cautious bandwagoning policy toward Russia, post-Soviet Georgia has been consistently edging westward since the 'Rose Revolution,' despite its contiguity with Russia and vulnerability to economic and military threats." ${ }^{31}$ Gvalia's study provides a sense of optimism on how scholars can better explain alignment outcomes in the post-Soviet space; however, their effort falls short because they only focus on Georgian President Saakashvili with no effort to examine the ideas from previous or subsequent administrations or in other former Soviet states.

This review of the dominant theoretical approaches to explaining alignment reveals several important takeaways. First, in general, systemic approaches are deficient because they do not, on their own, consistently explain why states sometimes balance against a more powerful or threatening regional great power, but then in other instances pursue a bandwagoning strategy. Second, domestic-level explanations may potentially offer a higher degree of analytical granularity on the alignment tendencies of states; however, on their own they create a new set of problems since they are again too narrowly focused and because they do not account for other potential systemic- or individual-level factors. Third, a constructivist approach to alignment

\footnotetext{
${ }^{30}$ Gvalia, Giorgi, David Siroky, Bidzina Lebanidze and Zurab Iashvili. 2011. Political Elites, Ideas and Foreign Policy: Explaining and Understanding the International Behavior of Small States in the Former Soviet Union. Tbilisi: Ilia State University; Gvalia, Giorgi, David Siroky, Bidzina Lebanidze, and Zurab Iashvili. 2013. "Thinking Outside the Bloc: Explaining the Foreign Policies of Small States.” Security Studies 22 (1).

${ }^{31}$ Gvalia et. al. 2011, 100-101.
} 
offers a potential opportunity to better understand why, when, and how states may balance against a regional great power because it is individuals who ultimately make the state's foreign decisions based on their independent assessments of the strategic environment. According to Fareed Zakaria, “a good account of a nation's foreign policy should include systemic, domestic, and other influences, specifying what aspects of the policy can be explained by what factors." 32 Taken together, it becomes clear that to achieve a more holistic understanding of small state alignment, an eclectic theoretical approach is in order. By first viewing alignment through a constructivist lens that is responsive to systemic and domestic-level pressures, this study can potentially help fill this gap in the literature and add to our cumulative knowledge on this topic.

\section{My Argument}

The inherent weaknesses associated with each of the dominant theories on alignment make them less relevant when examining the post-Soviet space. As a result, this study sees high value in a multi-level theoretical approach that begins with a close examination of the belief systems of the leading political leaders comprising the state's foreign policy executive (FPE). It is through a leader-centric approach one can better understand the alignment trajectories of ruling governments in former Soviet states. The validity of a leader-centric analysis takes its lead from Bruce Bueno de Mesquita, who notes "leaders, not states, choose actions. Leaders and their subjects enjoy the fruits and suffer the ills that follow from their decisions." ${ }^{\prime 33}$ More specifically for this study, Daniel Byman and Kenneth Pollack also conclude that all too often, "scholars fail

\footnotetext{
32 Zakaria, Fareed. 1992. "Realism and Domestic Politics: A Review Essay.” International Security 17 (1), 198.

${ }^{33}$ Bueno de Mesquita, Bruce. 2002. "Domestic Politics and International Relations." International Studies Quarterly $46(1), 4$.
} 
to acknowledge that common international behavior-balancing against a threat, choosing a grand strategy, or marching off to war-results from decisions made by individuals." ${ }^{34}$

Looking beyond Walt's balance of threat theory, this dissertation advances a markedly different approach to small state alignment since other alignment theories are not relevant owing to their focus on the great powers or inapplicability to countries in the post-Soviet space.

Specifically, under conditions of great power competition, small states will tend to exhibit one of two forms of alignment: positive bandwagoning and great power bridging.

Positive Bandwagoning. In marked contrast to some scholars, who view bandwagoning as a negative action, this study argues this political phenomenon should be understood as a positive endeavor. Specifically, small states will not bandwagon with a more threatening or powerful state because ruling governments are forced to choose sides as war looms or because they anticipate material gains in the near- or long-term. On the contrary, positive bandwagoning occurs because leading elites in a ruling government believe an alignment with a particular regional great power is in the best, long-term good of the state and their interests. In this case, ruling governments in small states will prefer and often adopt more cooperative foreign policies with one regional great power over another. Of significance, this form of alignment occurs even when there are no guarantees a small state's alignment with a regional great power will lead to the country's accession into a military alliance or regional economic grouping in the short- or mid-term. However, if consistently applied by multiple, like-minded ruling governments over time, consistent positive bandwagoning could lead to the country entering into a formal military alliance or economic bloc with that regional great power.

\footnotetext{
${ }^{34}$ Byman, Daniel L. and Kenneth M. Pollack. 2001. "Let Us Now Praise Great Men: Bringing the Statesman Back In.” International Security 25 (4), 145; emphasis added.
} 
Great Power Bridging. Great power bridging occurs when political leaders opt to equally cooperate with two or more regional great powers in the diplomatic, economic, and military realms. Unlike positive bandwagoning, political leaders following a great power bridging strategy eschew taking sides. The underlying logic here is that by cooperating with two or more regional great powers on an almost equal basis, the ruling government will likely realize more long-term economic, political, or military benefits. Furthermore, this alignment approach helps to stave-off any political, economic, or military backlash by various regional great powers, which are themselves in competition with each other in different regions of the world.

By first conceptualizing small state alignment as positive bandwagoning and great power bridging, it now becomes necessary to identity the key factors that independently influence these outcomes. By leveraging aspects of social identity theory ${ }^{35}$ and self-categorization theory, ${ }^{36}$ it is argued a political leader's ideas about the state's identity, his/her ${ }^{37}$ threat perceptions, and foreign policy orientation as conditioned by domestic politics are the primary explanatory variables independently shaping Azerbaijan, Georgia, Moldova, and Ukraine's alignment trajectory with the United States and Russia from 1995-2015. From one perspective, a political leader's beliefs about world politics represent a center of gravity ${ }^{38}$ for understanding the state's alignment with one regional great power over another. Furthermore, small state alignment can vary over time

\footnotetext{
${ }^{35}$ See Tajfel, Henri. 1978. Social Categorization, Social Identity, and Social Comparison. In Henri Tajfel (ed.) Differentiation Between Social Groups: Studies in the Social Psychology of Intergroup Relations. London: Academic Press and Tajfel, Henri and John C. Turner. 1979. "An Integrative Theory of Intergroup Conflict.” In William Austin, and Stephen Worchel (eds.) The Social Psychology of Intergroup Relations. Monterey, CA: Brooks/Cole.

${ }^{36}$ See Turner, John C., Michael A. Hogg, Penelope J. Oaks, Stephen D. Reicher, and Margaret Wetherell. 1987. Rediscovering the Social Group: A Self-Categorization Theory. Oxford, UK: Blackwell.

${ }^{37}$ When applicable, this study will use gender neutral pronouns.

${ }^{38}$ I borrow this phrase from Karl von Clausewitz, who applied these words to armed conflict between states. According to Clausewitz, a center of gravity is best understood as "...the hub of all power and movement on which everything depends..." In line with Clausewitz, I argue that a 'hub' from which everything depends on with respect to the alignment tendencies of small states with a regional great power resides in the ideas held by political leaders. Clausewitz, Carl von. 1989. On War. Michael Howard and Peter Paret (eds). Princeton: Princeton University Press, 485-486 and 595-596.
} 
owing to changes in the national political leadership. The key takeaway here is that small state alignment is not an enduring "either-or" characterization, but rather an "adaptive" process subject to the dynamic interplay of ideational and material considerations, which in turn changes as new political leaders come to power. ${ }^{39}$

To more fully capture the relevance of these variables, this study sees value in using multiple methods to analyze how a ruling leader's political ideas and beliefs independently and collectively lead to positive bandwagoning or great power bridging. As depicted in Figure 1 below with the large bold arrows, this study's primary focus is on an examination of how each of the three independent variables (state identity, threat perceptions, and foreign policy orientation as conditioned by domestic politics) on their own, can exert a direct influence on a small state's alignment trajectory with different regional great powers. A broad-brush effort is also made to examine the interaction of the three independent variables and the dependent variable. A summary of these efforts is presented in the proceeding paragraphs.

\section{Figure 1: Small State Alignment}

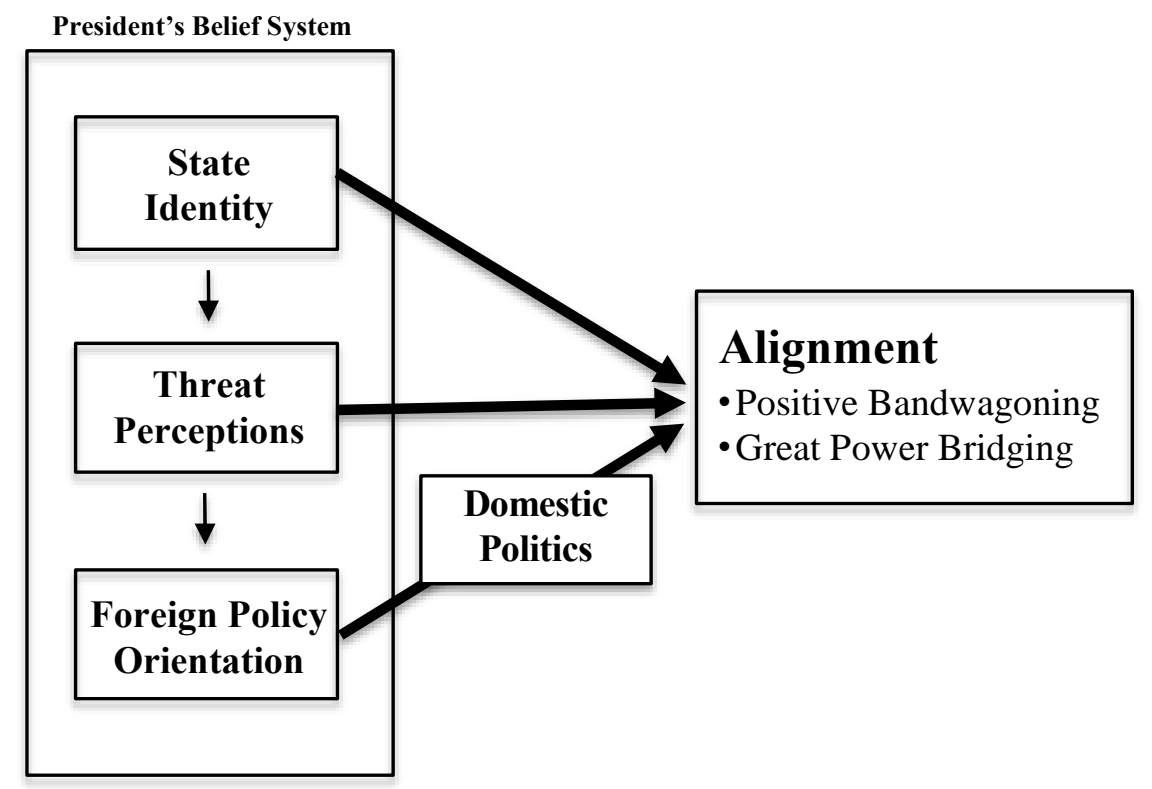

\footnotetext{
${ }^{39}$ Lobell, Steven E., Norrin M. Ripsman, and Jeffrey W. Taliaferro. 2009. Neoclassical Realism, the State, and Foreign Policy. Cambridge: Cambridge University Press, 30.
} 
To begin, the primary focus of this study centers on how the three primary independent variables (state identity, threat perceptions, and foreign policy orientation as conditioned by domestic politics) can lead ruling governments to follow a positive bandwagoning or great power bridging alignment. First, these three variables can help explain positive bandwagoning under certain conditions. For the explanatory variable on state identity, it is posited that when a political leader envisages the state as having a similar state identity to a particular regional great power, higher levels of verbal cooperation will follow, which will be associated with a preference for a positive bandwagoning alignment.

Next, for the independent variable on threat perceptions, it is anticipated that a president who perceives a high threat from one regional great power is expected to espouse higher levels of verbal confrontation with this country and higher levels of verbal cooperation with a different regional great power. When this occurs, one should observe a preference for a positive bandwagoning alignment with the latter. Of note, it is here this study recognizes how Walt's balance of threat theory has some applicability in the post-Soviet space. But, unlike Walt, who primarily focuses on material factors, this study posits ideational factors take precedence and that there are gradations of threat perceptions leading to different alignment outcomes.

Finally, one must take an accounting of strategy and the ability of a ruling elites to translate their alignment preferences into action. For this variable, the central focus is on a president's foreign policy orientation. Specifically, when a head of state exhibits an accommodative foreign policy orientation with a particular regional great power, one should expect a positive bandwagoning alignment. As a corollary, a president who retains a confrontational foreign policy orientation with one regional great power is more apt to follow a positive bandwagoning alignment with a different regional great power. However! Because presidents cannot act in the 
foreign policy realm without impunity, domestic politics represents a conditioning factor in this process. Specifically, varying levels of issue polarization over the head of state's alignment preferences and government fragmentation may constrain or enable the chief executive's ability to transform his/her words into material cooperation. If there are low levels of government fragmentation and issue polarization, domestic politics may than serve as enabler allowing a president to more easily translate his alignment preferences into material action. Alternatively, when there are high levels of government fragmentation and issue polarization, domestic politics may serve as a constraint on the head of state's ability to realize his/her alignment preferences. Of note, while a small state may follow a positive bandwagoning alignment with a particular regional great power, routine interstate activities such as cross-border trade, tourism, cultural exchanges, etc. continue, which reflect how all states pursue multi-vector foreign policies.

Second, these three independent variables (IVs) may also explain why small states may follow a great power bridging alignment. For the IV on state identity, this dissertation postulates that when leading elites in the FPE primarily conceptualize the state as an independent actor in world politics, equal or almost equal levels of verbal cooperation with multiple regional great powers will occur. As will be discussed in the theory chapter (Chapter 3), political leaders can retain multiple conceptions of the state's identity; however, it is posited that the most important state identity conception will exert the greatest influence on a political leader's alignment preferences.

Next, for the IV on threat perceptions, it is hypothesized a political leader who perceives a particular regional great power as a moderate threat will still align with that country. Here, one can expect to see almost equal levels of verbal confrontation and cooperation with that regional great power and others. Finally, when considering alignment strategy, it is expected a president 
with a pragmatic foreign policy orientation will tend to follow a great power bridging alignment. In this case, a president is able to successfully transform his/her alignment preferences into action. In this process, domestic politics can be an enabler or constraint. Specifically, changing levels of issue polarization and government fragmentation can restrain or facilitate the head of state's capacity to convert his/her preferences into action. When government fragmentation and issue polarization are low, domestic politics may function as an enabler. When government fragmentation and issue polarization are high, domestic politics may represent a constraint on the head of state's ability to realize his/her alignment preferences.

In line with Timothy Colton and his research on the voting tendencies of Russian citizens since the end of the Cold War, this study recognizes how each of three independent variables may also exert an indirect influence on the alignment tendencies of political leaders ${ }^{40}$ Although not examined in detail owing to time and space constraints, it is posited that a political leader's ideas about the state's identity can influence his/her ideas about external threats, which in turn frame his/her foreign policy orientation with other states in the international system. The prediction here is that a shared sense of state identity with a particular regional great power reduces a political leader's threat perceptions, which is then associated with an accommodative foreign policy orientation and positive bandwagoning. When state identities diverge, threat perceptions of a target state increase leading to a pragmatic foreign policy orientation and great power bridging or a confrontational orientation and positive bandwagoning with another regional great power.

For clarity, the examination of the interaction of state identity, threat perceptions, and foreign policy orientation is a distant secondary effort that will only analyze the findings from the

\footnotetext{
${ }^{40}$ Colton, Timothy J. 2000. Transitional Citizens: Voters and What Influences Them in the New Russia. Harvard
} University Press, 22-25. 
relationship of these three IVs with the dependent variable as outlined in the three substantive chapters of this dissertation (Chapters Five to Seven). This analysis will be presented in the concluding chapter of this dissertation and will serve as a point of departure for future research.

\section{Key Findings}

An examination of the alignment trajectories of Azerbaijan, Georgia, Moldova, and Ukraine between 1995 and 2015 yielded several key findings. First, ideational factors, more so than material consideration better explain the alignment of small states along Russia's geographical periphery. With Russia consistently maintaining a favorable balance of military power, each of the president's ideas about state identity, threat perceptions, and accompanying foreign policy orientation as conditioned by domestic politics better explained why one state would adopt a positive bandwagoning or great power bridging alignment. Second, in the post-Soviet space, great power bridging was the dominant alignment tendency. Of the ruling governments under examination, seven presidents preferred great power bridging as compared to five, who preferred to follow a positive bandwagoning alignment with the U.S. or Russia.

Third, when examining the relationship between a political leader's ideas about the state's identity and his/her alignment preferences, this study found a correlation between those presidents, who primarily viewed the state as independent and a tendency to follow a great power bridging alignment. This was the case with Azeri Presidents Heydar and Ilham Aliyev, Georgian President Eduard Shevardnadze, Moldovan Presidents Petru Lucinschi and Vladimir Voronin (2003-2009), and Ukrainian President Leonid Kuchma. Those presidents conceptualizing the state as one based on democracy, freedom, or as Western-European was associated with a president's proclivity to prefer a positive bandwagoning alignment with the United States. These presidents included Georgian Presidents Mikheil Saakashvili and Giorgi Margvelashvili, 
Moldovan President Nicolae Timofti, and Ukrainian Presidents Viktor Yushchenko and Petro Poroshenko. Vladimir Voronin (2001-2002) and Viktor Yanukovych viewed the state primarily Eastern and Eurasian, which was correlated with positive bandwagoning with Russia.

Fourth, this dissertation determined all the governments in Azerbaijan, Georgia, Moldova, and Ukraine viewed Russia as the primary existential threat to the state's security and the country's territorial sovereignty. Despite this reality and in contradiction to realist expectations, these presidents did not outright bandwagon with the most threatening or powerful state (i.e. Russia) as realists predict. On the contrary, there was significant variation in the intensity of each president's perception of the Russian threat, which was subsequently correlated with a different alignment tendency. When a president perceived Russia as a moderate threat, great power bridging was observed. This was the case with Heydar and Ilham Aliyev, Petru Lucinschi, Vladimir Voronin, Eduard Shevardnadze, Giorgi Margvelashvili (only during his first year in office), and Leonid Kuchma. A president with high threat perceptions of Russia was correlated with a positive bandwagoning alignment with the United States. Presidents falling into this category included Mikheil Saakashvili, Giorgi Margvelashvili (2014-2015), Nicolae Timofti, Viktor Yushchenko, and Petro Poroshenko. Finally, Viktor Yanukovych's low threat perceptions of Russia were associated with a preference for positive bandwagoning with Moscow.

Fifth, when examining each president's foreign policy orientation and ideas about strategy, a majority of presidents viewed pragmatism as an optimal approach to interstate relations, which was associated with a great power bridging alignment. This pragmatic approach was associated with Heydar Aliyev, Ilham Aliyev, Eduard Shevardnadze, Giorgi Margvelashvili (before 2014), Petru Lucinschi, Vladimir Voronin (after 2003), and Leonid Kuchma, who all implemented a great power bridging alignment with Russia and the United States. When presidents 
simultaneously exhibited an accommodative orientation with Washington and a confrontational one with Moscow, positive bandwagoning with the U.S. was observed. Mikheil Saakashvili, Nicolae Timofti, Viktor Yushchenko, and Petro Poroshenko fell into this category. Only Vladimir Voronin from 2001-2003 and Viktor Yanukovych's accommodative foreign policy orientations with Moscow were associated with a positive bandwagoning alignment with Russia.

Domestic politics (i.e. issue polarization and government fragmentation) did not appear to be a decisive conditioning variable impacting a president's ability to translate his alignment preferences into action. Frequently, a president's strategic leadership skills and his ability to build a supporting coalition across the state's bureaucratic organizations for his alignment preferences helped to minimize the impact of domestic politics. Additionally, presidential appointees, the election of like-minded political figures, and/or coercive tactics helped the president overcome domestic political opposition to his alignment preferences. There were two instances where domestic politics was of consequence; in Moldova under Vladimir Voronin with the Kozak Memorandum and in Ukraine under Viktor Yanukovych following his decision to not sign the EU Association Agreement. Although issue polarization helped fuel political opposition, the role of domestic politics remained secondary to the importance of a president's ideas and beliefs about the state's alignment.

Finally, in the concluding chapter of this study, the indirect influence of the three independent variables was considered. The overarching finding is that when a president's primary ideas about the state's identity were similar to either the U.S. or Russia, he/she perceived the target country as less of a threat. Low threat perceptions were subsequently associated with an accommodative foreign policy orientation and a tendency for positive bandwagoning. When state identity similarities were less pronounced, threat perceptions would increase. Presidents, who primarily 
perceived the state as independent generally viewed Russia as a moderate threat and had a pragmatic foreign policy orientation. In this case, presidents gravitated toward great power bridging. When a president perceived Russia as a high threat, a confrontational foreign policy orientation was observed and a preference for positive bandwagoning with the United States.

\section{Purpose and Significance of this Study}

This dissertation is a comparative foreign policy study of the alignment trajectories of Azerbaijan, Georgia, Moldova, and Ukraine with the United States and Russia from 1995-2015. The overarching purpose of this study is to flesh out the key determinants of change and continuity in the strategic alignment patterns of former Soviet states. To accomplish this task, this dissertation asks: why do similarly placed, small states opt to pursue a closer alignment with one regional great power over another? From this purpose flows three key objectives of this dissertation. First, the primary theoretical purpose of this study is to develop a fresh approach for understanding change and continuity in the alignment patterns of small states. Second, this project seeks to understand the influence of elite belief systems on the alignment behavior of countries occupying the lower tiers of the international hierarchy. Third, this dissertation aims to discern the relevance of domestic pressures on alignment outcomes.

Understanding the alignment patterns of small states in the post-Soviet space with Russia and the United States is an important topic that is of high interest for the United States Army as well as academics, foreign policy practitioners, and intelligence professionals. First, this dissertation is a direct response to a priority research request from the Department of the Army (DA) to “assess Russia’s relationships with Europe and the United States." ${ }^{41}$ From an academic perspective, this dissertation adds to our cumulative knowledge on strategic alignment outcomes

\footnotetext{
41 “U.S. Army War College Key Strategic Issues List, 2012-2013.” 2012. U.S. Army Strategic Studies Institute, U.S. Army War College, Carlisle Barracks, PA. http://www.dtic.mil/dtic/tr/fulltext/u2/a565538.pdf, 29.
} 
in three ways. First, through the development of a more nuanced framework on alignment, this study makes a key theoretical contribution to understanding foreign policy change in small states. Specifically, with its focus on explaining alignment outcomes in the post-Soviet space, this dissertation is both theoretically and empirically significant because the case studies under consideration can serve as plausibility probes in which long-standing theories on alliance formation could be modified to address more specific questions.

Second, this dissertation advances analytical "eclecticism" to understand complex political phenomena. By using multiple methods, one can acquire a deeper understanding of state alignment stemming from the complex interaction between ideational and material factors. ${ }^{42}$ As noted by Christopher Hemmer and Peter Katzenstein,

Eclectic explanations highlight the causal importance of social facts such as power status and threat perceptions, in addition to the material facts and efficiency considerations stressed by rationalist approaches. Eclectic explanations also undercut reifications such as the distinction between domestic and international levels of analysis. ${ }^{43}$

Additionally, the use of multiple methods to examine state alignment bridges the work of scholars, who opt to pursue purely qualitative or quantitative approaches in their work. As Alexander George and Andrew Bennett remind us, "the increasingly evident complementarity of case studies, statistical methods, and formal models is likely to lead toward more collaborative work by scholars using these various methods." 44 Taken together, the findings from this research project can help refine our understanding of the most important factors affecting small state foreign policy decisions. By examining the post-Soviet space, these findings may be generalizable to other small states near other regional great powers such as China or India.

\footnotetext{
${ }^{42}$ Sorensen, George. 2008. "The Case for Combining Material Forces and Ideas in the Study of IR." European Journal of International Relations 14 (1).

${ }^{43}$ Hemmer, Christopher and Peter J. Katzenstein. 2002. "Why is There No NATO in Asia? Collective Identity, Regionalism, and the Origins of Multilateralism." International Organization 56 (3), 577.

${ }^{44}$ George, Alexander L., and Andrew Bennett. 2005. Case Studies and Theory Development in The Social Sciences. MIT Press, 34.
} 
For practitioners such as policymakers and strategists, understanding when and why small states decide to align with one regional great power over another may allow the U.S. government to develop more proactive foreign policies and military strategies that deter great power military adventurism, while also advancing American vital interests in the region. As was the case during the Cold War when U.S. policymakers and "...strategists understood that shoring up allies and ensuring the vitality of free-market democracies was at least as important as defending against military provocations," 45 this situation endures today where Azerbaijan, Georgia, Moldova, and Ukraine have become a "...battleground in the U.S.-Russian fight for influence that will be the essence of the new Great Game."46

Finally, this dissertation is of value for intelligence professionals because it highlights the necessity to give increased focused to non-material factors shaping small state foreign policies. By focusing on the political leader ideas about the state's identity and external state-based threats, intelligence analysts can improve strategic warning or provide more accurate assessments to U.S. policymakers. With this study's emphasis on of the role of state identity, intelligence professionals may also be able to garner new insight into the creation and longevity of contemporary security alliances. For instance, this study can be used as a springboard to further investigate the relationship between identity politics and national security matters. This study and subsequent similar endeavors may then be able to provide intelligence officials critical information that allow them to better support the strategy formulation process at the highest levels of the U.S. government.

\footnotetext{
${ }^{45}$ Lord, Kristin M. and William B. Taylor. 2016. “Tunisia and Ukraine: Linchpins of U.S. Interests.” United States Institute of Peace. https://www.usip.org/publications/2016/02/tunisia-and-ukraine-linchpins-us-interests. Accessed 05 January $2017,1$.

46 Trenin 2014, 25.
} 


\section{Organization of the Dissertation}

To acquire a more comprehensive understanding of small state alignment in the post-Soviet space, this dissertation is divided into eight chapters.

Chapter 1 -Introduction. As detailed above, this chapter provided a macro-overview of the research project. Key topics of discussion included the background and statement of the problem, a brief review of the relevant literature, a summary of this study's argument, a presentation of the key findings, and a rationale as to why this topic is important for academics and practitioners.

Chapter 2 - Literature Review. In the second chapter, an extensive review and assessment of the theoretical literature reveals that traditional approaches for explaining state alignment are deficient when applied to Azerbaijan, Georgia, Moldova, and Ukraine. As part of this literature review, various levels of analysis are considered (e.g. systemic, domestic, and ideational). At the systemic level, this review takes note of the potential relevance of system polarity finding that while the global power structure is an important consideration, it is not decisive in explaining state alignment outcomes. By taking account of the different levels of analysis, one can more easily discern how alignment may vary over time.

Chapter 3 - Theory. Chapter Three introduces the study's model explaining small state alignment. In contradiction to parsimonious systemic theories, explaining small state alignment requires an approach that begins with an accounting of the ideas held by those political leaders charged with developing and executing the state's foreign policies. While material factors like the balance of power are important, the political leader's ideas about the state's identity, his threat perceptions, and foreign policy orientation (as conditioned by domestic politics), do the heavy lifting in explaining each state's alignment with the United States or Russia. 
Chapter 4-Methods and Analysis. The fourth chapter provides the methodological foundation from which to explain small state alignment. In the first section, the concepts of alliance and alignment are examined in detail to establish definitions that can facilitate a more nuanced understanding of the empirical realities associated with both of these political phenomena. The second section focuses on case selection. Here, a series of alignment indicators as developed by Henry Teune and Sig Synnestvedt are applied to all 14 former Soviet states. Conducting this analysis identifies four outliers,- Azerbaijan, Georgia, Moldova, and Ukraine - which become the cases for this study.

Chapter 5 - State Identity and Small State Alignment. This chapter examines the relationship between a president's ideas about state identity and his alignment preferences. An automated content analysis and elite interviews are used to discern the primary state identity narratives for Azeri, Georgian, Moldovan and Ukrainian presidents from 1995 to 2015. Large-n event data on each president's level of verbal cooperation with the U.S. and Russia is used to discern their alignment preferences.

Chapter 6 - Threat Perceptions and Small State Alignment. This chapter focuses on the relationship between a president's threat perceptions and his alignment preferences with the U.S. and/or Russia. An operational code analysis of Azeri, Georgian, Moldovan, and Ukrainian presidents' philosophical beliefs orients a qualitative analysis on each president's threat perceptions of external states.

Chapter 7 - Foreign Policy Orientation, Domestic Politics and Small State Alignment. This chapter focuses on the relationship between a president's ideas about strategy and the state's alignment with the United States and/or Russia. An operational code analysis of Azeri, Georgian, Moldovan, and Ukrainian presidents is used to orient a qualitative analysis of each state's 
material cooperation with the United States and Russia. This chapter also takes into account how issue polarization and government fragmentation may constrain or enable a president's ability to transform his verbal pronouncements into policies that support his alignment preferences.

Chapter 8 - Conclusion. The final chapter of this dissertation begins with a review of the puzzle driving this research endeavor. The major empirical findings are then presented followed by an examination of the sequential relationship of three independent variables and how they may potentially indirectly influence the dependent variable. Next, a summary of the implications for theory, methods, and U.S. policy are presented. Finally, areas of future research are recommended.

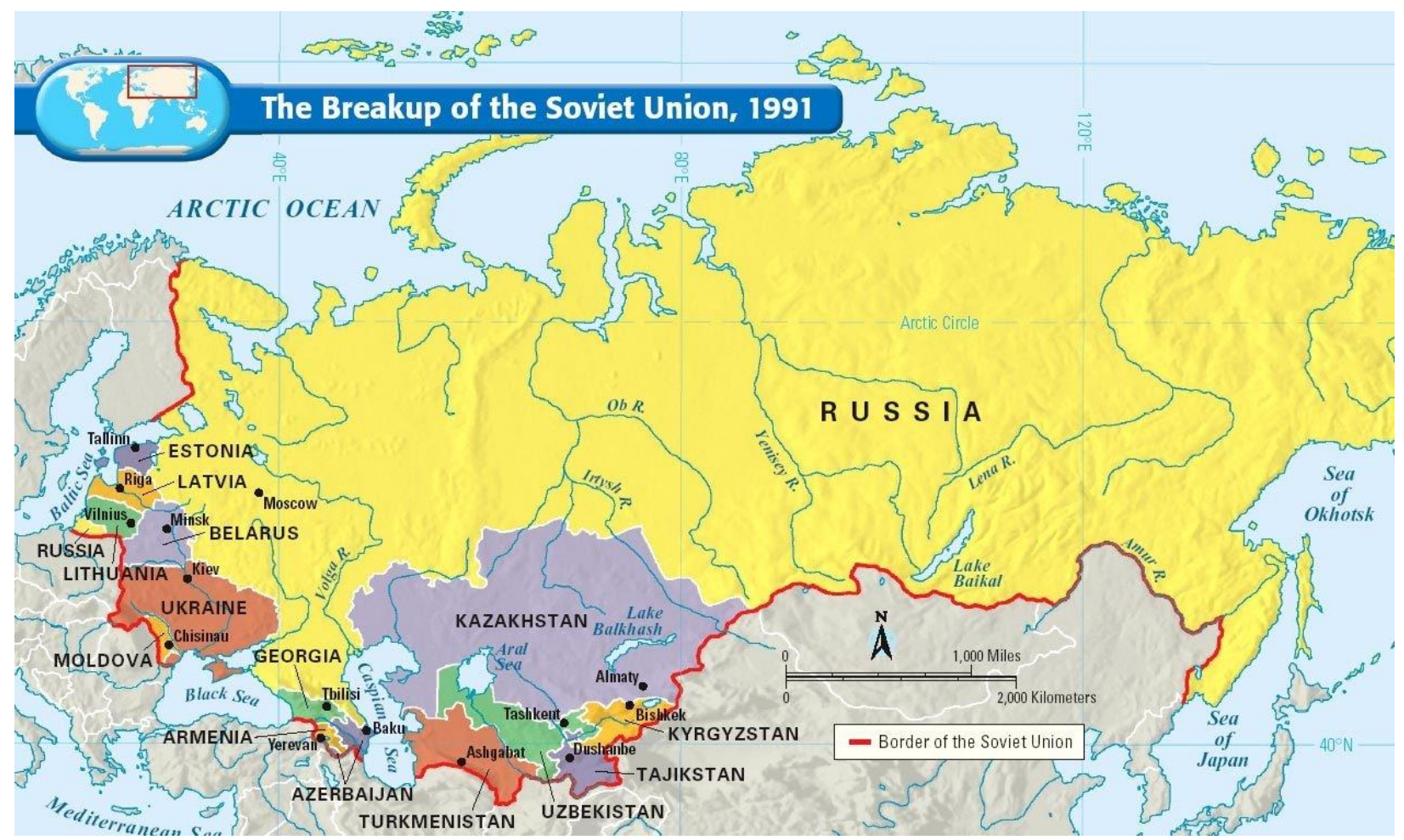

Map 1 - The Post-Soviet Space. ${ }^{47}$

\footnotetext{
47 “Map of the Post-Soviet Space.” 2012. World Press. https://mapcollection.wordpress.com/2012/07/02/thebreakup-of-the-soviet-union/. Accessed 15 August 2016.
} 
"History suggest[s] that it was usually more advantageous to align oneself with the weaker of two antagonistic partners, because this acted as a restraint on the stronger." - Henry Kissinger, 2011. ${ }^{48}$

\section{CHAPTER TWO - LITERATURE REVIEW}

\section{Introduction}

The purpose of this chapter is to review the dominant theories on state alignment and to assess their relevance for understanding this political phenomenon in the post-Soviet space. For decades, legions of IR scholars, foreign policy analysts, and practitioners have advanced a plethora of theoretical approaches grounded in a particular level of analysis to explain the alignment tendencies of states. As a result, their combined work has produced a disparate body of literature that fails to adequately explain why small states, such as those that reside in Russia's borderlands, may align with one regional great power over another.

In order to illuminate the shortcomings of the various theoretical approaches on alignment, there is high utility in surveying the extant literature on this topic. To accomplish this task, this chapter proceeds in six sections. First, of high importance for this study, the concepts of alliance and alignment are differentiated in order to achieve a clearer understanding of the empirical realities associated with these political phenomena. The second section considers systemic theories of alignment. As a part of this review, this section conducts a multi-stage and exhaustive review of the potential relevance and impact of the global power structure on a state's foreign policy behavior. The overarching finding is that while system polarity is an important consideration, its impact on the alignment of small states with the great powers is largely

\footnotetext{
${ }^{48}$ Kissinger, Henry. 2011. White House Years. Simon and Schuster.
} 
indeterminate because there will always exist a multitude of more powerful states thereby making the system multipolar at least from the vantage point of small states. Section three turns attention to domestic-level explanations, while section four details a series of alignment typologies that scholars have developed in recent years. In section five a brief discussion on nonalignment strategies is presented followed by a conclusion in section six.

\section{Alliance versus Alignment}

The concept of an alliance has been an enduring and fundamental aspect of the political relations between states for thousands of years. Whether it was the alliance between Sparta and Persia against Athens during the Peloponnesian War, the Triple Entente during World War I, or the 26-member countries of NATO today, states have used military alliances to ensure their security and an equitable balance of power in an anarchic international system. ${ }^{49}$ The extent to which alliances have played a central role in world politics is captured by George Liska, who notes. "it is impossible to speak of international relations without referring to alliances; the two often merge in all but name. ${ }^{, 50}$ Similarly, Ole Holsti and his colleagues assert that alliances are a "universal component of relations between political units, irrespective of time or place,"

Ken Booth concludes, "alliances have been pervasive features in both the theory of international politics and in the practice of foreign policy." 52

From an etymological standpoint, the terms alignment and alliance have historically conveyed distinct meanings and thus should be treated in that way in any scholarly undertaking. As a noun,

\footnotetext{
${ }^{49}$ One of the earliest works on alliances worthy of mention here is from Hans Morgethau. Morgenthau, Hans J. 1959. "Alliances in Theory and Practice." In Arnold Wolfers (ed.) Alliance Policy in the Cold War. Baltimore: Johns Hopkins University Press, 188.

${ }^{50}$ Liska, George. 1962. Nations in Alliance: The Limits of Interdependence. Baltimore: Johns Hopkins University Press, 3.

${ }^{51}$ Holsti, Ole R., P. Terrance Hoffman and John D. Sullivan (eds.). 1973. Unity and Disintegration in International Alliances. Lanham, MD: University Press of America, 2.

${ }^{52}$ Booth, Ken. 1987. “Alliances.” In John Baylis et al. (eds.) Contemporary Strategy I. New York: Holmes \& Meier, 258.
} 
alliance is derived from the French words 'aliance' and 'allier,' which mean 'to connect or unite or combine.' The French derived these terms from the Latin word 'alligare,' which meant 'to bind.' As a verb, alignment is derived from the French words 'alignier' and 'aligner,' which mean 'to line or to range into a line." 53 These points lead Collen Chidley to conclude that These terms, although related, originate indifferent understandings and is derived from different verbs where 'alignment' is the more generic term for things being in line or in agreement whereas 'alliance' is more value-laden being derived from the verb 'to ally' which connotes unity based on similarity. ${ }^{54}$

Given the central role of alliances in world politics, scholars in many cases have erroneously used the terms alliance and alignment as synonyms in their research forgetting Glenn Snyder's sage words that "the protean character of alliances and alignments makes a clear definition essential" $" 55$ where alignment is a broader concept encompassing several facets of interstate relations (e.g. diplomatic, economic, military, etc.) of which alliance is a more precise sub-class grounded exclusively in the security realm. ${ }^{56}$ For example, in his seminal work on alliances, Stephen Walt uses the terms alignment and alliance interchangeably in order to increase the number of relevant cases for his analysis. ${ }^{57}$ Separately, Eric Miller and Arkady Toritsyn view alignment and alliance as synonyms to explain the alignment tendencies of former Soviet states but then focus much of their analysis on multilateral and bilateral security agreements. ${ }^{58}$ Of

\footnotetext{
${ }^{53}$ Bergsmann, Stefan. 2001. “The Concept of Military Alliance.” In Erich Reiter and Heinz Gärtner (eds.) Small States and Alliances. Physica-Verlag, 7.

${ }^{54}$ Chidley, Colleen. 2014. "Towards a Framework of Alignment in International Relations." Politikon: South African Journal of Political Studies 41 (1), 7.

${ }^{55}$ Snyder, Glenn H. 1997. Alliance Politics. Ithaca, N.Y.: Cornell University Press, 3.

${ }^{56}$ Scholars noting the marked differences between alignment and alliance include Modelski, George, 1963. "The Study of Alliances; a Review." The Journal of Conflict Resolution 7 (4); Ward, Michael Don. 1982. Research Gaps in Alliance Dynamics Vol. 19. Graduate School of International Studies. University of Denver; Wilkins, Thomas S. 2012. “'Alignment', not 'Alliance'-the Shifting Paradigm of International Security Cooperation: Toward a Conceptual Taxonomy of Alignment." Review of International Studies 38 (1).

${ }^{57}$ Walt 1987, 12.

${ }^{58}$ Miller, Eric A., and Arkady Toritsyn. 2005. "Bringing the Leader Back In: Internal Threats and Alignment Theory in the Commonwealth of Independent States." Security Studies 14 (2), 333-337.
} 
particular concern here is how both inaccurately reference Walt's 1987 definition of an alliance, which these scholars mistake for alignment.

This scholarly tendency to view alliances and alignments as one in the same stems from what Giovanni Sartori calls conceptual stretching, where scholars attempt to extend their analysis to a larger number of cases in order to achieve a higher level of external validity. ${ }^{59}$ At issue is how conceptual stretching may extend a theory and set of hypotheses too far in such a way that the original concepts and definitions no longer validly fit new empirical observations or cases. As Sartori notes, this 'double-fitting' results in "vague and amorphous conceptualizations" 60 that fit observations because they are simply defined in broad generalities. For example, political scientists focusing on democratization have put forward a variety of different definitions for democracy over the years; however, some of these studies have come under criticism for stretching this concept too far to achieve higher levels of external validity. ${ }^{61}$ This was the case with Darius Rejali and his examination of torture in democracies. In this project, Rejali defines democracy so broadly that some authoritarian governments are deemed democratic. ${ }^{62}$ This example also illuminate how "without clear concepts..., scholars are apt to talk past each other, and policy-makers find it difficult to distinguish between alternative policies." ${ }^{\text {63 }}$

\footnotetext{
${ }^{59}$ Sartori, Giovanni. 1970. "Concept Misformation in Comparative Politics." American Political Science Review 64 (4), 1034-1035.

${ }^{60}$ Sartori 1970, 1036.

${ }^{61}$ The number of scholars positing a definition of democracy is legion. See for example, Gowa, Joanne. 2011. "The Democratic Peace After the Cold War." Economics \& Politics 23 (2); Maoz, Zeev and Bruce Russett. 1993. "Normative and Structural Causes of Democratic Peace, 1946-1986." American Political Science Review 87 (3); Welzel, Christian and Ronald Inglehart. 2008. "The Role of Ordinary People in Democratization.” Journal of Democracy 19 (1).

${ }^{62}$ According to Rejali, a democracy is "a form of government based on amateurism (citizens rule in turn by means of lots or elections in a free choice among competitors) and participation (a significant segment of the society has access to these means)." Rejali, Darius. 2007. Torture and Democracy. Princeton: Princeton University Press, 45. ${ }^{63}$ Baldwin, David A. 1997. "The Concept of Security." Review of International Studies 23 (1), 6.
} 
A second methodological issue centers on case selection in small-n, qualitative studies such as this one. Following Sartori, Charles Ragin raises a concern over what he labels "double fitting" where a concept's definition causes a change in the domain of cases and vice versa. In this situation, the problem arises whereby simply broadening the definition of a concept in order to harvest more cases that support a theory erodes the precision of the findings, while also preventing an accumulation of knowledge on the topic. ${ }^{64}$ As David Collier notes, "this process of double fitting should be used appropriately to refine concepts, and not inappropriately to come up with a set of cases that conveniently confirms the researcher's preferred hypothesis." 65

The scholarly tendency to use alliance and alignment interchangeably stems in part from the ambiguous and amorphous nature of what an alliance is and is not in international relations. ${ }^{66}$ As a result, there exists a lack of consensus on how best to conceptualize an alliance, which has led to the proliferation of a large number of definitions. For example, in his examination of the alliance literature, Stefan Bergsmann finds there are over 35 different definitions of an alliance. In reviewing the myriad of studies on this topic, he delineates three broad categories on the definition of an alliance: formal agreements, formal-informal agreements, and institutional. ${ }^{67}$

In the first category, scholars narrowly define an alliance as a formal agreement (e.g. a signed treaty) that binds two or more countries to act in a certain way on national security or military matters. ${ }^{68}$ For example, Holsti and his colleagues delineate three criteria for the existence of an

\footnotetext{
${ }^{64}$ Ragin, Charles C. 1998. "The Logic of Qualitative Comparative Analysis.” International Review of Social History 43 (S6).

${ }^{65}$ Collier, David. 1998. "Comparative Method in the 1990s." Newsletter of the American Political Science Association Organized Section in Comparative Politics 9 (1), 4.

${ }^{66}$ Fedder, Edwin H. 1968. "The Concept of Alliance.” International Studies Quarterly 12 (1), 70.

${ }^{67}$ Bergsmann, Stefan. 2001. "The Concept of Military Alliance.” In Erich Reiter and Heinz Gärtner (eds.) Small States and Alliances. Physica-Verlag, 20.

${ }^{68}$ Beres, Louis René. 1972. "Bipolarity, Multipolarity, and the Reliability of Alliance Commitments." The Western Political Quarterly 25 (4); Gibler, Douglas M. and Meredith Reid Sarkees. 2004. "Measuring Alliances: The Correlates of War Formal Interstate Alliance Dataset, 1816-2000." Journal of Peace Research 41 (2); Holsti et. al. 1973, 5; Morrow, James D. 1991. “Alliances and Asymmetry: An Alternative to the Capability Aggregation Model
} 
alliance between states. First, the actors must be nation-states. Second, there must be a formal, open, or secret treaty between each of the parties. Finally, the treaty must focus exclusively on security issues. These criteria allow them to subsequently define an alliance as a "formal agreement between two or more nations to collaborate on national security issues." 69 Similarly, Snyder defines an alliance as a "formal association of states for the use (or non-use) of military force, intended for the security or the aggrandizement of their members against specific other states, whether or not these others are explicitly identified."70

A second category builds upon the first where some scholars advance the proposition on how alliances can also come into existence based on informal agreements that encompass military and/or non-military matters. For example, Robert Osgood defines an alliance as a "latent war community based on general cooperation that goes beyond formal provisions and that the signatories must continually cultivate in order to preserve mutual confidence in each other's fidelity to specified obligations." ${ }^{71}$ Separately, Walt defines an alliance as a "formal or informal relationship of security cooperation between two or more sovereign states." ${ }^{, 72}$ For these scholars, actions among alliance members is based on a set of mutual expectations. ${ }^{73}$

There are two major issues with this second conceptualization. First, by including informal agreements, almost any security arrangement between states may now qualify as an alliance making it difficult to theorize about this concept. For example, when considering the 2014

\footnotetext{
of Alliances." American Journal of Political Science 35 (4); Snyder, Glenn H. 1990. “Alliance Theory: A Neorealist First Cut." Journal of International Affairs 44 (1); Sorokin, Gerald L. 1994. "Arms, Alliances, and Security Tradeoffs in Enduring Rivalries.” International Studies Quarterly 8 (3).

${ }^{69}$ Holsti et. al. 1973, 4.

${ }^{70}$ Snyder 1990, 103.

${ }^{71}$ Osgood, Robert. 1968. Alliances in American Foreign Policy. Baltimore: The Johns Hopkins Press, 19.

${ }^{72}$ Walt 1987, 12.

${ }^{73}$ See also Chun, Chae-Sung. 2000. "Theoretical Approaches to Alliance: Implications on the ROK-US Alliance." Journal of International and Area Studies 7 (2), 73; Beer, Francis A. (ed.). 1970. Alliances: Latent War Communities in the Contemporary World. New York: Holt, Rinehart and Winston Publishers; Liska 1962.
} 
Russia-Ukraine crisis, a non-binding verbal statement by the United States to provide non-lethal support to Kiev could have been potentially viewed on the same level as a binding requirement for NATO countries to use military force if a member comes under attack from a hostile country. Second, including informal arrangements broadens the definition of alliance so much that there is increased risk that scholars will fall victim to conceptual stretching mistaking how an alliance is a markedly different concept from alignment. Recognizing these shortfalls, Walt in his later work refined his definition of alliance as "a cooperative security relationship between two or more states, usually taking the form of a written military commitment." ${ }^{.74}$

Finally, using a neoliberal institutionalist lens, other scholars have developed a third set of definitions of an alliance. Robert Keohane asserts "alliances are institutions, and both their durability and strength (the degree to which states are committed to an alliance, even when costs are entailed) may depend in part on their institutional characteristics." 75 This definition allows Keohane to subsequently advance the argument that neoliberalism, more so than neorealism, can provide a better explanation about why states formed or joined an alliance during the Cold War. Beyond alliance formation, neoliberals have used an institutionalist approach to explain alliance durability. This is the case with Celeste Wallander and Robert Keohane, who define an alliance as a set of "institutions that combine risk-directed management functions with threat-directed power aggregation functions." ${ }^{76}$ This definition serves as a foundation from which they proceed to explain NATO's continued existence (and expansion) after the demise of the Soviet Union.

\footnotetext{
${ }^{74}$ Walt, Stephen M. 1993. “Alliance.” In Joel Krieger et al. (eds.) The Oxford Companion to Politics of the World. New York: Oxford University Press, 20.

${ }^{75}$ Keohane, Robert O. 1989. International Institutions and State Power: Essays in International Relations Theory. Boulder, Colorado: Westview Press, 15.

${ }^{76}$ Wallander, Celeste A., and Robert O. Keohane. 2002. "Risk, Threat, and Security Institutions." In Robert O. Keohane (ed.), Power and Governance in a Partially Globalized World. New York: Routledge, 99.
} 
With the myriad of definitions in place, it becomes clear how alliance and alignment may come to incorrectly mean the same thing.

To mitigate the risk that alliance and alignment will be used as interchangeable terms, various scholars have offered up different criteria to guide the research endeavors for those examining these concepts. This study argues that taking account of these perspectives will lead to more precise definitions of what an alignment and alliances are or are not. The starting point for this analysis begins with George Modelski, who notes that all forms of diplomatic, economic and military cooperation between states should not be classified as an alliance. On the contrary, these international acts of cooperation should be viewed as alignments with an alliance as a sub-class. Modelski offers up three ways to differentiate between alliances and alignment.

First, an alliance represents interstate cooperation in the military sphere whereas alignments cover all types of cooperation between states in the international system. In his words, "alliances connote military collaboration concerned with a third power; 'alignments' can be regarded as a blanket term referring to all types of international political cooperation (that is also specific and particularistic)." 77 The underlying logic here is that a state's entry into a war in support of another state is a serious matter that requires a high-level of precision (e.g. a signed, formal treaty). Failure to specify triggers for action risks the unnecessary loss of blood and treasure.

Second, alignments are generally shorter in duration, whereas alliances tend to last for longer periods of time. For example, the NATO alliance has endured for over 67 years while the U.S.Soviet alignment against France and Britain on the resolution of the 1956 Suez Crisis lasted only several months. A third way to differentiate between an alliance or alignment is to focus on a state's status as it relates to international cooperation. Using these criteria, an alliance is reserved

\footnotetext{
${ }^{77}$ Modelski 1963, 774-775.
} 
for states on an equal footing in terms of reciprocal contributions. When there is an absence of equal reciprocity such as a great power's unilateral declaration to protect or a small state's acquiescence to the leadership role of that great power, then there exists an alignment

This third approach is problematic in two ways. First, member input does not necessarily have to be equal in terms of total contributions for an alliance to exist. For example, although the United States provides the lion's share of manpower, money, and materiel for NATO (approximately 75 percent), each member's defense budget, as a percent of GDP is about the same. ${ }^{78}$ Second, using this criterion implies only the great powers are able to establish an alliance, which is not the case. For example, in December 2000 Saudi Arabia, Kuwait, Bahrain, Qatar, Oman, and the United Arab Emirates signed the "Defense Pact among the Gulf Cooperation Council." By signing this defense pact, member states agreed to come to each other's assistance in case of attack. ${ }^{79}$ In the post-Soviet space, Georgia, Ukraine, Azerbaijan, and Moldova have come together to form GUAM.

Following Modelski, Patrick McGowan and Robert Rood also view alliances as a subclass of alignments defining them as a military commitment between at least two states to go to war (or remain neutral) against a third state or group of states. An alliance is different from alignment in several ways. First, states entering into an alliance have identified an enemy or potential future enemy. Second, member states have a mutual interest in either maintaining or revising the international status quo through the possible use of the military instrument of national power. Third, unlike other scholars, McGowan and Rood argue alliances may be formal or informal.

\footnotetext{
${ }^{78}$ North Atlantic Treaty Organization. 2015. "NATO Published Defense Expenditures Data for 2014 and Estimates for 2015." 22 June 2015. http://www.nato.int/nato_static_fl2014/assets/pdf/pdf_2015_06/20150622 _PR_CP_2015_093-v2.pdf. Accessed 02 June 2016.

${ }_{79}$ Henderson, Simon. 2001. "The Gulf Cooperation Council Defense Pact: An Exercise in Ambiguity." The Washington Institute, 16 January 2001. http://www.washingtoninstitute.org/policy-analysis/view/the-gulfcooperation-council-defense-pact-an-exercise-in-ambiguity. Accessed 02 June 2016.
} 
Walt follows this approach by identifying the relationship between the U.S. and Israel as an informal alliance. For Walt, although there is no signed treaty between both states, the U.S. has always been an ardent defender of Israel's sovereignty. McGowan and Rood specify several areas of overlap between alliances and alignments. These include, but are not limited to pooling state resources, providing each other economic, military or diplomatic support, and interstate cooperation on topics of mutual interest. ${ }^{80}$

Michael Ward differentiates between alliances and alignment on two levels. First, alliances are more formal in nature since they are based on a written agreement that binds states to act under certain conditions. Alignments are more informal and reflect the behavioral tendencies of the political leaders in power. Second, Ward notes that alliances are predominately formed for military purposes whereas interstate alignment may occur along multiple lines of cooperation. In his words...

Alignment is not signified by formal treaties but is delineated by a variety of behavioral actions. It is a more extensive concept than alliance since it does not focus solely upon the military dimension of international politics. Degrees of alignments in political, economic, military, and cultural spheres present a multifaceted sculpture of national and supranational postures. ${ }^{81}$

Following suit, Glenn Snyder notes "alliances, however, are only the formal subset of a broader and more basic phenomenon, that of 'alignment.' Alignment amounts to a set of mutual expectations between two or more states that they will have each other's support in disputes or wars with particular other states." ${ }^{\prime 2}$ Snyder subsequently refines his definition to include nonmilitary matters noting how alignment is best understood as,

"...expectations of states about whether they will be supported or opposed in future interactions. Such interactions may arise from a variety of specific sources, but in general they stem from the

\footnotetext{
${ }^{80}$ McGowan, Patrick J., and Robert M. Rood. 1975. “Alliance Behavior in Balance of Power Systems: Applying a Poisson Model to Nineteenth-Century Europe.” American Political Science Review 69 (3), 859-860.

${ }^{81}$ Ward 1982, 7.

${ }^{82}$ Snyder 1990, 85.
} 
perceived interests, capabilities, and observed behavior of other states, including their alliance pledges." $" 83$

Snyder's revised definition does well to expand alignment beyond the military realm; however, it is still flawed because he fails to specify the most important strategic interactions between states. As a result, almost any form of interstate cooperation (military, economic, technical, diplomatic, religious, social, etc.) may be viewed as an alignment.

The preceding discussion and analysis illuminates several key takeaways. First, because there are no universally accepted definitions for the terms alliance and alignment owing to their ambiguous nature, it becomes extremely important to develop useful conceptualizations of these concepts in order to avoid several theoretical and methodological missteps. For example, blurring the lines that separate alignment from alliance makes theorizing extremely difficult because conflating any conceptualization of an alliance to include a broad array of activities outside formal military arrangements erodes our ability to understand how political elites may pursue broader alignment strategies designed to realize their non-security preferences. This was the case in Ukraine in November 2013 when President Viktor Yanukovych decided not to sign a political association and free trade agreement with the EU opting instead to accept a $\$ 15$ billion Russian economic aid package and lower natural gas prices. ${ }^{84}$ Yanukovych's actions represent one way a statesman may pursue formal economic agreements as part of a broader alignment strategy to advance the ruling government's ideas about what is in the best interest of the state.

Second, while the blending of the terms alliance and alignment under a rigid bipolar system during the Cold War may have proved useful during this time, such an approach is no longer

\footnotetext{
${ }^{83}$ Snyder 1997, 6.

${ }^{84}$ Grytsenko, Anatolii. 1999. “Ukraine's Defense Sector in Transition: Impacts on Foreign and Security Policy”. In Kurt R. Spillman, Andreas Wenger, and Derek Muller (eds.) Between Russia and the West: Foreign and Security Policy of Independent Ukraine. Bern: Peter Lang; Walker, Shaun. 2013. "Vladimir Putin Offers Ukraine Financial Incentives to Stick with Russia." The Guardian. 18 December 2013. http://www.theguardian.com/world /2013/dec/17/ukraine-russia-leaders-talks-kremlin-loan-deal. Accessed 20 November 2014.
} 
compatible in an international system dominated by multiple regional great powers. This new reality is captured by Bruno Tertrais, who asserts, "the very term 'alliance' may be a growing source of strategic misunderstanding" 85 in the post-Cold War era, while Stewart Woodman finds that since the demise of the Soviet monolith, "there has been a shift away from formal alliance structures based on military force to more transient marriages of convenience on specific issues." ${ }^{86}$ Because states now operate "in a world of alignments, not alliances" ${ }^{87}$ there exists a need for increased specificity of these terms in order to develop new theoretical approaches, which can adequately reflect the evolution of how states will align with one another in the $21^{\text {st }}$ century. Taken together, this study advances an argument on the necessity to advance a more holistic, yet specific conception of alignment in the $21^{\text {st }}$ century.

Given the preceding, alignment is defined as an informal or less-binding formal set of expectations between a small state and a regional great power. An alliance is then best understood as a formal written agreement or treaty between two or more sovereign states to take some form of military or economic-related action based on established protocols and provisions.

\section{Systemic Theories}

Structuralists attempt to explain state alignment by proceeding on the assumption that variables in the system, not domestic-level factors, best explain state action in a competitive global arena characterized by anarchy. While structuralists may agree on the centrality of systemic-based factors, they are at odds over which variable is more relevant than another. Four of the primary points of divergence center on whether states align with other states because of

\footnotetext{
85 Tertrais, Bruno. 2004. "The Changing Nature of Military Alliances.” The Washington Quarterly 27 (2), 148.

${ }^{86}$ Woodman, Stewart. 1997. "Beyond Armageddon? The Shape of Conflict in the Twenty-First Century." In D. Roy (ed.), The New Security Agenda in the Asia-Pacific Region. London: Macmillan, 81.

${ }^{87}$ Khanna, Parag. 2008. The Second World: Empires and Influence in the New Global Order. New York: Random House, 324.
} 
power imbalances, the level of threat, or for profit. A fourth point of divergence relevant to this study centers on whether the global power structure, as a systemic condition, has any impact on a small state's actions to align with a regional great power.

\section{Balance of Power Theory}

The overarching argument for balance of power theorists is that states balance against power, particularly military power, more than any other systemic factor. ${ }^{88}$ Although there are different versions of balance of power theory, most scholars incorporate realist assumptions into their theoretical frameworks. First, the primary shape agent for international outcomes is the distribution of power among states. Second, anarchy establishes a permissive environment for alignment by framing interstate relations in terms of fear, insecurity, competition, and conflicts of interest. Third, these conditions (anarchy, fear, uncertainty, etc.) drive states to take protective actions against more powerful states.

It is from these assumptions that states will attempt to balance against a more powerful state. Balancing can occur in two ways. The first option for states is that they can internally balance by using domestic resources to build-up the country's military capabilities that improve its position vis-à-vis a more powerful state. In essence, states pursuing a strategy of internal balancing have entered into a de facto arms race that may contribute to a 'slow' conflict spiral, which could then lead to war. As Mark Brawley notes, "whereas external balancing alters the distribution of power

\footnotetext{
${ }^{88}$ See Christensen, Thomas J., and Jack Snyder. 1990. "Chain Gangs and Passed Bucks: Predicting Alliance Patterns in Multipolarity." International Organization 44 (2); Haas, Ernst B. 1953. "The Balance of Power: Prescription, Concept, or Propaganda?" World Politics 55 (4); Levy, Jack S. and William R. Thompson. 2005. "Hegemonic Threats and Great Power Balancing in Europe, 1495 - 2000." Security Studies 14 (1); Vasquez, John A., and Colin Elman, eds. 2003. Realism and the Balancing of Power: A New Debate. Saddle River, NJ: Prentice Hall; Waltz 1979.
} 
quickly (and less permanently, since alliances can shift with the stroke of a pen), internal balancing is a way to alter the distribution of power over the long term." 89

On the other hand, states can externally balance by entering into a formal military alliance or signing a formal agreement with other like-minded states. Waltz specifically details the underlying logic of external balancing. In his words,

Secondary states, if they are free to choose, flock to the weaker side, for it is the stronger side that threatens them. On the weaker side, they are both more appreciated and safer, provided, of course, that the coalition they join achieves enough defensive or deterrent strength to dissuade adversaries from attacking. ${ }^{90}$

However, Jack Levy attempts to offer a theoretical point of clarification with Waltz's assertion. According to Levy, scholars should understand that Waltz is referring to great power balancing as was the case in the run-up to World War I where the United Kingdom, France, and Russia balanced against a powerful Germany, whereas "weaker states [such as Armenia, Belarus, Kazakhstan, etc.] in the [geographical] proximity of stronger states [like Russia] do what is necessary to survive . . bandwagoning with the strong instead of balancing against them."91

Annett Fox, Michael Handel, and Robert Rothstein find similar conclusions that small states gravitate towards bandwagoning with a threatening great power. ${ }^{92}$ For example, at the beginning of World War II, Romania and Bulgaria opted to align with Nazi Germany in 1940 and 1941 but then aligned with the Soviet Union at the conclusion of war. In this case, weak states tend to bandwagon with a great power because of the country's location, its military power, or the likelihood of future conflict that would threaten the small state's survival.

\footnotetext{
${ }^{89}$ Brawley, Mark. 2004. "The Political Economy of Balance of Power Theory.” In Balance of Power: Theory and Practice in the 21st Century, T. V. Paul, James J. Wirtz, and Michel Fortmann (eds). Stanford University Press.

${ }^{90}$ Waltz 1979, 127.

${ }^{91}$ Levy, Jack S. 1989. "The Causes of War: A Review of Theories and Evidence.” In Philip E Tetlock, et al. (eds.) Behavior, Society and Nuclear War. New York: Oxford University Press, 231; emphasis added.

${ }^{92}$ Fox, Annette Baker. 1959. The Power of Small States: Diplomacy in World War II. University of Chicago Press; Handel, Michael I. 1990. Weak States in the International System. London: Frank Cass Publishers; Rothstein, Robert L. 1968. Alliances and Small Powers. New York: Columbia University Press.
} 
Contradicting the findings of Levy and others, Eric Labs, in his examination of the wars of German unification (1860-1866) finds weak states are more likely to balance against a great power. In fleshing out the alignment tendencies of small states caught between an imminent or ongoing conflict between great powers, small states could choose from six strategies. In order of preference, they are neutrality; bandwagon with an aggressive regional hegemon; balance and not fight or fight against the aggressive hegemon, respectively; in the absence of great power opposition to the aggressive hegemon, band together in an alliance with other similarly placed states; or fight alone.

Of these available options, Labs concludes that, just like the most powerful states in the international system, weak states also have a proclivity to balance against an aggressive, rising hegemon. Furthermore, when there is a readily available third-party great power, the tendency to balance is even more pronounced. ${ }^{93}$ However, Lab's work has several shortcomings. First, he exclusively focuses his analysis on small states that are caught in the midst of a great power conflict. Noticeably absent is how these small states may align under conditions of great power competition where war is not imminent. Furthermore, realizing the limits of his argument, Labs subsequently acknowledges that history is replete with examples of small states bandwagoning with a threatening great power citing Czechoslovakia's 1938 decision to peacefully accept Nazi domination and Jordan's 1990 decision to back Iraq during the First Gulf War.

A contributing factor to this indeterminacy of when states may balance or bandwagon stems from how scholars have defined these concepts. Inis Claude and Jack Levy note some studies use the term balancing to mean a strategy. Others use the phrase 'balance of power' as a synonym for

\footnotetext{
${ }^{93}$ Labs, Eric J. 1992. “Do Weak States Bandwagon?” Security Studies 1 (3), 384-391.
} 
high politics. And still others use it to denote the distribution of material power in the system. ${ }^{94}$ Writing in the early 1900s, Richard Cobden notes the concept of balance of power is like "a chimera — an undescribed, indescribable, incomprehensible nothing." 95

\section{Balance of Threat Theory}

In similar systemic fashion, but in opposition to Waltz, Stephen Walt argues states do not balance against the most powerful state, but against the most threatening one. At issue for Walt is how Waltz proceeds on an erroneous assumption that the most powerful states are also the most threatening. As Walt notes, "although power is an important part of the equation, it is not the only one. It is more accurate to say that states tend to ally with or against the foreign power that poses the greatest threat." 96 To garner a more realistic appraisal of balancing, Walt believes state alignment rests on four factors: a state's aggregate power, the proximity of the more powerful state, its offensive [military] power, and intentions. The first three elements relate to structural conditions but the fourth captures a political leader's understanding of the external threat based on the actions of a more powerful state. This approach allows Walt to conclude that states are more likely to balance against rather than bandwagon with a threatening power. For Walt,

An alignment that preserves most of a state's freedom of action is preferable to accepting subordination under a potential hegemon. Because intentions can change and perceptions are unreliable, it is safer to balance against potential threats than to hope that strong states will remain benevolent. ${ }^{97}$

The sage insight of Winston Churchill serves as an excellent illustration of Walt's assertion.

For four hundred years the foreign policy of England has been to oppose the strongest, most aggressive, most dominating power on the Continent. ... it would have been easy ... and tempting to join with the stronger and share the fruits of his conquest. However, we always took the harder

\footnotetext{
94 Claude, Inis L. 1989. “The Balance of Power Revisited.” Review of International Studies 15 (2), 77; Levy 2004, 29-30.

${ }^{95}$ Cobden, Richard. [1903] 1969. The Political Writings of Richard Cobden. F. W. Chesson, ed. London: T. Fisher Unwin. 1903. Library of Economics and Liberty [Online]. http://www.econlib.org/library/YPDBooks/Cobden/ cbdPW6.html. Accessed 12 May 2016.

${ }^{96}$ Walt 1987, 21.

${ }^{97}$ Ibid, 15.
} 
course, joined with the less strong Powers, ... and thus defeated the Continental military tyrant whoever he was. ${ }^{98}$

Churchill's words and Walt's scholarly assertion on the rarity of state bandwagoning are poignant because it allows for the differentiation between the broad strategies of external balancing and bandwagoning. If balancing is defined as joining with like-minded, less powerful states, then bandwagoning, according to Walt, is best understood as "alignment with the source of danger." 99 States that bandwagon with a more threatening state do so to as a form of appeasement to stave off an imminent or future armed attack. Whether the threat of attack is short- or long-term in nature, a state attempts to extend its survival by trading some of its political autonomy for security that is provided at the leisure of the most threatening power.

However, the epistemological assertions of Walt and the example from Churchill must be placed in their proper context. While Churchill's words may exemplify the balancing tendencies of most states, one must not forget he is a political elite speaking about the actions of a great power, not a small state. Furthermore, like many structuralists, Walt exhibits a great power bias in his analysis and that the tendency for states to balance is more applicable to top-tier states. Walt subsequently clarifies his assertion, noting that some weak states will bandwagon with a threatening power. In his words, "weak states can do little to affect the outcome (and may suffer grievously in the process), they must choose the winning side. Only when they can affect the outcome is it rational for them to join the weaker alliance." 100

Walt's balance of threat theory, which integrates ideational factors (i.e. threat perceptions), represents a marked improvement over Waltz and other balance of power scholars, who simply

\footnotetext{
${ }^{98}$ Churchill, Winston S. 1948. The Second World War: Volume I - The Gathering Storm. Boston: Houghton Mifflin, 207-208.

${ }^{99} \mathrm{Ibid}, 17$

${ }^{100}$ Ibid, 29.
} 
focus on power to understand state alignment. In terms of shortcomings, Walt fails to elaborate on what constitutes "aggressive intentions" opting instead to list acts of aggression by Nazi Germany or Libya. The issue here is the concept of "aggressive intentions" is undertheorized and underspecified leading one to ask what constitutes a state threat and how does one adequately determine intent, especially since political leaders routinely make statements that are for domestic consumption but are also heard by other actors in the international system. Additionally, Walt's focus on bandwagoning as a negative action blinds him to the possibility of how small state alignment can be viewed positively. That is, the extent to which one regional great power is considered a threat is in the eye of the beholder. For example, in the run-up to the First Gulf War, Jordan opted to align with Iraq. In this case, a small state may bandwagon with a regional great power because it is not considered foreboding and that such action carries an advantage to ruling elites (e.g. security, economic prosperity, political power, etc.).

Another weakness is that Walt's theory does not hold up in the post-Soviet space. When applying Walt's criteria, Russia is clearly the most threatening state to its former satellites given its location and marked advantage in terms of aggregate power and offensive military capabilities. The argument for intentions rests on four assertions. First, over the last 25 years, Russia has conducted military operations in (or against) adversarial forces in Moldova, Georgia and Ukraine. Second, Moscow has had, at different times, military bases and personnel in Armenia, Moldova, Belarus, Georgia, Ukraine, Kazakhstan, Kyrgyzstan, and Tajikistan. Next, the Kremlin has provided military and financial support to a wide array of militant proxy groups and non-state cyber actors to destabilize the ruling governments from the Baltics to Georgia to 
Ukraine to name a few. ${ }^{101}$ Finally, since 1997 Russian defense spending has continued to rise at a rate and amount that far exceeds the defense budgets of countries along its periphery. ${ }^{102}$

Clearly, the preceding points demonstrate Russia has been, and will remain, the primary military threat to former Soviet states. As such, one would expect the newly-independent states to bandwagon with Russia. The empirical reality however, is that small state bandwagoning has not consistently been the case. For example, while Armenia, Belarus and Kazakhstan opted to bandwagon with Russia by joining the CSTO, the Baltic States pursued a balancing strategy by acquiring membership in NATO. There are two takeaways here. First, any theory that attempts to explain alignment patterns must take account of material and non-material factors. Second, while the external threat is an important consideration shaping a ruling government's alignment strategy, a more comprehensive conceptualization of state threat perception is needed; one this study finds begins with examining the ideas and beliefs of the leading political figures charged with making the foreign policy decisions for the state.

\section{Balance of Interest Theory}

Randall Schweller is critical of Walt noting how a balance of threat approach assumes alignment tendencies are based exclusively on security. On the contrary, Schweller argues profit, rewards, and gains are the primary factors driving alignment decisions to bandwagon with a more powerful state. As Schweller notes, "when profit rather than security drives alliance choices, there is no reason to expect that states will be threatened or cajoled to climb aboard the

\footnotetext{
${ }^{101}$ Hill, Fiona and Pamela Jewett. 1994. "Intervention in the Internal Affairs of the Former Soviet Republics and the Implications for United States Policy Towards Russia." Harvard University, John F. Kennedy School of Government. https://www.brookings.edu/wp-content/uploads/2016/06/Back-in-the-USSR-1994.pdf. Accessed 21 February 2016.

${ }^{102}$ Sandler, Todd, and Justin George. 2016. "Military Expenditure Trends For 1960-2014 and What They Reveal." Global Policy 7 (2), 183.
} 
bandwagon; they do so willingly." ${ }^{, 103}$ In advancing his balance of interest theory, Schweller concludes balancing and bandwagoning are not opposite behaviors as Walt and Waltz assert, but opposite systemic conditions where security drives cost-sensitive states to pay the high costs to maintain the status quo by balancing against revisionist states. When the status quo is in flux, states that care little about the costs, align with a revisionist state in anticipation of sharing in the gains. At issue however, is that Schweller suffers from a great power bias as well. Schweller explicitly admits this shortfall noting how his "bandwagoning argument and... cases focused on great powers, not weak ones." 104 This weakness proves true in the post-Soviet space where Belarus has consistently bandwagoned with Russia by joining the EEU when deeper integration with the EU may have proven more worthwhile.

Despite the shortcomings of Schweller's theory, his approach has two notable strengths. First, his theory takes account of systemic (balance of power) and state-level factors (domestic costs and interstate political goal compatibility) to understand alignment patterns. It is from this multilevel analysis that Schweller is able to develop an alignment typology to understand when and why states will balance or bandwagon. Second, his theory calls our attention to how alignment decisions are shaped by other factors than the external threat. As Schweller asserts, “...the most important determinant of alignment decisions is the compatibility of political goals, not imbalances of power or threat." ${ }^{105}$ This is a critically important assertion that Schweller uses to advance a material-based theory of alignment that focuses on profit and rewards. Less developed, however, is how ideational factors may drive a state to align with a regional great

\footnotetext{
${ }^{103}$ Schweller, Randall L. 1994. "Bandwagoning for Profit: Bringing the Revisionist State Back In." International Security 19 (1), 79.

${ }^{104}$ Schweller, Randall L. 1997. "New Realist Research on Alliances: Refining, Not Refuting, Waltz's Balancing Proposition." American Political Science Review 91 (4), 928.

${ }^{105}$ Schweller 1994, 88.
} 
power for something more than material profit.

The Relevance of the Global Power Structure

Schweller's assertion that balancing and bandwagoning behaviors should be regarded as opposite systemic conditions calls our attention to the necessity to examine other conditions in the international system and how they may potentially impact state alignment. Given this study's aim to develop a more nuanced explanation of small state alignment in the post-Cold War era, it is useful to consider how the polarity of the international system may potentially affect the behavior of states. This is especially important because just as the Soviet Union ceased to exist in 1991, so did the bipolar configuration of the international system. What replaced this bipolar system now represents another point divergence among IR scholars. On one side, there are those who advance a notion that with the dissolution of the Soviet Union, the United States with its omnipotent military and unmatched economic capacity became the world's unipole.

Oppositionists to this assertion advance a contradicting position that the world is multipolar with power defused across the system. Acknowledging the U.S. possesses a marked advantage over other countries in terms of military and economic power, this group highlights how geography, globalization, the presence of other nuclear-armed countries, or domestic constraints (e.g. public opinion or political opposition) are shape agents for a multipolar world.

With these points in mind, this section takes a full accounting of the relevance of the global power structure by positing four questions: What is the concept of polarity and how has this theoretical construct evolved in the IR literature? What is the relationship between the global power structure and system (in)stability? Is a unipolar system more stable than a world defined by two or more great powers? What is the relationship between system polarity and state 
alignment? Answers to these questions serve as a foundation from which to detail some of the alignment typologies that have been developed in the last several decades.

The Evolution of Polarity as a Theoretical Construct. The concept of polarity is by no means a new topic in IR, stretching back to the bipolar system of Ancient Greece and Thucydides' accounting of the Peloponnesian War. In the Melian Dialogue, polarity, power, and the prelude to war are on full display when the small state of Melos refuses to align with Athens in its conflict with Sparta. In response, the Athenians tell their Melian interlocutors that "right, as the world goes, is only in question between equals in power, while the strong do what they can and the weak suffer what they must." 106 While the concept of polarity has been either implicitly or explicitly a part of world politics for over two thousand years, it was only after World War II did this theoretical construct emerge in the IR literature.

With the advent of the Cold War, academics, security experts, and statesmen began to characterize the international system as bipolar with the Soviet Union in one corner and the United States in the other. During this time, scholars such as Morton Kaplan, Stanley Hoffmann, and Richard Rosecrance developed a framework for analysis that would become known as a systemic approach to IR. ${ }^{107}$ Criticizing Hans Morgenthau, who saw human nature and man's malicious tendencies as the source of state behavior, these individuals argued the structure of the international system better explained political outcomes like peace and war. ${ }^{108}$ Although these

\footnotetext{
106 Strassler, Richard B., ed. 1996. The Landmark Thucydides: A Comprehensive Guide to the Peloponnesian War. New York: The Free Press, 5:89; emphasis added.

${ }^{107}$ Kaplan, Morton A. 1957. System and Process in International Politics. New York: John Wiley \& Sons, Inc.; Hoffmann, Stanley N. 1959. "International Relations: The Long Road to Theory." World Politics 11 (3); Rosecrance, Richard N. 1963. Action and Reaction in World Politics. Boston: Little, Brown and Company. ${ }^{108}$ Morgenthau, Hans J. 1946. Scientific Man vs. Power Politics. Chicago: The University of Chicago Press. Morgenthau, Hans J. 1962. The Decline of Democratic Politics. Chicago: The University of Chicago; Post, Jerrold M. 2004. Leaders and Their Followers in a Dangerous World: The Psychology of Political Behavior. Ithaca: Cornell University Press.
} 
and other early structuralists did well to highlight the impact of systemic factors on state behavior, the concept of polarity in most instances remained underspecified.

Building on Kaplan, Hoffman, and others, it was the seminal works of Waltz, who in advancing his neorealist approach to interstate politics gave increased specificity to polarity by articulating three key attributes of the international system. Through the first two attributes (ordering principle and differentiation), it becomes clear how in an anarchic, self-help system a state's number one priority is survival because there is no higher authority to ensure its safety. However, it is the differences in the distribution of capabilities among states that serves as a foundation for articulating system polarity where disparities in the material means of states establishes a pecking order that separates the strong from the weak. ${ }^{109}$

From Waltz, scholars have come to a consensus that polarity can generally be defined as "the distribution of capabilities among the major structure-producing states." ${ }^{110}$ At the center of attention here is power, particularly material (e.g. military) power, which subsequently becomes a reference point from which to determine system polarity and its impact on the behavior of states. ${ }^{111}$ Given this focus on power, structuralists focus exclusively on how the number of 'great' powers determine the polarity of the international system.

In his analysis, Waltz differentiates states between 'great' and 'secondary' powers arguing it is the former that gives a system its polarity. ${ }^{12}$ Those states at the top of the international hierarchy are seen as a 'pole' in the global arena because they meet two key criteria: possession of a large proportion of global resources and a marked advantage in terms of capabilities (e.g.

\footnotetext{
${ }^{109}$ Waltz 1979, 88-99.

${ }^{110}$ Grieco, Joseph M. 2007. "Structural Realism and the Problem of Polarity and War." In Felix Berenskoetter and M. J. Williams (eds), Power in World Politics. New York: Routledge, 65.

${ }^{111}$ For one of the most recent examinations of the concept of power in IR see David Baldwin's recent work. Baldwin, David A. 2016. Power and International Relations: A Conceptual Approach. Princeton: Princeton University Press.

112 Waltz 1979, 70-71; 981 129-138; 158.
} 
military troops and weapons, economic productivity, population, natural resources, land area, economic productivity, and political-social stability). ${ }^{113}$ For Waltz, focusing on the great powers as a determinant of system polarity is warranted because they possess the capacity to influence events in the system. Barry Buzan captures this point succinctly noting,

Great powers control most of the material resources (military capability, production capacity, wealth, technology) in the system. Because of this, their activities, and of their ideas, dominate the international system, and their interests are sufficiently wide ranging to give them a strong interest in international order. ${ }^{114}$

More recently, Stephen Brooks and William Wohlforth also define the global power structure in material terms noting that a unipole exists when the system "contains one state whose share of capabilities place it in a class by itself compared to all other states." 115 Brooks and Wohlforth are highly critical of other scholars, who attempt to view a unipole as a global hegemon or misconstrue the real meaning of what a unipole is (or is not) by developing alternative definitions. Their central point is that the concept of unipolarity is not about state influence or political outcomes, but material power and where it resides in the international system. ${ }^{116}$ By counting poles, Greece in the $5^{\text {th }}$ century BC and the decades spanning the Cold War can then be viewed as bipolar, while the late 1800s and early 1900s were multipolar. In the post-Cold War era, Brooks and Wohlforth have defined the global power structure as unipolar; however, Buzan notes that given the material capabilities of other states, the current system is best viewed as one superpower and several great powers. ${ }^{117}$

\footnotetext{
${ }^{113}$ Ibid, 131.

${ }^{114}$ Buzan, Barry. 2004. The United States and the Great Powers: World Politics in the Twenty-First Century. Cambridge: Polity Press, 32. In his examination of political events in Europe from 1848-1918, Alan Taylor also find it is "the relations [and alliances] of the great powers... [that] determined the history of Europe" not the actions of small states. Taylor, Alan John Percivale. 1954. The Struggle for Mastery in Europe, 1848-1918. Oxford University Press, xix.

${ }^{115}$ Brooks, Stephen G., and William C. Wohlforth. 2008. World Out of Balance: International Relations and the Challenge of American Primacy. Princeton University Press, 13.

${ }^{116}$ Brooks, Stephen G., and William C. Wohlforth. 2011. "Assessing the Balance." Cambridge Review of International Affairs 24 (2), 202.

${ }^{117}$ Buzan 2004, 65.
} 
But what makes a great power different from a superpower or a middle power from a small

power? The answer to this question resides at the center of another scholarly disagreement over how to define, operationalize, and measure power. In 1950, Robert Bierstedt did well to characterize this challenge noting that...

Few problems in political science are more perplexing than the problem of power... yet, despite widespread use, power remains a slippery and problematic concept. There is little agreement upon basic definitions, individual theorists proposing their own more or less idiosyncratic terminology, and surprisingly little consideration of the implications of alternative usages. ${ }^{118}$

Since then, there has been little to no scholarly progress on how best to define power and measure it in a definitive and widely accepted way that allows for the accumulation of knowledge on a wide array of puzzles. As Wohlforth notes...

The problem for anyone who wishes to dismiss the importance of power is that the evidence consistently indicates that statesmen attach immense importance to it. The problem for anyone who wishes to establish the importance of power is that the concept is ambiguous enough to support seemingly contradictory generalizations. Statesmen can perceive equilibrium and hegemony simultaneously. ${ }^{119}$

Realists frequently focus on material matters from which to evaluate power between states in the international system. For example, Waltz, in advancing his parsimonious approach to power balancing, focuses on the distribution of capabilities (military strength, economic capability, resource endowment, etc.) to derive a ranking of states. ${ }^{120}$ As Brian Schmidt notes,

[Waltz's] commitment to parsimony necessitates he define power in terms of resources and, furthermore, that he assumes these resources are highly fungible. Waltz is most interested in providing a rank ordering of states so that he can ascertain the number of great powers in any given international system." 121

\footnotetext{
118 Bierstedt, Robert. 1950. “An Analysis of Social Power.” American Sociological Review 15 (6), 3.

${ }^{119}$ Wohlforth William C. 1993. The Elusive Balance: Power and Perceptions During the Cold War. New York: Cornell University Press, 138.

${ }^{120}$ Waltz 1979, 131. See also Copeland, Eale C. 2000. Origins of Major War. Ithaca: Cornell University Press and Mearsheimer, John J. 2014. The Tragedy of Great Power Politics. New York and London: W. W. Norton \& Company.

${ }^{121}$ Schmidt, Brian C, 2005. "Competing Realist Conceptions of Power." Millennium: Journal of International Studies 33 (3), 537.
} 
While realists may agree on the necessity to fixate on material capabilities, they disagree over which elements are the most important. ${ }^{122}$ For example, John Mearsheimer views power as "a reasonable prospect of defending itself against the leading state in the system by its own efforts." 123 If one follows Mearsheimer's view of power, then a second problem arises for balance of power theory where there may exist multiple great powers with similar power capabilities. For example, countries with nuclear weapons would then be categorized in the same power band. If this were true, then discerning state alignment based on the balance of power thesis becomes an extremely difficult endeavor because less powerful states now have a variety of options to choose from.

Separately, other scholars argue that economic or ideational factors determine power relations. For example, Stephen Krasner and Robert Keohane note that although the United States is the only remaining superpower, its position in the system is almost exclusively based on its military prowess. On the economic and technological planes, the U.S. has perhaps lost ground to Germany, Japan, and China to name a few in the post-Cold War era. ${ }^{124}$ Separately, Richard Rosecrance fixates on ideational considerations arguing that the international system from 18221848 and from 1918-1945 were comprised of two power blocs based on divisions between liberalism and conservatism and between fascism and democracy respectively. Rosecrance then

\footnotetext{
122 Schweller, Randall L. 1999. "Realism and the Present Great Power System: Growth and Positional Conflict Over Scarce Resources.” In Kapstein, Ethan B. and Michael Mastanduno (eds.) Unipolar Politics: Realism and State Strategies after the Cold War. Columbia University Press, 45.

${ }^{123}$ Mearsheimer, John J. 1990. "Back to the Future: Instability in Europe After the Cold War." International Security 15(1), 7.

${ }^{124}$ See Krasner, Stephen D. 1993. "Power, Polarity, and the Challenge of Disintegration." In Helga Haftendorn and Christian Tuschhoff (eds.) America and Europe in an Era of Change. Boulder, CO: Westview Press; Keohane, Robert O. 1993. "The Diplomacy of Structural Change: Multilateral Institutions and State Strategies." In Helga Haftendorn and Christian Tuschhoff (eds.) America and Europe in an Era of Change. Boulder, CO: Westview Press. See also Russett, Bruce M. 1965. Trends in World Politics. New York: Macmillan and Organski, A. F. K. and Jacek Kugler. 1980. The War Ledger. Chicago: The University of Chicago Press.
} 
notes that during the period 1945-1960, there were three power blocs owing to the struggle between the democracy, communism, and those states seeking a neutral course. ${ }^{125}$

The preceding paragraphs allow one to infer that the conceptualization of power frequently depends upon the specific theoretical context in which it is utilized, where usefulness is evaluated based on how well it "accomplishes the task the theorists set for themselves." ${ }^{126}$ If scholars are defining power in different ways, then the way they differentiate a great power from a major power or a middle power becomes extremely difficult. Buzan captures the challenges of analytical assessments based on system polarity:

Like most other attempts to turn IR into a hard science, polarity theory largely failed to fulfill the ambitions of those who tried to correlate it formally with war, peace, and system stability. The longstanding inability to quantify power in its international relations sense was one obstacle. Without such a measure, how can one reliably identify which states are, and which are not great powers? If the classification of great power is indeterminate, then so is the specification of polarity and the ability to know when or if polarity is undergoing change. ${ }^{127}$

System Polarity and State Behavior. Structuralists posit that the relational dynamics between state actors will vary based on the number of great powers in the system at any particular time. ${ }^{128}$ According to John Ikenberry, Michael Mastanduno, and William C. Wohlforth, the polarity of the international system "...structures the horizon of states' probable actions and reactions, narrowing the range of choice and providing subtle incentives and disincentives for certain types of behavior." 129 If this is indeed the case, then understanding how state behavior varies under different configurations of the global power structure may help us to understand why small states align with one regional great power over another.

\footnotetext{
125 Rosecrance 1963, 79-101, 169-215.

${ }^{126}$ Haugaard, Mark. 2010. “Power: A 'Family Resemblance' Concept.” European Journal of Cultural Studies 13 (4), 426.

${ }^{127}$ Buzan 2004, 41.

${ }^{128}$ See Russett, Bruce and Harvey Starr. 2010. World Politics: The Menu for Choice 9th edition. Boston: Cengage Learning, 88.

${ }^{129}$ Ikenberry, G. John, Michael Mastanduno, and William C. Wohlforth. 2009. "Unipolarity, State Behavior, and Systemic Consequences." World Politics 61 (1), 5.
} 
When examining the stability of a multipolar or bipolar system, Waltz, Mearsheimer, and other structuralists find the latter tends to exhibit lower levels of conflict and are more stable than a world with multiple great powers. ${ }^{130}$ Mearsheimer offers a particularly poignant summary on this argument. First, in a multipolar system, there are numerous conflict dyads that create more opportunities for war. Second, power imbalances are more common in a multipolar world thereby making conventional deterrence problematic. Third, there is a higher potential for strategic miscalculation since one state may think it has the capacity to win a war when it actually does not. Alternatively, bipolar systems are more stable for three reasons. First, there are relatively few opportunities for conflict given the fewer number of major power dyads. Second, there is more likely an equal distribution of power. Third, bipolarity discourages strategic miscalculation. While fear is constant, bipolarity does not magnify those fears. ${ }^{131}$

Contradicting these assertions and accompanying rationale, Karl Deutsch, Richard Singer, and Edward Mansfield find that a multipolar system exhibits higher levels of stability. ${ }^{132}$ The logic here is that as the number of great power dyads rise, there is an increased probability for the formation of a larger number of coalitions against any aggressive state(s), thus serving as a deterrent to belligerent behavior. Under a bipolar system, great power allies were usually too weak to play any meaningful balancing role vis-à-vis aggressive, more powerful states. Recalling Richard Grieco, this point seems valid in that as the number of great powers increase, so does the possibility for cooperation. In his words...

\footnotetext{
${ }^{130}$ See also Levy, Jack S. 1985. "The Polarity of the System and International Stability: An Empirical Analysis." In Alan Ned Sabrosky (ed.) Polarity and War: The Changing Structure of International Conflict. Boulder \& London: Westview Press; Morton, Jeffrey S. and Harvey Star. 2001. "Uncertainty, Change, and War: Power Fluctuations and War in the Modern Elite Power System." Journal of Peace Research 38 (1).

${ }^{131}$ Mearsheimer 2014, 278-279; 285.

${ }^{132}$ Morgenthau, Hans J. 1967. Politics Among Nations. 4 ed. New York: Knopf; Deutsch, Karl. W. and J. David Singer. 1964. "Multipolar Power Systems and International Stability." World Politics 16 (3); Mansfield, Edward D. 1988. "The Distribution of Wars Over Time." World Politics 41 (1); and Gulick, Edward V. 1955. Europe's Classical Balance of Power. Ithaca, NY: Cornell University Press.
} 
A state may believe that it might do better than some partners in a proposed arrangement but not as well as others. If it is uncertain about which partners would do relatively better, the state will prefer more partners, for larger numbers would enhance the likelihood that the relative achievements of gains advantaging (what turn out to be) better-positioned partners could be offset by more favorable sharings arising from interactions with (as matters develop) weaker partners. ${ }^{133}$

Additionally, given the prospect for increased cooperation among the great powers, in multipolar systems these states are linked together via multiple channels of interaction along military, cultural, or economic lines, which subsequently creates cross-cutting cleavages that can stave off crises that could lead to armed conflict. In a bipolar system, the number of links are limited and when an issue becomes polarizing (e.g. Soviet placement of nuclear missiles in Cuba) there is an increased potential for a disagreement to escalate into a crisis. ${ }^{134}$

If scholars and practitioners are at odds over the stability of the international system under conditions of bipolarity or multipolarity, then the demise of the Soviet Union and the emergence of the U.S. as a purported 'unipole' became a harbinger for system stability in the post-Cold War era. Neorealists posited the system would experience high levels of instability because the concentration of power in one state would represent a clear and present danger to all states leading them to pursue various actions designed to reestablish an equitable balance of power. ${ }^{135}$ Writing in 2000, Waltz noted,

Throughout the Cold War, what the United States and the Soviet Union did, and how they interacted, were dominant factors in international politics. The two countries, however, constrained each other. Now the United States is alone in the world. As nature abhors a vacuum, so international politics abhors unbalanced power. ${ }^{136}$

From Waltz and other neorealists, there emerged a consensus that unipolarity was a

\footnotetext{
${ }^{133}$ Grieco, Joseph M. 1988. "Anarchy and the Limits of Cooperation: A Realist Critique of the Newest Liberal Institutionalism.” International Organization 42 (3), 506; emphasis added.

${ }^{134}$ Levy and Thompson 2005, 33.

${ }^{135}$ Layne, Christopher. 1993. "The Unipolar Illusion: Why New Great Powers Will Rise.” International Security 17 (4); Mastanduno, Michael. 1997. "Preserving the Unipolar Moment: Realist Theories and U.S. Grand Strategy after the Cold War." International Security 21 (4); Waltz, Kenneth N. 1997. "Evaluating Theories." American Political Science Review 91 (4).

${ }^{136}$ Waltz, Kenneth N. 2000. "Structural Realism After the Cold War.” International Security 25 (1), 28.
} 
destabilizing condition, which would make the system fundamentally more volatile, uncertain, complex, and ambiguous. Although there have been no great power wars over the last 25 years, a U.S. decision to initiate a preventative war against Iraq in 2003, coupled with an unwillingness to ratify the United Nations Convention on the Law of the Sea, its renunciation of the 1972 AntiBallistic Missile Treaty, and most recently Washington's withdrawal from the Paris Climate Agreement serve as just a few points of light that illuminate how the unrestrained actions of a purported unipolar power may serve as a catalyst for regional or global instability. Such actions moved Russian President Vladimir Putin in 2007 to sound the alarm over the relationship between U.S. actions and system instability stating, "unilateral and frequently illegitimate actions [by the United States] have not resolved any problems. Moreover, they have caused new human tragedies and created new centres of tension." 137 Beyond the actions of the U.S., scholars have also pointed to the rise of China and a resurgent Russia along with two major wars in the Middle East, civil wars in southeastern Europe and Africa, and a host of unconventional (e.g. counterterrorism and/or counter-insurgency) operations as key indicators of system instability in the post-Cold War era.

The uneasiness exhibited by political leaders in other developed countries over U.S. unilateralism and their concerns about the negative impacts of unipolarity on system stability set in motion diplomatic calls for the establishment of a multipolar world order beginning as early as the mid 1990s. For example, in 1995 as NATO’s eastward expansion was beginning, Russian Foreign Minister Andrei Kozyrev stated, "Russia is a great power, and it is my conviction that its

\footnotetext{
${ }^{137}$ Putin, Vladimir. 2007. "Putin's Prepared Remarks at 43rd Munich Conference on Security Policy." The Washington Post, 12 February 2007. http://www.washingtonpost.com/wp-dyn/content/article/2007/02/ 12/AR2007021200555.html. Accessed 15 April 2016, 1; emphasis added.
} 
position in the world now is more stable and dignified than that of the former Soviet Union." 138

Following Russia, in 1999 French Foreign Minister Hubert Vedrine stated, "we cannot accept a world that is politically unipolar or culturally uniform. Nor can we accept the unilateralism of the single hyperpower. That is why we are fighting for a multipolar, diversified and multilateral world." 139 By 2001, spurred on by the continuing efforts of the United States to develop a national missile defense system, China and Russia signed a friendship treaty. Viewing U.S. unilateral actions as a threat to global stability, Chinese President Jiang Zemin stated,

We believe that more active cooperation between our countries [China and Russia] in discussing missile defenses and disarmament will enhance our efforts in building a multipolar world and establish a fair, rational [stable] international order. ${ }^{140}$

While these comments and actions have not put the major powers on a war footing with the United States, they are reflective of an international system characterized by regional great power competition in a system that exhibits various levels of instability.

In contrast to those taking a pessimistic view on the impact of unipolarity on system stability, others view this systemic condition positively arguing U.S. global dominance is a stabilizing factor in world affairs. In this case, the generally peaceful nature of the international system, as defined by the absence of great power wars, can be attributed to U.S. efforts to build or sustain mutually beneficial international institutions and organizations, America's benevolent nature or Washington's general proclivity to employ armed forced in a limited, non-threatening manner. ${ }^{141}$

\footnotetext{
${ }^{138}$ Kozyrev, Andrei. 1995. Cited in Valentina Starova, “Kozyrev: Russia Remains 'Great Power.”' UPI, 27 February 1995. http://www.upi.com/Archives/1995/02/27/Kozyrev-Russia-remains-Great-Power/1490793861200/. Accessed 02 November 2016.

139 Verdine, Hubert. 1999. Cited in Layne, Christopher. "What's Built Up Must Come Down.” Washington Post, 04 November 1999. http://www.washingtonpost.com/wp-srv/WPcap/1999-11/14/017r-111499-idx.html. Accessed 17 April 2016.

140 Zemin, Jiang. 2001. "Russia and China Sign 'Friendship' Pact.” New York Times, 17 July 2001. http://www. nytimes.com/2001/07/17/world/russia-and-china-sign-friendship-pact.html?pagewanted=all. Accessed 30 April 2016.

${ }^{141}$ For international and institutions see Ikenberry, G. John. 1998. "Institutions, Strategic Restraint, and the Persistence of American Postwar Order.” International Security 23 (3). For U.S. benevolence see Lemke, Douglas. 2004. "Great Powers in the Post-Cold War World: A Power Transition Perspective." In Balance of Power: Theory
} 
These empirical realities allow Wohlforth to conclude that a unipolar system is more stable than a bipolar or multipolar configuration because, "the leading state's power advantage removes the problem of hegemonic rivalry from world politics, and it reduces the salience and stakes of balance-of-power politics among the major states." ${ }^{142}$

The preceding discussion points to two key takeaways. First, there is no scholarly consensus on the relationship between system polarity and system stability. For every argument that a unipolar, bipolar, or multipolar system is more stable than the other, there exists a corresponding valid counterargument. For example, over a thousand years ago Thucydides argued Sparta's fear about Greece's growing military and political power and the uncertainty of its impacts to the stability of the bipolar system became the primary causes of war. According to Thucydides, "the growth of the power of Athens, and the alarm which this inspired in Sparta, made war inevitable." ${ }^{143}$ Fast forward to the multipolar world of the early $20^{\text {th }}$ century, the current balance of power was not enough to prevent war as it had done in the first and second Balkan Wars. ${ }^{144}$ Again, uncertainty created fear and when states are faced with a threat of physical destruction, they resort to war, which was the case in August 1914 with the outbreak of a great power war. Taken together, state actions in response to uncertainty can potentially be seen as an intervening

and Practice in the 21st Century, T. V. Paul, James J. Wirtz, and Michel Fortmann (eds). Stanford University Press and Schweller, Randall L., and David Priess. 1997. "A Tale of Two Realisms: Expanding the Institutions Debate." Mershon International Studies Review 41 (1). For the limited use of U.S. armed force see Walt, Stephen M. 2005. Taming American Power: The Global Response to U.S. Primacy. New York: W. W. Norton.

142 Wohlforth, William C. 1999. "The Stability of a Unipolar World." International Security 24 (1), 23.

${ }^{143}$ Strassler 1996, 1.23; emphasis added.

${ }^{144}$ On the efforts of the Great Powers to contain the crises in the Balkans, see Donald Kagan's On the Origins of War and the Preservation of the Peace (New York: Doubleday, 1995, 178-183). During the First and Second Balkan Wars (1912-1913), France, Germany, Great Britain, Russia, and Austria-Hungary were generally successful in restraining the actions of the primary belligerents (Serbia, Bulgaria, Greece, Montenegro, and Turkey) out of fear that these crises might spiral into a Great Power conflict. Despite diverging national interests, France, Germany, Great Britain, Russia, and Austria-Hungary gave precedence to diplomacy and political discourse as a way to contain both wars. 
variable between polarity and the stability of system. ${ }^{145}$

This leads to a second important takeaway where if fear and uncertainty are key drivers of state action, then the primary point of departure for understanding political outcomes must begin at the individual-level of analysis. In this case, taking account of the ideas, beliefs, and perceptions of ruling political elites can help us to understand their strategic calculations as they relate to war, peace, and for this study... alignment. This does not mean that systemic- and statelevel factors are not important. Rather they are secondary. Recalling Levy and Thompson, “a theoretically complete explanation of polarity and stability thus requires the incorporation of responses to uncertainty, which derives from the individual or possibly state level of analysis."146 As will be discussed in the next chapter, Levy and Thompson's sage insight become one of the many points of light guiding this study's theoretical model that focuses on the ideas and beliefs of political leaders and domestic politics.

System Polarity and State Alignment. The preceding discussion serves as a foundation from which to examine the scholarly assertions of how the global power structure may potentially shape the alignment tendencies of states under different system configurations. In line with the conclusions noted above, there is again no clear and unambiguous causal relationship between changes in the polarity of the international system and the alignment tendencies of states. Two points support this assertion.

First, like other efforts to develop a causal relationship between system polarity and various political outcomes, there is a high degree of ambiguity on the relationship between the global power structure and state alignment. One point of ambiguity centers on exactly when states will

\footnotetext{
${ }^{145}$ Bueno de Mesquita, Bruce. 2003. "Neorealism's Logic and Evidence: When Is a Theory Falsified?" In John A. Vasquez and Colin Elman (eds.), Realism and the Balancing of Power: A New Debate. Saddle River, NJ: Prentice Hall.

${ }^{146}$ Levy and Thompson 2010, 210; emphasis added.
} 
opt to pursue an external or internal balancing strategy. For example, Kenneth Waltz, Michael Barnett, Jack Levy, and William Thompson assert external balancing occurs more frequently in multipolar systems because the pooling of resources is a more effective cost option than independently allocating large sums of monies for a wide array of defense programs. Separately, internal balancing occurs more frequently in bipolar systems because there are no other great powers to align with via formal or informal treaties or agreements. ${ }^{147}$ However, there is little 'hard' empirical evidence to support the preceding assertions as both types of balancing can occur together in a complementary fashion. This was the case prior to the outbreak of the First World War when the major powers pursued internal and external balancing by engaging in an arms race (e.g. the naval arms race between Germany and Great Britain) and creating two alliances. Separately, during the Cold War the United States and the Soviet Union internally and externally balanced against each other by allocating billions of dollars to build-up their respective militaries and by creating NATO and the WARSAW Pact.

A second point of ambiguity focuses on the process by which states align themselves under different systemic configurations. Defensive realists tend to view alliances as an intervening variable between polarity and the overall stability of the system. When the system is bipolar, alignment activities do not create system-wide shocks leading to conflict because the two most powerful states can still act unilaterally to realize their long-term strategic objectives owing to their superior material capabilities or access to resources. As such, the interest of allies and their impact on the strategic calculus of the great powers is of little to no importance. In multi-polar systems, alliance formation has the potential to create high levels of instability. In this case, given the difficulty of acquiring timely and relevant intelligence on the activities of other states

\footnotetext{
${ }^{147}$ Barnett and Levy. 1991, 14; Levy, Jack S. and William R. Thompson. 2010. "Balancing at Sea: Do States Ally
} Against the Leading Global Power?” International Security 35 (1), 14; Waltz 1979. 
and the potential for like-minded great powers to band together in opposition to an aggressive pole, multi-polar systems are considered to be more conflict prone. ${ }^{148}$

Summary. The preceding discussion on system polarity yields several key insights. First, although there is a scholarly disagreement over the extent to which the global power structure may play a key role affecting a state's foreign policy behavior, the literature on polarity is a strong reminder for scholars to consider the state's material power capabilities. Specifically, material power should be viewed as an enabler of state action. For instance, U.S. power capabilities allow Washington to act across multiple fronts (e.g. diplomatic, military, information, economic) at an intensity level that exceeds other states. Despite this reality, other regional great powers can and will act on par with the United States and that these actions and the accompanying second- and third-order effects are what matters most; not whether the system is unipolar, bipolar, or multi-polar. For example, the actions of one of the many nuclear-armed countries in the world will certainly elicit a response from all states, regardless of their position in the international system. North Korea's nuclear weapons and ballistic missile tests in late 2017 and early 2018 are an excellent example of this strategic reality.

Second, although material considerations matter, focusing exclusively on the materialisticbased elements of system polarity is problematic because this concept fails to take a full accounting of how non-material factors may affect the behavior of states. For example, even though the United States possesses the most powerful military and largest economy in the world, this power is held in check by long-standing domestic institutions and political leader beliefs on its application in international affairs. According to Barry Buzan,

Polarity is essentially a material view of the system, resting on the relative accumulations of capability. Such an approach discounts the whole social side of life. It assumes that the actors in the system are at best rivals, at worst enemies, and never friends. It assumes that the drive for

${ }^{148}$ Waltz 1979, 163-171. 
power to preserve security always trumps other, more potentially collaborative motives, such as desire to increase wealth, welfare, and knowledge. Analyzing international relations in terms of power politics risks increasing the possibility that actors will behave in that way. ${ }^{149}$

Finally, due consideration should be given to how similarly placed states behave in the international system. Theories that attempt to explain the alignment patterns of a unipole or group of regional great powers may not adequately explain the behavior of small states. In his examination of how systemic conditions impact state behavior, Michael Mandelbaum concludes,

Similar security policies recur throughout history and across the international system in states that, whatever their differences, occupy similar positions in the system... The security policies of very strong states are different from those of very weak ones, and both differ from those of states that are neither very strong nor very weak. ${ }^{150}$

With respect to small state alignment, Levy provides additional emphasis to this point noting how small states can at best only generate minimal impacts on the system and because their actions are tied to the near-term, "they will sometimes balance and sometimes bandwagon, depending on the context." ${ }^{151}$ Levy's point on context is important; however, what is more important is how different political leaders view the strategic environment in which they reside.

\section{State-Level Theories}

A second group of scholars argue that domestic-level variables can markedly improve our understanding of small state alignment. The leading theorists at this level argue internal threats to the ruling government, institutions that make up the state's apparatus, and identity best explain why a small state may align with one regional great power over another. In many cases, these research efforts have also integrated system-level variables to garner increased clarity on a small state's alignment tendencies. Although these efforts represent a marked improvement over a

\footnotetext{
149 Buzan 2004, 42; emphasis added.

${ }^{150}$ Mandelbaum, Michael. 1988. The Fate of Nations: The Search for National Security in the Nineteenth and Twentieth Centuries. Cambridge: Cambridge University Press, 4 and 2.

${ }^{151}$ Levy 2004, 38.
} 
purely systemic explanation, on their own they too suffer from a unique set of shortcomings

leading to a new set of anomalies.

Internal Threats.

Building on Walt's balance of threat theory, some scholars posit that while the aggressive intentions of states are an important consideration shaping a small state's alignment with a regional great power, one must also consider domestic internal threats to the ruling government. In general, internal threats to the state include, but are not limited to insurgencies, separatist movements, domestic political opposition, or social unrest stemming from ethnic or religious divisions. Beginning with Stephen David, he argues small states will 'omnibalance' because they must account for internal threats and external threats in deciding the state's alignment with one regional great power over another. Specifically, David asserts that political leaders are more apt to appease a less threatening great power in order to concentrate on more threatening domestic challenges to their rule. ${ }^{152}$ In David's words,

Third World leaders, too, seek to appease secondary threats in order to counter those that are more pressing. But in the Third World, this often means appeasing other states (which often pose less pressing threats) to counter the more immediate and dangerous domestic threats. They seek to split the alignment against them and focus their energies on their most dangerous (domestic) opponents. To do this they appease the international allies of their domestic opponents. ${ }^{153}$

One of the central propositions of David's omnibalancing theory is that systemic-based theories (e.g. balance of power or threat) of state alignment only get us so far. In this case, the strategic decisions made by political leaders are the cornerstone for alignment outcomes. However, systemic and domestic-level variables are also a part of the strategic calculus leading foreign policy elites to align the state with one regional great power over another. David subsequently applies his theory to Ethiopia. Facing a rebellion in 1974, ruling leaders in Addis

\footnotetext{
${ }^{152}$ David 1991, 235-238.

${ }^{153}$ Ibid, 236.
} 
Ababa changed the state's alignment from Washington to Moscow because the Kremlin was prepared to provide more military assistance to help the ruling government more effectively deal with this internal threat. Similarly, David argues Egypt's volte-face from the Soviet Union to the U.S. after the 1973 war with Israel was the result of government opposition and public displeasure over the stalemate with Tel Aviv on the occupied territories. By aligning with the United States, Egyptian President Anwar Sadat sought to balance against this internal opposition by pressing Washington to advance a peace deal with Tel Aviv. In the end, political leaders in small states are more apt to align with regional great powers that will help them remain in power. ${ }^{154}$

There are several positive and negative takeaways from David's omnibalancing theory worth emphasizing. First, David garners increased analytical leverage to explain small state alignment outcomes by focusing the primary unit analysis at the individual-level. For David, once must first understand political leaders ultimately make the foreign policy choices of the state. Second, any attempt to understand why one small state aligns with one regional great power over another must also incorporate systemic and domestic-level variables. Events or conditions at each of these levels ultimately shape the strategic decision-making of ruling elites. Finally, given their materially weak condition, small states are more apt to bandwagon with a regional great power in order to achieve a particular strategic goal because they have the necessary resources.

Despite these notable strengths, David's theory suffers from two shortcomings. One of the primary weaknesses of David's theory is that he assumes internal and external threats are omnipresent. That is, because small states lack material power to defend themselves from external attack or because ruling leaders lack political legitimacy, they must continuously deal

${ }^{154}$ Ibid, 245-251. 
with both internal and external threats. Applying the omnibalancing thesis to the post-Soviet space does little to explain why the Baltic States, which experienced low or no internal threats decided to pursue a pro-West course that resulted in their accession in NATO. Beyond the Baltics, if one follows David's argument on Ethiopia with the Soviet Union's provision of military assistance, what explains Ukraine and Georgia's alignment with the U.S. under Petro Poroshenko and Mikheil Saakashvili respectively even when Washington refused to provide adequate levels of military assistance to resolve each country's separatist problems?

Meanwhile, other scholars have sought to explain alignment by integrating economic and threat considerations into the equation of small state alignment as was the case with Barnett and Levy in their examination of the alignment tendencies of countries in the Middle East. For both scholars, a combination of external threats, the condition of the country's economy, and domestic threats to the ruling government explain the alignment tendencies of small states. Focusing their analysis on Egypt's alignment with the Soviet Union from 1962-1973, Barnett and Levy find that Cairo tended to eschew a strong alignment with the Soviet Union when the following three conditions were present: a weak economy, low presidential threat perceptions (e.g. no attack from Israel), and the absence of domestic challenges to Sadat's rule. As Sadat's threat perceptions increased, the economy grew worse, and the number of domestic challenges multiplied, Cairo subsequently attempted to strengthen its alignment with Moscow. ${ }^{155}$

In the post-Soviet space, Eric Miller argues that when domestic threats and economic dependence are high, political elites tend to establish strong pro-Russian policies and strategies. To test his theory, Miller focuses his examination on Ukraine and Uzbekistan finding that these variables (internal threat and economic dependence with Russia) explain why each ruling

155 Barnett and Levy 1991, 393-395 
government at different times opted to pursue a strong pro-Russian, a moderately pro-Russian or an independent alignment trajectory. Furthermore, even when internal threats are low and economic dependence is high, political elites, while devoting less emphasis to establishing strong relations with Russia, will still bandwagon because "anti-Russian foreign policies would hamper access to the hegemon's market and its energy resources." 156

Miller's study contains several substantial positives and negatives. In terms of positives, the strength of Miller's theory centers on his ability to incorporate unit- and system-level variables in his analysis with each on their own not fully explaining why Kiev and Tashkent would align with their former imperial center. Another positive from Miller's study is how he assesses the change in the state's alignment over a long period of time (1994-2004). Finally, Miller's assertion on political elite aversion to crafting anti-Russian policies highlights the possibility that while one state may attempt to align with one regional great power, cooperation with other great powers continues. This conclusion is significant and can serve as a point of departure for a small state's alignment with more than one regional great power.

With respect to negatives, Miller's operationalization of alignment is too ambiguous because it is unclear where the dividing line is between a pro- or moderately-aligned former Soviet state. This is partly the result from a problem with measurement. According to Andrei Tsygankov, Miller “... is also not always rigorous in following his own coding of alignments, including attitudes toward the Russia-controlled CIS, Russia's military presence, and strength of bilateral security ties with Russia." ${ }^{157}$ A second negative is how Miller limits his cases to only two countries making it unlikely his theory will convey equally across all former Soviet states. For

\footnotetext{
${ }^{156}$ Miller, Eric A. 2006. To Balance or Not to Balance: Alignment Theory and Commonwealth of Independent States. Ashgate Publishing Limited, 31-32.

${ }^{157}$ Tsygankov, Andrei. 2007. Review of To Balance or Not to Balance: Alignment Theory and the Commonwealth of Independent States by Eric A. Miller. Slavic Review 66 (2), 340-341.
} 
example, it is questionable if Miller's theory would hold water in Georgia where despite a large internal threat from the separatist provinces and the country's economic reliance on Russia, one can argue Georgia under President Mikheil Saakashvili pursued a strong pro-West alignment.

\section{Institutions.}

In line with David's focus on internal threats as a primary driver for small state alignment, Deborah Larson and Miriam Fendius Elman takes a similar track arguing the institutional makeup of the state apparatus best explains small state alignment outcomes. Of particular relevance for Larson is how domestic opposition may act as a constraint affecting the strategic decisionmaking process of foreign policy elites to align with one regional great power over another. For Larson, the source of this conflict emanates from diverging conceptions of national identity between the state and society owing to ethnic, religious, or other cultural differences. According to Larson, "when domestic institutions are incongruent with the national identity, individuals do not identify with the state, but with their ethnic group, class, or political party." ${ }^{158}$ When this occurs, societal elements use their networks to engage regional great powers with the hopes of garnering support for their cause. If these opposition elements are successful, the state, fearing subversion, yields some concessions to the group by pursing a bandwagoning strategy with the targeted state in the hopes of checking the internal threat. According to Larson,

...political leaders' diplomatic strategies are constrained by their need to remain in office. Domestic structures vary, however, in their propensity to select and reward elites who will place the state's interests above those of class, ethnic group, or religion. It follows, then, that states that have similar capabilities may react differently to outside threats or opportunities for expansion. Elites bandwagon not to protect their state's territorial integrity or to enhance its power, but to preserve their rule. ${ }^{159}$

\footnotetext{
${ }^{158}$ Larson 1991, 88-89.

${ }^{159}$ Ibid, 87; emphasis added.
} 
Larson stresses the validity of her theory by pointing to the strategic situation in Central Europe in the decades between World Wars I and II. Here, the establishment of artificial borders by the Allied powers created a disparity in the location of wide array of different ethnic and religious groups in Czechoslovakia, Bulgaria, Macedonia, and Yugoslavia. Many of the groups in each of these countries held a perspective on the nation's identity that differed markedly from the state's vision. When the ruling government implemented policies that did not advance their best interests, these groups sought external support from like-minded regional great powers such as Nazi Germany or fascist Italy. This led ruling elites in countries like Czechoslovakia to appease Germany by signing a non-aggression treaty in return for Berlin's commitment not to foment political instability in the country. ${ }^{160}$

In a similar vein, Elman finds that domestic institutions constrain or enable political elite decisions on cooperation or confrontation with more powerful states. Viewing the U.S. as a small state in the early 1800s, she concludes, "US foreign-policy making prior to the Quasi War, the War of 1812 and the Mexican-American War reveals that pre-established domestic institutions affected both the timing and substance of subsequent U.S. military strategy." "161 This is an important finding because whether political leaders in one administration maintain or change the state's institutions, future political leaders must operate within this domestic-political context giving light to how domestic politics could become an important foreign policy shape agent.

Larson and Elman's work carry several strengths and shortfalls. A notable strength of Elman's work is her extended time horizon looking at several presidential administrations and a consideration of a political leader's perceptions of the external threat. As a result, one can better

\footnotetext{
${ }^{160}$ Ibid, 90.

${ }^{161}$ Elman, Miriam Fendius. 1995. "The Foreign Policies of Small States: Challenging Neorealism in its Own Backyard,” British Journal of Political Science 25 (2), 212.
} 
understand the underlying domestic factors affecting the strategic calculus of foreign policy elites over time. Larson's study is also useful because it calls our attention to the importance of considering identity and its impact on the institutional make-up of a state's bureaucratic apparatus with respect to alignment outcomes. A key takeaway in this case is that there exists a finite set of political leaders within a ruling government that have the power and influence to articulate their narrow conception of the state's identity vis-à-vis other states in the international system. Finally, Elman's work reminds us of the value from a multi-level analysis. In her words,

Any generalized claim for the causal priority of international or domestic explanations of small state behavior is unwarranted. Both levels of analysis matter because while the international environment influences domestic political choices, these institutional decisions shape foreign policies in later periods. ${ }^{162}$

A major shortfall in Larson's work is that she fails to articulate the alignment activities of a small state with other regional great powers. The problem here is how Larson narrowly focuses her analysis on the reactive efforts of the state to appease external states based on pressures from domestic groups with different conceptions of the national identity. What she does not consider is how the ruling governments in central Europe may have attempted to align with other regional great powers based on a similar state identity. Furthermore, not answered is to what extent did other domestic and systemic-level factors enable or constrain the alignment activities of foreign policy elites. One could argue domestic politics was also a key factor driving Czechoslovakia's appeasement strategy with Nazi Germany given the existence of opposition figures within the ruling government who were sympathetic to the cause of domestic groups that were themselves seeking external assistance from Berlin.

Further eroding the strength of her argument, Larson does not adequately define the concepts of state and national identity. Although both forms of identity overlap to some extent, state

${ }^{162}$ Elman 1995, 217; emphasis added. 
identity is best understood as a social construction in the context of inter-state relations while national identity is best described at a societal level and the extent to which individuals may exhibit a shared sense of history, language, culture, etc. Masahiro Matsumura offers a clear explanation of both of these concepts noting how state identity,

... is the state's perception of what role it should play and what status it should enjoy in international relations...[while] national identity... implies a sense of unity among a population that shares common historical experiences, ethnic backgrounds, cultural heritages, languages, creedal commitments and/or other characteristics. Certainly, national identity may be closely related to state identity, due to the former's implications for the latter. Yet the two concepts are distinct. $^{163}$

The implication here is that by viewing state and national identity as one in the same potentially skews Larson's findings on why some small states may bandwagon with a regional great power.

In the post-Soviet space, Larson's theory fails to hold water. In Ukraine, the presence of a large Russian population in the eastern provinces and its generally weak institutions have not forced Kiev to cede to Moscow's preferences for Ukraine to join the CSTO or the EEU. In Georgia, the separatist movements in South Ossetia and Abkhazia, while garnering Russian support and armed intervention, have also not been enough for Tbilisi to acquiesce to Moscow's demands, despite the state's spotty record on human rights, less than transparent elections, and history of government corruption.

Identity.

In recent years, scholars have attempted to understand foreign policy outcomes by viewing world politics through a constructivist lens. Peering deep inside the 'black box,' it is the ideas, ${ }^{164}$

\footnotetext{
${ }^{163}$ Matsumura 2008, 4.

${ }^{164}$ Goldstein, Judith, and Robert Owen Keohane, eds. 1993. Ideas and Foreign Policy: Beliefs, Institutions, and Political Change. Cornell University Press; Tannenwald, Nina. 2005. "Ideas and Explanation: Advancing the Theoretical Agenda." Journal of Cold War Studies 7 (2); Yee, Albert. 1996. "The Causal Effect of Ideas on Policies." International Organization 50 (1).
} 
ideological beliefs, ${ }^{165}$ perceptions, ${ }^{166}$ and images, ${ }^{167}$ held by political leaders that do the heavy lifting in shaping the strategic interactions between states. Although each of these approaches may provide increased leverage to understand state foreign policies, only a narrow band of constructivists have attempted to tackle the challenge of decrypting when, why, and how one state may align with another state by focusing on the concept of identity.

In line with Larson's study, Christopher Hemmer, Peter Katzenstein and Michael Barnett closely examine the relationship between identity and alignment outcomes. First, Hemmer and Katzenstein analyze U.S. alliance patterns following World War II arguing racial, historical, political, and cultural factors, more so than material and efficiency considerations, affected political elite perceptions on collective identity that led them to develop a multilateral alliance with European countries and bilateral security arrangements with Asian countries. In their words, "explicitly considering the role collective identities play in world politics can help advance our theoretical and empirical understanding of international relations." ${ }^{168}$ Separately, Michael Barnett finds a shared sense of state identity was a key factor affecting political elite threat perceptions and alignment outcomes in the Middle East. For Barnett, "it is the politics of identity rather than the logic of anarchy that often provides a better understanding of which states are viewed as potential or immediate threat to state security."169

\footnotetext{
${ }^{165}$ Larson, Deborah W. 1985. Origins of Containment: A Psychological Explanation. Princeton: Princeton University Press; Rosati, Jerel A. 1987. The Carter Administration's Quest for Global Community: Beliefs and their Impact on Behavior. University of South Carolina Press.

${ }^{166}$ Herrmann, Richard K. 1985. Perceptions and Behavior in Soviet Foreign Policy. Pittsburgh, PA: University of Pittsburgh Press; Jervis, Robert. 1976. Perceptions and Misperceptions in International Politics. Princeton: Princeton University Press; Levy, Jack S. 1983. "Misperception and the Causes of War: Theoretical Linkages and Analytical Problems." World Politics 36 (1).

${ }^{167}$ Herrmann, Richard K., and Michael P. Fischerkeller. 1995. "Beyond the Enemy Image and Spiral Model: Cognitive-Strategic Research After the Cold War." International Organization 49 (3); Herrmann, Richard K., James F. Voss, Tonya Y. E. Schooler, and Joseph Ciarrochi. 1997. "Images in International Relations: An Experimental Test of Cognitive Schemata." International Studies Quarterly 41 (3).

${ }^{168}$ Hemmer and Katzenstein 2002, 575.

${ }^{169}$ Barnett Michael N. 1996. "Identity and Alliances in the Middle East." In Peter Katzenstein (ed.) The Culture of National Security: Norms and Identity in World Politics. New York: Columbia University Press, 401.
} 
The work of Hemmer, Katzenstein, and Barnett represent a marked improvement over Larson's work because they more precisely differentiate between the concepts of national and state identity and how the level of threat, either internally or externally is of secondary importance. In Hemmer and Katzenstein's paper, this is important because collective identities between states can potentially help advance our theoretical and empirical understanding of state alignment. This reality is made clear with a comment from Undersecretary of State Robert Lovett who notes that, "the 'cement' of the [North Atlantic] treaty was not the Soviet threat, but the common Western approach and that Western attachment to the worth of the individual."170

Barnett's work also offers a marked improvement on how scholars can conceptualize threat perceptions by calling our attention to the importance of state identity to understand how ruling elites define a threat and their options for alignment. His study potentially offers a window from which to understand alignment volatility where changes in state identity can potentially change alignment patterns. As Barnett notes, "identity is not a static concept but rather is socially constructed, and this social construction process can be used to for understanding alliance dynamics and changes in security patterns." 171

In the post-Soviet space, Giorgi Gvalia and his colleagues specifically set out to explain change and continuity in small state alignment in their study on Georgia and Azerbaijan. Using data collected from elite interviews, Gvalia argues systemic explanations fall short and that individual-level variables best explain the foreign policy behavior of small states in their decision to balance or bandwagon. For Gvalia, political elite ideas about the identity and purpose of the state are critical factors that affect the formulation and implementation of a ruling

\footnotetext{
${ }^{170}$ Lovett, Robert. 1948. "Minutes of the Third Meeting of the Washington Exploratory Talks on Security, July 7 , 1948." Foreign Relations of The United States, 1948, Western Europe, Volume III. Office of the Historian, U.S. Department of State. https://history.state.gov/ historicaldocuments/frus1948v03/d114. Accessed 02 June 2016. ${ }^{171}$ Ibid, 447.
} 
government's foreign policies. Although elite ideas and state identity are the most important variables, their analysis also takes into consideration secondary factors such as geography, economic dependence and the regional balance of power. ${ }^{172}$ Testing their theory on Georgia and Azerbaijan, Gvalia and his colleagues conclude,

Although a state's external environment is certainly important for understanding its foreign policy, variations in an external threat environment are filtered through elite ideas. States therefore choose international alliances according to the compatibility of their social orders and ideas about state identity and not solely in response to changes in the balance of power. Material factors matter, but ideas often determine how (and how much) they matter. ${ }^{173}$

From these conclusions, it becomes clear why, despite systemic events (e.g. 2008 RussiaGeorgia War), Georgian President Saakashvili consistently followed a pro-West alignment and why Azeri President Ilham Aliyev tended to pursue a more pro-Russian course.

Gvalia's study is not without a series of flaws. First, in Georgia there is little analytical attention devoted to the state's alignment tendencies under President Eduard Shevardnadze. Rather than applying the theory to his administration, Gvalia advances an unsupported conclusion that while Shevardnadze espoused a pro-West alignment, he never aggressively pursued this course. As result, Georgia is best viewed in a conventional way as a small state that bandwagons with Russia under Shevardnadze. ${ }^{174}$ Second, Gvalia used elite interviews in his examination of Georgia, the findings on Azerbaijan's alignment rested on secondary sources alone. Although Azerbaijan under Ilham Aliyev had increased its cooperation with Moscow, relations with ruling government in the West remained stable indicating Baku's alignment with other regional great powers like the U.S. should be more accurately viewed as pragmatic.

\footnotetext{
172 Gvalia, Siroky, Lebanidze, and Iashvili 2013, 100-101.

${ }^{173}$ Ibid, 109-110.

${ }^{174}$ Ibid, 101.
} 
Finally, Gvalia's operationalization of state alignment (pro-West or pro-Russian), like many of the scholarly studies in this literature review, is too ambiguous and subject to different interpretations. It is on this point that is becomes necessary to understand some of the general categorizations scholars have developed to differentiate the alignment tendencies of states in the post-Cold War era. Although many of these typologies have been applied to the most powerful states in the system, their applicability to small states should not be discounted.

\section{Alignment Typologies in the Post-Cold War Era}

Just as scholars differ on the impact of systemic and unit-level variables leading one state to align or enter into an alliance with another, they are also at odds over the concepts that best define these political phenomena. One set of academics and practitioners initially put forward an argument that existing alliances in the post-Cold War era would become less important or would cease to exist with some predicting NATO's dissolution or at least a marked decline in this organization's military capabilities. ${ }^{175}$ For example, Thomas Mowle and David Sacko argue alliances for the United States since the end of the Cold War are less important because Washington has employed a "coalition of the willing" approach to military operations while allowing the EU to create a new military organization (the European Common Security and Defense Policy) independent of NATO. As a result, alliance formation has become more fluid over the past several decades. ${ }^{176}$

Despite these proclamations, the reality however is that after 25 years NATO remains intact adding 12 new members through 2009 and expanding the alliance's defensive capabilities, which

\footnotetext{
${ }^{175}$ See Chalmers, Malcolm. 1990. "Beyond the Alliance System.” World Policy Journal 7 (2); De Santis, Hugh. 1991. "The Graying of NATO." Washington Quarterly 14 (4); Hassner, Pierre. 1990. "Europe Beyond Partition and Unity: Disintegration or Reconstitution?" International Affairs 66 (3); Talbott, Strobe. 1990. "America Abroad: Defusing the German Bomb.” Time, 2 July 1990. http://content.time.com/time/magazine/article/0,9171,970497, 00.html. Accessed 20 April 2016.

${ }^{176}$ Mowle, Thomas S. and David H. Sacko. 2007. The Unipolar World: An Unbalanced Future. Palgrave Macmillan.
} 
as of May 2016 included a regional ballistic missile system. ${ }^{177}$ In a similar, albeit less intense manner, the Russian-led CSTO has also endured with the EEU coming into existence in 2015. What is still not known is exactly when, how, and why states will opt to align with one of these regional military or economic blocs reminding us that alignment politics remains a challenging and complicated endeavor in the post-Cold War era. Despite these challenges, one can discern how some states have pursued one of six alignment strategies over the last several decades: hard balancing, regional balancing, soft balancing, 'leash slipping,' bandwagoning, and bridging ${ }^{178}$

\section{Hard Balancing.}

In the wake of the collapse of the Soviet Union, neorealists argued that balancing, as originally envisioned by Waltz, would remain the predominate tendency of states in the international system. ${ }^{179}$ For example, Christopher Layne and Kenneth Waltz were quick to note how states would aggressively pursue balancing (internal and external) strategies to offset U.S. material power dominance with the intent of reestablishing an international system with more than one great power. ${ }^{180}$ By the end of the century however, structuralists were perplexed by the lack of great power balancing in system. Such a situation represented a puzzle for neorealists, who then attempted to qualify their assertions on hard balancing by extending the timing of when this would actually occur. In the words of Waltz, "realist theory predicts that balances disrupted will one day be restored. A limitation of the theory, a limitation common to social science theories, is that it cannot say when."181

\footnotetext{
${ }^{177}$ Stoltenberg, Jens. 2016. "Press Point by NATO Secretary General Jens Stoltenberg Following the Aegis Ashore Operationalisation Ceremony.” North Atlantic Treaty Organization, 12 May 2016. http://www.nato.int/cps/en/natohq/opinions_130698.htm. Accessed 12 May 2016.

178 The study uses Walt's descriptive analysis of the dominant forms of alignment in the post-Cold War era. Walt, Stephen M. 2009. “Alliances in a Unipolar World.” World Politics 61 (1), 101.

${ }^{179}$ Kupchan, Charles A. 2002. "Hollow Hegemony or Stable Multipolarity?" In G. John Ikenberry (ed.) America Unrivaled: The Future of the Balance of Power. Ithaca, NY: Cornell University Press; Layne 1993; Waltz 1997. ${ }^{180}$ Layne 1993, 7; Waltz 1997, 916.

${ }^{181}$ Waltz, Kenneth N. 2000. "Structural Realism After the Cold War.” International Security 25 (1), 27.
} 
Although hard balancing against the United States may not have manifested itself in a pronounced manner over a short-period of time, some neorealists have continued to highlight how balancing is ongoing albeit at lower levels of intensity. Recalling Waltz's two forms of balancing, there is some evidence several states are either adopting an internal balancing or external balancing strategy. With respect to internal balancing, both Russia and China have implemented a wide array of defense modernization programs that represent a first step in what will be a long-term endeavor to balance against the United States. ${ }^{182}$ Separately, countries such as North Korea and potentially Iran see the viability in an internal balancing strategy by acquiring nuclear weapons and conducting provocative military operations as a way to resist what they perceive to be U.S. unilateralism. For these countries, weapons of mass destruction can deter U.S. military actions (e.g. Iraq 2003) designed to remove hostile foreign governments from power. In the words of Iranian politician Mostafa Tajazadeh during a March 2003 interview with the Washington Post, "it is basically a matter of equilibrium... If I don't have a nuclear bomb, I don't have security."183

States are also externally balancing against the United States. Beginning in 1996, Russia and China, in concert with Tajikistan, Kyrgyzstan, and Kazakhstan formed the "Shanghai Five," which was transformed into the Shanghai Cooperation Organization (SCO) in 2001 adding Uzbekistan into the collective. Although the alliance's primary security objective focuses on terrorism, separatism, and extremism, Ariel Cohen asserts Beijing considers the SCO "as a

\footnotetext{
${ }^{182}$ See Pifer, Steven. 2016. "Pay Attention, America: Russia Is Upgrading its Military.” The Brookings Institution, 05 February 2016. http://www.brookings.edu/research/opinions/2016/02/05-russian-military-modernization-usresponse-pifer. Accessed 24 April 2016. Wang, Yuan-Kang. 2006. "China's Grand Strategy and U.S. Primacy: Is China Balancing American Power?” The Brookings Institution-Center for Northeast Asian Policy Studies. http://www.brookings.edu/fp/cnaps/papers/wang2006.pdf. Accessed 15 April 2016.

${ }^{183}$ Vick, Karl. 2003. "Iranians Assert Right to Nuclear Weapons.” Washington Post, 11 March 2003. https://www.washingtonpost.com/archive/politics/2003/03/11/iranians-assert-right-to-nuclear-weapons/2f8cd96d29ca-4765-bbef-6e08c53d5dc9/. Accessed 25 April 2016, 1.
} 
means of creating a new Eurasian order to reduce U.S. military power and limit America's democracy promotion." 184

Separately, Russia has aggressively pursued its own balancing agenda against the United States bringing along some of the former Soviet states in the process. In 1992, Russia in concert with Armenia, Kazakhstan, Kyrgyzstan, Tajikistan, Uzbekistan entered into a formal alliance by signing the CST with Belarus, Azerbaijan and Georgia joining in 1993. By 2002, Azerbaijan, Georgia, and Uzbekistan opted not to renew their membership setting in motion what is known today as the CSTO with five member countries including Russia, Armenia, Kazakhstan, Kyrgyzstan, Tajikistan. Of note, although Uzbekistan left the CST in 2002, Tashkent rejoined in 2006 only to leave once more in $2012 .{ }^{185}$ Working within their means, political leaders in Beijing and Moscow are proceeding on an aggressive balancing course, even though "they [China and Russia] lack the capabilities necessary to create a true counterpoise to..." 186 the United States.

There are two important takeaways to note with respect to the balancing behavior of states in the post-Cold War era. In most cases, countries residing near the top of the international hierarchy based on military power (e.g. Russia and China) are the ones conducting a majority of the hard balancing in the contemporary system. It is in this case, Walter Lippmann's assertion from 1943 as to which states are more likely to pursue a balancing strategy appears valid. In his words, "only a great power can resist a great power. Only a great power can defeat a great power." ${ }^{187}$ Second, if one posits that Russia is balancing against the United States, how can one

\footnotetext{
${ }^{184}$ Cohen, Ariel. 2006. "The Dragon Looks West: China and the Shanghai Cooperation Organization.” The Heritage Foundation, Lecture \#961 on Asia, Russia and Eurasia, Shanghai Cooperation Organization, 03 August 2001." http://www.heritage.org/research /lecture/the-dragon-looks-west-china-and-the-shanghai-cooperation-organization. Accessed 15 May 2016.

${ }^{185}$ Charter of the Collective Security Treaty Organization. 2002. President of Russia Website. http://en.kremlin. ru/supplement/3506. Accessed 02 June 2016.

${ }^{186}$ Walt 2009, 102.

${ }^{187}$ Lippmann, Walter. 1943. U.S. Foreign Policy: Shield of the Republic. Boston: Little Brown, 100. Quoted in Schweller 1998, 85.
} 
best characterize the alignment activities of the smaller states in the CSTO? Is it balancing or is it bandwagoning? This study argues the former because it represents the first step in a strategic process that is subject to a wide array of domestic and systemic pressures.

\section{$\underline{\text { Regional Balancing. }}$}

Proceeding on the assumption that hard balancing is for only the most powerful states in the international system, some academics and practitioners have attempted to capture when this form of alignment may apply to small states. Remaining true to structuralist assumptions, a small state may balance against an aspiring regional hegemon by aligning with a competing power from a different region of the world. Although on the surface this may appear as bandwagoning, in reality a small state will align with an extra-regional power as a way to balance against the closer, more powerful state. ${ }^{188}$ As such, the key driver moving small states is geography.

Walt applies this approach to explain why some former Soviet states and countries including Estonia, Latvia, Lithuania, Poland, and Hungary aligned with the U.S. and its Western European allies as a way to increase their material power and guarantee their security against a historically aggressive Russia. As Walt notes, "a desire to enhance their security against regional threats [like Russia] explains why East European states.... were so eager to join NATO and so willing to curry favor with Washington by backing the Iraq war." 189 Mearsheimer advances a similar argument with his 'offshore balancing' hypothesis. For Mearsheimer, weak states in close proximity to a regional hegemon seek out an external great power because "offshore balancers do not provoke balancing coalitions against themselves." 190

\footnotetext{
${ }^{188}$ Mearsheimer, John J. 2001. "The Future of the American Pacifier.” Foreign Affairs 80 (5); Mearsheimer 2014; Walt 2006.

${ }^{189}$ Walt 2006, 112.

${ }^{190}$ Mearsheimer 2001, 49.
} 
In terms of strengths, Walt and Mearsheimer do well on several levels. First, they highlight the importance of injecting geopolitics into analyses on the balancing and bandwagoning behavior of states in a particular region. Second, both either directly or indirectly extend their analysis beyond the major secondary powers by considering the actions of smaller states. With respect to shortfalls, while Walt is quick to point out the cases of Poland, Hungary, and the Baltic states, no reference is made to Belarus, Armenia, or Ukraine. Certainly, one can argue close historical and/or cultural ties explain the alignment patterns of former Soviet states; however, these explanations fall short in Ukraine where at times the country has sought closer ties with the West under Presidents Viktor Yushchenko and Petro Poroshenko, but under Viktor Yanukovych, the ruling government aggressively pursued closer economic and security relations with Russia. Furthermore, systemic explanations fall short since over the course of all three presidencies in Ukraine, the regional balance of power essentially remained the same.

\section{$\underline{\text { Soft Balancing. }}$}

In contrast to hard or regional balancing, states may also "soft balance" against a regional great power. ${ }^{191}$ For states pursing this alignment strategy, Walt helps us to understand this activity by narrowly defining soft balancing as "the conscious coordination of diplomatic action in order to obtain outcomes contrary to U.S. preferences; outcomes that could not be gained if the balancers did not give each other some degree of mutual support."192 Randall Schweller and Xiaoyu Pu take issue with his limited conception though, viewing soft balancing as a general

\footnotetext{
${ }^{191}$ On soft balancing, see Joffe, Josef. 2001. "Who's Afraid of Mr. Big?" The National Interest 64 (Summer 2001); Joffe, Josef. 2002. "Defying History and Theory: The United States as the Last Remaining Superpower.” In G. John Ikenberry (ed.) America Unrivaled: The Future of the Balance of Power. Ithaca, NY: Cornell University Press; Pape, Robert A. 2005. "Soft Balancing against the United States." International Security 30 (1); Paul, Thaza V. 2005. "Soft Balancing in an Age of U.S. Primacy," International Security 30 (1); Pressman, Jeremy. 2004. "If Not Balancing, What?" Discussion Paper 2004-02. Belfer Center for Science and International Affairs, Harvard University.

192 Walt 2009, 104.
} 
form of relations of domination and resistance between powerful and less powerful actors. They develop this approach based on the work of James Scott, who notes, "most of the political life of subordinate groups is to be found neither in overt collective defiance of powerholders nor in complete hegemonic compliance, but in the vast territory between these two polar opposites,"193 Schweller and Pu draw a parallel where secondary states, although lacking the material capacity to balance will pursue relations of resistance to delegitimize or impose a cost on the most powerful state in the political universe. ${ }^{194}$

Josef Joffe provides a more nuanced definition of soft balancing arguing there exists two distinct forms: politico-diplomatic and psycho-social. ${ }^{195}$ States engaging in politico-diplomatic balancing will withhold political support for U.S.-led endeavors on the global stage. For example, in 2001 Germany and France strongly resisted a U.S. decision to withdraw from the 1972 Anti-Ballistic Missile treaty and pursue a national missile defense program. If this were to occur, French President Jacques Chirac concluded that it would serve as a "fantastic incentive to proliferate" 196 conventional and/or nuclear weapons to overcome this new defensive system. Separately, in March 2003 France, Russia, and Germany collectively opposed a U.S.-sponsored draft resolution authorizing the use of force in Iraq. These "soft balancing" actions were not designed to change the distribution of power in the system but to facilitate a better outcome on a specific issue. The net result for the Iraq example was "these states denied [more or less] the

\footnotetext{
${ }^{193}$ Scott, James C. 1990. Domination and the Arts of Resistance: Hidden Transcripts. New Haven, Conn.: Yale University Press, 138.

194 Schweller, Randall L. and Xiaoyu Pu. 2011. “After Unipolarity: China's Visions of International Order in an Era of US Decline.” International Security 36 (1), 48.

195 Joffe 2002, 172-176.

${ }^{196}$ Bruni, Frank. 2001. "France and Germany Caution Bush on U.S. Missile Defense Plan." New York Times, 14 June 2001. http://www.nytimes.com/2001/06/14/world/14PREX.html?pagewanted=all. 14 June 2001. Accessed 23 April 2016.
} 
United States the legitimacy it had sought and thereby imposed significantly greater political and economic costs" ${ }^{197}$ on its unilateral actions to remove Saddam Hussein from power.

Separately, states may employ psycho-social balancing against the United States. Countries pursing this course of action attempt to stave off U.S. soft power activities by arguing the ‘American way' is morally, culturally, and socially bankrupt. For example, in 1993, France convinced the EU to implement what was called a 'cultural exception' policy that would exclude select products (e.g. audio-video products) from the free trade rules under the General Agreements on Trade and Tariffs (GATT). According to Joffe, "the purpose of this balance of power policy... [was] to contain American cultural clout — to erect trade walls instead of real turrets and battlements. The enemy is not America the Conqueror —not the 'Imperial Republic'—but America the Beguiling." 198

The concept of soft balancing is, however, plagued by several shortcomings. First, on one level soft balancing can be considered nothing more than routine diplomatic bargaining as it relates to high politics. ${ }^{199}$ In their analysis of the run-up to the 2003 Iraq War, Brooks and Wohlforth offer up a strong example of this reality noting the actions of Germany and Turkey.

Using the term "balancing" to describe bargaining amounts in practice to equating balancing with international relations writ large. If it becomes another word for bargaining, balancing is meaningless as an analytical concept-something that describes a constant, rather than a variable; a mundane rather than noteworthy development in international politics. ${ }^{200}$

In this case, it was domestic political constraints not directly related to power asymmetries that drove Berlin and Ankara to challenge the unilateral actions of the United States. An important

\footnotetext{
${ }^{197}$ Walt 2009, 105.

198 Joffe 2001, 45.

${ }^{199}$ See Art, Robert J., Stephen G. Brooks, William C. Wohlforth, Keir A. Lieber and Gerard Alexander. 2006.

"Correspondence: Striking the Balance." International Security 30 (3); Lieber, Keir A. and Gerard Alexander. 2005.

"Waiting for Balancing: Why the World is Not Pushing Back." International Security 30 (1), 109-110.

${ }^{200}$ Brooks and Wohlforth 2008, 104.
} 
point here is that in addition to not preventing the United States from acting anyway, soft balancing frequently occurs in the realm of "low politics" where there may exist a plethora of causes behind the counter actions of lesser states such as domestic preferences, economic statecraft, or simple cases of anti-Americanism. According to some, "the events used to detect the presence of soft balancing are so typical in history that they are not, and perhaps cannot be, distinguished from routine diplomatic friction between countries, even between allies."201

Another problem with "soft balancing" is that the scholarly emphasis on this alignment strategy often focuses on top-tier states or those that are already in a formal military alliance. Little scholarly examination is given to the actions of smaller, weaker states. Schweller and $\mathrm{Pu}$ fall into this trap as both focus their analysis on rising great powers such as China. Similarly, Walt gives precedence to the major powers over smaller states noting that opposition from Berlin, Paris and Moscow to oppose Washington's Iraq war plans paved the way for countries such as Cameroon and Mexico to more easily soft balance against the United States and to resist pressure to align with the coalition of the willing during the debate in the United Nations. ${ }^{202}$ Such a conclusion may be short-sighted because it excludes the extent to which the belief systems of ruling leaders are a primary driver impacting interstate relations.

On a positive note, several scholars have discerned soft bandwagoning tendencies by some former Soviet states. For example, Cristian Cantir and Ryan Kennedy provide a plausible explanation of variation in Moldova's alignment with Russia. Like David, Cantir and Kennedy focus on domestic and systemic factors; however, Chisinau did not appease Moscow in order to focus on the more pressing challenge of separatism. Rather, ruling elites opted to pursue a soft

\footnotetext{
${ }^{201}$ Lieber and Alexander 2005, 131.

${ }^{202}$ Walt 2005, 120.
} 
bandwagoning strategy ${ }^{203}$ vis-à-vis Russia to achieve the government's long-term goals of security and economic prosperity. The key takeaway here is that small state alignment is more complex than simply accounting for internal threats. In their analysis, three systemic-level factors (disparities in power, external threat intensity, and permissiveness of the international environment) and two domestic-level variables (internal threat intensity and permissiveness of the domestic environment) best explain variation in Moldova's alignment trajectories. ${ }^{204}$ Leash-Slipping.

Leash-slipping is a fourth alignment option available to states that are in an alliance and have a well-established cooperative relationship with a regional great power. In this case, political leaders in a ruling government decide to independently pool the state's resources to offset their respective dependencies on the leading country. ${ }^{205}$ In 2006, Layne first coined the term leashslipping, noting how some states that are facing an immediate threat from the most powerful state in an alliance will still build up their internal (i.e. military) capabilities as a way to acquire a degree of foreign policy autonomy. In essence, leash-slipping "is a form of insurance against a hegemon that might someday exercise its power in a predatory and menacing fashion." ${ }^{206} \mathrm{Kai} \mathrm{He}$ adds clarity to this form of alignment noting how leash-slipping falls into the "negative balancing

\footnotetext{
${ }^{203}$ According to T.V. Paul soft bandwagoning is routinely conducted by states that cemented their strategic alignment with another state or group of states. When a member of this collective disagrees with one of the most powerful states in this collective, the dissenting state attempts to purse a non-aggressive strategy to counter the former's actions. This is done by rallying other like-minded states into an opposition coalition or using international organization to engage in institutional bargaining with the ultimate goal of constraining the actions of the more powerful state. See Paul, Thaza V. 2005. "Soft Balancing in the Age of US Primacy." International Security 30 (1). ${ }^{204}$ Cantir, Cristian and Ryan Kennedy. 2014. "Balancing on the Shoulders of Giants: Moldova's Foreign Policy toward Russia and the European Union." Foreign Policy Analysis 11 (4).

${ }^{205}$ On leash-slipping, see Art, Robert J. 2004. “Europe Hedges Its Security Bets.” In T. V. Paul, James J. Wirtz, and Michel Fortmann (eds.) Balance of Power: Theory and Practice in the 21 st Century. Stanford: Stanford University Press; Jones, Seth G. 2006. The Rise of Europe: Great Power Politics and Security Cooperation. Cambridge: Cambridge University Press; Posen, Barry R. 2004. "ESDP and the Structure of World Power." International Spectator 2 (9).

${ }^{206}$ Layne, Christopher. 2006. “The Unipolar Illusion Revisited: The Coming End of the United States' Unipolar Moment.” International Security 31 (2), 9; 30.
} 
category since it mainly aims at undermining domination ...without a direct confrontation..." with a target state. ${ }^{207}$ For example, the EU's efforts to establish a common and distinct set of foreign and security policies through the EU's Common Security and Defense Policy (CDSP) is one attempt by European countries to lessen their dependence on U.S. military support.

There are several inherent problems with a leash-slipping strategy as it relates to small state alignment patterns. First, the EU's effort to form its own security forces should not be taken as an effort to free itself from the U.S.-led NATO alliance but rather as a move designed to complement existing power relations. According to the EU...

The CSDP enables the Union to take a leading role in peace-keeping operations, conflict prevention and in the strengthening of the international security. It is an integral part of the EU's comprehensive approach towards crisis management, drawing on civilian and military assets. Since 2003 the EU has launched some 30 peace missions and operations contributing to stabilization and security in Europe and beyond. ${ }^{208}$

This point is not missed by Brooks and Wohlforth, who assert "the forces that the Europeans are actually seeking to create complement, rather than compete with, U.S. capabilities because they provide additional units for dealing with Balkans-style contingencies or peacekeeping missions abroad." ${ }^{209}$ The key takeaway here is that just because secondary states formally or informally pursue enhanced military capabilities does not mean they are doing so as a way to hedge against the unipole in an uncertain future. Second, analyses on instances of leash-slipping tend to consider only major world powers...again. Beyond the EU, Layne uses Britain in the mid to late 1940s and France in the early 1960s as examples of how these nuclear-armed countries

\footnotetext{
${ }^{207}$ He, Kai. 2012. "Undermining Adversaries: Unipolarity, Threat Perception, and Negative Balancing Strategies after the Cold War." Security Studies 21 (2), 168.

${ }^{208}$ European Union. 2016. “Security and Defense." http://www.eeas.europa.eu/csdp/index_en.htm. Accessed 10 April 2016.

${ }^{209}$ Brooks, Stephen G., and William C. Wohlforth. 2005. "Hard Times for Soft Balancing." International Security 30 (1), 91-92.
} 
attempted to slip the leash of U.S. domination. As such, leash-slipping appears on the surface to have little applicability to small states and their alignment tendencies.

Bandwagoning.

Although regarded as the least likely course of action by many scholars, states may bandwagon with a more powerful (or threatening) state. This strategic approach can manifest itself in several ways. First, as conceptualized by Randall Schweller, states may bandwagon with a larger regional great power because ruling elites view such a course of action as the "wave of the future'. In this case, ideology is the primary driver moving states along an alignment trajectory towards a regional great power. During the Cold War, many ruling governments in the developing world willingly aligned with the Moscow because of its communist ideology. One requirement outlined by Schweller is that 'wave of the future' bandwagoning requires the larger power to have a charismatic leader as was the case with Adolf Hitler in Nazi Germany, Joseph Stalin in the Soviet Union, and Mao Tse-tung in China. Furthermore, there exists a near continuous stream of propaganda or demonstrations of success either during war or in times of economic growth. ${ }^{210}$

Schweller makes a brief reference to how this form of bandwagoning can be applied to former Soviet states noting how countries behind the 'Iron Curtain' have turned from communism to liberal democracy; however, he fails to elaborate or adequately support this assertion. The issue here is that if ideology is the primary driver of alignment for newlyindependent states, then why didn't Belarus or Armenia or Uzbekistan opt to catch this wave?

'Piling-on' bandwagoning is a second form of bandwagoning detailed by Schweller where non-aligned small states at the end of a great power war will side with one regional great power

\footnotetext{
${ }^{210}$ Schweller 1994, 96-97.
} 
over another because they want to be on the winning team. Whether it is a desire to share in the spoils of war or fear of great power retribution for not supporting the cause, Schweller categorized this form of bandwagoning as "predatory buck-passing with regard to the winning coalition." ${ }^{211}$ In the absence of great power conflict in the post-Cold War era however, piling-on bandwagoning appears to have little applicability.

In the absence of an East-West armed confrontation closing out the Cold War, in the years that followed some scholars have argued secondary states would bandwagon with the United States, not for ideological considerations, but because of America's general benevolent nature and disinclination for world conquest. As a result, political leaders would tend to view the U.S. and its liberal allies with less fear because these top-tier powers did not represent a clear and present danger to their survival interests. This was particularly true at the turn of the century where Kier Lieber and Gerard Alexander note how...

The past few years have certainly witnessed a surge in resentment and criticism of specific U.S. policies. But great power balancing against the United States has yet to occur... because the postSeptember 11 grand strategy designed by the George W. Bush administration... poses a threat only to a very limited number of regimes and terrorist groups. ${ }^{212}$

Part of their argument rests on the premise that balance of power theory is deficient because it only focuses on top-tier states. According to Brooks and Wohlforth, balancing only occurs against a rising great power, not against a well-established and dominant global state actor. Both scholars point to a second underlying consideration where because regional great powers like the United States possess such a marked advantage over secondary powers in terms of material resources and capabilities, pursuing a balancing strategy to offset this power differential would be too costly. ${ }^{213}$ Specifically, they assert, "counterbalancing is and will long remain prohibitively

\footnotetext{
${ }^{211}$ Ibid, 95.

${ }^{212}$ Lieber and Alexander 2005, 109-110.

${ }^{213}$ Schweller and Priess 1997, 24; Wholforth 1999, 8.
} 
costly for the other major powers... [and] the variables that drive balance-of-power theory itself are now configured so as to render the balancing constraint so improbable as to render it inoperative."214

Levy and Thompson take issue with Brooks and Wohlforth's explanation by qualifying how the development of balance of power theory is only reflective of Western military thinking for land-based powers close to each other. ${ }^{215}$ When the balance of power model is applied to the maritime realm—where states are separated by large bodies of water — this theory does not convey the same level of explanatory power. Citing the lack of balancing against two maritime superpowers - the Dutch in the $17^{\text {th }}$ century and Britain in the $19^{\text {th }}$ century-balancing against the U.S. will not occur because states with large land-based armies represent a higher threat than those with large navies. Using quantitative techniques, Levy and Thompson conclude...

The strategic dynamics of behavior in the European system have differed sharply from the strategic dynamics of behavior in the global maritime system. Counterhegemonic balancing has been common in the European system, but it is relatively rare in the global maritime system. ${ }^{216}$

The next form of bandwagoning takes its cue from Walt, who focuses his analysis on what can be best termed as 'shadow of the future threat." ${ }^{217}$ Although rare according to Walt, in some instances, a state may bandwagon with a regional great power to stave off the potential for a future armed attack that would threaten the country's survival. According to Walt,

The decision to bandwagon requires the weaker side to put its fate in the hands of a more powerful state whom it suspects (usually with good reason) of harboring hostile intentions. By bandwagoning with the main source of danger, a threatened state accepts greater vulnerability in the hope that the dominant power's appetites are sated or diverted. ${ }^{218}$

\footnotetext{
${ }^{214}$ Brooks and Wohlforth 2008, 23; 27.

${ }^{215}$ Levy and Thompson 2005; Levy and Thompson. 2010.

${ }^{216}$ Levy and Thompson 2010a, 35.

${ }^{217}$ Mearsheimer 2014; Mowle and Sacko 2007; Walt, Stephen M. 2006. Taming American Power: The Global Response to U.S. Primacy. New York: W. W. Norton.

218 Walt 2006, 108.
} 
Additionally, when small states have no other options for allies, this will accelerate the tendency to bandwagon with a threatening great power. In Mearsheimer's words, "bandwagoning is employed mainly by minor powers that stand alone against hostile great powers. They have no choice but to give in to the enemy because they are weak and isolated." 219

In the post-Soviet space, a close examination of the alignment patterns of states in the South Caucasus do not support Walt and Mearsheimer's assertions. If one proceeds on the assumption that Russia is the most threatening great power in the region, then the bandwagoning thesis for small states is valid given how Armenia has consistently aligned with its former imperial center. However, the same cannot be said for Georgia, which even after the 2008 Russia-Georgia War continued to pursue membership in Euro-Atlantic security and economic structures. Furthermore, Uzbekistan's on-again-off-again membership in the CSTO demonstrates there is more to consider than threat and power in understanding change and continuity in a small state's alignment patterns.

In contrast to Walt and Mearsheimer, Mowle and Sacko filter their analysis through a unipolar lens finding bandwagoning with the U.S. to be a common and more beneficial option for most states, not just the isolated ones. In their words...

...a strategy of bandwagoning, or sharing in the unipolar power's gains, is more beneficial. States have not formed military alliances that exclude the United States; their military spending has not kept pace with the United States, expect in the case of China...; states have not been developing weapon systems that target the United States, except for North Korea and Iran; and states have not physically blocked American power. Instead they have joined alliances with the United States and have often cooperated in its military missions. ${ }^{220}$

The weakness of Mowle and Sacko's argument is that they attempt to advance a key finding while simultaneously conditioning their conclusions with a list of exceptions. These outliers,

\footnotetext{
${ }^{219}$ Mearsheimer 2014, 163.

${ }^{220}$ Mowle and Sacko 2007, 4.
} 
from one perspective, erode the external validity of their central thesis and calls into question the generalizability of their research when there exist numerous examples of balancing behavior.

\section{Bridging.}

Finally, a highly underdeveloped and less explored alignment strategy for states is bridging. Political elites opting to employ this strategic approach walk a fine line in their bifurcated foreign policies, which are designed to develop cooperative relations between two or more regional great powers. According to Mathew Rhodes, "rather than cast its lot unambiguously with or against one side, a bridging state seeks to maintain good relations with both in order to narrow differences, minimize conflict, and promote cooperation between them."221 For example, following 9/11, Great Britain’s Prime Minister Tony Blair acted as a mediator between the United States and other European countries on Washington's policies in the Middle East. ${ }^{222}$ Although Rhodes focus his analysis on top tier states, a bridging strategy could also be applied to a research project designed to understand the alignment tendencies of small states.

\section{Non-Alignment Strategies}

Finally, some scholars have attempted to provide an explanation of state inaction with respect to strategies of non-alignment. Again, focusing on the great powers, some states can either buckpass or pursue a distancing strategy. First, structuralists posit that the second-best choice to balancing is buck-passing. In this case, a vulnerable state attempts to shift the burden of balancing against the most powerful or threatening power by having another state(s) take on this costly task. Mearsheimer notes that states will buck-pass for three reasons. First, it is less expensive in that other states expend limited resources to balance against an aggressive state. Second, in the event of war and after its conclusion, the buck-passer could be in a position where

\footnotetext{
${ }^{221}$ Rhodes, Matthew. 2004. “Central Europe and Iraq: Balance, Bandwagon, or Bridge?” Orbis 48 (3), 425.

${ }^{222}$ Gupta, Amit. 2006. The Second Bush Presidency: Global Perspectives. Pearson Education India, 68.
} 
it is stronger than both powers. Finally, if there are multiple threatening states, buck-passing allows the weaker state to handle each in sequence. ${ }^{223}$

In lieu of buck-passing, balancing, or bandwagoning, Schweller notes that weaker top-tier states may pursue a distancing strategy vis-a-vis a threatening great power. In this case, the threatened state attempts to distance itself from all parties. There are two reasons for this approach. First, while political elites in the threatened state would prefer to balance against a threatening power state by entering into an alliance with weaker states, there is a realization that such an effort would still not generate enough deterrence to ensure their collective survival. As Rothstein notes,

An alliance of small powers is an instrument of limited utility. It neither can nor is designed to handle major military threats. When small powers are threatened by great powers, they must turn to other powers for support... Statesmen are wrong in assuming that a combination of small powers is equivalent to a great power. ${ }^{224}$

Second, if this coalition is formed it would send a signal to the threating power that a balancing effort was underway, which in turn, could elicit a political, economic, or military backlash. With no other choices, political leaders avoid cooperation with all states opting for isolation as a way to extend its survival. ${ }^{225}$ Given globalization's impact on making the world more interconnected, such a strategy does not appear possible in current times.

Beyond these alternative strategies, which focus on the more powerful states in the international system, other scholars have attempted to tease out other strategic options. Robert Rothstein argues small states can choose from three strategies: isolation, nonalignment, and neutrality. ${ }^{226}$ Isolation follows Schweller's notion of distancing where a small state attempts to

\footnotetext{
${ }^{223}$ On buck-passing, see Mearsheimer 2014, 141-145.

${ }^{224}$ Rothstein 1968, 169-171.

225 Schweller, Randall L. 1993. "Tripolarity and the Second World War.” International Studies Quarterly 37 (1), 84.

${ }^{226}$ Rothstein 1968, 27.
} 
avoid engagement with the top-tier countries by going it alone. States following a strategy of nonalignment eschew membership in a military bloc opting, in some cases, to chart a new course independent of the ideological views of the leading great powers. Rothstein does note that nonalignment is more often than not an aberration because this strategy only applies to states that are not strategically important and politically unprovocative to the system's leading powers. Finally, a small state may declare itself neutral in world affairs dominated by regional great powers. Rothstein explains the logic of this course of action stating that small states, “...hope that they can be protected by their own insignificance. If they can appear detached enough, and disinterested enough, and if they can convincingly indicate that they are too powerless to affect the issue, they hope the storm will pass them by."227

Finally, Mark Webber asserts states can pursue three non-alignment choices: isolation, selfreliance, neutrality. Webber's notion of isolation follows Karl Deutsch's conception, but is also like Schweller and Rothstein, where a state decreases contact with a threatening power in order to minimize disagreements that could lead to war. ${ }^{228}$ An argument can be made that a strategy of self-reliance mirrors Waltz's internal balancing thesis. For Webber, a less powerful state will build-up its internal military capabilities to deter an attack from a threatening power. A state opting for neutrality attempts to avoid placing itself in the middle of a conflict between larger, more powerful states. This is accomplished by not signing formal military commitments, avoiding all forms of military cooperation, and disallowing the stationing of forces on the country's sovereign territory by any regional great power. ${ }^{229}$

\footnotetext{
${ }^{227}$ Ibid, 32-34; 47-48; 246-247.

${ }^{228}$ Deutsch, Karl W. 1968. The Analysis of International Relations. Vol. 12. Englewood Cliffs, NJ: Prentice-Hall, 194.

${ }^{229}$ Webber, Mark. 1996. The International Politics of Russia and the Successor States. Manchester: Manchester University Press, 205-210.
} 
The preceding strategies while potentially applicable to some states, do not convey to those in the post-Soviet space for several reasons. First, a strategy of isolation (or distancing) is nearly impossible for the newly-independent states given their geographical location and historical economic and social links to Russia. For example, many of the newly-independent states still rely heavily on Russia for trade and investment. Furthermore, Webber identifies a risk with this course noting how a strategy of "...isolation would be no guarantee against [Russian] interference and might, in fact encourage it, if withdrawal was taken as a sign of passivity."230

Next, neutrality and non-alignment are also not a viable option for most former Soviet states for two reasons. One, following the criteria set by Rothstein, former Soviet states must be viewed as strategically important. From Moscow's perspective, these countries have historically represented a buffer zone from foreign invaders. Additionally, most of the newly-independent states are key links in the web of oil and natural gas pipelines leading to countries throughout Eurasia. Two, a small state's capacity to maintain a position of neutrality is ultimately determined by the great powers. Allen Sens and Annette Fox help us to understand this situation. In their words...

Neutrality requires the tolerance, agreement, or approval of the great powers - at least those in the immediate vicinity - to underwrite or guarantee the neutrality of the small state, as in the case of Belgium and the Treaty of London. Several neutrality policies adopted in the interwar period were rendered superfluous when Nazi Germany simply chose not to honor them. Neutrality arrangements are usually founded on the mutual self-interest principle, and if this mutual selfinterest on the part of the great powers breaks down, so too does the viability of the neutrality policy. ${ }^{231}$

Fox comes to the same conclusion noting,

...[success] depended on convincing the power pressing the small state that its continued neutrality was advantageous to the great power too. The small state's leaders had to make clear that the belligerent's major requirements could be satisfied without the use of force or that the use

\footnotetext{
${ }^{230}$ Ibid, 205.

${ }^{231}$ Sens, Allen Gregory. 1994. The Security of Small States in Post-Cold War Europe: A New Research Agenda. Institute of International Relations, University of British Columbia.
} 
of force would be too expensive in terms of the benefits sought and the larger dividends available if applied elsewhere. ${ }^{232}$

Finally, like-minded small states, even if they pool their resources, are unlikely to make any significant headway in charting their own independent, non-aligned position in world politics. This was the case with Georgia, Ukraine, Azerbaijan, and Moldova's efforts to form the Organization for Democracy and Economic Development (GUAM). According to Tomas Valasjek, "the scarce resources of the member states will limit the depth of their cooperation,"233 in this organization. Furthermore, the formation of this collective has an implicit mission of aligning with the United States and its Western European allies; a point not missed by Valasjek, who concludes this collective "...was established with the express purpose of forging close institutional ties with the West, which, in the military realm, means NATO."234

\section{Conclusion}

The preceding literature review reveals the dominant theories to explain state alignment are deficient in many ways and that there is no scholarly consensus on why and when a small state may opt to align with one regional great power over another. In contrast to Jack Levy's assertion about the democratic peace thesis, ${ }^{235}$ there is by no means anything close to an empirical law on state alignment. Clearly, this political phenomenon is a complicated endeavor fraught with many pitfalls, especially as it applies to lesser powers. Given the preceding, one can discern several key takeaways that may serve as guideposts for the development of a fresh approach to understanding small state alignment in the post-Cold War era.

\footnotetext{
${ }^{232}$ Fox 1959, 180.

${ }^{233}$ Valasjek, Tomas. 2000. "Military Cooperation between Georgia, Ukraine, Uzbekistan, Azerbaijan, and Moldova in the GUUAM Framework." Belfer Center, Harvard Kennedy School for Science and Technology, Policy BriefCaspian Studies Program, 30 November 2000. http://www.belfercenter.org/publication/military-cooperationbetween-georgia-ukraine-uzbekistan-azerbaijan-and-moldova-guuam. Accessed 02 January 2017, 4.

${ }^{234}$ Ibid, 5.

${ }^{235}$ In his examination of armed conflict between states, Jack Levy concludes that "the absence of war between democracies comes as close as anything we have to an empirical law in international relations.” See Levy $1989,270$.
} 
Over Emphasis on Systemic Factors to Explain State Alignment. Because many of the dominant alignment theories have their roots in a neorealist approach to international relations, scholarly writings on when, why, and how one state may align with another has proceeded on the assumption that systemic factors (e.g. balance of power, balance of threat, etc.) are the most important variables explaining this political outcome. At issue here is how Waltz, Walt, and other structuralists fail to consider the relevancy (or supremacy) of domestic-level variables and how they may be able to offer a more nuanced explanation of why countries sometimes balance against or bandwagon with a particular great power.

Although neorealism carries a high degree of parsimony, such an approach on its own does not adequately account for the full range of state alignment options in the post-Cold War era. In some studies, scholars have attempted to integrate domestic-level variables; however, in nearly all cases they did not adequately capture the alignment tendencies of small states. For example, Franklin Weinstein is highly critical of scholars, who focus on systemic factors. From his perspective, greater emphasis should be given to small, transitioning states and how ruling elites in these countries use foreign policy to advance their political agenda. In his words...

A focus on the uses of foreign policy makes it possible to develop a framework in which the relationships among the [domestic] variables that determine policy are illuminated. Both attitudinal and historical data can be incorporated within that framework to yield propositions about the relation between foreign policy and the political and economic problems associated with the state of underdevelopment. ${ }^{236}$

For Weinstein, political elites in developing states like Indonesia use foreign policy as a tool to ensure the country's independence, facilitate economic development, and maintain an upper hand in domestic political affairs. A similar approach to alignment politics in the post-Soviet space could help narrow the field of independent variables.

\footnotetext{
${ }^{236}$ Weinstein, Franklin B. 1972. "The Uses of Foreign Policy in Indonesia: An Approach to the Analysis of Foreign Policy in the Less Developed Countries." World Politics 24 (3), 366.
} 
Additionally, when one attempts to apply a purely systemic model of alignment to former Soviet states, the theory at hand routinely does not convey. Furthermore, focusing just on systemic conditions to explain state alignment is problematic because "foreign policy choices are made by actual political leaders and elites, and so it is their perceptions of relative power that matter, not simply relative quantities of physical resources or forces in being." ${ }^{237}$ Similarly, Michael Fortman and his colleagues find that regardless of the number of perceived great powers in the system, the process by which balancing occurs is not mechanistic and that political elites are the ones to set in motion this action. In their words...

"...decision makers intervene in several ways in the working of the balance of power mechanics. They perceive (or not) a growing power differential, they define it (or not) as a threat, and they chose to act on it (or abstain from doing so). ${ }^{238}$

There are two lessons observed here. First, future studies on state alignment should incorporate variables that span different levels of analysis. By pursing a multi-level analytical approach, one can potentially achieve a more complete explanation of why countries sometimes balance against or bandwagon with a more powerful state. Additionally, such an approach can help fill the gap in our knowledge about small state alignment. If power or threat on their own can explain the alignment tendencies of some states, then integrating select domestic factors into the equation may be able to potentially yield a more powerful elucidation of alignment in which we come to understand why more states align with another state over another. Second, the inability of previous theoretical models to convey to other cases may stem, in part, to case selection bias. If a researcher selects cases based on the dependent variable, then the theory's

\footnotetext{
${ }^{237}$ Rose, Gideon. 1998. "Neoclassical Realism and Theories of Foreign Policy.” World Politics 51 (1), 147; emphasis added.

${ }^{238}$ Fortmann, Michel, T. V. Paul, and James J. Wirtz. 2004. "Conclusions: Balance of Power at the Turn of the New Century." In T. V. Paul, James J. Wirtz, and Michel Fortmann (eds.) Balance of Power: Theory and Practice in the 21 st Century. Stanford: Stanford University Press, 366.
} 
external validity will be significantly impaired. With this point in mind, Chapter Four conducts a painstaking analysis of former Soviet state alignment in order to understand variation in this political phenomenon and to identify optimal cases worthy of further research.

System Polarity is an Important, but not Necessarily Decisive Factor in Determining State Alignment Outcomes. Without a doubt, the demise of the Soviet Union was perhaps one of the most important systemic events of the $20^{\text {th }}$ Century. Because this dissertation attempts to unravel the puzzle of small state alignment in the post-Cold War era, considering the relevance of the global power structure was a prudent step. But, just as scholars have disagreed over when and how states will align with each other, there was also no clear scholarly consensus on how the configuration of the global power structure may impact the alignment tendencies of small states. The overarching conclusion from the discussion above is that while system polarity is an important consideration, it is not the most important given the inherent problems associated with defining, operationalizing, and measuring power. If the concept of power is indeterminate, attempting to establish clear relationships between system polarity and various political outcomes such as war, peace, alliance formation, and alignment is problematic for two reasons.

First, most studies give precedence to material factors (size of population, land area, economic indicators, and military capabilities) as a way to determine whether a country is a 'pole' in the system or simply a secondary state. This creates another problem where scholars may pick and choose from a menu of power-defining categories based on their specific research interests. When this occurs, the findings from one study may not necessarily support or adequately refute the results of another research project thereby preventing the timely accumulation of knowledge. Schweller notes the challenges associated with material-based calculations for system polarity where... 
This type of calculus is often misleading, especially when economic, military, and diplomatic resources are not integrally related-when a state can achieve military power without economic power, or economic and political power without military power, and so on."239

A second reason relates to the arbitrary assignment of thresholds that differentiate what is, or is not, a unipole, a great power, or a secondary state. What one study may define as a great power, others may view the same country as a secondary state. Even if one follows Waltz's formula for defining a great power, there is no agreement as to how secondary states may differ in terms of their actions in an anarchic system. Does Fiji respond to systemic factors in the same way as Germany? Probably not. But certainly, one can argue that Germany is a regional great power in Europe whereas Fiji is just simply another small country in the Pacific.

This does not mean that material power is not an important consideration. As noted above, a state's material power provides a basis for action in the political universe. With that, this study recognizes the United States is the most powerful country in the world in military and economic terms; however, there also exists a growing number of regional great powers that have the capacity to meet or exceed U.S. material power in select geographical spaces around the world. Because the U.S. continues to operate on a global scale, regional great powers routinely possess a local area power advantage and escalation dominance in the event of a crisis. This is clearly the case in Ukraine where Russia has a favorable balance of power over Ukraine and escalation dominance over the United States.

Beyond U.S. power dispersion to hundreds of locations around the world, geographical challenges (e.g. large oceans, rough terrain, improved anti-access/area denial capabilities, etc.) can also erode U.S. power projection. ${ }^{240}$ Separately, political will, budgetary limitations, or

\footnotetext{
239 Schweller 1999, 37.

${ }^{240}$ Kenneth Boulding and John Mearsheimer note how geography is the primary constraint preventing the emergence of a global hegemon.
} 
public opinion may serve as constraints on the application of U.S. power. Given this reality, this study concludes the contemporary international system is best characterized in a manner that mirrors Schweller's conceptualization of a "chandelier-type" construct comprised of "loosely coupled, regional constellations." In the end, while differences in each country's material power are important, they are not decisive in determining what a regional great power is or is not, its impact on system stability, and the (re)actions of other states.

The Neglect of Small States. Working in the shadow of Waltz, scholars have exhibited a great power bias in their research on state alignment giving little emphasis to small states. This tendency to focus on top-tier powers stems, in part, from an assumption that only the most powerful states are the primary shape agents in the international system owing to their economic prowess, sizable populations, or large armies. For many of these scholars, small states lack the material capabilities to have any meaningful impact on world politics. What is missed however, is that in many cases, a small state's geographical location, access to resources, and independent actions can make it an important and relevant actor in the international system.

First, geography can elevate the strategic importance of a small state. For example, Panama, Oman, Egypt, and Malaysia can exert some degree of control over the sea lines of communications for the world's supply of oil given the transit routes lay in close proximity to their territorial waters. In Eastern Europe and the South Caucasus, many of Russia's oil and natural gas pipelines transit through several former Soviet states on their way to customers in Western Europe. ${ }^{241}$ Second, some small states may have access to strategic natural resources that are of high value to the great powers. For example, many small countries in Africa and Southeast

\footnotetext{
${ }^{241}$ A variety of different studies have examined the topic of rentier states in the post-Soviet space. See as an example Franke, Anja, Andrea Gawrich, and Gurban Alakbarov. 2009. "Kazakhstan and Azerbaijan as Post-Soviet Rentier States: Resource Incomes and Autocracy as a Double 'Curse' in post-Soviet regimes." Europe-Asia Studies 61 (1).
} 
Asia have access to rare earth minerals that are used by developed states for defense purposes or to produce high-tech devices. Similarly, Kazakhstan and Azerbaijan's access and production of oil and natural gas elevate the strategic importance of both countries.

Finally, the actions of a small state can also increase its relevance in international affairs. In the UN, the ten non-permanent members of the Security Council are frequently filled by small states, whose votes can sometimes steer the actions of this organization on a variety of issues. At the regional level, a majority of NATO and EU members are small states, which have been given an equal voice in the decisions made by each organization. Christo Kassimeris provides a strong rationale for more closely examining the role of small states in international relations.

In an ever-globalized international community, the role of small powers has been magnified to an extent where their number along may come to signify powerful coalitions capable of resisting and even curbing the influence of what are traditionally perceived as larger powers. ${ }^{242}$

While some scholars have heeded Kassimeris' call, others have not focused their examination on former Soviet states. This reality represents a gap in the literature that this study seeks to fill.

Viewing Bandwagoning as Just a Negative State Endeavour. The preceding literature review also highlighted how there is a lack of scholarly agreement as to which alignment tendency (hard balancing, bandwagoning, soft balancing, etc.) states will pursue under differing system and domestic-level conditions. If scholars are at odds with one another over which alignment strategy states will pursue, they are in agreement that bandwagoning behavior is best viewed as a negative endeavor. In nearly all cases, scholars define bandwagoning as a form of appeasement, kowtowing, or ceding autonomy in exchange for long-term survival. Additionally, it appears that in most instances, support for state bandwagoning is derived from examples immediately prior to, during or just after the international system experienced a great power conflict.

${ }^{242}$ Kassimeris, Christos. 2009. “The Foreign Policy of Small Powers.” International Politics 46 (1), 96. 
Schweller's reference to wave of the future bandwagoning represents one notable exception to this scholarly trend. Another positive with Schweller's approach is how he supports his assertions with examples from the Cold War when the system was characterized by great power competition. While Schweller grounded his argument in ideological considerations, his approach represents an opportunity from which this study seeks to build upon in the next chapter. 
Giants still walk the earth. International relations cannot be understood if the role of the individual is ignored-Daniel L. Byman and Kenneth M. Pollack, 2001. ${ }^{243}$

\section{CHAPTER THREE - THEORY}

\section{Introduction}

The dissolution of the Soviet Union in 1991 and the establishment of 15 newly-independent states was arguably one of the most significant events of the late $20^{\text {th }}$ century. As the 'Iron Curtain' closed, gone were the days when Soviet republics received and directly implemented explicit foreign policy guidance from the Kremlin. In the post-Cold War era, political leaders in the new republics now have the authority to individually direct interstate relations with some former Soviet states reinforcing cooperative relations with Moscow, while others charting a new course with countries in the West. The questions of when, why, and how former Soviet states would attempt to align with one regional great power over another subsequently took on increased importance with the emergence of a new round of strategic competition between Russia and the U.S. for influence in the post-Soviet space.

As the preceding literature review demonstrated, the dominant theories on state alignment do not, on their own, adequately explain small state alignment. At issue is their focus on the great powers and a failure to account for the geostrategic realities in the post-Soviet space. These shortcomings in the literature demands a fresh approach; one that begins, as Byman and Pollack reminds us, with the political leaders charged with making the state's foreign policy decisions. To fill this gap in the literature, this study leverages the explanatory power of social identity theory (SIT) and social categorization theory (SCT) as a way to develop a more nuanced

${ }^{243}$ Byman and Pollack 2001, 145. 
approach for small state alignment. ${ }^{244}$ This model is comprised of five conceptual components, which include three primary independent variables, one intervening variable, and one dependent variable. The dependent variable in this study is a small state's alignment with a regional great power. Small state alignment manifests itself in two distinct forms: positive bandwagoning and great power bridging. The three primary independent variables are political elite ideas about the state's identity, his/her threat perceptions, and foreign policy orientation vis-à-vis different regional great powers. Additionally, domestic politics conditions the ability of a political leader to translate his/her alignment preferences into concrete foreign policy actions.

As a point of emphasis, each of the three primary independent variables will be examined separately in different chapters of this dissertation. This is done for several reasons. First, with respect to this study's theoretical contribution, this approach illuminates the reality on how multiple factors will simultaneously impact the alignment trajectories of former Soviet states. Second, this model of small state alignment allows this study to advance several general arguments. One. It is argued that to understand change and continuity in a small state's alignment with a regional great power, scholars must fixate on ideational factors, giving due consideration to political elite ideas, perceptions, and how they may impact their material actions in world affairs. While material factors like the balance of power or threat are important, political leader ideas and perceptions about the nature of the external threat and the state's purpose do the heavy lifting in alignment politics. Two. Although ideational factors are important, alignment politics is not "ideas all the way down." ${ }^{245}$ Here, due consideration must be given to domestic

\footnotetext{
${ }^{244}$ This study also recognizes the potential value of using role theory to explain the alignment of small states with a particular regional great power. As initially developed by Kalevi Holsti in the 1970s, role theorists argue each political leader retains his/her own unique set of ideas or images about the state's identity in world politics. These national role conceptions subsequently influence his/her foreign policy actions. See Holsti, Kalevi. J. 1970. National Role Conceptions in the Study of Foreign Policy. International Studies Quarterly 14 (3) and Walker, Stephen G. (ed.). 1987. Role Theory and Foreign Policy Analysis. Durham: Duke University Press.

${ }^{245}$ Wendt, Alexander. 1999. The Social Theory of International Politics. New York: Cambridge Univ. Press, 92.
} 
and systemic-level conditions, with emphasis on the former. Specifically, just because a ruling leader possesses a pre-established set of ideas and beliefs about aligning with a particular regional great power, his/her ability to do so is influenced first and foremost by domestic politics, which can constrain or enable a ruling government's foreign policy orientation potentially leading to a different alignment outcome. ${ }^{246}$

Separately, given the nature of the independent variables under examination, this study recognizes how these factors may interact with one another and thus indirectly influence the dependent variable. This potentiality is accounted for by comparing the findings from the examination on the relationships between each of the three independent variables and the dependent variable. The overarching purpose here is to establish a foundation for future research, which cannot be adequately attended to in this research project owing to time, space, and scope.

This chapter is organized into three sections. Section one provides a baseline overview of social identity theory and social categorization theory and their applicability to understanding small state alignment. In section two, the independent and dependent variables are discussed, and hypotheses presented. This section also includes a graphic depiction of this study's conceptualization of small state alignment, which was presented in Chapter One. Section three offers a brief conclusion.

\section{Social Identity Theory and Self-Categorization Theory}

This dissertation draws on social identity theory (SIT) and self-categorization theory (SCT) to explain political leader tendencies to align the state with one regional great power over another. The basis of SIT and SCT is developed on a key assumption that an individual's social identity is

\footnotetext{
${ }^{246}$ As an important point of clarification, the model advanced in this dissertation does not necessarily allow one to infer future events. As will be detailed below, each of the conceptual components of this model contains its own set of hypotheses owing to how each independent variable may exert a direct impact on the dependent variable.
} 
derived from his/her cognitive and motivational processes. ${ }^{247}$ As originally developed by Henry Tajfel and Robert Turner in the late 1970's and early 1980s, SIT posits that there exists three key cognitive processes that allow an individual to associate or disassociate with an 'in-group' or 'out-group' respectively: social categorization, social identification, and social comparison.

Social categorization is the process by which an individual places 'others' into a series of categories as a way to simplify the complex world and to structure social interactions. According to Tajfel and Turner, "social categorizations are conceived as cognitive tools that segment, classify, and order the social environment, and thus enable the individual to undertake many forms of social action... They create and define the individual's place in society." ${ }^{248}$ For example, the process of social categorization allows one to place himself/herself and others into different groups based on language, dress, employment, or religion. A key point here is that the 'self' and 'others' can simultaneously hold descriptors that place them into more than one group.

Social identification is a second cognitive process where an individual more strongly identifies with a particular in-group. In Tajfel's words, social identification is "that part of an individual's self-concept which derives from his knowledge of his membership of a social group (or groups) together with the value and emotional significance attached to that membership."249 A key point here is that the process of social identification can change over time owing to a variety of different factors. Hogg and Abrams capture this point noting,

Categories come and go (prior to the mid-twentieth century there was not such occupational category as 'computer programmer'), their defining features alter (historical modifications of stereotypes of North American Blacks), their relations with other categories change (inter-group relations between the sexes), and so on. ${ }^{250}$

\footnotetext{
${ }^{247}$ Hogg, Michael A. 1996. Intragroup Processes, Group Structure, and Social Identity. In Robinson, William (ed.), Social Groups and Identities: Developing the Legacy of Henri Tajfel. Oxford: Butterworth-Heinemann, 67.

248 Tajfel and Turner 1979, 40.

249 Tajfel 1979, 63.

${ }^{250}$ Abrams, Dominic, and Michael A. Hogg. 1988. Social Identifications: A Social Psychology of Intergroup Relations and Group Processes. London: Routledge, 14.
} 
Finally, based on the first two cognitive processes, an individual's actions are derived from the process of social comparison, which is guided by three premises. First, an individual must have internalized his/her affiliation or membership with an in-group. Second, the environment in which an individual resides must allow for a social comparison. Finally, an in-group will compare themselves to only a finite number of out-groups based on what the in-group perceives to be a relevant comparison. For example, an in-group may focus on education and gender but not skin color or age. The ultimate goal in this process is "to maintain or achieve superiority over an out-group on some dimensions." 251

SCT builds on many of the attributes of SIT but differs in that the focus transitions from personal identity to a collective social identity. While SIT attempts to explain inter-group discrimination based on the requirement for the development of a positive social identity, SCT shifts the focus from a self-categorization at the individual level to a social identity level at the group level. This allows one to explain higher order group behavior processes. According to Michael Hogg and Deborah Terry, “...targets are no longer represented as unique individuals but, rather, as embodiments of the relevant in-group prototype (cognitive representation of features that describe and prescribe attributes of the group)." ${ }^{252}$ Put another way...

Personal identity refers to self-categories which define the individual as a unique person in terms of his or her individual differences from other (in-group) persons. Social identity refers to social categorizations of self and others, self-categories which define the individual in terms of his or her shared similarities with members of certain social categories in contrast to other social categories. Social identity refers to the social categorical self (e.g., "us" versus "them," in-group versus outgroup, us women, us men, etc.) ${ }^{253}$

This transition from the individual- to the collective-level subsequently gives greater

\footnotetext{
251 Tajfel and Turner 1979, 41.

${ }^{252}$ Hogg, Michael A., and Deborah I. Terry. 2000. "Social Identity and Self-Categorization Processes in Organizational Contexts.” Academy of Management Review 25 (1), 123.

${ }^{253}$ Manstead, Antony and Miles Hewstone. 1996. The Blackwell Encyclopedia of Social Psychology. Blackwell Publishers, 1996. http://www.blackwellreference.com/public/tocnode?id=g9780631202899_chunk_ g978063120289921_ss1-6\#citation. Accessed 23 April 2017.
} 
specificity to the dynamics of group cohesion and in-group/out-group differentiation.

Furthermore, through the process of depersonalization, a group is then able to exhibit various internal and external normative behaviors such as empathy, enmity, ethnocentrism, cooperation, confrontation, inter and intra-group cohesion, etc. ${ }^{254}$ For example, one can argue that within the Chinese Communist Party, there is a high degree of cohesion over security issues in the South China Sea where the United States is viewed as the out-group because of its opposition to Beijing's territorial claims in the Spratly Islands. As a result, China often takes a more confrontational approach to U.S. military actions in the region and its support for other regional countries and their territorial claims in the South China Sea.

As a final point of emphasis, some SIT and SCT scholars have concluded individual and group identities may vary over time for several reasons. First, social identities may vary based on the salience of the select social categories that are in play at a particular moment in time for an individual or group. At the individual level for example, William McGuire and his colleagues find that children in a family with more siblings of the opposite sex are more likely to describe themselves in gender terms, while minority children in a classroom view themselves based on ethnicity. ${ }^{255}$ Second, the attributes of the members of a group and the social context in which they reside can affect variation in social identities. According to Hogg and his colleagues, "...social identity is highly dynamic: it is responsive, in both type and content, to intergroup dimensions of immediate social comparative contexts. ${ }^{, 256}$

As previously noted in this study's literature review, Hemmer and Katzenstein have

\footnotetext{
${ }^{254}$ Hogg and Terry note that depersonalization is defined as "...a change in self-conceptualization and the basis of perception of others; it does not have the negative connotations of such terms as deindividuation or dehumanization; Hogg and Terry 2000, 123.

${ }^{255}$ McGuire, William J., et al. 1978. "Salience of Ethnicity in the Spontaneous Self-Concept as a Function of One's Ethnic Distinctiveness in the Social Environment." Journal of Personality and Social Psychology 36 (5).

${ }^{256}$ Hogg, Michael A., Deborah J. Terry, and Katherine M. White. 1995. “A Tale of Two Theories: A Critical Comparison of Identity Theory with Social Identity Theory.” Social Psychology Quarterly 58 (4), 261.
} 
demonstrated the applicability of using SIT to understand state alignment and alliance formation. In their study, SIT was applied to understand why the United States after World War II opted to create a multi-lateral alliance in Western Europe and only bilateral arrangements with countries in Asia. The centrality of pursing an ideational approach to unravel the 'Gordian Knot' of alignment is made clear with their conclusion that, “...identification is the mechanism that helps connect the construction of specific regional groupings in Europe and Asia to particular institutional features—multilateral or bilateral—of particular military alliances." ${ }^{257}$ Although Hemmer and Katzenstein's study focused on a regional great power in a top-down way, this study argues that the same framework can be applied to small states in a bottom-up manner.

Leveraging key aspects of SIT and SCT offers several advantages. First, unlike a pure realist approach that uses the state as the primary unit of analysis, a social identity approach allows one to capture the impact of political elite ideas in order to develop an alternative accounting of state interests that drive foreign policy outcomes. A social identity-based model is particularly useful when it explains state foreign policies that are inconsistent with neorealist conceptions of state action and how their activities are exogenously driven or determined. Second, when balance of power between states remains constant, as is the case with Russia and the countries on its geographical periphery, integrating elements of SIT and SCT into a multi-level model can help explain different alignment outcomes. This is especially true when the internal composition of ruling government shifts from one political group to another. It is on this last point that the next section details the two primary alignment outcomes for small states in the post-Soviet space.

${ }^{257}$ Hemmer and Katzenstein 2002, 587-588. 


\section{Small State Alignment: A New Conceptual Framework}

As just discussed in the previous chapter, Stephen Walt does well to call our attention, albeit marginally, to the importance of considering ideational factors (e.g. aggressive intentions) to understand alliance formation; however, much of Walt's balance of threat theory is still based on material considerations. As such, this study seeks to go beyond Walt's model through the introduction of a new conceptual framework to understand small state alignment. To accomplish this task, this research project leverages the scholarly insights of Randall Schweller.

In his ground-breaking study on state alignment, Randall Schweller argued alignment is best understood in terms of a positive endeavor where states bandwagon with a larger power not because of power or threat, but for profit. Although Schweller does well to expand our understanding of when and how one state attempts to align with another, his explication of the bandwagoning tendency is highly underspecified. To garner increased fidelity on the meaning and variation of the dependent variable (alignment), this study builds on select elements of Schweller's balance of interest theory as a way to articulate two new forms of state alignment: positive bandwagoning and great power bridging. The explanatory variables leading to positive bandwagoning or great power bridging are based on a political leader's ideas about the state's identity, his/her threat perceptions of regional great powers, and his/her accompanying foreign policy orientation as conditioned by domestic politics. (See Figure 1 on the next page).

A few points of emphasis are in order here. First, this study focuses on two new forms of small state alignment for several reasons. First, the alignment theories presented in the previous chapter are not relevant because they do not sufficiently explain the alignment patterns of those states along Russia's geographical periphery. At issue is how many alignment theories tend to only focus on the great powers. Additionally, many of the major alignment theories give too 
much emphasis to material considerations over ideational factors. When ideational variables are introduced, they are routinely underspecified. Finally, this study sees high value in a dichotomous dependent variable as a way to discern alignment granularity in the context of the real world. It is through this parsimonious operationalization of alignment that future research can incrementally build a more complex conceptualization of this political phenomenon.

\section{Figure 2: Small State Alignment}

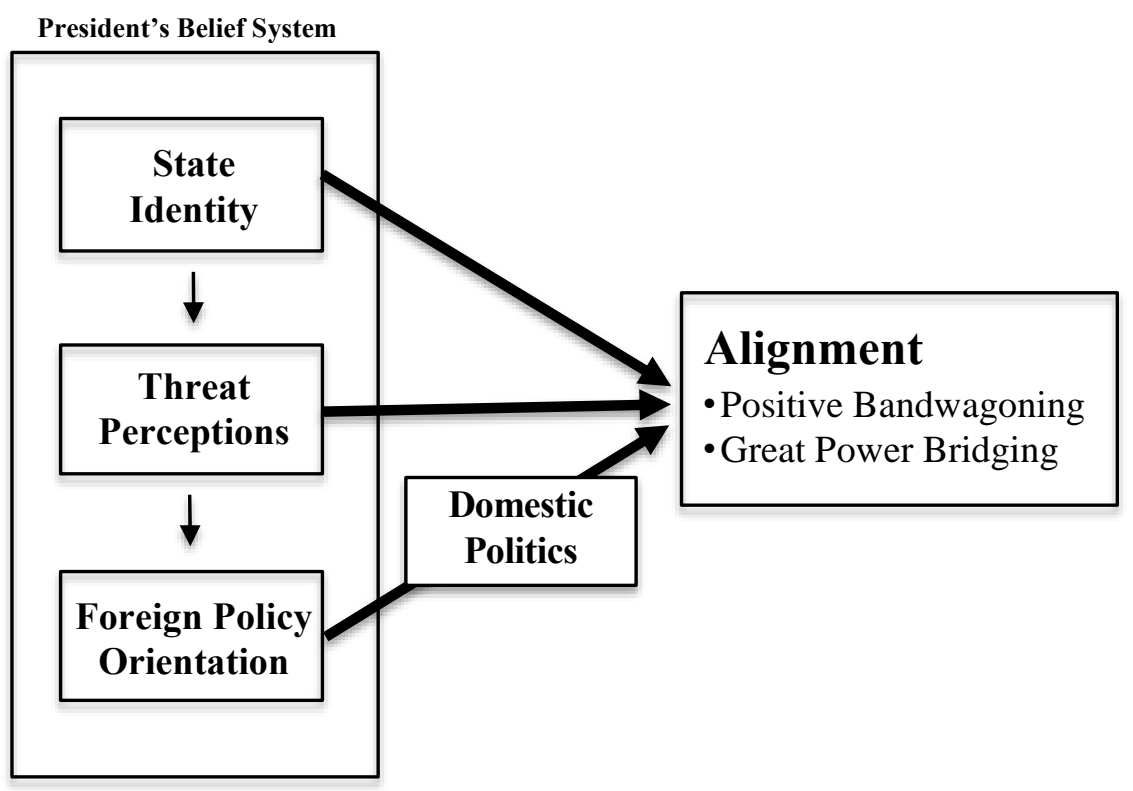

Second, the primary focus of this dissertation, as depicted by the bold arrows in the figure above, centers on the relationship between each of the three primary independent variables (state identity, threat perceptions, and foreign policy orientation as conditioned by domestic politics) and the dependent variable (alignment). The relationship between each of the three IVs and the dependent variable will be presented in three standalone chapters. Additionally, this study also examines how the three IVs may interact in a sequential manner (state identity $\rightarrow$ threat perceptions $\rightarrow$ foreign policy orientation) and their indirect influence on the dependent variable. Although a more detailed analysis of the interactions of the IVs is beyond the scope of this research project, this comparative analysis will help orient future research on this topic. 
Third, this study recognizes the pervasiveness of domestic politics in nearly all aspects of the state's foreign policy processes. One can look to Ukraine to see how domestic politics can be a reflection of a cultural divide affecting all three of the IVs in this study. Despite the omnipresent nature of domestic politics in the state and society, its applicability in this study is confined to a political leader's foreign policy orientation for two reasons. First, the relevance of state identity and threat perceptions in this study is considered in terms of their impact on a political leader's alignment preferences. However, a political leader's foreign policy orientation is best understood as his/her ideas about strategy and how to translate his/her alignment preferences into material action. As such, of the three independent variables under examination, domestic politics would be the most relevant to a political leader's foreign policy orientation because it is at this point like-minded and opposing political forces are the most active in enabling or constraining the ability of a political leader to implement policies to realize his/her alignment preferences.

Second, capturing the relevance of domestic politics as it relates to a political leader's ideas about the state's identity, his/her threat perceptions and corresponding alignment preferences is a very challenging empirical endeavor. At issue is discerning the extent to which domestic politics actually created a conflict in a political leader's belief systems. That is, prior to any effort to translate his/her preferences into action, it is unlikely one would be able to observe empirical evidence on how domestic politics may have changed a political leader's alignment preferences. More realistically, researchers would be able to gauge the impact of domestic politics by assessing the overt actions of different political groups prior to and after a political leader's efforts to transform his/her alignment preferences into material actions. The application of domestic politics to a political leader's foreign policy orientation appears to be the best course of action for this study. 


\section{Positive Bandwagoning.}

This study's conception of positive bandwagoning builds on two important aspects of Schweller's balance of interest theory. First, small states are best viewed as actors operating in the shadows of two or more powerful status quo and/or revisionist states that are engaging in a strategic competition with one another; not a conflict. In this case, political leaders in small states have time to act on their own to realize their primary long-term goals of security, economic prosperity, and re-election; however, they cannot do it on their own because of material deficiencies (e.g. lack of natural, technical know-how, large army, etc.) and/or internal constraints (ineffective institutions, social instability, etc.). For example, in defense matters, a small state "...cannot obtain security primarily by use of its own capabilities, and that it must rely fundamentally on the aid of other states, institutions, processes, or developments to do so..."258 Robert Keohane also comes to a similar conclusion noting how in nearly all instances, small states consider their position in the international system as unalterable, which drives them to seek out external assistance. ${ }^{259}$ Given this reality, the shadow of the future energizes political leaders in small states to pursue proactive foreign policies with larger powers that have the capacity to provide them the necessary political, economic, and military support to survive.

Second, unlike Schweller, this study posits bandwagoning should not be viewed exclusively as a negative state action, where political leaders appease, give-in, kowtow, or give up a slice of their political autonomy to achieve a greater good. In Schweller's words "lambs [small states] often bandwagon, as Walt implies, to divert and appease threats," ${ }^{260}$ On the contrary, this political phenomenon should also be viewed as a positive endeavor, where small states may

\footnotetext{
${ }^{258}$ Rothstein 1968, 29.

${ }^{259}$ Keohane 1969, 293.

${ }^{260}$ Schweller 1994, 102.
} 
engage in a series of cooperative military, diplomatic, and economic activities with a regional great power to achieve what ruling political leaders believe to be in the best, long-term good of the state or their political interests. ${ }^{261}$ This is what this dissertation calls positive bandwagoning.

To Schweller's credit, he does advance a specific positive form of small state bandwagoning referring to this activity as 'wave of the future' bandwagoning. However, positive bandwagoning, as conceptualized in this study, differs from how Schweller views 'wave of the future' bandwagoning, which he borrows from Larson's work. ${ }^{262}$ Like 'wave of the future' bandwagoning, small states that follow a positive bandwagoning strategy do so voluntarily based on the belief system of the lead actor in the foreign policy executive. Unlike 'wave of the future' bandwagoning, the inducements to pursue this strategy are different in two ways. First, positive bandwagoning does not occur as a response to the latest ideological fad as was the case for some small states during the 1950 s and 60s to align with the Soviet Union and its model of communism. Second, positive bandwagoning does not occur in response to the presence of a charismatic leader. Schweller posits that it is because of this enigmatic leader's use of propaganda and messaging campaigns, small states are enticed to bandwagon.

Finally, and of particular significance, positive bandwagoning can occur even when there are no guarantees a small state's alignment with a regional great power will lead to the country's accession into a military alliance or regional economic grouping in the short- or mid-term. As previously noted, most small states lack the economic capacity and military wherewithal to independently act in a meaningful manner in the international system. In some cases, these deficiencies have helped bring about instances of domestic instability that may manifest

\footnotetext{
${ }^{261}$ Schweller views small states as lambs, revisionist states as wolves, and status quo states as lions. Schweller 1994, 74-75; 93; 100-103.

${ }^{262}$ See Schweller 1994, 96-98 for his discussion of 'wave of the future' bandwagoning. See Larson 1991, 93-101 for her different conceptualizations of bandwagoning.
} 
themselves in separatist movements or various forms of intrastate conflict. As a result, leading political elites in small states realize these shortfalls will take time to remedy and that these conditions may preclude them from following a shortened path into a formal economic grouping or military alliance. However, if positive bandwagoning is consistently applied by multiple, likeminded ruling governments over time, these leaders believe those shortfalls will be overcome thus setting conditions for the country's entry into alliances led by a target regional great power. Great Power Bridging.

A second alignment strategy available to small states is great power bridging. Political leaders in a small state that pursue this strategy attempt to, on average, cooperate with two or more regional great powers to the extent that such efforts do not cross a tipping point of membership in a formal military alliance or economic union. When a small state follows a great power bridging alignment ruling elites exhibit higher levels of verbal and material cooperation with several regional great powers. Cooperation can occur across multiple lines of operation including political/diplomatic, economic, and military activities designed to align the small state with both regional great powers. It should be understood that a small state does not have to necessarily cooperate with a regional great power along all three lines of engagement. For example, a small state may eschew military cooperation focusing more on economic relations with both regional great powers and vice-versa. Furthermore, the levels of verbal and material cooperation can oscillate between both regional great powers over time.

Additionally, unlike positive bandwagoning, which has a higher potential for leading to membership in a military alliance or economic bloc with a reginal great power, foreign policy elites pursing this alignment strategy perceive binding economic or military commitments may produce negative second- or third-order effects. For example, accession into a regional economic 
union could undermine lucrative trade relations with non-member countries. Separately, when two regional great powers are engaged in a strategic competition, signing a defense pact with one regional great power may elicit a political, economic, or military backlash from the other.

If the two major alignment outcomes for a small state are positive bandwagoning and great power bridging, it now becomes necessary to discuss the three key factors leading to these two political outcomes. Again, as a reminder, this research project dedicates a separate chapter to an examination on the relationship of each of these three variables with the dependent variable.

\section{Determinants of Small State Alignment.}

The quintessential theoretical proposition in this research project is that ideas and beliefs of the leading political figure in a state's foreign policy executive are central to the study of small state alignment in the post-Cold war era. Specifically, it is posited that the president's ideas and beliefs about the nature of the political universe are a reflection of his/her life-long political experiences and expectations. It is these beliefs and expectations that subsequently play an important role in establishing a foundation for his/her decision-making process and actions as he/she leverages his/her influence inside the government to achieve his/her alignment preference.

Although a myriad of factors can directly or indirectly impact the state's established foreign policy decision making process, this study argues that to better understand the alignment trajectories of small states, one must take a leader-centric approach grounded in the ideas and beliefs of ruling elites. A leader-centric approach is warranted because government officials, especially those occupying positions within the foreign policy executive are the vanguard element responsible for developing and implementing foreign policies. These individuals establish the country's national interests and are charged with deciding when and how to use state resources to realize a wide array of strategic objectives. According to Hans Morgenthau, 
political leaders "speak for it [the state], negotiate treaties in its name, define objectives, choose the means of achieving them, and try to maintain, increase, and demonstrate power."263

It is from this leader-centric approach one must focus on a political leader's ideas and beliefs about the nature of the political universe and the viable strategic approaches within it. Following Goldstein and Keohane,

...ideas influence policy when the principled or causal beliefs they embody provide road maps that increase actors' clarity about goals or end-means relationships, when the affect outcomes of strategic in which there is no unique equilibrium... ${ }^{264}$

However, the question at hand is which ideas matter the most? In this study, it is argued a political leader's ideas about the state's identity, his/her threat perceptions, and foreign policy orientation as conditioned by domestic politics are central to understanding the alignment tendencies of states along Russia’s geographical periphery.

The selection of these three variables are based on the following rationale. First, this study takes its lead from the constructivist assumption that state identity can be an important shape agent for a political leader's preferences and subsequent actions. ${ }^{265}$ Second, because "social threats are constructed, not natural," 266 an argument can be made that a political leader's affinity for other states as defined by his/her ideas about the state's identity can affect his/her threat perceptions, which then impact his/her general foreign policy orientation and foreign policy actions. Finally, these constructivist-based determinants take their cue from SIT and SCT, which posit that groups with similar identities will tend to cooperate with one another more often than those in an out-group. ${ }^{267}$

\footnotetext{
${ }^{263}$ Morgenthau 1967, 108.

${ }^{264}$ Goldstein and Keohane 1993, 3.

265 Wendt 1999, 169-170.

266 Wendt 1992, 405.

${ }^{267}$ Tajfel, Henri. 1981. Human Groups and Social categories: Studies in Social Psychology. Cambridge: Cambridge University Press.
} 
Beyond the preceding rationale, a multi-faceted empirical probe using interviews and an experiment helped validate the necessity to focus on these ideational variables over public opinion, domestic politics, and the balance of power. ${ }^{268}$ See Appendix C for a detailed analysis of the findings from this empirical probe. Furthermore, as was noted in the introductory section of this chapter, this dissertation devotes a chapter each to an examination on the relationship of these three independent variables with the dependent variable.

Ideas about State Identity.

The first determinant of alignment for countries occupying the post-Soviet space is the state's identity as defined by the leading actor in the ruling government's FPE. As Jeffrey Mankoff reminds us, “... [a state's] international behavior is above all a function of [its] self-perception and the identity constructed by their elites." ${ }^{269}$ State identity is best understood as the public articulation of ruling group's ideas of the country's purpose in international affairs. ${ }^{270}$ Political elite ideas about the purpose of the state in world politics represent a quintessential touchstone that lead members of the FPE to identify and prioritize the national interests of the country. ${ }^{271}$ It

\footnotetext{
${ }^{268}$ Based on the professional assessments of over 25 area experts and regional specialists, a president's ideas and beliefs were a very important factor influencing the development and execution of a state's foreign policies. Domestic political opposition and public opinion were moderately important with the regional balance of power regarded as only slightly important.

${ }^{269}$ Mankoff, Jeffrey. 2009. Russian Foreign Policy: The Return of Great Power Politics. New York: Rowman and Littlefield, 41; emphasis added.

270 This definition of state identity draws up the work of various scholars. Masahiro Matsumura defines state identity as "the state's perception of what role it should play and what status it should enjoy in international relations, such as a Western state or a non-Western state on the one hand; and a superpower, a great power, or a middle power on the other hand. Shibley Telhami and Michael Barnett define state identity "as the corporate and officially demarcated identity linked to the state apparatus." Marc Lynch defines state identity as a "the set of beliefs about the nature and purpose of the state expressed in public articulations of state actions and ideals." Matsumura 2008, 3; Telhami, Shibley and Michael N. Barnett. 2002. Identity and Foreign Policy in the Middle East. Ithaca, NY: Cornell University Press; Lynch, Marc. 1998. "Abandoning Iraq: Jordan's Alliances and the Politics of State Identity." Security Studies 8 (2-3), 349.

${ }^{271}$ This study follows the Alan Stolberg in defining national interests as the perceived goals of the political leaders for the country vis-à-vis other countries in the international system. Stolberg, Alan G. 2012. "Crafting National Interests in the 21st Century." In J. Boone Bartholomees (ed.) The U.S. Army War College Guide to National Security Issues, Vol. II: National Security Policy and Strategy, 5th edition. Carlisle Barracks, PA: Strategic Studies Institute, 13-25.
} 
is from these national interests political elites develop foreign policies that define the state's actions in world affairs. The key takeaway here is that the actions of the state are first determined by the decisions of those occupying the highest levels of a ruling government. The importance of political elite ideas and national interests is a point not lost to Jutta Weldes, who notes,

State officials do not approach international politics with a blank slate on to which meanings are written only as a result of interactions among other states. Instead, they approach international politics with an already quite comprehensive and elaborate appreciation of the world, of the international system and of the place of their state within it. ${ }^{272}$

Weldes' sage insight subsequently becomes a foundational stone for this study's focus on the relevance of the state's identity as constructed by leading figures in the foreign policy executive. For this research effort, political elite ideas about the state's identity rests on five key premises. First, following Alexander Wendt, a state's identity is socially constructed by political leaders, especially those that occupy the highest positions in the ruling government (e.g. president, prime minister, foreign minister). ${ }^{273}$ As the vanguard representatives of the state, ruling elites possess the power within the bureaucratic apparatus to exert varying levels of influence on foreign policy issues and outcomes. ${ }^{274}$ Second, state identities are social identities in that they are relational in nature, containing references between the "self" and "others" in the international system. The interaction of individual political elites in the FPE leads to the creation of a group with a shared social (i.e. state) identity, which in turn allows them to delineate a boundary that differentiates members from non-members. This state identity takes account of national values and international status, which serve as a roadmap to guide political elite decisions on which external

\footnotetext{
${ }^{272}$ Weldes, Jutta. 1996. “Constructing National Interests.” European Journal of International Relations 2 (3), 280; emphasis added.

${ }^{273}$ Wendt 1992. "Anarchy is What States Make of It: The Social Construction of Power Politics." International Organization 46 (2), 405.

${ }^{274}$ Duffield, John S. 1999. "Political Culture and State Behavior: Why Germany Confounds Neorealism." International Organization 53 (4).
} 
states to cooperate with on a particular foreign policy issue. ${ }^{275}$

Third, state identities have a discursive narrative structure that serves as a signaling mechanism to internal and external actors on how ruling elites view various external threats and the country's purpose in world politics. ${ }^{276}$ This discursive narrative reflects the beliefs, attitudes, values, norms, and perceptions of the leading political leaders in the ruling government. Each of these five sub-elements warrant a brief synopsis.

Beliefs are perhaps the most important factor shaping political elite ideas. In this study, beliefs are best understood as a political leader's subjective interpretation of the strategic environment. ${ }^{277}$ For example, Georgia's prime minister may believe Russian military support for separatists in South Ossetia is a major source of domestic instability in the country. Separately, Ukraine's president may believe Russia's annexation of Crimea represents a threat to the country's sovereignty. However, Azeri presidents may not believe any of these actions are a challenge to their established national interests. For simplicity, this study follows Alexander George and his argument that there exists two primary dimensions to a political leader's beliefs: philosophical and instrumental. Philosophical beliefs focus on how political elites view world politics, political conflict, and the nature of the international system. Instrumental beliefs focus on strategy and how to achieve a particular end given available means. ${ }^{278}$

\footnotetext{
${ }^{275}$ On this premise, see Brewer, Marilynn B., and Rupert J. Brown. 1998. Intergroup Relations. McGraw-Hill; and Neumann Iver B. 1999. Uses of the Other: The East in European Identity Formation. Minneapolis: University of Minnesota Press.

${ }^{276}$ On the discursive nature of state identity, see Giddens, Anthony. 1991. Modernity and Self-identity: Self and Society in the Late Modern Age. Stanford University Press, 54; and Ehin, Piret and Eiki Berg. 2009. "Incompatible Identities? Baltic-Russian Relations and the EU as an Arena for Identity Conflict." In Eiki Berg and Piret Ehin (eds.) Identity and Foreign Policy: Baltic-Russian Relations and European Integration. Burlington, VT: Ashgate Publishing, 2.

277 Johnson, Allan G. 1995. The Blackwell Dictionary of Sociology. Cambridge: Blackwell Reference, 16.

${ }^{278}$ George, Alexander. 1969. "The 'Operational Code': A Neglected Approach to the Study of Political Leaders and Decision-making." International Studies Quarterly 13 (2), 199-216.
} 
Attitudes are those beliefs held by political leaders that have an evaluative component of the strategic environment. ${ }^{279}$ For example, many Kremlin leaders retain a suspicious attitude toward Western intentions in the post-Soviet space owing to their political and economic support for non-governmental organizations. Values reflect a political leader's ordering of material and immaterial objects based on its utility, goodness, or social desirability. ${ }^{280}$ The president of Estonia values increased economic cooperation with countries that have an open market system over those with a closed economic system. Following Robert Jackson, norms are "a legal or moral obligation or requirement or expectation, a standard of human conduct." ${ }^{281}$ Finally, perceptions are the publicly articulated verbal or written statements of a political leader's beliefs, attitudes, values, and norms. ${ }^{282}$

Fourth, in line with SIT and SCT, state identities are temporal and capable of changing in the short term based on the strategic context. ${ }^{283}$ It is on this premise that this study slightly diverges from the general constructivist notion that identities are "a relatively stable, role-specific understandings and expectations about self." ${ }^{284}$ On the contrary, this study acknowledges how state identities are more malleable and subject to change over short periods of time. In this case, ruling elites are in an optimal position to construct or manipulate a state's identity by strengthening or undermining existing "self-other" narratives based on changes in the domestic and international realms. From Barnett, a state "identity is not a static concept but rather is socially constructed, and that this social construction process can be used to good effect for

\footnotetext{
${ }^{279}$ Eagly, Alice H., and Shelly Chaiken. 1998. "Attitude Structure and Function.” In Daniel T. Gilbert, Susan T. and Gardner Lindzey (Eds) The Handbook of Social Psychology, Vols. 1-2, 4th ed. New York: McGraw-Hill, 269.

${ }^{280}$ Johnson 1995, 309.

${ }^{281}$ Jackson, Robert 2000. The Global Covenant. Human Conduct in a World of States. Oxford: Oxford University Press, 49.

${ }^{282}$ Reber, Arthur S. 1995. The Penguin Dictionary of Psychology. New York: Penguin Press, 514.

${ }^{283}$ Campbell, David. 1992. Writing Security: United States Foreign Policy and the Politics of Identity. University of Minnesota Press, 149.

${ }^{284}$ Wendt 1992, 397.
} 
understanding alliance dynamics and changes in security patterns." ${ }^{285}$ Such an assertion has merit, given how Karl Deutsch and his colleagues, in examining the formation of the NATO alliance after World War II find, "large numbers of people changed their political outlook and acquired new political loyalties in a very short time." 286 At a minimum, even if a political leader's ideas about the state's identity does not vary, when he/she is removed from office, there is a high probability that incoming leaders will have a different set of state identity narratives.

There is however, a lack of consensus among political scientists on identity formation with many at odds over process and determinants. Some IR scholars emphasize systemic-level conditions, while others focus on domestic-level factors. ${ }^{287}$ In contrast to these singular arguments that place one level of analysis over another, I assert the necessity to consider both, where ruling elite ideas are under near continuous influence from pressures from above and below. From this supposition, it is plausible that system-level events or domestic conditions can then serve as 'shape agents' for a political leader's state identity discourse. Examples of events and conditions include, but are not limited to, changes in the political leadership of foreign states, interstate war, economic downturns, technology, and domestic political opposition. ${ }^{288}$

Fifth, political leaders may hold multiple identities about the state at the same time. ${ }^{289}$ In the Middle East, some scholars have found that ruling elites have advanced a variety of different

\footnotetext{
${ }^{285}$ Barnett 1996, 447.

${ }^{286}$ Deutsch, Karl W., et al. 1957. Political Community and the North Atlantic Area. Princeton: Princeton University Press, 12.

${ }^{287}$ Dirk Nabers and Nina Tannenwald argue systemic factors are primary shape agents for identity while Jeffrey Checkel posits norms and institutions matter more. See Nabers, Dirk. 2009. "Filling the Void of Meaning: Identity Construction in US Foreign Policy after September 11, 2001.” Foreign Policy Analysis 5 (2); Tannenwald, Nina. 2007. The Nuclear Taboo: The United States and the Non-use of Nuclear Weapons Since 1945. Vol. 87. Cambridge University Press. Checkel, Jeffrey T. 1999. "Norms, Institutions, and National Identity in Contemporary Europe.” International Studies Quarterly 43 (1); Larson, Deborah Welch, and Alexei Shevchenko. 2003. "Shortcut to Greatness: The New Thinking and the Revolution in Soviet Foreign Policy." International Organization 57 (1). 288 Matsumura 2008, 3.

${ }^{289}$ See Hall, Rodney Bruce. 1998/1999. “Territorial and National Sovereigns: Sovereign Identity and Consequences for Security Policy." Security Studies 8 (2/3); Cronin, Bruce. 1998/1999. "From Balance to Community:

Transnational Identity and Political Integration.” Security Studies 8 (2/3).
} 
labels for the state such as Arab, Islamic, Palestinian, conservative, radical-Arabism, etc. ${ }^{290}$ Ronald Suny also notes that, "within limits elites can choose among the repertoire of available identities and discourses to promote interethnic peace or exacerbate conflict." ${ }^{291}$ For example, a Ukrainian president may characterize the state as independent and Slavic with a command oriented economy. After the next national election, the new president may articulate a state identity narrative using the terms independent and European, with a market-oriented economy. Given the preceding, state identity represents the chief variable from which to first understand alignment politics in small states.

As conceptualized in this study, positive bandwagoning can occur when the heads of state in Azerbaijan, Georgia, Moldova, and Ukraine view the state's identity as being similar to either the historical state identity narratives associated with the U.S. and Russia since the end of the Cold War. Based on interviews with area specialists and online surveys, enduring state identity narratives associated with the United States include, but are not limited to democratic, modern, free, independent, and Western. ${ }^{292}$ With Russia, the state identity narratives of Presidents Yeltsin, Putin, and Medvedev is somewhat of a contested concept where, according to one area specialist, the "state is the nation...it's imperial if you will." 293 Another factor in play is the sheer size of the country. Despite these challenges, regional specialists assessed political elite state identity narratives may include Russian, Slavic, Eastern, Eurasian, and independent. ${ }^{294}$

Based on SIT/SCT, we should then see political leaders exhibit higher levels of verbal cooperation with a specific regional great that move the state's strategic alignment in that

\footnotetext{
290 Telhami and Barnett 2002.

${ }^{291}$ Suny 1999/2000, 176.

${ }^{292}$ Interview on file with author.

${ }^{293}$ Interview on file with author.

${ }^{294}$ Interview on file with author.
} 
direction. Here, ideology is not the only element of consideration as political, economic, and cultural factors are taken into account as well. This is an important theoretical point, where different political leaders may conceptualize the state's identity in different ways giving emphasis to one or more facets, which then become the basis of the state's alignment. Political leaders following a positive bandwagoning alignment have as a long-term goal, formal membership in a military alliance or economic bloc that the target regional great power is directly or indirectly associated with. Alternatively, as state identities diverge or overlap with multiple great powers, a small state is more apt to align with more than one regional great power. The underlying logic here is that ruling elites can simultaneously hold multiple conceptions of the state's identity. When these narratives cross-cut more than one regional great power, there is an increased possibility the small state will follow a great power bridging alignment. This leads to the following hypotheses:

H1a: Presidents in small states prefer a positive bandwagoning alignment with a regional great power with a similar state identity.

H1b: When state identities diverge or overlap, presidents in a small state prefer a great power bridging alignment with multiple regional great powers.

\section{Ideas about Threats.}

If political elite ideas about the state's identity can help us to understand alignment outcomes, it becomes necessary to articulate how other ideas may exert a similar influence on the alignment policies of a small state with a particular regional great power. Moving from state identity, a political leader's ideas about threats emanating from the strategic environment is another key factor shaping alignment outcomes for small states in the post-Cold War era.

The merits for an analysis of a political leader's threat perceptions originate with the seminal work of Robert Jervis, who demonstrated the validity of examining leader perceptions and threat 
images as a way to explain foreign policy decisions. A key finding advanced by Jervis is that individual decision makers holding the same perceptions about actors in the political world will frequently act in a similar manner. ${ }^{295}$ Following Jervis and building on the work of David Singer, Raymond Cohen also finds an actor's threat perceptions is an instrumental variable shaping political outcomes. Of particular relevance, Cohen identifies a series of background factors that may contribute to an individual's threat perceptions of other actors in the system. These include previous interstate relations and historical experiences, the balance of national capabilities across all elements of power (diplomatic, information, military, etc.), and international institutional arrangements (i.e. international laws and norms). ${ }^{296}$

Given the central role of a political leader's threat perceptions in shaping the state's alignment trajectory, it may also be useful at this point to elaborate on the concept of national security to garner a better understanding of alignment politics. The starting point for this elaboration begins with how scholars have defined threats to the state. Neorealists like Waltz, Walt, and Mearsheimer typically define threats in two ways. First, threats are systemic in nature, emanating from outside the state, frequently from a more powerful or threatening country. Second, the threat is characterized in military terms based on an analysis of the ratio of combat forces and weapons systems, or a state's intentions to use armed force against other states.

This conceptualization of a national security based on military threats alone is problematic because it does not account for non-military challenges. Arnold Wolfers was one of the several early scholars in the post-World War II era to challenge how national security should be viewed in a more expansive way stating,

\footnotetext{
295 Jervis 1976, 29.

${ }^{296}$ Cohen, Raymond. 1979. Threat Perception in International Crisis. Madison: University of Wisconsin Press, 2526; Singer, J. David. 1958. "Threat-perception and the Armament-tension Dilemma." Journal of Conflict Resolution 2 (1).
} 
... together with the extent of the external threats, numerous domestic factors such as national character, tradition, preferences and prejudices will influence the level of security which a nation chooses to make its target. ${ }^{297}$

Following Wolfers, other scholars have argued the necessity for expanding our conceptualization of security to include non-military threats such as the environment, drugs, or poverty to name a few. ${ }^{298}$ The underlying rationale for considering these non-military threats is that they can equally create unstable domestic and international conditions, which could then topple a ruling government or bring harm to the citizens of a country.

There is, however, some scholarly opposition to this line of thinking. Walt is particularly critical of any scholarly endeavor to expand the concept of national security beyond military threats. Although Walt accepts that there are certainly other dangers to the state, military threats are frequently the most serious. Walt goes on to argue that conceptualizing threats to national security beyond the military realm is foolhardy in that,

Such proposals remind us that nonmilitary issues deserve sustained attention from scholars and policymakers, and that military power does not guarantee well-being. But this prescription runs the risk of expanding" security studies" excessively; by this logic, issues such as pollution, disease, child abuse, or economic recessions could all be viewed as threats to "security." Defining the field in this way would destroy its intellectual coherence and make it more difficult to devise solutions to any of these important problems. ${ }^{299}$

On one hand, Walt's point about conceptualizing threats to national security beyond military dangers is valid to the extent that developing a laundry list of threats could undermine any attempt to understand alignment politics. On the other hand, this dissertation posits any theory of small state alignment that simply focuses on external military threats fails to capture how other dangers may affect the strategic calculus of ruling elites in their development and

\footnotetext{
${ }^{297}$ Wolfers, Arnold. 1952. "National Security as an Ambiguous Symbol.” Political Science Quarterly 67 (4), 488. 298 See Brown, Neville. 1989. "Climate, Ecology and International Security.” Survival 31 (6) and Buzan, Barry. 1993. "Rethinking System and Structure." In Barry Buzan, Charles Jones, and Richard Little (eds.) The Logic of Anarchy: Neorealism to Structural Realism. New York: Columbia University Press, 19-80.

${ }^{299}$ Walt, Stephen M. 1991. “The Renaissance of Security Studies.” International Studies Quarterly 35 (2), 213.
} 
implementation of foreign policies. For example, Stephen Brooks argues ruling leaders may sometimes place economic considerations ahead of military power at least in the short term. According to Brooks, when security competition in the international system is low, "rational policymakers may trade off a degree of military preparedness if the potential net gains in economic capacity are substantial relative to the probability of security losses." ${ }^{300}$

The interconnectivity of economics and security demand that we take an accounting of both in a leader's perceptions of threats in the external environment where a ruling group's threat perception of other states can be based on a variety of different indicators. These indicators of external pressure include belligerent foreign policy statements, energy blackmail, and instances of military adventurism (e.g. troop deployments and exercises, intentional violations of a state's sovereign territory, or an armed attack).

Given the preceding, the theory advanced in this study considers a political leader's threat perceptions of the nearest regional great power as another important factor shaping the state's alignment. Following Walt, this study posits a political leader's threat perceptions are an important factor shaping foreign policy outcomes. But, because the focus of this study is grounded in a leader-centric approach, one cannot assume all presidents will view a particular threatening regional great power in the same way. For example, one president may perceive a nearby regional great power is a high threat to the state's security based on past or recent events. Contrary to Walt's prediction that small state's will bandwagon with the most threatening regional great power, this study predicts former Soviet states will attempt a positive bandwagoning alignment with another regional great power. Such an alignment can occur even when there are no guarantees that such actions may not lead to entry into a formal alliance with

\footnotetext{
${ }^{300}$ Brooks, Stephen G. 1997. "Dueling Realisms.” International Organization 51 (3), 447.
} 
the target regional great power.

Separately, a president in a neighboring country may view the same regional great power in a different light perceiving its past and/or current actions as a moderate threat to the state. As a result, ruling elites may believe an alignment with this regional great power remains possible in the short-term; however, they will also attempt align the state with other regional great powers as a way to maximize political, economic, or military returns that benefit the country, the ruling government, and/or individual elites. Finally, a different president may perceive the same nearby regional great power as a low threat believing the actions of this regional great power do not represent a clear and present (or future) danger to the state's security. As a result, it is highly plausible that a positive bandwagoning alignment with this state will occur. The preceding discussion generates three hypotheses:

H2a. When a president in a small state perceives a nearby regional great power as a high threat, he/she will prefer a positive bandwagoning with a different regional great power.

$H 2 b$. When a president in a small state perceives a nearby regional great power as a moderate threat, a great power bridging alignment preference is more likely.

H2c. When a president in a small state perceives a nearby regional great power as a low threat, a positive bandwagoning preference with that power is more likely.

Foreign Policy Orientation and Domestic Politics.

A core premise of the political psychology literature is that political elite perceptions, as framed by his/her ideas and beliefs, shape the broad contours of the state's national strategies with foreign states across different ruling governments. ${ }^{301}$ For example, John Lewis Gaddis argues the ideas and perceptions held by U.S. political leaders in different administrations during the Cold War resulted in alternative strategies of containment. ${ }^{302}$ Although Gaddis, like other IR

\footnotetext{
${ }^{301}$ For example, see Larson 1985 and Rosati 1987.

302 Gaddis, John Lewis. 1982. Strategies of Containment: A Critical Appraisal of Postwar American National Security Policy. Oxford University Press.
} 
scholars, falls into the 'great power bias trap,' this study believes his analytical approach has applicability to small states. As such, a third determinant of a small state's alignment with a regional great power is a political leader's foreign policy orientation, which is best understood as his/her ideas about strategy and policy vis-à-vis external states.

According to Joe D. Hagan, a ruling elite's foreign policy orientation towards the international system has the potential to vary based on his/her ranking of external state threats, their perceptions of the intensity of those threats, and a set of strategies to counter these threats. ${ }^{303}$ A political leader's foreign policy orientation can manifest itself in three distinct ways: cooperative, pragmatic, and confrontational. First, a political leader with a cooperative foreign policy orientation does not regard a regional great power as fundamentally hostile or directly threatening to the state's national security. Cooperative ruling leaders tend to see a wide array of important strategic issues in the international system that requires constructive engagement and collaboration in order to find mutually beneficial resolutions. As a result, this leader may view a particular regional great power in a positive light and will then attempt to develop and implement a wide array of mutually beneficial foreign policies with this state.

A political leader with a pragmatic foreign policy orientation perceives a regional great power to be a potential national security threat; however, this threat is manageable and does not require immediate consideration. Pragmatic rulers generally maintain restrained foreign policies vis-àvis a regional great power since this country is viewed as having limited goals that are frequently materially constrained thus making it difficult to exert excessive, consistent pressure. While confrontation is still possible, because this regional great power does not pose an immediate threat, pragmatic leaders have time to exercise diplomacy and engage in bargaining and mutually

\footnotetext{
${ }^{303}$ Hagan 1994, 147.
} 
beneficial cooperation. Pragmatic elites often espouse positive or mixed verbal statements about two or more regional great powers. Finally, these pragmatic political leaders routinely are able to translate their levels of verbal cooperation with multiple great powers into foreign policies that that place both regional great powers on the same level.

A political leader with a confrontational foreign policy orientation perceives a regional great power to be inherently dangerous where strategic interactions are almost always a zero-sum game. Political leaders with a confrontational foreign policy orientation believe a regional great power is pursuing a set of strategic objectives that are (or will be) detrimental to the small state's long-term good. This confrontational approach is exacerbated by the fact the regional great power has access to adequate material resources, political support, or public backing to realize its goals. Under these conditions, ruling elites in a small state frequently use negative statements about this regional great power as a threat to national security and regional stability.

While a president's foreign policy orientation may be a catalyst moving a state to implement a particular set of foreign policies with other actors in the international system, he/she does not operate in a political vacuum that would allow him to translate his/her ideas about strategy into action unhindered. With this point in mind, one must now ask: what are the major internal factors affecting the ability of a ruling group to align with one regional great power over another? While a plethora of internal factors such as public opinion, special interest groups, and the media can constrain the ruling group's public foreign policy actions, it becomes necessary to narrow the range of potential variables. Although each domestic factor on its own may be a viable constraint or enabler of state action, this study argues internal political opposition is the most important for two reasons. ${ }^{304}$ First, since the FPE is but one component of the state's bureaucratic apparatus,

\footnotetext{
${ }^{304}$ This argument follows the work of Joe Hagan, Barbara Salmore, Stephen Salmore, and Jack Snyder. See Hagan, Joe D. 1987. "Regimes, Political Oppositions, and the Comparative Analysis of Foreign Policy." In New Directions
} 
the first line of resistance to decisions from this element will likely occur from oppositionist elements within the state's bureaucracy. Second, in most instances, the elected representatives offering opposition or support to the leaders in the FPE to some extent represent the views held by various societal groups.

Separately, as noted above, this study recognizes how domestic politics can exert various levels of influence on all three of the explanatory variables under examination. However, given the structure of this study where state identity and threat perceptions help frame a political leader's alignment preferences and his/her foreign policy orientation represents a conduit for translating those preferences into action, the relevance of domestic politics is more applicable to the latter. The underlying logic here is that when ruling elites attempt to translate their alignment preferences into action, it is at this point domestic politics become the most relevant since likeminded and competing political groups are more likely to demonstrate their support or opposition for these leading political figures.

In this study, internal opposition is defined as the extent to which the chief executive is politically able to implement and maintain his/her preferred set of alignment policies. Internal opposition is comprised of two key elements: issue polarization and government fragmentation. Issue polarization refers to the level of consensus within the ruling government on the lead foreign policy executive's ideas about an alignment with a particular regional great power. Government fragmentation focuses on the characteristics of the state's bureaucracy and whether the power to implement strategy and policy is (de)centralized in the ruling government. ${ }^{305}$

Because ruling elites operate in a competitive domestic political environment comprised of

\footnotetext{
in the Study of Foreign Policy. Boston: Allen and Unwin; Hagan 1994; Salmore, Barbara G. and Stephen A. Salmore. 1978. "Political Regimes and Foreign Policy." In Why Nations Act. Beverly Hills: Sage; Snyder, Jack. 1991. Myths of Empire: Domestic Politics and International Ambition. Ithaca, NY: Cornell University Press. ${ }^{305}$ Hagan 1994, 151-156.
} 
groups with differing conceptions of the state's foreign policy priorities, each of these groups compete for position, power, and influence as a way to advance their own political agenda. When a foreign policy issue such as security cooperation becomes a polarizing topic across the state apparatus, the leading member in the FPE (e.g. the president) must form viable coalitions that ensure his/her preferred national security and economic preferences are implemented and sustained; however, this may become more challenging if the political system is fragmented or if there are other vital national interests such as the economic well-being of the country are at risk.

A primary factor reinforcing or constraining political polarization is the structure of the existing political system within a country. Recognizing the scholarly debate over the freedom of action of ruling elites in different regimes, a premise advanced in this study is that regardless of the type of the government (democracy, anocracy, or autocracy), all political leaders operate under a set of structural constraints, which can influence the state's foreign policies and alignment trajectory with regional great powers. For example, Hagan finds that in a fragmented government comprised of multiple autonomous political groups with various levels of power, the ability of ruling elites to realize their preferences becomes difficult unless these leaders build a political coalition without disenfranchising members from their political base. ${ }^{306}$

Beyond fragmentation, a variety of factors can intensify or temper polarization. For example, second to security, a country's economic standing is critically important. A variety of scholars have noted the centrality of economic factors in government and the relations between domestic political groups. ${ }^{307}$ On one hand, domestic economic prosperity can facilitate the stable functioning of the state's bureaucratic organizations thus allowing ruling elites to politicize the

\footnotetext{
${ }^{306}$ Ibid, 144-145.

${ }^{307}$ For example, see Magaloni, Beatriz. 2006. Voting for Autocracy: Hegemonic Party Survival and its Demise in Mexico. Cambridge: Cambridge University Press, 91-110.
} 
merits of their policies, while undermining the rhetoric of political opposition groups and the potential for defectors. Under deteriorating economic conditions, political opposition groups gain allies and the support of various societal elements (e.g. business groups) that allow them to exert increased pressure on the ruling group to change an alignment trajectory. For example, Kevin Narizny argues the involvement of domestic groups in the international economy determined British preferences over alignment in the early first half of the $20^{\text {th }}$ century. In his words...

When domestic groups with different alignment interests separate into opposing coalitions, societal debates over international strategy will become polarized along party lines. Each side will view "national interests" through the prism of its own economic interests, believing that what is best for itself is best for the country as a whole. ${ }^{308}$

This leads me to advance the following hypotheses:

H3a: A president who retains an accommodative foreign policy orientation with a regional great power is more likely to follow a positive bandwagoning with that target state.

H3b: A president who retains a pragmatic foreign policy orientation is more likely to pursue a great power bridging alignment.

H3c: (Corollary): A confrontational foreign policy orientation with one regional great power accelerates positive bandwagoning with a different regional great power.

\section{H3d: Higher or lower levels of government fragmentation and issue polarization will constrain or enable respectively a president's preferred alignment strategy.}

To recap, the preceding sections highlighted how a political leader's ideas about the state's identity, his/her threat perceptions of external regional great powers, and his/her accompanying foreign policy orientation as conditioned by domestic politics are the three primary variables explaining small state alignment in the post-Soviet space. As noted in the introductory section of this chapter, the primary focus of this dissertation is to examine the relationship between each of these three factors and the dependent variable (alignment). To accomplish this task, this study

\footnotetext{
${ }^{308}$ Narizny, Kevin. 2003. "Both Guns and Butter, or Neither: Class Interests in the Political Economy of Rearmament.” American Political Science Review 97 (2), 191.
} 
will devote a separate chapter to each explanatory variable. By doing so will also help facilitate a more holistic understanding of this political phenomenon and how one factor, on its own, cannot adequately explain small state alignment in the post-Soviet space.

\section{Accounting for the Indirect Influence of the Independent Variables}

The preceding discussion and hypotheses represent a center of gravity for this study's crossnational comparison on the relationship between a president's ideas about the state's identity, his/her threat perceptions, and foreign policy orientation as conditioned by domestic politics. However, it is plausible each of these three independent variables may also influence one another and in doing so, convey an indirect influence on the dependent variable. Although beyond the scope of this dissertation, a comparison of the findings on the direct influence of the three IVs on the dependent variable should also be undertaken in order to orient future research.

As noted above, this study's conceptual model noted how the three IVs may interact in a sequential manner: state identity $\rightarrow$ threat perceptions $\rightarrow$ foreign policy orientation. The foundation for this sequential relationship can again be derived from SIT and SCT. Here, how political leaders identify which states as threats or as friendly cannot occur unless the "self" is set in relation to "others" in the international system. A key point here is threat perceptions are fundamentally relational in nature and that there exists a two-way process that through "the identity/difference nexus" the 'self' is set apart from the 'other. ${ }^{309}$ An important corollary here is that a political leader's ideas about the state's identity can, in itself, affect his/her threat perceptions about different regional great powers. In this case, a shared sense of state-identity can serve as a demarcation for the identification of a regional great power as a friend or foe. For example, one could advance a general hypothesis that the more a ruling group perceives the state

\footnotetext{
${ }^{309}$ Rumelili, Bahar. 2004. "Constructing Identity and Relating to Difference: Understanding the EU's Mode of Differentiation." Review of International Studies 30 (1), 37.
} 
to be Pan-Islamic, the more antagonistic it may be towards Israel. Another general example is as follows: the more a ruling group espouses a revisionist state identity the more competitive and hostile it will be with status-quo states.

Subsequently, a political leader's threat perceptions may also be a shape agent for this foreign policy orientations with different regional great powers. In this case, a president who perceives a regional great power as a low threat, may then exhibit a more accommodative foreign policy orientation and a tendency for positive bandwagoning with this target state. Simultaneously, when a president's ideas about the state's identity are not as similar with a particular regional great power, there may be a tendency to view this state as more of a threat. When threat perceptions of a particular regional great power increase, a pragmatic orientation and great power bridging will follow. Finally, when a president's threat perceptions become so high, he/she may adopt a confrontational foreign policy orientation with that target country. This may then spur a president to prefer a positive bandwagoning alignment with a different regional great power.

\section{Conclusion.}

This chapter detailed a new approach to understanding small state alignment in the post-Cold War era. Leveraging aspects of SIT and SCT, this study posits that political leader ideas and their belief systems represent a center of gravity driving a ruling government to align with one regional great power over another. Specifically, a political leader's ideas about the state's identity, his/her threat perceptions, and foreign policy orientation as conditioned by domestic politics can independently impact the alignment trajectory of the state with different regional great powers. Building on Schweller's balance of interest theory, small state alignment can occur in two ways: positive bandwagoning or great power bridging.

As detailed in the graphic depicting the conceptual framework above, this study narrows the 
scope of research to an in-depth examination of the relationship between each of the explanatory variables (state identity, threat perceptions, and foreign policy orientation as conditioned by domestic politics) and the dependent variable (alignment). These examinations represent the main effort of this research project. Chapter Five will focus on the relationship between a political leader's ideas about state identity and his/her alignment preferences with the U.S. and Russia. Chapter Six then delves into an examination of how a political leader's threat perceptions may influence his/her alignment preferences. Finally, in Chapter Seven as assessment between a political leader's foreign policy orientation, as conditioned by domestic politics is undertaken.

Separately, a superficial analysis of the findings from each of these investigations is made in order to discern how the independent variables may sequentially interact with one another. Since this assessment, while important, is of secondary importance in this study owing to time, space, and scope, the findings of this endeavor are discussed in a separate section found in the concluding chapter of this dissertation. As will be discussed there, the conclusions derived from this effort can serve as a foundation for future research. 
"Treat your friend as if he will one day be your enemy, and your enemy as if he will one day be your friend." - Decimus Laberius, First Century B.C..$^{310}$

\section{CHAPTER FOUR - METHODS AND ANALYSIS}

\section{Introduction}

This dissertation is a structured focused comparison that uses multiple methods to examine the alignment tendencies of former Soviet states with the United States and Russian Federation between 1995 and 2015. To better understand small state alignment in the post-Cold War era, one must conduct a multi-level analysis, which begins with an examination of the ideas and beliefs of the lead actor in the state's foreign policy executive. Here, the locus of analysis centers on a president's conceptions about the state's identity and his/her threat perceptions of different regional great powers. While this examination provides insight into a president's alignment preferences, to more fully understand the state's alignment trajectory, one must also consider a president's ideas about strategy and how domestic politics may condition the ability of the president to translate his/her alignment preferences into action.

The purpose of this chapter is to detail the methods and the critically important preliminarily analyses guiding this study. In the first section, the key terms used in this study are defined in order to provide increased clarity on their usage. In section two, this study's research design is detailed. Specific topics include the qualitative and quantitative methods employed, the operationalization of variables, measurement, and case selection. With regard to case selection, to prevent selecting cases based on the dependent variable or other associated case-selection

\footnotetext{
310 This quote is attributed to Decimus Laberius, a Roman knight, who purportedly lived sometime during the first century, B.C. Citied in Pipes, Richard. 1997. "Is Russia Still an Enemy?" Foreign Affairs (76) 5, 65.
} 
biases, this study applied a series of alignment indicators developed by Henry Teune and Sig Synnestvedt to identify four outlier cases_-Azerbaijan, Georgia, Moldova, and Ukraine — worthy of a more in-depth investigation.

\section{Definition of Key Terms}

To adequately understand the alignment tendencies of small states requires a clear and succinct set of definitions of the key terms associated with this study.

Small State. Various scholars have advanced several hierarchical schemes to differentiate between great and small powers in the international system; however, most of these classifications focus exclusively on material factors. ${ }^{311}$ Given this study's emphasis on political elite ideas, beliefs, and perceptions, a psychological dimension to differentiate a hierarchy of states is warranted and not unprecedented given past scholarly efforts to do so. ${ }^{312}$ For simplicity, this dissertation follows Robert Keohane by defining a small state as a "...state whose leaders consider that it can never, acting alone or in a small group, make a significant impact on the system." ${ }^{\prime 313}$ From this conceptualization, small states are best understood as materially and/or institutionally weak in nature lacking the necessary resources or knowledge to act in an autonomously beneficial way in the international system.

Alliance versus Alignment. It is also very important to differentiate between the concepts of alliance and alignment. Recalling Teune and Synnestvedt's sage advice, "as a first step in

\footnotetext{
${ }^{311}$ See Clark, Ian. 1989. The Hierarchy of States: Reform and Resistance in the International Order. New York: Cambridge University Press, 2; Schweller, Randall L. 1998. Deadly Imbalances: Tripolarity and Hitler's Strategy of World Conquest. Columbia University Press, 17-18; Schweller and Pu 2011, 42; Waltz 1979, 131.

${ }^{312}$ See Bull, Hedley. 1977. The Anarchical Society: A Study of Order in World Politics. London and Basingstoke: Macmillan, 202; Guzzini, Stefano. 2006. "From (Alleged) Unipolarity to the Decline of Multilateralism? A Powertheoretical Critique." In Edward Newman, Ramesh Thakur and John Tirman (eds), Multilateralism Under Challenge? Power, International Order, and Structural Change. New York: United Nations University Press, 133.

${ }^{313}$ Keohane, Robert O. 1969. "Lilliputians' Dilemmas: Small States in International Politics." International Organization 23 (2), 296. On the differences between a strong and weak state, see Migdal, Joe S. 1988. Strong Societies and Weak States: State-Society Relations and State Capabilities in the Third World. Princeton: Princeton University Press, 4-5.
} 
developing a theory as to why countries are aligned, or establishing the factors pre-disposing them to align, the concept of alignment must be clarified." 314 Because there are no universally accepted definitions of alliance and alignment owing to their ambiguous nature, it becomes extremely important to develop useful conceptualizations of these concepts to avoid theoretical and methodological missteps. With these points in mind, this study conceptually defines alignment as an informal or less-binding formal set of expectations between a small state and a regional great power. This definition is grounded in Ward's notion of how alignment is a broadbased endeavor that is reflective of the ruling elites' beliefs and ideas about world politics. ${ }^{315}$ Unlike Modelski, who refers to alignment as an all-encompassing term that refers to all forms of international cooperation, this definition narrows the phenomenon to three vitally critical areas including political/diplomatic, economic, and military activities.

An alliance represents the cumulative alignment activities of a small state that results in its accession into a formal security or economic bloc. When political leaders sign a formal agreement, their act represents an unambiguous commitment to adhere to the protocols governing member behavior in a military alliance or economic union. An alliance is thus defined as a formal written agreement or treaty between two or more sovereign states to take some form of military or economic-related action based on established protocols and provisions.

Foreign Policy Executive. This dissertation adopts Norrin Ripsman's conception on the existence of a foreign policy executive (FPE) inside the state's bureaucratic apparatus. Following his lead, a state's FPE is defined as a decision-making unit comprised of the most senior political and military members of the state. This decision-making unit resides within the ruling government, which is subsequently defined as the set of mandated governmental organizations

\footnotetext{
314 Teune and Synnestvedt 1965, 23.

315 Ward 1982.
} 
that have legal control over the policymaking entities of the state's institutions. Individuals in the FPE are responsible for developing, approving, and directing the implementation of the state's foreign policies with other states. Individuals in this group also have the de facto authority to commit or withhold resources of the state as it relates to a particular foreign policy decision. Individuals comprising the FPE may include the president, prime minister, national security advisor, or the ministers of state and defense. ${ }^{316}$ In this study, the focus will be on the lead actor in the FPE, which is the president.

State Identity. To understand change and continuity in the alignment patterns of small states, this study advances an argument on the necessity to examine political elite ideas ${ }^{317}$ about the state's identity in world affairs. State identity is best understood as the public articulation of the foreign policy executive's ideas about the country's purpose in international affairs. ${ }^{318}$ As a key determinant of alignment, state identity serves as the primary point of departure from which to understand the why political elites prefer to align with one regional great power over another.

For the purpose of this study, state identity is differentiated from national identity in several ways; however, both overlap to some extent. First, from one perspective national identity is

\footnotetext{
${ }^{316}$ Ripsman, Norrin M. 2002. Peacemaking by Democracies: The Effect of State Autonomy on the Post-World War Settlements. University Park, PA: Penn State Press, 43-44. On decision units, see also Hermann, Margaret G., Charles F. Hermann and Joe. D. Hagan. 1987. "How Decision Units Shape Foreign Policy Behavior." In Charles F. Hermann, Charles W. Kegley, Jr. and James N. Rosenau (eds.) New Directions in the Study of Foreign Policy. London: Allen \& Unwin, 315-316; Hagan, Joe D. 1994. "Domestic Political Regime Change and Foreign Policy Restructuring: A Framework for Comparative Analysis." In Foreign Policy Restructuring: How Governments Respond to Global Change edited by Jerel A. Rosati, Joe D. Hagan, and Martin W. Sampson. Columbia, SC: University of South Carolina Press; Hagan, Joe D. 2015. "Coalition Politics and Foreign Policy Decision Making in Anocratic Regimes." Paper Prepared for Presentation at the Annual Meeting of the British International Studies Association, Edinburgh, UK; June 17-19, 2016.

${ }^{317}$ I follow Albert Hirschman's definition of ideas which are those "beliefs, principles and attitudes" driving foreign policy action. Hirschman, Albert O. 1961, "Ideologies of Economic Development in Latin America" In Albert O. Hirschman (ed.), Latin American Issues. New York: Twentieth Century Fund, 3.

318 This definition is based upon the work of Michael Barnett (1996), Marc Lynch (1998), Masahiro Matsumura (2008) and Virginia Tilley (2012). See Barnett 1996; Lynch 1998; Matsumura, Masahiro. 2008. "The Japanese State Identity as a Grand Strategic Imperative.” Working Paper for the 2006-2007 Visiting Fellows Program at the Brookings Institution's Center for Northeast Asian Policy Studies (CNAPS). The Brookings Institution Center for Northeast Asian Policy Studies, Washington D.C.; and Tilley, Virginia. 2012. "The Ethnic State.” In Emancipating Cultural Pluralism, edited by Cris E. Toffolo. New York: SUNY Press.
} 
determined internally by societal actors, who share a sense of communal unity and distinctness based on a historical myths, territory, language, norms, and religion. ${ }^{319}$ As Tsygankov notes, "national identity is a cultural norm that reflects emotional or affective orientation of individuals toward their nation and national political system." ${ }^{320}$ Second, internal and external factors (i.e. the strategic context) determine how a ruling government defines the state's identity. Internally, ruling elites can be a reflection of the shared national identity narratives that form the "imagined community;" ${ }^{321}$ however, a state identity is also relational in nature where the state understands itself in terms of purpose or function vis-à-vis the significant 'others' in the international system. According to Dovile Jakniunaite, "[state] identities are not defined and supported one-way, just by the self. How the other thinks about us influences our own identity constructions." 322 Given the preceding, while there may be one national identity in most cases, ruling elites may simultaneously hold several conceptions of the state's identity in world affairs.

Threat Perceptions. If political elite ideas about the state's identity can help us to understand a political leader's alignment preferences, it becomes necessary to articulate how these ideas influence policy. Another key mechanism by which a political leader's ideas may impact policy is through his/her perceptions of the strategic environment. ${ }^{323}$ Building on Randall Schweller's work, I conceptually define threat perceptions as a political leader's anticipation of military, diplomatic, and/or economic harm from other states in the international system that pose a risk to the security and economic well-being of the country, its citizens, and/or the ruling government.

\footnotetext{
319 See Telhami and Barnett 2002; also, Tsygankov, Andrei. 2001. Pathways After Empire: National Identity and Foreign Economic Policy in the Post-Soviet World. Rowman \& Littlefield Publishers.

320 Tsygankov 2001, 15.

${ }^{321}$ Andersen, Benedict. 1991. Imagined Communities: Reflections on the Origin and Spread of Nationalism. New York: Verso.

${ }^{322}$ Jakniunaite, Dovile. 2009. "Neighborhood Politics of Baltic States: Between the EU and Russia." In Eiki Berg and Piret Ehin (eds.) Identity and Foreign Policy: Baltic-Russian Relations and European Integration. Burlington, VT: Ashgate Publishing, 118.

323 Tannenwald 2005.
} 
Political leader threat perceptions can be actual (e.g. armed attack), potential (e.g. coercive diplomacy, the massing of military forces, etc.), or imagined (i.e. no valid empirical evidence to support an objective assessment of the situation). ${ }^{324}$

Foreign Policy Orientation. Foreign policy orientation is defined as those beliefs held by leading actors in the foreign policy executive about the optimal strategic approaches to achieve a pre-determined set of strategic objectives or preferences with respect to other states in the international system. In essence, a political leader's foreign policy orientation is all about strategy and how best to achieve a goal given available tangible (military capabilities, economic capacities, etc.) and intangible (political will, public support, etc.) resources. Additionally, political leaders are able to simultaneously hold multiple foreign policy orientations about different states in the system. For example, a president may view a strategy of cooperation with one regional great power but with another, confrontation is a more optimal approach.

\section{The Research Design}

The sections below detail the various facets of this project's research design.

\section{Unit of Analysis}

The lead actor (e.g. the president) in the state's foreign policy executive is the primary unit of analysis for this project. ${ }^{325}$ As noted above, the foreign policy executive is comprised of a set of senior political elites, who have the authority to develop and implement the state's foreign policies. The lead actor in this group, is assumed to have the most influence in the decisionmaking process to commit or withhold state resources to align with external powers. State-level

\footnotetext{
${ }^{324}$ Schweller, Randall L. 2010. Unanswered Threats: Political Constraints on the Balance of Power: Political Constraints on the Balance of Power. Princeton: Princeton University Press.

325 The various methods in this study delineate the unit of analysis as leader/year.
} 
factors (e.g. domestic politics) are also integrated into an analysis of the relationship between a president's foreign policy orientation and the state's alignment trajectory.

\section{Assumptions}

This dissertation makes several key assumptions. First, foreign policy elites are rational actors, who want to stay in office or move into positions of increased power. As such, this study assumes the words spoken by a president are related to his/her ideas and beliefs about foreign policies, and that these ideas and beliefs are subsequently linked to his/her actions. ${ }^{326}$ Second, the head of state (e.g. president) is one of the most influential actor(s) in the FPE because he/she sets the state's foreign policy agenda and priorities. Third, although the head of state sets the foreign policy agenda, other domestic political actors can exert varying levels of direct or indirect influence on different foreign policy outcomes.

Fourth, this dissertation assumes the international system since the end of the Cold War is best characterized as multipolar. ${ }^{327}$ Two reasons support this assumption. First, the five permanent members of the United Nations Security Council (UNSC) to include the United States, Great Britain, France, China, and Russia still retained the ability via the ballot in the United Nations (UN) to shape world affairs on a variety of issues. Second, countries such as India, Pakistan, and North Korea have a nuclear weapons capability. ${ }^{328}$ This reality allows these counties a marked advantage in shaping the actions of other states in a regional or global context.

\footnotetext{
${ }^{326}$ Suedfeld, Peter, Karen Guttieri, and Philip E. Tetlock. 2003. “Assessing Integrative Complexity at a Distance: Archival Analyses of Thinking and Decision Making." In Jerrold M. Post (ed.) The Psychological Assessment of Political Leaders: With Profiles of Saddam Hussein and Bill Clinton. Ann Arbor, MI: University of Michigan Press, 246-270.

${ }^{327}$ I define a multipolar system as an international system comprised of three or more countries that either regard themselves or are regarded by other states as being a regional center of power.

${ }^{328}$ Margaret Gowing and Arnold Lorna argue that France and Great Britain acquired nuclear weapons after World War II as a way to offset their loss of conventional military or economic prowess. See Gowing, Margaret, and Lorna Arnold. 1974. Independence and Deterrence. Britain and Atomic Energy, 1945-1952. Volume I. Policy Making. Palgrave Macmillan.
} 


\section{Qualitative and Quantitative Techniques}

This dissertation uses multiple methods to understand the alignment tendencies of political leaders in small states since the end of the Cold War. Following Michael Coppedge's sage insight on the utility of multi-methods, one can potentially acquire a more holistic understanding of complex political phenomena by combining qualitative and quantitative methods into a research project. While small-n studies provide 'thick' (i.e. complex and/or multidimensional) concepts and theories that produce in-depth description for making analytical inferences, they routinely are not easily generalized to other cases. Separately, econometric techniques frequently generate 'thin' (i.e. reductionist and/or simplistic) concepts and theories; however, they are wellsuited for testing hypotheses for a large number of cases and for making broad generalizations on causation. ${ }^{329}$ When combined, a multi-method approach allows scholars to bridge the various levels of analysis thereby providing a more comprehensive understanding of complex topics.

Qualitative Techniques. The qualitative component of this dissertation is best understood as a longitudinal structured focused comparison that uses case studies and process-tracing to understand a president's alignment tendencies. Charles Ragin asserts scholars can use cross-case comparisons to effectively examine complex conjunctural causation, where not one single factor on its own is responsible for a political outcome. ${ }^{330}$ Additionally, because this dissertation does not seek to create an all-encompassing, universal IR theory on small state alignment, a case study approach is also appropriate. According to John Mearsheimer and Stephen Walt, "grand theories such as realism or liberalism purport to explain broad patterns of state behavior, while so-called

\footnotetext{
${ }^{329}$ Coppedge, Michael. 1999. "Thickening Thin Concepts and Theories: Combining large N and Small N in Comparative Politics." Comparative Politics 31 (4), 465.

${ }^{330}$ Ragin, Charles C. 2014. The Comparative Method: Moving Beyond Qualitative and Quantitative Strategies. University of California Press.
} 
middle-range theories focus on more narrowly defined phenomena like economic sanctions, coercion, and deterrence," 331 and in the case of this dissertation, alignment.

This dissertation also employs process-tracing, which allows for an in-depth examination of the cases to explore the relationships between the independent and dependent variables. Again, George and Bennett reminds us, "process-tracing can strengthen the comparison by helping to assess whether differences other than those in the main variable of interest might account for the differences in outcomes." 332 Furthermore, because this study seeks to understand change and continuity in the alignment trajectories of former Soviet states, using process-tracing can reveal why a small state may attempt to align with one regional great power at one particular time, but then at a different time and under a different set of ruling elites align with a different regional great power. Taken together, this qualitative technique is well suited for this dissertation because it allows for an enhanced ability to determine the relevance of the factors affecting alignment while bolstering the validity of the analytical conclusions.

Quantitative and Statistical Techniques. This dissertation also uses various quantitative and statistical techniques as well as automated social analytical programs to better understand the relationship between the independent and dependent variables. First, this study used the MaxQDA software program to conduct an automated content analysis of each president's state identity narratives. To analyze a president's belief system, Social Science Automation's Profiler Plus was used to code the Verb in Context System (VICS) indices of all presidents from 19952015. Profiler Plus is a computerized content analysis software program that allows academics to identify the operational code of individuals by drawing inferences about his/her political beliefs

\footnotetext{
${ }^{331}$ Mearsheimer, John J. and Stephen M. Walt. 2013. "Leaving Theory Behind: Why Simplistic Hypothesis Testing is Bad for International Relations." European Journal of International Relations 19 (3), 432.

${ }^{332}$ George and Bennett 2005, 81.
} 
from their verbal or written statements. There are several advantages to using MaxQDA and Profiler Plus: expediency and efficiency. In terms of speed, these automated systems allow scholars to quickly process a large number of a president's speeches, interviews, or remarks. Second, Profiler Plus boasts 100 percent coder reliability. ${ }^{333}$

This study also uses R to conduct analysis of variance (ANOVA) and Tukey's Honest Significant Difference (HSD) tests. ${ }^{334}$ A One-way ANOVA will be used to make some general inferences about a president's operational code indices. As will be discussed below, there is value in using an operational code analysis of ruling elites as a way to establish a baseline understanding of their various beliefs about world politics and the strategies to realize their goals. In this study, ANOVA tests will only be applied when there are more than two presidential groups to be compared. As such, ANOVA test will be used to determine whether there are statistically significant differences in the operational codes for the three presidents in Georgia and Moldova, as well as the four presidents in Ukraine. The independent variable in this Oneway ANOVA is a categorical variable: president. The dependent variable is the mean of each president's master philosophical (P-1) or master instrumental beliefs (I-1) while in office.

While a One-way ANOVA can let us know if there are statistically differences in the operational codes of presidents, this test does not reveal where those differentiations exist. To achieve this level of granularity, a Tukey's HSD test is used as a post-hoc test to determine which presidents are the most similar and different in their operational codes for the P-1 and I-1

\footnotetext{
${ }^{333}$ Schafer, Mark, and Stephen Walker, eds. 2006. Beliefs and Leadership in World Politics: Methods and Applications of Operational Code Analysis. New York: Palgrave Macmillan, 39.

${ }^{334}$ The decision to use ANOVA and Tukey's HSD test in this study was guided by the scholarly work of Sam Robinson and Huiyun Feng. See Robison, Sam. 2006. "George W. Bush and the Vulcans: Leader-advisor relations and America's response to the 9/11 attacks." In Mark Schafer and Stephen Walker (eds.) Beliefs and Leadership in World Politics: Methods and Applications of Operational Code Analysis. New York: Palgrave Macmillan; Feng, Huiyun. 2006. "Crisis Deferred: An Operational Code Analysis of Chinese Leaders Across the Strait." In Mark Schafer and Stephen Walker (eds.) Beliefs and Leadership in World Politics: Methods and Applications of Operational Code Analysis. New York: Palgrave Macmillan.
} 
indices. Finally, descriptive statistics provided insight and perspective on various topics or events.

\section{$\underline{\text { Measurement }}$}

State Identity. To measure each president's ideas about the state's identity, this study used the MaxQDA analytical software program. ${ }^{335}$ In this study, a conceptual analysis is employed to understand the level of significance each president gave to a specific state identity concept. The methods employed in this conceptual analysis follows the steps outlined by Kathleen Clary in her 1993 article "Coding Choices for Textual Analysis: A Comparison of Content Analysis and Map Analysis." The level of analysis is the single word in each president's speeches, addresses, and interviews for each year in office.

Based on input from area specialists and a review of the literature, state identity was operationalized into 18 concepts under five general categories: political (independent, former Soviet, freedom, liberty), ideological (democracy, liberal and communism), economic (market and modern), cultural (European, Slavic, Western, Eastern, Eurasian), religious (Orthodox, Christian, Islamic, secular). The scale of measurement employed for state identity is an ordinal measurement. Specifically, this effort seeks to identify an order of magnitude for each of the state identity concepts by tabulating the frequency these concepts appear in the speeches of each president on an annual basis. Because the number of speeches will vary from year to year, the by-year order of magnitude of each concept will be divided by the total number of words in all the speeches for that year. Irrelevant words (e.g. 'a,' 'and,' 'with,' 'the', etc.) are not included in the word count. ${ }^{336}$

\footnotetext{
${ }^{335}$ MAXQDA, software for qualitative data analysis, 1989-2018, VERBI Software - Consult - Sozialforschung GmbH, Berlin, Germany.

${ }^{336}$ Carley, Kathleen. 1993. "Coding Choices for Textual Analysis: A Comparison of Content Analysis and Map Analysis.” Sociological Methodology 23, 81-87.
} 
Threat Perceptions. Measuring a president's threat perceptions can be a challenging and complicated endeavor for many reasons. In many instances, a country's head of state will never consent to a request by an academic for an elite interview. Even if a researcher is granted access, a high-level political figure may not disclose his/her true perceptions owing to political sensitivities or his/her knowledge of classified information. Despite these challenges, various research institutes like the Pew Research Center ${ }^{337}$ have used interviews with policy analysts and polls as one way to measure an individual or groups' ideas about the nature of various external threats. This study mirrors such an effort by interviewing area specialists and regional experts to garner their professional assessment of how each president in this study perceived the primary external threats to the state's security. Additionally, a content analysis of a president's public speeches helped derive empirical observations on how each president perceived the intensity of these external, state-based threats. Where this study diverges from others is in the incorporation of an operational code analysis for each president during his/her time in office. The rationale for undertaking this step is explained in the paragraphs below. ${ }^{338}$

A president's operational code will be used as a tool to establish a baseline of how each president views the nature of world politics. Introduced by Nathan Leites and subsequently enhanced by Alexander George and more recently reinvigorated by Mark Schafer and Stephen Walker, an operational code analysis is one way to understand a political leader's beliefs and

\footnotetext{
${ }^{337}$ The Pew Research Center routinely uses poll data as a way to discern how various individuals perceived different external threats to their country's national security. For example, see Poushter, Jacob and Dorothy Manevich. "Globally, People Point to ISIS and Climate Change as Leading Security Threats." The Pew Research Center, 01 August 2017. http://www.pewglobal.org/2017/08/01/ globally-people-point-to-isis-and-climate-change-as-leadingsecurity-threats/. Accessed 02 September 2017.

${ }^{338}$ Many thanks to Dr. Michael Young for all of his time, insight, and assistance with this part of my research project. Dr. Young is an Assistant Professor at the University of Albany and President of Social Science Automation, Inc. It is through his work and direct assistance on using the Profiler Plus program that I have come to appreciate the value in integrating an operational code analysis of political leaders into any leader-centric scholarly research effort.
} 
their potential impact on foreign policy. ${ }^{339}$ Using an operational code analysis can reveal the kind of president or prime minister in power, which in turn can directly or indirectly establish the nature of the state's actions in world politics. Of particular relevance is how this "at-distance" method can illuminate the extent to which beliefs may "steer the decisions of leaders by shaping the leaders' perceptions of reality, acting as mechanisms of cognitive and motivated bias that distort, block, and recast incoming information from the environment." 340 As a point of clarity, a president's operational code is by no means deterministic. Alexander George poignantly reminds us that an operational code is best understood as a "set of guidelines-heuristical aids to decision, that essentially frame's a political leader's bounded rationality." ${ }^{341}$ Put another way, an operational code analysis will not provide the necessary specificity on a president's alignment preferences with a specific regional great power. For this, a qualitative analysis will be utilized. As an analytical touchstone, a political leader's operational code is scaled along two master indices: philosophical (denoted as P-1) and instrumental (denoted at I-1) beliefs. To establish a baseline on a political leader's beliefs about threats in the international system, the focus of analysis centers on his/her philosophical beliefs (P-1), which detail his/her view of world politics, political conflict, and the nature of the international system. A key assumption with the master philosophical beliefs is that, “... beliefs about how others approach and pursue their goals in the political universe define the nature of politics, political conflict, and the image of the opponent for the leader." 342 While a president's master philosophical beliefs are the main focus

\footnotetext{
${ }^{339}$ Leites, Nathan C. 1951. The Operational Code of the Politburo. New York: McGraw Hill; George 1969; Schafer and Walker 2006.

340 Schafer and Walker 2006, 5.

${ }^{341}$ George, Alexander. 1979. "The Causal Nexus between Cognitive Beliefs and Decision-Making Behavior: The 'Operational Code' Belief System.” In Psychological Models of International Politics ed. Lawrence S. Falkowski. Boulder, CO: Westview, 103.

342 Walker, Stephen G., Mark Schafer and Michael D. Young. 1998. "Systematic Procedures for Operational Code Analysis: Measuring and Modeling Jimmy Carter’s Operational Code.” International Studies Quarterly $42: 178$.
} 
of this study, there are four other categories all related, in part, to the P-1 category: P-2:

Prospects for Realizing Fundamental Values; P-3: Predictability of the Political Universe; P-4:

Control Over Historical Development; P-5: Role of Chance. The category description,

measurement, and accompany questions related to a political leader's philosophical beliefs are as

follows: ${ }^{343}$

P-1: The Nature of the Political Universe. This all-encompassing belief captures the political leader's views about the nature of the international system and its actors. The index for this belief is a frequency ratio of a political leader's positive and negative comments about other actors. The value for this index varies between +1 to $-1(-1=$ very hostile; $-.50=$ definitely hostile; $-.25=$ somewhat hostile; $0.0=$ mixed $;+25=$ somewhat friendly; $+.50=$ definitely friendly; $+.75=$ very friendly). Beliefs P-2 to P-5 are subsequently related to the master belief (P-1) Questions in this category: What is the 'essential' nature of political life? Is the political universe essentially one of harmony or conflict? What is the fundamental character of one's political opponents?

P-2: Prospects for Realizing Fundamental Values. This belief measures the manner in which a political leader perceives the intensity of another actor's actions in the international system. Verbs in this category are first weighted ( +3 to -3$)$ based on an intensity value. This result is divided by the total number of coded verbs, which gives an index that ranges from -1 (pessimistic) to +1 (optimistic). The scale used in this study is as follows: $(-1=$ very pessimistic; $.50=$ definitely pessimistic; $-.25=$ somewhat pessimistic; $0.0=$ mixed $;+.25=$ somewhat optimistic; $+.50=$ definitely optimistic; $+.75=$ very optimistic. Questions in this category are as follows: What are the prospects for the eventual realization of one's fundamental values and aspirations? Can one be optimistic, or must one be pessimistic on this score; and in what respects the one and/or the other?

P-3: Predictability of the Political Universe. This index measures the extent to which political elites view other actors as acting in a predictable manner. This index, which varies between 0 (political leaders view the international system as less predictable; 0 to .50 ) to 1 (political leaders view the international system as more predictable; .51 to 1 ) is calculated using the Index of Qualitative Variation (IQV). Questions include: Is the political future predictable? In what sense and to what extent?

P-4: Control Over Historical Development. Taking account of verbal utterances about self and others, this index reflects the extent to which political leaders view themselves as being in control of the situation. This index is a frequency ratio of the instances of self-attributions to the total instances of actions a political leader attributes to other actors. The scale for this index ranges from 0 (political leader views control over the situation resides with others; 0 to .50 ) to 1 (political leader views he/she has more control; .51 to 1). Questions: How much 'control' or 'mastery' can one have over historical development? What is one's role in 'moving' and 'shaping' history in the desired direction?

P-5: Role of Chance. The role of chance is related to P-3 and P-4 in that if a political actor believes he/she has more control in a predictable system, then there is less chance in political outcomes. This index varies from 0 (higher role for chance; 0 to .50) to 1 (less role for chance; .51 to 1$)$. Questions: What is the role of 'chance' in human affairs and in historical development?

${ }^{343}$ Schafer and Walker 2006, 33-38. 
While an operational code analysis helps orient this study with respect to a president's beliefs about the political universe, it does little to help us understand how he/she views a specific state actor. As a result, specific measures of a president's threat perceptions are still needed. To operationalize and measure this variable, area specialists and regional experts were asked to categorize the intensity of each president's threat perceptions of Russia and the United States? Individuals were asked to categorize them as High (1)-the president perceives some form of military and/or economic conflict is very likely during his/her time in office; moderate (2)-a president perceives some form of military and/or economic conflict is somewhat likely; or low (3)-a president perceives some form of military and/or economic conflict is very unlikely.

Foreign Policy Orientation and Domestic Politics. In the first section of this chapter, foreign policy orientation was conceptually defined as a political leader's beliefs about the optimal strategic ways to achieve his/her foreign policy goals or preferences. To garner a more complete understanding of a president's foreign policy orientation, this study first uses an operational code analysis to measure his/her instrumental beliefs. The outcome of this broad-based measurement serves as a sounding board from which an analysis of the professional assessments of area experts helps to operationalize a president's foreign policy orientation into three categories: accommodative, pragmatic, or confrontational.

Beginning with the operational code, this study measures a political leader's instrumental beliefs (I-1), which focus on strategy and the "ways" by which a president can achieve his/her foreign policy goals given available means. ${ }^{344}$ While a president's master instrumental beliefs are the main focus, there are also four additional categories of instrumental beliefs related to the I-1 category: I-2: Intensity of Tactics; I-3: Risk Orientation; I-4: Importance of Timing of Action; I-

\footnotetext{
${ }^{344}$ George 1969, 199-216; Walker 1990, 405.
} 
5: Utility of Means. The category description, measurement, and accompany questions related to a political leader's instrumental beliefs are as follows: ${ }^{345}$

I-1: Direction of Strategy. This all-encompassing belief captures the political leader's views about the best courses of action to follow. This index is calculated in a similar manner as P-1; however, an actor's utterances are aggregated based on his comments about the self and the self's "in-group." The value for this index varies between +1 (a political leader views a strategy of cooperation has more utility) to -1 (a political leader views a strategy of confrontation has more utility). The measure for this index are as follows: $(-1=$ very conflictual; $-.50=$ definitely conflictual; $-.25=$ somewhat conflictual; $0.0=$ mixed $+.25=$ somewhat cooperative $;+.50=$ definitely cooperative; $+.75=$ very cooperative). Beliefs I- 2 to I -5 are subsequently related to the master belief (I-1). Questions: What is the best approach for selecting goals for political action?

I-2: Intensity of Tactics. This belief accounts for an actor's intensity level when pursuing a course of action. Like $\mathrm{P}-2$, verbs are first weighted $(+3$ to -3 ) based on an intensity value (punish -3 , threaten -2 , oppose -1 , support +1 , promise +2 , reward +3 ). This result is divided by the total number of coded verbs, which gives an index ranging from -1 (political leader believes there is more utility in hostile tactics; -1 to 0 ) to +1 (political leader believes there is more utility in cooperative tactics; 0.1 to 1 ). Questions: How are the goals of action pursued most effectively?

I-3: Risk Orientation. This index measures the extent to which political elites are averse or acceptant of risk in their actions. Using IQV again, this index examines the dispersion of a political leader's utterances across six verb categories. The underlying logic here is that a higher diversity of action equates to lower risk because not all eggs are in one basket. This index varies between 0 (political leaders are more risk averse; 0 to .5 ) to 1 (political leaders are more risk acceptant; .51 to 1). Questions: How are the risks of political action calculated, controlled and accepted? The measurement variable the following coding is used: 0 to $.24=$ very risk averse; .25 to $.49=$ somewhat risk averse; .50 to $.74=$ somewhat risk acceptant; .75 to $1=$ =ery risk acceptant.

I-4: Importance of Timing of Action. This belief focuses on a political leader's timing for his actions. This belief encompasses two indices: the diversity of a leader's choices with respect to conflictual and cooperation actions and the diversity of a leader's actions based on word/deed distribution. The scale for this index ranges from 0 (lower diversity in cooperative and conflictual tactics or lower diversity of tactics across words/deeds categories; 0 to .5) to 1 (higher diversity in conflictual and cooperative tactics or higher diversity of tactics across words/deeds categories; .51 to 1). Questions: What is the best 'timing' of action to advance one's interests?

I-5: Utility of Means. This category takes account of a political leader's beliefs about the utility of different tactics that may be employed based on his's political power. Using six indices (punish, threaten, oppose, appeal, promise, reward), the value for this index is calculated for each category as a percentage of the total coded verbs when the political leader is referring to him/herself. Each index varies from 0 (less utility; 0 to .5 ) to 1 (more utility; .51 to 1 ) for each category. Questions: What is the utility and role of different means for advancing one's interests?

A president's foreign policy orientation is operationalized in three specific ways:

accommodative, confrontational, and pragmatic. The operational definitions are as follows: A

president with an accommodative foreign policy orientation views cooperation with a particular

${ }^{345}$ Schafer and Walker 2006, 33-38. 
regional great power as the best approach to achieve his/her foreign policy goals. A political leader with an accommodative foreign policy orientation does not view this regional great power as fundamentally hostile or directly threatening to the state's security. An accommodative leader seeks to translate his/her verbal proclamations of engagement, cooperation, and support into material action.

Presidents exhibiting a confrontational foreign policy orientation eschew cooperation with a regional great power they view as a high threat. In some cases, a president may attempt to enact foreign policies that actually increase tensions with the target state. Finally, a political leader with a pragmatic foreign policy orientation views cooperation with multiple external powers as the best approach to achieve his/her foreign policy goals. A political leader with a pragmatic foreign policy orientation may view a regional great power as a moderate threat; however, this is not enough to deter cooperation. As such, pragmatic leaders seek to translate their verbal proclamations of engagement and cooperation into material action with multiple great powers. To measure a president's foreign policy orientation, this study analyzes the responses from area specialists and other primary and secondary sources including the content from each president's foreign policy speeches and the published works of regional experts.

In line with Joe Hagan's typology, this study operationalizes domestic politics into two categories: government fragmentation and issue polarization. Government fragmentation characterizes the locus of political power in the state's apparatus while polarization refers to the level of consensus among political elites on the president's alignment preferences. To measure government fragmentation, a numerical value (1 through 5) is assigned to each ruling government. A score of 'one' indicates the government is not highly fragmented meaning a president can more easily implement his/her alignment strategy. A score of two through five 
indicate increasing levels of fragmentation. The first category is a single-party government, which is led by one dominate leader (value $=1$ ). In this case, a single individual overshadows all other leading political elites and their organization. In many cases, this dominate leader is able to solidify his/her position and power because of the constitution, access to the state's instruments of coercion or his/her organizational skills, charisma, and political acumen.

The second category (value $=2$ ) is a government fragmented by the existence of autonomous political institutions and bureaucracies. A single political party controls the government; however, decision-making authority is decentralized in separate institutions and bureaucratic organizations. Although power is decentralized, leading political elites in the ruling political party are still able to ensure a high degree of cohesiveness with no major internal factions creating undue friction. As a result, the president's foreign policies require some consensus among relevant players and state organizations.

A government controlled by a single party, which is internally divided by established political factions is a third category (value $=3$ ). Although a single political party has a majority in the executive and legislative branches, this group lacks adequate levels of cohesion owing to the presence of multiple factions that have divided the party. These factions are in near-continuous competition for control of key leadership positions or the state's foreign policy agenda. These factions routinely have divergent policy positions, which make consensus-building on foreign policy issues a difficult endeavor for the president. As a result, the president may not be able to implement consistently his/her preferred foreign policies over time.

The fourth category (value $=4$ ) is characterized by a government ruled by a coalition of autonomous political groups in which one political leader still has a clear predominance. Here, power is decentralized across multiple political parties; however, there exists one individual, who 
can exercise a high degree of political power to mitigate fragmentation and increase cohesion among other elites within the government. The fifth category (value $=5$ ) is a government ruled by a coalition in which there is no clear, single dominant leader. In this case, there exists at least two political leaders (or parties) with equal authority that comprise a coalition in a ruling government. Since no single leader or group has the capacity to exert the necessary leadership, the ruling government becomes heavily fragmented making it extremely difficult for either of the leading political figures to implement their preferred foreign policies. ${ }^{346}$

Issue polarization focuses on the level of consensus among leading political elites about the president's alignment preferences with the United States or Russia. An important facet of issue polarization is the existence of politically powerful groups or leaders, who are either supportive of or in opposition to a president's alignment preferences. To measure issue polarization, three values are assigned to the level of consensus among political elites: $1=$ high consensus; $2=$ moderate consensus; 3 = low consensus. When there is a high consensus, a majority of ruing elites see high value in the president's actions. When there is moderate consensus, there is almost equal support or opposition to the president's alignment preferences. In this case, political compromises allow the president to pursue his/her preferred alignment without eliciting a violent or non-violent political and/or societal backlash. When there is a low consensus, the president's actions frequently are met with verbal opposition, which may delay or even prevent the advancement of his/her preferred alignment strategy. Under these conditions, any effort by the president to force his/her strategy forward could spur political and/or societal upheaval.

Alignment. In this study, alignment is a dichotomous variable that manifests itself in two ways: positive bandwagoning and great power bridging. To accurately measure the dependent

\footnotetext{
${ }^{346}$ Hagan 1994, 151-155.
} 
variable requires the establishment of conceptual and operational definitions of the concepts and a unit of measure for each. As noted above, this study conceptually defines alignment as an informal or less-binding formal set of expectations between a small state and a regional great power. Operationally defined, positive bandwagoning occurs when the leading actor in the state's foreign policy executive consistently demonstrates higher levels of political, economic, or military cooperation with one regional great power over another while in office. Alternatively, great power bridging occurs when a head of state displays an almost equal level of political, economic, or military cooperation with two regional great powers.

To measure alignment, this study uses the ICEWS event dataset and qualitative analyses for each of the three independent variables. The coding scheme for ICEWS data follows the Conflict and Mediation Event Observations (CAMEO) ontology, which was originally developed by Deborah J. Gerner, Philip A. Schrodt, Ömür Yilmaz, and Rajaa Abu-Jabr. ${ }^{347}$ This study follows Schrodt's version of CAMEO, which consists of 20 top-level categories of events. These 20 categories are aggregated into four groups: verbal cooperation, material cooperation, verbal conflict, and material conflict. A brief summary of each category follows.

Verbal Cooperation. Events in this category capture the oral statements or remarks associated with a political leader's intentions to pursue cooperative, friendly relations with a target actor. CAMEO categories for these events are as follows: Statement (01); Appeal (02); Express Intent to Cooperate (03); Consult (04); Engage in Diplomatic Cooperation (05).

Material Cooperation. Events in this category capture the physical actions of allocating or receiving tangible assistance such as humanitarian aid, farm equipment, reducing import bans, etc. CAMEO categories for these events are as follows: Material Cooperation (06); Provide Aid (07); Yield (08); Investigate (09).

Verbal Conflict. Events in this category capture the verbal statements or remarks associated with a political leader's intentions to pursue uncooperative or adversarial relations with a target actor. CAMEO categories for these events are as follows: Demand (10); Disapprove (11); Reject (12); Threaten (13); Protest (14).

\footnotetext{
${ }^{347}$ Gerner, Deborah J., et al. 2002. "Conflict and mediation event observations (CAMEO): A New Event Data Framework for the Analysis of Foreign Policy Interactions.” International Studies Association, New Orleans.
} 
Material Conflict. Events in this category capture the physical actions of confrontation including armed attacks, sabotage, target killings, etc. CAMEO categories for these events are as follows: Exhibit Military Posture (15); Reduce Relations (16); Coerce (17); Assault (18); Fight (19); Engage in Unconventional Mass Violence (20). ${ }^{348}$

To measure alignment preferences with respect to a president's ideas about the state's identity, this study uses the verbal cooperation subset of the ICEWS event dataset. Specifically, descriptive statistics are used to measure the frequency and intensity of a president's level of verbal cooperation with the U.S. and Russia. The intensity of an ICEWS event is measured on a cooperation-conflict continuum that mirrors the Goldstein scale used in the WEIS dataset. ${ }^{349}$ This scale runs from +10 to -10 where positive numbers from zero upwards to 10 equate to increasingly cooperative events while observations on the negative side equate to increasingly conflictual events. To gauge a president's general alignment, this study tabulated the frequency and corresponding intensity of events to find the mean based on an annual basis. A president who prefers positive bandwagoning will consistently demonstrate higher levels of verbal cooperation with a target state. A president who prefers great power bridging in its alignment trajectory will either apply the same level of cooperation to both regional great powers or oscillate between the two for varying lengths of time.

To measure a president's alignment preferences with respect to his/her threat perceptions this study adds the verbal conflict subset of the ICEWS event dataset. To increase specificity to this measurement, a qualitative analysis of each president's foreign policy speeches is undertaken to discern their specific ideas about the primary external state-based threats. President's consistently exhibiting higher levels of verbal conflict (and lower levels of verbal cooperation)

\footnotetext{
${ }^{348}$ Schrodt, Phillip A. and Omar Yilmaz. 2007. CAMEO Conflict and Mediation Event Observations Codebook. Lawrence: University of Kansas.

${ }^{349}$ Goldstein Joshua S. 1992. "A Conflict-Cooperation Scale for WEIS Events Data.” Journal of Conflict Resolution 36 (2).
} 
with one regional great power are more likely to prefer a positive bandwagoning alignment with a different regional great power. When a president's level of verbal conflict (and cooperation) oscillates between both regional great powers, he/she is more likely to prefer great power bridging.

Finally, to measure alignment with respect to a president's foreign policy orientation and the conditioning factor of domestic politics, this study examines the frequency and intensity of the president's (and the state's) material cooperation with the U.S. and Russia. To add specificity to this measurement, a qualitative analysis is undertaken to discern the extent to which a president was able to translate his/her alignment preferences (either positive bandwagoning or great power bridging) into material actions.

Data. Data for this project was derived from a wide array of primary and secondary sources. To understand elite ideas on the identity of the state, their respective threat perceptions, and the influence of domestic politics, this study acquired primary data through field research using semi-structured interviews with over 25 U.S. and foreign government officials, area specialists, and policy experts. ${ }^{350}$ Although interviewees opted to remain anonymous, these individuals either had direct access to the presidents under examination or had extensive time in the country. As part of this data collection effort, this study leveraged the keen insight of Vincent Pouliot and his recommendations on conducting interviews. ${ }^{351}$ As a result, interviews were fruitful because I was able to "corroborate what has been established from other sources and establish what a set of people think,"352 while avoiding researcher bias.

\footnotetext{
350 The author acknowledges that 25 interviews with area experts represents a small sample. Future research with additional foreign and domestic area specialists represents a future opportunity to confirm this study's findings.

${ }^{351}$ Pouliot, Vincent. 2010. International Security in Practice: The Politics of NATO-Russia Diplomacy. Vol. 113. Cambridge University Press, 68-85.

352 Tansey, Oisin. 2007. "Process Tracing and Elite Interviewing: A Case for Non-Probability Sampling." PS:

Political Science and Politics 40 (4), 776.
} 
This study also collected data from a scenario-based survey to understand the relevance of ideational factors in the foreign policy process. As an empirical probe, this effort replicated the work of David Rousseau to test the relationship between state identity, the balance of military power, and threat perceptions. Using Survey Monkey, four hypothetical scenarios were randomly disseminated to nearly 1,000 senior U.S. and foreign civilian and military officers assigned to the U.S. Army War College. Specifically, these scenarios measured three dichotomous dimensions: state identity (similar/dissimilar), balance of military power (favorable/ unfavorable), and government type (democratic/authoritarian). ${ }^{353}$ Appendix A contains the four scenarios and questions used in this experiment.

Next, this study reviewed over 6,000 presidential speeches, press interviews, and public statements of the 12 Azeri, Georgian, Moldovan, and Ukrainian presidents from official government websites and reputable foreign and domestic news outlets. After screening, approximately 3,300 speeches were used. The by-country breakdown is as follows: Azerbaijan (1,600); Georgia (850); Moldova (466); and Ukraine (450). Additionally, I derived data from the following data sets: Alliance Treaty Obligation and Provisions (http://atop.rice.edu), Third-Party Peacekeeping Missions Data Set (http://uca.edu/politicalscience/dadm-project/dadm-data-sets/), Stockholm International Peace Research Institute (for arms transfers), and the Militarized Interstate Dispute, and Joint Military Exercises (http://vitodorazio.weebly.com/data.html) data sets. This study also made extensive use of the Information Crisis Early Warning System (ICEWS) (https://dataverse.harvard.edu/ dataverse/harvard?q=ICEWS) event data set, which was

\footnotetext{
${ }^{353}$ Rousseau, David L. 2006. Identifying Threats and Threatening Identities: The Social Construction of Realism and Liberalism. Stanford University Press.
} 
available from Harvard's Dataverse website. In total, this study used nearly 20,000 publicly and non-publicly available events to measure the dependent variable. ${ }^{354}$

Finally, data was collected from a variety of different primary and secondary sources. These included, but are not limited to scholarly journals, books, monographs, and analytical papers from various government and non-government outlets. As part of this effort, the information harvested from these sources were used to build upon established data sets or create new ones as was the situation with this study's rigorous process on case selection.

\section{$\underline{\text { Limitations }}$}

Every research project carries a set of inherent limitations. This study is no different. First, there currently exists a deficit of available public speeches and interviews by leading members of the foreign policy executive for the period 1991-1994 and during some periods, for select presidents or interim presidents. To offset this limitation, this study primarily focused on a 20year period from 1995-2015. Additionally, in Moldova a dearth of public speeches and a lack of area expert insight prevented a close examination of the alignment trajectories of President Mircea Snegur and interim Presidents Mihai Ghimpu and Marian Lupu.

Second, although incorporating ideational considerations into a multi-level analysis on small state alignment, this study carries several methodological and empirical challenges. First, the concept of state identity is difficult to define and measure. According to Martha Finnemore and Kathyrn Sinkkink,

The ongoing difficulty in identity research is that there is still no clear, agreed upon definition of what we mean (and do not mean) by identity, how researchers can plausibly establish what state identities are, or what range of prominent identities may exist in international politics at any particular historical moment. Identity has become a catch-all term, helping to explain richly a

\footnotetext{
${ }^{354}$ Special thanks to Mark Hoffman, Senior Manager at Lockheed Martin Advanced Technology Labs, who was able to provide additional ICEWS events for the cases under examination in this study.
} 
wide variety of actions, but it does not yet permit us to suggest that states with particular types of identities will act in particular ways. ${ }^{355}$

As a result, my conceptualization of state identity may carry a danger of false precision. To offset this risk, this study uses elite interviews with area specialists and quantitative techniques to garner the predominant state identity narratives for each ruling government.

Third, by using public speeches to determine a president's ideas about state identity and their perceptions of external threats, the validity of this study's findings may be degraded if their words do not reflect what they truly think. In many instances, political leaders may convey public messages tailored for specific domestic or international audiences. Considering the target audience can help offset this limitation. Fourth, by using secondary sources (e.g. media reports, journal articles, etc.) it may be difficult to garner an in-depth understanding of a political leader's mindset if the data points are inaccurate or incomplete. Once again, interviews with area specialists and policy experts may partially mitigate these limitations.

Fifth, while using event data is one way to increase the precision of measuring alignment, the ICEWS scaling carries several inherent weaknesses. One. The captured event in the dataset may not reflect all the major foreign policy actions related to the individual or state. Two, when calculating the mean of a president's level of verbal or material cooperation, highly violent events may mask cooperative actions. For instance, the sum and mean of a short, but violent three-day armed conflict between two countries could offset a series of cooperative (e.g. peace negotiations) events for that week thereby producing a result of zero, which is the same value for days when several neutral events were registered. Separately, it is also possible a small number of violent events that produce a -10 score for example can offset a larger number of cooperative

\footnotetext{
${ }^{355}$ Finnemore, Martha, and Kathryn Sikkink. 2001. "Taking Stock: The Constructivist Research Program in International Relations and Comparative Politics.” Annual Review of Political Science 4 (1), 399.
} 
events thus skewing this study's analysis and conclusions. Despite these potential pitfalls, this measurement technique, coupled with the metrics from elite interviews and qualitative assessments of the secondary literature is part of a new and innovative approach to understanding alignment politics in the post-Soviet space. ${ }^{356}$

Finally, as an active duty U.S. Army intelligence officer, my ability to gain access and interview foreign civilian and military leaders in Azerbaijan, Georgia, Moldova, and Ukraine was highly constrained owing to various reasons. First given my career field, rank, and top-secret security clearance, foreign government officials were routinely disinclined to meet with me to discuss foreign policy issues associated with their government. Second, although this research project responds directly to unclassified U.S. government research priorities, DA requirements mandating interview questions with foreign nationals be made in their native language created too much of a high cost for this research endeavor at this time.

\section{$\underline{\text { Controls }}$}

This dissertation recognizes there are a plethora of factors potentially directly or indirectly shaping the alignment preferences of political leaders in the states along Russia's geographical periphery. Because one cannot possibly account for each of the major factors in one study, this research projects emplaces several controls on a variety of systemic and domestic considerations. At the international level, this study holds constant how a president may attempt to align with other regional great powers such as China, India, Germany, France, and Great Britain. At the domestic level, public opinion, the influence of special interest groups, and the media are held in check to more accurately consider the relationship between the key variables under examination.

\footnotetext{
${ }^{356}$ A special thanks to Dr. Jonathan Renshon, Associate Professor and Trice Faculty Scholar at the University of Wisconsin at Madison. During the 2017 Mid-West Political Science Association annual meeting, Dr. Renshon was extremely helpful with assisting me to refine how I used event data to measure alignment as well as my usage of an operational code analysis in this study.
} 


\section{$\underline{\text { Alternative Explanations }}$}

From one perspective, the ideas advanced in this study about when and why a small state may align with one regional great power over another are but trees in a forest of theories covering alignment politics. Certainly, there are alternative explanations to the puzzle at hand. First, some critics may view the current research endeavor as imprudent arguing the centrality of structuralist approaches to explain small state alignment. Following Waltz, balance of power theorists may argue power asymmetries are the primary drivers moving states to flock to a particular regional great power. Proceeding on the assumption the U.S. is the most powerful state in the system, these scholars expect small states to opt for positive bandwagoning with Russia.

A second plausible explanation of why small states may bandwagon with a particular regional great power stems not from power imbalances but threat intentions. Recalling Walt's central proposition, a state's alignment is based on four key variables: geographical proximity, aggregate power, superior (offensive) military capabilities, and most importantly, the probability of future conflict. Focusing on the fourth variable, balance of threat theorists may argue that because of Moscow's aggressive intentions against many of the former Soviet states since the end of the Cold War, political leaders in the region will view Russia as the most threatening regional great power. As a result, the threat emanating from the Kremlin is a key catalyst inducing positive bandwagoning behavior with the United States.

\section{Case Selection - Testing Realist Expectations}

On one level, the post-Soviet space represents fertile ground for realists and their respective theoretical propositions on small state alignment. Whether it is Waltz's balance of power or Walt's balance of threat theory, realists expect former Soviet states should consistently bandwagon with their former imperial center owing to power asymmetries or Moscow's 
historical aggressive tendencies with countries on its geographical periphery. But do the alignment tendencies of all former Soviet states conform to realist expectations? Are there any outliers? If so, then these countries may qualify as potential cases for this study, which seeks an ideational-based explanation for small state alignment. However, as has been made readily clear over the years, the topic of case selection is perhaps one of the most challenging and contentious facets of any research project. According to George and Bennett...

Case selection is arguably the most difficult step in developing a case study research design. It is an opportunistic process of seeking the intersection between the extant cases that history provides and the kind of cases and comparisons that are likely to best test or develop theories. ${ }^{357}$

In order to avoid the pitfalls associated with case selection (e.g. selecting cases based on the dependent variable), this research project conducted an exhaustive analysis of the general alignment tendencies of all the former Soviet states except Russia using a series of indicators developed by Henry Teune and Sig Synnestvedt. ${ }^{358}$ Beyond case selection, this analytical endeavor also helped sketch the broad alignment contours of former Soviet states from the early 1990s to 2015. Some of the findings from this effort were subsequently used in the substantive chapters as a way to provide increased specificity on when and how a former Soviet state may align with one regional great power over another.

Before proceeding, a review of Teune and Synnestvedt's scholarly work on measuring international alignments is in order. Writing in the 1960s, both were highly critical of academics and practitioners, who attempted to explain state alignment without developing sound operationalizations and measurements of this political phenomenon. In their words...

Alignment is crucial to the study of international relations. A nation's alignment history is written by individual scholars who evaluate the foreign policy decisions made in a country over some specified period of years. Obviously, in the past the judgements of these scholars rested upon a variety of factors. Yet the exact basis of judgement has never been clearly established. ${ }^{359}$

\footnotetext{
357 George and Bennett 2005, 234.

358 Teune, Henry and Sig Synnestvedt. 1965. "Measuring International Alignment." Orbis 9 (1).

359 Teune and Synnestvedt 1965, 23.
} 
Recognizing this methodological shortfall, Teune and Synnestvedt proposed 28 general

indicators to measure the strength of small state alignment with the Soviet Union or the United

States. These indicators include:

1. Signing a Military Commitment

2. Visits by heads of state

3. Important visitors other than heads of state

4. Protests or expulsions of diplomatic personnel

5. Diplomatic recognition of East Germany

6. Total recognition of controversial non-communist countries

7. Educational and cultural exchanges

8. U.S. or USSR military presence

9. Anti-U.S. or USSR riots

10. Number of U.S. government or communist bloc technicians

11. U.S. military aid

12. U.S. and USSR economic aid

13. Votes in the United Nations on the same side as the U.S. and USSR respectively

14. Non-military treaties and agreements with the U.S. and USSR

15. Percentage of unions affiliated with international groups other than the ICFTU or WFTU

16. Percentage of unions not affiliated with any international group

17. U.S. direct private investments

18. Total trade

19. Total trade with the U.S. and USSR

20. Total trade with OECD nations

21. Total trade with Soviet area nations

22. Professorial exchanges with U.S. and USSR

23. Student exchanges with U.S. and USSR

24. Books translated from English

25. Books translated from Russian

26. Radio broadcast hours from U.S. and USSR

27. U.S. propaganda expenditures

28. Air flights per week from U.S. and USSR

Teune and Synnestvedt subsequently refined their list through a validation process leveraging the expertise of over 125 area specialists and IR generalists via a questionnaire. The findings from this effort revealed the two most important indicators were military commitments (e.g. consultation, defense treaty, etc.) and UN voting. ${ }^{360}$ Applying these two indicators to the 14 former Soviet states, realist theories on the surface appear validated with Azerbaijan, Estonia,

\footnotetext{
${ }^{360}$ Teune and Synnestvedt 1965, 21.
} 
Georgia, Latvia, Lithuania, Moldova, and Turkmenistan, and Ukraine consistently aligning against Russia.

Although all eight may merit an in-depth examination, simply applying two indicators to understand when and why a small state aligns with one regional great power over another fails to achieve a high level of precision on alignment variation and case selection this study seeks to achieve. To garner increased fidelity, this study applies eight additional military (Participation in Combined Military Exercises, Basing of Foreign Military Forces, Arms Sales), diplomatic (Visits by Heads of State and Visits by other Country Leaders), and economic (Total Trade, Bilateral Investment Treaties, and Tariffs) indicators to improve our understanding of alignment variation and to better focus case selection. This second effort reveals four cases merit the most attention: Azerbaijan, Georgia, Moldova, and Ukraine.

\section{$\underline{\text { Testing Realist Expectations on Alignment - Part } 1}$}

Military Commitments. Teune and Synnestvedt's first indicator of alignment, which this study defines as an alliance, is a small state's willingness to sign a formal military commitment with a regional great power. When political leaders sign a formal military commitment, they are bound to act (or not act) in some capacity on matters of security as stipulated in the written protocols. Military commitments include a neutrality pact, nonaggression pact, consultation agreement, defensive pact, or an offensive pact. ${ }^{361}$ For example, NATO represents a defensive pact where member states are bound by the principle of collective defense as detailed in Article 5

\footnotetext{
${ }^{361}$ A neutrality pact obligates a state to not support the adversary of an ally during a war. A nonaggression pact is an agreement between two or more states not to engage in the use of armed force against one another. A consultation agreement directs states to communicate orally or in writing with each other during a crisis that could escalate into armed conflict. A defensive pact requires members to provide active military support when another member is a victim of an external armed attack. An offensive pact requires member states to provide active military support in all other situations not related to an attack upon an ally. See Leeds, Brett Ashley. 2005. Alliance Treaty and Obligations (ATOP) Codebook. Rice University, 3-12.
} 
of the treaty, where an attack on one country is considered an attack on all. When Article 5 is invoked, member states are required to take act in some manner as was the case following the 11 September 2001 terror attacks in the United States.

By examining the number and type of military commitments former Soviet states have become party to since the end of the Cold War may provide insight into how alignment may vary in the post-Soviet space. ${ }^{362} \mathrm{~A}$ review of the data in Table 1 yields the following general observations. First, on the surface, it appears realist expectations are validated with 10 of 14 former Soviet states signing more military commitments with Russia. To take this observation at face value, however, is folly because it does not consider temporal considerations of when each of these countries

\begin{tabular}{|c|c|c|}
\hline \multicolumn{2}{|c|}{ Table 1: Total Number of Military Commitments } \\
\hline & United States & Russia \\
\hline Armenia & 0 & 2 \\
\hline Azerbaijan & 0 & 1 \\
\hline Belarus & 0 & 2 \\
\hline Estonia & 1 & 0 \\
\hline Georgia & 0 & 1 \\
\hline Kazakhstan & 0 & 3 \\
\hline Kyrgyzstan & 0 & 3 \\
\hline Latvia & 1 & 0 \\
\hline Lithuania & 1 & 1 \\
\hline Moldova & 0 & 1 \\
\hline Tajikistan & 0 \\
\hline Turkmenistan & 0 & 3 \\
\hline Ukraine & 0 & 0 \\
\hline Uzbekistan & 0 \\
\hline Source: Alliance Treaty Obligations and Provisions (ATOP) database and Douglas Gibler's International Military Alliances, \\
1648-2008.
\end{tabular}
became a signatory to a military commitment and the longevity of these agreements. For example, while Armenia, Azerbaijan, Belarus, Georgia, Kazakhstan, Kyrgyzstan, Moldova, Tajikistan, and Uzbekistan signed the CST in the early 1990s, only Armenia, Belarus, Kazakhstan, Kyrgyzstan, and Tajikistan are members today. In 1999, Azerbaijan and Georgia decided not to renew their obligations under the CST. Uzbekistan followed suit but then rejoined again in 2006 only to leave again in 2012. Additionally, although Latvia signed a non-aggression pact with Russia in 1991, by 2004 Latvia, along with Estonia and Lithuania became NATO

\footnotetext{
362 Data for military commitments were collected from the Alliance Treaty Obligations and Provisions (ATOP) database and Douglas Gibler's International Military Alliances, 1648-2008. Leeds, Brett Ashley, Jeffrey M. Ritter, Sara McLaughlin Mitchell, and Andrew G. Long. 2002. Alliance Treaty Obligations and Provisions, 18151944. International Interactions 28: 237-260. http://atop.rice.edu. Accessed 05 August 2016; Gibler, Douglas M. 2008. International Military Alliances, 1648-2008. CQ Press.
} 
members. Furthermore Moldova, Ukraine, and Turkmenistan have never been party to either the CST or the North Atlantic Treaty.

In an effort to acquire increased fidelity on the relevance of military commitments and to identify outliers with respect to realist explanations of small state bandwagoning, this study narrows the scope by considering former Soviet state participation in defensive pacts.

Specifically, if a former Soviet state was party to a formal military treaty with either the U.S. or Russia for 11 or more years during the 21-year period 1995-2015, then that state is said to be aligned with that regional great power. Using this criterion, there emerges eight outliers:

Azerbaijan, Estonia, Georgia, Latvia, Lithuania, Moldova, and Turkmenistan, and Ukraine. ${ }^{363}$

United Nations Voting. The second most important indicator of alignment according to

Teune and Synnestvedt is a country's voting tendencies in the United Nations. A country's UN voting record is, from one perspective, a reflection of a ruling government's preferred foreign policies. For decades, scholars have examined the voting tendencies of countries in the UN as one way to understand foreign policy outcomes. ${ }^{364}$ The relevancy of focusing of UN votes is captured by Ambassador Jeane Kirkpatrick, who stated...

UN voting patterns provides Congress with a reliable, systematic basis for assessing the attitudes, policies, and decisions of UN members. They provide reliable evidence of what has happened on issues of importance [and] from this evidence, it is possible to make judgements about whose values and views are harmonious with our own, whose policies are consistently opposed to ours, and whose practices fall in between. ${ }^{365}$

\footnotetext{
${ }^{363}$ From 1995-2015, Armenia, Belarus, Kazakhstan, Kyrgyzstan, and Tajikistan were members of the CST for 21 years. The Baltic countries were NATO members for 12 years. Uzbekistan was a member of the CST for 12 years. Azerbaijan and Georgia were members of the CST for six years. Moldova, Ukraine, and Turkmenistan were never a member of NATO or CSTO.

${ }^{364}$ See for example Hagan, Joe D. 1989. "Domestic Political Regime Changes in Third World Voting Realignments and the United Nations, 1946 -84.” International Organization 43 (3); Kim, Soo Yeon and Bruce Russett. 1996. "The New Politics of Voting Alignments and United Nations General Assembly." International Organization 50 (4); Marin-Bosch, Miguel. 1987. "How Nations Vote in the General Assembly of the United Nations." International Organization 41 (4).

${ }^{365}$ Kirkpatrick, Ambassador Jeane J. 1985. "Introductory Statement." In Report to Congress on Voting Practices in the United Nations, 20 May 1985. Washington: United States Department of State.
} 
In the past, some scholars have attempted to understand a state's foreign policy behavior by focusing on resolutions that were only unanimous or on key votes for U.S. interests. ${ }^{366}$ In this study, maximizing the number of observations will help establish a more comprehensive understanding of this alignment indicator. Specifically, every UN vote cast by the 14 former Soviet state from 1992 to 2015 is considered. As such, a country is understood to align with Russia or the U.S. if a strong majority (76 percent or higher) of their UN votes are in line with either regional great power. ${ }^{367}$

Table 2 provides a summary of the voting trends, by percent, of the newlyindependent states with the U.S. or Russia from 1992 to 2015. Table 3 below

\begin{tabular}{|c|c|c|}
\hline \multicolumn{2}{|c|}{ Table 2: Total Number of UN Votes with the U.S. or Russia } \\
\hline & Votes With US / Percent & Votes With Russia / Percent \\
\hline Armenia & $79 / 8 \%$ & $893 / 92 \%$ \\
\hline Azerbaijan & $71 / 7 \%$ & $885 / 93 \%$ \\
\hline Belarus & $33 / 3 \%$ & $998 / 97 \%$ \\
\hline Estonia & $304 / 29 \%$ & $731 / 71 \%$ \\
\hline Georgia & $225 / 24 \%$ & $702 / 76 \%$ \\
\hline Kazakhstan & $88 / 9 \%$ & $933 / 91 \%$ \\
\hline Kyrgyzstan & $59 / 7 \%$ & $759 / 93 \%$ \\
\hline Latvia & $310 / 30 \%$ & $714 / 70 \%$ \\
\hline Lithuania & $300 / 29 \%$ & $744 / 71 \%$ \\
\hline Moldova & $280 / 27 \%$ & $740 / 73 \%$ \\
\hline Tajikistan & $46 / 6 \%$ & $762 / 94 \%$ \\
\hline Turkmenistan & $34 / 6 \%$ & $573 / 94 \%$ \\
\hline Ukraine & $223 / 22 \%$ & $792 / 78 \%$ \\
\hline Uzbekistan & $50 / 7 \%$ & $628 / 93 \%$ \\
\hline \multicolumn{2}{|c|}{ Source: Author's Analysis } \\
\hline
\end{tabular}

provides a 'by year' breakdown of the actual number of times these countries voted in line with each of the regional great powers. ${ }^{368}$ For this indicator, there were 12,956 observations where all 14 countries voted in a similar manner (yes, no, or abstain) with either the U.S. or Russia. In total, newly-independent states cast the same vote as their former imperial center 10,950 times (85 percent) as compared to only 2,106 votes with the U.S. (15 percent). Second, as noted in Table 3, there was only one instance when a former Soviet state cast more similar votes with the

\footnotetext{
${ }^{366}$ For studies focusing on unanimous votes see Rai, Kul B. 1980. "Foreign Aid in the U.N. General Assembly, 1967 - 1976." Journal of Peace Research 3 (17), 589. Te-Yu Wang uses an 'important issue' approach to screen voting. See Wang, Te-Yu. 1999. "US Foreign Aid and UN Voting: An Analysis of Important Issues.” International Studies Quarterly 43 (1).

${ }^{367}$ Because states in a similar geographical region may influence voting in the UN, stablishing the 76 percent benchmark for an alignment with Russia was done so in order to increase the analytical precision of this indicator. ${ }^{368}$ Data for UN voting was derived from votes levied by the 14 former Soviet states and recorded in the United Nations Bibliographic Information System (UNBIS) database during each of the UN General Assembly sessions from 1992 to 2015. In total, there were 1,649 resolutions during this time.
} 
United States; Georgia in 2011-2012 cast 16 votes on resolutions that were similar to the U.S.

and only 14 votes with Russia.

From these charts, several general observations can be derived. First, in line with realist predictions that small states will bandwagon with a weaker great power, Armenia, Azerbaijan, Belarus, Georgia, Kazakhstan, Kyrgyzstan, Tajikistan, Turkmenistan, Ukraine, and Uzbekistan overwhelmingly voted in line with the Russian Federation. The anomalies in this case include the Baltics and Moldova. These countries tended to vote in line with the U.S. at a higher rate (27 to 30 percent) that than of the other former Soviet states.

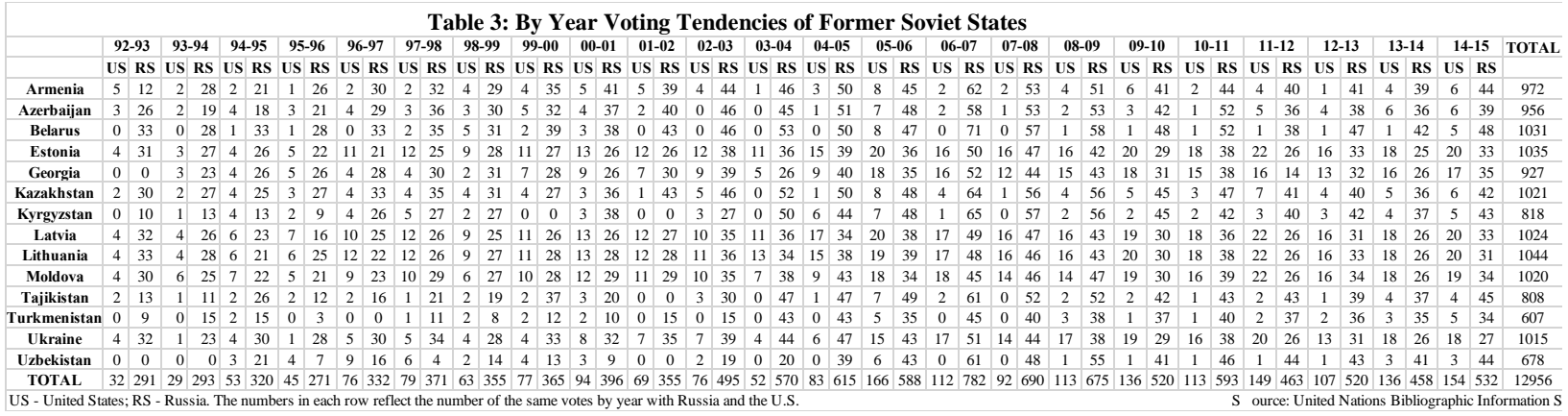

So, what else may explain the general tendency of these four states to note vote in line with Russia? From one perspective, a country's voting record in the UN is by default one expression of a ruling government's preferred foreign policies, which can be affected by a wide array of domestic and systemic factors. For example, at the systems level some scholars have found trade dependence or foreign aid affect a country's UN voting coincidence with regional great powers.

Other scholars have noted how domestic politics and changes in the ruling government best explain the voting tendencies of small states with larger powers. ${ }^{369}$ Separately, Arend Lijphart

\footnotetext{
${ }^{369}$ For trade dependence and UN voting, see Armstrong, Adrienne. 1981. "The Political Consequences of Economic Dependence." The Journal of Conflict Resolution 25 (3) and Richardson, Neil R., and Charles W. Kegley. 1980. Trade Dependence and Foreign Policy Compliance. International Studies Quarterly 24 (2). For foreign aid and UN voting, see Dreher, Axel, Peter Nunnenkamp, and Rainer Thiele. 2008. "Does U.S. Aid Buy U.N. General Assembly Votes? A Disaggregated Analysis." Public Choice 136 and Wang 1999. For political regimes and regime change, see Moon, Bruce E. 1985. "Consensus or Compliance? Foreign Policy Change and External Dependence." International Organization 39 (2) and Hagan 1989.
} 
posits that "agreement in voting [and by extension, alignment] may be caused...by similar attitudes ${ } 370$ of political leaders, who are key figures in a country's foreign policy executive.

The preceding points illuminate how analyzing military commitments and UN voting records may provide a baseline to discern variation in the alignment tendencies of a small state with a regional great power. Although this initial effort has uncovered eight possible cases worthy of future research (Azerbaijan, Estonia, Georgia, Latvia, Lithuania, Moldova, Turkmenistan, Ukraine and Uzbekistan), using just two major indicators may prevent the identification of the most viable set of cases worthy of further research. This reality demands a more comprehensive analysis using additional alignment indicators.

\section{Testing Realist Expectations on Alignment - Part 2}

To garner a more holistic understanding of variation in the alignment tendencies of all 14 former Soviet states, this study uses eight additional alignment indicators. The three military indicators are participation in combined military exercises, arms sales, and the basing of foreign military forces. The two additional diplomatic indicators are visits by heads of state and visits by other key political leaders. Finally, in marked contrast to Teune and Synnestvedt, who did not regard economic linkages as highly relevant, this study develops three new economic indicators of alignment: total trade, foreign direct investment, and tariffs.

Participation in Combined Military Exercises. Aleksandr Vasilevich Suvorov, the famous $18^{\text {th }}$ century Russian general, who supposedly never lost a battle during his career purportedly built his success by abiding by the simple principle of "Tiazhelo $v$ uchenii, legko $v$ boiu," which

\footnotetext{
${ }^{370}$ Lijphart, Arend. 1963. "The Analysis of Bloc Voting in the General Assembly: A Critique and a Proposal." American Political Science Review 57 (4), 904.
} 
in English roughly means "train hard, fight easy." ${ }^{371}$ Joint military exercises are but one way a country's armed forces can improve military readiness in the run-up to a planned or unforeseen armed confrontation with another country. When military exercises take on a combined nature with two or more countries participating, the concept of alignment begins to take on increased clarity. Specifically, when military forces from different countries exercise together, we can assume there is a distinct possibility the participants may fight together in a future conflict against a common enemy or adversarial coalition.

To help ensure accuracy in this study's assessment of this indicator, a combined military exercise is defined as a strategic, operational, or tactical-level field or command post event between select personnel, units, or organizations of the armed forces from two or more countries. To discern state alignment for this indicator, this study examines the frequency (i.e. number of exercise events on an annual basis) of all the combined military exercises between former Soviet states and the United States and Russia for the period 1991-2015. As such, former Soviet countries are considered to align with either Russia or the U.S. when the frequency of exercise events is higher than the other. ${ }^{372}$

\footnotetext{
${ }^{371}$ Norberg, Johan. 2015. Training to Fight: Russia's Major Military Exercises 2011-2014. Swedish Ministry of Defense, 11.

372 This study developed a new military excises data set by harvesting exercise events from a variety of existing and new resources from Vito D'Orazio, a compendium study of military exercises by Fort Leavenworth's Foreign Military Studies Office, foreign and domestic media reports, foreign government announcements, and think tank assessments. A special thanks to Vito D'Orazio, who was kind enough to email me his military exercise data set. See D'Orazio, Vito. 2012. "Advancing Measurement of Foreign Policy Similarity.” APSA 2012 Annual Meeting Paper. Also, special thanks to Matt Stein, whose work at FMSO was especially helpful. See Stein, Matthew. 2015. "Compendium of Central Asian Military and Security Activity." Foreign Military Studies Office (FMSO), Fort Leavenworth, KS.
} 
As shown in Table 4, realist

expectations that former Soviet states

will bandwagon with Russia by

participating in more combined

military exercises hold for Armenia,

Belarus, Kyrgyzstan, Tajikistan, and

Turkmenistan. In marked contrast to
Table 4: Average Number of Military Exercises Per Year

\begin{tabular}{|c|c|c|c|}
\hline Country & United States & Russia & Difference \\
\hline Armenia & 0.88 & 1.52 & 0.64 (Russia) \\
\hline Azerbaijan & 1.28 & 0.28 & 1.0 (U.S.) \\
\hline Belarus & 0.28 & 2.2 & 1.92 (Russia) \\
\hline Estonia & 1.32 & 0.04 & 1.28 (U.S.) \\
\hline Georgia & 1.6 & 0.16 & 1.44 (U.S.) \\
\hline Kazakhstan & 2.52 & 1.48 & 1.04 (U.S.) \\
\hline Kyrgyzstan & 1.72 & 2.82 & 1.1 (Russia) \\
\hline Latvia & 1.16 & 0.04 & 1.12 (U.S) \\
\hline Lithuania & 1.44 & 0.08 & 1.36 (U.S.) \\
\hline Moldova & 0.96 & 0.2 & .76 (U.S.) \\
\hline Tajikistan & 0.64 & 3.08 & 2.44 (Russia) \\
\hline Turkmenistan & 0.04 & 0.08 & .04 (Russia) \\
\hline Ukraine & 1.88 & 0.84 & 1.04 (U.S.) \\
\hline Uzbekistan & 1.12 & 0.96 & .16 (U.S) \\
\hline
\end{tabular}

realist expectations, Azerbaijan, Georgia, Kazakhstan, Moldova, Ukraine, and Uzbekistan and

the Baltic countries participated in more exercises with the United States. While one can derive some general inferences from these figures, a closer examination of the exercise regimen of each country for the period is warranted in order to understand how alignment may vary over time.

Beginning in Eastern Europe,

Chart 1 highlights how Belarus has

consistently aligned with Russia

with respect to military exercises.

On average, Belarussian armed

forces conducted 2.2 exercises

with Russia as compared to .28

Chart 1: Belarus Military Exercises with the United States and Russia

exercises with the United States. From 1998-2015, Minsk participated in combined military exercises with Russia and the United States in 1998-1999, 2001, 2006-2007, and 2012. For the remaining years (2003-2005, 2008-2011, 2013-2015) Belarus and Russia conducted exercises together. From 1993-1997 and in 2000, Minsk did not participate in any military exercises with either the United States or Russia. 
In Moldova, the country

Chart 2: Moldova Military Exercises with the United States and Russia

averaged .96 exercises with the

U.S. as compared to .20 exercises

with Russia. As detailed in Chart

2, from 1996-1998, 2002-2003,

2005-2007, 2009-2010, 2012,

and 2014, the country's armed

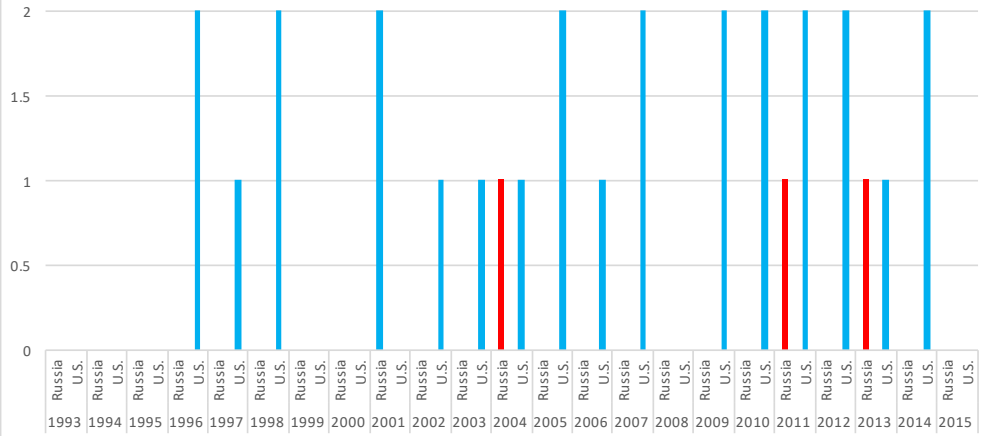

forces exercised with military units from the United States. It was only in 2001 did Chisinau conduct military exercises with Russia. In 2004, 2011, and 2013 Moldova conducted combined military exercises with both countries. For nine years (1991-1995, 1999-2000, 2008, and 2015), Moldova did not participate in any military exercise with the United States or Russia.

Ukraine gave a 2-1 emphasis

Chart 3: Ukraine Military Exercises with the United States and Russia

to exercise participation with the

United States (47 total exercises;

1.88 exercises/per year) over

Russia (21 total exercises; .84

exercises per year). As depicted

in Chart 3 , for nine of the 20

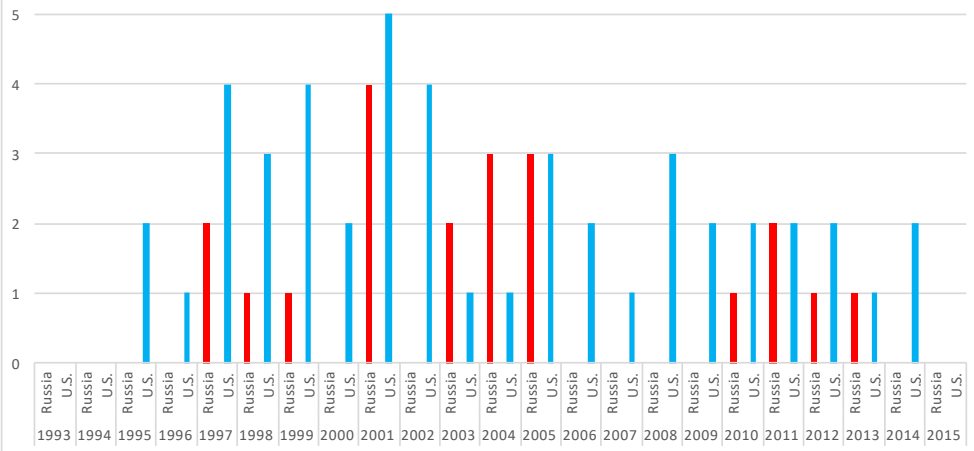

years (1995-1996, 2000, 2002, 2006-2009, and 2014), Kiev exercise with only the United States.

For the remaining years in which exercise activity occurred (1997-1999, 2001, 2003-2005, and 2010-2013), Ukraine trained with both regional great powers; however, during this time, there were 21 exercises with Russia and 28 exercises with the United States. From 1991-1994 and in 2015, Ukraine did not participate in any military exercises with either regional great power. 
Turning to the South

Chart 4: Armenia Military Exercises with the United States and Russia

Caucasus, since its

independence in 1991,

Armenia (Chart 4) has, on

average, participated in 1.52

combined military exercises

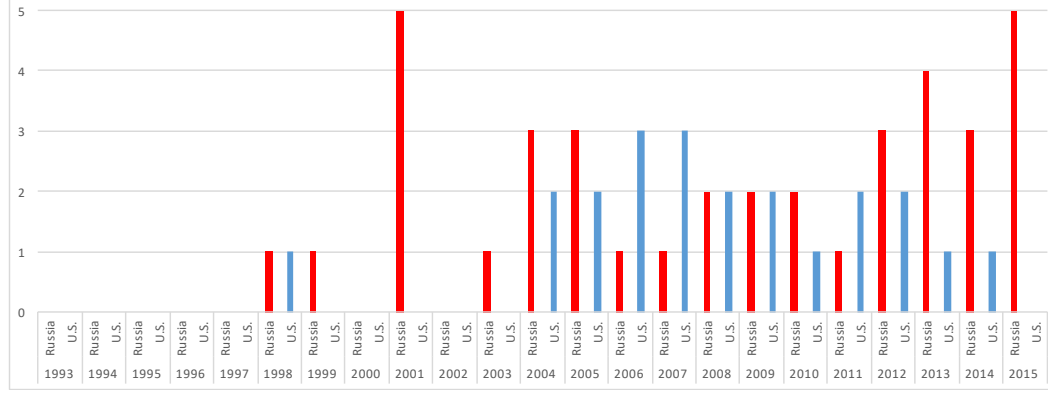

with Russia (38 total) as compared to .88 exercises with the United States ( 22 total). There were only four years $(1999,2001,2003,2015)$ in which Armenia exercised exclusively with Russia. During 12 of the years (1998, 2004-2014), Yerevan participated in U.S. and Russian exercises. For seven years (1993-1997, 2000, 2002) Armenia did not exercise with either country.

In Azerbaijan, Baku participated in .28 exercises with Russia and 1.28 exercises with the United States from 1991-2015. Chart 5 denotes that for 12 years $(1999$, 2002-2004, 2006-2010, 2012-2014),

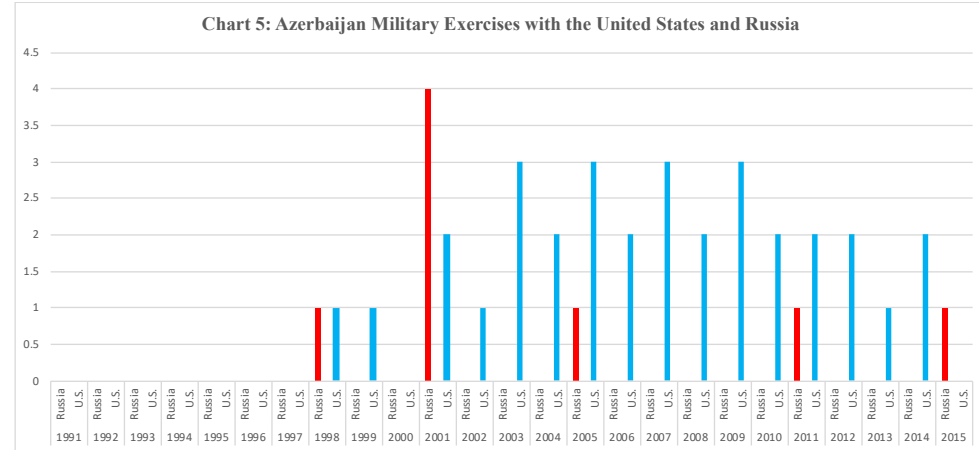
Azerbaijan exercised exclusively with the United States. For four years (1998, 2001, 2005, 2011), Azerbaijan exercised with both regional great powers. There was only one year (2015) in which Azerbaijan only conducted military drills with Russia. This is an interesting finding since Azerbaijan was a member of the CSTO from 1994-1999 where one would expect Baku to only conduct military exercises with this military alliance. For eight years (1991-1997, 2000), Baku did not exercise with either the United States or Russia. 
According to Chart 6, Georgian armed forces were involved, on average, in 1.6 exercises with the United States and .16 exercises with Russia during the 25-year period under examination. For 16 Chart 6: Georgia Military Exercises with the United States and Russia

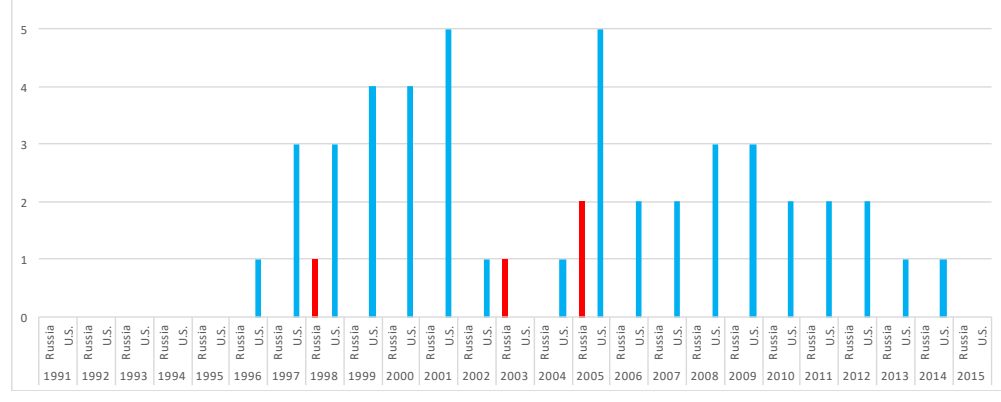
years (1996-1997, 1999-2002, 2004, 2006-2014), Tbilisi participated in combined military exercises with United States. The only year in which Georgia exercised with Russia and not the United States was in 2003. In 1998 and 2005, Tbilisi conducted military exercises with both countries. Georgia's pattern of exercise participation is particularly interesting for two reasons. First, despite being party to the CST from 1994-1999, Georgia exercised more heavily with the United States during this time. Second, even though Georgia exhibited a proclivity to exercise with the United States, in 2003 Georgia opted to exercise with only Russia.

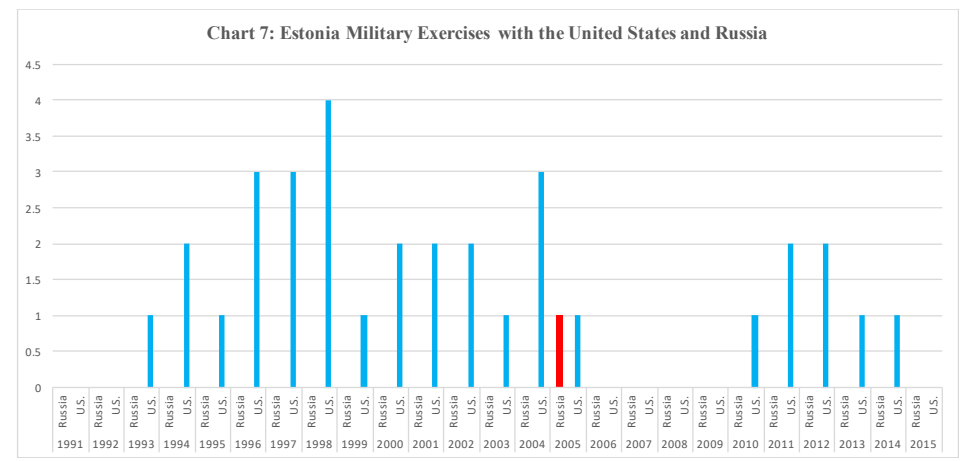

$$
\text { In the Baltics, Estonian military }
$$
forces conducted 1.32 exercises with the United States as compared to .04 exercises with Russia (Chart 7). From 1993-2004 and from 2010-2014, Estonia conducted combined military exercises with only the United States. In 2005, Tallinn participated in one combined exercise with the United States and Russia. From 1991-1992 and from 2006-2009, Estonia did not participate in any exercises with either regional great power. As depicted in Chart 8 below, Latvia's exercise preference is heavily skewed towards the United States. During the period under examination, Riga opted to participate in military 
exercises with the United States

for 17 of the 25 years at an

average rate of 1.16 exercises.

The only year Latvia conducted

an exercise with the Russian

Federation was in $2005(.04$

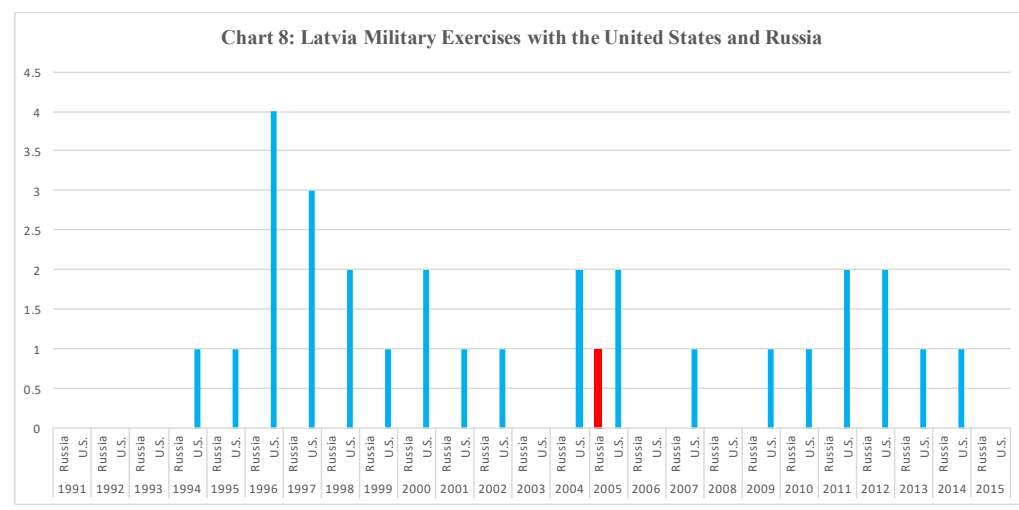

average); the same year in which the country's armed forces also participated in a combined

military exercise with the United States. There were seven years (1991-1993, 2003, 2006, 2008, and 2015) in which Latvia did not conduct any military exercises with either Russia or the United States.

Following Latvia, Lithuania

Chart 9: Lithuania Military Exercises with the United States and Russia

(Chart 9) also exhibited a

strong tendency to engage with

the United States in a wide

array of military exercises from

1994 to 2002, from 2006-2007,

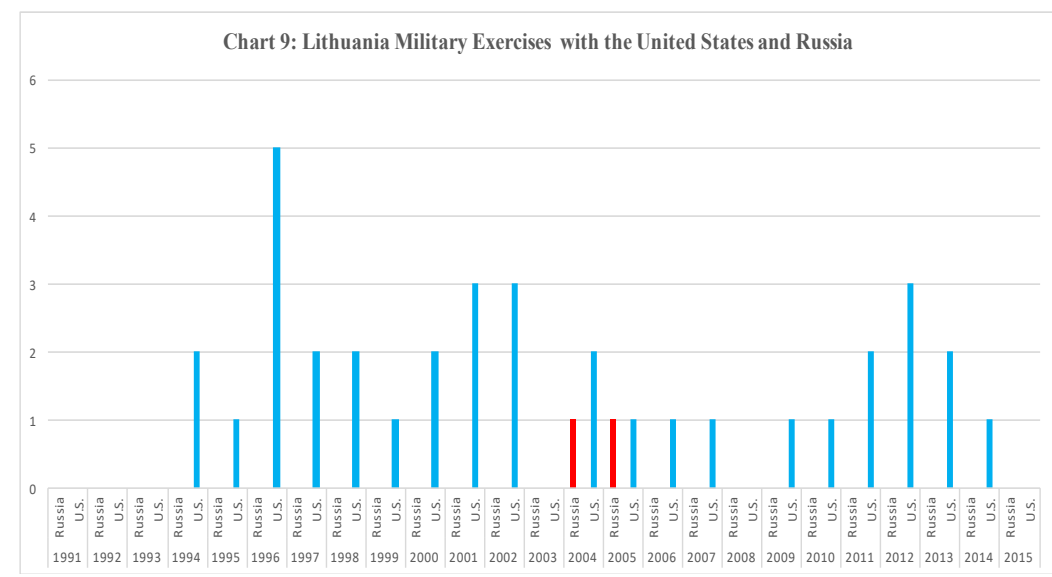

and from 2009 to 2014; a total of 17 years at a 25-year average of 1.44. In 2004 and 2005,

Vilnius conducted one combined exercise in each year with Russia (a .08 average) but had also

conducted exercises with the U.S. during this time. There were six years (1991-1993, 2003,

2008, and 2015) in which Lithuania did not conduct any military exercises with either of the

regional great powers. 
Turning to Central Asia, Astana's record of a higher exercise tempo with the United States over Russia is interesting, especially since Kazakhstan is a member of the CSTO. As Chart 10 reflects, this country participated Chart 10: Kazakhstan Military Exercises with the United States and Russia in 1.48 exercises with Russian military forces and 2.52 exercises with the United States. During this time, Kazakhstan conducted military exercises with the United

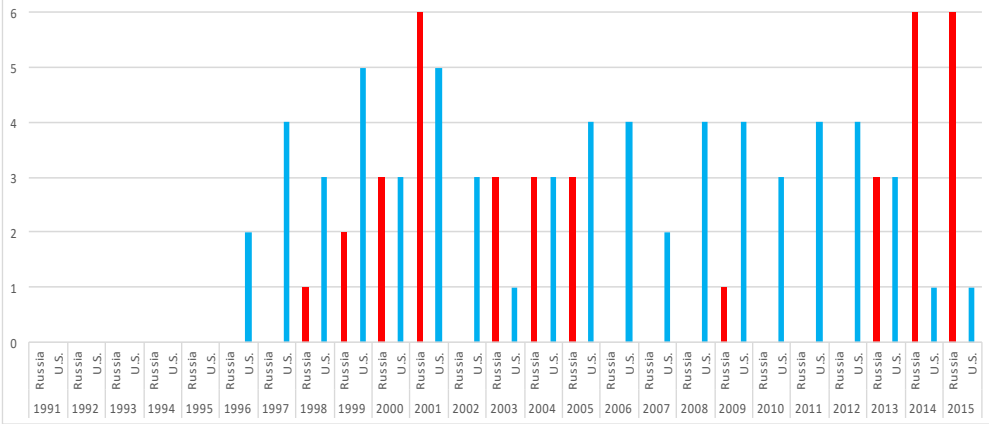
States during 10 different years (1996-1997, 2002, 2006-2008, 2010-2012) while never once participating in an exercise event where Russia was the leading regional power. Beginning in 1998, there were 11 years $(1998-2001,2003-2005,2009,2013-2015)$ in which Astana conducted exercises with the U.S. and Russia. From 1991-1995, Kazakhstan did not participate in any exercises with either country.

In examining Kyrgyzstan's exercise activity, this Central Asian country averaged 2.82 exercises with Russia as compared to 1.72 exercises Chart 11: Kyrgyzstan Military Exercises with the United States and Russia

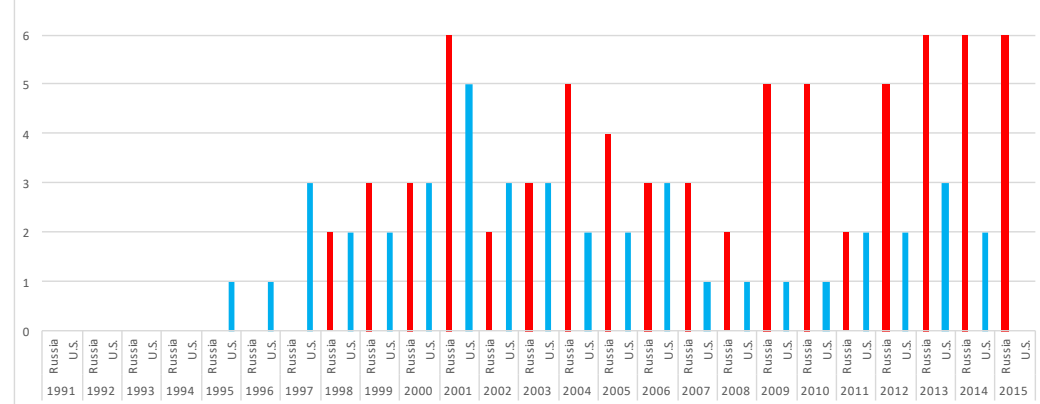

with the United States. According to Chart 11, from 1998-2015 Kyrgyz troops conducted separate exercises with military forces from Russia and the United States. For two years (19961997), Bishkek opted to participate in one military exercise in each year with the United States. From 1991-1994, Kyrgyzstan did not participate in any exercises with either the U.S. or Russia. 
Examining Chart 12 below, Tajikistan initially demonstrated a proclivity to exercise with Russia over the United States in 1994 and from 1999 to 2003. From 2004 onward, Dushanbe took a more balance approach participating in combined military exercises with each country 11 of the 12 years. In 1994, 1999-2003, and in 2006 did Tajikistan gave precedence to exercising with only Russia. This equates to an average of 3.08 and .64 exercises with Russia and the U.S.

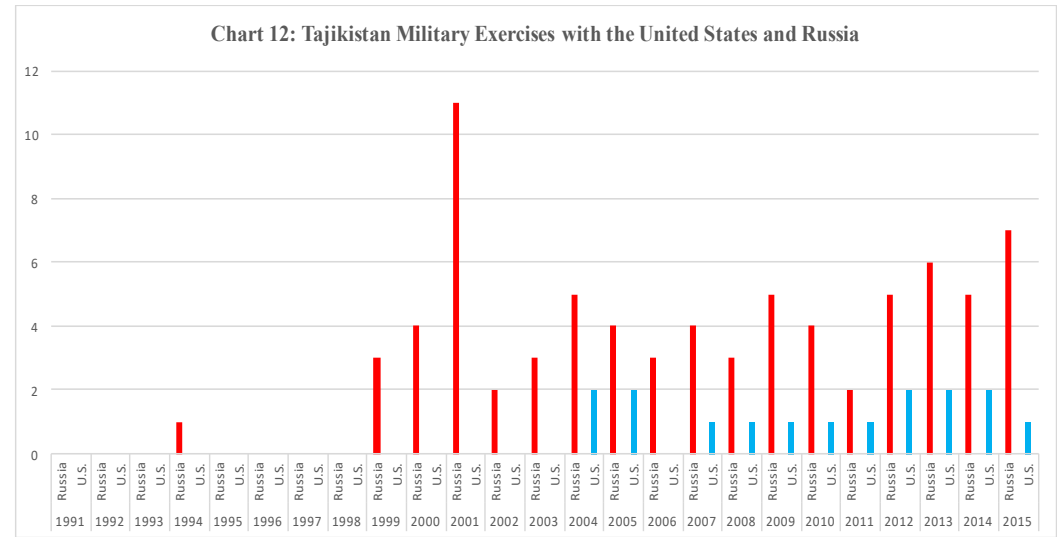
respectively. From 1991-1993 and from 1995-1998, Tajikistan did not participate in any military exercises with the United States or Russia. Turkmenistan has a sparse track record in this category registering only two combined military exercises with Russia (2005 and 2007; a .08 average) and one with the United States in 1999 (a .04 average). For the remaining 22 years, Ashgabat did not participate in any training events with either country.

Finally, in Chart 13: Uzbekistan Military Exercises with the United States and Russia Uzbekistan, the country's armed forces, on average, participated in .96 exercises with Russia

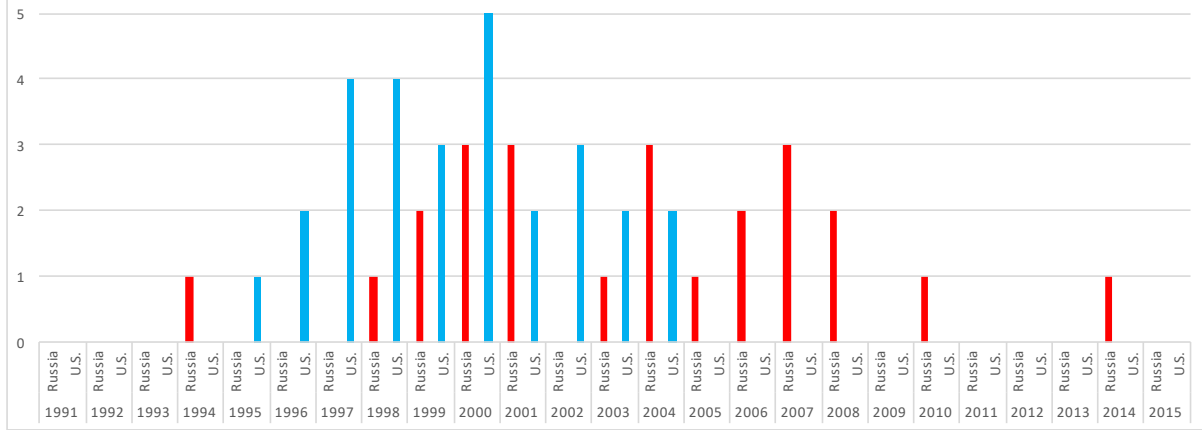
and 1.12 exercises with the United States in the post-Cold War era. As detailed in Chart 13, Tashkent conducted one exercise with Russia in 1994, but then proceeded to participate in one, two, and four exercises with the U.S. in from 1995-1997 respectively. In the period from 1998 to 
2004 (less 2002), Uzbekistan conducted exercises with both the United States (18 exercises) and Russia (13 exercises). In 2002, Tashkent conducted four exercises with only the United States; however, beginning in 2005 and ending in 2014, the country opted to participate in exercises with only Russia (10 total exercises).

Basing of Foreign Military Forces. Another indicator of state alignment is the extent to which former Soviet states have allowed the U.S. or Russia to station military forces on their sovereign territory. The deployment of armed forces abroad can be again traced back to Ancient Greece and the writings of Thucydides. During this time, Sparta and Athens deployed military personnel, equipment, and supplies in a network of bases designed to defend civilian populations, retain strategically important terrain, or ensure access to vital resources or key lines of communication. ${ }^{373}$ In the $20^{\text {th }}$ century, the Soviet Union and the United States made extensive use of foreign military bases to project military power or maintain a high level of influence around the world. Certainly, in many of the preceding examples, small states did not have a choice; however, some ruling governments sought out the stationing of foreign forces as part of a strategy to align with a particular regional great power.

Because foreign military bases carry with them political, economic, and security implications, examining their placement in the post-Soviet space can potentially yield some additional insight into a ruling government's alignment preferences since the end of the Cold War. According to Zdzislaw Lachowski, "observing changes in the way they [foreign military bases] are placed, owned and used can provide many clues to the most significant trends of security evolution."”374 To this end, this study broadly defines a foreign military base as a permanent or semi-permanent

\footnotetext{
${ }^{373}$ Havarky, R. H. 1989. Bases Abroad: The Global Foreign Military Presence. Oxford: Oxford University Press.

${ }^{374}$ Lachowski, Zdzislaw. 2007. Foreign Military Bases in Eurasia. Stockholm International Peace Research Institute. SIPRI Policy Paper 18, ii.
} 
physical structure located in another country whose primary purpose is to support military operations and/or national security-related activities. This structure can be referred to as an installation, camp, port, post, barracks, station, yard, center, compound, or facility. Although some scholars have advanced several different typologies for characterizing a country's foreign military presence abroad, this definition is detailed enough to discern the extent to which former Soviet republics have allowed the stationing of U.S. and/or Russian forces. ${ }^{375}$

With this definition in mind, this study examines the number of foreign military bases on the sovereign soil of the 14 newly independent states from 1991-2015. The central assumption is that former Soviet countries are considered to align with either Russia or the United States when there are a greater number of foreign military bases from one country than the other. To accomplish this task, this study employed a new data set of U.S. and Russian foreign military bases for the 14 former Soviet states. ${ }^{376}$ Chart 14 provides a summary of the number of military bases in each of the former Soviet states from 1995-2015.

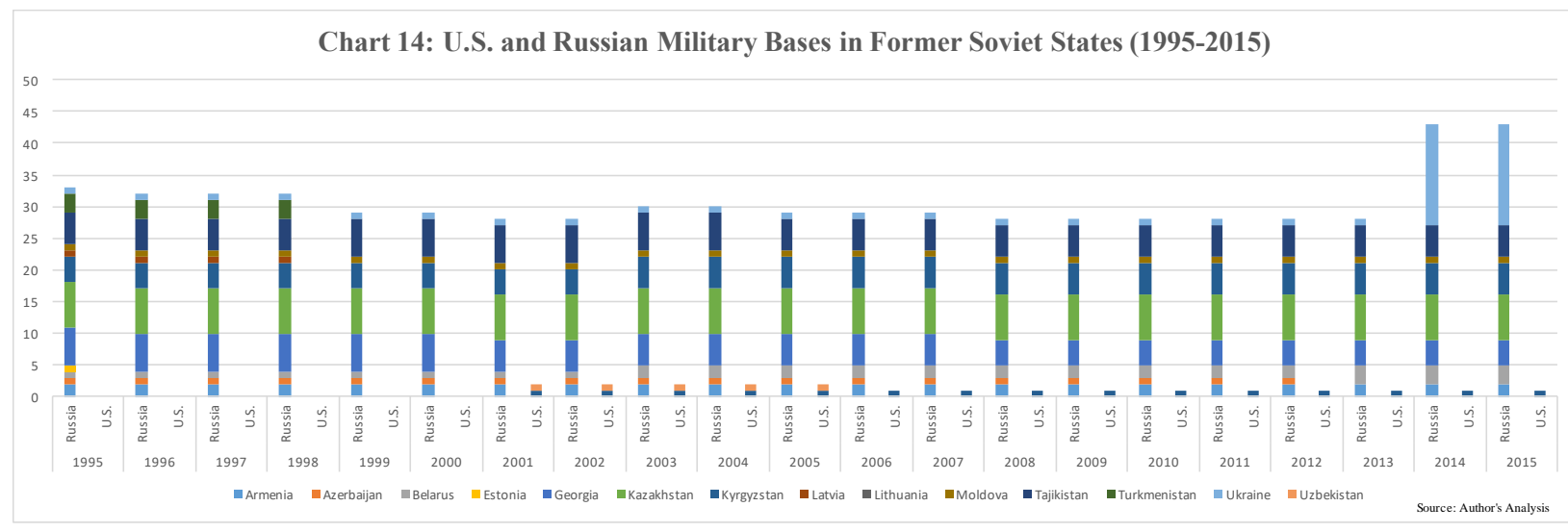

\footnotetext{
${ }^{375}$ J.E. Peterson examines a wide array of typologies scholars have used to define a foreign military presence. See Peterson, J. E. 2009. "Foreign Military Presence and its Role in Reinforcing Regional Security: A Double-Edged Sword." In Arabian Gulf Security: Internal and External Challenges. The Emirates Center for Strategic Study and Research, Dubai.

${ }^{376}$ Sources for this new data set include United Nations reports, foreign defense and official government studies, journal articles by area specialists, SIPRI publications, media reports, and assessments from various private entities. A spreadsheet of these sources is available upon request.
} 
The data in the chart above indicate that all newly-independent states consistently had a higher number of foreign military bases from Russia than the United States. If these figures are taken at face value, then one could conclude a strong majority of former Soviet states have exhibited (or continue to exhibit) a strong alignment with Russia thereby validating realist claims. This may be the case with Armenia, Belarus, Kazakhstan, Kyrgyzstan, Moldova, and Tajikistan, which have consistently allowed the stationing of Russian military forces and facilities. In direct opposition to realist claims, the Baltic States and Uzbekistan early on avoided the stationing of Russian personnel and facilities opting to immediately exert control over established military bases and evict Russian military personnel. There also exists a mixed group of states, which initially allowed Russian forces to operate within the boundaries of the country's sovereign territory, but then ejected them—or attempted to-owing to changes in the strategic environment. Countries comprising this category include Azerbaijan, Georgia, Turkmenistan, and Ukraine. ${ }^{377}$ For the purposes of this study, it is the second and third group of countries that require a closer examination to understand each country's primary alignment trajectory.

Arms Purchases. The third military indicator of alignment is arms purchases. Specifically, this study attempts to discern whether former Soviet states are buying more arms from either Russia or the United States. The sale of military weapons, equipment, and supplies is an

\footnotetext{
${ }^{377}$ In Azerbaijan, Russia rented the Gabala Radar Station until 2012. In 2013, the facilities at this location were transferred to Azerbaijan and the equipment transported back to Russia. See Lachowski 2007, 46 and 57. In Georgia, President Shevardnadze agreed to the stationing of Russian forces on Georgian territory in the early 1990s; however, in 2005, Moscow and Tbilisi reached an agreement to close Russian bases at Akhalkalaki and Batumi by the end of 2007 following a statement by Georgian President Saakashvili that Georgia would not allow any foreign military bases on its soil. See Kakachia, Kornely. 2008. "End of Russian military bases in Georgia: Social, Political and Security Implications of Withdrawal." Central Asia and the Caucasus 2 (50). In Turkmenistan, from 1992-1999, Russian forces helped guard Turkmenistan's border with Turkey and Iran. When Turkmenistan could conduct this mission on their own, Russian forces left the country in 1999. See Library of Congress. 2007. "Country ProfileTurkmenistan.” https://www.loc.gov/rr/frd/cs/profiles/Turkmenistan-new.pdf. Accessed 20 December 2016, 14. In January 1992, Uzbekistan took control over all Soviet facilities and equipment in the country, less those strategic forces under the CIS, which were quickly withdrawn. See Smith, Diane L. 1998. "Breaking Away from the Bear." U.S. Army War College Strategic Studies Institute, 33-34.
} 
important dimension of interstate relations. For political elites in small states, acquiring modern military hardware from external powers can help ensure they are able to defend the country's sovereignty and remain in power. For the regional great powers of the world, arms sales represent a tool of the state to accomplish a wide array of economic, diplomatic or security goals.

This study uses the Stockholm International Peace Research Institute's (SIPRI's) definition of arms sales, which is best understood as the "sales of military goods and services to military customers, including both sales for domestic procurement and sales for export." ${ }^{\prime 378}$ To discern alignment, this study assumes arms sales is a mutually beneficial endeavor. When interstate cooperation rises, one may also assume a positive, non-statistical correlation with arms sales. As such, a small state is said to align with one regional great power over another when the dollar value of arms exceeds the other.

Chart 15 details the arms purchases of the 14 former Soviet states from the United States and Russia from 1995-2015. An examination of the data yields the following general observations. First, arms purchases by select former Soviet states from Russia consistently exceeded that of the United States. For the period under examination, Russian arms purchases by all countries totaled $\$ 4.93$ billion as compared to the $\$ 1.76$ billion from the United States. Second, former Soviet states purchased more weapons and military equipment from Russia except for three countries;

\footnotetext{
${ }^{378}$ Of note, SIPRI further defines military goods and services as resources "that are designed specifically for military purposes and the technologies related to such goods and services. Military goods are military-specific equipment and do not include general-purpose goods, such as oil, electricity, office computers, uniforms and boots. Military services are also military-specific. They include technical services, such as information technology, maintenance, repair and overhaul, and operational support; services related to the operation of the armed forces, such as intelligence, training, logistics and facilities management; and armed security in conflict zones. They do not include the peacetime provision of purely civilian services, such as health care, cleaning, catering and transportation, but supply services to operationally deployed forces are included." Stockholm International Peace Research Institute (SIPRI). 2016. "Sources and Methods." https://www.sipri.org/databases/armsindustry/sources-and-methods. Accessed 03 December 2016, 2.
} 
Estonia, Moldova, and Ukraine. Third, on average Russia was the top arms provider to Armenia, Azerbaijan, Belarus, Kazakhstan, Kyrgyzstan, Lithuania, Tajikistan, and Turkmenistan.

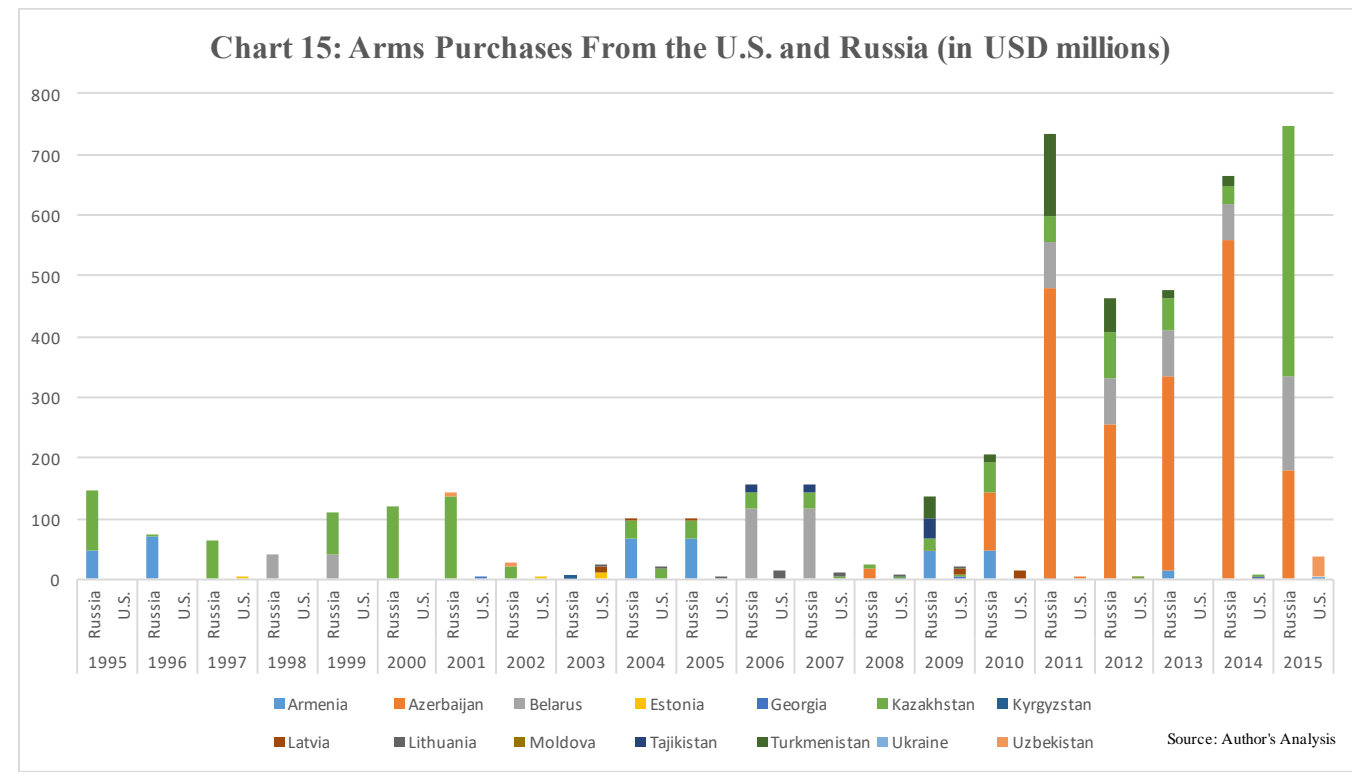

Given this reality and holding constant the assumption that arms purchases translate into influence, then these countries should exhibit bandwagoning behavior with Russia. The empirical world however does not support these propositions in total. While Armenia, Belarus, Kazakhstan, Kyrgyzstan, and Tajikistan exhibit consistent bandwagoning behavior with Russia by their participation in the CSTO, Turkmenistan never signed the CST, Azerbaijan left the alliance in 1999, and Lithuania became part of NATO in 2004. Separately, with the U.S. serving as the top arms provider to Estonia, Latvia, Georgia, Ukraine and Uzbekistan, these countries should have aligned with Washington; however, it was only Estonia and Latvia that aligned with the United States in the years prior to their entry into the NATO alliance. Of note, Moldova was the only country where neither the U.S. nor Russia sold arms according to SIPRI reporting.

Taken together, it appears realist propositions for this indicator have fallen short for several reasons. First, it is often difficult to derive valid judgements on interstate relations based solely on the transfer of arms from one state to another because not all actions are done in a transparent 
manner. Arms sales by the U.S. during the 1980s represents one of many examples of how great powers pursue clandestine operations to achieve a political purpose. ${ }^{379}$ Second, arms sales do not necessarily convey great power influence and a corresponding alignment of the smaller state. For example, during the Cold War Soviet arms sales to Indonesia as well as Iraq, Syria, and Congo did not result in these countries falling unequivocally into Moscow's orbit. ${ }^{380}$ In the late 1970 s, Former Assistant Secretary of State Hodding Carter III emphasized this point noting, "what nation has been brought permanently into the Soviet orbit because it could buy Soviet MiGs.”381 Similarly, the U.S. arms sales embargo on Turkey following its invasion of Cyprus created a backlash resulting in the closure of American military bases in the country and a deterioration of relations between Ankara and Washington. ${ }^{382}$ Taken together, one cannot definitively conclude a decision by ruling elites in a small state to purchase military arms from a particular regional great correlates with alignment. If some degree of alignment is observed, it may only be short in duration since there exists a multitude of other countries willing to sell the same type of weapons or equipment to a country so long as they pay. ${ }^{383}$

Head of State Visits. The foreign travels of a head of state represent another important component of the ruling government's ability to employ the diplomatic element of national power on the world's stage. While a visit from a head of state may serve a variety of political, economic, or social purposes, frequently the overarching goal of these visits center on improving

\footnotetext{
${ }^{379}$ Poindexter, John M. 1986. "Covert Action Finding Regarding Iran.” The White House. The National Security Archives. http://nsarchive.gwu.edu/NSAEBB/NSAEBB210/15-Reagan\%20Finding\%201-1786\%20(IC\%2002181). pdf. Accessed 02 December 2016.

${ }^{380}$ Pierre, Andrew J. 2014. The Global Politics of Arms Sales. Princeton: Princeton University Press, 273. See also Klare, Michael T. 1984. "Soviet Arms Transfers to the Third World." Bulletin of the Atomic Scientists 40 (5), 26; ${ }^{381}$ Klare 1984, 26.

${ }^{382}$ Costello, M. 1978. "Eastern Mediterranean Security." Editorial Research Reports 1978 (Vol. II). Washington, DC: CQ Press. http://library.cqpress.com/cqresearcher/cqresrre1978070700. Accessed 20 November 2016.

${ }^{383}$ Pierre 2014, 18.
} 
bilateral relations. Joel Krieger speaks to the importance of head of state visits to the United States noting...

When a head of state visits the White House, it is often considered a major event. The flags of the two countries are mounted at equal height, and a spirt of friendship reigns. Such meetings are considered a time of conceding equality of nations, a time of recognition of the shared use of the planet and a hope for better nation-to-nation relations in the future. ${ }^{384}$

Krieger's notion that the meeting of two heads of state may serve as an opportunity for improved state relations serves as another reference point for using this high-profile event as an indicator to measure state alignment.

Defining a head of state visit can be a challenging endeavor because different states have established different diplomatic protocols for various types of visits. ${ }^{385}$ In this dissertation, a head of state visit can take on four different forms: state, official, working, and private. A state visit occurs when a country's head of state meets with the host country's head of state at locations in the capital city. An official visit occurs when a visiting head of state meets with other members of the ruling government in the host country at locations in the capital city. A working visit occurs when a head of state meets with the host country's head of state in a less formal albeit meeting environment anywhere in the country. Finally, a private meeting occurs when a head of state meets with a host country's head of state for unofficial reasons.

To understand how the number of head of state visits are potentially related to a state's alignment trajectory, this study examines the frequency of head of state visits from the 14 former Soviet states on an annual basis to the United States and Russia for the period 1991-2015. When

\footnotetext{
${ }^{384}$ Krieger, Joel, ed. 2013. The Oxford Companion to Comparative Politics. Vol. 2. Oxford University Press, 185.

${ }^{385}$ For example, there are four types of head of state visits in Switzerland (state, official, official working, and courtesy), three in the United States (state, official working, and private) and one in the Philippines (state) with each offering generally similar definitions for each category. Federal Department of Foreign Affairs. 2016. "Protocols and Visits." https://www.eda.admin.ch/eda/en/home/fdfa/diplomacy/protocol-and-visits.html. Accessed 02 December 2016; French, Ambassador Mary Mel. 2010. United States Protocol: The Guide to Official Diplomatic Etiquette. Rowman \& Littlefield Publishers; Republic of Philippines. 2016. Official Gazette. http://www.gov.ph/ diplomatic-relations/differentiating-visits/. Accessed 02 December 2016.
} 
possible, presidential visits to a contested territorial area in another country are not counted as a valid event. For example, presidential visits by Dmitry Medvedev or Vladimir Putin to Georgia's breakaway provinces of South Ossetia and Abkhazia are not counted because these areas are still recognized by the international community as sovereign Georgian territory. As such, a country is considered to be aligned with either Russia or the U.S. when the frequency of state visits is higher than the other.

Table 5 details the total number of head of state visits to the United States and Russia from 1991 to 2015 . An examination of the table indicates a majority (10 of 14) of the head of states in the former Soviet states visited

Russia more frequently than the United

\begin{tabular}{|c|c|c|c|c|}
\hline \multicolumn{5}{|c}{ Table 5: Head of State Visits to the U.S. and Russia (1991-2015) } \\
\hline & Visits to US & US Average & Visits to Russia & Russia Average \\
\hline Kazakhstan & 16 & 0.64 & 78 & 3.12 \\
\hline Belarus & 3 & 0.12 & 76 & 3.04 \\
\hline Armenia & 14 & 0.56 & 71 & 2.84 \\
\hline Ukraine & 26 & 1.04 & 65 & 2.6 \\
\hline Kyrgyzstan & 7 & 0.28 & 56 & 2.24 \\
\hline Tajikistan & 18 & 0.72 & 46 & 1.84 \\
\hline Uzbekistan & 7 & 0.28 & 39 & 1.56 \\
\hline Azerbaijan & 11 & 0.44 & 35 & 1.4 \\
\hline Moldova & 12 & 0.48 & 37 & 1.48 \\
\hline Turkmenistan & 6 & 0.24 & 30 & 1.2 \\
\hline Georgia & 27 & 1.08 & 27 & 1.08 \\
\hline Lithuania & 30 & 1.2 & 10 & 0.4 \\
\hline Latvia & 30 & 1.2 & 6 & 0.24 \\
\hline Estonia & 27 & 1.98 & 2 & 0.08 \\
\hline \multicolumn{5}{|l}{} \\
\hline
\end{tabular}

States. ${ }^{386}$ The four outliers in this indicator are the Baltics, which made more trips to the United States during this time and Georgia, which made an equal number of visits to each country. For the ten countries making more trips to Russia, Kazakhstan tops the list with an average of 3.12 visits per year (78 total visits) while Turkmenistan made 1.2 visits (30 total visits). During this 25-year period, those states making more visits to Russia made less than one visit to the United states ranging from .12 visits/year (Belarus) to .72 (Tajikistan). The only exception here is Ukraine, which made 1.04 visits (26 total visits) to the U.S. during this time.

\footnotetext{
${ }^{386}$ This study created a new data on head of state visits to the United States and Russia by using a wide array of primary and secondary sources. Primary sources include the official websites of the President of Russia and the U.S. State Department's Office of the Historian as well as the homepages for various Ministries of Foreign Affairs and embassies of the 14 former Soviet states and the United Nations. Secondary sources include published books and articles by area specialists and scholars and media reports.
} 
From one perspective, one would expect Armenia, Belarus, Kazakhstan, Kyrgyzstan, and Tajikistan to make more trips to Russia and for the Baltics to make more trips to the United States given their membership in the CSTO or NATO respectively. But what explains why Turkmenistan, Ukraine, and Uzbekistan made more trips to Russia while Georgia made an equal number of trips? Certainly, geopolitics could be a factor driving these countries along a multivector foreign policy azimuth; however, simply taking the average number of visits over the 25year period fails to account for the variation in visits by each ruling government.

In Chart 16, one begins to understand that the alignment tendencies of each country vary markedly during different years. Specifically, there appears to be a substantial amount of variation with respect to state visits when observing these events over time. For example, in Moldova from Chart 16: Total Head of State Visits to the U.S. and Russia (1991-2015) 1991-1996

President Mircea

Snegur made an average of 1.83 visits to Russia as compared to only .45 visits to the

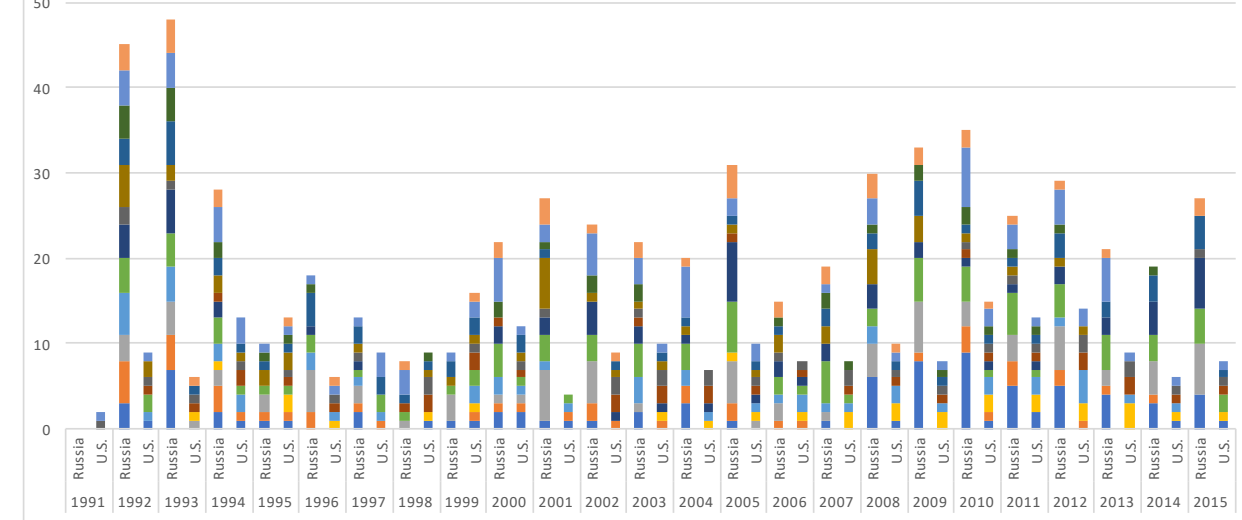
United States. Following the election of Petru Lucinschi in 1997, this head of state proceeded to make only .5 visits to Russia during his 4 years in office as compared to .75 visits to the United States. Similarly, in Georgia from 1993 to 2003, President Eduard Shevardnadze made an average of 1.36 visits to Russia and .72 visits to the U.S. as compared to his successor, Mikheil Saakashvili. Here, from 2004-2012 Saakashvili made an average of .78 visits per year to Russia 
and 1.78 visits to the United States. In Azerbaijan, Heydar Aliyev averaged .75 trips per year to Russia and the U.S. from 1996 to 2003; however, his successor Ilham Aliyev averaged .25 trips to the U.S. and 1.33 visits to Russia. These figures indicate the necessity to consider time and how alignment patterns may vary between ruling governments.

Visits by other Country Leaders. Head of state visits provide one point of reference from which to understand a state's alignment trajectory since this individual is frequently the vanguard actor in the ruling government's foreign policy executive. In many instances, however, head of state visits are few in number owing to a wide array of constraints (e.g. time) and the necessity for this person to address domestic-level issues. As a result, there is value in examining the number of foreign visits by other government and non-government leaders, who have been either directly or indirectly tasked to represent the head of state on foreign policy matters. According to Erika Young,

Exchange visits between dignitaries from different countries are a major part of international relations. Meetings between... heads of government and Ministers of Foreign Affairs are an opportunity to discuss key topics of common interest, strengthen political, economic, cultural and social bilateral relations, establish diplomatic relations, and solve controversial issues. ${ }^{387}$

To understand how the number of visits by government and non-government officials are potentially correlated with a state's alignment trajectory, this study examines the frequency of these visits by the 14 former Soviet states on an annual basis to the United States and Russia for the period 1991-2015. A country is considered to be aligned with either Russia or the U.S. when the frequency of exercise events is higher than the other. ${ }^{388}$

\footnotetext{
${ }^{387}$ Young, Erika G. 2014. "The Diplomatic Protocol of the Republic.” Ministry of Foreign Affairs of Italy. http://www.esteri.it/mae/cerimoniale/cerimoniale/pdf/3.\%20cerimoniale\% 20diplomatico\%202.0\%20\%20versione\% 20in\%20inglese\%20(marzo\%202014).pdf, 15. Accessed 20 December 2016.

${ }^{388}$ Data for this indicator is derived the DARPA-funded Integrated Conflict Early Warning System (ICEWS) located at Harvard's Dataverse website at https://dataverse.harvard.edu.
} 
Table 6 highlights the

number of visits by other

country representatives do not

parallel the visits by the

country's head of state.

Noticeably different is how

Latvian representatives made
Table 6: Visit By Other Government Leaders to the U.S. and Russia (1995-2015)

\begin{tabular}{c|c|c|c|c}
\hline & Visits to US & US Average & Visits to Russia & Russia Average \\
\hline Georgia & 557 & 26.52 & 1187 & 56.52 \\
\hline Ukraine & 497 & 23.67 & 898 & 42.76 \\
\hline Armenia & 119 & 5.67 & 288 & 13.71 \\
\hline Kyrgyzstan & 68 & 3.23 & 260 & 12.38 \\
\hline Azerbaijan & 336 & 16 & 243 & 11.57 \\
\hline Belarus & 49 & 2.33 & 230 & 10.95 \\
\hline Latvia & 164 & 7.81 & 197 & 9.38 \\
\hline Moldova & 31 & 1.48 & 189 & 9 \\
\hline Tajikistan & 38 & 1.81 & 153 & 7.29 \\
\hline Kazakhstan & 115 & 5.47 & 151 & 7.19 \\
\hline Lithuania & 186 & 8.86 & 136 & 6.48 \\
\hline Turkmenistan & 42 & 2 & 56 & 2.67 \\
\hline Estonia & 52 & 2.48 & 51 & 2.43 \\
\hline Uzbekistan & 40 & 1.9 & 51 & 2.43 \\
\hline \multicolumn{5}{r|}{} \\
\hline
\end{tabular}

more trips to Russia while representatives from Azerbaijan made more visits to the United

States. In total, 11 of the 14 countries met realist expectations in this category (Armenia, Belarus,

Georgia, Latvia, Kazakhstan, Kyrgyzstan, Moldova, Tajikistan, Turkmenistan, Ukraine, and

Uzbekistan) with representatives making more trips to Russia while only three countries made

more trips to the United States (Azerbaijan, Estonia, and Lithuania). Of the 11 countries favoring

visits to Russia, Georgia and Ukraine were at the top with an average of 56.52 and 42.76 visits

per year respectively. It should also be noted that both of these countries beat out other former

Soviet states in terms of average visits with Ukraine making 26.52 trips per year to the U.S.

while Georgians made 23.67 visits during the same time period.

Trade. Table 7

summarizes trade data

between 11 former Soviet

states and the U.S. and

Russia from 1994 to 2015.

Of note, while trade data
Table 7: Total Exports-Imports to-from the U.S. and Russia (1994-2015; in 1000 USD)

\begin{tabular}{c|c|c|c|c|}
\hline & Exports to US & Exports to Russia & Imports from Russia & Imports from U.S. \\
\hline Armenia & 784,710 & $2,403,097$ & $9,720,316$ & $1,958,261$ \\
\hline Azerbaijan & $15,721,041$ & $8,234,575$ & $14,683,433$ & $4,506,908$ \\
\hline Belarus & $2,508,777$ & $152,099,860$ & $256,052,313$ & $5,349,145$ \\
\hline Estonia & $8,679,510$ & $26,394,297$ & $26,574,526$ & $4,894,285$ \\
\hline Georgia & $1,441,322$ & $1,546,071$ & $5,900,346$ & $2,963,400$ \\
\hline Kazakhstan & $7,513,687$ & $70,219,783$ & $145,465,336$ & $21,039,909$ \\
\hline Kyrgyzstan & 121,225 & $2,721,223$ & $13,243,354$ & $1,729,689$ \\
\hline Latvia & $2,231,238$ & $13,247,554$ & $17,980,228$ & $1,878,537$ \\
\hline Lithuania & $9,424,199$ & $48,668,667$ & $95,220,826$ & $5,854,666$ \\
\hline Moldova & 465,184 & $5,407,401$ & $8,679,894$ & $1,025,578$ \\
\hline Ukraine & $15,991,137$ & $168,590,459$ & $265,694,443$ & $25,076,207$ \\
\hline
\end{tabular}

Source: Wolrd Bank and United Nations Conference on Trade and Development 
during this time was generally robust, there were several notable gaps. ${ }^{389}$ First, there was little data on the level of exports and imports for Tajikistan, Turkmenistan, and Uzbekistan to either the U.S. or Russia. Second, there were several years in which there were no export or import data for select countries (Armenia, 1994-1996; Azerbaijan, 1994-1995 and 2014; Belarus, 1994-1997; Estonia, 1994; Georgia, 1994-1995; Kazakhstan, 1994; Kyrgyzstan, 1994, 1997-1999, and 2014; and Ukraine, 1994-1995).

A country is assessed to be aligned with the U.S. or Russia when total trade with one country is greater than the other. Based on the figures in the table above, realists may conclude all former Soviet states, less Azerbaijan are aligned with Russia given how this country was the number one exporter and importer of goods to and from these countries. In the case of Azerbaijan, the United States was the country's top exporter delivering $\$ 15.7$ billion in goods as compared to 8.2 billion to Russia. Specifically, from 2008 to 2015 , Baku exported more goods to the United States than Russia. Given energy resources is one of Azerbaijan's biggest export products, the completion of the Baku-Tbilisi-Ceyhan crude oil pipeline in 2006 is one possible reason why there was an increase in the level of exports to the United States. Beginning in 2007, U.S. oil imports from Azerbaijan more than doubled from 10,091,000 to 22,809,000 barrels/year. ${ }^{390}$

Bilateral Investment Treaties. Bilateral investment treaties (BITs) are economic agreements that establish rules and guidelines for foreign investment between two countries. For hundreds of years, states have entered into these type of agreements, but it was not until the 1950s when they

\footnotetext{
${ }^{389}$ Data for these three indicators are derived from two primary sources: The World Integrated Trade Solution (WITS) at http://wits.worldbank.org/about_wits.html is used for data on trade and tariffs. Data on bilateral investment treaties was collected from World Bank and UNCTAD data sets at https://icsid.worldbank.org/en/Pages/ resources/Bilateral-Investment-Treaties-Database.aspx and http://investmentpolicyhub.unctad.org/IIA. Data collected in March to June 2016.

${ }^{390}$ United States Energy Information Administration (USEIA). 2016. “U.S. Imports from Azerbaijan of Crude Oil and Petroleum Products." https://www.eia.gov/dnav/pet/hist/LeafHandler.ashx?n=PET\&s=MTTIM_NUSNAJ_1\&f=M. Accessed 02 December 2016.
} 
made a reemergence with Pakistan and the Federal Republic of Germany signing one of the first BITs in the post-World War II era. ${ }^{391}$ According to Mary Hallward-Driemeier, since the end of the Cold War, "countries have increasingly turned to signing BITs as a way to entice foreign investors to their shores. BITs are heralded by their proponents as an important means of attracting new foreign direct investment." ${ }^{392}$ In this study, a BIT is defined as a formal written agreement between two countries that established the terms and conditions of how, when, and where companies from one country may invest resources (time, money, etc.) in another country based on pre-agreed guidelines. ${ }^{393}$

According to Table 8, it is not clear the extent to which realist assertions on small state alignment holds. In this case, former Soviet states, on average tended to sign a BIT with the United

States over Russia in

\begin{tabular}{|c|c|c|c|c|c|c|}
\hline \multicolumn{8}{|c|}{ Table 8: Bilateral Investment Treaties (BITS), 1992-2015 } \\
\hline & Russia & Year Signed & Year In force & U.S. & Year Signed & Year In force \\
\hline Armenia & 1 & 2001 & 2006 & 1 & 1992 & 1996 \\
\hline Azerbaijan & 1 & 2014 & & 1 & 1997 & 2001 \\
\hline Belarus & 0 & None & & 1 & 1994 & \\
\hline Estonia & 0 & None & & 1 & 1994 & 1997 \\
\hline Georgia & 0 & None & & 1 & 1994 & 1999 \\
\hline Kazakhstan & 1 & 1998 & 2000 & 1 & 1992 & 1994 \\
\hline Kyrgyzstan & 0 & None & & 1 & 1993 & 1994 \\
\hline Latvia & 0 & None & & 1 & 1995 & 1996 \\
\hline Lithuania & 1 & 1999 & 2004 & 1 & 1998 & 2004 \\
\hline Moldova & 1 & 1998 & 2001 & 1 & 1993 & 1994 \\
\hline Tajikistan & 1 & 1999 & & 0 & None & \\
\hline Turkmenistan & 1 & 2009 & 2010 & 0 & None & \\
\hline Ukraine & 1 & 1994 & 1996 & 1 & 1998 & 2000 \\
\hline Uzbekistan & 2 & $1997 / 2013$ & $/ 2014$ & 1 & 1994 & \\
\hline \multicolumn{7}{|l|}{} \\
\hline
\end{tabular}
contradiction to realist expectations. Those countries consistently showing a tendency to not align with Russia include Belarus, Estonia, Georgia, Kyrgyzstan, and Latvia. Seven countries (Armenia, Azerbaijan, Kazakhstan, Lithuania, Moldova, Ukraine, and Uzbekistan) took a bifurcated approach signing a BIT with both regional great powers. Only Tajikistan and

\footnotetext{
${ }^{391}$ United Nations. 2007. "Bilateral Investment Treaties 1995-2006: Trends in Investment Rulemaking." United Nations Conference on Trade and Development. Geneva, February 2007.

${ }^{392}$ Hallward-Driemeier, Mary. 2003. "Do Bilateral Investment Treaties Attract Foreign Direct Investment? Only a Bit and They Could Bite." World Bank Policy Research Working Paper 3121, 1.

393 This definition is derived from the Legal Information Institute (LII). 2016. "Bilateral Investment Treaty." Cornell Law School. https://www.law.cornell.edu/wex/bilateral_investment_treaty. Accessed 02 December 2016.
} 
Turkmenistan did not sign a BIT with the United States indicating a stronger preference to align with Russia. Of note however, the BITs for Belarus and Uzbekistan with Russia never entered into force potentially supporting realist claims.

Tariffs. The implementation of tariffs is the final economic indicator used to test realist propositions and discern alignment variation in the post-Soviet space. Examining when and to what extent a small country levies a tariff rate on a larger regional power may provide some insight as to whether a former Soviet state may prefer an alignment with the U.S. or Russia. A tariff is a customs duty, which is defined as a "charge levied on imports and listed in importing country's tariff schedules. Duties may be specific or ad valorem or a combination of the two (ad valorem with a specific minimum, or the greater of the two)." 394

According to the World Trade Organization (WTO), there exists a variety of different types of tariffs to include Bound, Applied, Most-Favored Nation (MFN), and Preferential with each levying a different rate based on a variety of different factors (e.g. member of the WTO, member of a Preferential Trade Agreement, etc.). For simplicity, this study uses MFN tariffs, which is "what countries promise to impose on imports from other members of the WTO, unless the country is part of a preferential trade agreement (such as a free trade area or customs union)."${ }^{\circledR 395}$ Newly-independent states are said to be more aligned with either the United States or Russia if the MFN tariff rates are lower for one and not the other.

For the period 1992-2015, while there is generally an absence of available tariff data for all 14 countries, some general inferences can be made from the table below, which depicts those countries that imposed a higher MFN tariff rate on the United States or Russia. To more easily

\footnotetext{
${ }^{394}$ Azita, Amjadi, Philip Schuler, Hiroaki Kuwahara, and Susanne Quadros. 2016. World Integrated Trade Solutions User Manual 2.01, World Bank, 216.

${ }^{395}$ Ibid, 91.
} 
discern which country received a higher tariff rate, the table uses a color coding scheme. When a block is colored either red or blue, a higher tariff rate was applied to Russia or the U.S.

\begin{tabular}{|c|c|c|c|c|c|c|c|c|c|c|c|c|c|c|c|c|c|c|c|c|}
\hline \multicolumn{21}{|c|}{ Table 9: Former Soviet States MFN Tariff Rates on Russia and the U.S. (1995-2005) } \\
\hline & \multicolumn{2}{|c|}{1995} & \multicolumn{2}{|c|}{1996} & \multicolumn{2}{|c|}{1997} & \multicolumn{2}{|c|}{1999} & \multicolumn{2}{|c|}{2000} & \multicolumn{2}{|c|}{2001} & \multicolumn{2}{|c|}{2002} & \multicolumn{2}{|c|}{2003} & \multicolumn{2}{|c|}{2004} & \multicolumn{2}{|c|}{2005} \\
\hline & US & RS & US & RS & US & RS & $\mathbf{U S}$ & RS & US & RS & US & RS & US & RS & US & RS & US & RS & US & RS \\
\hline Armenia & & & & & & & & & & & 3 & 2.2 & & & 3.1 & 2.8 & \begin{tabular}{|l|}
3.3 \\
\end{tabular} & 3 & 3.6 & 3 \\
\hline Azerbaijan & & & & & & & & & & & & & \begin{tabular}{|l|}
9.6 \\
\end{tabular} & \begin{tabular}{|l|}
8.7 \\
\end{tabular} & & & & & 9.9 & 9.5 \\
\hline Belarus & & & 11.6 & 11.6 & 12.6 & 12 & & & 11 & 10.5 & 10.4 & \begin{tabular}{|l|l|}
9.9 \\
\end{tabular} & 11.2 & 11 & & & & & & \\
\hline Estonia & 0.1 & 0 & & & & & & & 0.6 & 0.8 & 0.3 & 0.7 & 0.5 & 0.5 & 0.5 & 0.6 & & & & \\
\hline Georgia & & & & & & & 9 & 10 & & & 9.7 & \begin{tabular}{|l|}
9.8 \\
\end{tabular} & 9.6 & 10 & 7.2 & 7.7 & \begin{tabular}{|l|}
7.2 \\
\end{tabular} & 7.5 & 6.8 & 6.8 \\
\hline Kazakhstan & & & & & & & & & & & & & & & & & 2.5 & 2.7 & & \\
\hline Kyrgyzstan & & & & & & & & & 4 & 3.5 & 3.7 & 3.6 & 8.5 & \begin{tabular}{|l|l}
7.3 \\
\end{tabular} & 4.9 & 3.8 & & & & \\
\hline Latvia & & & 4 & 1.8 & 4.8 & 2.4 & & & & & 2.7 & 2.7 & & & & & & & & \\
\hline Lithuania & 3.1 & 1.9 & & & \begin{tabular}{|l|}
3.1 \\
\end{tabular} & 1.9 & & & & & & & \begin{tabular}{|l|}
2.3 \\
\end{tabular} & 2.1 & 2 & 2 & & & & \\
\hline Moldova & & & \begin{tabular}{|l|}
5.7 \\
\end{tabular} & 4.1 & & & & & 5 & 4 & 5.2 & 4.4 & & & 5 & 4.8 & \begin{tabular}{|l|}
5.5 \\
\end{tabular} & 4.8 & 5 & 4.9 \\
\hline \multicolumn{21}{|l|}{ Tajikistan } \\
\hline Turkmenistan & & & & & & & & & 2.2 & 3.6 & & & & & & & & & & \\
\hline Ukraine & 7.4 & 6 & & & \begin{tabular}{|l|}
8.4 \\
\end{tabular} & 7.3 & & & & & & & 7.5 & \begin{tabular}{|l|}
6.8 \\
\end{tabular} & & & & & & \\
\hline \multirow[t]{3}{*}{ Uzbekistan } & & & & & & & & & & & 6.1 & 10 & & & & & & & & \\
\hline & \multicolumn{2}{|c|}{2006} & \multicolumn{2}{|c|}{2007} & \multicolumn{2}{|c|}{2008} & \multicolumn{2}{|c|}{2009} & \multicolumn{2}{|c|}{2010} & \multicolumn{2}{|c|}{2011} & \multicolumn{2}{|c|}{2012} & \multicolumn{2}{|c|}{2013} & \multicolumn{2}{|c|}{2014} & & 015 \\
\hline & US & RS & \begin{tabular}{|l|} 
US \\
\end{tabular} & RS & \begin{tabular}{|l|} 
US \\
\end{tabular} & RS & US & RS & US & RS & US & RS & \begin{tabular}{|l|} 
US \\
\end{tabular} & \begin{tabular}{|l|l} 
RS \\
\end{tabular} & US & RS & \begin{tabular}{|l|} 
US \\
\end{tabular} & RS & US & RS \\
\hline Armenia & 3.4 & 2.8 & 3.1 & 3 & 3.3 & 2.9 & 4 & \begin{tabular}{|l|}
3 \\
\end{tabular} & 3.4 & 3.3 & 3.3 & 3.3 & 4.2 & 4.3 & 4.1 & 4.1 & 4.2 & 4.2 & 6 & 6.5 \\
\hline Azerbaijan & & & 9.3 & 9.2 & 9.1 & 9.4 & 9 & 9 & & & 9.1 & 9.3 & 8.9 & \begin{tabular}{|l|}
9.2 \\
\end{tabular} & 8.9 & 9.2 & 8.7 & 9.4 & & \\
\hline Belarus & & & & & 9.4 & 10 & 9 & 10 & \begin{tabular}{l|l}
7.9 \\
\end{tabular} & 8.9 & 8 & 8.8 & 8 & 9 & 8 & 8.8 & 7 & 7.5 & 6.2 & 7 \\
\hline Estonia & & & & & & & & & & & & & & & & & & & & \\
\hline Georgia & 6.9 & 6.8 & 0.5 & 0.7 & 0.6 & 0.8 & 1 & 1 & 0.5 & 0.7 & 1.2 & 1.5 & 1.3 & \begin{tabular}{|l|}
1.7 \\
\end{tabular} & 1.3 & 1.6 & & & 1.4 & 1.5 \\
\hline Kazakhstan & & & & & \begin{tabular}{|l|}
4.9 \\
\end{tabular} & 5.4 & & & 8.2 & 8.6 & 8.2 & \begin{tabular}{|l|}
8.7 \\
\end{tabular} & 8.4 & \begin{tabular}{|l|}
8.9 \\
\end{tabular} & 8.3 & 8.8 & 7.4 & 7.6 & 6.8 & 7 \\
\hline Kyrgyzstan & 3.1 & 3.7 & 3.5 & 3.6 & 4.2 & 3.8 & 4 & 4 & 3.6 & 3.8 & 3.3 & 3.8 & 3.4 & 3.7 & 3.4 & 3.7 & 3.5 & 3.7 & 5.5 & \\
\hline Latvia & & & & & & & & & & & & & & & & & & & & \\
\hline Lithuania & & & & & & & & & & & & & & & & & & & & \\
\hline Moldova & 5 & 5.1 & \begin{tabular}{|l|}
4.4 \\
\end{tabular} & 4.3 & \begin{tabular}{|l|}
4.9 \\
\end{tabular} & 4.5 & 5 & 5 & 4.8 & 4.6 & 4.5 & 4.5 & 4.4 & \begin{tabular}{|l|}
4.6 \\
\end{tabular} & \begin{tabular}{|l|}
10.2 \\
\end{tabular} & 9.1 & \begin{tabular}{|l|}
4.7 \\
\end{tabular} & 4.8 & 4.1 & \\
\hline Tajikistan & 6.1 & 7.2 & & & & & & & 6.4 & 7.5 & & & 6 & 7.6 & \begin{tabular}{|l|}
6.3 \\
\end{tabular} & 7.7 & 6.1 & 7.5 & 6 & \\
\hline Turkmenistan & & & & & & & & & & & & & & & & & & & & \\
\hline Ukraine & 5.4 & 4.7 & 5.2 & 4.8 & 5.3 & 4.9 & 4 & 4 & 4.4 & 4.2 & 4.4 & \begin{tabular}{|l|l|}
4.1 \\
\end{tabular} & 4.3 & 4.1 & 4.4 & 4.2 & \begin{tabular}{|l|}
4.4 \\
\end{tabular} & 4.1 & 4.3 & 3.9 \\
\hline Uzbekistan & 12 & 14 & 10.8 & 14.1 & \begin{tabular}{|l|}
11.3 \\
\end{tabular} & 14 & 11 & 13 & & & & & 12.5 & 14 & & & \begin{tabular}{|l|}
11 \\
\end{tabular} & 13 & 12 & \\
\hline & & Sam & e Tarif & f Rate & & & Higl & her $\mathrm{F}$ & Ki & Tar & & & & $\mathrm{H}$ & S & Tarif & & & & \\
\hline
\end{tabular}

respectively. If the blocks are yellow, both countries received the same tariff rate.

According to Table 9 above, realist expectations held for only three countries with Ukraine, Armenia, and Moldova emplacing higher tariff rates against the U.S. than Russia. First, only Ukraine consistently enacted higher tariff rates against the United States in all 13 years where data is available. Following Ukraine, Armenia and Moldova emplaced higher tariff rates on the U.S. than Russia but at a lower frequency. In Armenia, nine out of the 14 years saw higher tariff rates levied against the U.S. as compared to two years (2012 and 2015) for Russia. In the other 
three years, tariff rates were the same. In Moldova, during ten of the 15 years, Chisinau enacted higher tariffs against the U.S. as compared to three years $(2006,2012,2014)$ where rates were higher for Russia. In 2008 and 2011 the rates in Moldova were the same for the U.S. and Russia. The remaining countries fell outside realist predictions where Georgia, Kazakhstan, Kyrgyzstan, Belarus, Azerbaijan, Tajikistan and Uzbekistan registered higher tariff rates against Russia than the United States. At the top of the list, Georgia and Kazakhstan routinely charged Russia a higher tariff rate. Not far behind, Georgia during 12 of the 14 years charged Moscow higher tariff rates for Russian products. In 2006, the rate was higher for the U.S. while in 2005 and 2008 tariff rates were the same for both regional great powers. Kyrgyzstan, in seven of the 13 years, charged Russia a higher tariff rate. From 2000-2003 and again in 2008, Bishkek recorded higher tariffs for the U.S. while in 2009, both countries had the same MFN tariff rate. Interestingly, while Belarusian tariff rates were higher for the U.S. than Russia in 1997 and from 2001-2002, for eight years straight (2008 to 2015), Minsk opted to enact higher tariff rates for Russian products than those from the United States. Azerbaijan's record of tariffs was mixed with three years $(2002,2005,2007)$ of higher tariffs for the U.S. as compared to five years (2009 and 2011-2014) for Russia. Finally, Tajikistan and Uzbekistan also consistently showed a willingness to enact a higher tariff rate against Russia. In 2006, 2010, and from 2012 to 2014, Dushanbe enacted higher tariffs against Moscow while Tashkent followed suit levying higher rates during all seven years in 2001, 2006-2009, 2012, and 2014.

Although the preceding analysis on tariffs provides some insight into former Soviet alignment, the unavailability of a consistent set of data makes it difficult to draw sound inferences on former Soviet state alignment. For example, in Moldova from 1996-2005, Chisinau consistently enacted higher tariff rates against the United States; however, in the second 10-year 
period the situation changes. Specifically, the U.S. received higher tariffs for four years as comparted to Russia, which received higher rates in three years. Furthermore, in two of the years, both countries received the same tariff rate. Second, in those instances where a country was a member of NATO or the CSTO, one might expect a lower tariff rate to the corresponding regional great power. While this was the case with Estonia charging the U.S. lower tariff rates, Lithuania tended to do the opposite. Similarly, a majority of the countries in the CSTO tended to charge Russia higher tariff rates.

\section{$\underline{\text { Striving for Precision }}$}

The preceding two-stage analysis has increased our understanding of how alignment may vary in the post-Soviet space and which countries are worthy of further research. Despite the progress made on case selection, this endeavor has not narrowed the potential number of cases to a manageable level. As depicted in Table 10, the ten indicators of alignment revealed 13 different countries in one way or another did not align with Russia.

\begin{tabular}{|l|l}
\hline \multicolumn{2}{|c}{ Table 10: Summary of Small State Alignment in the Post-Soviet Space } \\
\hline \multicolumn{1}{|c}{ Indicator } & \multicolumn{1}{c}{ Country } \\
\hline Military Commitements & Azerbaijan, Estonia, Georgia, Latvia, Lithuania, Moldova, Turkmenistan, Ukraine \\
\hline United Nations Voting & Estonia, Latvia, Lithuania, Moldova \\
\hline Military Exercises & Azerbaijan, Estonia, Gerogia, Latvia, Lithuania, Kazakhstan, Moldova, Ukraine, Uzbekistan \\
\hline Foreign Basing & Estonia, Latvia, Lithuania, Uzbekistan \\
\hline $\begin{array}{l}\text { Arms Sales } \\
\text { Head of State Visits }\end{array}$ & Estonia, Moldova, Ukraine \\
\hline $\begin{array}{l}\text { Other Political Leader Visits } \\
\text { Total Trade }\end{array}$ & Estonia, Georgia, Latvia, Lithunia \\
\hline Bilateral Investment Treaties & Azerbaijan, Estonia, Lithuania \\
\hline Tariffs & Bzerbaijan \\
\hline & Azerbaijan, Estonia, Georgia, Latvia, Kyrgyzstan \\
\hline
\end{tabular}

Given this precarious situation, it becomes necessary to narrow the range of cases by assigning a weight to each of the indicators. Following Teune and Synnestvedt's order of priority for the most important categories, a ' 3 ' weighting was assigned to military indicators, a ' 2 ' weighting to diplomatic indicators, and a ' 1 ' weighting to economic indicators. When applied to 
the 13 potential cases, the rank order of outliers from low to high is as follows: Tajikistan (1), Kyrgyzstan (2), Belarus (2), Turkmenistan (3), Kazakhstan (3), Uzbekistan (5), Georgia (6.5), Ukraine (7), Azerbaijan (8.5), Moldova (10), Lithuania (11.5), Latvia (12.5), and Estonia (16). Taking the mean score of the 13 countries establishes a cut line whereby Georgia, Ukraine, Azerbaijan, Moldova, Lithuania, Latvia, and Estonia are placed in the top 50 percent of the group worthy of further investigation. While a scholarly investigation of these six cases is certainly warranted, such an undertaking exceeds the boundaries of this project with regard to time and space. As such, because Estonia, Latvia, and Lithuania are already members of NATO, this study opts to focus on Azerbaijan, Georgia, Moldova, and Ukraine. The Baltic countries are thus placed in the category of future research for this dissertation.

\section{Conclusion}

This chapter served two major purposes. First, through the application of ten alignment indicators as developed by Teune and Synnestvedt, this study attempted to discern how alignment varied in the post-Soviet space by sketching the broad contours of former Soviet state alignment with the United States and Russia from 1991-2015. This analytical endeavor was undertaken to identify viable cases for this study in the most regimented way possible. A part of this effort, realist explanations were tested where small states, because they are materially weak, will bandwagon with a more powerful or more threatening regional great power in close proximity. The overarching conclusion is the theoretical propositions advanced by realists do not consistently explain when and why the newly independent states will align with their former imperial center. After applying a weighting to the military, diplomatic, and economic indicators, the four cases for this study are Azerbaijan, Georgia, Moldova, and Ukraine. 
"There are associations between powers that seem to be deeper than formal alliances, to be based on affinity and tradition as much as interest, to be not so much utilitarian as natural." Martin Wright, 2002. ${ }^{396}$

\section{Chapter Five: State Identity and Small State Alignment}

\section{Introduction}

This chapter explores the extent to which a president's ideas and beliefs about the state's identity in world politics may contribute to his alignment preferences with the United States or Russian Federation in the post-Cold War era. The essence of my argument follows Martin Wright's sage insight from above in that when ruling elites in Azerbaijan, Georgia, Moldova, and Ukraine conceptualize the state's identity in ways that mirror the enduring state identities in either the United States or Russia, these political leaders will exhibit a stronger preference to align with one regional great power over the other. This empirical reality is what this study calls positive bandwagoning. As state identities between a small state and a regional great power become ambiguous or begin to diverge, political leaders in Baku, Tbilisi, Chisinau, and Kiev will prefer a great power bridging alignment.

Although realists attempt to explain alignment outcomes by focusing on aggressive intentions, military power balances, or other material-based systemic factors as key drivers for threat identification and the choice of strategic partners, such approaches appear deficient when examining the post-Soviet space. At issue is how the balance of military power between Russia and its former Soviet satellites has consistently favored Moscow, yet the alignment tendencies of ruling governments in these countries have oscillated over the last several decades. Take Ukraine for example. Academics and practitioners alike have argued Leonid Kuchma was a skilled

\footnotetext{
${ }^{396}$ Wight, Martin. 2002. Power Politics. A\&C Black, 123.
} 
balancer, who preferred to align the state with Russia, the United States, and other lesser powers in Western Europe. After his election as president in 2005, Viktor Yushchenko preferred a Western alignment; however, his successor Viktor Yanukovych saw higher value in an alignment with Russia. ${ }^{397}$ What explains this empirical reality in Ukraine?

In order to garner a more holistic understanding of alignment politics, this study argues one must begin with a close examination of the president's ideas and beliefs about the state's identity in world politics. As Suny reminds us, it is very important to consider "whether an elite views its state as a democracy, a great power, an empire, the victim of others, or a carrier of civilization..." ${ }^{n 98}$ Furthermore, because the presidents under examination govern in countries best understood as anocracies, they are uniquely positioned to exert a high degree of influence on the state's identity. Andrei Spruds captures succinctly this situation noting,

Political elites are instrumental in the process of constructing and reconstructing identities. Although influenced by shared societal images, symbols and historical experiences, they simultaneously are in a position to manage these perceptions in the context of interstate relations, as well as inadvertently or calculatingly to shape, manipulate and even create them. ${ }^{399}$

The research questions this chapter seeks to answer are as follows: to what extent does a political leader's ideas about the state's identity influence his alignment preferences with the United States and the Russian Federation? Supporting questions include: what are the state identity narratives of the presidents of Azerbaijan, Georgia, Moldova, and Ukraine from 1995 to 2015? What are the enduring state identity narratives of the United States and Russia in the postCold War era? What is the relationship between a president's ideas about state identity and his alignment preferences? It is hypothesized Azeri, Georgian, Moldovan, and Ukrainian presidents

\footnotetext{
${ }^{397}$ Interview on file with author.

${ }^{398}$ Suny 1999/2000, 140.

399 Sprūds, Andrei. 2009. "Entrapment in the Discourse of Danger? Latvian-Russian Interaction in the Context of European Integration." In Eiki Berg and Perit Ehin (eds.) Identity and Foreign Policy: Baltic-Russian Relations and European Integration. New York: Ashgate Publishing, 103; emphasis added.
} 
are more likely to prefer a positive bandwagoning with a regional great power they believe share their primary state identity conceptions. When there is a lack of congruence in the primary state identity conceptions, one is more likely to see a president prefer great power bridging.

As outlined in chapter 4 , this study conducted a conceptual content analysis using available speeches, interviews, and addresses for each president while in office. The level of analysis is the single word, which takes an accounting of 18 state identity concepts. These concepts are then placed under five general categories: political (independent, former Soviet, freedom, liberty), cultural (European, Slavic, Western, Eastern, Eurasian), economic (market and modern), ideological (democracy, liberal and communism), and religious (Orthodox, Christian, Islamic, secular). ${ }^{400}$ Separately, interviews with area specialists and online surveys established a baseline of the enduring state identity narratives associated with the United States and Russia. In the United States, political leaders have historically described the state as democratic, modern, independent, and Western. ${ }^{401}$ Russian state identity narratives are more ambiguous but in this study are defined as Russian, Slavic, Eastern, Eurasian, and independent. ${ }^{402}$

The proceeding paragraphs provide the findings of a content analysis of each president's ideas about the state's identity from 1995 to 2015. As a reminder, in Moldova, Mircea Snegur's

\footnotetext{
${ }^{400}$ These 18 concepts of a state's identity were derived from an analysis of the secondary literature, elite interviews, and a word cloud analysis of a random sample of 40 foreign policy speeches ( 10 from each case). The word cloud analysis revealed Azerbaijani, Georgian, Moldovan, and Ukrainian presidents frequently identified the state as either independent, European, or developing with emphasis also being given to the CIS and NATO. In the secondary literature, Gvalia finds modernizing, European, and Western integration are three of Georgia's state identity narratives under President Saakashvili. Ronald Suny notes how some states can view themselves as democratic, communist, and Slavic. Elite interviews revealed that political leaders in former Soviet states often viewed the state in a variety of different ways including Western, Eurasian, free, liberal, secular, and orthodox. Taking into consideration these potential narratives, this study adds Christian, Islamic, liberal, former soviet. See Gvalia et. al. 2013, 110; Suny 1999/2000, 152-159; author interviews.

${ }^{401}$ Interviews on file with author.

${ }^{402}$ Interviews on file with author.
} 
presidency (1990-1997) and acting presidents Mihai Ghimpu and Marian Lupu (2009-2011) are excluded owing to the lack of available data.

\section{Findings}

Through a content analysis of presidential speeches, interviews with area specialists, and the use of online surveys and event data, this study identified several key findings. First, each president under examination espoused multiple state identities. Second, those presidents who gave emphasis to the state's identity as being independent tended to prefer great power bridging. These presidents included Heydar Aliyev, Ilham Aliyev, Eduard Shevardnadze, Petru Lucinschi, Vladimir Voronin (after 2003), and Leonid Kuchma. Third, Mikheil Saakashvili, Giorgi

Margvelashvili, Nicolae Timofti, Viktor Yushchenko, and Petro Poroshenko viewed the state as Western-European and/or one based on democracy and freedom. These presidents tended to favor a positive bandwagoning with the United States. Fourth, frequently referring to Ukraine as an eastern country, Vladimir Voronin (before 2003) and Viktor Yanukovych preferred a positive bandwagoning alignment with Russia.

\section{Azerbaijan}

From the time when the Bolsheviks seized control of Azerbaijan in 1920 until the country's independence in August 1991, leading political elites in Baku followed Moscow's direction for the state's actions on the world stage. Guided by Marxist-Leninist principles, Azerbaijani leaders mirrored the Kremlin's ideological narratives helping to establish the state's identity as a Soviet satellite and a cog in the international communist movement. ${ }^{403}$ To ensure the continued advancement of a Soviet-centric state identity, Kremlin leaders began a process of indigenization

\footnotetext{
${ }^{403}$ For a discussion on ideology and Soviet foreign policy, see Ulam, Adam B. 1959. "Soviet Ideology and Soviet Foreign Policy." World Politics 11 (2) and Cornell, Svante E. 2011. Azerbaijan Since Independence. Routledge, pgs. 31-45.
} 
(korenizatsiia) in the early 1920s to help facilitate the rise to power of loyal Azerbaijani political figures, who would give legitimacy to a Soviet-style state identity. ${ }^{404}$

From the 1930's through the early 1980s, Azerbaijani political leaders, who were members of the Communist Party of the Soviet Union (CPSU) generally adhered to the conception of a Soviet state identity. For example, Heydar Aliyev's communist-style political acumen and strong leadership allowed him to achieve high prominence in Soviet Azerbaijan becoming the President of the CPSU (1967-1987) and a full politburo member in 1982. ${ }^{405}$ Azerbaijan's Soviet identity was also made possible through an informal social contract whereby the republic would fall in line with the ruling Soviet government in exchange for the populace being allowed to retain some aspects of Azerbaijan's culture. According to Tadeusz Swietochowski,

In return for the acceptance of and cooperation with the Soviet regime, the nationalities received the guarantees of the right to develop their distinct cultures, to use freely and develop their languages, and to train and employ native cadres in their republics. The legacy of the Russian rule of the past, with its imperialism, chauvinism and Russification, was to be explicitly rejected. ${ }^{406}$

However, a turning point occurred in 1988 with the arrival of Mikhail Gorbachev as the Soviet Union's head of state. During this time, Gorbachev's reform efforts of glasnost (transparency) and perestroika (restructuring) facilitated the emergence of numerous opposition political parties, including the Azerbaijan Popular Front (APF), which reflected nationalist (e.g. independence) and ethnic (e.g. anti-Armenian) conceptions that differed from the CPSU, particularly in its relationship to other Soviet republics namely Armenia. ${ }^{407}$ Gorbachev's actions subsequently gave way to the outbreak of ethnic conflict in the Nagorno-Karabakh region (1988-

\footnotetext{
${ }^{404}$ Cornell 2011, 37-38.

${ }^{405}$ Central Intelligence Agency. 1988. "Unrest in the Caucasus and the Challenge of Nationalism." Declassified Research Paper, Director of Intelligence, August 1988, iii.

${ }^{406}$ Swietochowski, Tadeusz. 1995. Russia and Azerbaijan: A Borderland in Transition. New York: Columbia University Press, 110.

${ }^{407}$ These state identity narratives of Azerbaijan are based on analysis of the writing of Shala Sultanova. See Sultanova, Shahla. 2014. "Challenging the Aliyev Regime: Political Opposition in Azerbaijan."

Demokratizatsiya 22 (1).
} 
1994), Azerbaijan's 1989 resolution of sovereignty, and large-scale protests leading to Baku's declaration of independence in August 1991 under communist President Ayaz Mutalibov.

In the immediate aftermath of Azerbaijan's breakaway from the Soviet Union, political, economic, and social chaos severely hindered Mutalibov's political actions designed to move the country towards complete independence from the Soviet Union and its successor, the Russian Federation. This initial period of anarchy also inhibited Mutalibov's ability to articulate a new state identity and given the current state of affairs, he gravitated back to his communist roots and a deference for an alignment with Moscow. Although independence was to be the leading 'bumper sticker' for the state, Mutalibov did little to transform the deeply entrenched communist institutions or build new democratic ones. According to Svante Cornell, “...Mutalibov had declared the independence of the country, but just like the other post-Soviet leaders, he sought to reinvent himself as a national leader without introducing meaningful political reforms." ${ }^{408}$ One indicator of Mutalibov's proclivity to align Azerbaijan with Russia was his decision to sign the Alma-Ata Declaration for the country's accession into the CIS in December 1991.

Mutalibov's inactions as they related to the country's transition and the escalating crisis in the Nagorno-Karabakh moved political opposition groups to action resulting in his resignation in February 1992. By June of that year, APF leader Abulfez Elcibey became Azerbaijan's first democratically-elected president. Elcibey's conceptions about the state in international affairs can be best described as independent, democratic, liberal, open market, and secular. ${ }^{409}$ While

\footnotetext{
${ }^{408}$ Cornell 2011, 61.

${ }^{409}$ Ayca Ergun identifies independence and democracy as two signature characterizations for Elcibey's administration during his time in office. Cornell's analysis specifies liberalism and an open market system as two facets of the state's identity. Finally, Murinson finds the Elcibey government went to great lengths to portray the state as secular in world affairs. See Ergun, Ayca. 2005. "Democratization from Below: The Role of Civil Society in Azerbaijan.” In Ayes Gunta-Ayata, Ayca Ergun, and Isil Celimli (eds.) Black Sea Politics: Political Culture and Civil Society in an Unstable Region. London: IB Tauris, 108; Cornell 2011, 53-54; 67-68; Murinson, Alexander. 2009. Turkey's Entente with Israel and Azerbaijan: State Identity and Security in the Middle East and Caucasus. Routledge, 29-30.
} 
facing the same problems as Mutalibov, Elcibey's ruling government achieved some limited success in implementing reforms in Azerbaijan's transition from Soviet rule. For example, during Elcibey's time in office over 30 political parties were formed and nearly 500 news or media outlets established ${ }^{410}$ In the foreign policy realm, Elcibey attempted to align the state with the United States and the West through various actions, which included opening an embassy in Washington in March 1993 and rejecting his predecessor's decision to join the CIS. ${ }^{411}$

Despite the minimal progress made by Elcibey, he was only able to remain in power for less than a year owing to a myriad of challenges. First, like Mutalibov, Elcibey's inability to resolve the crisis in the Nagorno-Karabakh elicited outcries from the public and political pressure from political opposition elements. ${ }^{412}$ Additionally, religion began to exert an influence on the political dynamics in both the domestic and foreign policy realms. In this case, Azerbaijan's Muslim population with its accompanying traditions (e.g. limited social and political rights) served as a constraint on Elcibey's political actions to incorporate Western ideals into the state and society. ${ }^{413}$ Finally, Elcibey's failure to reconfigure the state's communist institutions hindered his ability to advance a new state identity. In this case, domestic politics served as a check on his alignment preferences because the ruling government was "...unable to free itself from the formal as well as informal power brokers in the republic, or to take the initiative and lay down new rules of the game." ${ }^{414}$ Quickly all of these challenges would converge resulting in Elcibey's fall from power in 1993 and Heydar Aliyev's rise to the presidency.

\footnotetext{
${ }^{410}$ Wasserman, Aryeb. 1995. In Yaacov Ro'i (ed.) Muslim Eurasia: Conflicting Legacies. Portland: Frank Cass, 143.

${ }^{411}$ Czerewacz-Filipowicz, Katarzyna, and Agnieszka Konopelko. 2016. Regional Integration Processes in the Commonwealth of Independent States: Economic and Political Factors. Springer, 22.

${ }^{412}$ Horowitz, Shale. 2003. "War After Communism: Effects on Political and Economic Reform in the Former Soviet Union and Yugoslavia." Journal of Peace Research 40 (1).

${ }^{413}$ Taghiyeva, Gulia. 2000. "Liberal Democracy in Transitional Azerbaijan: Challenges and Prospects." In Calder, Gideon, Garrett, Edward and Jess Shannon Liberalism and Social Justice: International Perspectives. Aldershot, England: Ashgate, 14.

${ }^{414}$ Cornell 2011, 67.
} 


\section{$\underline{\text { Heydar Aliyev's State Identity Narratives and Azerbaijan's Alignment }}$}

The removal of Elcibey opened the door for the peaceful return of Heydar Aliyev to power in October 1993 following a new round of elections. Within the first year of his time in office, Aliyev's extensive political experience and expert organizational skills allowed him to bring order to the state apparatus, implement a series of economic reforms, and realize an armistice with Armenia in the Nagorno-Karabakh conflict. ${ }^{415}$ It is from Aliyev's early successes the country would begin to experience a modicum of political and social stability and eventually economic stabilization by late $1995 .{ }^{416}$ From 1995 onward, Azerbaijan began a sustained period of stabilization that subsequently allowed Aliyev the strategic maneuver room to begin the process of defining the state's identity in world politics.

But what were Heydar Aliyev's ideas about Azerbaijan's state identity since his assent to the presidency? As a diehard former communist, did Aliyev follow Mutalibov or as a would-be democratic reformist did he emulate Elcibey? An examination of a small random sample of Aliyev's foreign policy speeches ${ }^{417}$ during the country's most tumultuous years (1993-1994) reveal some insight into his conceptions of Azerbaijan's state identity in the post-Cold War era. Aliyev's state identity conceptions included independent, free, and democratic.

\footnotetext{
415 Sultanova 2014, 18.

${ }^{416}$ In terms of economic stability, Azerbaijan's decline in GDP halted in 1995 at $\$ 3.05$ billion (U.S.). In 1996 Azerbaijan's GDP increased to \$3.17 billion (U.S.). Source: World Bank. 2017. World Development Indicators, Azerbaijan. http://databank.worldbank.org/data/reports.aspx?source=2\&type=metadata\&series=NY.GDP. MKTP.CD. Accessed 02 September 2017.

417 Aliyev, Heydar. 1993. "Speech of Heydar Aliyev, Chairman of the Supreme Soviet of the Republic of Azerbaijan, at the meeting of the Parliament - June 15, 1993." Heydar Aliyev Heritage International Online Library. http://lib.aliyev-heritage.org/en/3857190.html. Accessed 29 July 2017; Aliyev, Heydar. 1994. "Speech of the President of Azerbaijan Heydar Aliyev at 49th session of the UN General Assembly - New York, September 29, 1994." Heydar Aliyev Heritage International Online Library. http://lib.aliyev-heritage.org/en/7119983.html. Accessed 29 July 2017; Aliyev, Heydar. 1994a. "Speech of the President of the Republic of Azerbaijan Heydar Aliyev at the meeting of the Heads of states and governments of the OSCE member-countries in Budapest. December 6, 1994." Heydar Aliyev Heritage International Online Library http://lib.aliyevheritage.org/en/2003842.html. Accessed 29 July 2017.
} 
Although this superficial review may be a good starting point, interviews with area specialists and a content analysis of over 800 speeches reveals a more nuanced understanding of Heydar Aliyev's ideas about the state's role in world affairs. Specifically, Heydar Aliyev predominantly viewed the state in political terms as independent registering the highest frequency among the 18 state identity concepts. The average rate at which Aliyev emphasized ideas about independence was double of what was observed by all the presidents in Moldova and three times as much as compared to Georgia and Ukraine. The centrality of Aliyev's independent state identity narrative is captured during a May 1995 speech in Baku. In his words...

Now we live in an independent state. Independent Republic of Azerbaijan is our greatest historical achievement. I am sure that we will keep the independent state of Azerbaijan live and march forth. Our existing intellectual and economic potentials, the might and courage of our people will keep the independent Azerbaijan live and pass from generation to generation. ${ }^{418}$

Seven years later in 2002, one can still discern Aliyev's commitment to his ideas about

Azerbaijan as an independent state actor on the world stage.

The Azerbaijan people establishing the first democratic republic in the Moslem East in the beginning of 20th century, has restored its independence and has entered qualitatively new stage of the development at the end of the century. Today independent Azerbaijan is the full member and representative of the world community, international and regional organizations. ${ }^{419}$

Heydar Aliyev's primary emphasis on viewing the state as an independent actor appears logical for several reasons. First, with the country's vast supply of energy resources, an independent Azerbaijan could avoid the external constraints that come with formal membership in a security alliance or regional economic grouping. This would subsequently place the state in a favorable position to align with multiple great powers to fully develop Azerbaijan's economic

\footnotetext{
${ }^{418}$ Aliyev, Heydar. 1995c. "Speech of the President of the Republic of Azerbaijan Heydar Aliyev at the 60th Anniversary of the Prominent Azerbaijani Writer and Cinematograph Magsud Ibrahimbeyov, 14 May 1995." Heydar Aliyev Heritage International Online Library. http://lib.aliyev-heritage.org/en/2908961.html. Accessed 29 July 2017.

419 Aliyev, Heydar. 2002. "Address of Heydar Aliyev, the President of the Republic of Azerbaijan to the World Azerbaijanis on the occasion of the Day of Solidarity - Baku, December 26, 2002." Heydar Aliyev Heritage International Online Library. http://lib.aliyev-heritage.org/en/3750555.html. Accessed 29 July 2017.
} 
capacities. Second, an independent state identity narrative would allow Aliyev to assume a more proactive foreign policy to resolve the Nagorno-Karabakh issue. In this case, if Kremlin elites were to drag their feet on an issue or topic, Aliyev could potentially use an alignment with Washington, for example, to move Moscow to action.

The extent to which one can discern Heydar Aliyev's bifurcated alignment trajectory with the United States and Russia is made clear in a longitudinal analysis of event data in Chart 17 below.

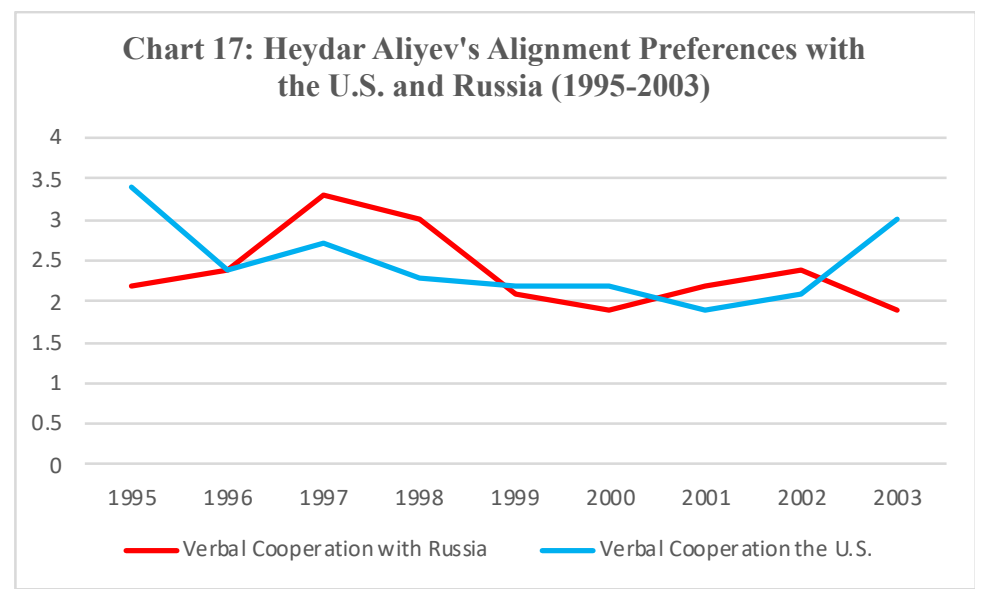

Recalling SIT and SCT, Aliyev's level of verbal cooperation with the U.S. and Russia can serve as one indicator of his proclivity for great power bridging. In this case, the process of social comparisons at the individual level are seen in Aliyev's ideas about his affinity with external states, which are then conveyed through his verbal actions. While in office, Heydar Aliyev oscillated his level of verbal cooperation with the United States and Russia preferring to develop an almost equal alignment with both regional great powers.

The significance of Aliyev's ideas about independence and his alignment preferences are relevant for three reasons. First, the centrality of Azerbaijan's independence in Aliyev's conceptions of the state's identity serves as a major point of reference from which to craft multivector foreign policies that would help ensure Azerbaijan remained independent on the world 
stage. The critical importance afforded to Aliyev's ideas about independence and his alignment preferences are captured perfectly in 1999 and 2001.

You can't be friends with some countries and enemies with others despite the fact that this is the way most countries function. Azerbaijan doesn't want to be an enemy with any country. At the same time, we will not become victim to another country's policies. Azerbaijan has its own independent policy. At the same time, we are developing good relations with Europe and America and seek to benefit from their experiences while preserving our own national identity and our own resources. ${ }^{420}$

Azerbaijan will never repudiate its independent foreign policy. Its independent foreign policy is a basic symbol, a primary proof of independence of Azerbaijan. Carrying out an independent foreign policy means further strengthening of independence. Although we face great difficulties both in foreign relations and within Azerbaijan itself, we, protecting our own independence pursue an independent policy in the world. ${ }^{421}$

Second, Aliyev's ideas about the importance of independence were amplified given the country's access to vast amounts of energy resources. In this case, independence would be a conduit by which the state could reap the economic benefits of exporting oil and natural gas to a variety of different customers worldwide. Put another way, economic prosperity would help ensure Azerbaijan would remain independent. Third, and perhaps most important, Aliyev's conception of independence is designed to move the state in directions that help ensure the continued existence of the ruling government. ${ }^{422}$

Beyond Heydar's Aliyev's emphasis on Azerbaijan as an independent state, it is also important to take an accounting of his supporting identity narratives, which can help us to understand more fully his preference for great power bridging. In addition to viewing the state as independent, Heydar Aliyev's verbal discourse described Azerbaijan as European, Eastern, democratic, and secular. First, Heydar Aliyev gave secondary emphasis to two cultural

\footnotetext{
${ }^{420}$ Blair, Betty. 1999. "Looking Back on the Century, Personally and Professionally." Azerbaijan International 7 (4), 20. http://www.azer.com/aiweb/categories/magazine/74_folder/74.articles/74_aliyev3.html.

${ }^{421}$ Aliyev, Heydar. 2001. "Speech of President of the Republic of Azerbaijan Heydar Aliyev at the I Congress of the World Azerbaijanis - Baku, 10 November 2001.” Heydar Aliyev Heritage International Online Library. http://lib.aliyev-heritage.org/en/2428604.html. Accessed 22 July 2017.

${ }^{422}$ Interview on file with author.
} 
narratives: European and Eastern. This study's content analysis indicates Heydar Aliyev viewed the state (and Azerbaijan) as a member of Europe. Although less emphasized, Aliyev's references to an Eastern orientation indicated that both were of importance in his conceptions of the state's identity. From one perspective, Aliyev's ideas about these state identities are grounded in his beliefs about the country's geographical position in the South Caucasus. Reflecting on this reality in 1998 , Aliyev noted...

We are on the European continent. But at the same time, in the intersection of Europe and Asia, our country in the history of its people, its national culture, historical roots and mentality are the synthesis of the East and the West, Europe and Asia. ${ }^{423}$

Heydar Aliyev's European state identity narrative must be placed into proper context however. While Aliyev may have espoused the merits of select aspects of 'western' European values during his time in office, the country's history, culture, and geographical location exerted enough influence to morph the state's identity into a different form of westernization. According to Barry Buzan and Thomas Dietz, countries such as Azerbaijan are best regarded as 'Westernistic' because political leaders in Baku will "never be purely Western or European by definition[s]" ${ }^{\text {"424 }}$ commonly accepted in the United States and Western Europe.

This hybrid form of Europeanism also conveys to Heydar Aliyev's ideas about Azerbaijan as a democracy. The results of the content analysis indicate for this ideological category, Aliyev's narratives of describing the state's identity in democratic terms occurred at a level on par with his conceptions of Azerbaijan as European. Despite Aliyev's proclivity to frequently reference democratic ideals in his foreign policy discourse, interviews with regional specialists and reports from various international organizations reveals democracy in Azerbaijan does not conform to

\footnotetext{
${ }^{423}$ Aliyev, Heydar. 1998a. "Speech of the Azerbaijani President Heydar Aliyev in his Inauguration Ceremony October 18, 1998." Heydar Aliyev Heritage International Online Library. http://lib.aliyevheritage.org/en/7958721. html. Accessed 22 July 2017; emphasis added.

${ }^{424}$ Buzan, Barry and Thomas Dietz. 1999. “The European Union.” Survival 41 (1), 49.
} 
the mold as developed in the United States or Western Europe. ${ }^{425}$ At the direction of Heydar Aliyev, the pillars of democracy (e.g. rule of law, a free press, respect for human rights, and transparent elections, etc.) were micromanaged by ruling elites leading to a semi-authoritarian state. Marina Ottaway describes Azerbaijan's semi-authoritarian government as... ...an ambiguous system that combines rhetorical acceptance of liberal democracy, the existence of some formal democratic institutions, and respect for a limited sphere of civil and political liberties with essentially illiberal or even authoritarian traits. ${ }^{426}$

As such, Aliyev's attempts to portray a democratic state identity for Azerbaijan must be placed in its proper context. According to Turkey's ambassador to the United States...

[Heydar] Aliyev is a remarkable man and very tough politician, he did not share his powers with his minister or his people. There was very little opposition in the Azeri parliament which acted mostly as his rubberstamp. He was described by a diplomat serving in Baku, who knew him as a smooth operator... He himself made all the decisions with no power sharing. He groomed his son to succeed him against criticism that he was creating a dynasty, which became true. ${ }^{427}$

Other regional specialists have also viewed Heydar Aliyev in a similar way. In this case, Azerbaijan under Aliyev is best understood as an authoritarian government with a smattering of controlled capitalism that generates economic prosperity for a select few. ${ }^{428}$

The preceding evidence leads to several key takeaways. First, on one level it appears Heydar Aliyev may be apt to publicly articulate a state identity narrative that garners the state maximum benefits from multiple regional great powers. For example, during his political career, Aliyev was quick to espouse the country's democratic principles without truly implementing the corresponding reforms in order to gain U.S. support to build-up the country's energy

\footnotetext{
${ }^{425}$ Interview on file with author.

${ }^{426}$ Ottaway, Mariana S. 2003. Democracy Challenged: The Rise of Semi Authoritarianism. Washington, D.C: Carnegie Endowment for International Peace, 3.

427 Turkish Daily News. 2003. Cited in Murinson, Alexander. 2009. Turkey's Entente with Israel and Azerbaijan: State Identity and Security in the Middle East and Caucasus. Routledge, 155.

${ }^{428}$ Heradstveit, Daniel. 2001. "Local Elites Meet Foreign Corporations: The Examples of Iran and Azerbaijan." Norwegian Institute of International Affairs Working Paper 617 (June), 12.
} 
infrastructure. ${ }^{429}$ On another level, Heydar Aliyev may have viewed the state's identity as an instrument of power to secure foreign support from a regional great power to help him realize his conceptions of the national interest.

Finally, Aliyev also tended to view the state as secular. ${ }^{430}$ Aliyev's placement of Islam in the development of the state's identity was of secondary importance given its potential to exert a high degree of influence if left unchecked as was the case in Iran during the 1970s. This is not to say Islam did not have its place in Azerbaijani society, where many of the key tenets of this religion remained an important part of the country's national identity. At the state level however, Aliyev opted to paint a secular label on the government and its identity among other states in the international system. This reality is captured perfectly by Aliyev himself...

This is a part of my strategy - to preserve the national moral values of Azerbaijan. A part of these values is connected to Islam. We do not deny Islam. This is our religion. At the same time, I am trying to synthesize the national moral values of Azerbaijan with European values, the values known to the entire world. I want to see my country as a secular nation, but not separated from its national roots. ${ }^{431}$

The solidification of the state's secular identity under Heydar Aliyev occurred in 1995 when the country's constitution was formally adopted. During a meeting with Iranian foreign leaders in 2001, Aliyev adamantly stressed the secular nature of the state's identity stating, "we are following the path of secularism and will continue to follow that path of statehood." ${ }^{432}$

In 2001, the relationship between Heydar Aliyev's ideas about the state as secular and his alignment preference with the United States was made clear when he stated, "Azerbaijan will never become a religious state like Iran, nor will it sever relations with the United States..."433

\footnotetext{
${ }^{429}$ Altstadt, Audrey L. 2003. “Azerbaijan and Aliyev: A Long History and an Uncertain Future.” Problems of PostCommunism 50 (5), 3-4.

${ }^{430}$ Interview on file with author.

${ }^{431}$ Murinson 2009, 30.

432 Ibid, 30.

${ }^{433}$ Ibid, 30.
} 
Finally, as late as 2003 Aliyev continued to demonstrate a stable state identity narrative with respect to Azerbaijan's secularism in world politics. During a meeting with Iranian leaders he stated, "Azerbaijan is a secular state, and this is our strategic path. We will not be able to turn from this path neither to this or the other side. We will not be able to turn away, not because we don't want to, but because we consider this way the most appropriate for us." $" 434$

\section{$\underline{\text { Ilham Aliyev's State Identity Narratives and Azerbaijan's Alignment }}$}

In October 2003, Ilham Aliyev succeeded his father as president in an election viewed by the Organization for Security Cooperation in Europe (OSCE) as not meeting internationally accepted election standards owing to the existence of partisan election commissions, pre-election police violence, and the absence of international observers to name a few. ${ }^{435}$ Upon entering office, Ilham Aliyev brought with him many similar conceptions of the state's identity held by his father. Specifically, Ilham Aliyev primary viewed the state's identity as independent. Secondary conceptions included European, modern, and market-oriented.

Following in the footsteps of his father, the output of a content analysis of Ilham Aliyev's foreign policy speeches indicates he tended to define the Azeri state as independent above all other characterizations. The high value afforded to this state identity narrative was immediately seen after his election in 2004. During a press interview with a Russian news outlet, Aliyev declared, "the greatest achievement of Azerbaijan's people is the country's independence... Despite the difficulties, we must preserve Azerbaijan's independence, strengthen statehood, and ensure the integrity of its territory." ${ }^{436}$ The "so what' here is that Aliyev the younger continued to

\footnotetext{
${ }^{434}$ Ibid, 30.

${ }^{435}$ Ereli, Adam. 2003. "Press Statement, Presidential Election in Azerbaijan." U.S. Department of State, 21 October 2003. https://2001-2009.state.gov/r/pa/prs/ps/2003/25502.htm. Accessed 03 August 2017.

${ }^{436}$ Aliyev, Ilham. 2003a. "Ilham Aliyev: Policy Innovations? No Way! Azerbaijani President-Elect on His Father, Himself, and Opposition." Rossiyskaya Gazeta, 21 October 2003.
} 
reinforce the state's independent identity on the world stage as a signal to other foreign powers that Azerbaijan would not be dominated by any one country.

A longitudinal analysis of event data in Chart 18 below indicates Ilham Aliyev's changing level of verbal cooperation with the United States and Russia is a strong indicator of his ideas about the merits of great power bridging. For the years under examination, Ilham Aliyev oscillated his level of verbal cooperation with the United States and Russia seeking to develop an almost equal alignment with both regional great powers. According to several area specialists, Azerbaijan's primary emphasis on independence makes the state open to dealing equally with a variety of different regional great powers. For example, on one hand Aliyev would attempt to align with Moscow as a way to resolve the Nagorno-Karabakh stalemate. On the other hand, Ilham pursed a Western trajectory by engaging with Washington on energy development. ${ }^{437}$ At times, when there was confrontation with Russia, this was followed by higher levels of verbal cooperation with the United States and vice versa.

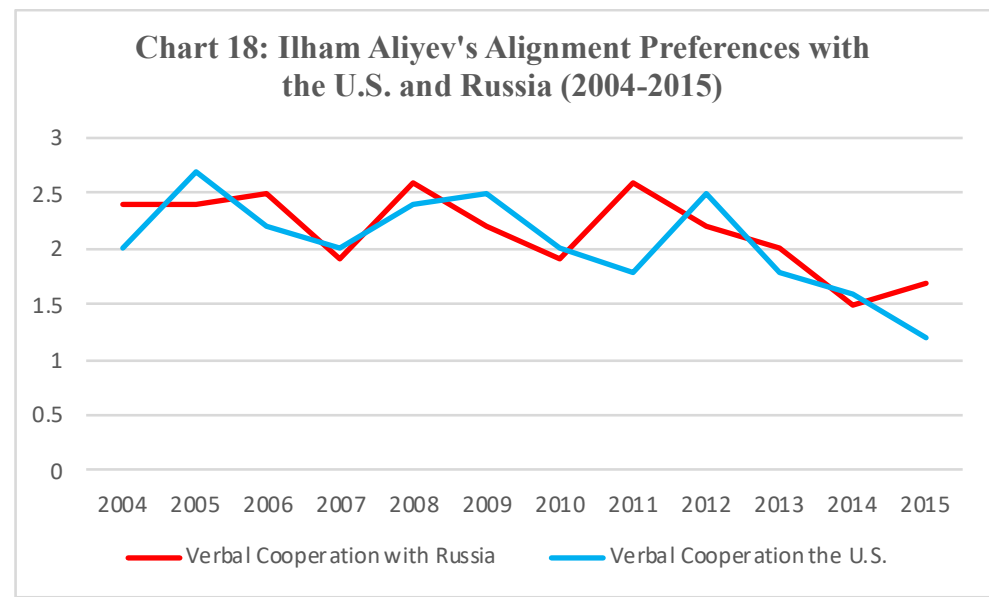

Furthermore, Ilham's continuing focus on the importance of maintaining Azerbaijan's independence had influence on his preferences to align with multiple regional great powers. One

\footnotetext{
${ }^{437}$ Interview on file with author.
} 
example to support this observation is a decision by President Aliyev to approve the publication of the updated national security concept in 2007. In this document, the critical importance of the country's independence was greatly emphasized. As explicitly noted, "the National Security Concept... is a set of goals, principles and approaches to the policies and measures, which underline the [country's] independence... and multidimensional and balance foreign policy"438 in the $21^{\text {st }}$ century. The publication of state's approach to world politics in 2007 in essence represented the formalization of Aliyev's enduring commitment to great power bridging where Baku would continue to eschew formal alliances opting instead to prefer a path in which the state would align with the United States, it allies, and Russia simultaneously.

In addition to Ilham Aliyev's characterization of the Azeri state as independent, several supporting state identity narratives provide a more in-depth understanding of his tendency to follow a great power bridging alignment. As supporting state identity narratives, Ilham Aliyev also viewed the state as European, modern, and market-oriented. After entering office, Ilham Aliyev's cultural views of the state's identity slightly deviated from his predecessor, who primarily saw the state as a gateway between the East and West. For Ilham however, Azerbaijan's place in the international arena gravitated towards the West and in particular Europe. Although Azerbaijan remained at the crossroads between Europe and Asia, Ilham Aliyev tended to view the state's role in Western terms. In his words,

The period of independence that we have experienced has already shown that our country is capable of having a totally independent policy. We maintain very good relations with the United States, and we also have very good relations with Russia. But we consider ourselves part of Europe. Azerbaijan is indeed Europe's eastern border, a country that views its future in terms of integration into the European structures. ${ }^{439}$

\footnotetext{
438 Aliyev, Ilham. 2004c. "President Ilham Aliyev spoke in the sitting of spring session of PACE." President of Azerbaijan Speech Archive. http://archive.president.az/articles.php?item_id=20070813045408862\&sec_id=11. Accessed 03 August 2017, 3; emphasis added.

${ }^{439}$ Aliyev, Ilham. 2004a. "Azerbaijan's Aliyev Interviewed on Relations with France, Russia, U.S. Le Figaro, 23 January 2004.
} 
Despite this increased emphasis towards Europe, Aliyev's adherence to multi-vectorism remained a linchpin in his preference for great power bridging. Recalling the 2007 National Security Concept, Azerbaijan would continue to adhere to a balanced, multidimensional foreign policy where friendly relations with all countries was the primary goal. ${ }^{440}$

In marked contrast to Heydar Aliyev, under Ilham's rule the state's identity in economic terms took on increased importance with his narratives giving increased emphasis to Azerbaijan as a modern and market-oriented state. The driving force behind Aliyev's beliefs about these narratives centered on the country's vast supply of oil for markets in the West, which would create new revenue streams for the state. These monies would have a dual purpose of modernizing the country (e.g. new infrastructure), while also helping Ilham to remain in power. ${ }^{441}$ However, Aliyev’s ideas about Azerbaijan and a modern, market-oriented country did not equate to an exclusive alignment preference for the United States. On the contrary, the Azeri president believed an economic alignment with Russia would also be highly beneficial. For example, in 2004 Ilham Aliyev praised the country's economic relations with Russia noting a myriad of accomplishments including the transport of oil through Russian ports, Russian natural gas imports, and foreign direct invest from companies in Russia. According to Aliyev, "this proved possible only with the help of political will and a good political basis. Our peoples are becoming even closer. For this reason, I highly value the level of bilateral relations and can wish only one thing: to continue developing them this way." 442

\footnotetext{
${ }^{440}$ Aliyev, Ilham. 2007. "National Security Concept of the Republic of Azerbaijan." The President of the Republic of Azerbaijan, 23 May 2007. https://www.files.ethz.ch/isn/154917/Azerbaijan2007.pdf. Accessed 04 August 2017. ${ }^{441}$ Cornell 2011, 112.

${ }^{442}$ Aliyev, Ilham. 2004. “Azerbaijan: President Praises Relations with Russia Ahead of Visit.” RIA-Novsti, 02 February 2004.
} 
In summary, the ideas of Heydar and Ilham Aliyev about the state's identity as first and foremost one that is independent, helped frame their alignment preference with both the United States and Russia. By characterizing the Azeri state as an independent actor on the world stage, each president was able to avoid formal entanglements in military alliances and regional economic organizations. Such an approach produced several marked benefits. First, both presidents acquired a high degree of strategic maneuverability that allowed them to maximize their material returns from multiple regional great powers. Second, a preference for great power bridging helped prevent foreign meddling in the state's internal affairs by playing off one regional great power over another. In essence, both presidents' ideas about the state's identity as independent became a cornerstone for great power bridging. Arzu Geybullayev captures this reality perfectly where on one hand, Azerbaijan remains a key strategic partner with Russia given its historical ties, trade relations, and Moscow's hand in the Nagorno-Karabakh. With Washington, she notes...

Officially, Baku does not want to distance itself from... the US. The country's leadership puts a lot of effort into portraying itself as an increasingly European - culturally, economically and politically. Whether it is succeeding at this is another question, but it is certainly trying very hard to come across as European and yet to strike a balance between the two political powers, in the meantime acting as an independent state. ${ }^{43}$

\section{Georgia}

In the decades preceding the dissolution of the Soviet Union, Georgia became one of the most ardent proponents of independence, where opposition elements were able to organize quite effectively beginning as early as the 1970 s. ${ }^{444}$ Unlike other Soviet republics with the exception

\footnotetext{
${ }^{443}$ Geybullayeva, Arzu. 2015. “Azerbaijan: Striking a Balance between Russia and the West." In Anahit Shirinyan and Louisa Slavkova (eds.) Unrewarding Crossroads? The Black Sea Region amidst the European Union and Russia. Sofia Platform, 36.

${ }^{444}$ For example, Zviad Gamsakhurdia, who became Georgia's first post-Soviet president, helped organize the Georgian Helsinki Watch Group in the mid 1970's. See Slider, Darrell. 1991. "The Politics of Georgia's Independence." Problems of Communism 40 (6), 64-65.
} 
of the Baltic States, the release of Gorbachev's policies on openness and restructuring in the late 1980s had a monumental impact on the political climate in Soviet Georgia. One of the most immediate effects to be seen was the open establishment of political opposition groups, one of the most prominent being the Ilia Chavchavadze Society. Established by dissident leader and future first president Zviad Gamsakhurdia along with several other opposition figures in 1987, the Ilia Chavchavadze Society espoused an anti-Soviet agenda that viewed nationalism and Georgian independence as a strategic imperative for the country's future. ${ }^{445}$

As political discord in Georgia continued to foment in 1988, the leader of Georgia's Communist Party, Dzhumber Patiashvili, attempted unsuccessfully to contain the rising social opposition. As demonstrations and hunger strikes increased, in April 1989 tens of thousands of protestors took to the streets in Tbilisi paralyzing the city. The response from Moscow was swift when Gorbachev directed an armed response resulting in the deaths of 20 innocent civilians at the hands of Soviet soldiers. ${ }^{446}$ According to a declassified CIA report...

For Georgians, the killing of 20 Georgian demonstrators in Tbilisi by Soviet troops on 09 April 1989 was a turning point in the recent history of their nation and the spark for a meteoric growth of modern Georgian nationalism and the drive for independence. ${ }^{447}$

In the wake of this massacre, the Georgian Communist Party lost all of its legitimacy ceding influence and power to a galvanized political opposition that would lead to open parliamentary elections in October 1990, a Georgian declaration of independence on 09 April 1991, and the election of Zviad Gamsakhurdia as Georgia's first post-Soviet president on 11 April 1991.

Although Gamsakhurdia may have been an ardent nationalist, who could move Georgian society to action, his political ineptness, authoritarian tactics, and gravitation towards corruption

\footnotetext{
${ }^{445}$ Ekedahl, Carolyn, and Melvin A. Goodman. 2010. Wars of Eduard Shevardnadze. Penn State Press, 261.

${ }^{446}$ Rayfield, Donald. 2013. Edge of Empires: A History of Georgia. Reaktion Books, 378.

${ }^{447}$ Central Intelligence Agency. 1990. "Georgia: Independence Drive Accelerating." Directorate of Intelligence, 24 April 1990, 2.
} 
elicited a strong socio-political backlash. The ensuing political crisis was made even more difficult as a result of the ethnic conflict and separatist efforts in the provinces of Abkhazia and South Ossetia. As anarchy set in, a violent revolt followed resulting in the dissolution of parliament and Gamsakhurdia's removal from power in early January $1992 .{ }^{448}$ An interim State Council was established to fill the political vacuum paving the way for the return of Eduard Shevardnadze. A highly charismatic political leader, Shevardnadze was previously the first secretary of the Central Committee of the Communist Party of Georgia from 1972 until 1985 before becoming President Gorbachev's minister of foreign affairs in $1985 .{ }^{449}$

Eduard Shevardnadze's arrival to Tbilisi brought some semblance of stability to Georgia. By October 1992, a new round of parliamentary elections resulted in Shevarnadze becoming Georgia's second head of state. Once in office, Shevardnadze, with Russian backing, was able to affect a cessation of hostilities in the restive province of South Ossetia by June 1992. Despite these gains, domestic political issues would consume Shevardnadze over the next several years as conflict in Abkhazia raged and political oppositionists attempted on several occasions to assassinate the head of state. In the words of Donald Rayfield, "the year 1995 was independent Georgia's nadir..." ${ }^{450}$ and the primary point of departure for deciphering Shevardnadze's ideas and beliefs about the state's identity in a new age. From a 1994 peace agreement halting the conflict in Abkhazia to the implementation of a new constitution in 1995, and a fresh round of national elections solidifying Shevardnadze's hold on power, one can now begin to garner the Georgian president's ideas about state identity.

\footnotetext{
${ }^{448}$ Rayfield 2013, 379-382.

${ }^{449}$ Suny, Ronald G. 1996. Armenia, Azerbaijan, and Georgia. Diane Publishing, 209-210.

${ }^{450}$ See Schmemann, Serge. 1992. "A Day's Work in Georgia: Shevardnadze Dodges a Coup and Ends a War." New York Times, 25 June 1992. http://www.nytimes.com/1992/06/25/world/a-day-s-work-in-georgia-shevardnadzedodges-a-coup-and-ends-a-war.html?mcubz=1. Accessed 29 July 2017; Ekedahl and Goodman 2010, 387.
} 


\section{$\underline{\text { Eduard Shevardnadze's State Identity Narratives and Georgia's Alignment }}$}

Interviews with regional experts, coupled with a content analysis of his foreign policy speeches indicate Eduard Shevardnadze gave primary emphasis to one political and two cultural state identity narratives: independent, European and Western. A distant fourth, the Georgian president also gave some emphasis to Georgia as a democratic state. Like Heydar and Ilham Aliyev in Azerbaijan, Eduard Shevardnadze's tendency to define the state as an independent actor in international affairs was correlated with a preference for great power bridging.

As depicted in Chart 19 below, President Shevardnadze's level of verbal cooperation with Washington and Moscow crisscrossed during his time in office. According to one regional expert, Shevardnadze's state identity narratives were at times contradictory. On one hand, he believed Georgia's independence was a catalyst for a political and economic alignment with the West; however, Georgia’s geographical location and economic reliance on Russia demanded he remain tethered in various fashions to the country's former imperial center. ${ }^{451}$

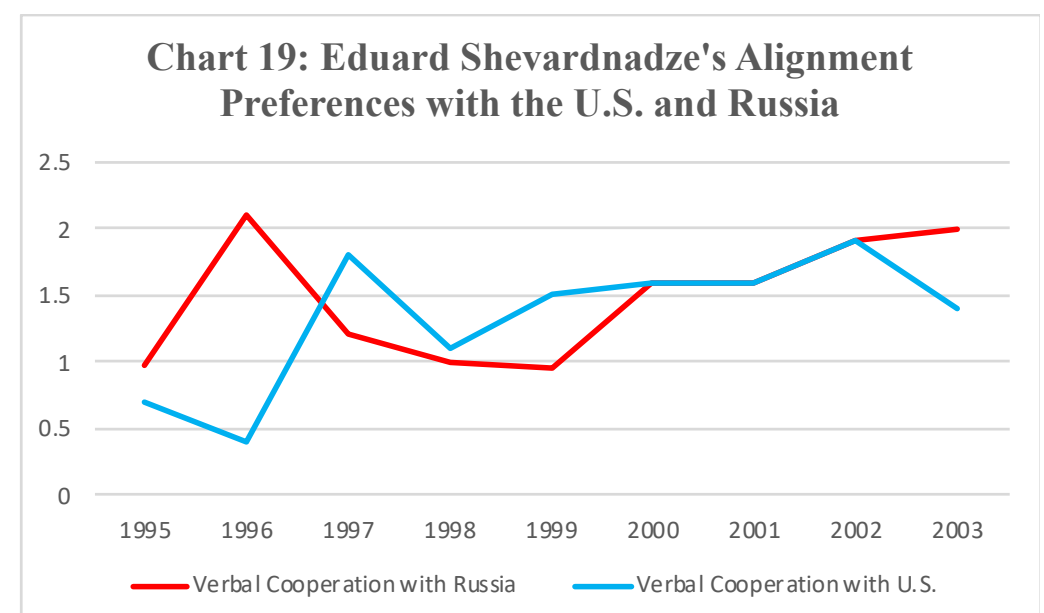

For the nine years in office, an independent Georgia was the primary state identity narrative espoused by Eduard Shevardnadze. The level of importance afforded to this particular concept by the Georgian president was made clear in his 1995 inaugural address. During this speech,

\footnotetext{
${ }^{451}$ Interview on file with author.
} 
Shevardnadze promoted the qualities of an independent Georgia and its increasing political, economic, and security relevance to the stability of the South Caucasus, the European continent, and the global order. In his words, "the image of Georgia as an independent, sovereign, and democratic country on the international arena will become more profound in the next few years. ${ }^{452}$ For Shevardnadze, the breaking of the country's Soviet bonds represented an opportunity to craft a new set of foreign policies that would allow Georgia to establish productive external relations with a wide array of other countries both near and far.

Shevardnadze's adherence to an independent state identity narrative was nearly omnipresent throughout his time in office. In 1998 Shevardnadze proclaimed “...however difficult the situation may be, we must always bear in mind that independence and statehood are our greatest achievements... ${ }^{453}$ By 2003 , there was little change in his ideas about the centrality of an independent Georgia on the world stage. For example, during a press interview Shevardnadze asserted, "we will use all available means and we will not spare our lives to defend our country's independence... independence should be the main proviso for the realization of individual aspirations and the happiness of each resident of Georgia. Only in this case will people see the true value of independence." ${ }^{454}$ Shevardnadze's words clearly convey his ideas about the importance of an independent Georgia and how these ideas also came to shape the Georgian president's preferences to align with multiple regional great powers.

There are at least two factors helping shape Shevardnadze's ideas about Georgia as an independent actor in international politics and his alignment preferences. The first centers on the

\footnotetext{
452 Shevardnadze, Eduard. 1995a. "Shevardnadze Delivers Inauguration Speech.” First Program Television Network, 26 November 1995; emphasis added.

${ }^{453}$ Shevardnadze, Eduard. 1998. "Georgia's Shevardnadze on Abkhaz Conflict.” Radio Tbilisi Network, 25 May 1998.

${ }^{454}$ Shevardnadze, Eduard. 2003a. "President Shevardnadze Focuses Weekly Interview on Georgian Energy Sector Problems." Georgian Radio 1, 04 August 2003.
} 
issue of separatism within Georgia. Specifically, the provinces of South Ossetia and Abkhazia remained a hotbed of separatist-related activity, which frequently would erupt into political and social violence. This was particularly true in Abkhazia when in 1992 Abkhazian Supreme Soviet Chairman Vladislav Ardzinba led an effort to secede from Georgia. The Georgian government's military response led to an intense period of violence that was halted only through a Russianbrokered peace agreement in July 1993. This agreement established a ceasefire between warring parties, created a Georgian-Abkhazian-Russian control group to enforce the peace, and authorized the deployment of Russian peacekeeping forces to Abkhazia. ${ }^{455}$

Second, with Moscow anchored as a major party to the resolution of Georgia's separatist problems, this reality challenged Shevardnadze's ideas about Georgia's independence and the necessity to align not only with Russia, but other major powers such as the United States, as a way to achieve an enduring resolution. For example, in the late 1990s Shevardnadze's shuttle diplomacy helped establish a diplomatic alignment with the U.S. but not to the extent it would undermine Tbilisi's alignment with Russia on the separatist issue. As noted by Shevardnadze,

Can you imagine what Georgia would have been without the great material, financial, moral, and political support and help provided by the United States and Europe? We have to strengthen these trends. My visits are not directed against any other party. I will be happy if I manage to make my humble contribution to understanding among the countries of the world. ${ }^{456}$

Beyond his independent state identity narrative, two cultural (European and Western) and one ideological (democratic) narrative helped shape Shevardnadze's tendency to prefer a great power bridging alignment. Beginning in 1995 Eduard Shevardnadze viewed the state in European terms. A content analysis of his foreign policy speeches revealed Shevardnadze's emphasized

\footnotetext{
${ }^{455}$ Kozhokin, Evgeny. 1996. "Chapter 5: Georgia-Abkhazia.” In Jeremy R. Azrael and Emil A. Payin (eds.) US and Russian Policymaking with Respect to the Use of Force. Rand Corporation. https://www.rand.org/pubs/conf_ proceedings/CF129/CF-129-chapter5.html. Accessed 02 April 2016, 80.

${ }^{456}$ Shevardnadze, Eduard. 1997. "Shevardnadze Discusses Latest Developments." Radio Tbilisi Network, 07 July 1997,3 .
} 
how Georgia was an integral part of Europe and the West. Shevardnadze's commitment to steering the state and country towards the West endured through much of his political career. As late as 2000 , Shevardnadze frequently made reference to state's identity as European. As outlined in the state's 2000 Foreign Policy Concept, Georgia was destined "to achieve full integration into European political, economic, and security structures, thus fulfilling the historical aspiration of the Georgian nation to participate fully in the European community..." The Western narrative would, by extension, convey to the United States. A prime example of the relevance of Shevardnadze's ideas about Georgia's independence and an alignment preference with the United States was seen in a statement from 2001. According to Shevardnadze, "since Georgia is independent, we have ideal relations with the United States. It helps us hugely."458 Finally, following closely behind Shevardnadze's Western narrative was his articulation of Georgia as a burgeoning democracy. As a supporting state identity narrative, the Georgian president frequently called attention to his efforts to implement reforms designed to bolster civil liberties, rule of law, and a level political playing field. From his 1995 inauguration speech, Shevardnadze emphasized his ideas about the state's democratic identity in world affairs noting how, "the image of Georgia as an independent, sovereign, and democratic country on the international arena will become more profound in the next few years." 459

Shevardnadze's ideas about Georgia's democratic identity were brought to the fore by his corresponding beliefs that by taking the road to democracy would bring closer engagement with the United States, Germany, France, and Great Britain. These engagements would then bring

\footnotetext{
${ }^{457}$ Shevardnadze, Eduard. 2000. “Georgia and the World: A Strategy for the Future.” http://www.bits.de. NRANEU/ docs/CFE/Georgia Strategy.pdf. Accessed 03 August 2017.

${ }^{458}$ Shevardnadze, Eduard. 2001a. "Georgia's Shevardnadze Cited on NATO Membership." Le Figaro, 27 June 2001.

${ }^{459}$ Shevardnadze 1995a, 4-5.
} 
him, the state, and the country much needed foreign economic and diplomatic assistance to help Georgia's transition from Soviet rule. The importance of external support from the United States and its allies in Europe was made clear as early as June 1995 when Shevardnadze said...

I do not think we need to explain how important the assistance by the EU, the United States, and other countries is. Georgia will receive further political and financial assistance provided it takes an irreversible road toward democratization and economic reforms. I believe, an agreement on cooperation with the European Union, which is under preparation now, will play an extremely important role. ${ }^{460}$

As in Azerbaijan under both presidents, Shevardnadze's ideas about the state as a beacon of democracy must be qualified however. Specifically, although Shevardnadze may have done well to continuously frame the state as a 'vanguard' of democratic ideals, little progress was actually achieved under his leadership. According to reporting from the Polity IV project, ${ }^{461}$ Georgia under Eduard Shevardnadze was best understood as an anocracy with a mix of democratic and authoritarian characteristics. ${ }^{462}$ Two factors contributing to this reality included Shevardnadze's lack of commitment to actually affecting 'real' democratic reforms and domestic political opposition. Specifically, rampant corruption and political resistance to democratic reforms helped ensure Georgia's post-Soviet transition would be held in check. Taken together, “...Shevardnadze himself increasingly fell back on his instincts and skills, honed during the Brezhnev years, of managing the myriad of conflicting personalities that surrounded him rather than solving policy problems and implementing necessary reforms. ${ }^{463}$

\footnotetext{
${ }^{460}$ Shevardnadze, Eduard. 1995b. "Weekly Interview with President Shevardnadze." Tbilisi Radio Tbilisi Network, 05 June 1995.

${ }^{461}$ Owing to the complex nature of this study's focus on a political leader's belief system, Polity scores are used as a rough measure in a larger, more refined qualitative analysis on the topics at hand.

462 Marshall, Monty G. Ted Robert Gurr, and Keith Jaggers. 2017. Polity IV Project: Political Regime Characteristics and Transitions, 1800-2016. http://www.systemicpeace.org/inscr/p4manualv2016.pdf.

463 Ó Beacháin, Donnacha, and Frederik Coene. 2014. "Go West: Georgia's European Identity and its Role in Domestic Politics and Foreign Policy Objectives.” Nationalities Papers 42 (6), 929.
} 
In summary, an examination of the alignment tendencies of Eduard Shevardnadze between 1995-2003 indicates this president primary viewed Georgia's state identity as independent. In concert with this characterization, Shevardnadze articulated several supporting state identities for Georgia including European, Western, and to a lesser degree, democratic. With respect to his ideas about alignment, Shevardnadze preferred great power bridging with the United States and the Russian Federation for his entire political career.

Mikheil Saakashvili's State Identity Narratives and Georgia's Alignment

Shevardnadze's hollow words on implementing democratic reforms to match his state identity rhetoric, coupled with unabated corruption and the government's inability to provide basic services and supplies to the population set the conditions for his fall from power. Shevardnadze's domestic missteps and preference for great power bridging gave way to a "Rose Revolution" and the rise of Mikheil Saakashvili as Georgia's president from 2004 until 2013. In marked contrast to Shevardnadze, Saakashvili primarily conceived the state's identity as Western-European, free, and democratic, which was associated with a preference for positive bandwagoning with the United States.

As depicted in Chart 20 below, President Saakashvili consistently devoted higher levels of verbal cooperation with Washington over Moscow for the 10 years under examination. 


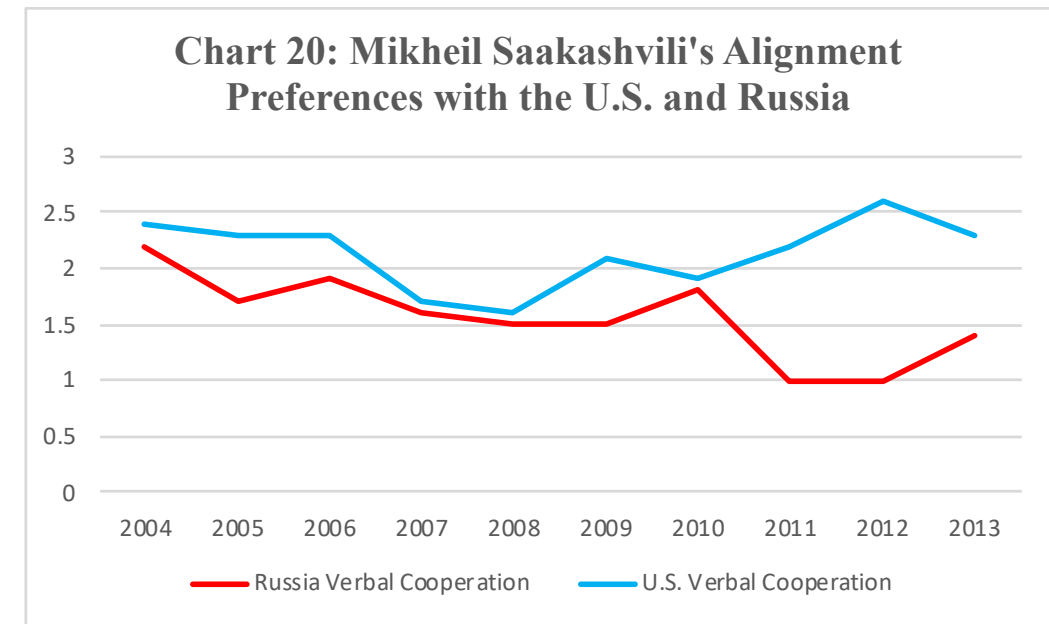

With Saakashvili's ideas about the state defined in terms of Western, European, freedom, and democratic, his pattern of verbal cooperation, as conceptualized in this research project, correlates with a positive bandwagoning alignment with the United States. Although Saakashvili still believed a cooperative approach with Moscow was necessary, the intensity and persistence of the Georgian president's verbal pronouncements was less than what was seen with Washington. Interviews with various regional experts and an analysis of the secondary literature validate this qualitative correlation. According to one area specialist, Georgia's tumultuous history under the Soviet Union and the prospect the Kremlin would seek to reestablish its political control and influence the South Caucasus was a primary catalyst shaping the ideas and beliefs of President Saakashvilli. ${ }^{464}$

From the moment he entered office, Mikheil Saakashvili's ideas about the state and country as Western and European were reflected in many of his foreign policy speeches. For example, during his January 2004 inaugural address, Saakashvili had both the EU and Georgian flags on display. During his remarks, he asserted, "today, we have not raising the European flag by

\footnotetext{
${ }^{464}$ Interview on file with the author.
} 
accident. This flag is a Georgian flag as well, as far as it embodies our civilization, our culture, the essence of our history and perspective, and our vision for our future. ${ }^{265}$ His ideas here were meant to place Georgia in the same light as other former Soviet republics (e.g. the Baltics) that had been welcomed into the Euro-Atlantic fold. With such an early emphasis on viewing the state and the country as European, it is no surprise to find Saakashvili would come to prefer a positive bandwagoning alignment with the United States.

Saakashvili's fervent ideas about the state's European-Western identity were instrumental in shaping his alignment preferences; many of which were reflected in his administration's national security documents. In 2005, the National Security Concept of Georgia explicitly referenced the state's alignment aspirations with the United States.

Georgia continues to develop its strategic partnership with the United States of America. From the very day Georgia declared independence, the United States has strongly supported development and strengthening of Georgia's statehood, democracy, defense capabilities and economy. Georgia's pledge to become a full democracy with a viable market economy, and to its aspirations to move toward European and Euro-Atlantic integration. ${ }^{466}$

...and Western Europe, where Georgia is best understood as...

....an integral part of the European political, economic and cultural area, whose fundamental national values are rooted in European values and traditions [with the intent of achieving] full integration into Europe's political, economic and security systems [and a] return to its European tradition [as] an integral part of Europe. ${ }^{467}$

Saakashvili's state identity narrative persisted through 2012 when the Georgian president's ideas were reflected in an updated national security concept, which stated "Georgia is a part of the European and Euro-Atlantic space." ${ }^{268}$ That same year, Saakashvili's seized the opportunity to

\footnotetext{
${ }^{465}$ Saakashvili, Mikheil. 2004a. "President Saakashvili's Inauguration Speech." Civil Georgia Online, 25 January 2004. http://www.civil.ge/eng/article.php?id=26694. Accessed 06 August 2017.

${ }^{466}$ Saakashvili, Mikheil. 2005a. National Security Concept of Georgia. Parliament of Georgia. http://www. parliament.ge/files/292_880_927746_concept_en.pdf. Accessed 05 August 2017, 9.

${ }^{467}$ Ibid 2005, 1.

${ }^{468}$ Saakashvili, Mikheil. 2012a. National Security Concept of Georgia. Parliament of Georgia. https://mod. gov.ge/assets/up-modul/uploads/pdf/NSC-ENG.pdf. Accessed 05 August 2017, 3.
} 
emphasize his alignment preferences by explicitly referencing his European-Western ideas in a speech to NATO's parliamentary assembly. In his words, Georgia's “...NATO aspiration is an integral part of our identity... the bedrock of [our] values..." ${ }^{469}$

Following closely behind Saakashvili’s ideas about Georgia as a member of Western civilization, the Georgian president gave emphasis to the state as a beacon of freedom in the West's outer rim where the 'Russian Bear' and its authoritarian tendencies cast a long shadow of opposition to Tbilisi's Western trajectory. An example of Saakashvili's commitment to the idea of the Georgian state as one based on freedom was seen in his May 2005 speech from 'Freedom Square' during the first-ever visit by a U.S. President, George W. Bush. As Saakashvili so eloquently stated, “...Georgians have fought everywhere for freedom... [and] George Bush's presence here is confirmation of what unity can achieve, our common quest for freedom..."470

Saakashvili's articulation of freedom as a key element of the Georgian state remained generally constant from 2004 through 2013 with two notable spikes; one in 2005 and the second in the 2011-2012. As just noted in the preceding paragraph, President Bush's visit to Georgia likely amplified Saakashvili's ideas about this state identity concept. The increase in 2011 and 2012-Saakashvili's last years in office - likely reflected his frustration over his beliefs about Russian meddling in the country's parliamentary elections.

[Russia] ...thought that now is the right time to use [a] different approach with [the] Georgians; they thought: "We've failed through economic embargos, provocations, explosions and invasion... maybe the Georgian people are now tired and as a result of these elections...let's seize this beautiful country with kind words and bribes." No. We will have freedom, we want Europe, we want NATO, we want development and better life. ${ }^{471}$

\footnotetext{
${ }^{469}$ Kornely, Kakachia, and Cecire Michael. 2013. "Georgian Foreign Policy: The Quest for Sustainable Security." Tbilisi, GA: Konrad-Adenauer-Stiftung, 24; emphasis added.

${ }^{470}$ Saakashvili, Mikheil. 2005. "Georgian TV: Saakashvili Bestows First 'St George's Order' Award to US President.” Rustavi-2 Television, 10 May 2005; emphasis added.

${ }^{471}$ Saakashvili, Mikheil. 2012. "UNM Holds Series of Day-Long Rallies." Civil Georgia Online, 08 September 2012. http://www.civil.ge/eng/article.php?id=25193\&search=. Accessed 05 August 2017; emphasis added.
} 
Given Saakashvili's inclination to define the state as a vanguard element for freedom, it is not surprising democracy was his third idea about the state's identity. Saakashvili's conceptions of the Georgian state as democratic was made visible in his 2005 speeches about how open and free elections were held at the national, parliamentary, and regional elections in Georgia. These achievements moved Freedom House to improve Georgia's freedom rating from 4 to 3 (partly free) ${ }^{472}$ The extent to which democracy was regarded as a major thread in Saakashvili's ideas about the state were illuminated in a 2006 speech in response to Russian economic sanctions. In his words, "[Georgia] cannot be broken...we want democracy and to live in a country like the Germans, Dutch, Czechs, Poles, Estonians, Lithuanians, Latvians and other free citizens in other free countries. ${ }^{" 473}$ As a point of emphasis, democracy for Saakashvilli should not be regarded as a bottom-up process. On the contrary, the Georgian president believed democratization must be a top-down process. Any bottom-up approach was viewed as suspect and a potential threat to his hold on power. Additionally, democratization took a backseat to Saakashvilli's quest to join NATO. For example, Saakashvilli's 2007 heavy-handed crackdown on prison riots demonstrated he still viewed authoritarian tactics against civilians as a useful tactic to maintain order. ${ }^{474}$

From Saakashvili's ideas about Georgia as a democratic state, one can discern several important points about the relationship between his ideas about the state's identity and alignment preferences. Under Saakashvili, the compatibility of his ideas about the state with those enduring state identity narratives in America and Western Europe led him to prefer positive bandwagoning

\footnotetext{
${ }^{472}$ Freedom House. 2006. "Georgia." Freedom in the World 2006. https://freedomhouse.org/report/freedomworld/2006/georgia. Accessed 05 August 2017.

${ }^{473}$ Saakashvili, Mikheil. 2006. “Georgia ‘cannot be broken' Saakashvili tells Russia” Rustavi-2 Television, 04 October 2006.

${ }^{474}$ Interview on file with author.
} 
with the United States. The extent to which Saakashvili believed his ideas about an alignment

with the U.S. were made clear during his visit to Washington in February 2004.

Georgia has a special relationship with the United States of America. I make this claim that this evaluation is based on the realization that Georgians and Americans share a common set of values. We share common beliefs and common aspirations to make our societies more free and more prosperous. We believe in government that serves people. We believe in the sacred principle that the power of the State derives from its citizens and that no man is above the law. These values, which were at the very core of the Revolution, have served to re-enforce the bonds that unites our countries and our peoples! $!^{475}$

Second, the convergence of state identities was a catalyst for similar national interests involving security and economic prosperity. According to a Georgian government official, "the world order that the US and the EU promote is fully in the interests of Georgia." ${ }^{476}$ Given the preceding, one can begin to understand how the compatibility of identities between a small state and regional great power may have a direct or indirect impact on the alignment of Georgia with the United States. From one perspective, the intensity of Saakashvili's conceptualizations of the state as Western, free, and democratic exerted a direct impact on the Georgian president's predilection to align with the U.S. over Russia. Under Shevardnadze, his personal interests (e.g. stay in power) and his conceptions of the national interests (domestic security and stability as well as the removal of Russian military forces to just name a few) drove him towards a great power bridging. ${ }^{477}$

Giorgi Margvelashvili’s State Identity Narratives and Georgia's Alignment

In 2012, Saakashvili's United National Movement (UNM) party suffered a defeat at the hands of the Georgian Dream, a coalition of political parties led by Bidzina Ivanishvili. The following

\footnotetext{
${ }^{475}$ Saakashvili, Mikheil. 2004b. "Speech Delivered by Mikheil Saakashvili at John Hopkins University." The President of Georgia Speeches and Statements, 04 February 2004, 2-3. http://www.saakashviliarchive. info/en/PressOffice/News/SpeechesAndStatements?p=2779\&i=1. Accessed 27 September 2016.

${ }^{476}$ Kakachia, Kornely and Salome Minesashvili. 2015. "Identity Politics: Exploring Georgian Foreign Policy Behavior.” Journal of Eurasian Studies 6 (2), 177.

${ }^{477}$ Interview on file with author.
} 
year at the end of his two terms in office, President Giorgi Margvelashvili replaced Saakashvili in a national election that witnessed a peaceful transfer of power at the highest levels of government. During the two years under examination, President Margvelashvili emphasized two cultural, one political, and one ideological state identity narratives. In order of importance, Margvelashvili viewed Georgia as European, Western, free, and democratic.

As depicted in Chart 21 below, President Margvelashvili consistently devoted higher levels of verbal cooperation with Washington over Moscow. With Margvelashvili's ideas about the state defined in terms of European, Western, freedom, and democratic, his pattern of verbal cooperation correlates with a positive bandwagoning preference with the United States.

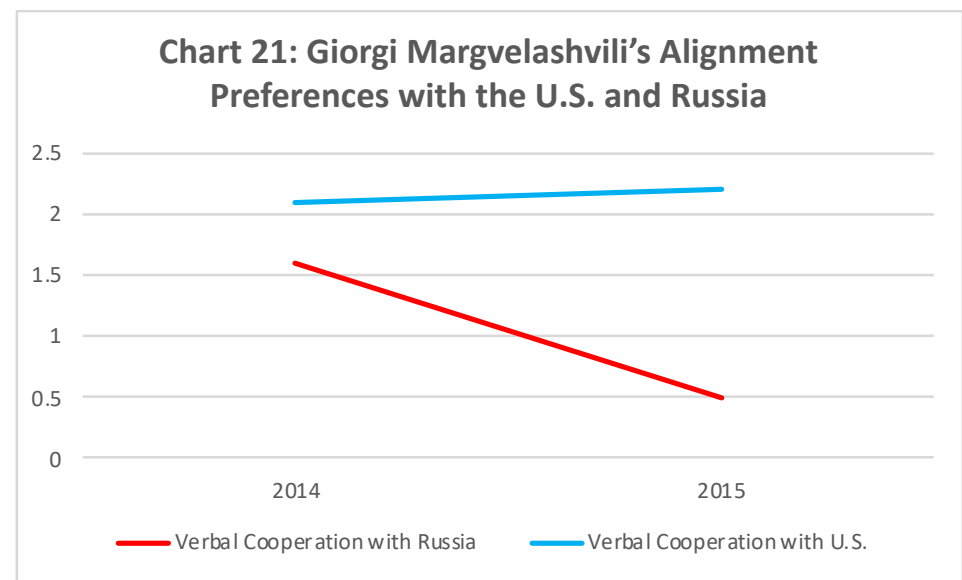

Margvelashvili also believed a cooperative approach with Moscow was necessary in order to restore Georgia's territorial integrity following South Ossetia and Abkhazia's declaration of independence. However, the intensity of Margvelashvili's verbal pronouncements toward the United States—nearly double of what was observed with Russia — points toward a positive bandwagoning alignment. This finding is validated from area specialists, who note Margvelashvili initially sought to mend relations with Moscow by tempering his and the ruling 
governments confrontational rhetoric; however, he was adamant in his ideas about Georgia's alignment with the U.S. and its Western European allies. ${ }^{478}$

A European-Western state identity narrative dominated Giorgi Margvelashvili’s foreign policy discourse. The intensity of the Georgian president's ideas about the state in these categories were nearly 2.5 times higher than his predecessor. Margvelashvili's fervent beliefs about Georgia's European-Western identity were revealed during his November 2013 inauguration. In his speech, Margvelashvili stated, "as an individual, a Georgian national is European in terms of self-awareness and an integral part of Western civilization by nature. Until now, however, we have failed to translate our being European into institutional dimensions." ${ }^{\text {"49 }}$ For Margvelashvili, Georgia was unequivocally a Western state without few linkages to Russia. A contributing factor to Margvelashvili's high verbal cooperation stems, in part, from his ideas about Westernizing the state's institutions. In this case, Margvelashvili firmly believed Georgia was a historical and integral part of Europe and that as president, he had a mandate to move the country along this path. From one perspective, while Saakashvili had done rather well to implement reform and move Georgia along a Western trajectory, much work still had to be done in terms of setting the cultural and political conditions for an enduring presence of these conceptions at the state level. ${ }^{480}$ Once achieved, any attempt to associate Georgia as being within Russia's geopolitical orbit would become null and void.

Following the pattern set by Mikheil Saakashvili, freedom was another primary state identity narrative articulated by President Margvelashvili from 2014 to 2015. The content analysis

\footnotetext{
${ }^{478}$ Interview on file with author.

${ }^{479}$ Margvelashvili, Giorgio. 2013. "President Margvelashvili's Inauguration Speech.” Civil Georgia, 17 November 2013. http://www.civil.ge/eng/article.php?id=26693. Accessed 06 August 2017; emphasis added.

${ }^{480}$ Margvelashvili, Giorgio. 2013a. "After Initialing the EU Association Agreement "Euronews" Talked to the President of Georgia." Official Website of the President of Georgia, 29 November 2013.

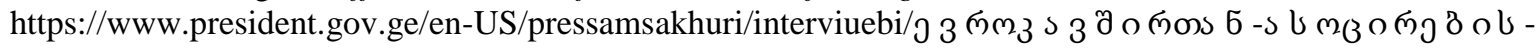

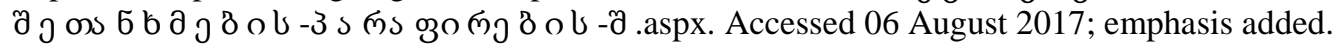


revealed Margvelashvili gave emphasis to the terms free and freedom as supporting narratives in his foreign policy discourse. In 2015, the value placed on this identity narrative was made clear in the Georgian president's remarks to Polish leaders. From Margvelashvili, Georgia has been able to overcome a myriad of political and economic challenges because there were political leaders in Western governments, who shared his same commitment and respect for upholding the principle of freedom in world affairs. ${ }^{481}$ For Margvelashvili, freedom would become a thread binding Georgia to the U.S. and other like-minded states

Finally, this study's content analysis of President Margvelashvili's speeches indicates democracy was the third-most emphasized state identity narrative. An excellent example illuminating the relationship between his ideas about the Georgian state as democratic and his alignment preferences is found in the president's November 2013 inaugural address. In this speech, Margvelashvili states, “Georgia's democratic and peaceful development and economic growth constitute the cornerstone of our public policy. All this will enable us to overcome challenges facing our country and ensure that it develops into a reliable international partner." ${ }^{82}$ Under Margvelashvili's rule, Georgia made substantial progress in implementing democratic reforms, garnering a 3-ranking from Freedom House for the period 2014-2015. This was significant because during Saakashvili’s last several years in office, Georgia's ranking dropped to a "4 rating" as a result of his semi-authoritarian tactics. ${ }^{483}$

In summary, in examining the alignment tendencies of Georgian presidents between 1995 and 2015, this study finds that when a president gave emphasis to an independent state identity

\footnotetext{
${ }^{481}$ Margvelashvili, Giorgio. 2014c. "Toasts Offered by the Presidents of Georgia and Poland at the Official Dinner." Official Website of the President of Georgia, 02 April 2014. https://www.president.gov.ge/enUS/pressamsakhuri/siakhleebi/The-toasts-offered-by-the-Presidents-of-Georgi-(1).aspx; Accessed 06 August 2017 ; emphasis added.

482 Margvelashvili 2013a, 2; emphasis added.

${ }^{483}$ Freedom House. 2015. "Georgia." Freedom in the World 2015. https://freedomhouse.org/report/freedomworld/2015/georgia. Accessed 05 August 2017.
} 
narrative, the volatility of their verbal cooperation with the United States and Russian Federation was higher indicating a proclivity for great power bridging. This was the case with Eduard Shevardnadze. Separately, when Georgian presidents conceptualized the state in terms of Western-European, democratic and one based on freedom, verbal cooperation with the U.S. was consistently higher. This pattern was seen with Presidents Saakashvili and Margvelashvili, who preferred a positive bandwagoning alignment with the United States.

\section{Moldova}

During the Soviet era, political opposition in the Moldavian Soviet Socialist Republic could be best described as fragmented and unorganized given the ability of communist leaders to successfully prevent the formation of any viable political opposition to the ruling government. ${ }^{484}$ As a result, although ethnic Moldovans occupied the highest positions in the state apparatus, these individuals towed the party line in articulating a state identity that conformed to Kremlin directives until the arrival of Mikhail Gorbachev. In a similar manner to what occurred in Azerbaijan and Georgia, perestroika and glasnost created an opportunity for open political expression in Moldova by all of the country's ethnic groups. Although slow to start, by 1989 a collective of political and cultural groups had banded together to form the Moldovan Popular Front (MPF). Following Moldova's first democratic elections in February 1990, Mircea Snegur, a communist, became the MPF's chairman and eventually the president following the country's declaration of independence on 27 August 1991.485

\footnotetext{
${ }^{484}$ Katchanovski, Ivan. 2006. Cleft Countries: Regional Political Divisions and Cultures in Post-Soviet Ukraine and Moldova. Vol. 33. Columbia University Press, 64.

${ }^{485}$ Crowther, William. 1997. "The Politics of Democratization in Postcommunist Moldova." In Dawisha, Karen, and Bruce Parrott (eds.) Democratic Changes and Authoritarian Reactions in Russia, Ukraine, Belarus and Moldova Vol. 3. Cambridge University Press, 291-293.
} 
In parallel with Snegur's rise to the presidency and the MPF's radical nationalist policies, which included a union with Romania, the permissive political environment elicited calls for independence by various minority groups. In southern Moldova, the Turkic-speaking Orthodox Christians, who made up the Gaguaz minority and hardline communists in the Transnistria declared their own independence in August 1990. ${ }^{486}$ In response, Snegur's strong-armed response resulted in widespread violence in the separatist areas, particularly in the Transnistria. ${ }^{487}$ The introduction of Russian military forces in June 1992 on the side of the separatists brought a halt to the violence in the Transnistria. The following month, President Snegur and Russian President Boris Yeltsin signed an agreement in Moscow, which established of a formal ceasefire and a guarantee of limited autonomy for the Transnistria. ${ }^{488}$

The shock of Moldova's transition from Soviet rule began to subside in 1995 owing to several key events. First, in March 1994 a new round of parliamentary elections saw the exit of the MPF and its radical nationalist members as the Democratic Agrarian Party of Moldova, with its less zealous national agenda, gained a majority in the legislature. Second, in August 1994 parliament ratified a new constitution formalizing Transnistria and Gagauzia's autonomy in the new republic. Third, and perhaps the most important, in 1994 a national referendum on the country's statehood found nearly 98 percent of the population favored Moldova's continued independence and non-union with Romania. ${ }^{489}$ These factors helped establish higher levels of political stability in the government through 1997 when Petru Lucinschi replaced Mircea Snegur as the country's second president.

\footnotetext{
${ }^{486}$ Crowther, William and Helen Fedor. 1995. Belarus and Moldova Country Studies. Washington D.C.: Government Printing Office, 109.

${ }^{487}$ This study uses the term Transnistria and, Transdniestrian Trans-Dniester interchangeably.

${ }^{488}$ Organization for Security and Cooperation in Europe. 1994. "The Transdniestrian Conflict in Moldova: Origins and Main Issues." Vienna, 10 June 1994, CSCE Conflict Prevention Centre, 2-3.

${ }^{489}$ Nohlen, Dieter, and Philip Stöver. 2010. Elections in Europe: A Data Handbook. Baden-Baden, Nomos, 1330.
} 


\section{$\underline{\text { Petru Lucinschi’s State Identity Narratives and Moldova's Alignment }}$}

In 1997, Petru Lucinschi assumed the presidency in Moldova after defeating incumbent Mircea Snegur in a run-off election that saw Lucinschi receiving 54 percent of the popular vote. Frustrated with Snegur's inability to resolve the situation in the Trans-Dniester and a struggling economy, Moldovans believed the best way forward was through the leadership of Petru Lucinschi. ${ }^{490}$ For the time he was in office (1997-2000), a content analysis of his foreign policy speeches reveal he primarily viewed the state as independent, European, and democratic.

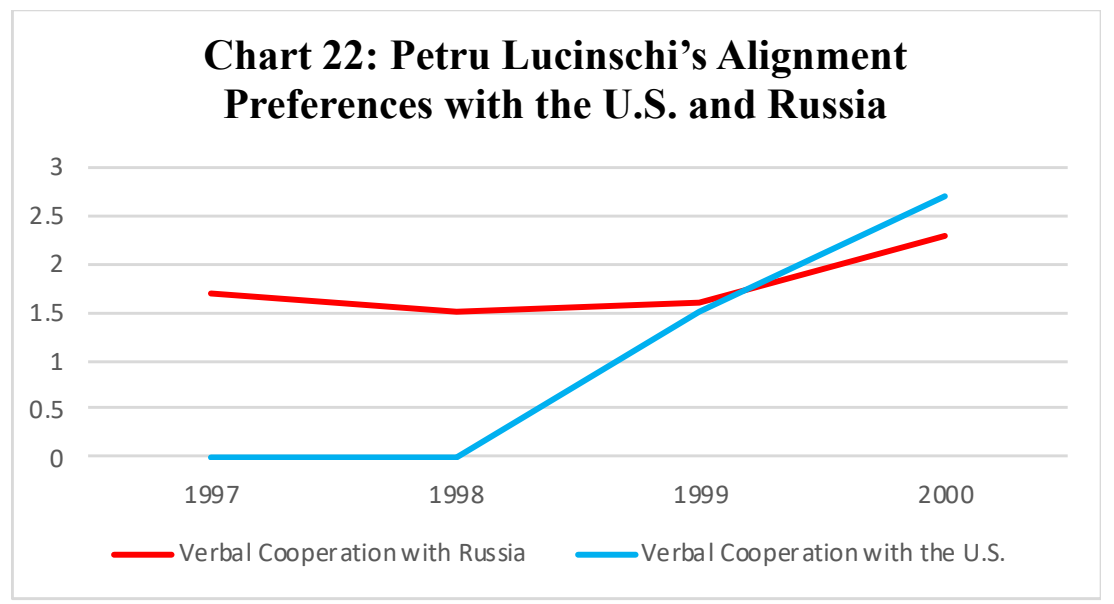

As depicted in Chart 22 above, President Lucinschi devoted varying levels of verbal cooperation with the U.S. and Russia from 1999 to 2000; however, a lack of available event data in 1997-1998 between Lucinschi and the U.S. prevents a more detailed analysis of this indicator. Interviews with area specialist and an analysis of the secondary literature indicate the Lucinschi tended to retain a multi-faceted conception of the state's identity and a preference for great power bridging.

\footnotetext{
${ }^{490}$ Mazo 2004, 27; Stiftung, Bertelsmann. 2003. "Moldova Country Report.” Bertelsmann Transformation Index 2003-Towards Democracy and Market Economy. Gütersloh, Germany: Bertelsmann Stiftung, 2.
} 
Moldova as an independent state was one of Lucinschi's top state identity narratives while in office. Much of Lucinschi's oratory comments in this category focused predominately on Romania, Russia, and the unresolved situation in the Trans-Dniester. The Moldovan president also tended to emphasize the importance of using Moldova's independence to establish mutually beneficial foreign relations with other major international powers to include the United States, Russia, and countries in Western Europe. ${ }^{491}$ Such an approach would help him to bolster the country's fledging economy and to re-establish the country's territorial integrity. Lucinschi's ideas about the importance of the state's independence and his preference for great power bridging was made clear when he stated...

Small countries differ from large ones in that they may assert themselves only by pursuing an active foreign policy. Only by making joint efforts can we overcome our uneasy transitional period. Having done so, we shall be able to start fulfilling the main strategic task of strengthening our state system, independence and sovereignty. ${ }^{492}$

The relationship between Lucinschi's independent state identity narrative and his alignment preferences were also on display in 1997. According to the Moldovan president...

In my opinion Moldova has simply begun to find its place. We do not want to move away from Romania to an extent which would deteriorate our relations with it, but we also do not want to approach Moscow so closely that this will evoke fears of losing our independence. We are a non-bloc state, and we are of no a danger to anybody. All we want is respect for our independence. We have a specific multinational population. Therefore, we have to be very careful and we cannot bend to one side or to the other, for in such situation we will always be an instable country. ${ }^{493}$

In concert with President Lucinschi's independent state identity narrative, he also viewed the state and Moldova writ large as European. During a 1998 interview, Lucinschi emphasized on how it was necessary for all Moldovans to embrace the idea of European patriotism. According to Lucinschi, "[European] patriotism may become a unifying idea for the citizens of the country

\footnotetext{
${ }^{491}$ Lucinschi, Petru. 1999. "Lucinschi on Dniester Issues, GUUAM.” Interfax, 18 November 1999.

${ }^{492}$ Lucinschi, Petru. 1999c. "Moldovan President Views Bilateral Relations, Tasks." Nepszabadsag, 30 August 1999; Lucinschi, Petru. 1999b. "Moldova: President Says to Attend Sarajevo Summit." Interfax, 27 July 1999. ${ }^{493}$ Lucinschi, Petru. 1997a. "President on Ties with Ukraine, Dniester." Holos Ukrayiny, 12 March 1997.
} 
which means that people should be masters in their homes and citizens of Big Europe...I think that a sense of belonging to the European civilization and culture should be common for us despite the natural differences. ${ }^{\prime 494}$ President Lucinschi’s ideas on Moldova as a European state would subsequently guide his alignment preferences steering the country towards economic integration with the EU. In 1997 Moldova petitioned to become an EU Associate member and by 1998, parliament had ratified the 1994 EU Partnership and Cooperation Agreement. ${ }^{495}$

Petru Lucinschi's European state identity narrative had its limits however. On one hand, he envisioned Moldova as being economically aligned with Western Europe. On the other hand, Lucinschi did not believe Moldova should be exclusively committed to a Western alignment with the United States and its European allies. For example, in 1999 Lucinschi noted how just because Moldova seeks to be a part of Europe, this does not mean the state is 'pro-Western.' In his words, "we [Moldova] strive for integration into Europe as an independent, sovereign state with its own specific identity and we do not want to lose that identity..."496 While Lucinschi placed high value on Moldova's European identity, his ideas about the state as an independent actor and the necessity to align with multiple regional great powers took precedence.

Finally, Petru Lucinschi's foreign policy discourse indicated he viewed the Moldovan state as democratic. The frequency of his usage of terms democracy, democratic, and democratization, while important, occurred at a lower frequency than the European and independent narratives. For example, in 1998 during his speech at the UN General Assembly, Lucinschi emphasized his ideas about Moldova as a transitioning democratic state noting how his government was,

\footnotetext{
${ }^{494}$ Lucinschi, Petru. 1998. "Moldovan President Urges 'European Patriotism' as Ideal.” Moscow Interfax, 04 December 1998.

${ }^{495}$ Gombos, Catalin and Dragos C. Mateescu. 2012. "Moldova's Political Self and the Energy Conundrum in the Context of the European Neighborhood Policy." Central European Journal of International and Security Studies 6 , 63.

${ }^{496}$ Lucinschi, Petru. 1999a. “Lucinschi: Moldova Pro-European, Not Pro-Western.” Itar-Tass, 27 April 1999.
} 
"committed to the path of democracy... [and how] Moldova is steadily striving to create basic institutions for the rule of law and the legislative framework necessary for transition to a market economy. ${ }^{297}$ Although plagued by many institutional and organizational challenges, Moldova under Lucinschi continued to make progress on political reforms even eliciting the praise of President Clinton in 1998, who referred to Moldova as a model of democracy. ${ }^{498}$

\section{Vladimir Voronin's State Identity Narratives and Moldova's Alignment}

Over the course of his 4-year presidential term, Petru Lucinschi attempted to bolster his powers by aggressively pushing for a presidential republic. By 2000, frustrated MPs in parliament had enough of Lucinschi's political maneuvers and passed an amendment to the constitution transforming Moldova into a parliamentary republic. According to Paul Quinlan, parliament's actions were not meant to further bolster Moldova's move towards democracy, but to simply rid themselves of Lucinschi. ${ }^{499}$ Following this change to the constitution and the country's continued economic decline, in February 2001 Moldovans voted overwhelmingly for the Party of Moldovan Communists resulting in their acquisition of 71 of the 101 seats. ${ }^{500} \mathrm{By}$ April 2001, parliament had selected Vladimir Voronin to be Moldova's next president.

Once in office, this study finds Vladimir Voronin exhibited the most diverse set of state identity narratives of any president under examination. Additionally, this study finds that there were two distinct periods in which Voronin exhibited different sets of state identity narratives.

\footnotetext{
${ }^{497}$ Lucinschi, Petru. 1998a. "Speech of the President of Moldova Petru Lucinschi at the UN General Assembly." United Nations General Assembly Speech, September 29, 1998. http://www.un.org/ga/search/view_doc.asp?symbol=A/53/PV.14. Accessed 02 July 2017.

${ }^{498}$ Wróbel, Jacek. 2004. "The European Union and Moldova." Center for European Studies 13. Harvard University, 63.

${ }^{499}$ Quinlan, Paul D. 2002. "Moldova under Lucinschi.” Demokratizatsiya 10 (1), 99.

${ }^{500}$ Office for Democratic Institutions and Human Rights. 2001. "Republic of Moldova: Parliamentary Elections, 25 February 2001 (Final Report). Organization for Security and Cooperation in Europe, 03 April 2001. http://www.edemocracy.md/files/elections/parliamentary2001/final-report-osce-elections-2001-en.pdf. Accessed 20 July 2017, 13.
} 
From 2001-2002, Voronin tended to primarily view the state in Eastern-Eurasian terms and as communist, which was associated with a preference for positive bandwagoning with Russia. After 2003 and until the end of his presidency, Voronin viewed the state predominately as independent with a democratic narrative in support.

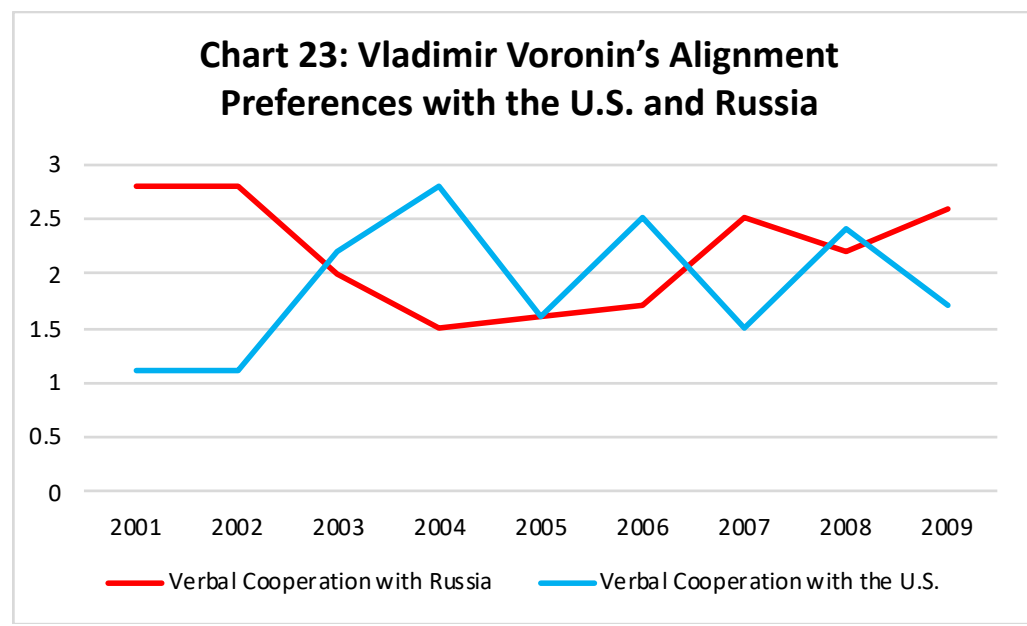

According to one area expert, Moldova is like a "checkerboard" when it comes to state identity and as a result, Voronin tended to keep his narratives purposely ambiguous in order to pursue his multi-vector foreign policies. ${ }^{501}$ As depicted in Chart 23 below, President Voronin's initial emphasis on defining the state as Eastern-Eurasian and communist was associated with a markedly higher level of verbal cooperation with Russia. Beginning in 2003, Voronin's level of verbal cooperation with the U.S. and Russia oscillated between both regional great powers reflecting his preference to follow a great power bridging alignment.

Vladimir Voronin's State Identity Narratives (2001-2002). Once installed as Moldova's third president, Voronin immediately began framing the state's identity in Eastern-Eurasian terms. During this time, Voronin frequently referred to his party's communist ideals as a basis from which to chart a fresh approach to the country's relations with external powers. A content

\footnotetext{
${ }^{501}$ Interview on file with author.
} 
analysis of Voronin's foreign policy speeches during 2001 and 2002 indicate he primary viewed the state as Eastern and/or Eurasian with a secondary emphasis defining the state as communist.

Voronin's ideas about the state's characterization as Eastern-Eurasian were, in part, a reflection of his frustrations with his predecessor's inability to resolve the country's problems in Transnistria and with the economy. From Voronin's perspective, Snegur and Lucinschi had placed too much faith in the West to help Chisinau with its socio-economic problems. In his inaugural speech in 2001 Voronin asserted, "Moldova is now a zone of humanitarian catastrophe, poverty and primitive state policy; the notions 'democracy, reform, rule of law' have become synonyms of 'corruption, stagnation, poverty'.". ${ }^{502}$ For Voronin, Moldova's road to success lay to the east with Russia, the CIS, and their corresponding economic and political support. For example, from an economic perspective, Chisinau remained highly reliant on Russian energy supplies and had chalked up a significant amount of debt to Moscow over the first decade of the country's independence. ${ }^{503}$ On the issue of Transnistria, Voronin firmly believed a favorable resolution could be realized by giving the Kremlin increased latitude to solve the problem on terms favorable to his ruling government. Voronin's ideas about Russia's crucial role in the country's development and the state's foreign affairs were made clear in 2001 when he stated...

We see Russia as a guarantor of the process of political settlement of the Trans-Dniester problem [and] our first steps will be towards economic integration not only with the Russia-Belarus Union but with the Eurasian community of the CIS member-states. ${ }^{504}$

\footnotetext{
${ }^{502}$ Voronin, Vladimir. 2001b. "Moldovan President Urges Pragmatic Foreign Policy in Inaugural Speech." Basapress, 07 April 2001.

${ }^{503}$ According to the IMF, Moldova owed Russia over $\$ 122$ million dollars in debt. International Monetary Fund Staff Country Report. 2002. "Republic of Moldova: 2002 Article IV Consultation, First Review Under the ThreeYear Arrangement Under the Poverty Reduction and Growth Facility and Request for Waiver of Performance Criteria." International Monetary Fund, 2-190, 56.

${ }^{504}$ Voronin, Vladimir. 2001c. "Excerpts from the Transcript of a Joint Press Conference with President Vladimir Voronin of Moldova." President of Russia Website, 19 November 2001. http://en.kremlin.ru/events/president/ transcripts/21405. Accessed 12 August 2017; Voronin 2001a, 1.
} 
As the leader of Moldova's Communist Party, it is not surprising Voronin's ideas about the state as one defined by the principles of communism was a second supporting identity narrative. For the period 2001-2002, Voronin's frequently gave emphasis to communist narratives during his foreign policy speeches and interviews. Voronin's increased emphasis on his ideas about Moldovan communism stem in part from the country's poor economic standing and how previous administrations, which had emphasized a Western open market system were wrong. By employing a discourse that reflected a theme of the state's struggle to overcome poverty, "the ideas of social justice, fraternity, [and] internationalism..., which existed in our communist party under the Soviet power" ${ }^{\circ 05}$ would help Moldova to regain a respected position in world affairs and return a sense of dignity to all Moldovans. ${ }^{506}$

Finally, during his first two years in office Vladimir Voronin sometimes viewed Moldova as European. Although Voronin' ideas about the state's path lie to the east, the European facet was not totally excluded from his conceptions of Moldova's role in world politics. For example, in early 2001 Voronin stated, “....as it concerns the West, as regards to integration in the European community, we do not object to entering it, but no one is throwing the doors open to us, first of all. Secondly, it would be great if we were able to enter it together with Russia, Belarus and other CIS member-states, it would be more correct." ${ }^{507}$ However, Voronin's European narrative was not meant to usurp his ideas about the state's Eastern-Eurasian identity. From one perspective, Voronin's European narrative was a signal he was prepared to engage in routine interstate

\footnotetext{
505 Voronin 2001a, 1.

${ }^{506}$ Iglesias, Julien Danero. 2013. "Constructing National History in Political Discourse: Coherence and Contradiction (Moldova, 2001-2009).” Nationalities Papers 41 (5), 786.

${ }^{507}$ Voronin, Vladimir. 2001a. "Moldovan President Looks with Interest at Russia-Belarus Union.” Itar-Tass, 17 April 2001. Accessed, 12 August 2017, 1.
} 
relations with other major powers, but his preference for a positive bandwagoning alignment with Russia was the number one and only priority.

Vladimir Voronin's State Identity Narratives (2003-2009). Beginning in 2003, this study's content analysis finds that for the remaining years in office Vladimir Voronin tended to view the state as independent, European, and democratic. Voronin's discourse on Moldova as an independent state was the president's primary state identity narrative. Voronin's ideas about this concept was grounded in his beliefs that only an independent Moldova would become a prosperous country capable of promoting its own active foreign policies. For example, President Voronin's ideas about Moldova as an independent actor in world affairs were made explicit in 2006 when he noted,

We [Moldova] cannot endlessly give up our goals and interests in order to please someone else, neighbors or friends, who are strategic or less strategic and who have various goals. We should think and continue to solve strategic problems, which will indeed guarantee our country's sovereignty and independence, not only through declarative statements, coat-of-arms, anthem and other state symbols, but in depth, economically, socially and, last but not the least, politically. ${ }^{508}$

More so than his predecessor, the separatist issue in the Trans-Dniester was a key internalexternal factor negatively impacting Voronin's ideas on independence. ${ }^{509}$ Additionally, the presence of Russian military forces on sovereign Moldovan soil and Moscow's political backing of separatist leaders in Tiraspol were major obstacles to Voronin's ideas of Moldova as a fully independent actor in world politics. Although Voronin initially looked to Russia for a peaceful resolution, Moscow's ‘Kozak Memorandum’ put demands on Chisinau that would further erode the country's independence. The Kremlin's actions subsequently reinforced Voronin's ideas about the merits of a great power bridging alignment with external powers.

\footnotetext{
${ }^{508}$ Voronin, Vladimir. 2001. "Moldovan Leader Addresses Nation on Independence Day.” Moldova TV, 27 August 2001.

${ }^{509}$ Interview on file with author.
} 
Voronin's ideas about Moldova as an independent state increasingly conveyed to the United States. For example, in 2004 Voronin sent a message to President George W. Bush's stating, "We [Moldova] highly assess the US support for strengthening Moldova's statehood, unity and sovereignty, including ...the United States' involvement in finding a viable solution for the Dniester Region conflict.. ${ }^{, 10}$ For Voronin, an independent Moldova would help the ruling government to seek out the assistance of other regional great powers on all the issues pressing the state. More importantly, emphasizing Moldovan's independence, Voronin could avoid a repeat of another situation similar to the Kozak Memorandum.

Although Voronin's state identity narrative about Moldovan independence gave increased emphasis to the United States and Europe, Russia remained an important element in his alignment preference equation. According to Voronin, the "interests of tiny Moldova cannot concentrate on one place only. We must be wherever our interests are. But we cannot stop our relations with Russia, which have been developing for more than 300 years. These relations are in Moldovans' genetic code, and I cannot break them." ${ }^{511}$ It is from Voronin's focus on independence and the Trans-Dniester we are able to begin to sketch the contours of his preference for great power bridging.

A secondary state identity helping to bring Voronin's alignment preference for great power bridging was his ideas that Moldova was also part of the European landscape. For example, speaking in August 2003 Voronin proclaimed,

For Moldova, this [European integration] is also the most reliable mechanism to regain territorial integrity, to guarantee the protection of its ethnic and cultural identity and to ensure civil rights for all nationalities living in our country. Therefore, the program for Moldova's

\footnotetext{
${ }^{510}$ Voronin, Vladimir. 2004b. "Moldovan President Congratulates George Bush on Winning Election." Basapress, 04 November 2004. Accessed 13 August 2017, 2.

${ }^{511}$ Voronin, Vladimir. 2005c. "Moldovan President Says Russia Remains Strategic Partner. Itar-Tass, 08 May 2005. Accessed 13 August 2017, 1.
} 
European integration is the country's main strategic document. It is a document that stands above party programs or current tasks of all the branches of the power. ${ }^{512}$

Voronin's European discourse continued to resonate in his foreign policy speeches through the latter part of his presidential career when in 2007, he noted how "Moldova has proven its capability for being a sovereign and independent nation. It has a European future it won't waive. We have certain problems and principles, and we will seek the EU membership together with friends." ${ }^{, 513}$ For Voronin, emphasizing Moldova's 'Europeaness' could help open the door to closer relations with countries in the West, to include the United States.

President Voronin's European narrative did not come at the exclusion of Russia however. On an almost regular basis, Voronin reminded domestic and international audiences that just because he believed Moldova was part of Europe's geopolitical landscape, he remained committed to maintaining the state's alignment with Russia. Speaking in 2005, Voronin's preference for a great power bridging alignment was made clear when he stated, "we have defined Moldova's strategic vector as European integration. But that does not mean that we are turning our back on [Russia]. That is too primitive." 514

Finally, Voronin's state identity discourse indicates he gave increased emphasis to the concept of democracy and its applicability to the Moldovan state. For example, during a November 2003 Council of Europe meeting in Chisinau, Voronin underscored the state's continuing progress on implementing institutional reforms as a way to accelerate the country's movement along the path of democracy. ${ }^{515}$ While Voronin may have spoken highly of the state's transition to democracy,

\footnotetext{
512 Voronin, Vladimir. 2003b. “Moldovan President Reiterates EU Bid in Independence Day Speech.” Infotag, 28 August 2003. Accessed 13 August 2017, 1.

${ }^{513}$ Voronin, Vladimir. 2007a. "Moldova Targets for Consistent Integration Into EU.” Itar-Tass, 19 June 2017. Accessed 12 August 2017.

${ }^{514}$ Voronin, Vladimir. 2005c, 1.

${ }^{515}$ Voronin, Vladimir. 2003d. "Opening speech by Vladimir Voronin, President of the Republic of Moldova." Council of Europe, 06 November 2003. http://www.coe.int/T/e/Com/files/CM_chair-sessions/session/Nov2003/disc_voronin.asp. Accessed 13 August 2017, 1.
} 
various government and non-government agencies had mixed reviews on Moldova's democratic progress. For example, Moldova's Polity scores under Lucinschi (2001-2004) rose from 7 to 8 (democracy). From 2005 until Voronin left office, Moldova's Polity score rose to 9, reflecting the country's continued progress at implementing democratic reforms. ${ }^{516}$ However, the United States Agency for International Development (USAID) found Moldova's democracy rating during this time should be placed in proper context because too much political power still resided with Vladimir Voronin and his inner circle. According to a USAID report,

This concentration of power in the executive branch builds on Moldova's Soviet heritage of central authority and citizen apathy. While somewhat constrained by their agreement with the opposition following the 2005 elections, central authorities continue to outweigh all other voices both in the opposition and in the wider society -- to the detriment of democratic development. ${ }^{517}$

\section{$\underline{\text { Nicolae Timofti's State Identity Narratives and Moldova's Alignment }}$}

In the years between Vladimir Voronin's downfall in 2009 and the rise of Nicolae Timofti as president in 2012, the Moldovan state experienced a political stalemate that lasted nearly three years in which the country witnessed the installation of two interim presidents Mihai Ghimpu (2009-2010) and Marian Lupu (2011). In April 2009 following a contested parliamentary election, which returned Vladimir Voronin's Party of Communists for the Republic of Moldova (PCRM) to power, nationwide anti-communist protests and the failure of the newly-established legislature to elect a new president resulted in the dissolution of parliament. After a second round of elections in July 2009, four parties (the Liberal Democratic Party of Moldova, the Liberal Party, the Democratic Party of Moldova, and Our Moldova Alliance) formed a new parliamentary majority under the name of the Alliance for the European Integration (AEI). With the appointment of President Mihai Ghimpu as interim president, AEI represented the death knell

\footnotetext{
516 Marshall et. al. 2017.

${ }^{517}$ Black, David, Jeff Chinn, Robert Herman and Charlotte Watson. 2005. "Moldova Democracy and Government Assessment.” United States Agency for International Development, December 2005, 2.
} 
for Vladimir Voronin and his communist party's decisive hold on power in Moldova. ${ }^{518}$ In 2011 , as Moldova's political turbulence continued, the Democratic Party's Marian Lupu became interim president. Together, both interim presidents exhibited a high degree of foreign policy impotence owing to their inability to wield enough power to shape decisively the country's domestic and foreign policies amidst high levels of political opposition.

It was not until March 2013 when political elites in Moldova's parliament would achieve a consensus electing Nicolae Timofti, an independent and former Chairman of the Supreme Council of Magistrates, as president. From 2012 to 2015, a content analysis of President Timofti's foreign policy speeches revealed he concentrated on four state identities, with emphasis going to two cultural narratives (European and Western), one political (freedom), and one ideological (democratic).

Overlaying Timofti's state identity narratives with his level of verbal cooperation with Russia and the U.S. indicates a preference by the Moldovan president to follow a positive bandwagoning alignment with Washington. Specifically, from 2012-2015, Timofti's alignment preferences did not follow in the footsteps of predecessors with this Moldovan president registering higher levels of verbal cooperation with the United States than the Russian Federation as depicted in Chart 24 below.

\footnotetext{
${ }^{518}$ For election results, see Association for Participatory Democracy. 2009. Parliamentary Elections in Moldova, 29 July 2009. http://www.e-democracy.md/en/elections/parliamentary/20092/results/. Accessed 11 August 2017. See also Herbert, Rudolph. 2009. "Interview with Moldovan Prime Minister Vlad Filat." Euronews, 08 August 2009. http://www.euronews.com/2009/10/07/interview-moldovan-prime-minister-vlad-filat. Accessed 13 July 2017.
} 


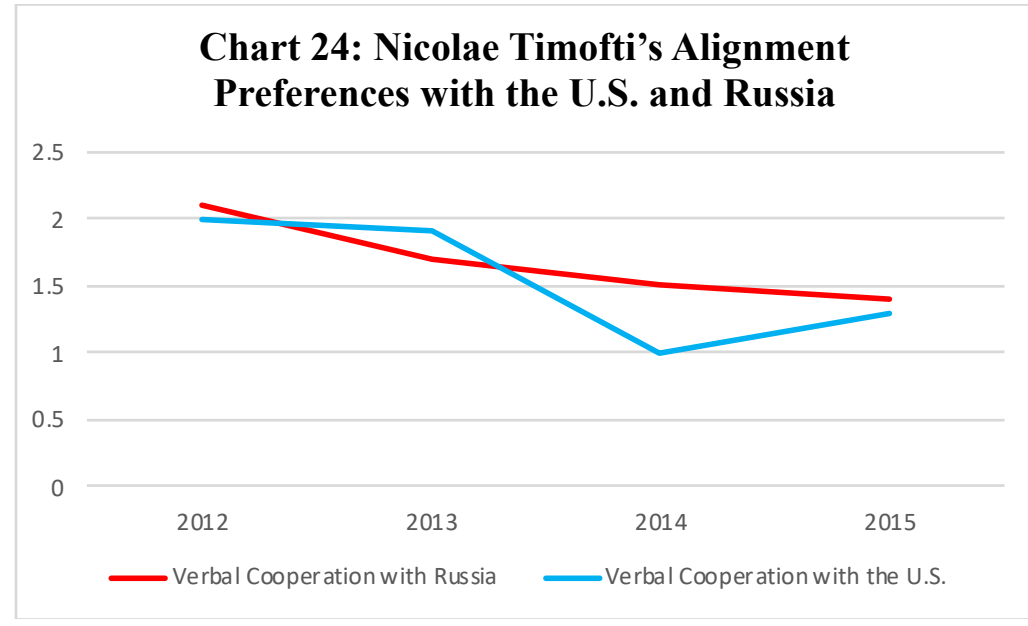

One notable difference distinguishing Nicolae Timofti from Presidents Lucinschi and Voronin was how he devoted more emphasis to a European-Western state identity narrative for Moldova over all others. Specifically, Timofti gave emphasis to a European narrative during his speeches and interviews at a rate five-times more than what was observed with other narratives. ${ }^{519}$ According to Timofti, "it is obvious that Moldova belongs to the European civilization. The EU standards are taken over and adjusted naturally by our institutions and by entire Moldovan society. Moldova is part of the European culture..." ${ }^{520}$ The president's ideas about Moldova as integral part of Europe endured throughout his presidency. Speaking in 2015, Timofti asserted, we will “...continue our European integration efforts and continue to maintain the rhythm of the reforms in all the sectors. People need to believe in Moldova's European future and be sure that the chosen path is a correct one." 521

Timofti's beliefs that Moldova should be viewed by other states in the international system as European and Western served as a point of departure for his ideas about the high utility of an

\footnotetext{
519 Author's analysis.

${ }^{520}$ Timofti, Nicolae. 2013a. "President Nicolae Timofti Delivers Speech on National Day of Romania." Presidency of the Republic of Moldova Website, 01 December 2013. http://www.presedinte.md/eng/comunicate-depresa/nicolae-timofti-speram-sa-devenim-ct-maicurnd-parte-a-spatiului-european. Accessed 12 August 2017.

${ }^{521}$ Timofti, Nicolae. 2015a. "Moldovan President Urges Change of Constitution, Criticizes Visits of Russian Officials in Gagauzia.” Teleradio-Moldova Online, 16 March 2015.
} 
alignment with the United States and other countries in this regional great power's orbit.

Speaking in 2014 about the critical importance of the United States to Moldova and how leading powers in Europe could facilitate a closer alignment with Washington Timofti concluded...

I am firmly convinced that the friendship and cooperation relations between Moldova and the USA will continue to develop dynamically for the benefit of both countries and nations. We are streamlined to become part of a community of prosperous countries, relations between which are based on observance of international law. Association with the EU allows us to contribute to promoting peace and security at international level, to participate in preventing and settling crisis within the UN missions, OSCE, and in partnership with NATO. ${ }^{522}$

For President Timofti, his heavy emphasis on defining the state as European were driven by his beliefs of how closer economic integration with the West could potentially bring the country increased political stability and economic prosperity.

Timofti's preference for positive bandwagoning with the United States did not change his ideas about how Moldova's ongoing economic and political activities with Russia should still continue unhindered. This was especially true with cross-border trade and Russia's role with the frozen conflict in the Trans-Dniester. According to Timofti, “... I would like to underline that Moldova's European choice does not mean hostility towards our partners from the Commonwealth of Independent States, including Russia. I believe that these countries, with which we have traditional cooperation ties, will have only to gain together with a stronger and more prosperous Moldova." ${ }^{523}$

Next, President Timofti's state identity discourse indicated he held ideas about Moldova as a democracy and one based on freedom. During many of his public addresses, Timofti highlighted

\footnotetext{
522 Timofti, Nicolae. 2014b. "National Army Receives Military Equipment from US Government.” President of Moldova Website, 12 November 2014. http://www.presedinte.md/eng/comunicate-de-presa/presedintele-nicolaetimofti-a-participat-laceremonia-de-donare-a-unui-lot-de-tehnica-militara-din-partea-guvernului-sua-catrearmatanationala. Accessed 20 August 2017.

${ }^{523}$ Timofti, Nicolae. 2014. "Association Agreement with European Union is Absolute Priority of Present Government, Moldovan President Says.” President of Moldova Website, 26 June 2014. http://www.presedinte.md/ eng/comunicate-de-presa/presedintele-nicolae-timofti-a-facut-o-declaratie-de-presa-cu-ocazia-semnarii-acorduluide-asociere-cu-uniunea-europeana. Accessed 18 August 2017.
} 
how the state has made significant progress with implementing democratic reforms. The

Moldovan president would also note the extent to which democracy had taken root at all levels of government. For example, speaking in July 2012 Timofti declared democracy was the country's only path and to fully realize the goal of Moldova joining with the "big family of the democracies" 524 in the West. His ideas on this concept continued through 2014 when during his speech to mark the $20^{\text {th }}$ anniversary of the country's constitution, Timofti emphasized how the country's transition from totalitarian rule to one based on the principles of democracy had markedly improved rule of law and bolstered the human rights and freedoms for all Moldovans. ${ }^{525}$ Finally, the Moldovan president also viewed Moldova as one built on the value of freedom. Speaking in 2014 during a national ceremony to commemorate Europe Day, Timofti emphasized how freedom was a cornerstone for the Moldovan state and its membership in the Western community. ${ }^{526}$

In summary, between 1997 and 2015, Presidents Lucinschi, Voronin, and Timofti framed the state's identity in political, cultural, and ideological terms. In all three cases, each president's state identity narratives were multi-faceted with each predominately viewing the state through a political and/or ideological lens. As was seen in Azerbaijan with Heydar and Ilham Aliyev as well as in Georgia with Eduard Shevardnadze, Moldovan presidents (Lucinschi and Voronin (after 2003)), who primary viewed the state as independent tended to vary their respective levels of verbal cooperation with the United States and Russia, which was associated with a great

\footnotetext{
524 Timofti, Nicolae. 2012a. “Moldovan Leader Calls for Broad Autonomy for Rebel Region.” Infotag, 23 July 2012.

525 Timofti, Nicolae. 2014d. "President Nicolae Timofti Conveyed a Message on the Occasion of the 20th anniversary of Moldova's Constitution Adoption. Presidency of the Republic of Moldova Website, 29 July 2014. http://www. presedinte.md/eng/discursuri/mesajul-presedintelui-nicolae-timofti-cu-prilejul-celeide-a-20-aaniversari-a-adoptarii-constitutiei-republicii-moldova. Accessed 18 August 2017.

526 Timofti, Nicolae. 2014c. "President Nicolae Timofti Attends Events Dedicated to Europe Day." President of Moldova Website, 10 May 2014. http://www.presedinte.md/eng/comunicate-de-presa/nicolae-timofti-republicamoldova-a-pasit-ireversibil-pe-calea-integrarii-europene. Accessed 18 August 2017.
} 
power bridging preference. When Western-European and/or democracy and freedom were emphasized, as was the case with President Timofti, a higher level of verbal cooperation with the United States was observed indicating a positive bandwagoning preference with Washington.

\section{Ukraine}

Prior to the downfall of the Soviet Union, political elites occupying the highest positions in the Ukrainian Soviet Socialist Republic (SSR) espoused state identity narratives that mirrored the political and ideological dictates of the Kremlin. It was once again Mikhail Gorbachev's policies of transparency and restructuring that became lightning rods for change in the Ukrainian SSR. Here, Ukraine's independence can be attributed to several key factors. First, in the Ukrainian SSR there already existed political, cultural, and administrative structures inside the state apparatus capable of affecting positive change within the limits of Gorbachev's policies. ${ }^{527}$ Second, following the 1986 Chernobyl nuclear accident there emerged an ecological movement inside society that would increasingly gain influence and power to challenge the ruling government.

These two factors help set the conditions for the establishment of one of the country's first civil-political movements known as the People's Movement of Ukraine for Reconstruction or RUKH in 1989 and open parliamentary elections in 1990. As a pro-communist organization, the RUKH did not necessarily seek independence, desiring to see a change in the state's identity whereby Ukraine was not simply a Soviet satellite but a republic best understood as Ukrainian and of equal status with the center. ${ }^{528}$ Although the communists were still able to maintain a

\footnotetext{
${ }^{527}$ Szeptycki, Andrzej. 2015. "Independent Ukraine.” In Klaus Bachmann and Igor Lyubashenk (eds.) The Maidan Uprising, Separatism and Foreign Intervention: Ukraine's Complex Transition. Frankfurt: Peter Lang.

${ }^{528}$ Magocsi, Paul Robert. 2002. Roots of Ukrainian Nationalism. University of Toronto Press, 63; Hrycak Jarostaw. 2000. Historia Ukrainy 1772-1999. The Birth of a Modern Nation. Institute of Central and Eastern Europe. Lublin. http://shron.chtyvo.org.ua/Hrytsak_Yaroslav/Historia_Ukrainy_17721999_Narodziny_nowoczesnego_narodu_pol.p df. Accessed 01 September 2017, 313-316.
} 
majority in the Rada (Ukraine's parliament) following the March 1990 parliamentary elections, the Democratic Bloc, consisting of the RUKH and various ecological groups were able to gain approximately 88 seats. ${ }^{529}$ The Ukrainian SSR's new legislative configuration would subsequently pave the way for the Rada to issue a declaration of sovereignty in July 1990 followed by a declaration of independence on 24 August 1991, and the election of Leonid Kravchuk as the country's first president in December $1991 .^{530}$

Leonid Kuchma's State Identity Narratives and Ukraine's Alignment

Leonid Kravchuk's tenure as Ukraine's first president would last until 1994 when the country's dire economic situation and high political opposition forced him to call an early national election. Following a contested election, Leonid Kuchma became Ukraine's second president in July 1994 winning 52 percent of the vote with many Ukrainians from the country's east backing his political bid. ${ }^{531}$ From 1995 until the end of his presidential career, an analysis of Kuchma's foreign policy speeches, interviews, and press statements indicates he conceptualized the state's identity in three ways. Kuchma primarily viewed state as independent (political). Supporting narratives included European (cultural) and democratic (ideological).

As depicted in Chart 25 below, President Kuchma's level of verbal cooperation with Washington and Moscow varied up and down during the ten years under examination.

\footnotetext{
${ }^{529}$ For the 1990 parliamentary election see Birch, Sarah. 2000. Elections and Democratization in Ukraine. New York: MacMillan Press, 55-57. For the Rada's declaration of sovereignty see Government of Ukraine. 1990. "Declaration of State Sovereignty of Ukraine." Verkhovna Rada of the Ukrainian SSR, 16 July 1990. http://static. rada.gov.ua/site/postanova_eng/Declaration_of_State_Sovereignty_of_Ukraine_rev1.htm. Accessed 01 August 2017.

${ }^{530}$ Krawciw, Nicholas. 2016. "Ukrainian Perspectives on National Security and Ukrainian Military Doctrine.” In Bruce Parrot (ed.) State Building and Military Power in Russia and the New States of Eurasia 5. Routledge, 149150.

${ }^{531}$ Kuzio, Taras. 1996. "Kravchuk to Kuchma: The Ukrainian Presidential Elections of 1994.” The Journal of Communist Studies and Transition Politics 12 (2), 130-131.
} 


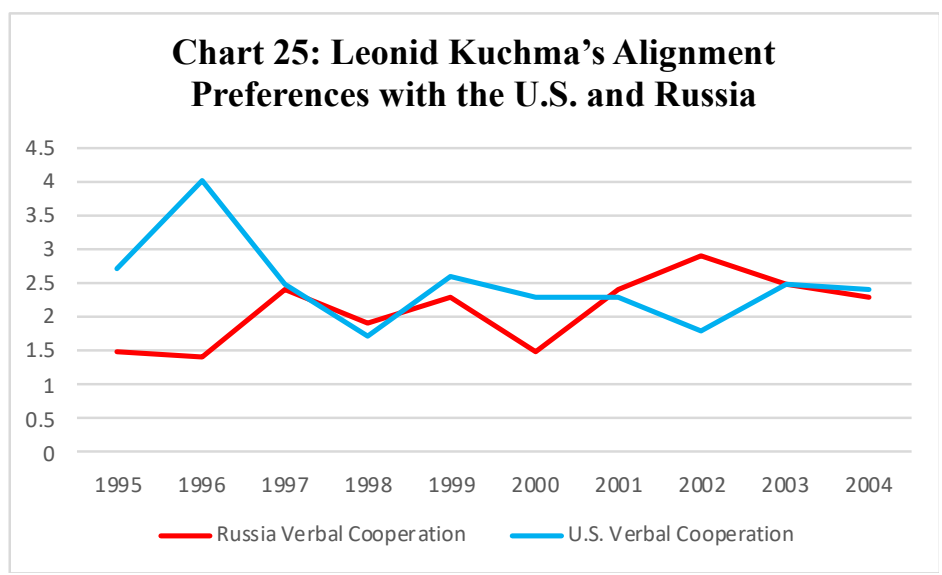

According to one regional expert, Kuchma's state identity narratives were somewhat unpredictable at times. On one hand, Kuchma would emphasize Ukraine's identity as one in the same with Russia based on their shared histories. On the other hand, Kuchma would seemingly turn his back on Russia by embracing Western and European ideals centered on democracy, freedom, and civil liberties. ${ }^{532}$ Kuchma's vision of Ukraine with one foot in the West and the other in the East contributed to his preference for great power bridging with the U.S. and Russia.

A primary state identity narrative for Kuchma was his tendency to view Ukraine as an independent actor in the international arena. In 1996, Kuchma heavily emphasized the country's independent status in world affairs asserting, "as far as Ukraine's independence is concerned, let us proceed from the fact that we have an independent state and that it depends primarily on us [and an]... independent and sovereign Ukraine... is a signpost on our road to Europe." 533 Kuchma's strict adherence to the idea that Ukraine was an independent state was a point not missed by academics or practitioners alike. For example, John Edwin Mroz and Oleksandr Pavliuk find Kuchma was best viewed as an ardent defender of Ukraine's independence and his nationalist fervor represents a linchpin in the development of the state's foreign policies. ${ }^{534}$

\footnotetext{
${ }^{532}$ Interview on file with author.

${ }^{533}$ Kuchma, Leonid. 1996a. "Kuchma Interview on State of Nation.” Krymskaya Gazeta, 17 August 1996; Kuchma, Leonid. 1996b. "Kuchma Interviewed on Poland, NATO, Russia.” Zycie Warszawy, 25 June 1996.

${ }^{534}$ Mroz, John Edwin, and Oleksandr Pavliuk. 1996. “Ukraine: Europe's Linchpin.” Foreign Affairs 75 (3): 53.
} 
Kuchma's ideas and beliefs about the state have their origins, in part, from his time as a leading figure in the Soviet Union's rocket and space technologies industry. From these experiences, Kuchma's expert management skills served him well as a pragmatic leader, who would pursue a strategy of great power bridging dealing with Russia and the United States in ways beneficial to not only his ruling government but Ukraine as well. Ukraine's sense of independence under Kuchma was critical as he made every effort to establish a precedent for making the country not a distinct part of the new Russian Federation in any way. In his book, Ukraine is not Russia, Kuchma makes reference to the many divisions in the country, singling out the differences between Ukrainians in the western part of the country, who wanted to align with the West with those in the east, who preferred close foreign relations with Russia.

Additionally, Kuchma's ideas and beliefs about the state's identity and external threats were based on his keen awareness of Russian and Ukrainian history. In this case, the centuries of domination by the Russian empire and Soviet Union instilled a sense of urgency for Kuchma to craft a set of foreign policies that made Ukraine an independent actor in the world arena. In his 1995 Independence Day speech, Kuchma stated, "the emergence of the Ukrainian independent state on the political map of the world became one of the most outstanding events in the world history of the second half of the 20th century and is a natural result of our people's centuries-long aspiration to be masters in their own home." 535

As a secondary state identity narrative, President Kuchma also tended to view Ukraine in European terms. During his first several years in office, Kuchma frequently highlighted Ukraine's placement in the world order as being a member of the group of European countries. For example, in a 1996 interview with reporters from Radio Liberty, Kuchma noted how “...the

\footnotetext{
${ }^{535}$ Kuchma, Leonid. 1995a. "President Kuchma Independence Day Speech.” Kiev Radio, 24 August 1995.
} 
future of Ukraine lies in Europe, for our country is located in the very heart of Europe."536

Kuchma's European discourse continued at a steady rate throughout much of his presidency. In April 2002, Kuchma stated, "Ukraine is a European country. Naturally, integration in the European structure is one of our foreign policy priorities. ${ }^{537}$

Although President Kuchma may have given a secondary emphasis on categorizing Ukraine as European, his discourse must be placed into its proper context. On one hand, the Ukrainian president believed that by defining Ukraine as European, such actions would create a gateway for a political and economic alignment with the United States. Speaking in 1998, Kuchma noted,

Our basic task in relations with the United States is to shape them in such a way so that when Poland joins NATO they formally become relations between the allies and that they are special within the area. Active political relations have fundamental significance. Besides efforts to achieve a good result in the ratification of the accession protocol by the US Senate, we will be trying to gain the support of our American partner and other members of the alliance in our wish to ensure such a role in NATO for Poland which corresponds to our involvement and potential. Poland has been a consistent supporter of a permanent and significant US presence in Europe and of treating the US not just as a global superpower but also as a European one. ${ }^{538}$

However, President Kuchma's European state identity narrative must be placed in its proper context where the Ukrainian president's conceptualization of this state identity is much more inclusive than one might suspect. In this case, Kuchma also viewed Russia as part of the European community along with other CIS countries and the United States. Speaking in 1998 after returning from a visit to Russia, Kuchma added clarity to his ideas about the state's identity and his alignment preferences.

And now I will try to answer the fundamental question, as far as Ukraine is concerned: who we are and where are we moving? For us the main answer coincides with the re-establishment of statehood and formation of a nationwide idea. Meanwhile, the tasks of elaborating a stable, dynamically developing pattern of the economic and political systems are closely linked with the specific features of the country which identifies itself as part of Central, Eastern and SouthEastern Europe simultaneously. The total of these three vectors -- the European choice of Ukraine

\footnotetext{
${ }^{536}$ Kuchma, Leonid. 1996. "Kuchma Discusses 'Road to Europe'.” Kiyevskiye Novosti, 06 December 1996.

${ }^{537}$ Kuchma, Leonid. 2002a. "Ukrainian President on Mideast Peace, Ties with Iraq, Iran, Russia, Europe.” Beirut AlNahar Online, 23 April 2002.

${ }^{538}$ Kuchma 1998a, 1; emphasis added.
} 
-- nonetheless does not mean one-way orientation towards Europe. We are talking about a system of Ukraine's relations in the following area: Russia, Europe, North America, the Black Sea region and the CIS. Incidentally, within the global context, this forms a set of strategies and prospects for Ukraine's way in the 21st century. ${ }^{539}$

Finally, in addition to Kuchma's attentiveness to articulating an independent and European state identity narratives for Ukraine, he also cultivated a democratic discourse in his foreign policy speeches. For the years in office, Kuchma almost consistently touted the state's democratic leanings noting in 1997 how “Ukraine's relevant norms and tenets are among the most democratic in the world." ${ }^{540}$ Kuchma's narrative on the centrality of democracy in the Ukrainian state continued through 2001. Following a series of meetings with the EU, Kuchma stated, “...I am nevertheless convinced that Ukraine, as virtually the whole world, and first and foremost Europe, will follow the democratic path." ${ }^{, 541}$

Kuchma's ideas about democracy represented a conduit for his alignment preferences with the United States. However, once again Kuchma's ideas about the Ukrainian state as democratic must be qualified. While this study's content analysis may identify democracy as a secondary state identity narrative, the assessments of area experts and secondary sources do not completely validate his ideas. On one hand, in 1994 U.S. President William Clinton commended President Kuchma and his efforts to advance democratic reforms in Ukraine.

We congratulate you, Mr. President, and all Ukrainians on your remarkable achievements in the almost 3 years since regaining your freedom. You held a historic referendum and began the hard work of reform and building democratic institutions. ${ }^{542}$

\footnotetext{
${ }^{539}$ Kuchma, Leonid. 1998b. "Kuchma's Speech at Moscow University." UT-1 Television Network, 28 February 1998; emphasis added.

${ }^{540}$ Kuchma, Leonid. 1997. "Kuchma Addresses II Forum of Ukrainians.” Uryadovyy Kuryer, 23 August 1997.

${ }^{541}$ Kuchma, Leonid. 2001. "President Kuchma Sums up Ukraine-EU Summit." UT-1 Television Network, 11 September 2001.

${ }^{542}$ Clinton, William Jefferson. 1994. "Remarks Welcoming President Leonid Kuchma of Ukraine." The American Presidency Project-William J. Clinton, 22 November 1994. http://www.presidency.ucsb.edu/ws/index.php?pid= 49506. Accessed 19 August 2017.
} 
On the other hand, beginning in 1999 and continuing through to the end of his presidency, democracy took a back seat to Kuchma's desire to stay in power. During this time, the Ukrainian president's authoritarian tendencies became increasingly visible in the state organs and in society. In 1999, Freedom House issued a negative report on Ukraine observing a democratic retrenchment owing to, “...increased government pressure on the independent media, presidential elections in October-November which were not free and fair, and attempts by the executive after the elections to increase presidential powers at the expense of parliament." ${ }^{543}$ The following year, Ukraine's Polity score also registered a setback moving from seven to six in 2000 . As specified in a 2010 Polity IV Report, Kiev began to feel “...the strains of post-communist transition and [the state] began to unravel during the 1999 election campaign as Kuchma began to assert his independence and attempted to consolidate power."544 Taken together, Kuchma, much like Georgian President Eduard Shevardnadze, sacrificed the state's democratic transition by relying on authoritarianism to stay in power.

\section{Viktor Yushchenko's State Identity Narratives and Ukraine's Alignment}

The last four years of Leonid's Kuchma's time in office witnessed growing opposition to his presidency from various political parties and civil society. Although the Rada's April 2001 'no confidence' vote against Prime Minister Viktor Yushchenko dealt him a major political blow, Yushchenko and his 'Our Ukraine' party did not back down. In 2002, 'Our Ukraine' made significant gains in the 2002 parliamentary elections, which spurred an 'Orange Revolution' in Ukraine and the election of Yushchenko to the presidency in December 2004 and his

\footnotetext{
${ }^{543}$ Freedom House. 1999. "Ukraine.” Freedom in the World 1999. https://freedomhouse.org/report/freedomworld/1999/ukraine. Accessed 19 August 2017.

544 Polity IV Country Report. 2010. “Ukraine.” http://www.systemicpeace.org/polity/Ukraine2010.pdf. Accessed 19 August 2017.
} 
inauguration in January 2005. ${ }^{545}$ For the period 2005 until 2009, a content analysis of President Yushchenko's foreign policy speeches reveals he gave emphasis to the following state identity narratives: European-Western, democracy, and market.

The chart below provides a visual illustration of President Yushchenko's levels of verbal cooperation with Russia and the United States from 2005 until 2009. During this time Yushchenko consistently maintained a higher level of verbal cooperation with Washington over

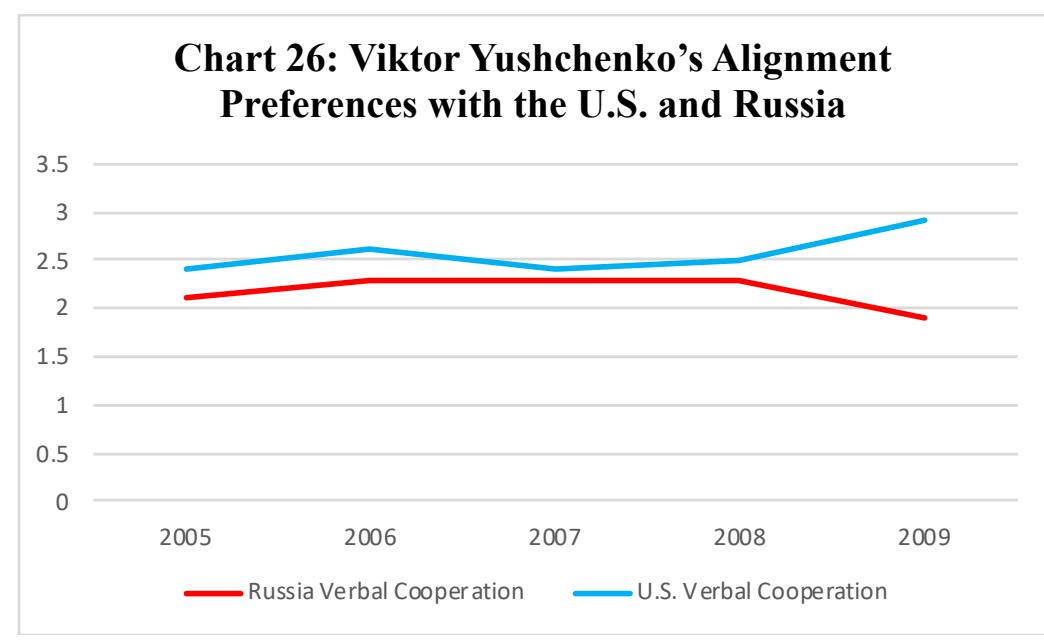

Moscow. ${ }^{546}$ With Yushchenko's ideas about the state defined as European and Western as well as democratic and market-oriented, this pattern of verbal cooperation is best understood as a preference for positive bandwagoning with the United States. Like Saakashvili in Georgia, Yushchenko still believed a cooperative approach with the Kremlin was necessary. Interviews with various regional experts and an analysis of the secondary literature validate this nonstatistical correlation. According to one area specialist, Yushchenko was an ardent pro-West president, who viewed the country's integration into Euro-Atlantic security and economic

\footnotetext{
${ }^{545}$ Kuzio, Taras. 2005. "From Kuchma to Yushchenko Ukraine's 2004 Presidential Elections and the Orange Revolution.” Problems of Post-Communism 52 (2), 29-30.

${ }^{546}$ Author's analysis.
} 
structures as essential. By becoming part of NATO and the EU, Yushchenko believed these organizations could help ensure the country’s long-term security and economic prosperity. ${ }^{547}$

President Yushchenko’s ideas about Ukraine as a European state on the global chessboard were brought to the fore during a 2006 visit to the College of Europe in Warsaw, Poland. During his speech, Yushchenko averred how he had always believed Ukraine was part of Europe. In his words, "I was born at Europe's center. I am convinced that Ukraine is a European country. Our values were and continue to be European values." 548 President Yushchenko's efforts to frame Ukraine as European was driven by a belief that the country's path to stability resided in the West with Europe and the United States. From this stability, Ukraine would achieve economic success and a newfound sense of security from external threats.

President Yushchenko's ideas about Ukraine as Western manifests itself in several narratives, which highlight the state's role as a productive member in the Euro-Atlantic economic and security communities. For example, during his visit to Washington DC in 2005, President Yushchenko delivered a speech to the U.S. Congress detailing his ideas of how Ukraine's placement in the world order is best understood as residing in the West.

The Orange Revolution gave evidence that Ukraine is an advanced European nation, sharing the great values of the Euro- Atlantic civilization. I'm convinced that the European and Euro-Atlantic aspirations of Ukraine may not be viewed as an additional hindrance. Ukraine's integration is not a problem, but rather great new opportunities opening before our civilization. ${ }^{549}$

Given Ukraine had become a less important foreign policy agenda item in Washington, Yushchenko hoped to convey the idea that ruling leaders in Kiev shared the same ideas and values as political elites in Washington and in other European capitals.

\footnotetext{
${ }^{547}$ Interview on file with author.

548 Yushchenko, Viktor. 2006. "Address of Ukrainian President Viktor Yushchenko to the Students of the College of Europe, 12 May 2006.” College of Europe. Natolin, Poland, 1.

${ }^{549}$ Yushchenko, Viktor. 2005e. "Ukraine's Yushchenko Addresses Joint Session of U.S. Congress.” U.S. Department of State, 06 April 2005. http://iipdigital.usembassy.gov/st/english/texttrans/2005/04/200504061638281 cjsamoht0. 3202631.html\#axzz41g7IIUAg. Accessed 20 August 2017, 2.
} 
The 'Orange Revolution' and Viktor Yushchenko's rise to the presidency was from the very beginning equated with democracy's return to Ukrainian politics. Based on this study's content analysis, from his first days in office Yushchenko consistently espoused a state identity narrative that cast the state (and country) as democratic. For example, in his 2005 Council of Europe speech, Yushchenko framed his ideas about the state and democracy in the following way: I will take every effort to secure the irreversibility of democratic changes in my country. The Ukrainian public authorities will do their utmost to secure the fundamental principles of the Council of Europe - human rights protection, pluralist democracy and the rule of law. ${ }^{550}$

Yushchenko's consistent focus on the central importance of democratic ideals were also reflected in a December 2009 address on human rights where he noted, "we have today made our place as a democratic state, we have eliminated any forms of political persecutions. Freedom of speech, conscience and choice is already a standard... [in Ukraine]. ${ }^{" 551}$ Polity and Freedom House analysts recognized Yushchenko's commitment to democracy. From 2004 to 2009, Ukraine's Polity score rose from six to seven and Freedom House's rating rose from 4 to 2.5. ${ }^{552}$

Finally, Viktor Yushchenko espoused an economic-based discourse viewing Ukraine as a market economy. In 2005, Yushchenko's ideas about this state identity were made clear in a speech to the U.S. Chamber of Commerce. According to Yushchenko, "our government and our power is going to turn [Ukraine's] market into a transparent market and a competitive market without providing preferences to anybody.... ${ }^{, 553}$ The following year, Yushchenko raved about

\footnotetext{
${ }^{550}$ Yushchenko, Viktor. 2005. "Address of the President Viktor Yushchenko at the Parliamentary Assembly of the Council of Europe." Council of Europe, 25 January 2005. http://assembly.coe.int/Sessions/2005/Speeches/ Yuschenko_250105_E.htm. Accessed 20 August 2017, 3.

${ }^{551}$ Yushchenko, Viktor. 2005d. "Ukraine Makes Its Place as Democratic State.” Ukrinform, 10 December 2009. https://www.ukrinform.net/rubric-other_news/888303ukraine_makes_its_place_as_democratic_state__president _yushchenko_175322.html. Accessed 19 August 2017.

${ }_{552}$ Marshall et. al. 2017; Freedom House. 2009. "Ukraine.” Freedom in the World 1998-2003. https://freedomhouse. org/report/freedom-world/2009/ukraine. Accessed 03 April 2017.

${ }^{553}$ Yushchenko, Viktor. 2005c. "Remarks by Ukrainian President Viktor Yushchenko to the U.S. Chamber of Commerce." U.S. Chamber of Commerce Washington, D.C., 04 April 2005. http://www.usubc.org/AUR/ aur465.php. Accessed 19 August 2017.
} 
how major foreign powers had validated his ideas. Specifically, in 2005 he proclaimed, "over the past eight months we have succeeded in having Ukraine and the Ukrainian economy, recognized by the European Union and the United States as a market economy." 554 Yushchenko's discourse viewing Ukraine as a market economy reflects his beliefs about an alignment preference with the United States over Russia. By fostering an economic alignment with the U.S., economic growth would follow thus making Ukraine a key member in the global economy.

$\underline{\text { Viktor Yanukovych's State Identity Narratives and Ukraine's Alignment }}$

The seeds of Viktor Yanukovych's rise to power can be traced back to 2005 just after Viktor Yushchenko became president. During this time, the 'Orange Revolution' began to unravel owing to among many challenges, political infighting between the president and his first Prime Minister Yulia Tymoshenko. For the time Tymoshenko was prime minister, she vehemently opposed the president on many aspects of his ideas about foreign and domestic policy. This political infighting helped Yanukovych's Party of Regions win a majority in the 2006 parliamentary elections temporarily propelling him to the post of prime minister. In late 2007, elections in the legislature saw Tymoshenko's party and President Yushchenko's 'Our Ukraine' party join together into a coalition that allowed Tymoshenko to again become prime minister. ${ }^{555}$

Although Yanukovych may have been sidelined by the concerted efforts of the president and Tymoshenko, over the next two years he was able to skillfully use his political acumen to accentuate the strength of his leadership. Simultaneously, Yanukovych shown a spotlight on the shortcoming of the Yushchenko-Tymoshenko bloc and their failure to unite the country and bring Ukraine to a position of international prominence. By 2008, Tymoshenko and her party

\footnotetext{
554 Yushchenko 2006, 3.

555 Woehrel, Stephen. 2012. "Ukraine: Current Issues and U.S. Policy." Congressional Research Service, 12 January 2012. https://digital.library.unt.edu/ark:/67531/metadc84058/m1/1/high_res_d/RL33460_2012Jan04.pdf. Accessed 19 August 2017, 1.
} 
even sided with the communists and the Party of Regions to limit the powers of the president. ${ }^{556}$ Taken together, in January 2010 Yanukovych won the presidency in a close race with Tymoshenko. Once in office, President Yanukovych articulated three cultural state identity narratives. His first two state identity narratives included Eastern and Eurasian and were given the most emphasis. As a supporting conception, Yanukovych also viewed Ukraine as European. As reflected in the chart below, President Yanukovych's level of verbal cooperation was consistently higher with the Russian Federation than the United States from 2010 until $2013 .{ }^{557}$ With Yanukovych's ideas about the state defined as one that is an amalgamation of Eastern and Eurasian, and to a lesser degree European, his pattern of verbal cooperation is best understood as a preference for positive bandwagoning with Russia. Although Yanukovych gravitated towards an alignment with Russia, he still viewed cooperation with the West, particularly Europe, as important but not necessarily a vital part of his foreign policies. Interviews with various regional experts and an analysis of the secondary literature validate this correlation. According to one area expert, Yanukovych strived to reposition Ukraine into a closer geopolitical orbit with

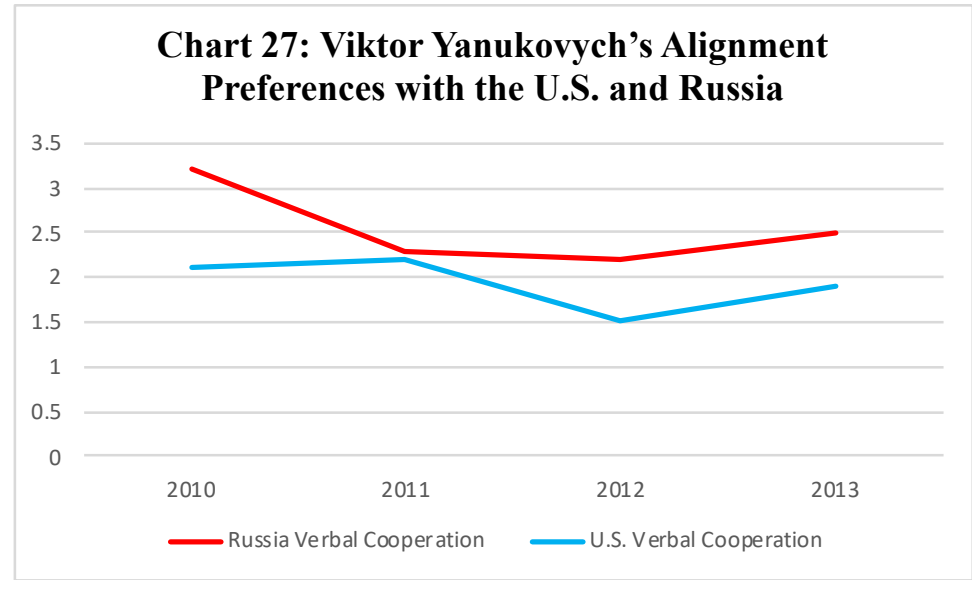

\footnotetext{
556 Olearychyk, Roman. 2008. "Yushchenko Stands Firm on Foreign Policy." Financial Times Online, 04 September 2008. https://www.ft.com/content/e88c17ce-7aaf-11dd-adbe-000077b07658. Accessed, 03 June 2017.

${ }^{557}$ Author's analysis.
} 
Russia; however, he also sought to maintain economic relations with countries in the West. From one perspective, Yanukovych was pro-EU, not pro-NATO. ${ }^{558}$

The logic of this trifecta of narratives and its potential impact on the state's foreign policies was captured perfectly in President Yanukovych’s 2010 inaugural address.

As president, I have a clear understanding of what kind of foreign policy corresponds today with the national interests of Ukraine. Being a bridge between East and West, an integral part of Europe and the former Soviet Union at the same time, Ukraine will select the kind of foreign policy that would allow our state to receive the maximum benefit from the development of equal and mutually beneficial relations with the Russian Federation, the European Union and the United States and other countries that influence the situation in the world. ${ }^{559}$

With respect to President Yanukovych's articulation of a European narrative, shortly after entering office and during a meeting with the president of the European Commission, the Ukrainian president stated, "European integration is the key priority of our foreign policy, and also a strategy for carrying out systemic social and economic reforms." ${ }^{560}$ However, while Yanukovych may have opted to first visit Brussels on 01 March 2010, by the time he got to Russia, he was espousing the merits of Ukrainian-Russian brotherhood. Specifically, in his meetings with President Medvedev on 05 March, Yanukovych proclaimed he was in adamant agreement with the Kremlin's patriotic beliefs about the importance of Soviet history in modern times. Yanukovych then suggested veterans from Ukraine and Russia should hold a joint celebration to commemorate the 65 th anniversary of their victory over Hitler and Fascism. ${ }^{561}$

\footnotetext{
${ }^{558}$ Interview on file with author.

${ }^{559}$ Yanukovych, Viktor. 2010b. "President Victor Yanukovych's Inaugural Speech in Parliament." Kyiv Post, 25 February 2010. https://www.kyivpost.com/article/content/ukraine-politics/president-victor-yanukovychs-feb-25inaugural-spee-60475.html. Accessed 20 August 2017.

${ }^{560}$ Yanukovych, Viktor. 2010c. “Ukraine's Yanukovich pledges to work for EU Integration.” Euractiv, 02 March 2010. https://www.euractiv.com/section/europe-s-east/news/ukraine-s-yanukovich-pledges-to-work-for-euintegration/. Accessed 20 August 2017.

${ }^{561}$ Harding, Luke 2010. "Viktor Yanukovych Promises Ukraine will Embrace Russia." The Guardian, 05 March 2010. https://www.theguardian.com/world/2010/mar/05/ukraine-russia-relations-viktor-yanukovych. Accessed 13 January 2017.
} 
An Eastern and Eurasian discourse were also an integral part of President Yanukovych's repertoire of state identity narratives while in office. As a former governor in the Donetsk region, Yanukovych frequently linked the identity of the Ukrainian state and the country to Russia. For example, in 2010 Yanukovych noted how "the citizens of our countries... are linked by kinship and by the history of our nations." ${ }^{562}$ By 2013 , there was little notable change in his ideas about the state's Eastern and Eurasian identities. Another example is in order here when in his annual address to the Ukrainian parliament in 2013, Yanukovych stated,

European integration vector along with the consistent realization of national interests on the Eurasian track, active employment of the CIS platform and intensification of bilateral relations constitute the scope of Ukrainian national interests. ${ }^{563}$

Clearly, Europe may have retained some degree of importance for Yanukovych, by 2013 his ideas about Ukraine and its relevancy in Eurasia had become increasing important in his public addresses. The clearest indicator of Yanukovych's ideas about the state's Eastern identity came in 2013 when decided to take a $\$ 15$ billion Russian economic package in lieu of signing the EU Association agreement. According to one area specialist, Yanukovych's decision amounts to a "civilizational choice." 564

\section{$\underline{\text { Petro Poroshenko's State Identity Narratives and Ukraine's Alignment }}$}

Viktor Yanukovych's decision to accept a Russian economic aid package was a key event contributing to his removal from power and the state's Western realignment. Following these decisions, tens of thousands of Ukrainians poured into Maidan Square to show their disapproval

\footnotetext{
${ }^{562}$ Yanukovych, Viktor. 2010a. "News Conference Following Russian-Ukrainian Summit Talks." President of Russia Website, 17 May 2010. http://en.kremlin.ru/events/president/transcripts/7781. Accessed, 21 August 2017. ${ }^{563}$ Yanukovych, Viktor. 2013. "Annual Address of the President of Ukraine to the Ukrainian Parliament." Embassy of Ukraine to the United Kingdom of Great Britain and Northern Ireland, 12 June 2013. http://mfa.gov.ua/en/newsfeeds/foreign-offices-news/13010-shhorichne-poslannya-prezidentaukrajini-viktora-janukovicha-do-verkhovnojiradi-ukrajini. Accessed 20 August 2017.

${ }^{564}$ Kelly, Michael. 2013. "Ukraine Just Made A 'Civilization Defining' Decision — And It Picked Russia Over the West." Business Insider, 21 November 2013. http://www.businessinsider.com/ukraine-wont-sign-eu-agreement2013-11. Accessed 19 November 2013.
} 
for Yanukovych's decisions. These protests, and a strong-armed response from security and ministry of interior forces subsequently set the conditions for a revolution and the removal of Yanukovych from power. By May 2014, Petro Poroshenko was Ukraine's new president. ${ }^{565}$ For the two years this study examines President Poroshenko's foreign policy speeches, three consistent state identity discourses emerge: democratic, freedom, and European.

The chart below provides a visual illustration of President Poroshenko's alignment preferences with Russia and the United States. Although limited in duration, during 2014 and 2015 President Poroshenko exhibited a higher level of verbal cooperation with the United States.

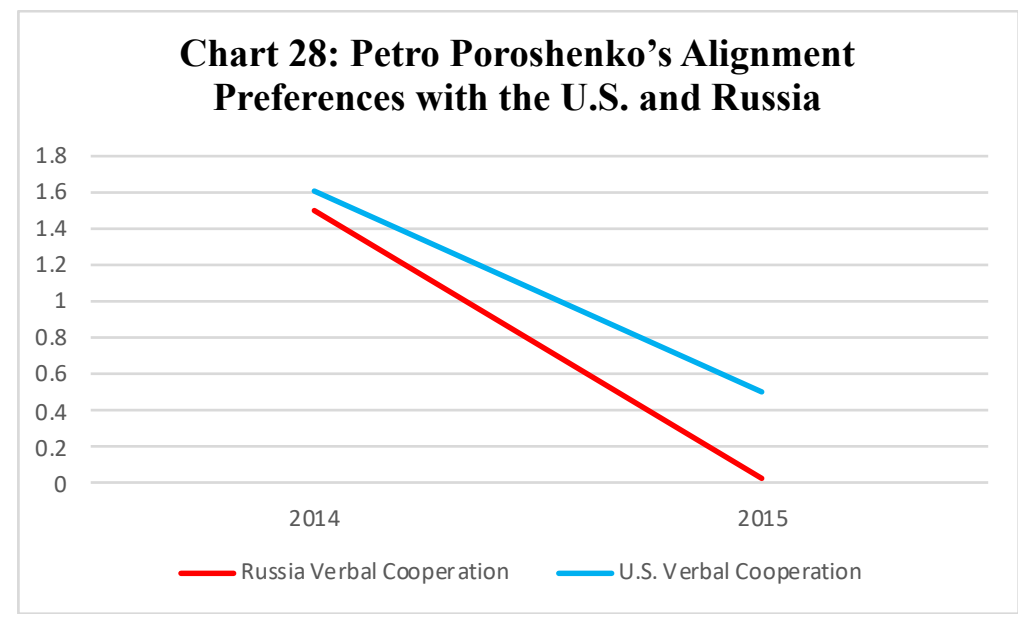

With Poroshenko's ideas about the state defined as democratic, free, and European, this pattern of verbal cooperation is best understood as a preference for positive bandwagoning with the United States. Like Yushchenko, Poroshenko still believed cooperation with the Kremlin was necessary; however, a majority of this effort was directed towards re-establishing Ukraine's territorial integrity following Moscow's annexation of Crimea in 2014 and its political, economic, and military support for separatists in Donetsk and Luhansk. Interviews with area experts and an analysis of the secondary literature validate this non-statistical correlation.

\footnotetext{
${ }^{565}$ Walker 2013, 1; Grytsenko, Oksana. 2013. "Yanukovych Confirms Refusal to Sign Deal with EU.” Kyiv Post, 26 November 2013. http://www.kyivpost.com/content/politics/yanukovych-confirms-refusal-to-sign-deal-with-eu332493.html. Accessed 20 November 2016.
} 
According to one area specialist, the current strategic situation in the east demanded Poroshenko pursue a cooperative diplomatic approach with Russia; however, his ideas about Ukraine as one with the West was unequivocal. For Poroshenko, Ukraine's accession into Euro-Atlantic economic and security structures was his and the state's number one priority. ${ }^{566}$

For the two years under examination, President Poroshenko advanced a democratic state identity narrative for Ukraine. As viewed by Poroshenko, Yanukovych's turn from democracy towards an authoritarian-style government was a key factor that had incited mass political and social unrest throughout the country. Only be reestablishing the hallmarks of democracy within the state could Poroshenko and other like-minded elites hope to move the country forward. Speaking in 2014, Poroshenko noted how “... democracy for me is the best form of government invented by mankind. ${ }^{~} 567$ By emphasizing the necessity to build-up the state's democratic institutions and a more accountable government, Poroshenko sought to cast Ukraine in a similar light to other former Soviet states such as the Baltics, which had successfully made their transition into the West by gaining membership in Euro-Atlantic economic and security structures.

A content analysis of President Poroshenko's speeches indicates 'freedom' was also one of his primary discourses about the state's identity. For example, Poroshenko's ideas about the freedom were made explicitly clear during his 2014 inauguration speech when he asserted, "the whole Ukraine and all Ukrainians worldwide [are] united around the idea of ... freedom." ${ }^{568}$ Russian-backed separatist efforts in Luhansk and Donetsk was likely a key factor spurring

\footnotetext{
566 Interview on file with author.

${ }^{567}$ Poroshenko, Petro. 2014b. “Ukraine President Poroshenko’s Inauguration Speech: No Compromise with Donesk and Lugansk." Global Research, 08 June 2014. https://www.globalresearch.ca/ukraine-president-poroshenkosinauguration-speech-no-compromise-with-donesk-and-lugansk/5386120. Accessed 20 August 2017, 4.

${ }^{568}$ Ibid, 6; emphasis added.
} 
Poroshenko's idea about the importance of freedom for Ukraine. Without a peaceful resolution to this ongoing crisis in the Donbas, Ukraine would never truly be free.

Petro Poroshenko also emphasized the concepts of Europe and European during 2014 and 2015. A content analysis reveals the European discourse was espoused on an equal basis with democracy and freedom. ${ }^{569}$ From out of the gate, Poroshenko's ideas about Ukraine's role in world politics was undeniable. During his inaugural speech, President Poroshenko proclaimed,

We, Ukrainians, "are a living spark in the family of European nations and active members of European civilizational work." These are the words of Ivan Franko. "To stand with one's feet and heart in Ukraine and one's head in Europe," Mykhailo Drahomanov commanded. The return of Ukraine to its natural, European state has been long-awaited by many generations. ${ }^{570}$

Poroshenko's views about Ukraine as European continued into 2015. In a speech to the Ukrainian National Security and Defense Council in September 2015, Poroshenko was adamant about how, "Ukraine is the eastern outpost of Euro-Atlantic civilization. We have made a choice towards European values and European civilizational development." ${ }^{\text {571 }}$ As viewed from Kiev, Russia's illegal annexation of Crimea and military and economic support for separatist elements in the Donbas were the shape agents impacting President Poroshenko's ideas about Ukraine and its placement in the European civilization.

Like Yushchenko, Petro Poroshenko's ideas about Ukraine as European was a causeway that also led to the United States and his preference for an alignment with this regional great power. Speaking in September 2017, Ivanna Klympush-Tsintsadze, the Vice Prime Minister of Ukraine for European and Euro-Atlantic Integration commented on how her country's Western trajectory since 2014 can be compared to a long road that begins in Kiev with exits in Berlin, Paris, and

\footnotetext{
${ }^{569}$ Author's analysis.

570 Ibid, 1.

${ }^{571}$ Poroshenko, Petro. 2015a. "Speech by President of Ukraine Petro Poroshenko at the session of the National Security and Defense Council of Ukraine." President of Ukraine Website, 22 September 2015. http://www. president.gov.ua/en/news/vistup-prezidenta-ukrayini-poporoshenka-na-zasidanniradi-na-36007. Accessed 20 August 2017.
} 
London ending in Washington. The vice prime minister was also quite clear that as viewed from Kiev, the leadership of the United States in European security remains a linchpin in her government's preference to align with the United States. For this reason, President Poroshenko believes that a final solution to Russia's interference in Ukraine can only be achieve through close relations with the United States. ${ }^{572}$

In summary, between 1995 and 2015, the presidents of Ukraine conceptualized the state's identity in various political, cultural, and ideological terms. President Kuchma's primary state identity narrative centered on independence, which was associated with a preference for great power bridging. Presidents Yushchenko and Poroshenko's focus on defining the state as democratic, free, and Western-European was associated with a tendency for positive bandwagoning with the United States. Finally, President Yanukovych viewed the state in terms of Eastern, Eurasian, and European which was associated with a positive bandwagoning preference with Russia.

\section{Conclusion}

The purpose of this chapter has been to examine the relationship between a political leader's ideas about the state's identity and his alignment preferences with the United States and Russia. Using multiple methods and event data, this chapter found presidents would assign a wide array of different political, cultural, ideological, and economic identities to the state. To discern the alignment preferences for these presidents, state alignment was operationalized using ICWES event data focusing on each leader's level of verbal cooperation with the United States and Russia. Those presidents emphasizing an independent state identity fluctuated their levels of

\footnotetext{
${ }^{572}$ Klympush-Tsintsadzen, Ivanna. 2017. "U.S.-Ukraine Relations in the Context of Euro-Atlantic Security.” Small Group Event at the Center for Strategic and International Studies (CSIS), 11 September 2017. The author was a small group participant in this visit by Ukraine's Ivanna Klympush-Tsintsadzen to CSIS.
} 
verbal cooperation with both regional great powers indicating what this study defines as a great power bridging preference.

Additionally, a majority of the presidents, who saw the state as defined by democracy and freedom had higher levels of verbal cooperation with the United States, which can be understood as a preference for positive bandwagoning alignment with this regional great power. Separately, Ukraine's Viktor Yanukovych was the only president to give emphasis to an Eastern-Eurasian state identity narrative, which corresponded to higher levels of verbal cooperation with Russia and a positive bandwagoning preference with this regional great power.

These findings help frame several important conclusions. First, this study concludes a president's ideas about the state's identity are an important variable exerting influence on his alignment preferences with the United States and/or Russia. Specifically, by using a president's level of verbal cooperation with both of these regional great powers allows one to infer a nonstatistical correlation between a president's ideas about the state's identity and his alignment preferences. Second, as was seen with Moldovan President Vladimir Voronin, a political leader's ideas about the state have the potential to vary based on key systemic- and/or domestic-level events. The point here is that while a political leader's ideas and beliefs may be the most important factor affecting his/her alignment preferences, systemic and/or domestic events may also carry some degree of influence on a president's ideational lens of world politics.

Another important conclusion centers on methodology whereby using just event data to measure a president's alignment preferences has its limits. Certainly, using a president's level of verbal cooperation may serve as one indicator of a president's inclination to align with the U.S. or Russia, it is plausible a head of state may give emphasis to a particular state identity narrative in hopes of eliciting external support from a particular regional great power. For example, one 
president may continually emphasize the democratic nature of the state as a way to garner political or economic support from the United States. From a methodological perspective, the use of quantitative techniques and descriptive statistics may be too broad of an instrument to achieve a higher level of fidelity on a small state's alignment with a regional great power. As a result, using qualitative techniques and expanding the analysis to consider others independent variables (e.g. a political leader's ideas about external threats and strategy) may be able to provide a more nuanced understanding of a political leader's alignment preferences and the state's foreign policies vis-à-vis Russia and the United States. 
"Often the central question for statesmen...[is] which state, if any, poses a threat so severe that all other considerations must be subordinated to it." - Robert Jervis, 1997. ${ }^{573}$

\section{Chapter Six: Threat Perceptions and Small State Alignment}

\section{Introduction}

Robert Jervis reminds us that one of the most important tasks for political leaders in their duties as caretakers of the state is the identification of would-be international challengers that could threaten the country's national security. But what makes one particular state a valid threat? Janice Stein argues the first step in discerning whether one state represents a clear and present danger is to focus on the verbal or physical threats of other states. ${ }^{574}$ But do the verbal pronouncements of foreign leaders or the state's diplomatic and military actions alone represent a 'true' threat to a state's national security? This study posits it does not. What is missing here is how ruling elites in one state understand those verbal or physical acts. Put another way, it is a political leader's perceptions of these actions that matter most. As Stein reminds us, "threats do not unambiguously speak for themselves. Understanding the meaning of threats is mediated by the perception of the target. Perception is the process of apprehending by means of the senses and recognizing and interpreting what is processed." 575

\footnotetext{
573 Jervis, Robert. 1997. System Effects: Complexity in Political and Social Life. Princeton: Princeton University Press, 227.

${ }^{574} \mathrm{~A}$ verbal threat is best understood as a provisional declaration by political elites in one state to ruling leaders in a target state that if certain requirements are not met, negative consequences will follow. Verbal threats may include the overt political statements to use armed force in order to achieve a particular objective. Verbal threats may also include statements to support subversive activities designed to foment domestic political-economic instability. Such actions may include cutting energy supplies, imposing economic sanctions, or closing a border. Physical threats are visible demonstrations that are meant to signal a state's willingness to employ the military instrument of national power in order to achieve a desired outcome. Physical threats include mobilizing and deploying ground forces to a border, conducting unscheduled, large-scale military exercises, recalling an ambassador, or illegally detaining foreign nationals. See Stein, Janice. 2013. "Threat Perception in International Relations." In Leonie Huddy, David O. Sears, and Jack S. Levy (eds.) The Oxford Handbook of Political Psychology, $2^{\text {nd }}$ edition. Oxford: Oxford University Press, 364.

575 Stein 2013, 365.
} 
The central purpose of this chapter is to examine the relationship between a political leader's ideas about external threats from different regional great powers and their alignment preferences. The essence of my argument is that a political leader's threat perceptions are an important factor shaping his/her alignment preferences. Specifically, political leaders will perceive the hostile actions of regional great powers in different ways based on their own distinctive belief system. As a result, different presidents will assign different levels of threat to different regional great powers, which in turn will be associated with different alignment preferences.

This chapter posits four research questions: How does each president in Azerbaijan, Georgia, Moldova, and Ukraine view the nature of the political universe? To what extent, if any, did each president's beliefs about the political universe vary? Which regional great powers does each president perceive to be the greatest threat to the state? What is the relationship between each president's threat perceptions and his/her alignment preferences with the United States and Russian Federation?

In addressing these research questions in a systematic way, this chapter first conducts an operational code analysis to discern each president's philosophical beliefs. By understanding how each president perceives the nature of the political universe can serve as a guide for a qualitative analysis of a head of state's threat perceptions of specific regional great powers. For the research questions on threat perceptions, it is hypothesized that when a president perceives a nearby regional great power as a high threat, a president will prefer a positive bandwagoning alignment with a different regional great power. When a president perceives this nearby regional great power as a moderate threat, the head of state will prefer great power bridging. Finally, when a president perceives a nearby regional great power as a low threat, he will prefer a positive bandwagoning alignment with that power. 
This chapter is organized into six sections. The first section highlights the key findings from this chapter. In sections two through five, the cases are addressed in the following order: Azerbaijan, Moldova, Georgia, and Ukraine. Each of these sections begin with an analysis of a president's operational code, which is then followed by a qualitative analysis of a president's threat perceptions and his accompanying alignment preferences with Russia and the United States. Section six provides a brief conclusion.

\section{Findings}

The major findings from this chapter are as follows. First, all of the presidents in Azerbaijan, Georgia, Moldova, and Ukraine perceived Russia to be the greatest threat to the state's national security. The United States was consistently regarded as a low or moderately low threat. ${ }^{576}$ Second, although Russia represented the greatest threat, the intensity of each president's perception of this danger varied based on his interpretation of Moscow's actions in the strategic environment. Here, each president viewed the nature of the Russian threat in his own unique way whether it be military, economic, informational, political or a combination thereof.

Third, contrary to realist expectations that small states will bandwagon with the most powerful or threatening state, this study finds a majority of the presidents preferred great power bridging. A president preferred to follow this alignment when his threat perceptions of Russia were moderate. This was the case in Azerbaijan with Presidents Heydar and Ilham Aliyev; in Moldova with Petru Lucinschi and Vladimir Voronin (after 2003); in Georgia with Eduard Shevardnadze and Giorgi Margvelashvili (in 2013); and in Ukraine with Leonid Kuchma. Next, when a president's threat perceptions of Russia were high, presidents favored a positive bandwagoning alignment with the United States. This was the case with Georgian Presidents

\footnotetext{
${ }^{576}$ In general, presidents, who viewed the U.S. as a moderately low threat took offense to Washington's support of pro-democracy groups in their countries.
} 
Saakashvili and Margvelashvili from 2014-2015, Moldovan President Nicolae Timofti, and Ukrainian Presidents Yushchenko and Poroshenko. When a president perceived Russia as a low threat, a positive bandwagoning preference with Moscow was observed. This was the case with Vladimir Voronin (2001-2002) and Viktor Yanukovych.

\section{Azerbaijan: Findings and Analysis}

Beginning in Azerbaijan, from 1995 to 2015 Azeri Presidents Heydar and Ilham Aliyev maintained a moderately low threat perception of the Russian Federation, which was associated with a preference for great power bridging. ${ }^{577}$ While Armenia represented a near-peer security challenge to Azerbaijan, when it came to regional great powers, both presidents perceived Russia as a latent threat given Moscow's ability to influence Yerevan and use its military footing in the Nagorno-Karabakh to keep Baku in line. Given the indirect manner in which the Russian military power mattered to Azeri presidents, this study finds Russia's military power exerted less influence on the alignment preferences of Heydar and Ilham Aliyev than each president's threat perceptions owing to their beliefs about how Russia was a manageable challenge.

\section{The Philosophical Beliefs of Azeri Presidents}

An analysis of each president's philosophical beliefs provides a baseline to understand their general alignment preferences with external powers. Beginning with their master philosophical beliefs (P-1), Heydar and Ilham Aliyev both viewed the nature of the political universe as definitely friendly. ${ }^{578}$ This pattern continued with each president's beliefs about realizing their

\footnotetext{
${ }^{577}$ Author's analysis. Threat perceptions were operationalized as follows: High (1)-the president perceives some form of military and/or economic conflict is very likely during his time in office; moderate (2)-a president perceives some form of military or economic conflict is somewhat likely; or low (3)-a president perceives some form of military or economic conflict is very unlikely. To increase analytical fidelity of these scores, average values are assessed in the following way: 1-1.5 (high); 1.6-2.0 (moderately high); 2.1-2.5 (moderately low); 2.6-3 (low). ${ }^{578}$ As a reminder, this measurement for a political leader's master philosophical beliefs (P-1) are as follows: $(-1=$ very hostile; $-.50=$ definitely hostile; $-.25=$ somewhat hostile; $0.0=$ mixed; $+.25=$ somewhat friendly; $+.50=$ definitely friendly; $+.75=$ very friendly).
} 
fundamental values (P-2) where Ilham Aliyev retained a higher degree of optimism than his father, who scored slightly lower on this index.

When examining the predictability of the political universe (P-3) category, both presidents scored .10 indicating they generally viewed the international system with a high degree of uncertainty and unpredictability. The presidents' beliefs about their control over historical developments (P-4) were also very similar registering a score of .30. These P-4 scores indicate

\section{Table 11: The Philosophical Beliefs of Azeri Presidents}

\begin{tabular}{|c|c|c|c|c|c|c|c|c|c|c|c|c|c|c|c|c|c|c|c|c|c|c|c|}
\hline \multirow[b]{2}{*}{$\begin{array}{l}\text { Philosophical Beliefs / } \\
\text { Year }\end{array}$} & \multicolumn{10}{|c|}{ Heydar Aliyev } & \multicolumn{13}{|c|}{ Ilham Aliyev } \\
\hline & 1995 & 1996 & 1997 & 1998 & 1999 & 2000 & 2001 & 2002 & 2003 & AVG & 2004 & 2005 & 2006 & 2007 & 2008 & 2009 & 2010 & 2011 & 2012 & 2013 & 2014 & 2015 & AVG \\
\hline $\begin{array}{l}\text { P-1: The Nature of the } \\
\text { Political Universe }\end{array}$ & 0.53 & 0.54 & 0.55 & 0.51 & 0.47 & 0.46 & 0.43 & 0.55 & 0.34 & 0.5 & 0.58 & 0.55 & 0.57 & 0.59 & 0.71 & 0.71 & 0.55 & 0.61 & 0.52 & 0.58 & 0.62 & 0.46 & 0.6 \\
\hline $\begin{array}{l}\text { P-2: Prospects for Realizing } \\
\text { Fundamental Values }\end{array}$ & 0.35 & 0.33 & 0.31 & 0.3 & 0.27 & 0.27 & 0.24 & 0.35 & 0.21 & 0.3 & 0.38 & 0.36 & 0.39 & 0.4 & 0.51 & 0.46 & 0.37 & 0.42 & 0.34 & 0.4 & 0.41 & 0.29 & 0.4 \\
\hline $\begin{array}{l}\text { P-3: Predictability of the } \\
\text { Political Universe }\end{array}$ & 0.12 & 0.13 & 0.13 & 0.12 & 0.11 & 0.12 & 0.11 & 0.13 & 0.1 & 0.1 & 0.12 & 0.12 & 0.13 & 0.14 & 0.17 & 0.17 & 0.1 & 0.15 & 0.12 & 0.13 & 0.14 & 0.1 & 0.1 \\
\hline $\begin{array}{l}\text { P-4: Control Over Historical } \\
\text { Development }\end{array}$ & 0.37 & 0.36 & 0.36 & 0.36 & 0.35 & 0.31 & 0.32 & 0.37 & 0.31 & 0.3 & 0.3 & 0.32 & 0.3 & 0.34 & 0.34 & 0.33 & 0.35 & 0.34 & 0.36 & 0.29 & 0.31 & 0.32 & 0.3 \\
\hline P-5: Role of Chance & 0.96 & 0.95 & 0.95 & 0.96 & \begin{tabular}{|l|l|}
0.96 \\
\end{tabular} & 0.96 & \begin{tabular}{|l|}
0.96 \\
\end{tabular} & \begin{tabular}{|l|}
0.95 \\
\end{tabular} & \begin{tabular}{|l|}
0.97 \\
\end{tabular} & \begin{tabular}{|l|}
0.96 \\
\end{tabular} & 0.96 & \begin{tabular}{|l|l|}
0.96 \\
\end{tabular} & \begin{tabular}{|l|}
0.96 \\
\end{tabular} & 0.95 & 0.94 & \begin{tabular}{|l|}
0.94 \\
\end{tabular} & \begin{tabular}{|l|}
0.97 \\
\end{tabular} & \begin{tabular}{|l|}
0.95 \\
\end{tabular} & \begin{tabular}{l|l|}
0.96 \\
\end{tabular} & 0.96 & 0.96 & 0.97 & 0.96 \\
\hline
\end{tabular}

each president believed that control over the strategic situation resides with others in the political universe. Finally, both presidents' beliefs about the role of chance (P-5) in political outcomes were extremely high. The high scores in this category are in line with each president's lower P-3 and P-4 scores, where because Heydar and Ilham believed they have less control over strategic events, the role of chance was an important factor shaping political outcomes.

The preceding analysis of Heydar and Ilham Aliyev's philosophical beliefs represents a starting point from which to better understand their threat perceptions about 'others' in the international system. While it is known each president viewed the political universe as friendly, what is not known is with which specific actors did these beliefs apply. In the next section, interviews from area specialists, a content analysis of foreign policy speeches, and various secondary sources provide a more nuanced understanding of each president's threat perceptions and alignment preferences with the United States and Russia. 


\section{$\underline{\text { Azeri President Threat Perceptions and State Alignment }}$}

As a group, Azerbaijani presidents maintained the lowest threat perceptions of Russia as compared to presidential group averages in Georgia, Moldova, and Ukraine. During this time, the combined average of the intensity of Heydar and Ilham's threat perceptions of Russia was moderately low. ${ }^{579}$ While Russia consistently maintained a favorable balance of power with military forces stationed in Armenia, neither Heydar nor Ilham Aliyev believed such actions represented an imminent threat to the state. On the contrary, both viewed the Russian threat as a latent one that took on a diplomatic, informational or military nature. Based on their beliefs the Russian threat was a manageable one, each president preferred to follow a great power bridging alignment with Russia and the United States. In the paragraphs below, an analysis of the relationship between each president's threat perceptions and his alignment preferences with the United States and Russian Federation are presented.

President Heydar Aliyev. From 1995 to 2003, President Heydar Aliyev's moderately-low threat perceptions of Russia and his low threat perceptions of the United States served to guide his preferences for a bifurcated alignment with both regional great powers. Based on an analysis of Aliyev's foreign policy speeches, one can detect slight variations in his perceptions of a latent military, economic, and informational threat emanating from the Moscow. The minute differences in Heydar Aliyev's threat perceptions, however, were never significant enough to drive him to follow a positive bandwagoning alignment with Washington or kowtow to Moscow as realists expect. Additionally, an analysis of ICEWS event data indicate Aliyev's level of

\footnotetext{
579 Author's analysis. As a reminder, to increase the analytical fidelity of these scores, averaged values are assessed in the following way: 1-1.5 (high); 1.6-2.0 (moderately high); 2.1-2.5 (moderately low); 2.6-3 (low).
} 
verbal confrontation with the U.S. and Russia was almost equal during his presidency. ${ }^{580}$ For Aliyev, an alignment with the United States and Russia could afford him maximum opportunity to leverage the support capacities of each great power.

From 1994 through 1996, the latent Russian threat to Azerbaijan came in the form of diplomatic pressure and informational campaigns designed to influence Heydar Aliyev's decision-making on the state's energy policies with the United States and other Western countries. For example, in December 1994 and January 1995, Moscow closed transportation routes from Azerbaijan and implemented a series of new customs and control measures in response to Baku's purported material aid to Chechen terrorists. The Kremlin also embarked on a mass media campaign portraying Azerbaijan as a supporter of international terrorism. These actions, coupled with political pressure from Russian defense and foreign ministry officials, were meant to force Aliyev's hand into giving more emphasis to Kremlin interests in Chechnya and the export of Azeri oil through Russian pipelines. ${ }^{581}$

Despite Russia's provocative actions, there was little change in Aliyev's beliefs about the merits of an economic alignment with the United States. Speaking in late 1995, Aliyev lauded how Azerbaijan's strategic partnership with the U.S. represented a linchpin not only in the country's future economic development, but in the restoration of the country's territorial

\footnotetext{
${ }^{580}$ Author's analysis. Of note, the total number of events on Heydar Aliyev's level of verbal confrontation was much less than what was observed with his level of verbal cooperation with the U.S. and Russia. This is to be expected since Heydar Aliyev's philosophical beliefs indicated he viewed the political universe as definitely friendly.

${ }^{581}$ Interview on file with author; Daniloff, Ruth. 1995. "Oil and Blood in the Caucasus." The Washington Post, 01 October 1995. https://www. washingtonpost.com/archive/opinions/1995/10/01/oil-and-blood-in-thecaucasus/a7855658-019c-4f5e-b2e2-75b1413cb152/?utm_term=.10d55814af64. Accessed 01 October 2016; “United States State Department Reports 'Goof' on Azerbaijan.” 2000. Eurasia Daily Monitor 6 (144). https://jamestown.org/program/u-s-state-department-report-goofs-on-azerbaijan/. Accessed 01 October 2016.
} 
integrity and state's transition to democracy. ${ }^{582}$ For example, during a signing ceremony in April

1995 that brought Exxon into the Azeri energy consortium, Heydar Aliyev proclaimed,

When Exxon joined the oil contract signed in Baku the number of the companies of the United States of America participating in the operation...rose to five. The cooperation of five great USA oil companies with Azerbaijan and durability of these relations undoubtedly will assist to the development of economic relations between two countries. ${ }^{583}$

Moscow's actions did, however have some effect on Aliyev's foreign policy actions and the state's economic alignment with Russia. By January 1996, Aliyev agreed to sign the BakuNovorossiysk Agreement, which would send Azeri oil through Russia with Moscow partially opening border crossings later that year.

Russia's military presence in Armenia was also a shape agent for Heydar Aliyev's threat perceptions of the country's former imperial center and a catalyst for his political alignment with both Washington and Moscow. The Azeri president was fully aware of how Russian troops in Armenia represented a 'sword of Damocles' against his strategic movements on the international stage. Despite this reality, Aliyev remained steadfast against this Russian military threat opting not to partake in the CIS' combined air defense system, which sought to provide monitoring, early warning, and counter-air response options for member states ${ }^{584}$ However, Russia's latent military threat was still not enough to affect Aliyev's decision-making process to withdraw from the CIS outright or increase Azerbaijan's role in the U.S.-led NATO alliance.

Although Heydar Aliyev may have viewed Russia as the primary existential threat to Azerbaijan, he was also somewhat wary of Washington's actions and the potential threat this

\footnotetext{
${ }^{582}$ Aliyev, Heydar. 1995. “Aliyev on Ties with U.S., Pipeline Route, Karabakh. Azerbaycan Televiziyasi, 23 October 1995.

${ }^{583}$ Aliyev, Heydar. 1995b. "Speech of the Azerbaijani President Heydar Aliyev at the Ceremony of Signature Documents on Giving a share of Azerbaijan at the International Oil Consortium to Exxon." Heydar Aliyev Heritage International Online Library, 19 April 1995. http://lib.aliyev-heritage.org/en/19981.html.

584 Aliyev, Heydar. 1995a. “Aliyev Sees `Possible' Agreement on Karabakh.” Die Zeit, 26 May 1995, 10; Webber, Mark. 1997. CIS Integration Trends: Russia \& the Former Soviet South. Brookings Institution Press, 41.
} 
regional great power may pose to the state. For example, during the late 1990s Aliyev became increasingly frustrated with the U.S. government's deference to the Armenian lobby as well as Washington's lukewarm efforts to help Baku resolve the Nagorno-Karabakh stalemate. Aliyev conveyed his ideas about American intransigence on these matters during a June 1996 visit to America where he was highly critical of Congressional actions on the continuation of Amendment 907 to the Freedom Support Act, which banned U.S. government support to Azerbaijan over Baku's blockade with Armenia. According to Aliyev, "we [Azerbaijan] consider the U.S. an important economic partner, and that is confirmed by the oil contracts, but unjust decisions of the Congress cause our indignation... The amendment of the congressman Porter is a strike on Azerbaijan and undermines its territorial integrity." 585 Adding to Aliyev's potential discontent was the U.S. State Department's continued poor human rights rating for Azerbaijan. In November 1996, Aliyev censured the activities of human rights groups in Azerbaijan for what he deemed as collusion with "foreign special services" from unnamed countries. ${ }^{586}$

It is from Aliyev's perceptions about Washington's lack of commitment to Azerbaijan one can discern his proclivity to promote a stronger alignment with Russia. For example, in a 1996 visit to Moscow, Aliyev underscored his commitment to bolstering a strong partnership with Russia. In his verbal pronouncements during a press interview, Aliyev affirmed how...

Our countries are linked by a history of many centuries, which can neither be canceled out nor rewritten. And this constitutes the basis for the existence of clean, honest, good, and friendly between Russia and Azerbaijan. I, as head of state, consider that good relations with Russia-a great country-are a very important factor for our republic's independence. ${ }^{587}$

\footnotetext{
585 Aliyev, Heydar. 1996. “Aliyev Complains to U.S. Envoy About Congress Resolution.” Turan, 14 June 1996.

${ }^{586}$ United States Department of State. 1997. “Azerbaijan Country Report on Human Rights Practices for 1996."

Bureau of Democracy, Human Rights, and Labor, January 30, 1997. https://reliefweb.int/report/azerbaijan/ azerbaijan-country-report-human-rights-practices-1996. Accessed 15 October 2017, 10.

${ }^{587}$ Aliyev, Heydar. 1996a. “Aliyev on Domestic, International Issues.” Sobesednik, 01 July 1996.
} 
However, during the late 1990s, the Azeri president made clear there were limits to his alignment with the Russian Federation. Although Aliyev continued to view Moscow as a primary conduit for resolving the Nagorno-Karabakh conflict and a key economic partner, the Azeri president would never allow Azerbaijan to be placed in a binding, long-term relationship with Russia. Evidence to support this assertion was seen in August 1996 when Aliyev rendered skepticism about the Russia-Belarus Union noting, "I do not really see the purpose of this agreement. I cannot say we will follow the same path. I favor the development and strengthening of bilateral relations between Russia and Azerbaijan on a mutually advantageous basis, on the basis of parity and complete sovereignty, independence, and noninterference in one another's affairs." 588 Separately, in 1997, Aliyev stated, "Azerbaijan will not participate in any attempt to achieve greater integration within the CIS until a 'just solution' of the Karabakh conflict is reached." 589

Heydar Aliyev's threat perceptions of Russia experienced a slight uptick from 1997 to 1999 based on a series of military and informational-related events. First, in 1997 Russian politicians revealed the Kremlin had been providing Armenia with military arms worth over $\$ 1$ billion (U.S.) from 1994 through $1996 .{ }^{590}$ This was followed by the establishment of a RussianArmenian joint air defense system in February 1999 and the Kremlin's transfer of heavy weapons from Georgia to Armenia. ${ }^{591}$ For Aliyev, it appeared Russia was more interested in militarizing the region and creating a frozen conflict in the Nagorno-Karabakh than brokering a peace settlement. Such actions were clearly indicative of an attempt by Moscow to gain leverage

\footnotetext{
${ }^{588}$ Aliyev, Heydar. 1996b. "Moscow Paper Interviews President Aliyev." Pravda Pyat, 21 August 1996. 589 “Azerbaijan Links CIS Integration to Karabakh Conflict.” 1997. Radio Free Europe/Radio Liberty Newsline 1 (148), 29 October 1997. http://www.hri.org/news/balkans/rferl/1997/97-10-29.rferl.html\#02. Accessed 30 July 2017. ${ }^{590}$ Cherniavskiy, Stanislav. 2010. "Russia and Azerbaijan: the Special Features and Main Vectors of Interstate Cooperation in the Post-Soviet Period." The Caucasus \& Globalization 4 (1-2), 29-30.

${ }^{591}$ Nicol, Jim. 2009. "Azerbaijan: Current Developments and U.S. Interests." Congressional Research Service. Washington D.C., 10 May 2004. https://www.justice.gov/sites/default/files/pages/attachments/2015/10/14/crsreports_azerbaijan-current-developments.pdf. Accessed 29 August 2016; The Jamestown Foundation. 1999. "Russian-Armenian Air Defense System Inaugurated." The Jamestown Foundation Monitor 5 (74), 1.
} 
over Baku. Separately, Russian media outlets continued to heavily criticize Baku's alleged support for Chechen terrorists by allowing them safe harbor and/or passage through Azerbaijan.

The rising uncertainty with Moscow subsequently reinforced Aliyev's ideas about the merits of great power bridging with Washington. On one hand, the latent military and information threat from Russia eroded the strength of Aliyev's ideas about a political and military alignment with Russia. For example, in 1999 Aliyev opted not to renew Azerbaijan's membership in the CST believing this alliance gave preference to select members at the expense of others. On the other hand, Aliyev still believed the latent threat from Moscow was manageable and could be overcome. Speaking in 1999 about the Russian threat, Aliyev noted,

There has recently been massive anti-Azerbaijani propaganda under way in Russia by the media, which is worrying. The propaganda is based on distorted and false information and even with the absence of any information at all. This is mainly connected with the events in Chechnya. Despite everything, Azerbaijan will be in friendship with Russia and will develop friendship and cooperation. I think that when Russia is able to ensure stability in the North Caucasus, there will be more chances. Because the events in the North Caucasus are restricting our economic cooperation and many other things. Fabrications cause discontent among our people, but I think this will end as well. I am sure that Russia will ensure stability in the North Caucasus and defend its state and territorial sovereignty and integrity. ${ }^{592}$

Russia's actions also served as a catalyst for Aliyev's ideas about strengthening his political and military alignment with the United States. For example, following the establishment of the Russian-Armenian joint air defense system, Baku made a direct request to the United States for the deployment of American and NATO military forces and the potential establishment of a permanent base. ${ }^{593}$ Although U.S. and NATO military forces never established permanent facilities in Azerbaijan, Aliyev's request demonstrates his willingness to leverage a stronger military alignment with the West as one way to acquire political leverage over Russia.

\footnotetext{
592 Aliyev, Heydar. 1999. “Aliyev Sees 'Negative Aspects' in Azeri-Russian Ties.” ANS Television Network, 17 December 1999.

593 Thomas, Timothy L., and John Shull. 1999. "Russian National Interests and the Caspian Sea." Journal of International Affairs 4 (4), 3.
} 
With the election of Vladimir Putin to the office of the presidency, Heydar Aliyev's threat perceptions of Russia decreased following the first-ever visit in the post-Soviet period by a Russian president to Azerbaijan in January 2001. Speaking in June 2000, Aliyev was optimistic about the prospect of strengthening his alignment with Russia noting, "as far as the new Russian president is concerned, I think that following the transfer of power in Russia, there are great opportunities for improving and developing relations between Azerbaijan and Russia." ${ }^{2594} \mathrm{By}$ 2002 after several presidential visits by Presidents Putin and Aliyev to Baku and Moscow respectively, Azerbaijan's alignment with Russia was on a much stronger footing than what was seen with the United States. The extent to which Heydar Aliyev gave higher value to his alignment with Russia was made evident in early 2002 when the Azeri president espoused how Russian-Azerbaijani relations were at a 10-year high and that further cooperation between both countries must be expanded in all spheres. ${ }^{595}$

Heydar Aliyev's inclination to follow a great power bridging strategy with the U.S. also continued through his last several years in office. During this time, the Azeri president's alignment with Washington was primarily seen in the area of counter-terrorism following alQaida's attacks in the U.S. homeland on 11 September 2001. Immediately following these terror attacks, Heydar Aliyev was one of the first presidents from the newly independent states to offer the United States verbal support in America's war against al-Qaida and other transnational terrorist groups. ${ }^{596}$ By 2003, Aliyev's level of verbal cooperation with the U.S. hit an apex as the Azeri president provided steadfast support for the United States and its war in Iraq. The intensity

\footnotetext{
${ }^{594}$ Aliyev, Heydar. 2000. “Azerbaijani President Confident of Improved Relations with Russia.” Moscow Mayak Radio, 15 June 2000.

${ }^{595}$ Aliyev, Heydar. 2002a. “Azerbaijani President Pleased with Visit to Moscow.” Azerbaijani TV 1, 27 January 2002.

${ }^{596}$ Aliyev, Heydar. 2001a. "Statement of the Azerbaijan President Heydar Aliyev in Connection with the Act of Terrorism Occurred in the United States of America on September 11, 2001." Heydar Aliyev Library, 11 September 2001. http://lib.aliyev-heritage.org/en/2735953.html. Accessed 29 August 2016.
} 
of Aliyev's alignment with the United States eclipsed that of Russia in this year. To understand

Aliyev's ideas here, one can turn to his April 2003 speech, where he asserts,

The United States of America declared the indispensable necessity to lead operations and take military measures for the liquidation of the weapons of mass destruction in Iraq. But unfortunately, a lot of countries, including the members of NATO, were against it. As you know, we immediately joined this coalition. It seems very strange that 21 days ago the USA completed its operations in Iraq, now the countries opposing these operations want to be engaged in the reconstruction works in Iraq. All this testifies that Azerbaijan has adopted the decision to join the Euro-Atlantic Union, in order to be near to the USA even when the other members of the organization ignored it. ${ }^{597}$

The preceding analysis of Heydar's threat perceptions and their impact on his alignment preferences reveal the Azeri president tended to prefer a strategy of great power bridging with the United States and Russia. As has been argued, while the balance of power consistently favored Russia, Aliyev's ideas that Russia represented a moderate threat were an important catalyst shaping his alignment preferences. Additionally, the extent to which the Russian threat did make itself known in political, economic, informational, or military circles was not enough to cause the Azeri president to positively bandwagon with the United States. For Aliyev, great power bridging was preferred because "our republic wants to establish equal relations with all the countries. Of course, we want to establish close relations with the United States of America. At the same time, we have good relations with Russia, and we want to make them better." President Ilham Aliyev. From 2004 to 2015, President Ilham Aliyev's moderately-low threat perceptions of Russia and the United States was associated with a proclivity to follow a great power bridging alignment with both regional great powers. For Ilham Aliyev, the threat from Russia was best understood to be long-term in nature with Kremlin pressure being applied across

\footnotetext{
${ }^{597}$ Aliyev, Heydar. 2003. "From the conversation of the Azerbaijani President Heydar Aliyev with Bruce Jackson, Director of the Project on Transition of Democracies, Co-chairman of the Committee on NATO. Heydar Aliyev Library, 18 April 2003. http://lib.aliyev-heritage.org/en/9085432.html. Accessed 20 August 2016.

${ }^{598}$ Interview on file with author; also see Aliyev, Heydar. 1998. "Interview of the President of Azerbaijan Heydar Aliyev to the Reporter of the Japanese Newspaper.” Heydar Aliyev Heritage International Online Library, 27 February 1998. http://lib.aliyev-heritage.org/en/562426.html. Accessed 21 September 1996.
} 
the diplomatic, information, and economic spectrums at different times. The Russian military threat was again a latent one. Here, Ilham Aliyev realized that if he cut across Russian interests too deeply, Moscow could direct proxies to stir up trouble in Dagestan or the Nagorno-Karabakh as a way to foment political, economic, or social instability across Azerbaijan. ${ }^{599}$ From the United States, the threat was best understood in terms of Washington's support for democratic opposition groups. At issue was how these actions could ignite a colored revolution similar to what occurred in Georgia in 2003 and Ukraine in 2004.

As graphically illustrated in the preceding chapter, Aliyev's alignment preferences indicate he was more apt to pursue a strategy of great power bridging as his level of verbal cooperation between the U.S. and Russia were almost equal, slightly oscillating back and forth over his presidency. Additionally, an analysis of ICEWS event data also indicated Ilham Aliyev's level of verbal confrontation with the United States and Russia was almost equal during his time in office providing a second indicator of his preferences for a great power bridging strategy. ${ }^{600}$ While the latent military threat from Russia was omnipresent, it was not enough to drive Ilham Aliyev to prefer a positive bandwagoning alignment with the United States. For Aliyev, a bifurcated strategic alignment with Moscow and Washington would provide the necessary balance by which Azerbaijan could prosper economically and more importantly, allow the Azeri president to remain in power. The proceeding paragraphs detail the relationship between Ilham Aliyev' threat perceptions and his alignment preferences with the United States and Russia.

\footnotetext{
${ }^{599}$ Interview on file with author.

${ }^{600}$ Author's analysis. Of note, the total number of events on Ilham Aliyev's level of verbal confrontation was much less than what was observed with his level of verbal cooperation with the U.S. and Russia. As previously noted, this is to be expected since Ilham Aliyev's philosophical beliefs indicated he viewed the political universe as definitely friendly.
} 
As early as 2004, Ilham Aliyev's low threat perceptions of Russia served as a catalyst for an alignment preference with Moscow. The extent to which Aliyev viewed Russia as a low threat was brought to the fore in February 2004 prior to his visit to Moscow. During an interview with Russian media, Aliyev praised the progress Azerbaijan had made towards the establishment of a strong strategic partnership with Russia. According to Aliyev...

It is no secret that during the initial period of independence after the collapse of the Soviet Union, relations were complicated at times, there was a mass of problems, mutual complaints and difficulties. Sharp changes happened exactly in 2000 when... under President Putin, Russia gave up on its lopsided policy on settling the Nagornyy Karabakh conflict. So, our countries have established neighborly relations. And now, I think, these relations can be an example of relations between neighbors, as well as between a bigger and a smaller state. ${ }^{601}$

During a 2004 visit to Moscow, Aliyev conveyed a strident commitment to developing a closer alignment with Moscow in the areas of economics, counter-terrorism, and science and technology. ${ }^{602}$ These important meetings between Aliyev and Kremlin elites subsequently served as an anchor for his great power bridging approach with Moscow on one side and Washington on the other. In the years ahead, Aliyev routinely touted the high-value of a strategic partnership with Russia; however, like his father, he would never go so far as to lock Azerbaijan into any formal economic or military bloc. In a demonstration of Ilham Aliyev's tendency to not exclusively align with one regional great power over another, in 2011 Azerbaijan became a member of the Non-Alignment Movement. ${ }^{603}$ This singular act served as a signal of Aliyev's preference to avoid entering into any formal alliance with any one regional great power.

An analysis of Ilham Aliyev's foreign policy speeches indicates he also consistently touted the high merits of aligning with the Russian Federation in the economic realm. Whether it was

\footnotetext{
601 Aliyev, Ilham 2004.

${ }^{602}$ Aliyev, Ilham. 2004d. "Russia: Azerbaijani President Plans to Increase Bilateral Trade, Military Cooperation." Itar-Tass, 07 February 2004.

${ }^{603}$ Kazimova, Arifa. 2011. “Azerbaijan Joins Ranks of Non-Aligned Movement.” Radio Free Europe/Radio Liberty, 25 May 2011. https://www.rferl.org/a/azerbaijan_join_nonaligned_movement/24200776.html. Accessed 23 October 2016.
} 
during CIS meetings, the Russia-Azerbaijan Economic Forum, Caspian Summits, or head of state visits to Russia, Aliyev's ideas about Russia as a non-threatening great power framed his verbal pronouncements on a wide array of economic issues. For example, in 2004 during the Russia-Azerbaijan Economic Forum, Aliyev highlighted how the presence of over 300 Russian businesses in Azerbaijan had helped improve the country's economic productivity. ${ }^{604}$ Aliyev continued this trend through 2014 when during the $4^{\text {th }}$ Caspian Summit, he noted the importance of Moscow's lead role in resolving Caspian Sea issues and how he would work more closely with the Kremlin in the future as a way to build on past economic successes. ${ }^{605}$ The key takeaway here is how Ilham Aliyev's low threat perceptions of Russia served as a catalyst for his preference for great power bridging. As one area specialist noted, under Ilham Aliyev "Azerbaijan moved away from fearing an unpredictable and unstable Russia, which instead began to acquire the image of a pragmatic and constructive partner." ${ }^{906}$

In the diplomatic arena, Ilham Aliyev also demonstrated a preference to align with Russia on various regional and international issues. In 2007, Aliyev responded positively to a Russian-led counter proposal to a U.S. ballistic missile defense plan for Europe. According to Aliyev, the use of the Qabala Russian radar facility in Azerbaijan as part of a European missile defense shield would be in the state's long-term security interests. ${ }^{607}$ In early 2008, Aliyev backed Russia by also not recognizing Kosovo's declaration of independence noting how Pristina's move violated

\footnotetext{
${ }^{604}$ Aliyev, Ilham. 2004f. "Speech of President of Azerbaijan Ilham Aliyev at the first Azerbaijan-Russia Economic Forum.” President of Azerbaijan Website, 07 April 2004. http://archive.president.az/articles.php?item_id=2007 0813043859856\&sec_id=11. Accessed 22 February 2017.

${ }^{605}$ Aliyev, Ilham. 2014. "Speech by Ilham Aliyev at the 4th Summit of the Heads of State of Caspian Littoral States." President of Azerbaijan Website, 29 September 2014. http://en.president.az/articles/13039. Accessed 22 February 2017.

${ }^{606}$ Valiyev, Anar. 2011. "Azerbaijan-Russia Relations After the Five-Day War: Friendship, Enmity, Or Pragmatism?” Turkish Policy Quarterly 10 (3), 134.

${ }^{607}$ Collin, Mathew. 2007. “Azeri Radar Eyed for U.S. Shield.” BBC News, 18 June 2007. http://news.bbc.co.uk/ 2/hi/europe/6764079.stm. Accessed 20 October 2016.
} 
international law. ${ }^{608}$ Additionally, Aliyev believed such actions represented a bad precedent for achieving a solution with the Nagorno-Karabakh. Finally, a lack of Kremlin criticism over Azerbaijan's less than stellar human rights record helped reinforce Aliyev's preference for aligning with Russia as part of his great power bridging strategy.

Finally, in the latter years of his presidency Ilham Aliyev's preference for an alignment with Russia was also evident in the domain of military affairs. Beginning in 2011, Aliyev believed a tenuous military alignment with Russia, while limited in nature, may serve three purposes. First, acquiring arms from Russia could help diversify the state's list of arms suppliers and improve Baku's access to advance weaponry. Frustrated with Washington's tit-for-tat foreign policies with Azerbaijan, Aliyev proclaimed "the United States has a tendency to dictate terms to other countries. Russia's position regarding the supply of arms has always been that Russia puts no political pressure on its customers. It is Russia's flexibility in arm deals and the effectiveness of its military products that make it one of the leaders in the global arms market." ${ }^{309}$

Second, beyond arms purchases, Aliyev also increased, albeit minimally, the number of bilateral military exercises with Russia. ${ }^{610}$ Such actions had a net effect of improving the combat proficiency of the country's armed forces. Finally, and perhaps most important, a tepid military alignment with Russia may help foment friction between Yerevan and Moscow that could erode the strength of their alliance. Speaking in 2014, the director of the Armenian Institute for International and Security Affairs stated, "whereas formerly, Yerevan officially said that it trusted Moscow and that the Kremlin was maintaining the balance of power... now they don't

\footnotetext{
${ }^{608}$ Ismayilov, Ravshon. 2008. "Kosovo and Karabakh: How Azerbaijan Sees the Connection.” Eurasianet, 28 March 2008. https://reliefweb. int/report/azerbaijan/kosovo-and-karabakh-how-azerbaijan-sees-connection. Accessed 24 September 2016.

${ }^{609}$ Aliyev, Ilham. 2012a. Cited in Sultanova, Shahla. 2012. "Azerbaijan Brings in the Big Guns." Transitions Online, 12 July 2012. http://www.tol.org/client/article/23254-azerbaijan-military-spending.html. Accessed, 23 January 2018.

${ }^{610}$ As detailed in Chapter Four, Azerbaijan held bilateral military exercises with Russia in 2011 and 2015.
} 
believe Moscow anymore." ${ }^{\prime 11}$ Although Russian arms purchases served Aliyev's interests, they also served as a mechanism for bolstering Moscow's influence in the South Caucasus.

The preceding paragraphs on Aliyev's alignment preferences with Russia was not without challenges. In several instances, Aliyev demonstrated a willingness to push back against Kremlin elites. For example, beginning in 2006 Aliyev's verbal confrontation spiked when he threatened to stop importing Russian natural gas after Gazprom vowed to double its price. In 2007, Moscow and Baku were again at odds over pricing for Azeri oil exports to Russia with Aliyev accusing the Kremlin of energy blackmail. In response, Aliyev ordered the halt of all oil exports to Russia. ${ }^{612}$ Despite these periods of tension, Aliyev's low threat perceptions of Russia, coupled with his ideas about the economic benefits of this deal and other projects facilitated a closer alignment with Russia in the economic sphere.

In 2009 and 2010, Aliyev's threat perceptions about Russia increased owing to his ideas about Moscow's long-term intentions in the South Caucasus. First, Russia's invasion of Georgia likely contributed to Aliyev's ideas about Moscow's willingness to intervene in the internal affairs of former Soviet states; however, the extent to which the Azeri president actually viewed this as a direct military threat to Azerbaijan remains unclear. During bilateral meetings in Turkey in late August 2008, Aliyev did not speak of Russian military aggression in Georgia opting to focus more on the negative impacts to the economies of all countries in the region. ${ }^{613}$

\footnotetext{
${ }^{611}$ Safaryan, Stepan. 2014. Cited in Gevorgyan, Tigran. 2014. "Yerevan Angry at Russian Arms Sales to Baku." Institute for War and Peace Reporting. https://iwpr.net/global-voices/yerevan-angry-russian-arms-sales-baku. Accessed 25 January 2018.

${ }^{612}$ Collin, Matthew. 2006. “Azeris Warn Russia on Gas Prices.” BBC News, 24 December 2006. http://news. bbc.co.uk/2/hi/europe/6207257.stm. Accessed 20 October 2016.

${ }^{613}$ Aliyev, Ilham. 2008. "Statements for Media Representatives by President Ilham Aliyev and Prime Minister of Turkey Recep Tayyip Erdogan.” President of Azerbaijan Website, 20 August 2008. http://archive.president.az/ articles.php?item_id=20080903105812573\&sec_id=70. Accessed 20 October 2016.
} 
Aliyev's ideas about Russia as an economic threat were also visible in 2009 when Gazprom attempted to purchase nearly all of the State Oil Company of Azerbaijan Republic's (SOCAR) natural gas production. Realizing Moscow's efforts to acquire leverage over the EU and its dependence on energy supplies from external states Aliyev stated, "Azerbaijan makes decisions itself on whom it will sell natural gas to. We try to separate the issue from politics, and this stance has proved fruitful." ${ }^{, 614}$ Although Azerbaijan would conclude a modest natural gas agreement with Moscow, its actions reinforced Aliyev's ideas about Russia as a latent threat and the value of a great power bridging, which also included an alignment with the United States.

The Kremlin's enduring political and economic support for Armenia as well as Moscow's direct military assistance to Yerevan in the Nagorno-Karabakh stalemate were two final contributing factors shaping Ilham Aliyev's threat perceptions of Russia. Additionally, Armenia's continued membership in the CSTO helped to amplify Aliyev's threat perceptions since Yerevan would most receive additional Russian military backing if the conflict in this region were to escalate to all-out war. Finally, Yerevan's continued willingness to host Russian armed forces at the $102^{\text {nd }}$ military base in Gyumri and a 2010 agreement to lease this base to Russia until 2044 reinforced Aliyev's ideas about the latent military threat from Russia. ${ }^{615}$

Beginning in 2011, Aliyev's threat perceptions of Russia experienced a slight down-tick. During a meeting with President Medvedev, Aliyev noted the existence of a series of positive dynamics in their bilateral ties, which the Azeri president said needed to be expanded with more 'practical acts' of cooperation. ${ }^{616}$ During this time, Aliyev began to tout the importance of

\footnotetext{
${ }^{614}$ Aliyev, Ilham. 2009. “Azerbaijan Considers Nabucco Gas Pipeline Project as Commercial.” Itar-Tass, 26 January 2009.

${ }^{615}$ Smith, Roger. 2010. "Russia Extends Lease on Military Base in Armenia through 2044.” Defense News, 21 August 2010. http://defensenews-updates.blogspot.sg/2010/08/dtn-news-russia-extends-lease-on.html. Accessed 01 August 2017.

${ }^{616}$ Aliyev, Ilham. 2012. "Meeting with President of Azerbaijan Ilham Aliyev." President of Russia Website, 23 January 2012. http://en.kremlin.ru/catalog/persons/192/events/14347. Accessed 29 July 2017.
} 
building-up the Azeri military with the implementation of a defense modernization program, which he believed could best be realized with Russia's assistance. As detailed above, starting in 2011 these practical acts came in the form of a series of negotiated arms agreements beginning with Azerbaijan's purchase of Russian attack helicopters. ${ }^{617}$

In near lock-step with his efforts to align with Russia, Ilham Aliyev simultaneously believed an alignment with the United States across the economic and military lines of operation was in the state's best interests as well. President Aliyev's ideas about aligning with the U.S. in these key areas was on full display during his first visit to Washington in 2004. Speaking at Columbia University, Ilham Aliyev heavily emphasized Azerbaijan's commitment to developing strong economic and security ties with Washington, citing a proven track record of cooperation in the fields of energy and how Baku was the one of the first post-Soviet countries to join the U.S. global campaign against terrorism. ${ }^{618}$ From the beginning of his presidency, Aliyev believed continuing the state's alignment with the U.S. would help ensure Washington would not curtail its support for Azerbaijan's energy projects. More importantly, an economic alignment with the U.S. could potentially be used as a counter-balance to Russia if Moscow attempted to exert too much political or economic pressure on Baku that jeopardized Azeri energy interests.

Aliyev's inclination to align with the U.S. on an equal basis was most readily visible in the economic sector where he continued to proclaim the merits of working closely with Washington and American energy corporations to bring oil and natural gas to the West. For example, during the Azeri president's 2006 visit to Washington, Aliyev noted how Baku's close ties with the U.S.

\footnotetext{
${ }^{617}$ Kucera, Joshua. 2011. “Azerbaijan Makes Big Helicopter Buy.” Euarasia.net, 03 March 2011. http://www. eurasianet.org/node/62995. Accessed 29 July 2017.

${ }^{618}$ Aliyev, Ilham. 2004e. "Speech of Azerbaijani President Ilham Aliyev at meeting at the Columbia University in New York." President of Azerbaijan Website, 24 September 2004. http://archive.president.az/articles.php?item_id= 20070813060710459\&sec_id=11. Accessed 28 October 2016.
} 
has made Azerbaijan a key actor on the international stage. In his words, "we [Azerbaijan] are much pleased to have high-level bilateral ties with our partner - USA and this is a very important factor in our successful regional political and economic development." ${ }^{3619}$ While Aliyev was steadfast in his ideas about the merits of an economic alignment with the United States, he also realized the symbiotic nature of this strategic relationship. In the words of one area specialist, "while Baku needed Washington, Aliyev knew that Washington, at times, needed him more" given how Azerbaijan was destined to become a leading provider of energy for the West. ${ }^{620}$

Following in the footsteps of his father, Ilham Aliyev also espoused the merits of a narrowlydefined alignment with the United States in the military sphere. The frequency and intensity of Aliyev's preference for a military alignment with the U.S. occurred at a higher frequency and intensity than what was seen with Russia owing to the Azeri president's lower threat perceptions about Washington and its long-term interests in Azerbaijan. While in office, Aliyev consistently touted the importance of working with the U.S. in the areas of counter-terrorism, exercises, and peacekeeping in vitally important regions of the world. One of the most visible signs of Aliyev's alignment with the United States was seen in late 2003 during a visit by Secretary of Defense Donald Rumsfeld, when the Azeri president expressed his unequivocal support for U.S.-led military operations around the world. Aliyev also singled out the central importance of Azerbaijan's past military cooperation and the necessity for those ties to increase in the future. ${ }^{621}$ Aliyev's preference for a stronger military alignment with the United States persisted through 2015. For example, speaking in 2013 during the Azerbaijan-U.S. forum, Aliyev continued to tout

\footnotetext{
${ }^{619}$ Aliyev, Ilham. 2006b. "Speech of Azeri President Ilham Aliyev at the Washington the 6th Business and Investment Conference." President of Azerbaijan Website, 27 April 2006. http://archive.president.az/articles.php? item_id=20070813062030377\&sec_id=11. Accessed 23 October 2016.

${ }^{620}$ Interview on file with author.

${ }^{621}$ Aliyev, Ilham. 2003. “Azeri President, US Defense Secretary Discuss Military Ties.” Azerbaijani TV 1, 03 December 2003.
} 
his support for America's global military operations noting how American and Azeri soldiers were serving side-by-side as well as Azerbaijan's role in facilitating the safe passage of over 40 percent of U.S. military supplies to Afghanistan. ${ }^{622}$ Clearly, Aliyev placed high importance in developing a military alignment with the United States, which was also nested in a great power bridging strategy with Russia.

Aliyev's alignment with the United States was not without its own challenges however. In this case, Washington's criticisms over the Azeri president's authoritarian tendencies, his country's poor human rights record, and the government's suppression of the press created brief demonstrations of noncooperation. For example, in April 2010 Baku canceled the U.S.-Azeri military exercise "Computer Supported Headquarter Trainings," which was to occur in May 2010. Although the Ministry of Defense did not provide a specific reason, Western analysts speculated Aliyev was miffed by President Obama's decision to not invite him to the Nuclear Summit and for Washington's renewed efforts to improve relations with Armenia. ${ }^{623}$

To sum up, for the period 2004 to 2015, Ilham Aliyev's alignment preferences are best understood in terms of great power bridging. A primary driver of Aliyev's alignment preferences was his low to moderate threat perceptions of Russia and the United States, which moved him to prefer to an almost equal level of cooperation with the Washington and Moscow across various political, economic, and military topics. Although there were periods of heightened tensions with Russia and the U.S., Aliyev consistently maintained an oratory line that Azerbaijan would not enter into any formal economic or military alliance. Second, Ilham Aliyev had come to believe

\footnotetext{
${ }^{622}$ Aliyev, Ilham. 2013. "Speech by President Ilham Aliyev at the opening of the Azerbaijan-USA forum "Vision for the Future" in Baku." President of Azerbaijan Website, 29 May 2013. http://en.president.az/articles/8311. Accessed 24 October 2016.

623 "Azerbaijan Cancels Military Exercise with the United States." 2010. Radio Free Europe/Radio Liberty Newsline, 20 April 2010. https://www.rferl.org/a/Azerbaijan_Cancels_Military_Exercises_With_United_States/ 2019023.html. Accessed 22 October 2016.
} 
the state would have to rely on its own tangible and intangible resources to realize his goals of bringing increased levels of security and economic prosperity to the country. It was by aligning with both the regional great powers Aliyev believed he could realize this strategic endstate. ${ }^{624}$

\section{Georgia: Findings and Analysis}

In Georgia, this study finds Walt's prediction that small states in close proximity to a threatening regional great power have no other option but to bandwagon with that state as a form of appeasement does not hold water. ${ }^{625}$ Although the regional balance of power is an important systemic consideration, a president's threat perceptions were more important. Specifically, moderate threat perceptions of Russia shaped Eduard Shevardnadze and Giorgi Margvelashvili's (2013 only) preferences for great power bridging. Separately, President Saakashvili's high threat perceptions of the Russian Federation was a key shape agent for a positive bandwagoning preference with the United States.

\section{The Philosophical Beliefs of Georgian Presidents}

An examination of the operational codes of Georgian presidents from 1995 to 2015 indicate that just because Russia is the most powerful state in the region, former Soviet satellites may not necessary be inclined to wholeheartedly give-in and align with their former imperial center. As depicted in the table below, a content analysis of speeches by Presidents Shevardnadze, Saakashvili, and Margvelashvili indicate they viewed the political universe as friendly

\footnotetext{
${ }^{624}$ In 2006 Ilham Aliyev stated, "Basically, since Azerbaijan acquired independence it differed from other postSoviet states in that we received practically no assistance from anyone. This has taught us to rely only on our own resources. And the fact that we do not join coalitions is probably also the result of this. I believe that a country should first depend on itself, on its own economic and intellectual capabilities, on competent policies that minimize external risks." See Aliyev, Ilham. 2006. "Azerbaijan Is Accustomed to Relying Only on Its Own Resources and Therefore Does Not Join Coalitions.” Security Index 1-81 (13). http://www.pircenter.org/media/content/files/0/ 13413248491.pdf. Accessed 03 March 2017.

${ }^{625}$ Recalling Walt, small states “...can do little to affect the outcome (and may suffer grievously in the process), they must choose the winning side. Only when they can affect the outcome is it rational for them to join the weaker alliance..." Levy adds, “...weaker states in the proximity of stronger states do what is necessary to survive... bandwagoning with the strong instead of balancing against them.” Walt 1987, 29; Levy 1989, 231.
} 
registering positive scores across all indices. From one perspective, this finding may fly in the face of realist expectations that former Soviet states would view the strategic environment as hostile given Russia's superior military capabilities and Moscow's historical proclivity to use political coercion or military force against neighboring countries.

Table 12: The Philosophical Beliefs of Georgian Presidents

\begin{tabular}{|c|c|c|c|c|c|c|c|c|c|c|c|c|c|c|c|c|c|c|c|c|c|c|c|c|}
\hline \multirow[b]{2}{*}{$\begin{array}{l}\text { Philosophical Beliefs / } \\
\text { Year }\end{array}$} & \multicolumn{10}{|c|}{ Shevardnadze } & \multicolumn{10}{|c|}{ Saakashvili } & \multicolumn{4}{|c|}{ Margvelashvili } \\
\hline & 1995 & 1996 & 1997 & 1998 & 1999 & 2000 & 2001 & 2002 & 2003 & AVG & 2004 & 2005 & 2006 & 2007 & 2008 & 2009 & 2010 & 2011 & 2012 & AVG & 2013 & 2014 & 2015 & AVG \\
\hline $\begin{array}{l}\text { P-1: The Nature of the } \\
\text { Political Universe }\end{array}$ & 0.5 & 0.5 & 0.5 & 0.5 & 0.5 & 0.5 & 0.6 & 0.4 & 0.5 & 0.5 & 0.4 & 0.3 & 0.3 & 0.3 & 0.2 & 0.2 & 0.3 & 0.3 & 0.3 & 0.3 & 0.6 & 0.5 & 0.6 & 0.6 \\
\hline $\begin{array}{l}\text { P-2: Prospects for Realizing } \\
\text { Fundamental Values }\end{array}$ & 0.3 & 0.3 & 0.3 & 0.3 & 0.3 & 0.3 & 0.3 & 0.2 & 0.3 & 0.3 & 0.2 & 0.2 & 0.1 & 0.2 & 0.1 & 0.1 & 0.2 & 0.2 & 0.2 & 0.1 & 0.4 & 0.3 & 0.4 & 0.4 \\
\hline $\begin{array}{l}\text { P-3: Predictability of the } \\
\text { Political Universe }\end{array}$ & 0.1 & 0.1 & 0.1 & 0.1 & 0.1 & 0.1 & 0.1 & 0.1 & 0.1 & 0.1 & 0.1 & 0.1 & 0.1 & 0.1 & 0.1 & 0.1 & 0.1 & 0.1 & 0.1 & 0.1 & 0.1 & 0.1 & 0.1 & 0.1 \\
\hline \begin{tabular}{|l} 
P-4: Control Over Historical \\
Development
\end{tabular} & 0.2 & 0.2 & 0.2 & 0.2 & 0.3 & 0.3 & 0.3 & 0.3 & 0.2 & 0.2 & 0.3 & 0.3 & 0.3 & 0.3 & 0.3 & 0.3 & 0.3 & 0.3 & 0.3 & 0.3 & 0.4 & 0.3 & 0.3 & 0.3 \\
\hline P-5: Role of Chance & 1.0 & 1.0 & 1.0 & 1.0 & 1.0 & 1.0 & 1.0 & 1.0 & 1.0 & 1.0 & 1.0 & 1.0 & 1.0 & 1.0 & 1.0 & 1.0 & 1.0 & 1.0 & 1.0 & 1.0 & 1.0 & 1.0 & 1.0 & 1.0 \\
\hline
\end{tabular}

A review of the table above reveals several general insights about each president's philosophical beliefs. First, when focusing exclusively on the master beliefs category (P-1), Presidents Shevardnadze and Margvelashvili both viewed the nature of the political universe as definitely friendly with the latter registering the higher score of .60 in this category. On the other hand, President Saakashvili only had a somewhat friendly view of the political universe across the P-1 index. ${ }^{626}$ This pattern continued across the P-2 index where Margvelashvili outperformed his predecessors retaining a higher degree of optimism (.4) about the prospects for realizing his fundamental values as compared to Shevardnadze (.30) and Saakashvili (.10).

With respect to the predictability of the political universe (P-3), all three presidents scored .10 indicating they generally viewed the strategic environment with a high degree of uncertainty and unpredictability. The presidents' beliefs about their control over historical developments (P-4) were also very similar with Margvelashvili, Saakashvili, and Shevardnadze receiving a score of

\footnotetext{
${ }^{626}$ As a reminder, philosophical beliefs are measured as follows: $(-1=$ very hostile; $-.50=$ definitely hostile; $-.25=$ somewhat hostile; $0.0=$ mixed $+.25=$ somewhat friendly; $+.50=$ definitely friendly $;+.75=$ very friendly).
} 
$.30, .30$ and a .20 respectively. These scores indicate each president believed that control over the strategic situation resides with others in the political universe. Finally, all three presidents' beliefs about the role of chance (P-5) in political outcomes were extremely high. The high scores of all three presidents in this category is not surprising, given their lower scores in the P-3 and P4 categories. Specifically, because Georgian presidents believe they have less control in an unpredictable international system, the role of chance is pervasive in many political outcomes. Validating Convergence and Divergence

The preceding analysis provides a baseline understanding of the philosophical beliefs about world politics for the three Georgian Presidents. Still unanswered is to what extent are these findings statistically significant. Based on the results of an ANOVA test, the null hypothesis that there are no statistically significant differences in the philosophical beliefs of Georgian presidents is invalidated. The alternative hypothesis that a statistically significant difference exists is validated at the .001 level.

Table 13: ANOVA Results - Georgian Presidents Philosophical Beliefs

\begin{tabular}{|c|c|c|c|c|c|}
\hline & & Sum of Squares & $d f$ & Mean Square & $\mathrm{F}$ \\
\hline \multirow{2}{*}{$\mathrm{P}-1$} & $\begin{array}{l}\text { Between } \\
\text { Groups }\end{array}$ & .262733 & 2 & 0.131366 & $46.698 * * *$ \\
\hline & $\begin{array}{l}\text { Within } \\
\text { Groups }\end{array}$ & .053449 & 19 & 0.002813 & \\
\hline
\end{tabular}

Although an ANOVA test allows us to understand there are differences between each president's belief system, what remains unclear is exactly where the points of divergence occur. To discern these relationships requires a post-hoc test of the ANOVA results. For this study, a Tukey's HSD test provides a more nuanced analysis on the differences with each president's 
operational code. For the purpose of this study, the focus of this chapter's analysis will be on the P-1 master belief category. Based on the findings from the table below, Presidents

Margvelashvili and Shevardnadze are the most similar in their beliefs about the nature of the international system registering an adjusted P-value of 0.1367086.

Table 14: Georgia - Mean Comparisons of Tukey's HSD Test Results (P-1)

\begin{tabular}{l|cccc}
\hline \multicolumn{1}{c|}{ Pair } & Difference & Lower Bound & Upper Bound & Adjusted P-Value \\
\hline $\begin{array}{l}\text { Saakashvili- } \\
\text { Margvelashvili }\end{array}$ & -0.2680 & -0.3566981 & -0.17930192 & 0.0000009 \\
$\begin{array}{l}\text { Shevardnadze- } \\
\text { Margvelashvili }\end{array}$ & -0.0711 & -0.1609392 & 0.01871693 & 0.1367086 \\
$\begin{array}{l}\text { Shevardnadze- } \\
\text { Saakashvili }\end{array}$ & 0.1968 & 0.1349792 & 0.25879859 & 0.0000004 \\
\hline
\end{tabular}

95\% Family-wise Confidence Level

These findings appear logical for several reasons. First, with Russia's invasion of Georgia in 2008, coupled with a tepid response from the West, Saakashvili's image of international affairs is more likely to reflect a less friendly view than Margvelashvili. Alternatively, while South Ossetia and Abkhazia remain separated from Georgia proper, improving relations with the Kremlin and higher levels of U.S.-European political and economic support may have added to Margvelashvili's more positive view of the political universe during his first several months in office. However, as will be detailed below, Margvelashvili's moderate threat perceptions and associated great power bridging preference were short lived. When Moscow refused to compromise on the status of South Ossetia and Abkhazia, Margvelashvili perceived Russia as a high threat and a preference for positive bandwagoning with the United States. 


\section{$\underline{\text { Georgian President Threat Perceptions and State Alignment }}$}

Georgian presidents, more so than their counterparts in Azerbaijan, Moldova, and Ukraine, perceived Russia to be the greatest threat to the state for the period 1995 to 2015. During this time, Presidents Shevardnadze, Saakashvili, and Margvelashvili’s combined average of the intensity of their threat perceptions of Russia was moderately-high. ${ }^{627}$ The specific nature of the threats from Russia were primarily economic and to a lesser degree military under Shevardnadze. With Saakashvili and Margvelashvili, Russian military and economic threats were dominant.

In the proceeding paragraphs, each president's threat perceptions are analyzed in the context of his alignment preferences with the United States and Russia from 1995-2015. The key findings are as follows: First, when a president's threat perceptions were in the moderate range, a preference for great power bridging was observed. This was the case with Presidents Shevardnadze and Margvelashvili during their first year in office. Second, when a president's threat perceptions of Russia were high, a president preferred a positive bandwagoning with the United States. President Saakashvili’s alignment preference typifies this form of political behavior as does President Margvelashvili’s from 2014-2015. Less President Margvelashvili, each president's threat perceptions of Russia remained stable during their time.

President Eduard Shevardnadze. From 1995 to 2003, President Shevardnadze perceived Russia to be the greatest long-term threat to Georgia. The intensity of Shevardnadze's threat perceptions, as assessed by various area specialist was moderately-low, while the threat from the United States was low. ${ }^{628}$ In his words, "we [Georgia] are a small country, but we are not unimportant in strategic terms. Therefore, our foreign policy must be based on finding partners

\footnotetext{
${ }^{627}$ Author's analysis. The average score of the three presidents was 1.7 , which fell in the moderate high range.

${ }^{628}$ Author's analysis; Shevardnadze threat perception score is derived from interviews with area specialists.
} 
and friends everywhere -- close to home as well as far away." ${ }^{\circ 29}$ It is these core beliefs that would subsequently guide Shevardnadze's preferences for a great power bridging alignment with the United States and Russia. Such an approach would help facilitate the country's transition from Soviet rule, while also allowing him to retain power.

As graphically illustrated in the preceding chapter, Shevardnadze's alignment preferences indicated he preferred great power bridging as his level of verbal cooperation with the Washington and Moscow oscillated back and forth while he was president. Additionally, an analysis of ICEWS event data also indicated President Shevardnadze's level of verbal confrontation tended to be higher with Russia than the United States, which is in line with how this president tended to view the former as the greatest long-term threat to Georgia. ${ }^{630}$

During his time in office, Shevardnadze's ideas about the threat from Russia were primarily economic in nature and to a lesser degree military given the continuing presence of Russian military bases in Georgia, which was tempered somewhat by the overall weak standing of the Russian armed forces. From 1995 to 1996, Shevardnadze's threat perceptions of Russia were at their lowest owing to his belief that aligning with Moscow could deliver an enduring resolution to the separatist movements in South Ossetia and Abkhazia while at the same time providing Tbilisi with the necessary economic and military support to help Georgia stand on its own. Speaking in 1995, Shevardnadze stated, "we must establish Georgian armed forces, which is not possible without Russia' help because we lack our own weapons and weapons technology. There

\footnotetext{
${ }^{629}$ Shevardnadze, Eduard. 1995. "Shevardnadze Calls Break with Russia `Mistake.”' Die Tageszeitung, 03 November 1995, 1.

${ }^{630}$ Author's analysis. The total number of events on President Shevardnadze's level of verbal confrontation was much less than what was observed with his level of verbal cooperation with the U.S. and Russia. As previously noted, this is to be expected since Shevardnadze's philosophical beliefs indicated he viewed the political universe as definitely friendly.
} 
is no other partner for this in the world. The second problem is regaining Abkhazia and settling the Georgian-Ossetian conflict. Here, too, Russia will give the decisive word." $" 631$

By the late 1990s however, Shevardnadze's overall threat perceptions about Russia experienced a slight up-tick as he became increasingly wary of the Kremlin's long-term intentions in Georgia. At issue was the Georgian president's frustration with a lack of progress on Moscow's commitment to building-up Georgia's armed forces and resolving the country's separatist challenges. Shevardnadze's beliefs on these issues were made clear in 1998 when he stated, "already in 1994 we had worked out an agreement with the Russians about the military bases, which did not come into force. This agreement set down the condition that the Russian Army helps in settling the Abkhazia conflict and in establishing our young Georgian Army. Both have not been done." ${ }^{632}$ Shevardnadze's beliefs about Moscow's unreliability on the separatist issue was validated in May 1998 when Russian peacekeepers failed to prevent a surge in violence causing the displacement of nearly 35,000 Georgians from Gali district. ${ }^{633}$

Additionally, Shevardnadze's ideas about the growing irrelevance of Russian-led security and economic structures were contributing factors to his de-emphasis on fostering a strategic alignment with just Russia. For example, during the 1998 CIS summit in Moscow, Shevardnadze expressed frustration over the inability of the Commonwealth to resolve the many internal conflicts of member states. In Shevardnadze's words, “...there is no need for an international organization that is incapable of establishing peace in conflict zones. An organization like this is

\footnotetext{
${ }^{631}$ Shevardnadze 1995, 3.

${ }^{632}$ Shevardnadze, Eduard. 1998b. "Shevardnadze: Russia Planned Recent Attack." Frankfurter Rundschau, 14 March 1998, 7.

${ }^{633}$ Fuller, Liz. 1998. "1998 in Review: Little Progress in Caucasus Conflicts.” Radio Free Europe / Radio Liberty, 09 December 1998. https://www.rferl.org/a/1090161.html. Accessed 19 July 2016.
} 
doomed to collapse eventually." ${ }^{\prime 634}$ From Shevardnadze's perspective, the CIS was a mechanism designed to advance Russian interests at the expense of other members.

It was during this time Shevardnadze's ideas about a stronger alignment with the United States came to fruition and how America's backing could help solidify Georgia's economic and political independence. For example, Shevardnadze's inclination to align with Washington was readily seen in the run-up to his five-day visit to the United States in July 1997. Prior to his departure, Shevardnadze exclaimed, "we have found many friends and supporters all over the world. Can you imagine what Georgia would have been without the great material, financial, moral, and political support and help provided by the United States? We have to strengthen these trends. ${ }^{635}$ Subsequently during his meetings with President Clinton, the U.S. president and Shevardnadze committed themselves to improving economic relations in the areas of trade and investment. President Clinton also pledged support for Georgia's accession into the World Trade Organization and participation in NATO’s Euro-Atlantic Partnership Council. ${ }^{636}$ President Clinton's pronouncements were significant and help validate Shevardnadze's ideas about the centrality of a strategic alignment with the United States.

By 2000 and continuing through to the end of his presidency, Shevardnadze's predisposition to pursue a great power bridging alignment was on full display. With the election of President George W. Bush and Vladimir Putin in 2000, Shevardnadze believed a bifurcated alignment with both regional great powers could return maximum benefits to Georgia both internationally and domestically. Furthermore, such an approach could translate into higher levels of economic and

\footnotetext{
${ }^{634}$ Shevardnadze, Eduard. 1998a. "Shevardnadze Gives Weekly Interview.” Radio Tbilisi Network, 04 May 1998.

${ }^{635}$ Shevardnadze 1997, 3.

${ }^{636}$ Clinton, William J. 1997. Public Papers of the Presidents of the United States: William J. Clinton, 1997. Best Books On, 953.
} 
political stability for Georgia thus allowing him to remain in power. Evidence to support this conclusion is found in an April 2000 interview where Shevardnadze is quoted as saying,

I consider the talk of Georgia's "pro-Russian" or "pro-Western" policy completely pointless. Our main principle is state pragmatism, that is, defense of the legitimate interests of democratic Georgia and its multiethnic people. We are prepared to cooperate with all countries that help us resolve several fundamental problems of our state system and our democracy... ${ }^{637}$

As detailed above, Shevardnadze's operational code analysis reflects his new approach to world politics where there was a .10 tick upward in his views about the friendly nature of the political universe from 2000 to 2001.

Key events highlighting Shevardnadze's alignment preference with the United States began with a 2001 visit to Washington. During this trip, Shevardnadze offered his support for U.S.-led global counter-terrorism operations, while also making a commitment to advance the country's democratic course. According to Shevardnadze, "Georgian-American relations have proved to be clear evidence of the possibility to build friendly relations between a small country and a great state and base it on the principles of equality." ${ }^{638}$ By 2002, Shevardnadze's ideas about a strong alignment with the U.S. began to move towards one of an alliance. Citing U.S. political and military support under the Georgia Train and Equip Program (GTEP), as well as the country's participation in the Partnership for Peace program, Shevardnadze aired his aspirations for Georgia to become a future member of NATO. ${ }^{639}$

In near lock-step however, Georgia's alignment with Russia continued along a positive trajectory for several reasons. First, Shevardnadze fully understood how Georgia's accession to NATO would be a long and arduous process given the country's poor economic standing and

\footnotetext{
${ }^{637}$ Shevardnadze, Eduard. 2000a. "Reelected Shevardnadze Promises 'State Pragmatism."' Kommersant, 11 April $2000,110$.

${ }^{638}$ Shevardnadze, Eduard. 2001. “Georgia: Shevardnadze Says Relations with US Entering New Phase.” Tbilisi Georgian Radio 1, 08 October 2001.

${ }^{639}$ Shevardnadze, Eduard. 2002. "Statement by President of Georgia Eduard Shevardnadze at the EAPC Summit." NATO, 22 November 2002. https://www.nato.int/docu/speech/2002/s021122h.htm. Accessed 20 July 2016.
} 
continuing problems with secessionism. Second, Georgia's entry into NATO would be subject to the approval of all members of the alliance. Given this reality, continuing an alignment with Russia was in Shevardnadze's interests in the short and mid-terms. Finally, Shevardnadze likely believed an alignment with Russia could still return Georgia political and economic dividends. In this case, Shevardnadze's threat perceptions about Russia were at an all-time low following Moscow's closure of the Vaziani Airbase in 2001 as outlined in the 1999 Istanbul Agreement. Although Russia still retained three military bases in Georgia, the withdrawal of 1,500 Russian personnel served as a catalyst for Shevardnadze to continue a closer alignment with Russia in order to realize his long-term goals of a Georgian state free of a Russian military presence. ${ }^{640}$

President Mikheil Saakashvili. From 2004-2012, President Saakashvili perceived the Russian threat to be high and because of that, he believed a positive bandwagoning strategy with the United States and its Western European allies was the optimal approach for his ruling government. ${ }^{641}$ In order, the nature of the Russian threat was: military (e.g. Russian military bases in Georgia; fear of a direct armed attack), economic (e.g. trade ban, cut in energy supplies), diplomatic (e.g. recalling diplomats), informational (verbal threats and criticisms). These threats played a key role in shaping President Saakashvili's alignment preference with the United States and Russian Federation from 2004 to 2013.

For Saakashvili, the Russian military threat was of the highest concern representing both a short-term and long-term strategic problem. In the short-term, the continuing presence of Russian bases in Batumi and Akhalkalaki embodied a clear and present danger to the Georgian state. The short-term challenge of Russian bases was finally resolved in 2005 when Moscow and Tbilisi

\footnotetext{
${ }^{640}$ The Jamestown Foundation. 2001. "Russian Military Hands over Vaziani Base to Georgia.” The Jamestown Foundation Monitor, 03 July 2001. https://jamestown.org/program/russian-military-hands-over-vaziani-base-togeorgia/. Accessed 16 July 2016.

641 Author's analysis; Saakashvili threat perception score of 1.2 is derived from interviews with area specialists.
} 
reached an agreement whereby Russia would close both bases by the end of 2007 in exchange for a statement by President Saakashvili that Georgia would not allow any foreign military bases on its soil. ${ }^{642}$ The removal of Russian military forces from Batumi and Akhalkalaki in late 2007 tempered Saakashvili's short-term threat concerns of Russia; however, this was a fleeting moment. Less than one year later in August 2008, Saakashvili's high threat perceptions of Russia were validated following Russia’s invasion of Georgia and the Kremlin's political, economic, and military support for South Ossetia and Abkhazia.

Unlike his predecessor, Saakashvili threat perceptions of Russia had a major economic component. When Saakashvili entered office in 2004, Georgia relied on Russia for 100 percent of its natural gas supplies. ${ }^{643}$ With his ideas about the state as one aligned with the United States and the West, Saakashvili knew very well his beliefs could elicit a Russian economic backlash. $\mathrm{f}$ Moscow's willingness to use its energy supplies as weapon was seen as early as 2005 when Gazprom began raising the price of natural gas from $\$ 50$ to as high as $\$ 235$ per thousand cubic meters by $2007 .{ }^{644}$ Saakashvili's threat perceptions of Moscow were validated in January 2006 when a series of purported terrorist attacks in North Ossetia (southern Russia) severed Russian gas supplies and cut approximately 25 percent of its imported electricity to Georgia. ${ }^{645}$ Several months later, Russia banned Georgian wine and water citing quality and health concerns. ${ }^{646}$

\footnotetext{
${ }^{642}$ Nygren, Bertil. 2007. The Rebuilding of Greater Russia: Putin's Foreign Policy Towards the CIS Countries. Vol. 4. Routledge, 132-33.

${ }^{643}$ Gelb, Bernard. 2007. "Russian Natural Gas: Regional Dependence." Congressional Research Service, 05 January 2007, 3. http://www.dtic.mil/dtic/tr/fulltext/u2/a460847.pdf. Accessed 20 August 2016.

${ }^{644}$ Newnham, Randall. 2011. "Oil, Carrots, and Sticks: Russia's Energy Resources as a Foreign Policy Tool." Journal of Eurasian Studies 2 (2), 139.

${ }^{645}$ Chivers, C.J. 2006. "Explosions in Southern Russia Sever Gas Lines to Georgia." The New York Times, 23 January 2006. http://www.nytimes.com/2006/01/23/world/europe/explosions-in-southern-russia-sever-gas-lines-togeorgia.html. Accessed 21 September 2016.

${ }^{646}$ Walsh, Nick Paton. 2006. "First Wine, Now Russia Bans Georgian Water.” The Guardian, 05 May 2006. https://www.theguardian.com/world/2006/may/06/russia.nickpatonwalsh. Accessed 21 September 2016.
} 
In political circles, Russia's frequent use of coercive diplomacy served to reinforce President Saakashvili's Russian threat perceptions. For example, following the arrest of several Russian spies by Georgian authorities in September 2006, Russia recalled its ambassador from Tbilisi along with many Russian diplomats and their families from Georgia. Other Russian actions during this time included the closure of key transportation links (rail and road) to Georgia and a refusal to issue visas to Georgians traveling to Russia. ${ }^{647}$

Finally, the Russian threat also resided in the information realm where various Kremlin officials and Russian government agencies frequently portrayed Saakashvili as an inept leader, war monger, or fascist. For example, in August 2008 Russia's Ambassador to NATO, Dmitry Rogozin, referred to Saakashvili as a war criminal asserting the necessity for him to be punished for starting the 2008 war with Russia. ${ }^{648}$ Separately, in late 2008 Russian Prime Minister Vladimir Putin compared Saakashvili to Saddam Hussein and threatened to hang him by his private parts. ${ }^{649}$ The Kremlin's overarching goal with these efforts was to undermine Saakashvili's ideas about the utility of aligning with the United States and the consequences of proceeding along a Western alignment trajectory.

Given the preceding, President Saakashvili almost consistently espoused the merits of a strategic alignment with the United States. For example, during his time in office the Georgian president demonstrated a consistent preference to align with the United States over Russia than

\footnotetext{
${ }^{647}$ Dzhindzhikhashvili, Misha. 2006. "Russia Recalls Ambassador." The Washington Post, 29 September 2006. http://www.washingtonpost.com/wp-dyn/content/article/2006/09/28/AR2006092800658.html. Accessed 22 September 2016; Myers, Steve Lee. 2006. "Russia Severs Transportation Links with Georgia." The New York Times, 03 October 2006. http://www.nytimes.com/2006/10/03/world/europe/03russia.html?mtrref=www. google.com\& gwh=E755F9C82F0F7E9AA5332FE311041760\&gwt=pay. Accessed 22 September 2016.

${ }^{648}$ Kramer, Andrew and Ellen Berry. 2008. "Russia, In Accordance with Georgia, Set Withdrawal." The New York Times, 12 August 2008. http://www.nytimes.com/2008/08/13/world/europe/13georgia.html?mtrref=www.google. com\&gwh=6337FB545276FA5EB97C9CF44CDA0F2D\&gwt=pay. Accessed 22 September 2016.

${ }^{649}$ Bremner, Charles. 2008. "Vladimir Putin Threat to Hang Georgian President 'by balls." The Guardian, 15 November 2008. http://www.theaustralian.com.au/archive/news/putin-threat-to-hang-leader-by-balls/newsstory/fbf5f998da1deaf583419ad8392d4c53. Accessed 22 September 2016.
} 
what was seen with Shevardnadze or Margvelashvili. As noted in the previous chapter,

Saakashvili's average intensity of verbal cooperation with the U.S. was always higher than what was observed with Russia. An analysis of ICEWS event data on Saakashvili's level of verbal conflict with Russia also indicates the Georgian president's level of verbal conflict with Moscow was always significantly higher than what was observed with Washington. ${ }^{650}$

An analysis of Saakashvili's speeches indicates the nature of his alignment preference with the United States was most visible in the military and economic arenas. In the military sphere, President Saakashvili consistently touted Georgia's alignment with the U.S. noting how “... the Americans are our natural allies."651 Whether it was Saakashvili's support for Washington's actions in Iraq or the ongoing presence of U.S. military trainers under the GTEP, he believed Georgia represented an indispensable ally to America in Russia's borderlands.

To recap, Saakashvili's high threat perceptions of from Russia, both in the short-term and long-term was a key factor affecting his preference to align with the United States and its European allies. For Saakashvili, there was no other option. To have given in to Kremlin demands for subservience would have violated his core beliefs about where Georgia belonged on the world stage. In the end, Saakashvili saw the United States and Georgia as one. In his words, "Georgia and the United States are partners. We are allies and we are friends...."652

President Giorgi Margvelashvili. President Giorgi Margvelashvili initially perceived the Russian threat to be moderately high; however, after Kremlin intransigence on the status of South Ossetia and Abkhazia, the Georgian president perceived Russia to be a high threat. During

\footnotetext{
${ }^{650}$ Author's analysis. For his time in office, Saakashvili's levels of verbal conflict with Russia and the U.S. were 2.6 and -0.6 respectively. Like other presidents, there were fewer events detailing President Saakashvili's level of verbal conflict with the U.S. and Russia. Even though Saakashvili viewed the political universe as somewhat friendly, it is not surprising that ICEWS would register fewer conflict events for this president.

${ }^{651}$ Saakashvili, Mikheil. 2004. "Belgian Daily Interviews Georgia's Saakashvili on Relations with Russia, US." Le Soir, 08 April 2004.

${ }^{652}$ Saakashvili 2004b.
} 
his time in office, Margvelashvili perceived the U.S. threat to be low. ${ }^{653}$ As detailed in the previous chapter, Margvelashvili's level of verbal cooperation with the United States was always higher than what was observed with Russia. However, his levels of verbal conflict with Russia and the U.S. were the same with the Georgian president initially tempering his criticisms of Moscow's armed aggression against Georgia. Specifically, for the fourth quarter of 2013 (October to December) when Margvelashvili was elected and entered office, his level of verbal conflict with Russia and the U.S. registered a zero (neutral) on the CAMEO coding scheme for this time period. ${ }^{654}$

Unlike Saakashvili, who consistently preferred positive bandwagoning with the United States, Margvelashvili clearly understood the current strategic realities facing him when he entered office. On one hand, political elites in the United States and Europe, while remaining supportive of Margvelashvili's opposition to Moscow's interference in Georgian affairs, were not willing to accord Tbilisi the necessary levels of political, economic, and military backing to resolve decisively the situation in South Ossetia and Abkhazia. On the other hand, Margvelashvili realized that given his country's geographical location, a reset in Georgia's political relations with Russia was necessary at least in the short-term to re-establish the country's territorial integrity. As a result, Margvelashvili believed a tepid great power bridging strategy was an optimal course of action in the short-term, but when there was no progress with Russia, positive bandwagoning with the U.S. became his leading preference.

\footnotetext{
${ }^{653}$ Author's analysis; Margvelashvili threat perception score is derived from interviews with area specialists. ${ }^{654}$ Author's analysis. As a reminder, the intensity of an ICEWS event is measured on a cooperation-conflict continuum that mirrors the Goldstein scale used in the WEIS dataset. This scale runs from +10 to -10 where positive numbers from zero to 10 equal increasingly cooperative (verbal or material) events while observations on the negative side equate to increasingly conflictual (verbal or material) events.
} 
Margvelashvili's threat perceptions of Russia was an important shape agent leading him to initially prefer a strategy of great power bridging in late 2013. During this time, the moderatelyhigh Russian threat was best understood in military terms where the continued stationing of Russian Army units in South Ossetia and Abkhazia as well as the Kremlin's military backing of the separatist governments represented a sufficient danger to the Georgian state. Speaking in 2014, Margvelashvili threat perceptions were made clear when he stated...

The developments occur as follows: Global order is violated and the policy of the Russian Federation indicates that there are special interest areas, which includes the former Soviet Union. Naturally, this is a tension issue for us [and] we are carefully watching this and are vigilant. Is there a direct and instant danger? I have previously stated that we have no such immediate threat from the Russian Federation. However, this does not mean that there is no danger. ${ }^{655}$

President Margvelashvili also perceived an economic threat from Russia, but at a much lower level than had been observed in previous years by his predecessor since Georgia had successfully reestablished partial trade relations (e.g. export of Georgian wine and mineral water) with Moscow in 2013. An increased economic alignment with Western Europe as well as a series of energy agreements with Azerbaijan helped to temper his threat perceptions; however, a majority of the Kremlin's economic sanctions remained in place. When coupled with decreased remittances by Georgians working in Russia and the country's relatively high unemployment, Margvelashvili realized that Georgia remained in a vulnerable position. ${ }^{656}$

With the Russian threat defined in these ways, Margvelashvili believed a strategy of great power bridging was the optimal approach for Georgia going forward. A content analysis indicates that Margvelashvili's verbal pronouncements gave emphasis to a weak diplomatic alignment with Russia as a way to reestablish Georgia's territorial integrity. During his inaugural

\footnotetext{
${ }^{655}$ Margvelashvili, Giorgi. 2014. "President: Russia Poses No Immediate Threat to Georgia." Agende.ge, 22 April 2014. http://agenda.ge/news/12671/eng. Accessed 23 September 2016.

${ }^{656}$ Newnham, Randall. 2015. "Georgia on My Mind? Russian Sanctions and the End of the "Rose Revolution."” Journal of Eurasian Studies 6 (2), 168.
} 
speech Margvelashvili proclaimed, "despite the difficult situation we are facing today and in parallel with integrating into Euro-Atlantic structures, we reiterate our commitment to further dialogue with Russia and build confidence to solve the problems existing today. This dialogue will be built upon unequivocal respect for Georgia's national interests. That is respect for our internationally recognized borders and the principles of territorial integrity and sovereignty." ${ }^{657}$ According to one Georgian journalist, "there isn't more love for Putin and Russia. It's just a realization that we're left face-to-face with Russia, and we have to deal with it." ${ }^{\prime 658}$

An important point here is how because Margvelashvili perceived the Russian threat to be less severe, diplomacy with Moscow represented the best way to achieve a peaceful solution to the security and economic issues at hand. Although Margvelashvili and the politically powerful Georgian Prime Minister Bidzina Ivanishvili were able to affect an economic compromise that saw the lifting of Russia's trade ban on wine and other goods, no progress was made on resolving the status of South Ossetia and Abkhazia during 2013 and 2014. ${ }^{659}$

Despite these 'olive branch' efforts, Moscow continued to take a hardline approach to its relations with Georgia when it came to the issue on the status of the separatist provinces.

Through 2014 Kremlin leaders consistently asserted South Ossetia and Abkhazia would remain independent states, regardless of whether the international community did or did not recognize this reality. For example, Russian Foreign Minister Sergey Lavrov stated,

I can say that South Ossetia and Abkhazia are sovereign countries for Russia. We recognized their sovereignty, signed friendship and reciprocal aid agreements with them, we ensure the

\footnotetext{
${ }^{657}$ Margvelashvili 2013a, 4.

${ }^{658}$ Shaverdashvili, Shorena. 2015. Cited in Michael Birnbaum, "Spurned by the West, Georgians Look to Russia Despite Past Quarrels.” Washington Post, 04 July 2015. https://www.washingtonpost.com/world/europe/despitepast-quarrels-with-russia-georgians-are-returning-to-its-orbit/2015/07/01/40d64c24-1b49-11e5-bed81093ee58dad0_story.html?utm_term=.f2aa43313634. Accessed 07 December 2016. ${ }^{659}$ Buckley, Neil. 2013. "Georgian Wine to Flow as Russia Lifts Ban." Financial Times, 04 February 2013. https://www.ft.com/content/13269432-6ee9-11e2-9ded-00144feab49a. Accessed 23 September 2016.
} 
safety of their borders and their military safety (our military bases are there on the basis of signed agreements). These are new realities in the Transcaucasia, and we have to acknowledge them. ${ }^{660}$

Russia's staunch position on the separatist provinces continued through 2014 as Moscow bolstered its security and economic relations with Abkahzia and South Ossetia in an attempt to solidify their independence and status as a Russian satellite. The Kremlin's efforts to make this a reality were advanced in November 2014 when Abkhaz political leaders signed a collective defense agreement with the Russian Federation. ${ }^{661}$ These events taken together help shape President Margvelashvili's beliefs about how even the most tenuous alignment with Russia would not result in the realization of his government's strategic goals on Georgia's sovereignty.

It is in early 2014 one can discern an increase in Margvelashvili's threat perceptions of Russia owing to a lack of progress on the security situation in the separatist provinces. During his annual address to parliament, Margvelashvili noted how "the occupation and militarization of a part of Georgian territory increases the threat of detribalization in the South Caucasus and Black Sea regions, and therefore the Russian Federation poses a serious problem for our security." ${ }^{662}$ It is these changes in his threat perceptions that subsequently framed his tendency to align more closely with the United States and countries in Western Europe.

For the remaining two years under examination, Margvelashvili's alignment preferences were best understood as positive bandwagoning with the United States. The nature of Margvelashvili's

\footnotetext{
${ }^{660}$ Lavrov, Sergey. 2013. "Speech by the Russian Foreign Minister, Sergey Lavrov." The Ministry of Foreign Affairs of the Russian Federation. http://www.mid.ru/en/press_service/minister_speeches /-/asset_publisher/ 7OvQR5KJWVmR/content/id/85330. Accessed 20 January 2017.

${ }^{661}$ Harding, Luke. 2014. "Georgia Angered by Russia-Abkhaz Military Agreement." The Guardian, 25 November 2014. https://www.theguardian.com/world /2014/nov/25/georgia-russia-abkhazia-military-agreement-putin. Accessed 22 March 2017.

${ }^{662}$ Margvelashvili, Giorgi. 2015. "2015 Annual Report of the President of Georgia.” Official Website of the President of Georgia. https://www.president.gov.ge/en-US/prezidenti/cliuri-mokhseneba/2015-clis-saparlamentomokhseneba.aspx. Accessed 23 September 2016.
} 
alignment during this time gravitated toward one defined in military, political, and economic

terms. For example, during his annual speech to parliament in 2014, Margvelashvili stated...

In 2014, we should reinforce and strengthen the cooperation with the United States - our strategic partner. In this regard, we act within the United States-Georgia Charter on Strategic Partnership, that has not completely addressed its opportunities yet, moreover, it has even greater possibilities and prospects for further development. The cooperation in the defense sector is noticeably promoted. The U.S.-Georgia joint military trainings were conducted in Georgia several times in 2013. We also hope to enhance economic cooperation with the United States, which will open new markets and attract new investments to Georgia. ${ }^{63}$

During this time, President Margvelashvili's threat perceptions of Russia spiked to a high-level owing to Russian intransigence on South Ossetia and Abkhazia and continued Kremlin military threats if Tbilisi did not fall in line. Among the many factors shaping President Margvelashvili's ideas about the Russian threat were decisions by political elites in the breakaway provinces to sign a military treaty with Russia. These treaties formalized Russia's military presence in South Ossetia and Abkhazia, created a new Russian-led combined force, and established protocols for the provision of defense articles to Abkhaz and South Ossetian forces. ${ }^{664}$ These events, as well as Russia's illegal annexation of Crimea in 2014 and support for separatists in the Donbas, would solidify Margvelashvili's high threat perceptions of Russia going forward. ${ }^{665}$

Despite aversions from NATO to bring Georgia fully into the alliance's fold, President Margvelashvili’s alignment preferences with the U.S. and its European allies persisted. For Margvelashvili, while the door to NATO may be closed, a strategic alignment with United States could still help him to at least maintain the status quo. For example, during a visit to Washington

\footnotetext{
${ }^{663}$ Margvelashvili, Giorgi. 2014. "State of the Nation Address." Official Website of the President of Georgia, 21 February 2014. http://civil.ge/eng/article.php?id=26971\&search=president\%20state\%20of\%20nation\%20address. Accessed 23 January 2018.

${ }^{664}$ Harding 2014; Saul, Heather. 2015. "Putin Signs Deal Calling for Almost Complete Integration of South Ossetia into Russia - on Anniversary of Crimea Annexation.” The Independent Online, 19 March 2015. http://www. independent.co.uk/news/world/europe/putin-signs-deal-calling-for-almost-complete-integration-of-south-ossetiainto-russia-on-anniversary-10120690.html. Accessed 10 January 2018.

${ }^{665}$ Margvelashvili, Giorgi. 2014a. "The Processes that are Developed in this area by Russian Federation are not Leading to Further Partnership Between Nations." Official Website of the President of Georgia. https://37.46.105. 69/en/PressOffice/News?p=9178\&i=3. Accessed 10 January 2018.
} 
in 2015, Margvelashvili noted how, “...we have experienced and enjoyed United States support..., but that does not exclude intensifying and improving and enhancing GeorgianAmerican relationships, which has to happen. And this could be in many areas, in many fields, not only the areas that are linked with security or building the defensibility of our country."

To recap, this section found that when a Georgian president perceived Russia as a moderate threat, he preferred great power bridging as was the case with Eduard Shevardnadze and Giorgi Margvelashvili in late 2013 and early 2014. Second, when a president's threat perceptions of Russia were high as was the case with Mikheil Saakashvili and Giorgi Margvelashvili in 20142015, a preference for positive bandwagoning with the United States was observed.

\section{Moldova: Findings and Discussion}

In Moldova, there were no empirical observations to support realist predictions that Russia's decisive power advantages would drive senior foreign policy executives to prefer a bandwagoning alignment with Moscow out of fear or because the state had no other strategic options. This is not to say Russian military power was not an important consideration given the continued stationing of Russian military units at bases in the Trans-Dniester. However, this research project concludes this systemic condition was not the most important factor shaping the alignment preferences of Moldovan presidents. More important was how each political leader interpreted Russia's regional actions.

An examination of the relationship between Moldovan presidents' threat perceptions and their alignment preferences yielded several findings. First, all three presidents viewed the nature of the political universe in friendly terms. Second, statistical tests indicate Presidents Lucinschi and Timofti were the most similar in their master philosophical beliefs, but this association did not

\footnotetext{
${ }^{666}$ Margvelashvili, Giorgi. 2015a. "A Conversation with Giorgi Margvelashvili." Council of Foreign Relations, 29 September 2015. https://www.cfr.org/event/conversation-giorgi-margvelashvili. Accessed 23 September 2016.
} 
convey to their threat perceptions and alignment preferences. Third, Presidents Lucinschi and Voronin (after 2003) perceived Russia as a moderate threat, which was associated with a preference for great power bridging. President Timofti perceived Russia as a high threat, which was associated with his preference for positive bandwagoning with the United States. Vladimir Voronin was the only president whose threat perceptions and alignment preferences varied. During his first several years in office, Voronin perceived Russia as a low threat, which was associated with a proclivity for positive bandwagoning with Moscow. After the Kozak Memorandum debacle, Voronin's moderate threat perceptions of the Russian Federation were associated with great power bridging.

\section{The Philosophical Beliefs of Moldovan Presidents}

In the table below, an analysis of the output from Profiler Plus on the master philosophical beliefs of Presidents Lucinschi, Voronin, and Timofti indicate these political leaders were somewhat analogous in their operational codes about the nature of the political universe. First, all three generally viewed the nature of international system as friendly with some minor variation.

Table 15: The Philosophical Beliefs of Moldovan Presidents

\begin{tabular}{|c|c|c|c|c|c|c|c|c|c|c|c|c|c|c|c|c|c|c|c|c|}
\hline \multirow[b]{2}{*}{$\begin{array}{l}\text { Philosophical Beliefs / } \\
\text { Year }\end{array}$} & \multicolumn{5}{|c|}{ Petru Lucinschi } & \multicolumn{10}{|c|}{ Vladimir Voronin } & \multicolumn{5}{|c|}{ Nicolae Timofti } \\
\hline & 1997 & 1998 & 1999 & 2000 & AVG & 2001 & 2002 & 2003 & 2004 & 2005 & 2006 & 2007 & 2008 & 2009 & AVG & 2012 & 2013 & 2014 & 2015 & AVG \\
\hline $\begin{array}{l}\text { P-1: The Nature of the } \\
\text { Political Universe }\end{array}$ & 0.46 & 0.48 & 0.60 & 0.48 & 0.51 & 0.55 & 0.40 & 0.40 & 0.40 & 0.39 & 0.34 & 0.55 & 0.44 & 0.45 & 0.44 & 0.58 & 0.56 & 0.67 & 0.36 & 0.54 \\
\hline $\begin{array}{l}\text { P-2: Prospects for Realizing } \\
\text { Fundamental Values }\end{array}$ & 0.23 & 0.26 & 0.32 & 0.25 & 0.27 & 0.28 & 0.18 & 0.26 & 0.21 & 0.20 & 0.16 & 0.35 & 0.18 & 0.27 & 0.23 & 0.35 & 0.32 & 0.40 & 0.20 & 0.32 \\
\hline $\begin{array}{l}\text { P-3: Predictability of the } \\
\text { Political Universe }\end{array}$ & 0.15 & 0.12 & 0.16 & 0.15 & 0.15 & 0.12 & 0.13 & 0.09 & 0.10 & 0.10 & 0.09 & 0.07 & 0.12 & 0.11 & 0.10 & 0.10 & 0.13 & 0.13 & 0.07 & 0.11 \\
\hline $\begin{array}{l}\text { P-4: Control Over Historical } \\
\text { Development }\end{array}$ & 0.23 & 0.25 & 0.31 & 0.31 & 0.28 & 0.29 & 0.28 & 0.24 & 0.20 & 0.27 & 0.28 & 0.27 & 0.32 & 0.24 & 0.27 & 0.36 & 0.35 & 0.30 & 0.30 & 0.33 \\
\hline P-5: Role of Chance & 0.97 & 0.97 & 0.95 & 0.95 & 0.96 & 0.97 & 0.96 & 0.98 & 0.98 & 0.97 & 0.97 & 0.98 & 0.96 & 0.97 & 0.97 & 0.96 & 0.95 & 0.96 & 0.98 & 0.96 \\
\hline
\end{tabular}

Beginning with the master belief category (P-1), Presidents Lucinschi and Timofti viewed the nature of the political universe as definitely friendly with the latter registering the higher score of .54 as compared to the former's .51 score. On the other hand, President Voronin retained a 
somewhat friendly view of the political universe across the P-1 index (.44) ${ }^{667}$ This pattern continued across the P-2 index where both Lucinschi (.27) and Timofti (.32) outperformed Voronin (.23) by retaining a higher degree of optimism about the prospects for realizing their fundamental values.

When examining each president's beliefs about the predictability of the political universe (P3), all three generally viewed the strategic environment with a high degree of uncertainty and unpredictability registering scores of .15 or less. Each presidents' beliefs about control over historical developments (P-4) were also similar with Lucinschi, Voronin, and Timofti scoring $.28, .27$, and .33 respectively in this category. These similar scores suggest each of the Moldovan presidents believed control over events in world politics resides with other states. Finally, all three presidents believed the role of chance (P-5) was a very important factor in political outcomes. The high scores of all three presidents in this category is logical, given their low scores about the predictability of the world politics and their control over historical developments. For these presidents, because they believe they have less control in an unpredictable world, the role of chance in shaping political outcomes is higher.

\section{$\underline{\text { Validating Convergence and Divergence }}$}

The preceding analysis helps establish a frame of reference about the philosophical beliefs for Presidents Lucinschi, Voronin, and Timofti. From one perspective, there appears to be some variation in their master philosophical beliefs; however, whether these differences are statistically significant needs to be discerned. As depicted in the table below, an ANOVA test invalidates the null hypothesis that there are no statistically significant differences in the

\footnotetext{
${ }^{667}$ A political leader's master philosophical beliefs (P-1) are measured in the following way: $(-1=$ very hostile; -.50 $=$ definitely hostile; $-.25=$ somewhat hostile; $0.0=$ mixed; $+.25=$ somewhat friendly; $+.50=$ definitely friendly; $+.75=$ very friendly).
} 
philosophical beliefs of the three Moldovan presidents. The alternative hypothesis that a statistically significant difference exists is validated at the .01 level.

The ANOVA test below demonstrated there are differences in the master beliefs of the Moldovan presidents; however, where those differences exist is still not apparent. In Table 17, the results of a Tukey's HSD test reveal Presidents Lucinschi and Timofti retain the most similar beliefs about the nature of the political universe with an adjusted P-value of 0.29.

Table 16: ANOVA Results - Moldovan Presidents Philosophical Beliefs

\begin{tabular}{c|ccccc}
\hline & & Sum of Squares & $d f$ & Mean Square & F \\
\hline \multirow{2}{*}{ P-1 } & $\begin{array}{l}\text { Between } \\
\text { Groups }\end{array}$ & .069679 & 2 & 0.034840 & $8.1611^{* *}$ \\
& $\begin{array}{l}\text { Within } \\
\text { Groups }\end{array}$ & .060097 & 19 & 0.004293 & \\
\hline **prob <.01 & & & & & \\
\hline
\end{tabular}

Table 17: Moldova - Mean Comparisons of Tukey's HSD Test Results (P-1)

\begin{tabular}{l|cccc}
\hline \multicolumn{1}{c|}{ Pair } & Difference & Lower Bound & Upper Bound & Adjusted P-Value \\
\hline $\begin{array}{l}\text { Timofti- } \\
\text { Lucinschi }\end{array}$ & 0.07250000 & -0.04875466 & 0.19375466 & 0.2925341 \\
$\begin{array}{l}\text { Voronin- } \\
\text { Lucinschi }\end{array}$ & -0.08194444 & -0.18499109 & 0.02110221 & 0.1298146 \\
Voronin- & -0.15444444 & -0.25749109 & -0.05139779 & 0.0040897 \\
Timofti & & & & \\
\hline
\end{tabular}

95\% Family-wise Confidence Level 


\section{Moldovan President Threat Perceptions and State Alignment}

For the period 1997-2015, the combined average of Presidents Lucinschi, Voronin, and Timofti's perceptions of the Russian threat were moderately low. ${ }^{668}$ Presidents Lucinschi and Voronin (after 2003) perceived Russia as a moderate threat, while Timofti held ideas that Russia was a high threat to Moldova. With respect to variation in threat perceptions, Lucinschi and Timofti's threat perceptions of Russia remained stable while in office; however, Vladimir Voronin's perceptions experienced some volatility. During his first several years in office, Voronin perceived Russia as a low threat, but after Kremlin elites attempted to force an unfavorable Trans-Dniester peace agreement on Chisinau, Voronin's threat perceptions of Russia increased to moderate. Separately, Presidents Lucinschi and Timofti's threat perceptions of Washington were low while President Voronin viewed the United States as a moderately low threat. For each president, the Russian threat came in three forms: military, economic, and/or political/diplomatic.

When examining the associations between threat and alignment preferences, Voronin's low threat perception of Russia was associated with a predilection for positive bandwagoning with Moscow. When Voronin's threat perceptions of Russia increased to moderately low, he saw higher value in great power bridging. In a similar fashion, President Lucinschi's moderately low threat perceptions were also associated with a preference for great power bridging. Finally, President Timofti's high threat perception of Russia was associated with a preference for positive bandwagoning with the United States. In the proceeding paragraphs, an analysis of the

\footnotetext{
${ }^{668}$ Author's analysis. The assessed scores from area experts were as follows: Lucinschi (2.4); Voronin (2.1); Timofti (1.5); combined average was 2 . As a reminder, the intensity of a president's threat perceptions were measured in the following way: 1-1.5 (high); 1.6-2.0 (moderately high); 2.1-2.5 (moderately low); 2.6-3 (low).
} 
relationship between Moldovan presidential threat perceptions and each president's alignment preferences are detailed.

President Petru Lucinschi. For his time in office, President Petru Lucinschi viewed Russia as the primary external threat to the state and the country's territorial security. During his four years in office, President Lucinschi perceived Russia as a moderately-low threat. A qualitative analysis of Lucinschi's verbal pronouncements indicate his ideas about the Russian threat were associated with a preference for great power bridging. Although the ICEWS event data set reveal Lucinschi's level of verbal conflict with Russia was higher than what was observed with the United States, analyzing the data from speeches and area experts indicates he preferred to align with both the U.S. and its European allies as well as Russia. By doing so would help him restore Moldova's territorial integrity and improve the country's economy. ${ }^{669}$ Several key points support these assertions.

First, upon entering office, Lucinschi's moderately-low threat perceptions of Russia were framed, in part, by his beliefs Russia had been and would remain the state's most important strategic partner. This was most readily seen in Lucinschi's ideas about the state's top security priorities: achieving a peaceful resolution to the separatist movement in the Trans-Dniester and the removal of Russian military forces in Moldova. In his January 1997 inaugural speech, Lucinschi asserted,

Normalization of the situation in Dniester is one of first-priority tasks to fulfill. I count very much on Russia's support in extinguishing this hotbed of tension in Europe. This may well serve an example of how external policy should be conducted by a great state. Another important factor for the conflict's final settlement would be the withdrawal of Russian troops from our territory in accordance with the known bilateral agreement. ${ }^{670}$

\footnotetext{
${ }^{669}$ Author's analysis. As noted in Chapter Five, there is a gap in the ICEWS dataset for events related to President Lucinschi's verbal cooperation with the United States. There are also gaps with events detailing his verbal conflict with the U.S. and Russia. As a result, increased weighting is given to the data collected from elite interviews and a qualitative analysis of the Lucinschi's speeches and secondary sources.

${ }^{670}$ Lucinschi, Petru. 1997e. "New President Delivers Inaugural Speech.” Infotag, 15 January 1997.
} 
With his extensive network of personal relations to political figures in the Kremlin stemming from his time as Moldova's ambassador to Moscow, Lucinschi likely believed a closer alignment with Russia would help him to realize these foreign policy goals. ${ }^{671}$

Second, over the course of his presidency, Lucinschi's frequently expressed a preference for developing a closer economic and political alignment with countries in the West, to include the United States. For Lucinschi, such alignments would help Chisinau to implement economic and democratic reforms. ${ }^{672}$ However, Lucinschi's ideas about a military alignment with the United States was much less emphasized. While Lucinschi was open to routine military activities with the U.S. via NATO, Chisinau only worked with both actors via the Partnership for Peace Program. A key factor shaping his alignment actions in this case was Moldova's constitution, which stipulated the country would remain neutral in world affairs. By highlighting the country's neutrality, Lucinschi sought to avoid a potential Russian backlash that could exacerbate tensions in the Trans-Dniester or elicit negative political or economic pressure on his government. ${ }^{673}$

Through the end of presidency, Lucinschi's great power bridging preference came into clearer perspective where an analysis of Lucinschi's verbal statements during these years indicate his tendency to align with the U.S. and Russia on an almost equal basis. Beginning in 1999, Lucinschi appeared to give some emphasis to fostering a strong alignment with the United States. Now in his third year of office, Lucinschi had grown frustrated with Moscow and the lack of progress on a resolution of the Trans-Dniester issue. While Russian leaders continued to talk

\footnotetext{
${ }^{671}$ From 1991 to 1992, Lucinschi was the senior scientific collaborator at the Institute for Social-Political Research of the Russian Academy of Sciences in Moscow. From 1992 to 1993, he was Moldova's ambassador to Russia. In December 1996, during an interview on Russian television, Lucinschi went to great lengths to emphasize how his personal and professional contacts in Moscow would help him to realize his domestic and international goals. See Petru Lucinschi's professional biography at http://www.presedinte.md/eng/petru-lucinschi and Lucinschi, Petru. 1996. "New President Lucinschi Interviewed." Moscow NTV, 03 December 1996.

${ }^{672}$ Lucinschi, Petru. 1997. "Lucinschi Reaffirms Independence, Sovereignty, Neutrality." Itar-Tass, 15 January 1997.

${ }^{673}$ Lucinschi, Petru. 1997a. “Lucinschi on Dniester Issues, GUUAM.” Interfax, 18 November 1999.
} 
about achieving a balanced compromise, Lucinschi began to realize the Kremlin's preference for maintaining the status quo in the Trans-Dniester as a way to keep Moldova in Russia's orbit. For example, during a meeting with Lucinschi, Russian President Vladimir Putin emphasized how "Russia is interested that Moldova be a sovereign, independent and territorially integral state..." the status of Trans-Dniester cannot be fully realized "....without counting the interests of all groups in society, including Transdnistria's residents." ${ }^{" 674}$ This strategic reality helped shape Lucinschi's ideas about aligning with other regional great powers in order to help manage the Trans-Dniester issue.

Second, following the collapse of the Russian economy in 1998, Kremlin leaders began to focus more on internal political-economic priorities giving less emphasis to foreign policy issues. During this window of Moscow's inattentiveness, Lucinschi believed bolstering a political and economic alignment with the United States could return several short-term gains for Moldova. In the political sphere, a closer alignment with the United States would help Lucinschi manage the challenges in the Trans-Dniester. On the economic front, the Moldovan leader still believed a closer alignment with Washington could help the country's struggling economy, which was hit particularly hard by the Russian economic crisis. Lucinschi's efforts to foster a closer alignment with the United States subsequently equated to an increase in economic assistance. Specifically, U.S. foreign assistance to Moldova increased from \$33 million in 1998 to \$45 million in 1999 and $\$ 50$ million in $2000 .{ }^{675}$ It is on this point that one can begin to see how systemic conditions (e.g. collapse of Russia's economy) can impact a president's ideas and beliefs. While events in

\footnotetext{
${ }^{674}$ Baleanu, Virgil George. 2000. "In the Shadow of Russia: Romania's Relations with Moldova and Ukraine." Conflict Studies Research Centre. Royal Military Academy Sandhurst, 13.

675 Tarnoff, Curt. 2002. "US Assistance to the Former Soviet Union, 1991-2001: A History of Administration and Congressional Action." Congressional Research Service, 15 January 2002, 58.
} 
the international system are important, what is more important is how individual political leaders perceive these happenings and the subsequent actions they take to realize their goals.

In the military sphere, Russia's stubbornness on facilitating a Trans-Dniester resolution shaped Lucinschi ideas about Washington's potential role on this issue. For example, as a lead agent in the OSCE, the United States, in concert with other OSCE members, facilitated an agreement requiring Russia to withdraw all of its military forces from Moldova by $2002 .{ }^{676}$ As part of this effort, in May 1999 the Washington offered Chisinau a \$30 million grant as part of a Russian-led effort to remove weapons stockpiles and military equipment in Trans-Dniester. ${ }^{677}$

Coinciding with Lucinschi's preferences to align with the United States and Kremlin footdragging on the Trans-Dniester issue, as well as the removal of arms from this region, the Moldovan president's threat perceptions of Russia remained stable. Furthermore, President Lucinschi continued to espouse the necessity for the state to continue an alignment with Russia. For example, in 2000 during President Putin's visit to Chisinau, the Moldovan president emphasized the high value of Russia to the Moldovan state. In his words... "Russia is our strategic partner - it is our biggest trade and economic partner and many of our people have personal ties with Russia." ${ }^{678}$ Lucinschi subsequently highlighted Russia's central role as "the guarantor and intermediary in the solution of the Trans-Dniester conflict and a host of other problems, including the set of economic problems." ${ }^{679}$ Taken together, while Lucinschi may

\footnotetext{
${ }^{676}$ Perina, Rudolf, William Hill, Ceslav Ciobanu, Craig Dunkerley, and Charles King. 2002. "The 1999 OSCE Istanbul Summit Decisions on Moldova and Georgia: Prospects for Implementation.” Woodrow Wilson International Center for Scholars, December 2002, 6. https://www.wilsoncenter.org/sites/default/files/op284 _1999_osce_instanbul_summit_conference_2002.pdf. Accessed 21 October 2016.

${ }_{677}$ Quinlan, 2002, 94.

${ }^{678}$ Lucinschi, Petru. 2000. "News Conference on the Results of the Russian-Moldovan Talks." President of Russia Website, June 17, 2000. http://en.kremlin.ru/events/president/transcripts/24217. Accessed 21 October 2016. ${ }^{679}$ Ibid.
} 
have given increased emphasis to aligning with the United States and Europe, Russia would continue to remain of central importance to him and the realization of his strategic objectives. President Vladimir Voronin. From 2001 to 2009, President Voronin viewed Russia as the primary external threat to the state and the country's territorial security. For his two terms in office, Voronin perceived Russia as a moderately-low threat. ${ }^{680}$ When considering variation, during his first two and half years in office (April 2001- November 2003) the Moldovan president perceived the Russian threat as low moving to moderately low from 2004 to 2009. Separately, Voronin perceived the United States to be a moderately low threat during his presidency. Unlike other research endeavors, which have concluded Voronin's alignment trajectory was either pro-Russian or pro-West, this study finds Voronin first preferred positive bandwagoning with Russia, which then gave way to one of great power bridging with the Washington and Moscow. The paragraphs below provide evidence to support this conclusion.

After entering office, the extent to which Voronin did not view Russia as a threat was made clear when he and his communist party sought a closer political and economic alignment with Russia. For example, within days of taking office, Voronin was in Moscow meeting with senior Kremlin leaders. During his visit with President Putin, Voronin signed a new Treaty of Friendship and Cooperation going so far as to entertain the idea of joining the Belarus-Russia economic union. According to Voronin, "our first steps will be towards economic integration not only with the Russia-Belarus Union but with the Eurasian community of the CIS memberstates. ${ }^{681}$ For Voronin, establishing an alignment with Russia was based, in part, on his beliefs

\footnotetext{
${ }^{680}$ Interviews on file with author. Voronin's threat perceptions of Russia averaged 2.0 making this regional great power a moderately low threat.

${ }^{681}$ Voronin 2001a, 1.
} 
that Moscow was the key to resolving the separatist movement in the Trans-Dniester and for improving Moldova's economy.

In 2002, President Voronin's low threat perceptions of Russia and preference for positive bandwagoning with Russia continued unabated. An analysis of his verbal pronouncements indicated the Moldovan president's top foreign policy priority was a strategic alignment with Moscow. In November 2002, Voronin touted how a close political alignment with Russia had elicited strong support from Kremlin elites on upholding Moldova's territorial sovereignty resulting in progress to bring about an enduring solution to the Trans-Dniester stalemate. In the economic sphere, Voronin even made several public statements that he would consider the merits of Moldova joining the Eurasian Economic Union as a way to further align the state with Russia and improve the country's economy. ${ }^{682}$ According to Voronin, "a strategic partnership with Russia is necessary, above all, to promote the welfare of the Moldovan people." 683

President Voronin's low threat perceptions of Russia continued throughout much of 2003. In July, Voronin declared Moldova's alignment with Russia had resulted in significant improvement in all areas ranging from trade and investment to cultural and humanitarian topics. ${ }^{684}$ His preference for a positive bandwagoning alignment with Russia intensified in the late summer as Chisinau and Moscow hashed out a political compromise for Moldova's separatist regions. By mid-November, Voronin himself had verbally agreed to a Russian political compromise developed by Russia's special envoy Dmitri Kozak. Known as the 'Kozak Memorandum," this agreement allowed Russia to continue its stationing of military forces in

\footnotetext{
${ }^{682}$ Demidetsky, Valery. 2002. "Moldova Willing to join Eurasian Economic Community." Itar-Tass, 09 October 2002.

${ }^{683}$ Voronin, Vladimir. 2002a. "President Voronin: Partnership with Russia necessary for Moldova's Prosperity." Itar-Tass, 19 November 2002.

${ }^{684}$ Voronin, Vladimir. 2003a. "Moldovan Leader Pleased with Ties with Neighboring Countries." Infotag, 30 July 2003.
} 
Moldova for 30 years. Voronin's support for this agreement was based on a condition that "extending the Russian peacekeeping mission [would occur] if stabilization forces involved units from European Union, the OSCE in Europe, and Ukraine" ${ }^{685}$ were also involved.

November 2003 represented a critical juncture that would witness a marked increase in Voronin's threat perceptions of Russia and a transition in his alignment preferences from positive bandwagoning to great power bridging. Specifically, as conditions of the Kozak Memorandum continued to change and as these updates yielded more political power to leaders in Transnistria and Gagauzia, President Voronin ultimately rejected the agreement. For example, one of the last versions of the memorandum allowed Transnistria and Gagauzia to retain their independent governments, veto international treaties, receive disproportionate representation in the upper house, and secede if Moldova joined the EU. ${ }^{686}$ As will be detailed in the next chapter, domestic politics was certainly an important component in Voronin's rejection; however, he too realized the Kremlin's ill-intentions. Speaking in December 2003, he claimed...

The rules of the game were changed at the last moment. New formulations on which the Dniester region insisted appeared. Initially, they were in none of these documents. We keep 18 different versions of the memorandum for the record. But new points appeared. You know, it is impossible in high-level politics to build a house on sand or on such a principle as mistrust. And when absolutely new cards started to be pulled out of sleeves during the last days, the last evening or the last night, of course we could not sign such a document. This was the most dangerous, therefore I could not accept this despite anything. ${ }^{687}$

Beginning in 2004 and continuing through 2006, Voronin's threat perceptions of Russia became moderately high as the Kremlin increased its political and economic pressure against Chisinau. Voronin's higher threat perceptions of Russia during this time are best characterized in military and economic terms. First, Moscow's continued military presence in the Trans-Dniester

\footnotetext{
${ }^{685}$ Voronin, Vladimir. 2003. "Moldova: Voronin says Transdnestria Needs Peacekeepers for Transitional Period." Interfax, 21 November 2003.

${ }^{686}$ Cantir and Kennedy 2015, 403.

${ }^{687}$ Voronin, Vladimir. 2003c. "Moldovan President Sums Up Work in 2003." Moldova TV, 29 December 2003.
} 
represented a source of friction and instability in Moldova. In May 2004 at the NATO summit in Istanbul, Voronin for the first time publicly called for the removal of Russian forces from Moldova in accordance with the 1999 Istanbul Agreement. ${ }^{688}$ Later that year, Voronin was highly critical of the Kremlin on this issue asserting, "what could be the reason for preserving Russia's presence in Moldova, especially taking into account its symbolic scale? Are we capable of being friends with Moscow only under the threat of a thousand Russian gunmen? Or maybe these soldiers are resolving Russia's global strategic tasks in the Balkans?" 689 At issue was how Russia's military forces in Moldova served to embolden political leaders in the Trans-Dniester to continue along the road of separatism.

Second, in early 2005 MPs in the Russian Duma tabled a discussion on implementing economic sanctions against Chisinau, which included cuts in energy supplies and a ban on certain imports from Moldova. By early 2006, the Kremlin took action enacting a series of economic sanctions on Moldova, which included a ban on wine imports, various meats, fruits and vegetables. The Kremlin's decision was significant given how 80 percent of Moldovan wine was sold to Russia, which made up nearly 30 percent of the country’s GDP. ${ }^{690}$ Although Moscow lifted its sanctions in 2007, this event served as a lasting example of how the economic threat from Russia would remain front and center in the years ahead.

Voronin's growing mistrust of Moscow and its long-term strategic intentions in Moldova, coupled with his ideas about how Euro-Atlantic countries could help him realize his foreign policy goals, caused the Moldovan president's alignment preferences to gravitate toward great

\footnotetext{
${ }^{688}$ Gribincea, Mihai. "Russian Troops in Transnistria - a Threat to the Security of the Republic of Moldova. Moldova.org. "http://www.moldova.org/en/russian-troops-in-transnistria-a-threat-to-the-security-of-the-republic-ofmoldova-20998-eng/. Accessed 01 December 2016.

${ }^{689}$ Voronin, Vladimir. 2004a. "Moldovan President Calls Russian Military Presence 'Humiliating."' Interfax 11 December 2004.

${ }^{690}$ Karmanu, Yaras. 2006. "Russia Ending Ban on Moldovan Products.” The Associated Press, 28 November 2006. http://www.washingtonpost.com/wp-dyn/content/article/2006/11/28/AR2006112801119.html.
} 
power bridging. From 2004 forward, Voronin frequently espoused the merits of a strategic alignment with the United States as well. For example, in 2004 Voronin sent a message to President George W. Bush’s Voronin stating, “...the development and deepening of partnership, and cooperation and friendly relations with the United States will continue to remain a priority for my country in future. We would also like to express our deep gratitude for... the technical assistance offered to Moldova to implement social and economic reforms. The United States will remain a leader in building a fairer, more prosperous and stable world, a world based on democratic values and equality between states." 991

Voronin also preferred a closer military alignment with the United States. For example, Voronin's verbal pronouncements helped characterize him as a strong proponent of U.S. military and/or NATO operations in Afghanistan and Iraq. Separately, Voronin expressed how Chisinau's military alignment with Washington via Moldova's participation in U.S. and NATO military exercises would strengthen the country's security. ${ }^{692}$ But Voronin's military alignment with the United States and NATO had its limits, where at no time was there a vision of Moldova becoming a member of NATO. Speaking in 2006, Voronin's ideas about a military alignment with NATO and its relationship with Russia brought clarity to his alignment preferences.

As far as the present authority and ruling majority are concerned, we do not have any phobias with respect to NATO. Our level of cooperation with NATO is not as great as that of Russia, of course. Yet it enables us to resolve a whole host of purely civilian problems, from scientific projects to programs for the elimination of missile fuel and anti-personnel mines remaining from Soviet times. But we do not intend to join NATO. ${ }^{693}$

\footnotetext{
${ }^{691}$ Voronin 2004b, 2.

${ }^{692}$ Interview on file with author; Voronin, Vladimir. 2005a. “Opening Statements by Secretary General, Jaap de Hoop Scheffer and H.E. Mr. Vladimir Voronin, President of Moldova.” NATO Online Library, 07 June 2005. https:// www.nato.int/docu/speech/2005/s050607b.htm. Accessed 22 January 2018.

${ }^{693}$ Voronin, Vladimir. 2006. "President of Moldova Discusses Perceived Deterioration of Relations Between Moldova and Russia.” Nezavisimaya Gazeta, 07 April 2006.
} 
As noted in the quote above, although Voronin had given increased emphasis to his alignment preferences with the United States and other Western countries, Russia was still a part of his alignment equation albeit at a lesser intensity than what was seen during his first years in office. For example, in 2004 and 2005 President Voronin frequently made public statements noting how Chisinau's relations with Moscow remained in good standing, despite the suspension of negotiations on the status of Trans-Dniester following his refusal to sign the Kozak Memorandum. In 2004, Voronin stated, "friendly relations with Russia are a historical factor and a tradition of our nations spanning many centuries." ${ }^{994}$ The following year, Voronin then proclaimed it was not necessary to restore Moldova's alignment with Russia because “...they were not interrupted... We have no problems with Russia. ${ }^{695}$ " The point here is that Voronin still believed the state's political and economic alignment with Russia remained strong and in good order despite several minor setbacks.

By 2007 and continuing through the end of his presidency, Voronin's perceptions of the Russian threat appeared to temper gravitating towards moderately low. It is during this time one can still discern his preference for a great power bridging alignment with Russia and the United States with the former being given increased preference. With respect to the Trans-Dniester, Voronin's frustration with the inability of the United States and EU to spur the five primary actors towards a meaningful solution served to reinvigorate the Moldovan president's ideas that Russia remained the most important participant on this issue. Additionally, Voronin began to exhibit a high degree of disappointment over U.S. and EU investment in Moldova. ${ }^{696}$

\footnotetext{
${ }^{694}$ Voronin, Vladimir. 2004. "Moldovan Leader Says Relations with Russia Improved Despite No Dniester Solution." Infotag, 07 July 2004.

${ }^{695}$ Voronin, Vladimir. 2005. "Moldovan President Refutes Reports of Deteriorating Relations with Russia." Infotag, 13 April 2005.

${ }^{696}$ Socor, Vladmir. 2007. “Is Moldova's President Dropping the European Banner?” Eurasia Daily Monitor, 4 (127). https://jamestown.org/program/is-moldovas-president-dropping-the-european-banner/. Accessed 03 December 2016.
} 
One of the most significant events helping validate Voronin's lower threat perceptions of Russia and the state's closer alignment with Moscow occurred in 2008. After a series of highlevel meetings in the early part of that year, Chisinau agreed to maintain its policy of neutrality and eschew any ideas of joining NATO in exchange for a stronger political commitment by Kremlin leaders to resolve the Trans-Dniester deadlock. Although Russia's invasion of Georgia in August may have been a cause of concern for Voronin, it does not appear they were decisive. Capping his commitment to a strong alignment with the Russian Federation across various issues, Voronin during his last year in office declared,

A friend in need is a friend indeed. We are particularly grateful for the personal position of the Russian president and the Russian Foreign Ministry who so actively supported our statehood in one of the most critical moments in its history. I am talking about their support for the statehood rather than to any separate political force. ${ }^{697}$

In 2009, a minor downtick in Voronin's alignment with the United States was also noted. One potential explanation stems from Moldova's political crisis whereby Voronin likely believed Moscow, more so than Washington, would be able to provide the necessary backing for him and his communist party to stay in power. Evidence to support this assertion was seen in a May 2009 interview where, when queried about his relations with Moscow after the April 2009 elections, Voronin “....wished to thank Russian President Dmitri Medvedev for the attention and concern he personally showed during those tense days. He [Medvedev] fully supported and understood the measures we undertook during those days. I believe that only such attitude and interest prove that our relations are very stable, solid and have great prospects." ${ }^{698}$

\footnotetext{
${ }^{697}$ Voronin, Vladimir. 2009a. "Voronin Thanks Russia for Support of Moldovan Statehood.” Itar-Tass, 21 June 2009.

${ }^{698}$ Voronin, Vladimir. 2009. "Moldovan President Comments on Political Crisis, ties with Romania, Russia." Ekho Moskvy Online, 24 May 2009; interviews with area experts also support this assertion.
} 
In sum, over the course of his presidency, Vladimir Voronin exhibited both forms of alignment as conceptualized by this study. During his first 30 months in office, Voronin's low threat perceptions of Russia was associated with a positive bandwagoning preference with this regional great power. In the wake of the Kozak Memorandum debacle, beginning in 2004 Voronin perceived Russia as a moderately low threat, which was associated with a preference for great power bridging.

President Nicolae Timofti. From 2012 to 2015, President Timofti viewed Russia as the primary short- and long-term threat to the state and country. During the four years under examination, Timofti perceived Russia to be a high threat to Moldova. From Timofti's perspective, the nature of this threat was primarily economic (e.g. sanctions) and military (e.g. Russia's armed forces in the Trans-Dniester). With the United States, Timofti's threat perceptions were low owing to his beliefs Washington and its influence in Western Europe could play an important role in the country's economic development and the resolution of the ongoing Trans-Dniester problem. ${ }^{699}$

As graphically illustrated in the preceding chapter, Timofti's alignment preferences indicated he preferred a positive bandwagoning alignment with the United States as his level of verbal cooperation with Washington was consistently higher than what was observed with Moscow. An analysis of ICEWS event data indicated President Timofti consistently espoused a higher level of verbal conflict with Russia over the United States. ${ }^{700}$ Timofti's high threat perceptions of Russia remained stable during his time in office, which was associated with a positive bandwagoning preference with the United States.

\footnotetext{
${ }^{699}$ Author's analysis; interviews on file with author.

${ }^{700}$ Author's analysis. The total number of events detailing President Timofti level of verbal conflict were, in general, few in number. The ICEWS event data set registered conflictual verbal events with Russia but none with the U.S.
} 
In examining Nicolae Timofti’s foreign policy speeches, it initially appeared the Moldovan president believed the threat from Russia was a moderate one and that a great power bridging alignment was in order. For example, in a speech prior to the March 2012 presidential elections, Timofti's foreign policy discourse appear to reflect a preference for aligning Moldova with multiple great power powers. According to Timofti, because Moldova is a small country...

...it is doomed to make a wise policy. Our country should continue to build good relations with of strategic partnership with Russia, the USA, Germany and other states for the benefit of people. Moldova should efficiently use its strategic geographical position, all the opportunities provided by regional cooperation mechanisms to get maximum benefits. ${ }^{701}$

Although Timofti may have initially viewed political relations with Moscow in an optimistic way, his ideas about charting an alignment with the countries in the West, to include the United States became a centerpiece of his foreign policy agenda. Although Timofti still sought to maintain good relations with Russia, especially on resolving the Trans-Dniester issue, such relations appeared to be of secondary importance. Speaking several months after his inauguration, one can gather how Timofti's threat perceptions may have influenced this Moldovan president's alignment preferences.

We [Moldova] will maintain and continue to develop our relations with Russia, for the benefit of both parties, not just for the benefit of one side. I regret to say we give in a lot in our relations with Russia. Very often, this happens under the pretext they will stop the gas supply. However, we do not get gas for free. We pay the highest price for it. This is Russia's policy in the case of countries that have no alternative. This is why we are analyzing and exploring other directions, trying to find an alternative solution to energy problems. ${ }^{702}$

Moscow's potential to employ punitive economic and military actions would help solidify Timofti's beliefs about the high threat from Russia and the necessity to align with the West. For example, in late 2013 Moscow imposed an import ban on the Moldovan wines in what some

\footnotetext{
701 Timofti, Nicolae. 2012. "Moldova's New President Outlines Priorities." Publika TV, 16 March 2012.

702 Timofti, Nicolae. 2012c. "Timofti Interviewed on Moldova's Relations With EU, Russia, Poland." Radio Chisinau, 01 December 2012.
} 
analysts concluded was a response to Chisinau's ongoing collaboration with the EU under the

Eastern Partnership Program. In response to Russia’s actions, Timofti stated,

The Russian side's actions represent an unfriendly, non-Christian, disloyal act. I do not know the true reason of this decision - it is either about wine quality or a coincidence with the nearing of the Eastern Partnership Summit in Vilnius. If Russia resorts to such levers for Moldova to be with the Russian Federation, it is their business. Therefore, we will take actions to have alternative sources of gas, as well as other sales markets. We cannot depend on one single partner. ${ }^{703}$

The economic threat from Russia intensified after Moldova signed an EU Association

Agreement in June 2014. This time, the Kremlin's economic backlash included a ban on

Moldovan wine, processed pork, canned vegetables, and fruits. Additionally, Russia also revoked

a provision of the 2011 Russia-Moldova Trade Agreement that provided Chisinau an exemption

on trade duties for commodities in 19 different categories. ${ }^{704}$ Timofti attempted to temper

Russian concerns over his preference for an economic alignment with the West noting how "the signing of the Moldova-EU free trade agreement does not hamper relations with CIS countries.

On the contrary, these two economic spaces, the EU and the CIS, complement each other."705

However, his words did little to change Moscow’s approach. On a positive note, the overall economic threat from Russia appeared to diminish somewhat for Timofti, given the ability of Moldovan companies to find alternate markets for its goods. ${ }^{706}$ In light of these developments, Chisinau still conducted routine economic activities with Russia in other areas not affected by Moscow's trade ban.

\footnotetext{
703 Timofti, Nicolae. 2013b. "Russia’s Actions Represent an Unfriendly Act.” President of Moldova Website. http:// www.presedinte.md/eng/comunicate-de-presa/nicolae-timofti-actiunile-rusiei-reprezinta-un-act-neprietenesc. Accessed 02 January 2017.

${ }^{704}$ Cenusa, Denis, Michael Emerson, Tamara Kovziridse and Veronika Movchan. 2014. "Russia's Punitive Trade Policy Measures Towards Ukraine, Moldova and Georgia." CEPS Working Document No. 400, 5-6.

705 Timofti, Nicolae. 2014a. "Moldovan Leader Comments on Ties with NATO, Dniester, Russian Embargo." Infotag, 01 April 2014.

706 Calus, Kamil. 2014. "Russian Sanctions against Moldova. Minor effects, Major Potential." Centre for Eastern Studies, 11 November 2014. https://www.osw.waw.pl/en/publikacje/osw-commentary/2014-11-06/russiansanctions-against-moldova-minor-effects-major-potential. Accessed 04 January 2017.
} 
With the West, Timofti entered office with a clear agenda to move Moldova in that direction. Although his primary focus was on fostering an economic alignment with the EU, the Moldovan president also placed high value on a diplomatic, economic, and even a military alignment (via NATO) with the United States. An analysis of Timofti’s verbal pronouncements from 2012 to 2015 validate this assertion. Beginning in 2012, Timofti's ideas about a strategic alignment with the United States were made clear in a letter to President Barrack Obama. In Timofti's words,

The USA has always been an important partner and friend of Moldova as regards its democratic course, market economy and social progress, and contributes to the promotion of my country's European integration and territorial reintegration. We value the USA's support and we voice our wish to expand and enhance bilateral cooperation in sectors of mutual interest. ${ }^{707}$

In 2013, Timofti continued to espouse the necessity of a close alignment with Washington. During a visit by U.S. Secretary of State John Kerry, Timofti stressed how Moldova would continue to look to America as a source of stability and security for his country. ${ }^{708}$ Here, Timofti continued to view how an alignment with Washington could provide Chisinau some leverage over Moscow on the Trans-Dniester problem set. By 2015, Timofti continued to maintain his higher level of verbal cooperation with the United States and verbal conflict with Russia. For example, in 2015 Timofti praised the state's relationship with Washington noting how there had been an upward development in diplomatic and economic cooperation. Timofti also committed to building on this trend. ${ }^{709}$ With Russia, Timofti was highly critical of Moscow's actions noting how, "all states of the world, including neutral ones, must get united and act as a solid front

\footnotetext{
707 Timofti, Nicolae. 2012b. "Moldovan President Congratulates Obama on Reelection." Presidency of Republic of Moldova, 07 November 2012. http://www.infotag.md/news-en/598186/. Accessed 03 August 2016.

${ }^{708}$ Timofti, Nicolae. 2013. "Nicolae Timofti." Presidency of Republic of Moldova, 04 December 2013. http://www.presedinte.md/eng/presa/nicolae-timofti-avem-nevoie-de-o-participare-puternica-a-statelor-unite-inasigurarea-securitatii-in-regiune. Accessed 03 August 2016.

${ }^{709}$ Timofti, Nicolae. 2015b. "Speech delivered by President Nicolae Timofti at the Reception Offered to the Representatives of Diplomatic Missions Accredited in Chisinau." President of Moldova Website, 30 January 2015. http://www.presedinte.md/eng/discursuri/discursul-rostit-de-presedintele-nicolae-timofti-la-receptia-oferita-pentrumembrii-corpului-diplomatic-acreditati-la-chisinau. Accessed 03 August 2016.
} 
against terror actions encroaching on the most important values of the mankind. Russia has never respected the Republic of Moldova's neutrality.",710

Finally, in the military sphere, although Moldova is a neutral state according to the country's constitution, President Timofti almost consistently espoused the advantages of aligning closer with the United States via NATO. In 2012 after assuming the presidency, Timofti gave high praise to Chisinau's growing military partnership with Washington specifically calling out the high value of being a member of the U.S.-funded Global Peace Operations Initiative. Membership in this program provided Moldova a \$1.6 million grant to improve the army’s peacekeeping training facilities. ${ }^{711}$ Next, speaking in 2014 on U.S. military assistance to Moldova, President Timofti concluded, "the support of Western partners, firstly, from the United States gives us confidence that we will manage to face the challenges of regional security."712 Perhaps the most vivid example demonstrating Timofti's preference to align with the United States came in the form of his verbal pronouncements on the possibility of Moldova joining NATO in late 2014 and early 2015. Following Moscow's annexation of Crimea, the movement of Russian military forces into the Donbas, and Kremlin support for pro-Russian rebels, Timofti's threat perceptions of Russia spiked. According to the Moldovan president, given the current strategic setting in the region, the country's constitutional provision on neutrality should be revised espousing critical words for Moldovan political leaders, who wrote the country's 1994 constitution. At issue was how Moldovan territory then and now remained under Russian occupation and how the naivety of the framers of the constitution may have encouraged the

\footnotetext{
710 Timofti, Nicolae. 2015c. "Moldova Says Participation in Peacekeeping Missions not in Breach of Neutrality." Infotag, 14 December 2015.

${ }^{711}$ Interview on file with author; see also Minzarari, Dumitru. 2012. "Russian Military Developments in Transnistria Worry Moldovan Officials.” Eurasia Daily Monitor 9 (195), 26 October 2012. https://jamestown.org/program/ russian-military-developments-in-transnistria-worry-moldovan-officials/. Accessed 14 January 2018.

712 Timofti 2014b, 1.
} 
Kremlin's military adventurism in the post-Soviet space. In Timofti's words, “the constitution should be adjusted to reality. The presence, despite Chisinau's will, of the Russian 14th Army on Moldova's territory is a violation of our neutrality status...and that there are serious risks and threats to Moldova's security that could be overcome and prevented by cooperation with NATO." ${ }^{\prime 13}$ Timofti's position in this case helps to explain his preference for a positive bandwagoning alignment with the United States.

In sum, this study finds realist expectations about Moldovan presidents did not come to fruition. Rather than preferring to simply kowtow to Russia and align with their former imperial center, Moldovan presidents perceived the Russian threat in their own unique way. Presidents Lucinschi and Voronin (after 2004) perceived Russia as a moderate threat, which was associated with a great power bridging preference. Prior to 2004, Voronin regarded Russia as a low threat and preferred a positive bandwagoning with Moscow. Separately, President Timofti perceived Russia as a high threat, preferring a positive bandwagoning alignment with the United States. Finally, Presidents Lucinschi and Timofti were the most similar in their philosophical beliefs; however, they had different alignment preferences. As a result, while an operational code analysis may be a useful tool for discerning a president's beliefs about world politics, qualitative techniques are needed to achieve a more precise understanding of his/her alignment preferences.

\section{Ukraine: Findings and Discussion}

In Ukraine, realist predictions about the balance of power or threat and state alignment did not ring true. Although Russia's military prowess was an important factor, especially as it applied to Ukraine's strategic situation in 2014 and 2015, each Ukrainian president viewed the Russian threat in his own distinct way. As detailed below, there are statistically significant differences in

\footnotetext{
713 Timofti, Nicolae. 2015. "Moldovan Leader Comments on Ties with NATO, Dniester, Russian Embargo." Infotag, 01 April 2015.
} 
the philosophical beliefs of Ukrainian presidents with all viewing Russia as the primary threat to the state; however, variation in the intensity of their threat perceptions was associated with different alignment preferences for each president. Viktor Yanukovych's low threat perceptions of Russia were associated with a preference for positive bandwagoning with Moscow, while Viktor Yushchenko and Petro Poroshenko's high threat perceptions of Russia were linked to a positive bandwagoning preference with Washington. Finally, Leonid Kuchma's moderately low threat perceptions of Russia were associated with a predilection for great power bridging. The Philosophical Beliefs of Ukrainian Presidents

The side-by-side results of the content analysis from Profiler Plus for Ukrainian presidents returned mixed results. First, from 1995 to 2015 Presidents Kuchma, Yushchenko, Yanukovych, and Poroshenko viewed the political universe as friendly registering positive scores across all indices. From a realist perspective, these findings are in conflict with an expectation that small states, like those on Russia's periphery, should view the strategic environment as extremely hostile given Russia superior military capabilities, and Moscow's historical track record of using political coercion or military force against countries Kremlin elites believe reside in Russia's zone of influence. From another perspective, given Ukraine is a small, transitioning state in the international system, it is not unrealistic to think Ukrainian presidents may prefer to take a cooperative approach to world politics in order to garner the necessary economic and military support of other countries. This is especially true with regional great powers, which are better positioned to help Ukrainian leaders ensure the long-term security of the state and country. 
Table 5: The Philosophical Beliefs of Ukrainian Presidents

\begin{tabular}{|c|c|c|c|c|c|c|c|c|c|c|c|c|c|c|c|c|c|c|c|c|c|c|c|c|c|}
\hline \multirow[b]{2}{*}{ Philosophical Beliefs / Year } & \multicolumn{11}{|c|}{ Kuchma } & \multicolumn{6}{|c|}{ Yuschenko } & \multicolumn{5}{|c|}{ Yanukovych } & \multicolumn{3}{|c|}{ Poroshenko } \\
\hline & 1995 & 1996 & 1997 & 1998 & 1999 & 2000 & 2001 & 2002 & 2003 & 2004 & AVG & 2005 & 2006 & 2007 & 2008 & 2009 & AVG & 2010 & 2011 & 2012 & 2013 & AVG & 2014 & 2015 & AVG \\
\hline $\begin{array}{l}\text { P-1: The Nature of the Political } \\
\text { Universe }\end{array}$ & 0.44 & 0.44 & 0.46 & 0.45 & 0.52 & 0.39 & 0.39 & 0.54 & 0.48 & 0.36 & 0.45 & 0.54 & 0.61 & 0.48 & 0.5 & 0.28 & 0.48 & 0.54 & 0.52 & 0.58 & 0.53 & 0.54 & 0.09 & 0.35 & 0.22 \\
\hline \begin{tabular}{|l|} 
P-2: Prospects for Realizing \\
Fundamental Values \\
\end{tabular} & 0.27 & 0.24 & 0.26 & 0.24 & 0.3 & 0.19 & 0.19 & 0.32 & 0.24 & 0.16 & 0.24 & 0.34 & 0.33 & 0.28 & 0.25 & 0.17 & 0.27 & 0.31 & 0.31 & 0.36 & 0.3 & 0.32 & 0.01 & 0.19 & 0.10 \\
\hline $\begin{array}{l}\text { P-3: Predictability of the } \\
\text { Political Universe }\end{array}$ & 0.09 & 0.11 & 0.11 & 0.12 & 0.14 & 0.09 & 0.09 & \begin{tabular}{|l|}
0.13 \\
\end{tabular} & 0.14 & 0.1 & 0.11 & 0.11 & 0.15 & \begin{tabular}{|l|}
0.08 \\
\end{tabular} & 0.13 & \begin{tabular}{|l|}
0.07 \\
\end{tabular} & 0.11 & \begin{tabular}{|l|}
0.12 \\
\end{tabular} & 0.09 & 0.11 & 0.1 & 0.11 & 0.05 & \begin{tabular}{|l|}
0.08 \\
\end{tabular} & 0.07 \\
\hline $\begin{array}{l}\text { P-4: Control Over Historical } \\
\text { Development }\end{array}$ & 0.25 & 0.25 & 0.23 & 0.22 & 0.27 & 0.22 & 0.22 & 0.24 & 0.34 & 0.23 & 0.25 & 0.36 & 0.28 & 0.32 & 0.36 & 0.22 & 0.31 & 0.37 & 0.36 & 0.31 & 0.36 & 0.35 & 0.26 & 0.28 & 0.27 \\
\hline
\end{tabular}

A closer examination of the data above indicates Presidents Kuchma and Yushchenko both viewed the political universe as somewhat friendly (.45 and .48 respectively) while Viktor Yanukovych perceived international politics as definitely friendly with a score of .54 in the P-1 (master beliefs) category. President Poroshenko's score of .23 indicates his beliefs about other actors in world politics is mixed. Poroshenko's lower score is perhaps reflective of the current strategic environment with Russia's illegal annexation of Crimea in 2014 and direct support for Donbas rebels in eastern Ukraine. This pattern continued in the P-2 index as Kuchma (.24), Yushchenko (.27) and Yanukovych (.32) demonstrated higher levels of optimism in achieving their goals, while Poroshenko was less optimistic (.12). In the P-3 and P-4 categories the same similarities and differences between each president are observed. Here Presidents Kuchma, Yushchenko, and Yanukovych all registered higher scores than Petro Poroshenko about the predictability of their political future and control over historical developments. There was one exception in the P-4 category where Poroshenko registered a slightly higher score (.27) over Kuchma (.25). Again, the role of chance (P-5) was high for all four presidents (Kuchma and Yushchenko $=.97 ;$ Yanukovych $=.96 ;$ and Poroshenko .98).

\section{Validating Convergence and Divergence}

The output from Profiler Plus provides a set of quantitative measures of the philosophical beliefs for the four Ukrainian presidents. While there appears to be some differences in how each political leader views the nature of world politics, the results of an ANOVA test detailed below 
invalidate the null hypothesis that there are no statistically significant differences in the philosophical beliefs of Ukrainian presidents. The alternative hypothesis that there is a statistically significant difference is validated at the .001 level.

Table 19: ANOVA Results - Ukrainian Presidents Philosophical Beliefs

\begin{tabular}{c|ccccc}
\hline & & Sum of Squares & $d f$ & Mean Square & $\mathrm{F}$ \\
\hline \multirow{2}{*}{$\mathrm{P}-1$} & $\begin{array}{c}\text { Between } \\
\text { Groups }\end{array}$ & .183347 & 3 & .061157 & $8.684 * * *$ \\
& $\begin{array}{l}\text { Within } \\
\text { Groups }\end{array}$ & .12676 & 18 & .007042 & \\
& & & & & \\
$* * *$ prob $<.001$ & & & & &
\end{tabular}

As noted in the preceding sections, the ANOVA test above does not tell us exactly where those differences exist between each president. Based on a Tukey's HSD test detailed in the table below, this study finds Presidents Kuchma and Yushchenko were more similar in their beliefs about the nature of the international system registering an adjusted P-value of 0.8705892 . Although Kuchma and Yushchenko may exhibit the same beliefs about the nature of the political universe, they did not share the same alignment preferences. As will be discussed in detail below, President Kuchma preferred great power bridging, but Yushchenko gravitated toward a positive bandwagoning alignment with the United States. This is important for two reasons. First, while a quantitative analysis of a president's foreign policy speeches can help us to understand a president's beliefs systems about world politics, the findings are of a general nature and should be regarded as a starting point for an examination of different political phenomena. On this point, in then becomes necessary to use qualitative techniques to acquire increased specificity on the relationship between a president's threat perceptions and his alignment preferences. 
Table 20: Ukraine - Mean Comparisons of Tukey's HSD Test Results (P-1)

\begin{tabular}{l|cccc}
\hline \multicolumn{1}{c|}{ Pair } & Difference & Lower Bound & Upper Bound & Adjusted P-Value \\
\hline $\begin{array}{l}\text { Poroshenko- } \\
\text { Kuchma }\end{array}$ & -0.2170 & -0.37313174 & -0.06086826 & 0.0049636 \\
$\begin{array}{l}\text { Yanukovych- } \\
\text { Kuchma }\end{array}$ & 0.0955 & -0.04481825 & 0.23581825 & 0.2534253 \\
$\begin{array}{l}\text { Yushchenko- } \\
\text { Kuchma }\end{array}$ & 0.0350 & -0.09490946 & 0.16490946 & 0.8705892 \\
$\begin{array}{l}\text { Yanukovych- } \\
\text { Poroshenko }\end{array}$ & 0.3125 & 0.13134991 & 0.49365009 & 0.0006430 \\
$\begin{array}{l}\text { Yushchenko- } \\
\text { Poroshenko }\end{array}$ & 0.2520 & 0.07878739 & 0.42521261 & 0.0033369 \\
$\begin{array}{l}\text { Yushchenko- } \\
\text { Yanukovych }\end{array}$ & -0.0605 & -0.21960595 & 0.09860595 & 0.0708799 \\
\hline
\end{tabular}

95\% Family-wise Confidence Level

Ukrainian President Threat Perceptions and State Alignment

Following their counterparts in Georgia, Ukrainian presidents perceived Russia as the greatest threat to the state. From 1995 to 2015, the combined average of the four Ukrainian presidents' threat perceptions of Russia was moderately-high. ${ }^{714}$ The specific nature of the threats from Russia were economic and military under all four presidents with the latter being emphasized during Petro Poroshenko's tenure as president.

The key findings from this section are as follows: First, when the threat perceptions of Ukrainian presidents were high as was the case with Viktor Yushchenko and Petro Poroshenko, these heads of state preferred a positive bandwagoning with the United States. Second, when threat perceptions were low as was the case with President Yanukovych, a preference for positive bandwagoning with Russia was observed. Next, President Kuchma's moderately low

\footnotetext{
${ }^{714}$ Author's analysis. The assessed average registered a score of 1.9, which fell into the moderately-high category.
} 
threat perceptions of Russia was associated with a great power bridging alignment preference. Of particular relevance for Kuchma is how he believed maintaining friendly relations with both the United States and Russia would help him to stay in power. ${ }^{715}$ Presidents Kuchma, Yushchenko, and Poroshenko perceived the United States to be a low threat, while President Yanukovych perceived Washington to be a moderately-low threat. In the paragraphs below, an analysis of the relationship between each president's threat perceptions and his alignment preferences with the United States and Russian Federation are presented.

President Leonid Kuchma. From 1995 to 2004, President Kuchma viewed Russia as a latent external threat. Kuchma's Soviet experiences and Moscow's refusal to treat Ukraine as an equal partner reinforced his ideas that Russia would remain the primary external threat. ${ }^{716}$ During his time in office, Kuchma perceived Russia as a moderately low threat. With respect to variation, Kuchma's perception of the Russian threat generally remained stable; however, there were some minor fluctuations, during which he may have temporarily viewed the Kremlin as a moderately high threat. Kuchma's overall threat perceptions were associated with a great power bridging preference.

As graphically illustrated in Chapter 5, President Kuchma's alignment preferences indicated he preferred great power bridging as his level of verbal cooperation with the United States and Russia oscillated back and forth while in office. Additionally, an analysis of ICEWS event data also indicated President Kuchma's level of verbal confrontation with Russia and the United States was almost equal, frequently fluctuating between both regional great powers. ${ }^{717}$

\footnotetext{
715 Interview on file with author.

${ }^{716}$ Interview on file with author.

717 Author's analysis. The total number of events on President Kuchma's level of verbal confrontation was much less than what was observed with his level of verbal cooperation with the U.S. and Russia. As previously noted, this is to be expected since Kuchma's philosophical beliefs indicated he viewed the political universe as somewhat friendly.
} 
President Kuchma's moderately low threat perceptions of Moscow were visible in his ideas about the economic and military dangers emanating from Russia. First, Kuchma was well aware of Ukraine's dependence on Russia for its energy supplies and trade; however, the Ukrainian president also understood Russia needed Ukraine as well. Speaking in 1995, Kuchma was quick to discount the economic threat from Russia. In his words,

No, there is no such [economic] threat... and here is why. First, there is a mutual dependence. For Russia, Ukraine is not only, and not so much, a supplier of important commodities. Ukraine for Russia is primarily one of the essential markets for Russian commodities, first and foremost, basic Russian exports: gas, oil, oil products, and nonferrous metals. Second, we must not forget about interdependence in the production cooperation between many thousands of Ukrainian and Russian enterprises working in single production cycles. Third, it is necessary to take into account the fact that a huge quantity of goods, amounting to a large percentage of Russian foreign trade turnover, is transported by motor vehicles, railways, pipelines, or energy supply lines across Ukrainian territory. I could continue fourth, fifth, but the point is not in this. The point is in the fact that both we and our Russian colleagues realize such interdependence. Therefore, we are resolutely seeking to create equal and mutually beneficial mechanisms in our trade relations. ${ }^{718}$

Kuchma's ideas about the Russian economic threat appear to have some validity when looking at the import/export data for each country from 1996 to 2004 in the chart below. Although Russia maintained an overall advantage in terms of trade vis-à-vis Ukraine, Kiev's trade relations with the U.S. and EU likely helped mitigate the long-term economic threat from Russia. Still, Kuchma

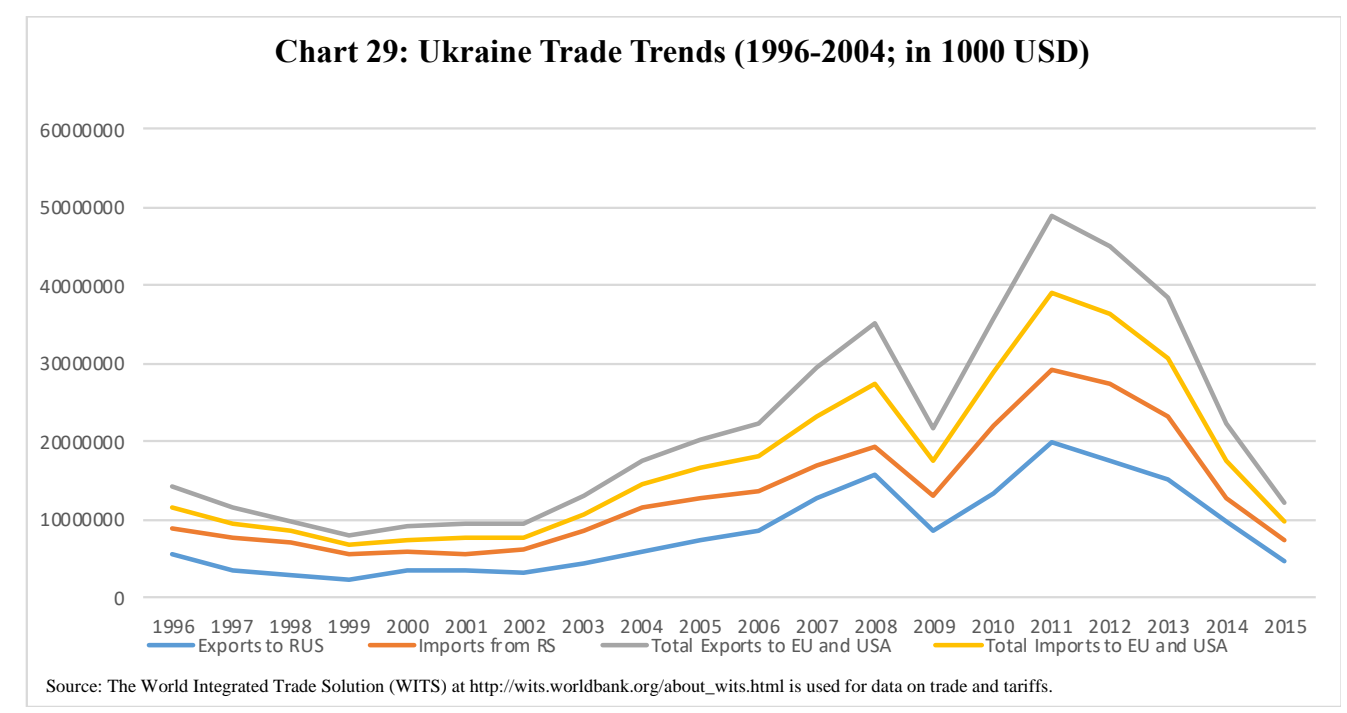

${ }^{718}$ Kuchma, Leonid. 1995. "Kuchma Interviewed on CIS, Russia, Parliament's Stance.” Zerkalo Nedeli, 14 October 1995. 
believed that by maintaining amiable relations with Moscow, he could stave off any potential short-term threat that may jeopardize the country's fragile economy.

Additionally, Kuchma's threat perceptions of Russia were somewhat tempered following positive statements from the Kremlin. For example, in 1997 during his trip to Kiev, Boris Yeltsin proclaimed, "Ukraine is an independent country, and we hold this promise sacred...[Russia] does not lay claim on any part of Ukraine or any of its cities."719 Perhaps the most important aspect in Yeltsin's characterization of Russia-Ukraine relations was how for the very first time, Moscow had come to view Ukraine as an independent state. Kuchma's low threat perceptions continued into 1998 when after returning from a trip to Russia, the Ukrainian president hailed Kiev's relations with Moscow noting progress on many fronts. In the words of Kuchma, "good neighborly relations with the Russian Federation and the strategic partnership with Ukraine are [now] permanent elements of our approach to Eastern Europe." ${ }^{\prime 720}$ The Duma's subsequent ratification of the 1997 treaty in 1999 further reinforced Kuchma's generally low threat perceptions of Russia.

The overall stability of Kuchma's threat perceptions of Russia remained relatively stable through his presidency. From 2000 to 2002, Kuchma's threat perceptions of Russia were at their best with the arrival of Vladimir Putin. During this time, Kremlin leaders, including Putin himself, espoused how Ukraine had a right to chart its own path in international affairs. In a June 2002 interview, President Kuchma was very forthcoming about the low threat from Moscow. According to Kuchma, "today, Russia is demonstrating that it is not a threat to peace as the USSR was before. Russia is not creating problems; on the contrary, it is striving for economic

\footnotetext{
719 Yeltsin, Boris. 1997. “1997 Year in Review.” Ukrainian Weekly 52 (65). http://www.ukrweekly.com/old/archive/ 1997/529706.shtml. Accessed 20 December 2017.

${ }^{720}$ Kuchma, Leonid. 1998a. "Ukraine's Kuchma Hails Ties with Russia.” Radio Ukraine World Service, 07 March 1998.
} 
cooperation..."721 It is from this change in Russian leadership Kuchma would continue to view Moscow as a moderately low threat through the end of his presidency.

Kuchma's moderately low threat perceptions of Russia can also be attributed to the state of disarray in the Russian armed forces. Although Moscow still maintained a favorable balance of power, much of the Russian armed forces were in disarray owing to Kremlin budget cuts, poor leadership in the senior ranks, antiquated equipment, and low troop morale. Separately, in 1997 the military threat from Russia was minimized when Ukrainian Prime Minister Pavlo Lazarenko and Russian Prime Minister Viktor Chernomyrdin signed an agreement on the status of the Black Sea Fleet, which saw both country's splitting equally the military assets at the Sevastopol military complex. Although Russia was granted a military lease of the port facilities, it was only for a 20-year period with Crimea receiving a designation as the sovereign territory of Ukraine. ${ }^{722}$

Kuchma's moderately low threat perceptions of Russia subsequently became a touchstone by which he would prefer a great power bridging alignment with Moscow and Washington during his presidency. In describing the state's optimal alignment trajectory, Kuchma characterized Ukraine's foreign policies as multi-vector with one azimuth pointed towards Russia, a second to the United States, and a third toward Western Europe. For example, in a speech to his government's heads of diplomatic missions, Kuchma stated,

Our European future is indivisible from a strategic partnership with Russia. This is indisputable. Additionally, the role and significance of the strategic partnership between Ukraine and the USA will further increase as a significant factor of Euro-Atlantic stability and an important component of the security architecture of the 21 st century. ${ }^{723}$

\footnotetext{
${ }^{721}$ Kuchma, Leonid. 2002. “Ukrainian President Discusses NATO Bid, Relations with Russia.” Hospodarske Noviny Online, 07 June 2002.

722 Woronowycz, Roman. 1997. "Ukrainian, Russian PMs Sign Pact on Black Sea Fleet.” The Ukrainian Weekly 22 (65), 01 June 1997. http://www.ukrweekly.com/old/archive/1997/229701.shtml. Accessed 12 December 2016.

${ }^{723}$ Kuchma, Leonid. 2000. "Ukraine: Kuchma to Envoys on Foreign Policy.” Uryadovvy Kuryer, 20 January 2000.
} 
With the United States, Kuchma also espoused the merits of a political and economic alignment during his time in office. The primary venues through which Kuchma would articulate his alignment preferences with Washington was seen during meetings of the Gore-Kuchma Commission, the U.S.-Ukraine Foundation, or the Central and East European Coalition. For example, in 1998 Kuchma stated, "special mention should be made of the dynamism in the development of our strategic partnership with the United States. One of the latest examples of such cooperation was the conference of donor countries in New York under our joint chairmanship with Vice President Al Gore." ${ }^{27}$ Kuchma's alignment preferences endured through 2004 when he stated,

I have always consistently advocated the idea that the establishment of a strong partnership with the USA, especially in the military and political field, is of strategic importance to us, in particular in view of Ukraine's Euro-Atlantic strategy and common views on the fight against terrorism and strengthening the security in Eastern Europe, and Black Sea and Caspian regions. ${ }^{725}$

With these verbal pronouncements and others related to democratic and market-based reforms, his actions subsequently paved the way for the allocation of over $\$ 1.5$ billion in U.S. foreign assistance between 1995 and $2001 .{ }^{726}$

Kuchma's alignment preference with the U.S. was not without its own set of challenges. At issue was Washington's growing frustration with Kuchma's leadership and the Ukrainian president's inability to enact 'true' democratic reforms and reduce corruption, as well as his censorship of the media. Furthermore, Kuchma's alignment preference with the U.S. were strained when Washington elites began viewing Kuchma unfavorably after his purported involvement in the murder of journalist Georgiy Gongadze and the sale of an advance military

\footnotetext{
${ }^{724}$ Kuchma, Leonid. 1998d. "Ukrainian President Addresses Foreign Diplomats.” UT-1 Television Network, 27 January 1998.

${ }^{725}$ Kuchma, Leonid. 2004. “Ukrainian President Pledges to Hold Fair Election.” Itar-Tass, 20 April 2004. See also Kuchma, Leonid. 2004a. "Ukrainian President: US Partnership of Strategic Importance." Itar-Tass, 20 April 2004. 726 Tarnoff, Curt. 2002. "U.S. Assistance to the Former Soviet Union 1991-2001: A History of Administration and Congressional Action.” Congressional Research Service, 15 January 2002, 58.
} 
radar system to Iraq in 2000. In response, NATO officials did not issue Kuchma an invite to attend the alliance's summit in Prague, which was followed by the first-ever cancellation of the U.S.-Ukraine Presidential summit. ${ }^{727}$ Taras Kuzio characterizes the years 2000 to 2004 as a period of Western disillusionment where the foreign relations between Ukraine and the United States deteriorated. ${ }^{728}$ Although Kuzio's characterization of U.S. foreign policy with Ukraine is perhaps fitting, it does not necessarily convey to Kuchma, who continued to still view positively an alignment with Washington and its allies in Western Europe. In his last year in office, Kuchma still proclaimed the U.S.-Ukraine partnership, particularly in the military and political spheres, has been and will remain strategic priority for Kiev. ${ }^{729}$

Given the preceding analysis, one can conclude President Kuchma's alignment preferences gravitated toward great power bridging. For Kuchma, an alignment with the U.S. and Russia was a strategic imperative that would help him acquire the necessary political and economic support for Ukraine's transition from Soviet rule and for him to stay in power. A key theme supporting his verbal discourse about great power bridging was Ukraine’s non-aligned status. For example, as early as 1996, President Kuchma asserted...

We believe that Ukraine's nonaligned status does not prevent it from full-fledged participation in European programs in the sphere of security, military and political aspects included. While integrating with Europe, we naturally are going to develop equal, mutually beneficial cooperation with the post-Soviet states, primarily with Russia. ${ }^{730}$

\footnotetext{
${ }^{727}$ Kuzio, Taras. 2002. “In Wake of Kuchma Snub, Whither Relations with NATO?” The Ukrainian Weekly 45 (70). http://www.ukrweekly.com/old/archive/2002/450204.shtml. Accessed 18 December 2016.

${ }^{728}$ Kuzio, Taras. 2003. "Ukraine's Relations with the West: Disinterest, Partnership, Disillusionment.” European Security 12 (2), 26.

${ }^{729}$ Matarykin, Vitaliy. 2004. "Ukrainian President: US Partnership of Strategic Importance.” Itar-Tass, 20 April 2004.

${ }^{730}$ Kuchma, Leonid. 1996c. “Kuchma 8 Oct Speech to Spanish Legislature.” Uryadovyy Courier, 10 October 1996.
} 
Through 2002 President Kuchma continued to emphasize the central importance of Ukraine's non-aligned status noting how Kiev would seek to establish strategic alignments with the United States, Russia, and other major European and CIS powers. ${ }^{731}$

President Viktor Yushchenko. Following his electoral victory over Viktor Yanukovych, President Viktor Yushchenko, from 2005 to 2009 viewed Russia as a clear and present danger to the security of the state, the Ukrainian people, and the territorial integrity of Ukraine. For the five years in office, President Yushchenko perceived Russia as a high threat. ${ }^{732}$ Yushchenko's ideas about the Russian threat were primarily economic and military in nature. His threat perceptions of the Russia also generally remained stable spiking in 2009 following the Kremlin's decision to invade Georgia. Here, Russia's military actions against a former Soviet republic reinforced Yushchenko's beliefs of the future high danger its northern neighbor posed to Ukraine. With the U.S., Yushchenko maintained a low threat perception.

Yushchenko's alignment preferences with the United States and the Euro-Atlantic community was a primary lens from which Yushchenko viewed international affairs and from which he came to view Russia as a direct threat to the Ukrainian state. Although Yushchenko's first foreign visit was to Russia on 25 January 2005, just several days earlier in his inaugural address he indirectly referenced the Kremlin's ill-intentions in the post-Soviet space stating, "Ukrainians will find their rightful place in the community of nations. Ukraine will be neither a buffer, nor a field on which others will compete. We are ready to respect the interests of other countries. But for me, as well as for you, the national interests of Ukraine will be paramount!"733 By February, Yushchenko made clear his beliefs about the strategic priority of an alignment with the United

\footnotetext{
${ }^{731}$ Kuchma, Leonid. 2002b. "Kuchma Delivers State of the Nation Address." Ukrainian Radio 1, 18 June 2002.

${ }^{732}$ Author's analysis. The average coded score from regional specialists was 1.2.

${ }^{733}$ Yushchenko, Viktor. 2005a. "Inaugural address by President Viktor Yushchenko." The Ukrainian Weekly 5 (73). http://www.ukrweekly.com/old/archive/2005/050523.shtml. Accessed 12 January 2017.
} 
State and the NATO alliance. During a meeting of the NATO-Ukraine Council, Yushchenko proclaimed, "we believe that Ukraine's participation and engagement in the North Atlantic community of democratic peoples will strengthen peace and security on the European continent. We are ready to make all necessary efforts to achieve this noble goal." 734

From the beginning of his presidency, Yushchenko exhibited high disdain for Russia and Moscow's interference in Ukraine's internal domestic political affairs. Furthermore, although never unambiguously proven, Yushchenko believed Kremlin elites were behind an attempted assassination that involved the use of a poisonous dioxin. Taken together, these events reinforced his threat perceptions of Russia and rather than kowtowing to Russia, Yushchenko preferred to follow a positive bandwagoning alignment with the United States, even without guarantees Ukraine would be admitted to NATO and/or the EU.

The economic threat emanating from Russia was nearly pervasive during Yushchenko's tenure. Beginning in early 2005, Russia's Gazprom began a series of meetings with Ukrainian energy officials on raising the cost of natural gas. When negotiations stalled in December 2005, Gazprom threatened to cut off energy supplies to Ukraine if Yushchenko's ruling government did not agree to pay market price (approximately $\$ 230$ per 1,000 cubic meters) for Russian natural gas instead of its previously subsidized rate of $\$ 50$ per 1,000 cubic meters. When Kiev balked, Gazprom followed through with its threat on 01 January 2006 by reducing the flow of gas to Ukraine. In the process, Kiev reportedly used some of the gas intended for European customers, which subsequently elicited direct involvement from major European powers. With the involvement of political leaders from Germany, Italy, and France, Russia and Ukraine were

\footnotetext{
${ }^{734}$ Yushchenko, Viktor. 2005b. "Opening Statement by Viktor Yushchenko at the meeting of the NATO-Ukraine Council.” NATO, 22 February 2005. http://www.nato.int/docu/speech/2005/s050222e.htm. Accessed 12 January 2017.
} 
able to come to an agreement by 04 January 2006 that saw the restoration of gas flows to Western Europe. ${ }^{735}$

President Yushchenko's ideas about the extent to which Russia represented an economic threat to Ukraine persisted into 2008. In early February of that year, Gazprom again threatened to cut natural gas supplies to Ukraine unless Kiev paid the company approximately $\$ 1.5$ billion it back debt. When both sides failed to achieve a compromise, Gazprom halted natural gas flows to Ukraine and Western Europe on 01 January 2009. Only after several weeks did Ukrainian Prime Minister Yulia Tymoshenko successfully negotiate a new deal in Moscow. ${ }^{736}$ For Yushchenko, Gazprom's actions validated his ideas about the enduring nature of the Russian threat and the Kremlin's neo-imperialistic attempts to steer Ukraine away from the West.

Beyond Moscow's use of the energy lever against Ukraine, Yushchenko's Western lens also brought into perspective how Russia could use its military capabilities to force former Soviet states to fall in line. For example, during a meeting of the Russian-Ukrainian Intergovernmental Commission in February 2008, President Yushchenko was given a stark reminder of Moscow’s proclivity to use military force as a leading instrument in the state's foreign policies. In this case, during a joint press conference with Yushchenko, a reporter queried Vladimir Putin about his thoughts on a proposed U.S. missile defense shield in Europe. Although Ukraine was not even a country of consideration for the U.S. missile defense system, the Russian President stated, "it is horrible to say and even horrible to think that, in response to the deployment of such facilities in Ukrainian territory, which cannot theoretically be ruled out, Russia could target its missile

\footnotetext{
${ }^{735}$ Nichol, Jim, Steven Woehrel, and Barbara Gelb. 2006. "Russia's Cutoff of Natural Gas to Ukraine: Context and Implications." Congressional Research Service, 15 February 2006. https://pdfs.semanticscholar.org/edde/8d92a 925c6fe040a76f3cb97ad7c226a7ccb.pdf. Accessed 14 January 2017.

736 Waterfield, Bruno. 2009. "Russia Resumes Gas Flow to Ukraine and Europe.” The Telegraph, 20 January 2009. http://www.telegraph.co.uk/news/worldnews/europe/russia/4293979/Russia-resumes-gas-flow-to-Ukraine-andEurope.html. Accessed 14 January 2017.
} 
systems at Ukraine." ${ }^{, 737}$ Putin's bombastic pronouncement in the context of a high-level diplomatic served as a key event reinforcing Yushchenko's ideas about the enduring military threat from Russia and how crossing a 'redline' may elicit an armed backlash.

The negative consequences of crossing a Kremlin 'redline' was subsequently demonstrated in August 2008 when Russian military forces invaded Georgia following an escalation of hostilities in South Ossetia. In the weeks after the Russia-Georgia War, Yushchenko characterize Russia's actions as a direct threat to Ukraine and all of Europe. In his words...

The military conflict between Russia and Georgia is a rigorous challenge to the Caucasus region and to Europe and the entire civilized world. The decision made by the Russian leadership is a threat to peace and stability in our region and in Europe, it undermines the current international order, violates the integrity of the principles sealed by the UN Charter and other international acts, is an instance of illegitimate redrawing of the state borders and a manifestation of pressure and interference with the use of force. ${ }^{738}$

Russia's brazen actions in Georgia served only to reinforce Yushchenko's preference for a positive bandwagoning alignment with the United States and its Western European allies.

Finally, the threat from Russia took on a political facet. Two points support this assertion.

First, during the hotly contested presidential election in 2004, Russian political elites provided full backing for Viktor Yanukovych in his bid to defeat Yushchenko for the presidency. According to Taras Kuzio, Russian political experts with ties to Putin himself were hired to showcase Yanukovych's strengths and to undermine the credibility and legitimacy of Yushchenko. ${ }^{739}$ For Yushchenko, Moscow's political influence in the 2004 election would be a harbinger for future meddling in Ukrainian politics that could threaten his hold on power. Second, in 2009 President Medvedev published a scathing letter criticizing Yushchenko's ill-

\footnotetext{
${ }^{737}$ Putin, Vladimir. 2008. Cited in "Putin Threatens Ukraine Over NATO." The Washington Post, 13 February 2008. http://www.washingtonpost.com/wp-dyn/content/article/2008/02/12/AR2008021201658.html. Accessed 14 January 2017.

738 Yushchenko, Viktor. 2008. "Yushchenko: Kyiv Does Not Support Recognition of South Ossetia, Abkhazia." Interfax, 27 August 2008. Accessed 14 January 2017.

${ }^{739}$ Kuzio, Taras. 2005 "Russian Policy toward Ukraine during Elections.” Demokratizatsiya, 13 (4), $494-496$.
} 
conceived anti-Russia foreign policies and his continued adherence to align with the West by attempting to join NATO. In response, Medvedev decided he would not assign Russia's new ambassador to Kiev until the political climate in Ukraine changed. ${ }^{740}$

Despite Yushchenko's preferences to align with the United States and the West, NATO did not offer Ukraine an invitation to join the alliance in 2008 owing to reservations from Germany and France about the country's qualifications and Kiev's tense relations with Russia. Alliance officials did however convey optimistic assertions that Ukraine would eventually become a member. Although NATO did not offer Ukraine a Membership Action Plan (MAP), Yushchenko's ideas about joining NATO remained steadfast. Speaking after NATO's decision the Ukrainian president proclaimed, "this can only be seen as a victory, and I will explain why. It is because in today's document, for the first time, the 26 NATO member states formulated the basic principle that [Ukraine] will become members of NATO. I would say this even exceeded our expectations regarding this document."741 Yushchenko's commitment to stay the course with a positive bandwagoning preference returned dividends in 2009 when Ukraine and NATO signed a Declaration to Complement the Charter on a Distinctive Partnership. ${ }^{742}$

In the shadow of Ukraine's alignment with the U.S. under Yushchenko's rule, Kiev continued to engage in routine diplomatic or economic activities with Russia. For example, in early 2008 during a visit to Moscow for the biannual meeting of the Russian-Ukrainian Intergovernmental Commission, President Yushchenko signed a Russian-Ukrainian Action Plan, which sketched

\footnotetext{
${ }^{740}$ Coalson, Robert. 2009. "Russia's Message to Ukraine Echoes across Former Soviet Union.” Radio Free Europe/Radio Liberty, 12 August 2009. https://www.rferl.org/a/Russias_Message_To_Ukraine_Echoes_Across_ Former_Soviet_Union/1798413.html. Accessed 14 January 2017.

741 "NATO: No MAP for Georgia or Ukraine, but Alliance Vows Membership." Radio Free Europe/Radio Liberty, 03 April 2008. https://www.rferl.org/a/1079726.html. Accessed 15 January 2017.

742 The Charter on a Distinctive Partnership between NATO and Ukraine was signed in 1997. See Declaration to Complement the Charter on a Distinctive Partnership. 2009. NATO, 21 August 2009. https://www.nato.int/cps/ ua/natohq/official_texts_57045.htm. Accessed 15 January 2017.
} 
out trade and economic cooperation between the two countries over the next year. Specific areas of emphasis included the aircraft manufacturing, agriculture, communications, energy, machinebuilding, and transport sectors. ${ }^{743}$

President Viktor Yanukovych. In 2010, Ukraine's tendency to positively bandwagon with the U.S. took a U-turn with the arrival of Viktor Yanukovych as president. For the four years he was in office (2010-2014), President Yanukovych viewed Russia as a very low threat. ${ }^{744}$ With the United States, Yanukovych's threat perceptions were moderately low owing to fears about Washington's support for pro-democracy groups in Ukraine. President Yanukovych's threat perceptions of Russia remained stable through early 2014 as the social-political situation in the country degenerated into chaos following his decision to accept a Russian economic package in lieu of signing an EU Association Agreement. During this tense period, Yanukovych purportedly requested military assistance from the Kremlin as a way to restore peace. ${ }^{745}$ Yanukovych's verbal pronouncements indicated that with his low threat perceptions of Russia, he preferred a positive bandwagoning alignment with Russia.

Even before assuming the presidency, as early as 2008 Viktor Yanukovych's ideas about the nature of the Russian threat were made clear in several public speeches. In the aftermath of Russia’s invasion of Georgia, Yanukovych, as the leader of the Party of Regions, explicitly stated Ukrainians should not feel threatened by Russia in any way. Following Moscow’s recognition of South Ossetia and Abkhazia's declarations of independence, Yanukovych's Party of Regions then attempted to pass a parliamentary resolution recognizing both of the breakaway

\footnotetext{
743 "Vladimir Putin Held Talks with Ukrainian President Viktor Yushchenko and Hosted a Meeting of the RussianUkrainian Intergovernmental Commission.” President of Russia Website, 12 February 2008. http://en.kremlin.ru/ events/president/news/43796. Accessed 14 January 2017.

${ }^{744}$ Author's analysis. The average coded score from regional specialists was 2.8.

745 Bryant, Nick. 2014. "Ukraine's Yanukovych asked for troops, Russia tells UN.” BBC, 04 March 2014. http://www.bbc.com/news/world-europe-26427848. Accessed 12 January 2017.
} 
provinces. Speaking on the matter, Yanukovych argued his party's support for Russia and the Georgian provinces was comparable to U.S. support for Kosovo's independence. Although political opposition in the Rada blocked the resolution, Yanukovych's words illuminated his ideas about how Russia did not represent a threat to Ukraine. ${ }^{746}$

Once installed as president in 2010, Yanukovych's ideas about the historical and cultural ties between both countries were key concepts contributing to his lower threat perceptions of Russia and a preference for a positive bandwagoning alignment with Moscow. For example, during his trip to Moscow in early March 2010 Yanukovych informed President Medvedev, "we are all linked by immense and closely intertwined historical roots. I see my task as being to bring about a turnaround in relations between Ukraine and Russia and set them on the right track so as to work together to reach the goals to which both of our peoples aspire."747 For Yanukovych, believing Ukraine and Russia are connected by shared cultures was a powerful factor shaping his ideas that Moscow was not a threat in any way.

President Yanukovych's tendency to not view Russia as a threat was also visible in the military sphere. Several points support this assertion. First, during a British press interview in February 2010 - almost 2 months prior to his first trip to Moscow-Yanukovych indicated he was prepared to extend the Russian Navy's lease in Sevastopol beyond 2017 and give the Russian language equal status in Ukraine. ${ }^{748}$ Second, after Yanukovych was in office, he made it known Ukraine would halt its bid to join NATO giving emphasis to the country's non-aligned

\footnotetext{
${ }^{746}$ Yanukovych, Viktor. 2008. Cited in Kuzio, Taras. 2009. "Strident, Ambiguous and Duplicitous: Ukraine and the 2008 Russia-Georgia War.” Demokratizatsiya 17 (4), 365.

${ }^{747}$ Yanukovych, Viktor. 2010. "Beginning of Meeting with President of Ukraine Viktor Yanukovych." President of Russia Website, 05 March 2010. http://en.kremlin.ru/events/president/transcripts/7040. Accessed 12 January 2017. ${ }^{748}$ Yanukovych, Viktor. 2010e. "Yanukovych Says Ukraine Turned 'New Page,' West Has 'Nothing to Fear."' Telegraph, 15 February 2010. http://www.telegraph.co.uk/news/worldnews/europe/ukraine/7236642/Yanukovychsays-West-has-nothing-to-fear-from-Ukraine.html. Accessed 12 January 2017.
} 
status. For Yanukovych, working with NATO was acceptable; however, there was no benefit to joining the alliance. According to one area specialist, "it is definitely not the policy of Yanukovych to join NATO."749

The preceding discussion about Yanukovych's threat perceptions of Russia did not necessarily mean he was oblivious to how Russia may represent a military and/or economic threat to Ukraine. Certainly, the Ukrainian president realized that in numbers alone, Russian armed forces had a decisive quantitative and qualitative advantage over Ukraine. ${ }^{750}$ In the economic sphere, Yanukovych also realized Russia represented a potential economic threat. For example, during a 2010 interview Yanukovych noted, "there is such a threat as absorption of the Ukrainian economy by Russia. It does exist." ${ }^{751}$ However, Yanukovych played down this potential threat noting how Ukraine's continuing integration into the global economy would help the country to prosper. Finally, although Yanukovych preferred to align with Russia over the United States, the Ukrainian president did not completely discount the benefits of close cooperation with the EU. In this case, Yanukovych saw some utility with developing closer economic relations with Western Europe, but on his terms. ${ }^{752}$

In concert with Yanukovych's low threat perceptions of Russia, he increasingly perceived the West, to include the United States and leading powers in Europe as a moderately low threat to

\footnotetext{
749 Sushko, Oleksandr. 2010. "Yanukovych Kills Ukraine’s Bid for NATO.” Christian Science Monitor, 06 April 2010. https://www.csmonitor.com/World/Europe/2010/0406/Yanukovich-kills-Ukraine-s-bid-to-join-NATO. Accessed 13 January 2017.

${ }^{750}$ For an overview of the balance of military power between Russia and Ukraine in 2014 see Marcus, Jonathan. 2014. "Ukraine: The Military Balance of Power." BBC News Online, 03 March 2014. http://www.bbc.com/news/ world-europe-26421703. Accessed 27 January 2018.

${ }^{751}$ Yanukovych, Viktor. 2010d. "Yanukovych Aware of Threat of Ukrainian Economy's Absorption by Russia." Interfax, 09 October 2010.

${ }^{752}$ On Viktor Yanukovych's engagement with EU and the U.S. on his own terms, see Pifer, Stephen. 2011. 'Can Ukraine Join Europe as Yanukovych Moves Away from EU Values?” The Brookings Institution, 28 January 2011. https://www.brookings. edu/opinions/can-ukraine-join-europe-as-yanukovych-moves-away-from-eu-values/. Accessed 07 February 2018.
} 
the state. At issue was how Yanukovych believed Washington was responsible for the Orange Revolution and his political defeat in the years prior. Now as president, he sought to minimize this external threat by constraining the activities of Western NGOs and their efforts to promote democracy in Ukraine. For example, in late 2010 the George Soros foundation came under scrutiny from the Security Service of Ukraine and Yanukovych's Party of Regions. During this time, Oleksandr Yefremov, a Party of Regions political leader claimed the Soros organization had given monies to train Ukrainian activists so they could develop similar programs that were used in North Africa to bring around democratic reforms. ${ }^{753}$ By 2013, Yanukovych's ideas about the nature of the threat from the West was made clear when he stated, "I am categorically against others coming to our country and teaching us how to live. It is very important that other countries stay out of our home issues, that they don't think it's OK to do here as they please....754

Yanukovych's ideas about Russia represented a death knell for realists, who argue the balance of military power is one of the most important factors shaping the actions of states in the international system. In Yanukovych's case, Russia’s military superiority and demonstrated willingness to use armed force against former Soviet states were minor factors in his strategic alignment calculations. What mattered more was Yanukovych's ideas about the nature of the Russian threat, which when filtered through his belief system produced a low threat perception of his northern neighbor and a preference for positive bandwagoning with Moscow.

President Petro Poroshenko. In late February 2014 the Ukrainian parliament voted to remove Yanukovych from power and hold early presidential elections. By May 2014, Petro Poroshenko

\footnotetext{
${ }^{753}$ Kuzio, Taras. 2011. "Ukrainian Politicians Put the Squeeze on Civil Society." Radio Free Europe/Radio Liberty, 18 May 2011. https://www.rferl.org/a/ukrainian_politicians_puts_the_squeeze_on_civil_society/24178777.html. Accessed 13 January 2017.

${ }^{754}$ Yanukovych, Viktor. 2013a. "President Yankovych Press Conference." Sputnik News, 19 December 2013. http://sputniknews.com/voiceofrussia/news/2013_12_19/Ukraine-suspends-talks-with-EU-to-clarify-free-trade-areaterms-Yanukovych-4159/. Accessed 14 January 2017.
} 
had become the president of Ukraine. President Poroshenko entered office with the highest threat perceptions of all presidents under examination in this study. ${ }^{755}$ With Russia's violation of Ukraine's territorial integrity and continued political meddling in the state's internal affairs, Poroshenko's threat perceptions of Russia remained stable for the two years under examination. Separately, Poroshenko's threat perceptions of the U.S. were low. Given these conditions, rather than give-in to Russian military and economic pressure, Poroshenko's beliefs about aligning Ukraine with the West remained unwavering.

The nature of the Russian threat took on two forms during President Poroshenko's first two years in office: military and economic. In the military domain, the extent to which Russia represented a high threat was first demonstrated in March 2014 when Moscow annexed Crimea following a referendum to join the Russian Federation. By May 2014, with political and economic backing from Russia, separatists in Donetsk and Luhansk issued referendums for selfrule. ${ }^{756}$ By August, Russian military forces had crossed the border into eastern Ukraine as part of a conventional operation to support pro-Russian forces and to seize key terrain in the Donbass in order to establish a tactically advantageous line of control for the separatists. ${ }^{757}$ In his address to the U.S. Congress in September 2014, Poroshenko placed into context his ideas about the nature of the Russian threat stating, "the war that... [Ukraine] is fighting is not only Ukraine's war. It is Europe's, and it is America's war, too. It is a war of the free world and for a free world.'758

\footnotetext{
${ }^{755}$ Author's analysis. The average intensity of Petro Poroshenko's threat perceptions, based on the professional assessments of area experts, was a unanimous 1.0 (high threat).

${ }^{756}$ Vernon, Will. 2014. "Ukraine Rebels Hold Referendums in Donetsk and Luhansk." BBC, 11 May 2014. http://www.bbc.com/news/world-europe-27360146. Accessed 20 January 2017.

${ }^{757}$ Menkiszak, Marek, Rafał Sadowski, and Piotr Żochowski. 2014. "The Russian Military Intervention in Eastern Ukraine. The Centre for Eastern Studies (OSW), 03 September 2014. https://www.osw.waw.pl/en/publikacje/ analyses/2014-09-03/russian-military-intervention-eastern-ukraine. Accessed 20 January 2017.

${ }^{758}$ Poroshenko, Petro. 2014a. "Full Text of Poroshenko's Speech to Joint Session of US Congress." Kyiv Post, 19 September 2014. https://www.kyivpost.com/article/content/war-against-ukraine/full-text-of-poroshenkos-speech-tojoint-session-of-us-congress-365182.html. Accessed 20 January 2017.
} 
Poroshenko's threat perceptions of Russia also had an economic facet. Like his predecessors, he fully realized Ukraine's economic vitality was closely intertwined with Russia, especially in the areas of trade, energy, and industry. This realization, coupled with Moscow's previous track record with Ukraine on the emplacement of sanctions or cutting energy supplies contributed significantly to Poroshenko's perceptions of Russia as the most threatening regional great power. The Ukrainian president's ideas about the Russian threat were validated in June 2014 when, in the shadow of an escalating conflict in eastern Ukraine between pro-Russia rebels and government forces, the Kremlin cut natural gas supplies following a disagreement over price. ${ }^{759}$ Although the EU's intervention and financial support would see gas flowing by December, Moscow cut supplies again in November 2015 when Kiev refused to provide advanced payments for Russian natural gas. This time Ukraine was able to diversify its energy imports from Hungary and Slovakia, which helped partially mitigate the country's vulnerability of relying on Russian energy supplies. ${ }^{760}$

From 2014 to 2015, President Poroshenko tended to prefer a positive bandwagoning alignment with the United States over Russia consistently registering higher levels of verbal cooperation with the former. The first indicator of Poroshenko's alignment preference was made visible during a meeting with President Barrack Obama in Warsaw, Poland just several days after his election as president. According to Ukraine's former Ambassador to the U.S. Oleh Shamshur, Poroshenko's proclivity to align with the United States was driven by two key ideas. First, by seeking out the U.S. president, Poroshenko hoped to establish an informal political and

\footnotetext{
${ }^{759}$ MacFarquar, Neil. 2014. "Gazprom Cuts Natural Gas Supply to Ukraine. New York Times, 16 June 2014. https://www.nytimes.com/2014/06/17/world/europe/russia-gazprom-increases-pressure-on-ukraine-in-gasdispute.html?mtrref=www.google.com\&gwh=2941BAE7F435A6321A9B9B9055FDD5B6\&gwt=pay\&assetType=n yt_now. Accessed 20 January 2017.

${ }^{760}$ Iwański, Tadeusz. 2016. "Ukraine: Successful Diversification of Gas Supply.” The Centre for Eastern Studies (OSW), 03 February 2016. https://www.osw.waw.pl/en/publikacje/analyses/2016-02-03/ukraine-successfuldiversification-gas-supply. Accessed 14 January 2017.
} 
personal relationship with President Obama as a way to help foment future formal cooperation.

Second, Poroshenko's alignment preferences with the United States could help spur much needed political and military support from Washington that would allow Kiev to counter Russian military and political interference in Ukraine. ${ }^{761}$ For Poroshenko, a strategic alignment with the United States was the top foreign policy priority for his government. Realizing this goal would set conditions for him to better advance his domestic and foreign policy agendas.

A second indicator of Poroshenko's inclination to align with the United States was seen in the military sphere. Prior to his election, Poroshenko foreshadowed his alignment preference with Washington asserting, "we basically need a new security alliance with the United States and Europe to protect the Ukraine militarily. As president, I will fight for this alliance and undertake talks immediately." ${ }^{762}$ After his election, Poroshenko followed through on this promise by seeking to expand the U.S. military footprint and that of NATO's in Ukraine. During his first trip to Washington in September 2014, Poroshenko made a direct request to the U.S. Congress for military assistance to deal with the Russian threat and separatists in the Donbas. Poroshenko's efforts were successful with the U.S. allocating \$53 million in support, of which $\$ 46$ million was for non-lethal military items including counter-artillery radars, body armor, and general supplies. ${ }^{763}$ Although Poroshenko failed to secure lethal military aid, his demonstrated willingness to align with the United States was made explicitly clear.

\footnotetext{
${ }^{761}$ Patrikarakos, David. 2014. “A Billionaire Goes Begging.” Politico, 03 June 2014. https://www.politico.com/ magazine/story/2014/06/obama-ukraine-poroshenko-107383. Accessed 15 January 2017.

762 Poroshenko, Petro. 2014. "First Interview with Klitschco and Poroshenko." Bild, 29 May 2014. http://www.bild.de/politik/ausland/petro-poroschenko/first-interview-with-klitschko-and-poroshenko36172502.bild.html. Accessed 14 January 2017.

${ }^{763}$ Lamarque, Kevin. 2014. "Ukraine President Secures Military Aid but not Weapons." Newsweek, 18 September 2014. http://www.newsweek.com/ukraine-president-secures-us-military-aid-not-weapons-271624. Accessed 16 January 2017.
} 
Poroshenko's preference for a military alignment with the United States was also visible in his pronouncements on the country's accession into NATO; however, the Ukrainian president's comments were not necessarily the most optimistic given the ongoing crisis in the east and Moscow's attempt to create a frozen conflict. For example, in April 2014 a reporter queried Poroshenko about his ideas of Ukraine joining NATO. Poroshenko stated...

No! That decision is not for us, but for NATO. We have the feeling that the members of NATO are too divided for this to happen. We have previously seen these problems back in 2008, when Georgia was initially promised membership, and then it failed to come about after all. As president, I'd like to talk to our neighboring countries about new alliances, about extra scope for protection. ${ }^{764}$

However, following Moscow's decision to send Russian troops into Ukraine, Poroshenko was moved to introduce a bill to overturn 2010 legislation prohibiting the country from joining any military alliance. Although Poroshenko signed this bill into law in December 2014, he realized it would take five to six years to implement the necessary reforms. Furthermore, he acknowledged Ukraine's accession to NATO would also likely require a national referendum. ${ }^{765}$ Poroshenko's ideas about NATO may have also had a secondary purpose whereby after entering office, his level of verbal cooperation with the Russian Federation was almost as high as the level with the United States. An analysis of Poroshenko's foreign policy speeches in 2014 indicated the Ukrainian president retained some degree of optimism that negotiations with Russia could yield a compromise on Crimea and the Donbass. ${ }^{766}$ For example, Poroshenko initially did not believe Moscow would deploy Russian Army units into Ukraine to conduct offensive

\footnotetext{
764 Poroshenko, Petro. 2014c. 'Ukraine: Poroshenko Urges Germany To Boycott Russian Gas, Rejects 'Oligarch' Epithet." Bild, 02 April 2014.

${ }^{765}$ Bandow, Doug. 2014. "Ukraine Wants to Join NATO and Fight Russia: U.S. Must Say No and Make Alliance an Issue of Security, Not Charity." CATO Institute, 26 December 2014. https://www.cato.org/publications/commentary/ ukraine-wants-join-nato-fight-russia-us-must-say-no-make-alliance-issue. Accessed 14 January 2017.

${ }^{766}$ In June 2014, Poroshenko stated, “Look, again, Russia is our big neighbor. Maybe we can have other neighbors, maybe the United States, maybe Canada. But Russia is our long-term neighbor and to talk about long-term perspective of security, would be simply impossible without Russia." See Poroshenko, Petro. 2014e. Cited in Amanpour, Christiane. 2014. "Interview with Petro Poroshenko, President of Ukraine." CNN, 26 June 2014. http://edition.cnn.com/TRANSCRIPTS/1406/26/ampr.01.html. Accessed 16 January 2017.
} 
military operations in 2014. In his words, "I think an open war in the form of Russian ground troops crossing the Ukrainian-Russian border will not happen. This is dangerous for Russia because it would be a real war and people in Russia will not support that." ${ }^{\prime 767}$ Poroshenko's beliefs were subsequently reflected in his level of verbal cooperation with Russia but should be considered as diplomatic engagement, not an effort to align with Russia. Following a brief meeting in June 2014 to commemorate the $70^{\text {th }}$ anniversary of the Normandy invasion, Putin appeared open to diplomatic talks; however, by August Russian ground units were in Ukraine thereby solidifying Poroshenko's high threat perceptions of Russia.

In sum, this section finds Ukrainian presidents viewed Russia as the greatest external threat to the state. A quantitative analysis revealed there is statistically significant differences in each of the presidents' philosophical beliefs; however, those presidents (Kuchma and Yushchenko) with the most similar beliefs did not retain the same alignment preferences. In this case, Presidents Yushchenko and Poroshenko's high threat perceptions were associated with a preference for positive bandwagoning with the United States. Leonid Kuchma exhibited moderately low threat perceptions and preferred great power bridging. Although an operational code analysis is a useful econometric tool for discerning a president's beliefs about world politics, qualitative techniques are needed to achieve a more precise understanding of their alignment preferences. Finally, President Yanukovych viewed Russia as a low threat opting for a positive bandwagoning alignment with Moscow.

\footnotetext{
${ }^{767}$ Poroshenko, Petro. 2014f. In Weymouth, Lally. "Interview with Ukrainian Presidential Candidate Petro Poroshenko." Washington Post, 25 April 2014. https://www.washingtonpost.com/opinions/interview-withukrainian-presidential-candidate-petro-poroshenko/2014/04/25/74c73a48-cbbd-11e3-93eb6c0037dde2ad_story.html. Accessed 14 January 2017.
} 


\section{Conclusion}

This chapter examined the relationship between a president's perceptions of external threats and his accompanying alignment preferences with the United States and Russia between 1995 and 2015. The results of this endeavor returned several key findings. First, while the regional balance of power is an important factor shaping a president's threat perceptions, it is not the most important one. For the cases under examination, Russia consistently maintained a favorable balance of power; however, each of the twelve president's perceptions about this threat varied and were subsequently associated with a particular alignment preference. A majority of the presidents (Heydar and Ilham Aliyev, Petru Lucinschi, Vladimir Voronin, Eduard Shevardnadze, Giorgi Margvelashvili (in late 2013), and Leonid Kuchma) perceived Russia as a moderate threat, which was associated with a preference for great power bridging. Those presidents with high threat perceptions of Russia (Mikheil Saakashvili, Giorgi Margvelashvili (2014-2015), Nicolae Timofti, Viktor Yushchenko, and Petro Poroshenko) preferred a positive bandwagoning alignment with the United States. Viktor Yanukovych and Vladimir Voronin (before 2003) perceived Russia as a low threat, which was associated with a positive bandwagoning alignment preference with Moscow.

This chapter also found a quantitative analysis of each president's philosophical beliefs was a generally useful endeavor to understand a political leader's beliefs about world politics and the fundamental character of other state actors in the international system. Here, an operational code analysis of each president's master philosophical beliefs provided a baseline from which to understand how all presidents generally viewed the nature of the political universe in friendly terms. A qualitative analysis subsequently gave specificity to their threat perceptions and alignment preferences. 
An operational code analysis had it limits however. In this case, ANOVA and Tukey HSD test results identifying which presidents were the most similar in their master philosophical beliefs did not convey consistently to their ideas about the external threats and preferences for alignment. For example, Presidents Kuchma and Yushchenko were the most similar in their philosophical beliefs; however, Kuchma preferred great power bridging, while Yushchenko gravitated toward positive bandwagoning with the United States. Taken together, this study concludes using multiple methods can potentially garner a more holistic understanding of small state alignment in the post-Soviet space.

Finally, this study concludes a president's threat perceptions should not be regarded as a unitary causal factor in the state's foreign policy decision-making to align with one regional great power over another. More appropriate, a president's threat perceptions are best understood as important variable subject to changes in his/her ideas about the state's alignment, which in turn are affected by changes in the international system. This was particularly the case with Moldovan president Vladimir Voronin and Georgian President Giorgi Margvelashvili. Voronin initially preferred a positive bandwagoning alignment with Russia but then changed to great power bridging after the Kozak Memorandum fiasco. Margvelashvili initially preferred great power bridging but then opted for a positive bandwagoning alignment with the United States. 
We can on occasion make charming speeches. We can claim our foreign policy is idealistic... Actions speak louder than words - Hiram Bingham, 1914. ${ }^{768}$

\section{Chapter Seven: Foreign Policy Orientation, Domestic Politics \& Small State Alignment}

\section{Introduction}

Speaking in the months prior to the outbreak of the First World War, Hiram Bingham's poignant remark reminds us of the potential limits of the eloquent words of statesmen, who are charged with developing and implementing a state's foreign policies. As demonstrated in the previous chapter, one can discern how a president's philosophical beliefs may serve as a point of departure for a qualitative analysis on their threat perceptions and alignment preferences with the United States and Russia. However, a political leader's words and preferences, while very important, do not on their own bring about a desired policy outcome. Put another way, words are important, but actions speak louder. This is particularly true with ruling elites, who must be able to translate their alignment preferences into viable foreign policies, while operating in a competitive domestic political environment.

The purpose of this chapter is to examine the relationship between a president's ideas about strategy (i.e. his/her foreign policy orientation) and the state's alignment trajectory as conditioned by domestic politics. The essence of my argument is that ruling elites come to the foreign policy table with different ideas about strategy and how to align the state with different regional great powers. These different strategic approaches are based on a political leader's beliefs on the optimal tactics, which will help them realize their international and/or domestic goals. However, because ruling elites do not operate in a political vacuum, domestic politics can

\footnotetext{
${ }^{768}$ Bingham, Hiram. 1914. "Should We Abandon the Monroe Doctrine?" In Hubbard Blakeslee, George, Granville Stanley Hall, Harry Elmer Barnes (eds.), The Journal of International Relations, Volume 4. Worcester, MA: Clark University, 348.
} 
either constrain or enable a ruling leader's ability to translate his/her alignment preferences into material action.

This chapter posits four research questions. First, what are each president's instrumental beliefs about the best approaches to realize their foreign policy goals? Do presidents tend to see a strategy of cooperation or confrontation as the most optimal approach in international affairs? Answering these questions establishes a baseline from which to ask a more poignant question: What are the foreign policy orientations for the presidents in Azerbaijan, Georgia, Moldova, and Ukraine with respect to the United States and the Russia? Third, how did each president's beliefs about strategy and their corresponding foreign policy orientations translate into tangible or intangible actions with these regional great powers? Fourth, to what extent does domestic politics matter in a president's ability to translate his/her alignment preferences into action?

By addressing these questions in a systematic way, this chapter posits a corresponding set of supporting hypotheses. For the research questions on each president's instrumental beliefs, the null hypothesis is as follows: Within each country, there are no differences in the operational code (instrumental beliefs) of the presidents. The alternate hypothesis is: Within each country, there are differences in the operational code (instrumental beliefs) of the presidents. For the second and third research questions, it is anticipated that presidents with an accommodative foreign policy orientation with a particular regional great power will be more apt to follow a positive bandwagoning alignment while pragmatic presidents will steer towards a strategy of great power bridging. As a corollary, presidents with a confrontational foreign policy orientation with one regional great power are more likely to follow a positive bandwagoning alignment with a different regional great power. For the research question on domestic politics, it is hypothesized higher or lower levels of government fragmentation and issue polarization will 
constrain or enable respectively a president's ability to implement policies to realize his/her preferred alignment with the United States and/or Russia.

This chapter is organized into six sections. Section one highlights the key findings from this chapter. In sections two through five, the four cases are addressed: Azerbaijan, Moldova, Georgia, and Ukraine. Each of these sections begin with an examination of a president's instrumental beliefs (I-1) and the results from the ANOVA and Tukey's HSD tests when applicable. This is followed by a qualitative analysis of each president's ability to translate his alignment preferences into material action. As part of this effort, this study highlights the key events and policies associated with either positive bandwagoning or great power bridging. The last section provides a brief conclusion.

\section{Findings}

This investigation finds presidents in Azerbaijan, Georgia, Moldova, and Ukraine believed a strategy of cooperation was the best approach to achieve their foreign policy goals. As detailed in the table below, pragmatism was the dominant foreign policy orientation held by ruling presidents, while great power bridging was the most frequently enacted alignment strategy. Those presidents retaining an accommodative foreign policy orientation tended to implement a positive bandwagoning alignment with pragmatic presidents opting for a great power bridging strategy. The role of domestic politics was mixed where great power bridging and positive bandwagoning occurred regardless of the levels of government fragmentation or issue polarization. When fragmentation and polarization were higher, presidents were able to use their constitutional powers or political acumen to build consensus or a coalition that allowed them to translate their alignment preferences into action. 
Table 21: Summary of Chapter Seven Findings

\begin{tabular}{|c|c|c|c|c|c|}
\hline Country & President & Foreign Policy Orientation & \begin{tabular}{|c|} 
Political \\
Fragmentation \\
\end{tabular} & $\begin{array}{c}\text { Issue } \\
\text { Polarization } \\
\end{array}$ & Alignment Strategy \\
\hline Azerbaijan & Heydar Aliyev & Pragmatic & Low & Low & Great Power Bridging \\
\hline Azerbaijan & Ilham Aliyev & Pragmatic & Low & Low & Great Power Bridging \\
\hline Georgia & Eduard Shevardnadze & Pragmatic & Low & Low & Great Power Bridging \\
\hline Georgia & Mikheil Saakashvili & Accommodative (U.S.) & Low & Low & Positive Bandwagonning (U.S.) \\
\hline Georgia & Giorgi Margvelashvili & $\begin{array}{l}\text { Pragmatic (2013) / Accomodative } \\
\text { (U.S.; 2014-15) }\end{array}$ & Moderate & Moderate & $\begin{array}{l}\text { Great Power Bridging (2013) / Positive } \\
\text { Bandwagonning (U.S.; 2014-2015) }\end{array}$ \\
\hline Moldova & Petru Lucinschi & Pragmatic & High & Moderate & Great Power Bridging \\
\hline Moldova & Vladimir Voronin & $\begin{array}{c}\text { Accommodative (Russia; 2001-03) / } \\
\text { Pragmatic (2004-09) }\end{array}$ & Moderate & Moderate & $\begin{array}{c}\text { Positive Bandwagonning (Russia; 2001-03) / } \\
\text { Great Power Bridging (2004-09) }\end{array}$ \\
\hline Moldova & Nicolae Timofti & Accommodative (U.S.) & Moderate & Low & Positive Bandwagonning (U.S.) \\
\hline Ukraine & Leonid Kuchma & Pragmatic & Low & Low & Great Power Bridging \\
\hline Ukraine & Viktor Yushchenko & Accommodative (U.S.) & Moderate & Moderate & Positive Bandwagonning (U.S.) \\
\hline Ukraine & Viktor Yanukovych & Accommodative (Russia) & Low & Moderate & Positive Bandwagonning (Russia) \\
\hline Ukraine & Petro Poroshenko & Accommodative (U.S.) & Moderate & Low & Positive Bandwagonning (U.S.) \\
\hline
\end{tabular}

\section{Azerbaijan: Findings and Discussion}

In Azerbaijan, this study finds Presidents Heydar and Ilham Aliyev maintained a pragmatic foreign policy orientation while in office. ${ }^{769}$ In general, the pragmatism of both Azeri presidents was grounded in their ideas on how an alignment with Russia was a strategic necessity in order to achieve a resolution in the Nagorno-Karabakh. Separately, their respective alignment policies with the United States were driven by their beliefs of how Washington could act as a vanguard element paving the way for the development of Azerbaijan's energy infrastructure, which would send oil and natural gas to the West.

\section{The Instrumental Beliefs of Azeri Presidents}

In analyzing the results of Heydar and Ilham's instrumental beliefs, the output from Profiler Plus indicates that for their master beliefs on strategy (I-1) both presidents believed cooperation with external states was 'definitely' the best approach to achieve their foreign policy goals registering an intensity of .74 each. This positive trend continued on the 'intensity of tactics' (I-

\footnotetext{
${ }^{769}$ All area experts responded pragmatic to the following interview question: "How would you best categorize the foreign policy orientation of President Heydar Aliyev towards Russia, the United States, and Western European powers? Would you characterize their foreign policy orientation as accommodative, pragmatic, confrontational, or something else?"
} 
2) index with both presidents believing cooperative tactics were 'definitely' of higher utility than conflictual tactics. In this index, Heydar Aliyev had a slightly lower score (.36) than Ilham, who registered a score of .43. When viewing the specific 'utility of means' index (I-5), of the three cooperative tactics (appeal, promise, reward), Heydar and Ilham Aliyev found the highest value with making appeals to external states (.60 and .48 respectively) with their tendency to focus on rewards coming in second (.20 and .30 respectively). With respect to the timing of their actions, Heydar and Ilham's lower I-4a scores (.26 each) indicate they preferred to employ a lower diversity of tactics, which is in line with their tendency to give precedence to the appeal tactic and to a lesser degree, reward. Both presidents also exhibited a higher propensity to shift between their words and actions (I-4b: Heydar Aliyev=.52; Ilham Aliyev=.71). Finally, both presidents, on average tended to be less acceptant of risk with Heydar Aliyev being somewhat risk averse (.29) and Ilham Aliyev being very risk averse (.21). ${ }^{770}$

Table 22: The Instrumental Beliefs of Azeri Presidents

\begin{tabular}{|c|c|c|c|c|c|c|c|c|c|c|}
\hline \multicolumn{11}{|c|}{ Heydar Aliyev } \\
\hline Instrumental Beliefs / Year & 1995 & 1996 & 1997 & 1998 & 1999 & 2000 & 2001 & 2002 & 2003 & AVG \\
\hline I-1: Direction of Strategy & 0.74 & 0.76 & 0.78 & 0.76 & 0.74 & 0.76 & 0.71 & 0.75 & 0.69 & 0.74 \\
\hline I-2: Intensity of Tactics & 0.37 & 0.39 & 0.36 & 0.36 & 0.37 & 0.36 & 0.35 & 0.37 & 0.34 & 0.36 \\
\hline I-3: Risk Orientation & 0.28 & 0.3 & 0.33 & 0.3 & 0.29 & 0.32 & 0.28 & 0.31 & 0.24 & 0.29 \\
\hline \multicolumn{11}{|l|}{ I-4: Importance of Timing of Action } \\
\hline a. Flexiblity of cooperation/ conflict tactics & 0.26 & 0.24 & 0.22 & 0.24 & 0.26 & 0.24 & 0.29 & 0.25 & 0.31 & 0.26 \\
\hline b. Flexibility of word/deed tactics & 0.59 & 0.5 & 0.46 & 0.51 & 0.52 & 0.5 & 0.53 & 0.53 & 0.56 & 0.52 \\
\hline \multicolumn{11}{|l|}{ I-5: Utility of Means } \\
\hline a. Punish & 0.07 & 0.04 & 0.06 & 0.06 & 0.05 & 0.06 & 0.06 & 0.06 & 0.07 & 0.06 \\
\hline b. Threaten & 0.01 & 0.02 & 0.01 & 0.00 & 0.01 & 0.00 & 0.01 & 0.01 & 0.03 & 0.01 \\
\hline c. Oppose & 0.05 & 0.06 & 0.04 & 0.05 & 0.07 & 0.06 & 0.08 & 0.06 & 0.05 & 0.06 \\
\hline d. Appeal & 0.58 & 0.6 & 0.63 & 0.61 & 0.59 & 0.62 & 0.59 & 0.61 & 0.56 & 0.60 \\
\hline e. Promise & 0.07 & 0.07 & 0.09 & 0.08 & 0.06 & 0.07 & 0.06 & 0.06 & 0.08 & 0.07 \\
\hline 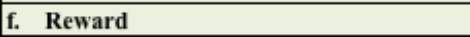 & 0.23 & 0.21 & 0.17 & 0.19 & 0.21 & 0.19 & 0.21 & 0.21 & 0.21 & 0.20 \\
\hline
\end{tabular}

\footnotetext{
${ }^{770}$ As a reminder, this measurement for a political leader's master instrumental beliefs (I-1) are as follows: $-1=$ very conflictual; $-.50=$ definitely conflictual; $-.25=$ somewhat conflictual; $0.0=$ mixed $+.25=$ somewhat cooperative; $+.50=$ definitely cooperative; $+.75=$ very cooperative. The coding for I-3 (Risk) is as follows: 0 to $.24=$ very risk averse; .25 to $.49=$ somewhat risk averse; .50 to $.74=$ somewhat risk acceptant; .75 to $1=$ very risk acceptant.
} 


\section{$\underline{\text { Azeri President Alignment }}$}

In the previous two chapters, this study found Heydar and Ilham Aliyev preferred a great power bridging strategy, exhibiting a tendency to verbally cooperate on an almost equal basis with the United States and Russia. In this chapter, both Azeri presidents were able to successfully translate their preferences into action with very little political opposition. Given the semi-authoritarian nature of the ruling government, the level of government fragmentation and polarization were low thus allowing Heydar and Ilham Aliyev an enhanced ability to realize their ideas about the state's alignment with the United States and Russia.

Heydar Aliyev. For his time in office, Heydar Aliyev exhibited a pragmatic foreign policy orientation believing it was of high importance to align Azerbaijan with the United States and Russia on an almost equal basis. For Aliyev, his ideas about developing the country's energy infrastructure and reaching a solution on the Nagorno-Karabakh were two important catalysts moving him to conclude agreements, but only in a way that did not lock Azerbaijan into a fixed geostrategic orbit around either of the regional great powers.

Low levels of government fragmentation and the absence of issue polarization over Aliyev's alignment preferences were enablers of the Azeri president's great power bridging strategy with the United States and Russia. The genesis of this empirical reality stems, in part, from Azerbaijan's 1995 constitution. This official document granted the president far-reaching powers to unilaterally develop and implement the state's foreign policies. Additionally, the constitution established a unicameral legislature (the Milli Mejlis), which acted as a rubber stamp for Aliyev's policies. For example, during deliberations on the state's foreign policies, Aliyev's New Azerbaijan Party (NAP) routinely encountered little parliamentary resistance given the absence 
of viable political opposition parties. Additionally, the prime minister, Artur Rasizade, was an Aliyev appointee from the NAP, who routinely conceded to Aliyev's policy preferences. ${ }^{771}$

Even when Washington and Western European governments would pressure Aliyev to allow the formation of opposition parties, the Azeri president was able to exert enough political control to ensure they did not gain a political footing in parliament. For example, in 2000 approximately 16 opposition parties were placed on the parliamentary ballot list; however, none of the most prominent opposition parties (e.g. National Independence, Democratic, Popular Front, and Musavat (Equality) parties)) received the minimum six percent of the vote to run thus continuing the trend of no domestic political opposition to Aliyev's alignment preferences. ${ }^{772}$

With respect to issue polarization, there was a consensus among leading political elites within Aliyev's party that a bifurcated alignment with the United States and Russia was the optimal strategy for Azerbaijan. Heydar Aliyev's willingness to use political repression and coercion to temper dissent within the ruling government was a major contributing factor to the low levels of issue polarization. According to Polity and Freedom House, Azerbaijan was categorized as a partly free autocracy under Heydar Aliyev. ${ }^{773}$ Throughout much of late 1990s and early 2000s, when political dissent did rear its head, the state's security services would harass, arrest, or torture leading opposition figures, occupy their party's headquarters, or censor the media to prevent wide-scale public demonstrations in opposition to Aliyev's foreign policies. ${ }^{774}$

\footnotetext{
${ }^{771}$ Nichol, Jim. 2006. “Armenia, Azerbaijan, and Georgia: Political Developments and Implications for U.S. Interests." Congressional Research Service, 09 May 2006. http://www.au.af.mil/au/awc/awcgate/crs/ib95024.pdf. Accessed 23 February 2017, 6.

772 Nichol, Jim. 2004. “Azerbaijan: Current Developments and U.S. Interests.” Congressional Research Service, 10 May 2004. https://www.justice.gov/sites/default/files/pages/attachments/2015/10/14/crs-reports_azerbaijan-currentdevelopments.pdf. Accessed 23 February 2017, 5.

773 The average Polity and Freedom House scores for Azerbaijan under Heydar Aliyev from 1995 to 2003 were -7 and 5.5. See Marshall et. al. 2017; Freedom House. 2017. “Azerbaijan.” Freedom in the World 1998-2003. https://freedomhouse.org/country/azerbaijan. Accessed 23 March 2017.

${ }^{774}$ See various reports from Human Rights Watch on Azerbaijan and the U.S. State Department Country Reports on Human Rights Practices. Human Rights Watch. 2017. “Azerbaijan-Reports.” https://www.hrw.org/publications
} 
Operating under conditions of low government fragmentation and issue polarization, domestic politics served as an enabler of Heydar Aliyev's preferred alignment strategy of great power bridging. A key point here is Aliyev was able to more effectively and efficiently translate his verbal proclamations into material actions to realize this particular foreign policy objective. In the paragraphs below, key instances of material cooperation with the United States and Russia are detailed to support this assertion.

In the economic sphere, Heydar Aliyev's ideas about the central importance of aligning with Russia and the United States was on full display from 1995 to 2003 following the signing of the "contract of the century," in 1994 where the oil companies from the United States and Russia were included in a 30-year agreement to develop Azerbaijan's energy sector. ${ }^{775}$ Beyond this landmark agreement, Aliyev was able to conclude other mutually beneficial agreements with the Washington and Moscow. For example, in 1996 Aliyev signed commercial-economic and scientific-technological agreements with Russia to bolster trade and economic development between Azerbaijan and the Republic of Tatarstan. ${ }^{776}$ With the United States, two important events included Aliyev's signing of the 1995 Trade Relations agreement and 1997 U.S.Azerbaijan bilateral investment treaty. ${ }^{777}$ These material actions were subsequently followed by other agreements including the opening of the American Chamber of Commerce Office in Baku and the creation of the Caspian-American telecom. ${ }^{778}$

\footnotetext{
?country\%5B0\%5D=9583; United States Department of State. 2017. "U.S. State Department Country Reports on Human Rights Practices - Azerbaijan.” Bureau of Democracy, Human Rights, and Labor. https://www.state.gov/j/ drl/rls/hrrpt/. Accessed 02 March 2017.

${ }^{775}$ Gutterman, Steve. 1994. “Azerbaijan Parliament Ratifies Oil Deal.” UPI, 15 November 1994. https://www.upi. com/Archives/1994/11/15/Azerbaijan-parliament-ratifies-oil-deal/2509784875600/. Accessed 02 February 2017.

${ }^{776}$ Aliyev, Heydar. 1996c. "Statement of Heydar Aliyev after Signing of the Agreement on Commercial-economic, Scientific-technical and Cultural Cooperation between the Republics of Azerbaijan and Tatarstan." Heydar Aliyev Library, 21 November 1996. http://lib.aliyev-heritage.org/en/7854107.html. Accessed 22 January 2017.

${ }^{777}$ Interview on file with author.

${ }^{778}$ Aliyev, Heydar. 2017. “Azerbaijan-U.S. Economic Relations.” Heydar Aliyev Library. http://lib.aliyevheritage.org/en/showmap.html. Accessed 30 August 2016.
} 
In the political realm, Aliyev's alignment with Russia was strengthened in 1997 when he signed a 29-article Treaty of Friendship, Cooperation, and Security with Russia and a series of intergovernmental agreements designed to promote a closer economic and political alignment between both states. Speaking on the significance of the Friendship Treaty, Aliyev asserted, By signing this document, we... realize our responsibility for implementing the document and we understand very well its very great significance. They are creating a good treaty base and legal foundation to further develop and deepen our cooperation in all spheres. Moreover, we have a joint historical destiny. Our historical links and what the Azerbaijani people gained from Russia, Russian culture and science is invaluable. We value all this, and this is a basis for our cooperation today and for our more successful cooperation in the future. ${ }^{779}$

Aliyev continued his political alignment with Russia into 2002 when during a visit to Moscow he signed over 70 intergovernmental agreements, including an official agreement demarcating each country's boundaries in the Caspian Sea. It was during this event Aliyev stressed how Russia, more than any other country, was Azerbaijan's most important strategic partner. ${ }^{780}$

With the United States, Aliyev's consistent political alignment resulted in numerous foreign visits and meetings with U.S. political leaders. This led to various diplomatic initiatives including the Baku-Houston Sister City Association, which has a mission of promoting greater understanding, mutual appreciation, and greater cooperation between citizens in the United States and Azerbaijan. ${ }^{781}$ Perhaps one of the most important tangible outcomes from Aliyev's concerted efforts with the United States was to reduce the influence of the Armenian lobby in Washington leading to the lifting of a ban on U.S. foreign aid in 2001 and arms sales in $2002 .^{782}$

\footnotetext{
${ }^{779}$ Aliyev, Heydar. 1997. "Yeltsin, Aliyev Comment on Friendship Treaty.” Mayak Radio Network, 03 July 1997. ${ }^{780}$ Fiefer, Gregory. 2002. "Caspian: Russia, Azerbaijan Sign Agreement on Sea Boundaries.” Radio Free EuropeRadio Liberty, 24 September 2002. https://www.rferl.org/a/1100881.html. Accessed 01 October 2016; Peuch, JeanChristopher. 2002. "Russia/Azerbaijan: Radar Deal: Win-Win Situation or Fool's Bargain?" Radio Free EuropeRadio Liberty, 29 January 2002. https://www.rferl.org/a/1098628.html. Accessed 01 October 2016.

${ }^{781}$ Houston-Baku Sister City Association. 2017. https://houstonbaku.org. Accessed 02 October 2016.

${ }^{782}$ Ibrahimov, Rovshan. 2014. "U.S.-Azerbaijan Relations: A View from Baku." Rethink Institute, 14 October 2014, 1; Danileyan, Emil. 2002. "U.S. Scraps Arms Ban on Armenia, Azerbaijan. Radio Free Europe/Radio Liberty, 29 March 2002. https://www.azatutyun.am/a/1567641.html. Accessed 02 October 2016.
} 
Finally, Aliyev's great power bridging alignment was visible in the state's military and security-related actions. With Russia, in January 2002 Aliyev signed seven bilateral agreements with Russia, the most important of which was a document extending Russia's lease of the Qabala Radar station for 10 years. Key events demonstrating Aliyev's equal alignment with the U.S. centered on his support for Washington's global counter-terrorism operations. Specifically, Aliyev allowed U.S. military forces to use the country's airspace to deliver supplies to Afghanistan in 2001 and the Azeri president committed a small contingent of troops to the International Security and Assistance Force (ISAF) in Kabul. Following a decision by President Bush to lift the ban on U.S. support as stipulated under the Freedom Support Act and to grant Azerbaijan 'most favored nation' status, Aliyev's strategic alignment with Washington was made even more pronounced with the deployment of 250 Azeri soldiers to the U.S.-led war in Iraq. ${ }^{783}$

Ilham Aliyev. As president, Ilham Aliyev was also a pragmatic leader, who believed Azerbaijan should develop a strategic partnership with the United States and Russia. In response to critics, who attempted to brand this Azeri president as pro-Russian or pro-U.S., he stated, "we [Azerbaijan] have no orientation, although there are attempts to interpret it in this way sometimes. Our orientation is to establish normal relations with our neighbors and international organizations in order for Azerbaijan to take a major place in the world." ${ }^{784}$ According to one area specialist, Aliyev's pragmatism was characterized by both accommodation and confrontation. When there were tensions with the United States, Aliyev assumed a more accommodative strategy with Russia and vice versa. For example, during the initial years of President Obama's administration, Aliyev took a confrontational approach with the U.S. owing

\footnotetext{
${ }^{783}$ Interview on file with author; also see Lansford, Tom. 2012. 9/11 and the Wars in Afghanistan and Iraq: A Chronology and Reference Guide. ABC-CLIO, 110.

${ }^{784}$ Aliyev, Ilham 2004.
} 
to Washington's criticisms of Baku's human rights record and attempts to foster peaceful ties between Armenia and Turkey. ${ }^{785}$ During this time, the Azeri president was more accommodative with Moscow.

With little change in the political architecture of the Azeri state, Ilham Aliyev faced little domestic opposition as he pursued a great power bridging alignment with the United States and Russia. Once again, low government fragmentation was a key enabler allowing Aliyev to bring to fruition a wide array of material actions with Moscow and Washington. Operating under the 1995 Constitution, Ilham Aliyev consistently prevented the emergence of any major political opposition groups. To help maintain this low degree of government fragmentation, Aliyev implemented a new tactic in 2005 by artificially increasing the number of pro-Aliyev independent candidates during parliamentary elections. ${ }^{786}$ This move helped to minimize government fragmentation by keeping the number of opposition parties to an absolute minimum. Additionally, in 2009 changes to the electoral code reduced candidate access to public campaign funding and shortened the campaign window from 28 to 22 days. ${ }^{787}$ Taken together, the level of government fragmentation in the Azeri state has remained low if not non-existent.

Issue polarization was also of no consequence under Ilham Aliyev as there was little opposition to his bifurcated alignment with the United States and Russia. As before, the Azeri state under Ilham continued to use political repression as a way to stave off issue polarization with the country's Polity (autocratic) and Freedom House (partly free) scores remaining the

\footnotetext{
785 Interview on record with author.

${ }^{786}$ Rovshan Ismayilov. 2005. “Azerbaijan's Parliamentary Election: When is an Independent Candidate Truly Independent?” Eurasianet.org, 30 October 2005. http://www.eurasianet.org/departments/insight/articles/ eav103105a.shtml. Accessed 01 March 2017.

${ }^{787}$ Freedom House. 2015. "Azerbaijan." Freedom in the World 2015. https://freedomhouse.org/report/freedomworld/2015/azerbaijan. Accessed 02 March 2017.
} 
same. ${ }^{788}$ For example, in the wake of the 2003 national election that brought Ilham Aliyev to power, violent demonstrations by various political opposition groups were met with an armed force resulting in the detention of over 700 oppositionists, of which 100 were convicted with many group leaders receiving prison sentences. ${ }^{789}$ Taken together, low levels of government fragmentation and issue polarization became an enabler for Ilham Aliyev's ideas about the merits of a great power bridging alignment strategy. In the proceeding paragraphs, the major political and military events supporting this conclusion are detailed.

Beginning with Russia, there were two major political events demonstrating Aliyev's alignment with Russia. The first occurred in February 2004 when the Azeri president signed "the Moscow Declaration." This document reaffirmed Azerbaijan's previous agreements with Russia and gave new emphasis for Baku and Moscow to develop stronger security and economic ties in the decade ahead. ${ }^{790}$ The second transpired in July 2008 when Aliyev signed a Declaration of Friendship and Strategic Partnership. Both events served as benchmarks guiding Azerbaijan's alignment with Russia while Aliyev was in office. ${ }^{791}$

Aliyev's visits to Moscow also served as opportunities for him to emphasize his ideas about achieving a resolution on the Nagorno-Karabakh issue; however, while Aliyev would frequently call out Russia's key role, he was also quick to note the central importance of the United States. For example, during his visit to Moscow in 2004 Aliyev stated, "the United States and Russia...

\footnotetext{
788 The average Polity and Freedom House scores for Azerbaijan under Heydar Aliyev from 2004-2015 were -7 and 5.6. See Marshall et. al. 2017; Freedom House. 2017. “Azerbaijan.” Freedom in the World 1998-2003. https://freedomhouse.org/country/azerbaijan. Accessed 23 March 2017.

${ }^{789}$ Nichol 2004, 5; For a list of opposition leaders receiving prison sentences, see Human Rights House. 2004.

“Azerbaijani Leaders Sentenced to Long Prison Terms." http://humanrightshouse.org/Articles/6171.html. Accessed 23 March 2017.

${ }^{790}$ Lansford, Tom. 2012a. Political Handbook of the World 2012. Sage, 94.

791 "Strategic Partners Russia and Azerbaijan." President of Russia Website, 03 July 2008. http://en.kremlin.ru/ events/president/news/651. Accessed 22 October 2016.
} 
should join together in elaborating an acceptable solution to this issue. They must facilitate the settlement of the problem so as to recover Azerbaijan's captured territory."

Perhaps the most visible indicator of Aliyev's pragmatic foreign policy orientation was seen in the area of economics where the Azeri president continued with or established new agreements or mutually beneficial projects with the United States and Russia. With the Washington, Aliyev continued to strengthen the state's alignment in the energy sector when in 2006 the U.S.-backed Baku-Tbilisi-Ceyhan (BTC) pipeline began sending oil to customers in the West. Aliyev's beliefs about the central role of the United States were made explicit during his speech at the opening of the BTC pipeline when he noted Azerbaijan has... "always felt America's support, relied on it, and in some cases that support played a key role."793 Separately, in 2007, both governments established the U.S.-Azerbaijan Economic Partnership Commission, which facilitated closer economic cooperation in finance, investment, trade, and energy. ${ }^{794}$

In parallel to these efforts, Aliyev also brought to fruition new initiatives with Russia. In the decade after Aliyev’s 2004 visit to Moscow, trade between Russia and Azerbaijan increased significantly. In 2004, Azerbaijan exports to Russia totaled \$210 million while imports from Russia came in at $\$ 570$ million (in U.S. dollars). By 2013, exports to and imports from Russia totaled $\$ 1.08$ billion and $\$ 1.5$ billion respectively. ${ }^{795}$ Beyond higher levels of trade, one of the most visible examples of Azerbaijan's alignment with Russia occurred in 2009 when

\footnotetext{
792 Aliyev, Ilham. 2004b. “Azeri President Quizzed on Russia's Caucasus Policy, Karabakh, NATO, EU.” Izvestiya, 04 February 2004.

793 Aliyev, Ilham. 2006a. "Inauguration of the Heydar Aliyev Baku-Tbilisi-Ceyhan Main Export Oil Pipeline." President of Azerbaijan Website, 13 July 2006. http://archive.president.az/articles.php?item_id=200708130 54416242\&sec_id=11. Accessed 23 October 2016.

794 The Ministry of Finance for the Republic of Azerbaijan. 2012. "The 3rd Meeting of the Azerbaijan - USA Intergovernmental Commission on Economic Cooperation. http://www.maliyye.gov.az/en/node/1323. Accessed 24 October 2016.

795 World Bank. 2016. World Integrated Trade Solution (WITS). http://wits.worldbank.org/about_wits.html. Accessed 04 April 2016.
} 
Azerbaijan's SOCAR signed an agreement on the sale of Azeri gas to Russia as a way for Moscow to maintain a higher degree of influence in the European energy market. ${ }^{796}$

Finally, in the military sphere, Aliyev's pragmatism served as a catalyst for his alignment with both regional great powers. With the United States, the Azeri president continued his predecessor's commitment to a military alignment signing a security cooperation agreement in 2004. Speaking in 2006 about his country's close alignment with the U.S., he emphasized how...

We are a member of antiterror coalition from the very start. We have the militaries in Kosovo and Afghanistan. Immediately after operation started in Iraq we sent there our soldiers. We work very actively with United States and our partners towards integration to NATO. We firmly cooperate with Union of Europe and integration to Euro-Atlantic place is our strategic choice. ${ }^{797}$

Beyond his military support for the U.S. and its missions in Kosovo, Afghanistan, and Iraq, Aliyev's s ideas about a military alignment with Washington represented a key component of his great power bridging strategy. In light of these key actions, there were limits to Aliyev's military alignment with the United States. For example, in response to U.S. support for Kosovo's declaration of independence, Aliyev order the withdrawal of Azeri military forces participating in the NATO-led peacekeeping mission in the newly-established country as a sign of protest. ${ }^{798}$

Finally, Aliyev's preference for an alignment with Russia was also evident, to a lesser degree, in the domain of military affairs. For example, a series of arms sales agreements in 2011 provided Baku with billions of dollars in high-tech Russian weapons and equipment, including T-90 tanks, MI-24 attack helicopters, and S-300 air defense systems. Separately, in 2014 Baku agreed to enter into a system of collective security for the Caspian region that would include

\footnotetext{
${ }^{796}$ Bachman, Jessica and Denis Dyomkin. 2010. "UPDATE 2-Russia buys Azeri gas to keep EU market -analysts." Reuters, 03 September 2010. http://uk.reuters.com/article/russia-azerbaijan-gas/update-2-russia-buys-azeri-gas-tokeep-eu-market-analysts-idUKLDE6820GJ20100903. Accessed 20 October 2016.

${ }^{797}$ Aliyev, Ilham. 2005. "Interview of President of Azerbaijan Republic to Great Britain." Sky News, 16 August 2005. http://archive.president.az/articles.php?item_id=20070810064109248\&sec_id=14. Accessed 22 October 2016. ${ }^{798}$ Ravshon 2008, 1.
} 
emergency response exercises between the Russia and Azerbaijan beginning in 2016. ${ }^{799}$

Although Russia's military presence in Armenia and its continuing military support for Yerevan had not changed, Aliyev still believed a tepid military alignment with Russia was possible.

To recap, Heydar and Ilham Aliyev exhibited a pragmatic foreign policy orientation vis-à-vis the United States and Russia. This pragmatism served to guide their great power bridging alignment resulting in a wide array of economic, military, diplomatic agreements and projects with both regional great powers. Constitutional mandates and the Azeri presidents' authoritarian tactics created low levels of government fragmentation and issue polarization allowing them to more easily translate their alignment preferences into action.

\section{Georgia: Findings and Discussion}

In Georgia, this study finds President Eduard Shevardnadze maintained a pragmatic foreign policy orientation, which was associated with a great power bridging strategy. With low levels of government fragmentation and issue polarization, Shevardnadze was generally successful in turning his verbal pronouncement into action. President Margvelashvili’s pragmatism was limited in scope and duration where during his first several months in office he sought to establish a tepid political alignment with Russia as a way to reestablish Georgia’s pre-2008 borders. In 2014 when Kremlin elites refused to compromise on issues related to South Ossetia and Abkhazia, Margvelashvili took on a confrontational approach with Moscow and a more accommodative one with the United States, which was associated with positive bandwagoning with this regional great power. With higher levels of government fragmentation, Margvelashvili

\footnotetext{
${ }^{799}$ Grove, Thomas. 2013. "Russia starts delivering \$1 billion Arms Package to Azerbaijan.” Reuters, 18 June 2013. https://www.reuters.com/article/us-russia-azerbaijan-arms/russia-starts-delivering-1-billion-arms-package-toazerbaijan-idUSBRE95H0KM20130618. Accessed 22 October 2016; Herszenhorn, David. 2012. "Russia to Close Radar Station in Azerbaijan." New York Times, 11 December 2012. "http://www.nytimes.com/2012/12/12/ world/europe/russia-to-shut-down-radar-station-in-azerbaijan.html. Accessed 22 October 2016; Sotnikov, Vladimir. 2014. "The Kremlin Shores up its Influence along Caspian Sea." Russia Direct, 14 October 2014. http://www.russiadirect.org/analysis/kremlin-shores-its-influence-along-caspian-sea. Accessed 22 October 2016.
} 
faced some challenges in turning his words into material actions. Finally, Mikheil Saakashvili exhibited an accommodative foreign policy orientation vis-à-vis the United States and a confrontational orientation with Russia, which was associated with a positive bandwagoning alignment with the former. ${ }^{800}$ Low levels of government fragmentation and issue polarization were key enablers allowing the Georgian president to more easily translate his ideas about a positive bandwagoning alignment with the United States into action.

The Instrumental Beliefs of Georgian Presidents

An analysis of the instrumental beliefs of Georgian presidents in the table below indicate they tended to view cooperation as a more optimal strategy than one grounded in confrontation.

\section{Table 23: The Instrumental Beliefs of Georgian Presidents}

\begin{tabular}{|c|c|c|c|c|c|c|c|c|c|c|c|c|c|c|c|c|c|c|c|c|c|c|c|c|}
\hline \multirow[b]{2}{*}{$\begin{array}{l}\text { Instrumental Beliefs / } \\
\text { Year }\end{array}$} & \multicolumn{10}{|c|}{ Shevardnadze } & \multicolumn{10}{|c|}{ Saakashvili } & \multicolumn{4}{|c|}{ Margvelashvili } \\
\hline & 995 & 1996 & 1997 & 1998 & 1999 & 2000 & 2001 & 2002 & 2003 & AVG & 2004 & 2005 & 2006 & 2007 & 2008 & 2009 & 20102 & 2011 & 2012 & AVG & 2013 & 2014 & 2015 & AVG \\
\hline I-1: Direction of Strategy & 0.64 & 0.64 & 0.6 & 0.6 & 0.64 & 0.64 & \begin{tabular}{l|l}
0.63 \\
\end{tabular} & 0.58 & \begin{tabular}{l|}
0.67 \\
\end{tabular} & 0.63 & 0.48 & 0.61 & 0.53 & 0.57 & \begin{tabular}{|l|}
0.53 \\
\end{tabular} & 0.5 & \begin{tabular}{l|l}
0.38 \\
\end{tabular} & 0.49 & 0.49 & \begin{tabular}{|l|}
0.51 \\
\end{tabular} & 0.6 & 0.73 & 0.76 & 0.70 \\
\hline I-2: Intensity of Tactics & 0.3 & 0.3 & 0.26 & 0.26 & 0.32 & 0.32 & \begin{tabular}{l|l}
0.29 \\
\end{tabular} & 0.26 & 0.32 & 0.29 & 0.23 & 0.28 & 0.26 & 0.26 & \begin{tabular}{|l|}
0.24 \\
\end{tabular} & 0.25 & \begin{tabular}{l|l|}
0.18 \\
\end{tabular} & 0.23 & \begin{tabular}{|l|}
0.23 \\
\end{tabular} & 0.24 & 0.22 & 0.37 & 0.4 & 0.33 \\
\hline I-3: Risk Orientation & 26 & 0.26 & 0.27 & 0.27 & 0.24 & 0.24 & \begin{tabular}{l|l}
0.27 \\
\end{tabular} & 0.24 & 0.25 & 0.26 & 0.14 & 0.24 & 0.14 & 0.19 & 0.18 & \begin{tabular}{|l|l|l|l|l|l|}
0.13 \\
\end{tabular} & 0.14 & 0.16 & \begin{tabular}{|l|}
0.16 \\
\end{tabular} & \begin{tabular}{|l|l|l|l|l|}
0.16 \\
\end{tabular} & \begin{tabular}{|l|l|l|l|}
0.23 \\
\end{tabular} & 0.27 & 0.29 & 0.26 \\
\hline \multicolumn{25}{|l|}{$\begin{array}{l}\text { I-4: Importance of Timing of } \\
\text { Action }\end{array}$} \\
\hline $\begin{array}{l}\text { a. Flexiblity of cooperation/ } \\
\text { conflict tactics }\end{array}$ & 0.36 & 0.36 & 0.4 & 0.4 & 0.36 & 0.36 & 0.37 & 0.42 & 0.33 & 0.37 & 0.52 & 0.39 & 0.47 & 0.43 & 0.47 & 0.5 & 0.62 & 0.51 & 0.51 & 0.49 & 0.4 & 0.27 & 0.24 & 0.30 \\
\hline $\begin{array}{l}\text { b. Flexibility of word/deed } \\
\text { tactics }\end{array}$ & 35 & 0.4 & 0.37 & 0.45 & 0.45 & 45 & 0.35 & 0.43 & 0.5 & 0.42 & 0.48 & 0.52 & 0.58 & 0.46 & 0.46 & 0.62 & 0.59 & 0.65 & 0.65 & 0.56 & 0.36 & 0.49 & 0.52 & 0.46 \\
\hline \multicolumn{25}{|l|}{ I-5: Utility of Means } \\
\hline a. Punish & 03 & 0.06 & \begin{tabular}{|l|l|}
0.06 \\
\end{tabular} & \begin{tabular}{|l|l|}
0.07 \\
\end{tabular} & \begin{tabular}{|l|l|}
0.04 \\
\end{tabular} & \begin{tabular}{|l|l|}
0.04 \\
\end{tabular} & 0.04 & \begin{tabular}{|l|}
0.07 \\
\end{tabular} & \begin{tabular}{|l|l|l|l|l|}
0.06 \\
\end{tabular} & 0.05 & 0.09 & 0.08 & 0.1 & 0.08 & 0.08 & 0.11 & 0.11 & 0.12 & 0.12 & \begin{tabular}{|l|l|}
0.10 \\
\end{tabular} & 0.1 & 0.04 & 0.04 & 0.06 \\
\hline b. Threaten & \begin{tabular}{l|l}
0.06 \\
\end{tabular} & 0.01 & 0.02 & 0.05 & 0.05 & \begin{tabular}{|l|l|l|l|}
0.05 \\
\end{tabular} & \begin{tabular}{l|l}
0.07 \\
\end{tabular} & 0.05 & 0.02 & 0.04 & 0.04 & 0.02 & 0.05 & 0.04 & 0.06 & \begin{tabular}{l|l}
0.03 \\
\end{tabular} & 0.04 & 0.03 & 0.03 & 0.04 & \begin{tabular}{|l|}
0.06 \\
\end{tabular} & 0.03 & 0.01 & 0.03 \\
\hline c. Oppose & 0.09 & 0.11 & 0.12 & 0.08 & 0.09 & 0.09 & \begin{tabular}{l|l}
0.08 \\
\end{tabular} & 0.09 & 0.08 & 0.09 & 0.13 & 0.09 & 0.09 & 0.09 & 0.09 & 0.11 & 0.16 & 0.11 & 0.11 & 0.11 & \begin{tabular}{|l|}
0.04 \\
\end{tabular} & 0.07 & 0.07 & 0.06 \\
\hline d. Appeal & 0.58 & 0.58 & 0.59 & 0.59 & 0.56 & 0.56 & 0.6 & 0.57 & 0.57 & 0.58 & 0.47 & 0.56 & 0.47 & 0.52 & 0.52 & 0.45 & 0.45 & 0.48 & 0.48 & 0.49 & 0.56 & 0.58 & 0.59 & 0.58 \\
\hline e. Promise & 0.09 & 0.1 & 0.08 & 0.06 & 0.07 & 0.07 & 0.08 & 0.07 & 0.08 & 0.08 & 0.13 & 0.07 & 0.11 & 0.12 & 0.09 & 0.1 & 0.05 & 0.06 & 0.06 & \begin{tabular}{|l|}
0.09 \\
\end{tabular} & \begin{tabular}{|l|}
0.16 \\
\end{tabular} & 0.08 & 0.07 & 0.10 \\
\hline f. Reward & 0.14 & 0.14 & \begin{tabular}{|l|l|}
0.13 \\
\end{tabular} & \begin{tabular}{|l|l|}
0.16 \\
\end{tabular} & \begin{tabular}{|l|l|}
0.19 \\
\end{tabular} & \begin{tabular}{|l|l|}
0.19 \\
\end{tabular} & \begin{tabular}{|l|l|}
0.14 \\
\end{tabular} & \begin{tabular}{|l|l|}
0.15 \\
\end{tabular} & \begin{tabular}{|l|}
0.19 \\
\end{tabular} & 0.16 & 0.15 & 0.17 & \begin{tabular}{l|l}
0.2 \\
\end{tabular} & 0.14 & $\begin{array}{ll}0.16 \\
\end{array}$ & \begin{tabular}{l|l}
0.2 \\
\end{tabular} & \begin{tabular}{l|l|}
0.18 \\
\end{tabular} & 0.2 & \begin{tabular}{l|l}
0.2 \\
\end{tabular} & \begin{tabular}{|l|}
0.18 \\
\end{tabular} & \begin{tabular}{|l|}
0.08 \\
\end{tabular} & 0.21 & \begin{tabular}{|l|}
0.22 \\
\end{tabular} & \begin{tabular}{|l|l|}
0.17 \\
\end{tabular} \\
\hline
\end{tabular}

Based on their I-1 scores, Presidents Shevardnadze, Saakashvili, and Margvelashvili believed a cooperative strategy with external states was definitely necessary to achieve their goals. ${ }^{801}$ When examining the intensity of tactics index (I-2) for each president, all three believed there was more utility in using cooperative tactics to achieve their goals with Presidents Margvelashvili (.33) and Shevardnadze (.29) registering higher scores than President Saakashvili (.24). When examining

\footnotetext{
${ }^{800}$ Interviews on file with author.

${ }^{801}$ A president's master instrumental beliefs (I-1) are measured as follows: $-1=$ very conflictual; $-.50=$ definitely conflictual; $-.25=$ somewhat conflictual; $0.0=$ mixed; $+.25=$ somewhat cooperative $+.50=$ definitely cooperative; $+.75=$ very cooperative.
} 
the 'means' each president employed in his strategic approach, all three gave priority to 'Appeal' scoring .50 or higher (Margvelashvili, .58; Shevardnadze, .58; and Saakashvili, .50). 'Reward' was the second most used tool for each of the presidents, albeit at a much lesser intensity (Saakashvili, .18; Margvelashvili, .17; Shevardnadze, .16). Based on these scores and a tendency to primarily focus on one cooperative tactic, Margvelashvili, Shevardnadze, and Saakashvili all retained a more risk-averse orientation scoring $.26, .26$, and .18 respectively.

$\underline{\text { Validating Convergence and Divergence }}$

The preceding analysis provides a baseline understanding of Presidents Shevardnadze, Saakashvili, and Margvelashvili's instrumental beliefs about strategy and tactics. The results of an ANOVA and Tukey's HSD tests are below.

Table 24: ANOVA Results - Georgian Presidents Instrumental Beliefs

\begin{tabular}{c|ccccc}
\hline & & Sum of Squares & $d f$ & Mean Square & F \\
\hline \multirow{2}{*}{$\mathrm{I}-1$} & $\begin{array}{c}\text { Between } \\
\text { Groups }\end{array}$ & 0.100625 & 2 & 0.050313 & $16.395 * * *$ \\
& $\begin{array}{l}\text { Within } \\
\text { Groups }\end{array}$ & 0.058307 & 19 & 0.003069 & \\
\hline$* * *$ prob $<.001$ & & & & &
\end{tabular}

Table 25: Mean Comparisons Tukey's HSD Test Results for Direction of Strategy (I-1)

\begin{tabular}{l|cccc}
\hline \multicolumn{1}{c|}{ Pair } & Difference & Lower Bound & Upper Bound & Adjusted P-Value \\
\hline $\begin{array}{l}\text { Saakashvili - } \\
\text { Margvelashvili }\end{array}$ & 0.181 & -0.27330783 & -0.08802550 & 0.0002486 \\
$\begin{array}{l}\text { Shevardnadze- } \\
\text { Margvelashvili }\end{array}$ & 0.070 & -0.16382135 & 0.02382135 & 0.167260 \\
$\begin{array}{l}\text { Shevardnadze- } \\
\text { Saakashvili }\end{array}$ & 0.111 & 0.04600476 & 0.17532857 & 0.0009646 \\
\hline
\end{tabular}

95\% Family-wise Confidence Level 
As detailed above, there are statistically significant differences at the .001 level between the three presidents. Additionally, Presidents Margvelashvili and Shevardnadze have the most similar beliefs registering an adjusted P-value of 0.167260 .

\section{$\underline{\text { Georgian President Alignment }}$}

In Georgia from 1995 through 2015, domestic politics generally played a mixed role with respect to each president's foreign policy orientation and accompanying alignment trajectories with the United States and Russian Federation. A qualitative analysis of the material actions of all three presidents validate the findings from the Tukey's HSD test above that Presidents Shevardnadze and Margvelashvili's initial ideas about strategy are the most similar; however, the role of domestic politics was different for each head of state. For Shevardnadze, the country's 1995 constitution established a strong presidential system, which minimized government fragmentation and issue polarization allowing him to more easily translate his alignment ideas about great power bridging into action. By 2013, constitutional amendments dispersed power from the president to parliament thus creating a moderate level of government fragmentation, which then served as a check on President Margvelashvili’s initial great power bridging actions and follow-on positive bandwagoning strategy with the United States. Finally, operating under what some analysts called 'super-presidentialism', government fragmentation and issue polarization were very low under President Saakashvili, which enabled him to follow a strategy of positive bandwagoning with the United States.

Eduard Shevardnadze. From 1995 to 2003, President Shevardnadze exhibited a pragmatic foreign policy orientation viewing the state's alignment with the United States as a strategic imperative, but not to the extent that it would undermine Georgia's alignment with Russia. Shevardnadze's pragmatism was a byproduct of his ideas that U.S. political and economic 
support could help Georgia's transition to democracy while allowing him to remain in power. With Russia, a pragmatic foreign policy orientation would help facilitate a solution to the state's separatist problems and the eventual removal of Russian military forces from the country.

The ability of President Shevardnadze to advance his ideas about the merits of a great power bridging strategy was derived, in part, from the country's 1995 constitution, which he had a direct hand in crafting beginning in 1993. As outlined in this document, the president is the country's head of state, who is not only the commander and chief, but also the individual responsible for planning and executing the state's foreign policies. By creating a strong presidency, Shevardnadze, along with his closest advisors, hoped to avoid the political gridlock that had plagued the state during the country's first several years of independence. According to one area specialist, following the 1992 parliamentary elections, there were over 24 different political parties in parliament. With so many political groups advancing their own agendas, making substantive progress on the country's pressing domestic and foreign policy issues had become too daunting. ${ }^{802}$ As a result, the presidential powers given to Shevardnadze via the constitution reduced government fragmentation and issue polarization allowing him increased latitude to implement his preferred foreign policies.

Rampant corruption in Shevardnadze's government was a second factor affecting lower levels of government fragmentation and issue polarization. Upon entering office, Shevardnadze purportedly sold various positions within his government as a way to generate revenue and to place like-minded individuals in positions to support his domestic and foreign agendas. In other instances, Shevardnadze diverted foreign assistance meant for improving the country's economy or advancing democratic reforms to the bank accounts of government officials in his

\footnotetext{
${ }^{802}$ Interview on file with author.
} 
administration. When political opposition parties or society would voice opposition about government corruption, Shevardnadze skillfully responded with empty promises of enacting new policies or appointing a special government commission to curtail these illicit activities. ${ }^{803}$

The preceding two factors helped bring about lower levels of government fragmentation and issue polarization in Georgia while Eduard Shevardnadze was in office. As a result, domestic politics did not represent a major constraint on the Georgian president's efforts to translate his verbal pronouncements about aligning with the U.S. and Russia into material actions. In the proceeding paragraphs, the most important key events demonstrating Shevardnadze's alignment with the U.S. and Russia are presented.

In the military sphere, Shevardnadze pursued a compartmentalized great power bridging strategy with Russia and the United States opting to align more so with Moscow in the early years (1995-1997) and then with Washington (1997-2003). The most important material action of Shevardnadze's alignment with the Russian Federation during the 1990s emanated from his February 1994 decision to sign a treaty of friendship with Moscow along with a series of military agreements on developing mutual security and defense relations between both countries. Of significance, the Russia-Georgia Treaty of Friendship informally obligated both parties to not enter into any formal military alliance that may be targeted against either country. More importantly, Shevardnadze agreed to become a member of the Russian-led CIS and to allow the stationing of Russian military forces in Georgia. ${ }^{804}$

While Georgian nationalist parties were adamantly against the ratification of the 1994 Friendship Treaty, Shevardnadze was able to minimize issue polarization by arguing the Kremlin

\footnotetext{
${ }^{803}$ Interview on file with author; Rayfield 2013, 387-389.

${ }^{804}$ Vashakmadze, Mindia. 2005. "Foreign Forces in Georgia: Status, Legitimacy, Prospects.” In Eden Cole and Phillip Fluri (eds.) From Revolution to Reform: Georgia's Struggle with Democratic Institution Building and Security Sector Reform. Vienna: GKS, 153-154.
} 
had committed to ensuring the territorial integrity of Georgia and, by extension, this meant Abkhazia and South Ossetia were part of Georgia's sovereign territory. ${ }^{805}$ This event paved the way for Shevardnadze to subsequently sign the Stationing Treaty with Russia in September 1995. In return for a commitment by Moscow to train and equip Georgia's armed forces, the treaty legalized Russia' military presence at four military bases in Georgia for 25 years. Citing a violation of the 1995 constitution, parliament strongly opposed Shevardnadze's unilateral action; however, by touting the benefits of Russia as a guarantor of peace and stability in Georgia Shevardnadze was able to minimize this political opposition. ${ }^{806}$

In concert with these key events, as Georgia's command-in-chief Shevardnadze also undertook an effort to increasingly align Georgia with the United States with little opposition from parliament. Shevardnadze's point of departure began in 1997 when Georgia joined the Euro-Atlantic Partnership Council. The following year, Tbilisi established formal relations with NATO and by 1999 the Shevardnadze had committed Georgian military forces to the NATO-led Kosovo Force Mission. ${ }^{807}$ Shevardnadze's commitment to working with the United States subsequently facilitated his approval of the NATO exercise 'Best Effort' on Georgian soil in 2002. ${ }^{808}$ Giving emphasis to Georgia's alignment with the U.S., Shevardnadze stated...

Our small country [Georgia] is developing partnership relations with the greatest and the most powerful democracy in the world. This means that our course is right, the course towards building a democratic and independent state which is oriented towards universal values. That is why we are being helped and a helping hand is being reached out to us. ${ }^{809}$

\footnotetext{
${ }^{805}$ Lansford, Tom. 2017. "Georgia.” Political Handbook of the World 2016-2017. Sage, 543.

${ }^{806}$ Of note, the Georgian parliament never ratified the 1995 Stationing Treaty. See Vashakmadze $2005,156$.

${ }^{807}$ Gotsadze, Elene. 2014. "Georgia in International Peacekeeping Missions." Information Center on NATO and EU. http://eu-nato.gov.ge/sites/default/files/ENGLISH.pdf, 7-8. Accessed 21 July 2016.

808 "Georgia: Shevardnadze Says Exercises Reflect 'High Level of Cooperation' with NATO.” 2002. Tbilisi Georgian Radio 1, 17 June 2002.

${ }^{809}$ Shevardnadze, Eduard. 1999. "Shevardnadze on Abkhaz 'Disaster,' US Ties.” Radio Tbilisi Network, 27 September 1999.
} 
By the early 2000s, Shevardnadze's military alignment with Washington came into closer focus after the terrorist attacks in the United States. For example, in 2002 the Georgian president approved the stationing of U.S. military personnel, equipment, and funding to build-up Georgia's armed forces under the GTEP. This program was specifically designed to bolster the army's counter-terrorism capabilities ${ }^{810}$ Finally, after U.S.-led military operations in Iraq and Afghanistan, Shevardnadze approved the deployment of Georgian military forces to support ongoing stabilization missions in both countries in 2003 and 2004 respectively. ${ }^{811}$

In the economic and political spheres, Shevardnadze also pursued a great power bridging strategy with United States and Russia. With Washington, Shevardnadze's major action was to sign a bilateral investment treaty in 1994, which came into force when the Georgian president exchanged the instruments of ratification with President Clinton in $1999 .{ }^{812}$ This treaty set the conditions for increased levels of U.S. investment in Georgia and vice versa for not only Shevardnadze's time in office but for his successors as well. Separately, under Shevardnadze Georgia's level of trade with the U.S. increased from \$111 million in 1995 to $\$ 185$ million by $2003 .{ }^{813}$ From a political standpoint, Shevardnadze's continued engagement with senior U.S. government leaders and his diplomatic backing for Washington's war in Afghanistan and Iraq translated into over one billion dollars in U.S. economic assistance to Georgia. ${ }^{814}$ Speaking in 1999, Shevardnadze highlighted the critical importance of an alignment with the United States.

\footnotetext{
${ }^{810}$ Areshidze, Irakly. 2002. “Helping Georgia?” Perspective 7 (4). http://www.bu.edu/iscip/vol12/areshidze.html. Accessed 16 September 2016.

${ }^{811}$ Gotsadze 2014, 10; 15.

${ }^{812}$ United Nations Conference on Trade and Development. 2017. "Georgia Bilateral Investment Treaties." http://investmentpolicyhub.unctad.org/IIA/CountryBits/77. Accessed 02 April 2016.

${ }^{813}$ United States Census Bureau. 2017. "Trade in Goods with Georgia.” https://www.census.gov/foreigntrade/balance/c4633.html\#1996. Accessed 24 April 2017.

${ }^{814}$ According to a 2005 Congressional Research Report, U.S. foreign assistance to Georgia between 1992 and 2004 totaled \$1.4 billion. See Nichol, Jim. 2005. "Armenia, Azerbaijan, and Georgia: Political Developments and Implications for U.S. Interests.” Congressional Research Service, 05 May 2015, 15. https://digital.library. unt.edu/ark:/67531/metacrs6897/m1/1/high_res_d/IB95024_2005May12.pdf. Accessed 02 April 2016.
} 
First of all, on behalf of my people, I would like to thank sincerely the leadership of the United States of America, the American people, and their envoy to Georgia, Mr. Kenneth Yalowitz. Thanks to this assistance, we have the right to say that the formation of one of the most important state institutions, the border guard forces, has been generally completed. These are no longer symbolic forces. They are equipped appropriately and are provided with everything needed to carry out their function. ${ }^{815}$

Separately, Shevardnadze's tendency to also align with Russia was driven in part by his ideas about how Georgia's economy could not stand on its own without Kremlin assistance. For Shevardnadze, Georgia's location in the South Caucasus and reliance on Russia for energy and trade demanded the utmost attention. The strongest indicator of Shevardnadze's alignment with its former imperial center was seen with the country's continued participation as a member of the CIS. Although frustrated with this organization's inability to resolve various regional security issues, Shevardnadze still regarded the CIS as an important conduit for economic cooperation with Russia and other former Soviet states. For example, in 1999 Shevardnadze signed a series of documents for Georgia's participation in a CIS free trade zone. According to Shevardnadze, "...we are not inclined to leave the CIS. We are for a strengthening of that organization, and it is precisely from those positions that I spoke at the Chisinau CIS summit and proposed bringing into the foreground problems of economic cooperation and the creation of free trade zones."816

Beyond Shevardnadze's alignment with Russia inside the CIS, the Georgian President signed a double taxation avoidance treaty with Russia in 1999. This treaty met with little opposition from parliament and was ratified in $2000 .{ }^{817}$ In terms of trade, under Shevardnadze Georgia's level of trade with Russia increased from \$148 million in 1996 to \$213 million in $2003 .{ }^{818}$

\footnotetext{
${ }^{815}$ Shevardnadze, Eduard. 1999a. "Shevardnadze on Elections, Thanks US." Radio Tbilisi Network, 12 July 1999. ${ }^{816}$ Shevardnadze, Eduard. 1999b. "Shevardnadze on NATO, GUUAM Issues." Moscow Vremya, 07 May 1999.

${ }^{817}$ CIS Legislation. 1999. "The Agreement between the Government of the Russian Federation and the Government of Georgia on Avoidance of Double Taxation." http://cis-legislation.com/document.fwx?rgn=6650. Accessed 31 July 2016.

${ }^{818}$ World Bank. 2016. World Integrated Trade Solution (WITS). http://wits.worldbank.org/about_wits.html. Accessed 04 April 2016.
} 
However, while Shevardnadze believed an economic alignment with Russia via Tbilisi's participation in the CIS and higher levels of trade could return some tangible benefits to Georgia, his ideas about entering into a formal economic alliance were unwavering till the end of his presidency. For example, in 2003 during a series of meetings in Saint Petersburg, Russian President Vladimir Putin tabled the topic of economic integration between Russia, Ukraine, Georgia, and Kazakhstan. Following these meetings Shevardnadze made it clear Georgia would not enter into any alliance that would undermine the country's economic ties with the West. ${ }^{819}$

Shevardnadze's pragmatic ideas with respect to Russia continued during his last years in office. In March 2003, Shevardnadze met with President Putin in Sochi where numerous agreements were made on a variety of economic and security topics. During this meeting, Shevardnadze agreed to allow Russian peacekeepers to remain in Abkhazia for an indefinite amount of time. Additionally, Shevardnadze committed Georgia to participating in Moscow's effort to create a new Eurasian economic zone of cooperation. Shevardnadze also consented to allowing Russia to operate the Inguri hydroelectric station. ${ }^{820}$ Taken together, operating under conditions of low government fragmentation and issue polarization, Shevardnadze was able to effectively translate his ideas about great power bridging into action.

Mikheil Saakashvili. From 2004 to 2012, President Saakashvili consistently exhibited a confrontational foreign policy orientation with Moscow and an accommodative orientation with Washington viewing the state's alignment with the United States as the single most important goal for Georgia. For Saakashvili, a strategic alignment with the United States in the military and

\footnotetext{
${ }^{819}$ Shevardnadze, Eduard. 2003. "Georgia: Shevardnadze Comments on St Petersburg Meeting During Interview." Tbilisi Georgian Radio 1, 02 June 2003.

${ }^{820}$ Nichol, Jim. 2003. "Armenia, Azerbaijan, and Georgia: Political Developments and Implications for U.S. Interests." Congressional Research Service, 27 June 2003, 5.
} 
economic areas would help ensure Georgia's accession into Euro-Atlantic structures with a primary focus on NATO and the EU.

During Saakashvili's presidency, there existed low levels of government fragmentation and issue polarization on aligning Georgia with the United States. There are three contributing factors here. First, after entering office Saakashvili skillfully worked with parliament to pass a series of constitutional amendments further strengthening the powers of the president. In addition to being the head of state, the commander-in-chief, the head of the executive branch, and the leading political figure responsible for planning and executing the state's foreign policies, Saakashvili was also given the power to appoint the prime minister and dissolve parliament. ${ }^{821}$ The establishment of a semi-presidential republic subsequently gave Saakashvili an enhanced ability to put into action his ideas about a U.S. alignment with little to no interference from other political groups or ruling elites in the state's bureaucratic organizations.

Beyond the 2004 constitutional amendments, political backing from other leading political figures was an enabler of Saakashvili's ideas about a strategic alignment with Washington. For example, two of the most important political figures behind the Rose Revolution, Nino Burjanadze (leader in the Democratic Movement party) and Zurab Zhvania (leader in the United Democrats party) fully supported Saakashvilli and his United National Movement party prior to and after the January 2004 national election. Furthermore, with Shevardnadze's removal from power, many of his appointees resigned clearing the way for the arrival of new political elites, who had similar ideas about aligning Georgia with the United States and Europe ${ }^{822}$ With these

\footnotetext{
${ }^{821}$ Parliament of Georgia. 2004. “The Constitution of Georgia.” http://www.parliament.ge/files/68_1944_95119 0_CONSTIT_27_12.06.pdf. Accessed, 11 December 2016.

${ }^{822}$ Gvalia $2013, \overline{1} 11$.
} 
conditions in place, it becomes clear as to how domestic politics was an enabler for Saakashvili and his efforts to translate his positive bandwagoning ideas with the U.S. into action.

Finally, although Saakashvili began his presidency with high expectations of stamping out corruption and completing Georgia's transition to democracy, when political or societal opposition to his ideas did make their presence known, the Georgian president sometimes used repressive techniques to put an end to such challenges. For example, in 2007 Saakashvili authorized the use of armed force to disperse mass protests against his policies. His actions were accompanied by a crackdown on political opposition parties, which eventually saw him step down as president in November 2007 before being re-elected again in January $2008 .{ }^{823}$ With power almost exclusively centered on the presidency, Saakashvili was able to effectively and efficiently translate his ideas about an alignment with the United States and Western Europe into material action. In the following paragraphs, key events surrounding Saakashvili's ability to realize a positive bandwagoning strategy with the United States from 2004 to 2012 are discussed.

The number of examples demonstrating Saakashvili's ability to translate his word to deeds on an alignment with the United States span his entire presidency with the strongest evidence surfacing in military affairs. First, Saakashvili's ideas about an alignment with Washington were formalized in the publication of his 2005 and 2012 National Security Concepts of Georgia, which explicitly defines the state's primary foreign policy objective as a strategic partnership with the United States. ${ }^{824}$ Low levels of government fragmentation and issue polarization over the state's alignment were two key enablers in this matter. For example, in 2011 the Georgian parliament overwhelmingly approved Saakashvili's foreign policy ideas voting 111 to 3 in favor

\footnotetext{
${ }^{823}$ Harding, Luke. 2007. "State of Emergency in Georgia as Street Protests Turn Violent." The Guardian, 17 October 2007. https:/www.theguardian.com/world/2007/nov/08/russia.georgia. Accessed 22 February 2017. ${ }^{824}$ Saakashvili 2005a, 9; Saakashvili 2012a, 19.
} 
of this 2012 strategic document. ${ }^{825}$ Despite whatever domestic political issues Saakashvili may have been contending with, at this late point in his presidency, he still retained ample support from his party and other political opposition groups to move his alignment agenda forward.

Second, in early 2009 President Saakashvili signed the United States-Georgia Strategic Partnership, which elevated Tbilisi's alignment with Washington to a historical high. ${ }^{826}$ According to Saakashvili, "never before has this term, strategic partnership, been used in our relationships and of course this is very important step made towards the strengthening of Georgia's position, its security and people's welfare. With this document, we not only codified what has been happening until now, but also what will happen from now on in our bilateral relationship." ${ }^{, 27}$ While Saakashvili and members of his ruling government perceived this charter as a U.S. security guarantee, various area specialists have noted how this document is a nonbinding agreement. ${ }^{828}$ Regardless, the manifestation of this key strategic document and Saakashvili's national security concepts added significant weight to the Georgian president's efforts to advance a positive bandwagoning strategy with the United States.

Although Saakashvili hotly pursued Georgia's economic integration into the EU, he also gave high emphasis to an economic alignment with the United States. Two examples support this assertion. First, in 2007 Georgia signed the Trade and Investment Framework Agreement with the United States. ${ }^{829}$ This agreement served as a key venue for leading political leaders in

\footnotetext{
${ }^{825}$ Georgia's New National Security Concept. 2011. Civil.ge, 23 December 2011. http://civil.ge/eng/article. php?id=24299. Accessed 16 April 2017.

${ }^{826}$ United States Department of State. 2009. "United States-Georgia Charter on Strategic Partnership." Bureau of European and Eurasian Affairs, 09 January 2009. https://www.state.gov/p/eur/rls/or/121029.htm. Accessed 06 January 2016.

${ }^{827}$ Saakashvili, Mikheil. 2009a. "President of Georgia, Mikheil Saakashvili held a conference regarding the signing of Charter between Georgia and the United States." President of Georgia Website, 11 January 2009. http://www. saakashviliarchive.info/en/PressOffice/News/SpeechesAndStatements?p=2204\&i=1. Accessed 15 April 2017. ${ }^{828}$ Interview on file with author.

${ }^{829}$ Executive Office of the President. 2007. "United States and Georgia Sign Trade and Investment Framework Agreement.” Office of the United States Trade Representative, June 2007. https://ustr.gov/about-us/policy-
} 
Georgia and the U.S. to develop new ways to increase trade and investment in both countries.

This agreement was followed by the establishment of a High-Level Dialogue on Trade and

Investment. This bilateral working group had the primary mission of developing and

implementing new measures to further bolster bilateral trade and investment ${ }^{830}$ Both actions

subsequently doubled trade levels between Georgia and the United States. Specifically, Georgian

exports to the U.S. rose from $\$ 58$ million in 2006 to $\$ 134$ million in 2013. Similarly, U.S.

imports to Georgia doubled, rising from \$129 million in 2006 to $\$ 253$ million in $2013 .{ }^{831}$

In lock step with Saakashvili's actions to align Georgia with the United States, he also took actions to steer the country out of Russia's orbit. For example, with full backing from parliament and the international community, Saakashvili made some progress on the removal of Russian forces from Georgia. In 2007, Moscow exited its last military base; however, Russian peacekeeping forces still remained in South Ossetia. ${ }^{832}$ Separately, in the days after the August 2008 Russia invasion, Saakashvili declared Georgia would leave the CIS. Saakashvili's verbal proclamation was made material with overwhelming support from parliament, which voted unanimously to leave this Russian-led organization. ${ }^{833}$ From Saakashvili's perspective, "the CIS totally failed as an international organization. It is some kind of post-Soviet kind of thing, that

offices/press-office/press-releases/archives/2007/june/united-states-and-georgia-sign-trade-and-inv. Accessed 14 January 2017.

${ }^{830}$ Georgia Country Commercial Guide. 2017. "Georgia, 2 Bilateral Investment Agreements. Export.gov, 19 July 2017. https://www.export.gov/article?id=Georgia-2-Bilateral-Investment-Agreements. Accessed 14 January 2017. ${ }^{831}$ World Bank. 2016. World Integrated Trade Solution (WITS). http://wits.worldbank.org/about_wits.html. Accessed 04 April 2016.

${ }^{832}$ Although Saakashvili was able to realize his goal of closing Russia's military bases, his efforts to remove Russian peacekeepers, even with parliament's backing never came to fruition. See Peuch, Jean-Christophe. 2006. "Georgia: Parliament Votes Russian Troops Out of South Ossetia." Radio Free Europe/Radio Liberty, 15 February 2006. https://www.rferl.org/a/1065805.html. Accessed 14 January 2017; Antidze, Margarita. 2007. "Russia Closes Last Military Base in Georgia." Reuters, 13 November 2007. https://www.reuters.com/article/us-georgia-russiabases/russia-closes-last-military-base-in-georgia-idUSL1387605220071113. Accessed 14 January 2017.

${ }^{833}$ Reuters Staff. 2008. “Georgian Parliament Votes to Quit CIS.” Reuters, 14 August 2008. https://www.reuters. com/article/us-georgia-ossetia-cis/georgian-parliament-votes-to-quit-cis-idUSLE26086620080814. Accessed 12 January 2017. 
basically could not do anything to prevent this tragedy from happening. And, you know, by leaving the CIS, we are giving final [goodbyes] to the Soviet Union." ${ }^{\text {,834 }}$

In sum, during his time in office, President Saakashvili effectively translated his ideas about an exclusive alignment with the United States into action. Domestic politics was a key enabler of the Georgian president's foreign policy initiatives, where low levels of government fragmentation and issue polarization helped the president realize his goals.

Giorgi Margvelashvili. During late 2013 and early 2014, President Margvelashvili, like Eduard Shevardnadze, exhibited a pragmatic foreign policy orientation within the framework of a great power bridging strategy vis-à-vis the United States and Russia. This short-lived foreign policy orientation was quickly replaced by a more accommodative one with the U.S. following Russian obstinacy on the status of South Ossetia and Abkahzia. Unlike Shevardnadze, Margvelashvili's foreign policy orientations were shaped, in part, by domestic political constraints. Specifically, the Georgian government under Margvelashvili experienced higher levels of government fragmentation and issue polarization owing to changes in the constitution and conflicting political personalities.

First, the strong presidential systems that existed during Presidents Shevardnadze and Saakashvili's time in office was cast aside in 2013 for a parliamentary form of governance. One area specialist notes the significance and how the constitutional changes "awkwardly split the executive power between the president and the prime minister... that created fertile ground for constant bickering between the head of state and the head of the government." 835 Additionally,

\footnotetext{
${ }^{834}$ Saakashvili, Mikheil. 2009. "Georgia Finalizes Withdraw from CIS.” Radio Free Europe/Radio Liberty, 18 August 2009. https://www.rferl.org/a/Georgia_Finalizes_Withdrawal_From_CIS/1802284.html. Accessed 12 January 2017.

${ }^{835}$ Rukhadze, Vasili. 2015. "The Conflict Between the President and the Prime Minister Continues to Dominate the Georgian Political Landscape.” Eurasia Daily Monitor 12 (15). https://jamestown.org/program/the-conflictbetween-the-president-and-the-prime-minister-continues-to-dominate-the-georgian-political-landscape/. Accessed 04 January 2017.
} 
constitutional amendments from 2010, which came into effect in 2013 gave the prime minister increased political power. These actions contributed greatly to higher levels of government fragmentation and issue polarization in the Georgian government. At issue was how President Margvelashvili, unlike his predecessors, was no longer the lead actor in the state's foreign policy executive thereby making it more difficult to translate his words into action.

Clashing political personalities between members of the state's foreign policy executive was a second factor contributing to the higher level of government fragmentation and issue polarization during Margvelashvili’s time in office. Specifically, Margvelashvili was almost consistently at odds with former Prime Minister Irakli Garibashvili over Georgia's domestic and foreign policies. For example, in the run-up to Georgia signing the EU Association Agreement, Margvelashvili and Garibashvili clashed over who would be the one to sign this agreement. The Georgian president finally conceded to the prime minister by issuing a special decree authorizing Garibashvili to sign this document; however, many political groups and non-governmental organizations viewed the president's decision as unconstitutional. ${ }^{836}$ Regardless, this event illuminates the extent to which Georgia's leading political figures quarreled over the political power to lead the country in international affairs.

Despite higher levels of government fragmentation and issue polarization, President Margvelashvili was still able to advance his initial ideas about a limited form of great power bridging and later, positive bandwagoning with the United States. One point of departure for Margvelashvili's early tendency to follow a great power bridging strategy begins with Russia, which must be understood as a superficial effort to politically align Tbilisi with Moscow. In this

\footnotetext{
${ }^{836}$ Robakidze, Ana. 2014. "Margvelashvili Decides PM will Sign Association Agreement with the EU." The Messenger Online, 28 April 2014. http://www.messenger.com.ge/issues/3124_may_28_2014/3124_ani.html. Accessed 15 January 2017.
} 
case, the Georgian president's foreign policy actions were done based on his ideas about engaging Moscow to achieve a favorable resolution with South Ossetia and Abkhazia. Key to the Georgian president's success was his ability to separate economic and social issues from the pressing security and military challenges. In the following paragraphs, several examples provide evidence about Margvelashvili’s early pragmatic foreign policy orientation vis-à-vis Russia.

First, in 2013 Margvelashvili appointed several foreign policy figures, who did not hold strident beliefs about the necessity to align exclusively with the United States and Europe. These individuals included the Secretary of the National Security Council, Irina Imerlishvili and presidential foreign policy advisor Vano Machavariani, who, according to one area specialist, had consistently argued for "...a more measured and careful approach to relations with the United States..." ${ }^{837}$ In concert with these appointments, Margvelashvili also suspended the television broadcasts from the Georgia's Russian-language PIK channel and decided to not boycott the 2014 Winter Olympic Games in Sochi, Russia. ${ }^{838}$ The Georgian president's initial expectations of how a low-key diplomatic alignment with the Russia could produce positive returns were validated when in February 2013 Moscow lifted a trade ban on wine, fruit, and mineral water that had been in place since 2006.

Beginning in mid 2014 and continuing through 2015, Margvelashvili’s foreign policy orientation tilted from pragmatism to one of confrontation with Russia and more accommodation with the United States. The genesis of this change stems from two key events: Moscow's unwillingness to recant is recognition of South Ossetia and Abkhazia's declarations of

\footnotetext{
${ }^{837}$ Rukhadze, Vasili. 2013. "New Georgian Presidential Administration: New Foreign Policy?” Eurasia Daily Monitor 10 (209). https://jamestown.org/program/new-georgian-presidential-administration-new-foreign-policy/. Accessed 29 March 2017.

${ }^{838}$ Rukhadze, Vasili. 2012. “Is Georgia's New Government Shifting the Country's Geopolitical Course Toward Russia?" Eurasia Daily Monitor 9 (208). https://jamestown.org/program /is-georgias-new-government-shifting-thecountrys-geopolitical-course-toward-russia/. Accessed 14 February 2017.
} 
independence and to cease support for the separatists; Russia's annexation of Crimea and support for separatists in eastern Ukraine. Speaking in 2014, one can begin to discern a change in Margvelashvili's foreign policy orientation. In his words,

Last year, we opened a new format of dialogue with Russia, within which we have started discussions on economic, trade, cultural and humanitarian issues. We think that there was some progress in this process, but the construction of barbwires and expansion of the 11 kilometers so-called border line in the depth of our territory, has seriously and harmfully affected this progress. ${ }^{839}$

Separately, Russia's annexation of Crimea reinforced Margvelashvili's threat perceptions of Russia moving him to realize there would be no changing Moscow's foreign policy actions to reestablish its influence in the post-Soviet space by creating and maintaining frozen conflicts in Ukraine, Moldova, Azerbaijan, and now Georgia.

Beginning in 2014, Margvelashvili's accommodative orientation and positive bandwagoning with the United States were readily observed. The strength of his alignment with Washington was the most pronounced in the area of military affairs given his leading role as the commanderin-chief and because much of Georgia's economic efforts were directed towards the EU. For the period 2014-2015, Margvelashvili aggressively pursued a strong military alignment with the United States along several lines of operations. First, the Georgian president continued to ardently support U.S.-led operations in Afghanistan by increasing the number of Georgian troops, which rose to 1,500 making Georgia the largest non-NATO contributor. Margvelashvili's commitment to NATO subsequently earned Georgia an upgraded status as a NATO enhancedopportunities partner in 2014. ${ }^{840}$ This enhanced status was significant because Georgia became eligible for additional NATO funding and training that would help set the stage for the country's

\footnotetext{
${ }^{839}$ Margvelashvili, Giorgi. 2014b. "The State of the Nation Address." Official Website of the President of Georgia, 21 February 2014. http://civil.ge/eng/article.php?id=26971\&search=president\%20state\%20of\%20nation $\% 20$ address. Accessed 3 August 2016.

${ }^{840}$ Jarvenpaa, Pauli. 2016. "NATO's Truly Enhanced Partnership Program." International Centre for Defense and Security, July 2016. https://www.icds.ee/fileadmin/media/icds.ee/failid/Pauli_Jarvenpaa_NATO_s_Truly_ Enhanced_Partnership.pdf. Accessed 15 January 2017.
} 
future accession into the alliance. Finally, Margvelashvili remained very open to a U.S. and NATO presence in the country resulting in the establishment of the NATO-Georgia Joint Training and Evaluation Center outside Tbilisi in 2015. This facility helped Georgian military leaders modernize the armed forces and improve their interoperability with NATO units. ${ }^{841}$ President Margvelashvili's success was not without challenges as he struggled at times to implement his ideas about foreign policies on a closer alignment with the United States in 2014 and 2015. The locus of resistance during this time came from Prime Minister Irakly Garibashvili, who appeared on several levels to favor a great power bridging alignment with the U.S. and Russia, even though Kremlin leaders remained steadfast in their foreign policies. Specifically, in 2014 Garibashvili fired the country's defense minister, who like Margvelashvili advocated a positive bandwagoning alignment with the United States. Additionally, Garibashvili was reticent in his remarks on Russia's actions in Crimea and eastern Ukraine ${ }^{842}$ Despite these political and constitutional challenges however, President Margvelashvili was not an inconsequential figure as he remained a prominent voice representing Georgia on the international stage. Additionally, the Georgian President was still the commander-in-chief of the armed forces and was responsible for appointing ambassadors and negotiating international treaties and agreements with other states. $^{843}$

Despite Margvelashvili's successful effort to align Georgia with the United States, some routine interstate activities with Russia continued. For example, in late 2014 the Georgian president, while condemning Russia's actions in Ukraine as a threat to regional stability, did not

\footnotetext{
${ }^{841}$ NATO-Georgia Joint Training and Evaluation Center. 2015. NATO Fact Sheet. https://www.nato.int/ nato_static_fl2014/assets/pdf/pdf_topics/20150827_150827-jtec-georgia.pdf. Accessed 02 February 2017. ${ }^{842}$ Antidze, Margarita. 2014. "Georgian President Challenges PM to affirm pro-Western Course." Reuters, 14 November 2014. https://www.reuters.com/article/uk-georgia-government-president/georgian-president-challengespm-to-affirm-pro-western-course-idUKKCNOIY1HH20141114. Accessed, 30 June 2017.

${ }^{843}$ Parliament of Georgia. 2010. "The Constitution of Georgia.” http://www.parliament.ge/uploads/other/28/ 28803.pdf. Accessed, 11 December 2016.
} 
see the necessity to impose economic sanctions to mirror what the U.S. and Western Europe actions less one; a ban on imports from Crimea and Sevastopol. His ideas on Georgia's actions mirrored the position of parliament and must be taken in their proper context. For Margvelashvili, the re-establishment of trade on certain items with Russia was an event of the past that should not be connected to Moscow's current actions. ${ }^{844}$

The preceding analysis of the foreign policy orientations of Georgian presidents reveal several takeaways. First, Presidents Shevardnadze and Margvelashvili (in late 2013 and early 2014) pursued a strategy of great power bridging by attempting to align Georgia with the U.S. and Russia by implementing a unique set of political, economic, or military-related foreign policy actions. The role of domestic politics in both cases was noticeable different. For Shevardnadze, government fragmentation and issue polarization were low owing to constitutional guidelines, political corruption, and his ability to place like-mined political figures in positions of power. As such, Shevardnadze was able to more easily translate many of his ideas about the state's alignment with both regional great powers into action. For Margvelashvili however, changes to the constitution created government fragmentation thereby limiting what he could accomplish during the time under examination. Despite these challenges, Margvelashvili was still able to bring some of alignment ideas to fruition. Finally, domestic politics was a key enabler of President Saakashvili's positive bandwagoning strategy with Washington. In this case, a strong executive, coupled with a like-minded parliament allowed Saakashvili to put into action a majority of his ideas about a strategic alignment with the United States.

\footnotetext{
${ }^{844}$ Soldak, Katya. 2014. “Georgian President Margvelashvili Condemns Russian Aggression, Says Georgia Looks to The West." Forbes, 08 October 2014. https://www.forbes.com/sites/katyasoldak/2014/10/08/georgian-presidentmargvelashvili-condemns-russian-aggression-says-georgia-looks-to-the-west/2/\#6f1b5fe14447. Accessed 15 January 2017.
} 


\section{Moldova: Findings and Discussion}

In Moldova, this study finds Presidents Petru Lucinschi and Vladimir Voronin (after 2003) maintained a pragmatic foreign policy orientation during their years in office. Each president's pragmatism was subsequently associated with a great power bridging alignment with the United States and Russian Federation. Of note, prior to 2004 President Voronin exhibited a highly accommodative foreign policy orientation with Moscow, which was associated with efforts to foment a positive bandwagoning alignment with Russia. Separately, President Nicolae Timofti took a limited confrontational approach with Russia and a more accommodative one with the United States. Despite differing levels of government fragmentation and issue polarization each president was still able to put into action his verbal pronouncements about an alignment with either the United States, Russia, or both.

The Instrumental Beliefs of Moldovan Presidents

The instrumental beliefs of each of the three Moldovan presidents are on the next page. An examination of the master instrumental beliefs (I-1) of Presidents Petru Lucinschi, Vladimir Voronin, and Nicolae Timofti indicate they tended to view a cooperative strategy as an optimal approach to foreign affairs scoring .68, .60 and .70 respectively. With respect to tactics (I-2), all three of the Moldovan leaders believed there was more utility in using cooperative methods to achieve their goals with Lucinschi, Voronin, and Timofti scoring .36, .31, and .32 respectively. 
Table 26: The Instrumental Beliefs of Moldovan Presidents

\begin{tabular}{|c|c|c|c|c|c|c|c|c|c|c|c|c|c|c|c|c|c|c|c|c|}
\hline \multirow[b]{2}{*}{$\begin{array}{l}\text { Instrumental Beliefs / } \\
\text { Year }\end{array}$} & \multicolumn{5}{|c|}{ Petru Lucinschi } & \multicolumn{10}{|c|}{ Vladimir Voronin } & \multicolumn{5}{|c|}{ Nicolae Timofti } \\
\hline & 1997 & 1998 & 1999 & 2000 & AVG & 2001 & 2202 & 2003 & 2004 & 2005 & 2006 & 2007 & 2008 & 2009 & AVG & 2012 & 2013 & 2014 & 2015 & AVG \\
\hline I-1: Direction of Strategy & 0.7 & 0.62 & 0.68 & 0.71 & 0.68 & 0.4 & 0.48 & 0.7 & 0.68 & 0.45 & 0.57 & 0.83 & 0.74 & 0.56 & 0.60 & 0.67 & 0.82 & 0.64 & 0.68 & 0.70 \\
\hline I-2: Intensity of Tactics & 0.42 & 0.31 & 0.37 & 0.34 & 0.36 & 0.17 & 0.23 & 0.4 & 0.42 & 0.2 & 0.28 & 0.46 & 0.31 & 0.29 & 0.31 & 0.3 & 0.34 & 0.31 & 0.32 & 0.32 \\
\hline I-3: Risk Orientation & 0.21 & 0.28 & 0.24 & 0.32 & 0.26 & 0.12 & 0.19 & 0.15 & 0.2 & 0.16 & 0.19 & 0.3 & 0.3 & 0.21 & 0.20 & 0.24 & 0.41 & 0.22 & 0.32 & 0.30 \\
\hline \multicolumn{21}{|l|}{$\begin{array}{l}\text { I-4: Importance of Timing of } \\
\text { Action }\end{array}$} \\
\hline $\begin{array}{l}\text { a. Flexiblity of cooperation/ } \\
\text { conflict tactics }\end{array}$ & 0.3 & 0.38 & 0.32 & 0.29 & 0.32 & 0.6 & 0.52 & 0.3 & 0.32 & 0.55 & 0.43 & 0.17 & 0.26 & 0.44 & 0.40 & 0.33 & 0.18 & 0.36 & 0.32 & 0.3 \\
\hline $\begin{array}{l}\text { b. Flexibility of word/deed } \\
\text { tactics }\end{array}$ & 0.61 & 0.34 & 0.49 & 0.52 & 0.49 & 0.55 & 0.56 & 0.81 & 0.82 & 0.52 & 0.57 & 0.5 & 0.56 & 0.38 & 0.59 & 0.47 & 0.31 & 0.69 & 0.43 & 0.48 \\
\hline \multicolumn{21}{|l|}{ I-5: Utility of Means } \\
\hline a. Punish & \begin{tabular}{|l|}
0.03 \\
\end{tabular} & 0.02 & \begin{tabular}{|l|}
0.03 \\
\end{tabular} & 0.06 & 0.04 & \begin{tabular}{|l|}
0.12 \\
\end{tabular} & 0.09 & 0.11 & 0.07 & 0.10 & 0.08 & 0 & 0.12 & 0.03 & 0.08 & 0.09 & 0.05 & 0.12 & 0.05 & 0.07 \\
\hline b. Threaten & \begin{tabular}{|l|}
0.01 \\
\end{tabular} & 0.03 & 0.01 & 0.02 & 0.02 & 0.05 & 0.03 & 0.01 & 0.02 & 0.05 & 0.05 & 0.04 & 0 & 0.03 & 0.03 & 0.02 & 0.01 & 0.01 & 0 & 0.02 \\
\hline c. Oppose & \begin{tabular}{|l|}
0.11 \\
\end{tabular} & 0.14 & 0.12 & 0.06 & 0.11 & 0.13 & 0.14 & 0.03 & 0.07 & 0.13 & 0.09 & 0.04 & 0.01 & 0.16 & 0.09 & 0.06 & 0.03 & 0.05 & 0.11 & 0.07 \\
\hline d. Appeal & \begin{tabular}{|l|}
0.49 \\
\end{tabular} & 0.59 & 0.55 & 0.62 & 0.56 & 0.45 & 0.5 & 0.42 & 0.45 & 0.49 & 0.51 & 0.58 & 0.6 & 0.53 & 0.50 & 0.56 & 0.69 & 0.52 & 0.62 & 0.57 \\
\hline e. Promise & \begin{tabular}{|l|}
0.08 \\
\end{tabular} & 0.06 & 0.07 & 0.04 & 0.06 & 0.1 & 0.05 & 0.14 & 0.05 & 0.08 & 0.06 & 0.08 & 0.1 & 0.09 & 0.08 & 0.13 & 0.12 & 0.07 & 0.05 & 0.09 \\
\hline 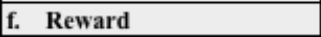 & 0.27 & 0.16 & 0.22 & 0.2 & 0.21 & 0.15 & 0.19 & 0.3 & 0.34 & 0.16 & 0.21 & 0.25 & 0.16 & 0.16 & 0.21 & 0.14 & 0.1 & 0.23 & 0.16 & 0.18 \\
\hline
\end{tabular}

The most frequently employed tactic for all three was 'appeal' with 'reward' being the second most used tool. Based on these scores and a tendency by each president to emphasize one cooperative tactic (i.e. appeal), they have a more risk-averse orientation scoring $.26, .20$, and, .30 respectively.

\section{Validating Convergence and Divergence}

As depicted in the table below, an ANOVA test validates the null hypothesis that there are no statistically significant differences in the instrumental beliefs of the three Moldovan presidents. The alternative hypothesis that a statistically significant difference exists is not validated thus indicating all three presidents tended to exhibit similar beliefs about strategy. As will be discussed below however, just because all three presidents had the same beliefs about strategy Presidents Lucinschi and Voronin (after 2003) retained pragmatic foreign policy orientation, which was associated with a great power bridging strategy. Before 2004, President Voronin's accommodative orientation with Russia was associated with positive bandwagoning actions with this regional great power. Finally, President Timofti had a more confrontational orientation with Russia, which was correlated with a positive bandwagoning alignment with the United States. 
Table 27: ANOVA Results - Moldovan Presidents Instrumental Beliefs

\begin{tabular}{l|ccccc}
\hline & & Sum of Squares & $d f$ & Mean Square & F \\
\hline \multirow{4}{*}{$\mathrm{I}-1$} & $\begin{array}{c}\text { Between } \\
\text { Groups }\end{array}$ & .034714 & 2 & 0.017357 & 1.2627 \\
& $\begin{array}{c}\text { Within } \\
\text { Groups }\end{array}$ & .192439 & 14 & 0.013746 & \\
& & & & & \\
\hline
\end{tabular}

\section{Moldovan President Alignment}

In Moldova from 1997 through 2015, a qualitative analysis of the material actions of all three presidents find Petru Lucinschi and Vladimir Voronin (after 2003) pursued a pragmatic foreign policy orientation as part of a great power bridging alignment with the United States and Russian Federation. Nicolae Timofti's foreign policy orientation took on a more accommodative characterization with the United States and a limited confrontational approach with Russia. During the tenure of each of the presidents under examination, domestic politics was an important shape agent that served as an enabler and/or constraint on his respective actions to implement policies to align with the United States and/or Russia. To begin, the country's 1994 constitution, which defines Moldova as a neutral state in world affairs is perhaps the quintessential factor shaping each president's alignment strategy. ${ }^{845}$ Although the constitution prevented Moldova from joining the CSTO or NATO, each president was free to develop an alignment with the United States and/or Russia in his own distinct way.

Beyond the constitution, government fragmentation and issue polarization were major factors impacting the alignment trajectories of each president. Since its independence, Moldova's domestic political landscape remained extremely fragmented owing to the existence of over 100

\footnotetext{
${ }^{845}$ Republic of Moldova. 2006. "Constitution of the Republic of Moldova." ConstituteProject.org. https://www. constituteproject.org/constitution/Moldova_2006.pdf?lang=en. Accessed 12 August 2017, 9.
} 
different political parties with competing visions about the priorities for state's domestic and foreign policy agendas. ${ }^{846}$ For example, contested political rivalries and the ever-changing composition of different coalitions served as a major check on a president's ability to implement his foreign policies. According to one area expert, "the legislature consistently constrained presidential authority to a degree not seen in Moldova's post-Soviet neighbors. ${ }^{" 847}$ In July 2000, parliament passed a series of constitutional amendments that gave Moldova a parliamentary form of governance. ${ }^{848}$ These changes contributed to the state's government fragmentation and issue polarization during the terms of Presidents Voronin and Timofti.

Petru Lucinschi. From 1997 to 2000, President Lucinschi maintained a pragmatic foreign policy orientation owing to high levels of government fragmentation and moderate levels of issue polarization, which impeded his ability to translate his verbal pronouncements on a strategic alignment with the United States and Russia into action. ${ }^{849}$ With respect to government fragmentation, because Lucinschi entered the presidency as an independent he did not possess the necessary political capital to more easily advance his foreign policy agenda. Although he was able to develop a working coalition of independents in parliament (the Bloc for a Democratic and Prosperous Moldova), the fluid nature of their changing loyalties made it extremely difficult for Lucinschi to advance his ideas about aligning with multiple regional great powers. The 1998 parliamentary elections contributed further to the level of government fragmentation with many independents expressing disagreement with Lucinschi's ideas about how to improve the country's economy, which focused on a closer economic alignment with Russia. As a result,

\footnotetext{
${ }^{846}$ Dix, Holger. 2011. "Republic of Moldova at the End of an Election Marathon?" KAS International Reports, 2011. http://www.kas.de/wf/doc/kas_21875-544-2-30.pdf?110209122237. Accessed 12 August 2017, 95.

${ }^{847}$ Way, Lucan. 2002. "Pluralism by Default in Moldova." Journal of Democracy 13 (4), 130.

${ }^{848}$ Quinlan 2002, 99.

${ }^{849}$ Interviews on file with author.
} 
Lucinschi was forced to either compromise or expend political capital in order to translate his ideas into action. ${ }^{850}$

Issue polarization over Lucinschi’s ideas about an alignment with Russia was particularly high during his time in office. Campaigning on a platform to improve Moldova's alignment with Russia, once in office Lucinschi was met with stiff opposition from nationalist and right-wing groups, who were highly critical of his pro-Russian foreign policy approach. As noted above, this was particularly true with respect to Chisinau's economic alignment with Moscow. For example, political leaders from Liberal Party of Moldova and the Christian Democratic Popular Front of Moldova (FPCDM) consistently argued Lucinschi was attempting to politically and economically subjugate Moldova to Russia. In the words of Iurie Rosca, the Chairman of the FPCDM, "Lucinschi is an exponent of Russian neo-colonialism, of Russian capital... [and that] Moldova's return to Moscow's orbit is being achieved not by force of weapons, but through the interference of the Russian capital into the key sectors of our economy." 851

On the other side of the aisle, political leaders from the communist party were consistently at odds with Lucinschi over his ideas to foment an alignment with the United States and Europe concluding he had 'sold out' Moldova to the West. Vladimir Voronin and leading communist party officials were highly critical of Lucinschi for not doing more to improve Moldova's economic ties to Russia and the CIS as a way to improve the country's economy. ${ }^{852}$ For example, during the 1997 CIS summit in Chisinau, not one official document or agreement was signed by

\footnotetext{
${ }^{850}$ Roper, Steven D. 2008. "From Semi-Presidentialism to Parliamentarism: Regime Change and Presidential Power in Moldova.” Europe-Asia Studies 60 (1), 119-120.

${ }^{851}$ Rosca, Iurie. 1997. “Opposition Leader: President Plays into Russia's Hands.” Infotag, 14 October 1997.

852 Demidetskiy, Valeriy. 1998. “Moldovan President Expresses Support for 'Centrists'.” Itar-Tass, 20 March 1998.
} 
Lucinschi or any other head of state with economic agenda items being directed back to each member state..$^{853}$

Despite the high level of government fragmentation and issue polarization, Lucinschi was able to translate some of his ideas about an alignment with Russia into action. For example, President Lucinschi's political alignment with Moscow in bilateral and multilateral forums (CIS, OSCE, etc.) facilitated the signing of the "Moscow Memorandum" that normalized relations between Chisinau and Tiraspol in 1997 and reduced Russia's military footprint in Moldova to approximately 3,000 troops. ${ }^{854}$ In the run-up to this key event, President Lucinschi went so far as to note how Russia's military presence in the Trans-Dniester was a stabilizing factor in the peace process. ${ }^{855}$ Moldova's improving alignment with Russia subsequently set the conditions in November 1999 for Russian President Boris Yeltsin to sign the Istanbul Declaration, which required Moscow to withdraw all Russian military forces from the Trans-Dniester by $2002 .{ }^{856}$ Taken together, these events demonstrate how an internal challenge can shape a president's ideas about an alignment with key regional great powers.

In the economic and military spheres, Lucinschi continued to advance Moldova's economic alignment with Moscow albeit at a slower rate owing to issue polarization among leading political figures over how to best address the country's poverty, high unemployment, and low economic productivity. For example, in late 1998 Chisinau signed the 'Program on Economic Cooperation, 1999-2008' with Moscow. ${ }^{857}$ This agreement established a framework for

\footnotetext{
853 “CIS Summit Ends; 'Not a Single Document' Signed.” 1997. Basapress, 23 October 1997.

${ }^{854}$ Smith, M.A. 2000. "Russian Foreign Policy 2000: The Near Abroad." Conflict Studies Research Centre. Royal Military Academy Sandhurst, 9.

${ }^{855}$ Lucinschi, Petru. 1997b. “Lucinschi Says `No Problem' With Russian Troop Presence.” Itar-Tass, 25 February 1997.

${ }^{856}$ Istanbul Document 1999. 2000. Organization for Security Cooperation in Europe. http://www.osce.org/mc/ 39569?download=true. Accessed 10 April 2016.

${ }^{857}$ Presidents Yeltsin, Lucinschi Signs Agreements. RIA Novosti, 02 September 1999.
} 
improving bilateral trade and investment. The 10-year treaty had an immediate impact with Moldovan exports to Russia rising from \$187 million in 1999 to $\$ 347$ million in $2004 .{ }^{858}$

President Lucinschi's alignment with the United States was less pronounced during this time; however, he was still able to set in motion a few alignment initiatives. With a majority of his efforts devoted to developing stronger economic ties with countries in Western Europe, ${ }^{859}$ Lucinschi's diplomatic efforts with the United States resulted in numerous trips to Washington by officials in his administration to showcase Chisinau's commitment to democratic reforms. By 1999, President Clinton recognized Lucinschi's efforts, characterizing Moldova as a model for democracy in Eastern Europe. ${ }^{860}$ President Lucinschi's political alignment with the U.S. subsequently paved the way for Washington to allocate funding in support of the Moldovan president's domestic agenda. For example, with USAID funding Lucinschi was able to launch his 1998 National Land Program to privatize the country's remaining collective farms. ${ }^{861}$

President Lucinschi's political maneuvering with the United States also generated support from Washington for Chisinau's efforts to resolve the Trans-Dniester problem. For example, in March 2000 U.S. special envoy Carey Cavanaugh stated Washington was prepared to support Moldova in the resolution of the Trans-Dniester conflict. This pronouncement was followed by a commitment by Washington to provide Lucinschi political and economic support towards the

\footnotetext{
${ }^{858}$ World Bank. 2016. World Integrated Trade Solution (WITS). http://wits.worldbank.org/about_wits.html. Accessed 04 April 2016.

${ }^{859}$ This study finds that given Moldova's dire economic situation and geostrategic location, President Lucinschi likely gave priority to developing a stronger economic alignment with the countries in Western Europe over that of the United States. See "European Integration Remains Moldovan Priority." Basapress, 28 August 2000. Another potential factor affecting Lucinschi's ideas here was how the U.S. did not necessarily regard Moldova as vital to U.S. national interests.

${ }^{860}$ Quinlan 2002, 89.

${ }^{861}$ Muravschi, Alexandro, Ivan Cernioglo, Sergiu Botezatu, Patricia Orlowitz, and Dorin Dumbraveanu. "Moldova Case Study - The National Land Program." Regional Workshop in Land Issues in Central and Eastern Europe and the CIS, 03-06 April 2002. http://pdf.usaid.gov/pdf_docs/PBAAD027.pdf. Accessed 03 June 2017, 4.
} 
withdrawal of Russian military forces from Moldovan territory ${ }^{862}$ Once again, internal challenges appear to be a driver shaping Lucinschi's ideas about the benefits of a strategic alignment with the United States. While Washington would have only a minimal impact on finding an enduring solution, Lucinschi found that with the United States having a seat at the table, he could potentially garner some leverage over Russia to support Moldovan interests.

Finally, President Lucinschi attempted to develop an indirect military alignment with the United States. Beginning in 1997, the Moldovan president sought out ways to bolster the country's participation in NATO's PFP program. According to Lucinschi, "Moldova regards the North Atlantic Cooperation Council as an element of both the all-European security and the republic's own security and is ready to enter into a dialogue with interested parties." 863

Subsequently Moldova would come to participate in a wide variety of PFP activities, which included sending military forces to the United States for exercises and training. ${ }^{864}$ From one perspective, Lucinschi's efforts to develop a tenuous alignment with Western military forces could at least help him improve the technical and tactical proficiency of Moldovan armed forces.

Vladimir Voronin. From 2001 through 2009, President Vladimir Voronin exhibited two distinct foreign policy orientations and alignment trajectories. From 2001 to early 2003, Voronin exhibited a highly accommodative orientation with Russia and a somewhat confrontational orientation with the United States and its allies in Europe. During this time Voronin pursued a positive bandwagoning alignment strategy with Russia. From 2004 till the end of his presidency, Voronin exhibited a pragmatic foreign policy orientation, which was followed by a great power

\footnotetext{
${ }^{862}$ Moldovan Leader Requests US Role in Dniester Settlement. 2000. Basapress, 09 March 2000.

${ }^{863}$ Lucinschi, Petru. 1997c. "Moldova Ready to Work with NATO on 'Conflict Prevention.'” Infotag, 09 July 1997.

${ }^{864}$ For example, in 1997 Moldova sent military forces to Fort Polk, LA for the PFP exercise COOPERATIVE NUGGET. See United States Department of Defense. 1997. "Exercise Cooperative Nugget '97 Scheduled.” DoD News, 12 June 1997. http://archive.defense.gov/news/newsarticle.aspx?id=41045. Accessed 04 January 2018.
} 
bridging strategy with the United States and Russia. According to one area specialist, after 2003, "Moldova's foreign policy under Voronin actually showed an element of continuity with the various "post-communist" administrations... in that it was balanced and pragmatic in pursuit of its national interest, seeking an equilibrium between its East and West interests..." ${ }^{865}$ While in office, moderate levels of government fragmentation and issue polarization enabled and constrained the Moldovan president's alignment strategies.

Upon entering office in 2001, government fragmentation and issue polarization were moderately low for Voronin even though Moldova had transitioned from a semi-presidential to a parliamentary form of governance following the PCRM's (Communists for the Republic of Moldova) victory in the 2001 parliamentary election. During this election, the PCRM secured 71 of the 101 seats with the center-left Braghis Alliance acquiring 19 seats and the Christian Democratic People's Party (CDPP) taking 11 seats. ${ }^{866}$ With a clear majority in parliament, the PCRM elected Voronin as president.

Once in office in 2001, Voronin was able to more easily advance his ideas about the necessity to align Moldova first and foremost with the Russian Federation. For example, in June 2001 Voronin set the conditions for a positive bandwagoning strategy with Russia when after his visit to Moscow, he stated "I paid my first visit to Russia of all the countries because it is our strategic ally. And, incidentally, the agreement we signed with Russian President Putin bears this very name—on strategic cooperation. A similar document had never been signed between Russia and Moldova." ${ }^{867}$

\footnotetext{
${ }^{865}$ Weiner, Robert. 2004. "The Foreign Policy of the Voronin Administration." Demokratizatsiya 12 (4), 545.

${ }^{866}$ Republic of Moldova-Parliamentary Elections 25 February 2001, Final Report. 2001. Organization for Security and Cooperation in Europe, Office for Democratic Institutions and Human Rights. http://www.osce.org/odihr/ elections/moldova/14837?download=true. Accessed 22 February 2017, 13.

${ }^{867}$ Voronin, Vladimir. 2001d. Moldovan President on Relations with Russia, Romania, Dniester Region Situation.” Rossiyskaya Gazeta, 09 June 2001.
} 
The nature of Voronin's alignment with Russia is best understood in political and economic terms. Several examples illuminate Voronin's ability to translate his verbal pronouncements into action. First, in November 2001 Voronin signed a new Treaty of Friendship and Cooperation with Russia, which outlined areas from which both countries would strengthen economic and political relations. Of particular importance, Russia recognized Moldova's territorial integrity and committed to withdrawing its remaining military forces from the Trans-Dniester by 2002. In December 2002, the Moldovan parliament quickly ratified this treaty. ${ }^{868}$

In 2002, Voronin and his communist party disseminated an updated foreign policy concept replacing the previously published version from 1995. In this strategic document, Moldova's eastern orientations with Russia and other CIS members were heavily emphasized. Of significance, this foreign policy concept explicitly identified Russia as Moldova's long-term strategic partner. ${ }^{869}$ Simultaneously, Voronin also began to deemphasize the country's participation in GUUAM noting the redundant nature of this regional grouping with the larger efforts of the Russian-led CIS. Speaking in 2002 Voronin noted how, “...[Moldova's] position is that the entire set of economic, social and cultural problems facing GUUAM today have already received effective solutions under CIS programs." ${ }^{870}$ With Uzbekistan withdrawing from GUAM in 2002, Voronin also believed this regional bloc was on the cusp of falling apart.

From 2001 through mid 2003, President Voronin was also able to bring to fruition his ideas about a closer economic alignment with Russia. Speaking in 2002, Voronin noted that since taking the presidency, Moldova had implemented a plethora of economic initiatives with Russia.

\footnotetext{
868 Tomiuc, Eugen. 2001. "Moldova: Moscow and Chisinau Initial Bilateral Agreement." Radio Free Europe / Radio Liberty, 06 November 2001. https://www.rferl.org/a/1097905.html. Accessed 21 February 2017.

${ }^{869}$ Skvortova, Alla. 2003. "Country Report Moldova.” In Iris Kempe (ed.) Prospects and Risks Beyond EU Enlargement. Eastern Europe: Challenges of a Pan-European Policy. Wiesbaden, Germany: Trade Media, 4; Weiner 2004, 544.

${ }^{870}$ Voronin, Vladimir. 2002b. “Moldovan President Laments Country's Role within GUUAM.” Interfax, 22 Jul 2002.
} 
As a result, Moldova by the end of 2002 was the number one country in the CIS receiving foreign investment from Russia. These projects included, but were not limited to, the construction of a cargo and passenger port in Giurgiulesti and the creation of a joint enterprise between Russia's United Power Systems Company and Moldovan power companies. ${ }^{871}$ Reflecting on these accomplishments, President Voronin concluded, a "strategic partnership with Russia is necessary, above all, to promote the welfare of the Moldovan people." ${ }^{872}$

Although Russia was the primary focus of President Voronin's alignment strategy during the early years of his presidency, the Moldovan president still sought to develop amicable ties with the United States and countries in Western Europe. For example, during a trip to the United States in 2002, Voronin conveyed his appreciation for Washington's efforts on the TransDniester problem set. In Voronin's words, “I am sincerely grateful to the U.S. government for the support they have shown to the process of Moldova's reintegration... [and] it is namely the United States that gave a new face to the talks... [and] to the discussions over the legal framework of post-conflict resolution in Moldova." ${ }^{873}$ Irrespective of these comments, Voronin believed Russia was the most important actor in this process. According to Voronin, "Russia is the strongest player in Dniester settlement, and nobody will ever be able to solve this problem without it." ${ }^{874}$ President Voronin also espoused the possibility of closer economic ties with the European Union; however, he realized the country's poor economic standing made this a longterm goal.

\footnotetext{
${ }^{871}$ Voronin, Vladimir. 2002c. "President Voronin: Partnership with Russia necessary for Moldova's Prosperity." Itar-Tass, 19 November 2002.

${ }^{872}$ Ibid.

${ }^{873}$ Voronin, Vladimir. 2002. "Moldovan President Interviewed on Visit to US, Bilateral Relations." Nezavisimaya, 13 December 2002.

${ }^{874}$ Voronin, Vladimir. 2003e. "Voronin Says Russia 'Essential' to Dniester Settlement. Itar-Tass 30 October 2003.
} 
As a point of emphasis, Voronin's political and economic actions with the United States and EU during his first several years in office must be put into proper perspective as some analysts may attempt to categorize Voronin as a pragmatist following a great power bridging strategy during his entire presidency. Certainly, Voronin's engagement with Washington was meant to improve interstate relations; however, they were not meant to signal a change in his accommodative orientation and positive bandwagoning actions with Russia. For example, after visiting the United States in 2002, Voronin was quick to dispel his trip to Washington as an indicator of a change in Moldova's alignment away from Russia. In Voronin's words...

The goal of his visit to the U.S. was to showcase Moldova as an independent state to Americans and others, to make Moldova recognizable abroad, and to enable other countries understand its foreign policy. Traditionally, we have had ties with Russia, Ukraine, other countries of the CIS, and we plan to develop those decade-old ties in future. Those ties are very valuable for Moldovan economy and it would be totally irrational to bury them in oblivion. ${ }^{875}$

Voronin's alignment with Russia and engagement with the United States, coupled with support from the OSCE, began to produce tangible results for an enduring resolution to Moldovan separatism. By 2003, proposals from Moscow and Washington for federalization gained traction with leading Moldovan political figures; however, what remained to be answered was how political power would be distributed between the central government, Transnistria, and Gagauzia. Although various parties had advocated for different options, Voronin publicly gravitated towards a Russian proposal developed by Dmitri Kozak. As noted in the previous chapter, the 'Kozak Memorandum' allocated substantial power to Transnistria and Gagauzia allowing each province to retain their independent governments, veto international treaties, and secede if Moldova joined the EU. The memorandum also included a provision for the continued stationing of Russian military forces in Moldova for 30 years.

${ }^{875}$ Voronin, Vladimir. 2002d. "Moldovan President Hopes for Better Ties with US." Itar-Tass 30 December 2002. 
In mid-2003, Voronin's willingness to sign the Kozak memorandum became a lightning rod for issue polarization that would prevent him from translating his ideas about an alignment with Russia into action. In parliament, the Braghis Alliance and CDPP formed the National Committee to Defend Moldova's Independence and Constitution. Political leaders on this committee were adamant that if Voronin signed the Kozak Memorandum, it would cause the "Transnistriazation" of Moldova or the country becoming a de facto Russian satellite. In concert with the formation of this committee, CDPP leaders also spurred Moldovans, who already opposed federalization, to hold public demonstrations protesting Voronin's pending action. ${ }^{876}$ Parliament's actions, backed by a public backlash became a key constraint that prevented Voronin from signing the Kozak Memorandum with Russia. This key event also represented a turning point moving Voronin to take on a pragmatic foreign policy orientation and a great power bridging strategy.

Following the Kozak Memorandum debacle, Voronin's pragmatism set the conditions by which the United States and Russia were both given consideration in the state's foreign policies. Because political power within Moldova's bureaucratic structures remained fragmented, Voronin's missteps with Russia helped political opposition groups to gain ground in the 2005 parliamentary elections. Although the PCRM won 56 seats with 46 percent of the popular vote, the newly-formed Democratic Moldova Bloc secured 34 seats, while the CDPP acquired the remaining 11 positions. Additionally, PCRM parliamentarians began to support opposition party ideas about the merits of an alignment with the West thus serving as an enabler for Voronin's great power bridging strategy with the Moscow and Washington. ${ }^{877}$

\footnotetext{
${ }^{876}$ Weiner 2004, 547.

877 The Democratic Moldova Bloc included the Social Liberal Party, the Democratic Party, and an adhoc coalition of four political parties under the name the banner of "Our Moldova" Alliance. See Crowther, William. 2007. "Moldova, Transnistria and the PCRM's Turn to the West." East European Quarterly 41 (3), 283-285.
} 
An analysis of Voronin's foreign policies from 2004 forward indicate he was able to bring to fruition alignment actions with the United States and its European allies. For example, Voronin's vocal calls in 2004 for increased U.S. involvement in the Trans-Dniester issue were realized in 2005 with the adoption of the Five (Moldova, Transnistria, Russia, Ukraine the OSCE) plus two (the United States and EU) program (or 5+2 program). Although the U.S. and EU were only granted observer status, Voronin clearly believed their presence could help advance negotiations leading to a final resolution on the Trans-Dniester.

Voronin's alignment with the United States was also seen in the military sphere where the Moldovan president fully supported the Bush Administration and its military operations in Iraq. Specifically, from 2003 to 2008 Voronin approved the deployment of Moldovan military forces to conduct demining operations in Iraq. ${ }^{878}$ Perhaps the most important event occurred in 2006 when Moldova signed an Individual Partnership Action Plan with the U.S.-led NATO alliance. ${ }^{879}$ In the 2004 and 2005, material cooperation between the United States and Moldova increased. For example, U.S. security assistance for Moldova's participation in the PFP increased during this time. Specifically, the U.S. provided Moldova excess defense articles and approximately $\$ 2$ million in funding through the Foreign Military Financing and International Military and Education Training programs. ${ }^{880}$ It was through these monies and materiel, Moldova was able to bolster its alignment with the United States and other NATO countries by improving the interoperability and peacekeeping capabilities of the country's armed forces.

\footnotetext{
${ }^{878}$ Carney, Stephen A. 2012. Allied Participation in Operation Iraqi Freedom. Government Printing Office, 82-83.

${ }^{879}$ North Atlantic Treaty Organization. 2017. "Individual Partnership Action Plans, 09 June 2017.” https://www. nato.int/cps/en/natohq/topics_49290.htm. Accessed 04 December 2016.

${ }^{880}$ Woehrel, Stephen. 2004. "Moldova: Background and U.S. Policy." Congressional Research Service, 17

December 2004, 6.
} 
Relatedly, Voronin's tendency to align itself with the West was also seen in 2004 with Moldova's inclusion in the EU's European Neighborhood Policy. The following year, Moldova and the EU signed an action plan designed to improve economic ties. Speaking at the signing ceremony in 2005, Voronin proclaimed, "European integration is an irreversible and priority option..., which is manifested first of all by the process of implementation of the Moldova-EU Action Plan. Integration of Moldova is a proof of the consensus among Moldovan political class concerning the vector of development of the country." $" 881$

In lockstep with President Voronin's alignment with the United States, he also continued the state's strategic partnership with Russia. For example, despite the higher level of tensions with Moscow, Voronin remained steadfast in his country's membership in the Russian-led CIS. According to Voronin, "you don't have to convince our population of how important it is to be in the CIS. Our people support membership of the CIS and close relations with Russia." ${ }^{882}$ Separately, the fact that between 2001 and 2006, Moldova also concluded approximately 26 different agreements with Russia represents a strong indicator of Voronin's ability to translate his verbal pronouncements about an alignment with Russia into action. ${ }^{883}$

Voronin's alignment with the Russian Federation and the United States remained positive for his last several years in office. With Russia, Voronin continued to call on the state to follow a pragmatic alignment with its former imperial center. In 2007, Voronin asserted Chisinau must build the best possible relations with Moscow again reemphasizing his ideas that Moldova's alignment with Russia would help solve the problem of separatism in the country. ${ }^{884}$ The

\footnotetext{
${ }^{881}$ Voronin, Vladimir. 2005b. "Speech of Vladimir Voronin." European Union Parliament, 08 June 2005. http://www.europarl.europa.eu/meetdocs/2004_2009/documents/fd/dmd20050621_08/dmd20050621_08en.pdf.

${ }^{882}$ Voronin, Vladimir. 2006a. "Moldovan President Says No Plans to Leave CIS Group." Itar-Tass, 21 July 2006.

${ }^{883}$ Honorary Consulate of Moldova in India. 2016. "Foreign Relations: Republic of Moldova." http://www.consulateofmoldova.in/foreign-relations.html. Accessed 03 September 2016.

${ }^{884}$ Voronin, Vladimir. 2007. "Moldovan President Calls for Pragmatism in Relations with Russia." Itar-Tass, 05 April 2007.
} 
following year, Voronin published a new national security strategy reaffirming Moldova's neutrality, which was backed by Voronin's commitment that Moldova would never join NATO. On the Trans-Dniester issue, Voronin signed a new joint declaration with Russia in March 2008. This declaration acknowledged the stabilizing role played by Russian peacekeepers while calling on members of the $5+2$ group to resume work on finding a solution. ${ }^{885}$

With the United States, Moldovan military personnel continued to support U.S. operations in Iraq through 2008. Voronin was also successful in eliciting additional political support from Washington on the Trans-Dniester issue. Voronin's continued diplomatic efforts produced several notable results. In May 2007, the U.S. House of Representatives introduced a resolution calling for the replacement of the Russian military forces in the Trans-Dniester with an OSCEled multinational force. Several months later, the U.S. Senate passed a resolution calling on Moscow to 'move speedily' in removing its military personnel and equipment from Moldova. ${ }^{886}$

In sum, moderate to high levels of government fragmentation and issue polarization were important shape agents on President Voronin's ideas about a positive bandwagoning strategy with Russia and later great power bridging. When Voronin would step too far to the right or left, as was the case with the Kozak Memorandum, political opposition groups would band together with public support to constrain the Moldovan president's actions. By emphasizing the country's neutrality, Voronin sought to formalize his great power bridging strategy by eschewing membership in NATO or the CSTO. Because of this he achieved the strategic maneuver room to align with the U.S. and Russia in different areas and at varying intensities over his presidency.

\footnotetext{
885 "Russia, Moldova and Trans-Dniester have adopted a joint declaration aimed at continuing efforts to settle the Trans-Dniester conflict." President of Russia Website, 08 March 2009. http://en.kremlin.ru/events/president/ news/44819. Accessed 09 November 2016.

${ }^{886}$ Woehrel, Stephen. 2009. "Moldova: Background and U.S. Policy." Congressional Research Service, 14 April 2009,8 .
} 
Nicolae Timofti. From 2012 through 2015, an analysis of Nicolae Timofti's foreign policy orientation reveals a higher degree of complexity. For the period under examination, Timofti took on a rather accommodative approach with the United States. In this case, Timofti was able to translate some of his ideas about aligning with the United States (and Europe) into action. With the Russians, Timofti attempted to advance a non-confrontation approach backed by verbal reassurances on how his efforts to align with the West did not represent a direct threat to Moscow.

As was the case with Lucinschi and Voronin, domestic politics stemming from the country's constitution remained a key shape agent for Timofti's alignment trajectories with the great powers once he arrived in office. First, the continuation of Moldova's parliamentary form of government helped ensure moderate levels of government fragmentation would remain where some of the foreign policy decision-making authority resided with leading figures in the legislature, including Prime Minister Vlad Filat. Second, multi-party ruling coalitions also amplified the levels of government fragmentation in Moldova during Timofti's time in office. For example, while Filat was the leader of the Democratic Liberal Party and prime minister, his actions, and those of the president were either constrained or enabled by the ideas put forward by influential political elites in the Democratic Party of Moldova and the Liberal Party. ${ }^{887}$

Issue polarization was less of a challenge under Timofti because the AEI, and successive ruling coalitions, were almost consistently in synch about the merits of a political and economic alignment with the West. Given Moldova's location, it is not surprising the first order of business

\footnotetext{
${ }^{887}$ The results of the 2010 parliamentary elections were as follows: PRCM (42 seats); center-right Liberal Democratic Party (32 seats); the Democratic Party of Moldova (15 seats); and the center-right Liberal Party (12 seats). See Republic of Moldova, Early Parliamentary Elections, 28 November 2010. 2011. Organization for Security and Cooperation in Europe. SCE/ODIHR Election Observation Mission Final Report, 26 January 2010. http://www.osce.org/odihr/75118?download=true. Accessed, 03 August 2017.
} 
for Timofti was to foster a closer economic alignment with the EU, which was realized in June 2014 when Chisinau signed an Association Agreement in Brussels. As an example of the low levels of government fragmentation and issue polarization on this topic, the Moldovan parliament ratified the EU agreement in a record five days after the document was signed. ${ }^{888}$ Taken together, domestic politics served as an enabler of Timofti's ability to enact policies to align Moldova more decisively with the United States. Several examples support this conclusion. First, the number of diplomatic visits to and from the United States serve as one indicator of Timofti's tendency to foster a stronger political and economic alignment with Washington from 2012 to 2015. During this time, Moldovan officials made 16 high-level visits to the United States as compared to only eight under President Voronin's two terms in office. Separately, U.S. officials visited Moldova at a higher rate registering 19 visits for the years Timofti was in office as compared to 18 under Voronin. ${ }^{889}$ As noted in chapter four, although diplomatic visits may count as one indicator of a state's alignment with a regional great power, what matters more is the extent to which one can discern substantive progress in this endeavor.

Second, the high number of diplomatic exchanges resulted in the formation of several key bilateral arrangements. With respect to the U.S., Moldova's alignment with Washington was bolstered in June 2012 with the establishment of the Congressional Moldova Caucus. This bilateral organization served as a platform for Chisinau's Euro-Atlantic integration. Separately, in December of this year, the U.S. Congress then voted to establish Normal Trade Relations status for Moldova. ${ }^{890}$ Timofti's tendency to align with the U.S. continued in 2014 with the

\footnotetext{
${ }^{888}$ Moldova Sets Record in Ratifying EU Agreement. 2014. Euractiv, 02 July 2014. http://www.euractiv.com/ section/europe-s-east/news/moldova-sets-record-in-ratifying-eu-association-agreement/. Accessed, 03 August 2017. ${ }^{889}$ Embassy of the Republic of Moldova to the United States and Mexico. 2015. Diplomatic Relations-Visits. http://www.sua.mfa.md/diplomatic-relations-en/. Accessed 22 December 2016.

${ }^{890}$ Woehrel, Stephen. 2014. "Moldova: Background and U.S. Policy.” Congressional Research Service, 23 April 2014, 9 .
} 
creation of the U.S.-Moldova Strategic Dialogue and the U.S.-Moldova Energy Working Group. The U.S.-Moldova Strategic Dialogue has a mandate to promote democracy and good governance in Moldova, energy independence, security cooperation and economic development. Separately, Moldova also became party to the U.S.-Moldova Energy Working Group, which has a primary goal of increasing the country's access to EU energy supplies via Romania.

In military affairs, Timofti was able to successfully seek out new ways to align Chisinau with the United States via Euro-Atlantic security structures such as NATO and other initiatives. Several points support this assertion. First, besides Moldova's participation in NATO's PFP, in 2013 Timofti authorized, and parliament approved, the deployment of 40 soldiers to support the NATO peacekeeping mission in Kosovo beginning in $2014 .{ }^{891}$ In 2014, Moldova inched closer to NATO and the United States. Beginning with NATO, during the Wales Summit in September in Brussels, Moldova became a member of the Defence and Related Security Capacity Building Initiative. As a participant in this program, Timofti's government NATO provided technical and material assistance to Chisinau to enhance the state's defense and security institutions and improve the military capabilities of the country's armed forces. ${ }^{892}$

Finally, as pointed out in Chapter 4, Moldova continued to participate in more military exercises with the United States than Russia. Additionally, in 2014 the United States donated military equipment to Moldova. According to Timofti, "this event is perfectly fitted into the practice of good cooperation between Moldova and the United States in terms of international security and peace, stability and democratic development of our state. I am firmly convinced that

\footnotetext{
891 "Moldovan Troops to Participate in International Peacekeeping Mission in Kosovo." 2013. Government of the Republic of Moldova. http://www.gov.md/en/content/moldovan-troops-participate-international-peacekeepingmission-kosovo. Accessed 21 October 2017.

892 North Atlantic Treaty Organization. 2017. "Relations with Moldova. NATO Topics, 08 December 2017. https://www.nato.int/cps/ic/natohq/topics_49727.htm. Accessed 14 January 2018.
} 
the friendship and cooperation relations between Moldova and the United States will continue to develop dynamically for the benefit of both countries and nations." $" 893$

With Russia, unlike other presidents, who assumed a more confrontational approach with Russia (e.g. Georgia's Mikheil Saakashvili or Ukraine's Viktor Yushchenko), Timofti deviated from this pattern somewhat opting to frame his alignment actions with the West in a nonconfrontational manner. For example, President Timofti attempted to convey how Moldova's association agreement with the EU and the country's alignment with the United States did not represent a threat to other states, particularly Russia. By taking such an approach, Timofti hoped it would help to temper Moscow's security concerns leading to renewed efforts to solve the Trans-Dniester issue, which never occurred.

In sum, this section found that when Moldovan presidents exhibited a pragmatic foreign policy orientation as was the case with Petru Lucinschi and Vladimir Voronin (after 2003) they followed a great power bridging strategy. Prior to 2004, Vladimir Voronin retained a very accommodative orientation with Russia, which was associated with a positive bandwagoning strategy with Moscow. Finally, President Timofti's accommodative orientation with the United States and Europe was associated with a positive bandwagoning strategy with Washington.

\section{Ukraine: Findings and Discussion}

Like their counterparts in Azerbaijan, Georgia, and Moldova, Ukrainian presidents believed cooperation not confrontation with external actors was the best strategy to achieve their foreign policy goals. Although their ideas about strategy represent an important starting point for understanding their alignment preferences, equally important was each president's foreign policy orientation and their ability to translate those ideas into action within a competitive domestic

\footnotetext{
${ }^{893}$ Timofti 2014b, 1.
} 
political environment. Here, President Leonid Kuchma exhibited a pragmatic foreign policy orientation, which was associated with a strategy of great power bridging. Presidents Yushchenko and Poroshenko retained an accommodative foreign policy orientation with the United States, which corresponded to a positive bandwagoning alignment with Washington. Simultaneously, both presidents also exhibited a more confrontational orientation with Russia. Finally, Viktor Yanukovych exhibited an accommodative foreign policy orientation and a positive bandwagoning alignment strategy with Moscow. The role of domestic politics was mixed as government fragmentation and issue polarization in some instances constrained and/or enabled each presidents' alignment strategies.

The Instrumental Beliefs of Ukrainian Presidents

An analysis of each president's instrumental beliefs indicates Viktor Yanukovych exhibited a 'very' cooperative approach (.82) with external actors while Presidents Kuchma and Yushchenko believed cooperation with external states was 'definitely' the best approach to achieve their goals registering an intensity of .61 and .52 respectively. Petro Poroshenko had the lowest I-1 score (.47) regarding cooperation with external actors as 'somewhat' beneficial. ${ }^{894}$ This positive trend in their beliefs about cooperation continued in the I-2 index ('intensity of tactics'), but with some notable differences. Both Kuchma (.27) and Yanukovych (.39) believed cooperative tactics were 'definitely' of higher utility while Yushchenko (.23) and Poroshenko (.20) believed cooperative tactics were 'somewhat' useful.

\footnotetext{
${ }^{894}$ The value for the I-1 index varies between +1 (political leader views a strategy of cooperation has more utility) to -1 (political leader views a strategy of confrontation has more utility). For this study, the measure for this index is as follows: $(-1=$ very conflictual; $-.50=$ definitely conflictual; $-.25=$ somewhat conflictual; $0.0=$ mixed; $+.25=$ somewhat cooperative; $+.50=$ definitely cooperative $+.75=$ very cooperative)
} 


\section{Table 28: ANOVA Results - Moldovan Presidents Instrumental Beliefs}

\begin{tabular}{|c|c|c|c|c|c|c|c|c|c|c|c|c|c|c|c|c|c|c|c|c|c|c|c|c|c|}
\hline \multirow[b]{2}{*}{ Instrumental Beliefs / Year } & \multicolumn{11}{|c|}{ Leonid Kuchma } & \multicolumn{6}{|c|}{ Viktor Yuschenko } & \multicolumn{5}{|c|}{ Viktor Yanukovych } & \multicolumn{3}{|c|}{ Petro Poroshenko } \\
\hline & 1995 & 1996 & 1997 & 1998 & 1999 & 2000 & 2001 & 2002 & 2003 & 2004 & AVG & 2005 & 2006 & 2007 & 2008 & 2009 & AVG & 2010 & \begin{tabular}{|l|}
2011 \\
\end{tabular} & 2012 & 2013 & AVG & 2014 & 2015 & AVG \\
\hline I-1: Direction of Strategy & 0.56 & \begin{tabular}{|l|l|}
0.55 \\
\end{tabular} & 0.56 & 0.63 & \begin{tabular}{|l|l|}
0.64 \\
\end{tabular} & 0.57 & 0.57 & 0.73 & 0.68 & 0.56 & 0.61 & 0.65 & 0.64 & 0.35 & 0.57 & 0.4 & 0.52 & 0.78 & \begin{tabular}{|l|l|}
0.83 \\
\end{tabular} & 0.96 & 0.69 & 0.82 & 0.34 & 0.59 & 0.47 \\
\hline I-2: Intensity of Tactics & 0.23 & \begin{tabular}{|l|}
0.23 \\
\end{tabular} & 0.25 & 0.28 & 0.31 & 0.21 & 0.21 & 0.4 & 0.32 & 0.25 & 0.27 & \begin{tabular}{|l|l|}
0.27 \\
\end{tabular} & 0.34 & 0.11 & 0.23 & 0.18 & 0.23 & \begin{tabular}{|l|l|}
0.37 \\
\end{tabular} & \begin{tabular}{|l|l|}
0.41 \\
\end{tabular} & 0.5 & 0.28 & 0.39 & 0.15 & 0.25 & 0.20 \\
\hline I-3: Risk Orientation & 25 & 0.25 & 0.24 & 0.24 & 0.24 & 0.31 & 0.31 & 0.22 & 0.3 & 0.25 & 0.26 & 0.3 & 0.23 & 0.21 & 0.33 & 0.27 & 0.27 & 0.28 & 0.28 & 0.31 & 0.29 & 0.29 & 0.13 & 0.24 & 0.19 \\
\hline \multicolumn{26}{|l|}{\begin{tabular}{|l} 
I-4: Importance of Timing of \\
Action
\end{tabular}} \\
\hline $\begin{array}{l}\text { a. Flexiblity of cooperation/ } \\
\text { conflict tactics }\end{array}$ & 0.44 & 0.45 & 0.44 & 0.37 & 0.36 & 43 & 0.4 & 0 & 0.32 & 0.44 & 0.4 & 0.35 & 0.36 & 0.6 & 0.43 & 0.6 & 0.48 & 0.22 & $\mid 0.17$ & 0.04 & 0.31 & 0.19 & 0.66 & 0.41 & 0.54 \\
\hline $\begin{array}{l}\text { b. Flexibility of word/deed } \\
\text { tactics }\end{array}$ & 28 & 0.38 & 0.4 & 0.45 & 0.42 & 0.51 & 0.51 & 0.59 & 0.39 & 0.42 & 0.44 & 0.47 & 0.54 & 0.43 & 0.32 & 0.27 & 0.41 & 0.5 & 0.48 & 0.42 & 0.39 & 0.45 & 0.6 & 0.47 & 0.54 \\
\hline \multicolumn{26}{|l|}{ I-5: Utility of Means } \\
\hline a. Punish & 0.05 & \begin{tabular}{|l|}
0.06 \\
\end{tabular} & 0.07 & 0.08 & \begin{tabular}{|l|}
0.05 \\
\end{tabular} & 0.11 & 0.11 & \begin{tabular}{|l|}
0.05 \\
\end{tabular} & 0.03 & \begin{tabular}{|l|}
0.06 \\
\end{tabular} & 0.07 & \begin{tabular}{|l|}
0.09 \\
\end{tabular} & 0.06 & \begin{tabular}{|l|}
0.11 \\
\end{tabular} & \begin{tabular}{|l|}
0.06 \\
\end{tabular} & \begin{tabular}{|l|}
0.03 \\
\end{tabular} & 0.07 & \begin{tabular}{|l|}
0.07 \\
\end{tabular} & \begin{tabular}{|l|}
0.04 \\
\end{tabular} & 0.02 & 0.08 & 0.05 & 0.12 & 0.09 & 0.11 \\
\hline b. 1 & & \begin{tabular}{|l|}
0.05 \\
\end{tabular} & 0.02 & 0.03 & \begin{tabular}{|l|}
0.03 \\
\end{tabular} & 0.02 & 0.02 & \begin{tabular}{|l|}
0.02 \\
\end{tabular} & 0.03 & 0.06 & 0.03 & \begin{tabular}{|l|}
0.02 \\
\end{tabular} & 0 & \begin{tabular}{|l|}
0.05 \\
\end{tabular} & \begin{tabular}{|l|}
0.01 \\
\end{tabular} & \begin{tabular}{|l|}
0.03 \\
\end{tabular} & 0.02 & \begin{tabular}{|l|}
0.01 \\
\end{tabular} & \begin{tabular}{|l|}
0.04 \\
\end{tabular} & 8 & 0.03 & 0.02 & 0.03 & 0.04 & 0.04 \\
\hline c. Opp & 12 & \begin{tabular}{|l|}
0.12 \\
\end{tabular} & 0.13 & 0.08 & 0.1 & 8 & 0.08 & \begin{tabular}{|l|}
0.07 \\
\end{tabular} & 0.1 & 0.1 & 0.1 & \begin{tabular}{|l|}
0.06 \\
\end{tabular} & 0.12 & \begin{tabular}{|l|}
0.16 \\
\end{tabular} & \begin{tabular}{|l|l|}
0.14 \\
\end{tabular} & \begin{tabular}{|l|}
0.23 \\
\end{tabular} & 0.14 & \begin{tabular}{|l|}
0.04 \\
\end{tabular} & 0 & 0 & 0.04 & 0.02 & 0.18 & 0.08 & 0.13 \\
\hline d. Appeal & 0.58 & \begin{tabular}{|l|}
0.58 \\
\end{tabular} & 0.57 & 0.57 & \begin{tabular}{|l|}
0.56 \\
\end{tabular} & 0.62 & 0.62 & \begin{tabular}{|l|}
0.52 \\
\end{tabular} & 0.61 & 0.57 & 0.58 & \begin{tabular}{|l|}
0.61 \\
\end{tabular} & 0.54 & \begin{tabular}{|l|l|}
0.54 \\
\end{tabular} & \begin{tabular}{|l|l|}
0.64 \\
\end{tabular} & \begin{tabular}{|l|}
0.57 \\
\end{tabular} & 0.58 & \begin{tabular}{|l|}
0.59 \\
\end{tabular} & \begin{tabular}{|l|}
0.59 \\
\end{tabular} & 0.58 & 0.61 & 0.59 & 0.44 & 0.57 & 0.51 \\
\hline e. Promise & 0.1 & \begin{tabular}{|l|}
0.07 \\
\end{tabular} & 0.09 & 0.1 & \begin{tabular}{|l|}
0.09 \\
\end{tabular} & 0.02 & 0.02 & \begin{tabular}{|l|}
0.09 \\
\end{tabular} & 0.06 & 0.06 & \begin{tabular}{|l|}
0.07 \\
\end{tabular} & \begin{tabular}{|l|l|}
0.06 \\
\end{tabular} & 0.07 & \begin{tabular}{|l|}
0.03 \\
\end{tabular} & 0.05 & \begin{tabular}{|l|l|}
0.03 \\
\end{tabular} & 0.05 & \begin{tabular}{|l|}
0.11 \\
\end{tabular} & \begin{tabular}{|l|}
0.13 \\
\end{tabular} & \begin{tabular}{|l|}
0.21 \\
\end{tabular} & 0.12 & 0.14 & 0.05 & 0.08 & 0.07 \\
\hline \begin{tabular}{|ll} 
f. & Reward \\
\end{tabular} & 0.09 & \begin{tabular}{|l|}
0.13 \\
\end{tabular} & 0.13 & 0.15 & \begin{tabular}{|l|}
0.16 \\
\end{tabular} & 0.14 & 0.14 & 0.25 & 0.16 & 0.15 & 0.15 & \begin{tabular}{|l|l|}
0.15 \\
\end{tabular} & 0.21 & \begin{tabular}{|l|l|}
0.11 \\
\end{tabular} & 0.1 & 0.1 & 0.13 & \begin{tabular}{|l|}
0.19 \\
\end{tabular} & 0.2 & \begin{tabular}{|l|}
0.19 \\
\end{tabular} & 0.11 & 0.17 & \begin{tabular}{|l|}
0.18 \\
\end{tabular} & 0.14 & 0.16 \\
\hline
\end{tabular}

A reading of the I-5 index (utility of means) indicates all four presidents found the highest value with making 'appeals' to external states with their tendency to focus on 'rewards' coming in second. Of note, President Yanukovych also believed 'promise' carried some importance with his strategy. Although cooperative tactics were given the primary focus, interestingly Presidents Yushchenko and Poroshenko found some value in conflictual tactics by invoking their authority to "oppose" the actions of other states (.14 and .13 respectively). Additionally, Poroshenko also viewed 'punishment' as a potential tactic scoring a .11 in this category.

With respect to the timing of their actions, Presidents Kuchma (.40), Yushchenko (.48), and Poroshenko's (.54) I-4a scores indicate a tendency for diversity in their tactics. An outlier in this category is Yanukovych, who had a .19 score, but this mirrored his predecessors and successor. In the 1-4b category, all four presidents also exhibited a propensity to shift between their words and actions (I-4b: Kuchma=.44; Yushchenko=.41; Yanukovych=.45; Poroshenko=.54). Finally, all four of the Ukrainian presidents were inclined to be less acceptant of risk. ${ }^{895}$

\section{$\underline{\text { Validating Convergence and Divergence }}$}

An ANOVA test invalidates the null hypothesis that there are no statistically significant

\footnotetext{
895 The measurement for a political leader's master instrumental beliefs (I-1) is as follows: $-1=$ very conflictual; -.50 $=$ definitely conflictual $;-.25=$ somewhat conflictual; $0.0=$ mixed $+.25=$ somewhat cooperative $+.50=$ definitely cooperative; $+.75=$ very cooperative.
} 
differences in the instrumental beliefs of the four presidents. The alternative hypothesis that a statistically significant difference exists is validated at the .01 level. A Tukey's HSD test indicates Presidents Yushchenko and Poroshenko were the most similar in their I-1 beliefs.

Table 29: ANOVA Results - Ukrainian Presidents Instrumental Beliefs

\begin{tabular}{c|ccccc}
\hline & & Sum of Squares & $d f$ & Mean Square & F \\
\hline \multirow{2}{*}{$\mathrm{I}-1$} & $\begin{array}{c}\text { Between } \\
\text { Groups }\end{array}$ & .024337 & 3 & 0.081123 & $7.7494 * *$ \\
& $\begin{array}{l}\text { Within } \\
\text { Groups }\end{array}$ & .18843 & 18 & 0.010468 & \\
\hline$*$ prob $<.01$ & & & & & \\
\hline
\end{tabular}

Table 30: Ukraine - Mean Comparisons of Tukey's HSD Test Results (I-1)

\begin{tabular}{l|llll}
\hline \multicolumn{1}{c|}{ Pair } & Difference & Lower Bound & Upper Bound & Adjusted P-Value \\
\hline $\begin{array}{l}\text { Poroshenko- } \\
\text { Kuchma }\end{array}$ & -0.105 & -0.29535599 & 0.08535599 & 0.4253421 \\
$\begin{array}{l}\text { Yanukovych- } \\
\text { Kuchma }\end{array}$ & 0.210 & 0.03892383 & 0.38107617 & 0.0132682 \\
$\begin{array}{l}\text { Yushchenko- } \\
\text { Kuchma }\end{array}$ & -0.083 & -0.24138576 & 0.07538576 & 0.4685766 \\
$\begin{array}{l}\text { Yanukovych- } \\
\text { Poroshenko }\end{array}$ & 0.315 & 0.09414161 & 0.53585839 & 0.0039745 \\
$\begin{array}{l}\text { Yushchenko- } \\
\text { Poroshenko }\end{array}$ & 0.022 & -0.18918101 & 0.23318101 & 0.9908094 \\
$\begin{array}{l}\text { Yushchenko- } \\
\text { Yanukovych }\end{array}$ & -0.293 & -0.48698214 & -0.09901786 & 0.0023753 \\
\hline
\end{tabular}

95\% Family-wise Confidence Level 


\section{Ukrainian President Alignment}

From 1995 through 2015, Ukrainian presidents exhibited the full gamut of foreign policy orientations vis-à-vis the United States and Russian Federation. A qualitative analysis of the material actions of all four presidents validate the findings from the Tukey's HSD test above that Presidents Yushchenko and Poroshenko's ideas about strategy and a strategic alignment with United States are the most similar. In both cases, Yushchenko and Poroshenko were able to translate their ideas and verbal pronouncements into action as part of a positive bandwagoning strategy with the United States. President Kuchma, on the other hand, retained a pragmatic foreign policy orientation, which subsequently served as a basis from which he would align with the United States and Russia via a strategy of great power bridging. Finally, in marked contrast to these three presidents, Viktor Yanukovych gravitated toward an accommodative orientation with Moscow leading to his positive bandwagoning alignment with Russia. Although each president retained a particular foreign policy orientation, varying levels of government fragmentation and/or issue polarization shaped the state's alignment trajectories.

Leonid Kuchma. From 1995 to 2004, President Kuchma retained a pragmatic foreign policy orientation believing an alignment with Russia and the United States was critically important to the country's transition from Soviet rule and for his ability to remain in power. Speaking in 1995, Kuchma openly stated, "I am a pragmatist" $" 896$ noting how Ukraine must advance a strategic partnership with Russia, the United States, and Western Europe. Low levels of government fragmentation did not constrain Kuchma's pragmatism and his ability to translate his words into action.

\footnotetext{
${ }^{896}$ Kuchma, Leonid. “Kuchma on Threat from Russian Nationalism.” Financial Times, 25 November 1995.
} 
The source of Kuchma's political prowess was based on the 1996 constitution, which established a strong presidential system that centralized a majority of the power in the office of the president. According to one area expert, "Ukraine's 1996 constitutional arrangements contributed to giving the president so much power that he had little incentive to collaborate with parliament. Moreover, the legislative power given to the president reduced the likelihood that parliament would form a stable governing coalition." ${ }^{" 897}$ As was seen in Georgia under President Saakashvili, the presidency under Kuchma could be categorized as one of hyper-presidentialism.

With power centralized in the executive branch, issue polarization in Ukraine was also generally low for Kuchma despite the highly eclectic nature of the Rada. During the 1994, 1998, and 2002 parliamentary elections, a myriad of candidates and political parties vied for seats in the 450-member Rada in order to advance their respective domestic and/or international agendas. For example, after the first two rounds of the 1994 parliamentary elections, Ukrainians elected 168 deputies from 14 different parties and 170 independents to fill the 450 -seat legislature. By 1995, the largest block of deputies (164 MPs) were from the 'left' and the Communist, Socialist, and Peasant parties. Deputies from the right secured 120 seats, while Centrist parties acquired 118 positions. ${ }^{898}$ With such a diversity in parliament, deputies and parties were more at odds with one another, rather than the president.

President Kuchma was also able to check any opposition to his ideas over aligning with the United States and/or Russia by employing a variety of different tactics, including political coercion, blackmail, and the appointment of like-minded political officials at all levels of

\footnotetext{
${ }^{897}$ D'Anieri, Paul J. 2007. Understanding Ukrainian Politics: Power, Politics, and Institutional Design. New York: ME Sharpe, 126.

${ }^{898}$ Centrist parties included the Inter-Regional Group of Deputies, Unity, Centre, and Independents. The Right consisted of the following parties: Rukh, Reforms, Statehood, and non-affiliated deputies. See Wolczuk, Kataryna. 2001. The Moulding of Ukraine: The Constitutional Politics of State Formation. Central European University Press, 129-134 and Birch, Sarah. 1995. "The Ukrainian Parliamentary and Presidential Elections of 1994." Electoral Studies 14 (1), 95-96.
} 
government. Contributing to lower levels of government fragmentation was Kuchma's ability to control key government agencies, including the interior ministry and those offices responsible for collecting intelligence and taxes. For example, during the 2002 parliamentary elections, although former Prime Minister Viktor Yushchenko's 'Our Ukraine' party won the largest number of seats (110 MPs), it was not enough to form a majority since the Communist Party won 66 seats and Kuchma's “For a United Ukraine' bloc, acquired 101 seats. Independents and a handful of minor parties filled-in the remaining positions. ${ }^{899}$ Despite this setback, Kuchma used material incentives and political pressure to form a coalition that allowed him to advance his foreign policy agenda. ${ }^{900}$ Taken together, Kuchma's political cunning, coupled with his ability to foment factionalism and induce inter-personal rivalries within various opposition parties, allowed the Ukrainian president to more easily implement his great power bridging alignment preferences.

Kuchma's tendency to align with Russia as part of his great power bridging strategy was reflected in a series of key events during his time in office. Beginning with Russia, the first, and perhaps one of the most important events occurred in 1997 when President Kuchma and his Russian counterpart, Boris Yeltsin, signed a Treaty of Friendship and Cooperation. Taking nearly two years to sign, this treaty became the backbone of Ukraine's alignment with Russia laying a foundation for Kiev's strategic partnership with Russia (and vice versa) in the realm of politics, economic development, energy supplies, military-technical cooperation, and culture. According to Kuchma, this treaty “....will enable us to advance our relations to a qualitatively

\footnotetext{
${ }^{899}$ Ukraine-Parliamentary Elections, Final Report. 2002. Organization for Security and Cooperation in Europe, Office for Democratic Institutions and Human Rights. http://www.osce.org/odihr/elections/ukraine/14947? download=true. Accessed 05 April 2017, 24.

${ }^{900}$ Name Redacted. 2004. "Ukraine: Background and U.S. Policy." Congressional Research Service, 27 February $2004,2$.
} 
new level. The results... have enabled the leaders of Ukraine and the Russian Federation to express confidence in the fact that continued friendly relations between the two states based on equal rights will become further intensified... ${ }^{901}$

The 1997 Friendship Treaty with Russia was immediately followed in 1998 with a 10-year comprehensive economic cooperation agreement. Signed in February, "the high parties signing the agreement, ...recognize the necessity to gradually shape and develop a joint economic space [and ...create favorable conditions for the harmonization of basic directions of social and economic change; [and] structural reconstruction; alignment of the normative and legislative foundations of economic co-operation with abroad, customs tariff policy, tax policy and antimonopoly legislation."902 However, the collapse of Russia's economy a few months later stymied this bilateral effort with economic progress first taking effect in 2000 when Ukraine's exports and imports to and from Russia went from $\$ 2.4$ billion and $\$ 5.6$ billion to 3.5 billion and 5.8 billion respectively. ${ }^{903}$

Kuchma's alignment with Russia was also made evident in his decision to replace his foreign minister, Boris Tarasyuk, who advocated for Ukraine's exclusive alignment with the West. In his place, Kuchma installed Anatolii Zlenko, who viewed Russia as the state's most important strategic partner. Although Zlenko was a strident supporter of Kuchma's beliefs about aligning Ukraine with Russia, he also believed the state's foreign policies must be multi-vector in nature where an alignment with other regional great powers such as the United States was in the state's

\footnotetext{
${ }^{901}$ Kuchma, Leonid. 1997a. “Kuchma on State of Mutual Relations.” Svobodnaya Gruziya, 28 October 1997.

902 Olszafski, Tadeusz Andrzej. 2001. "Ukraine and Russia: Mutual Relations and the Conditions that Determine Them.” Central European Studies. https:/core.ac.uk/download/pdf/11871235.pdf. Accessed 20 December $2016,37$. 903 World Bank. 2016. World Integrated Trade Solution (WITS). http://wits.worldbank.org/about_wits.html. Accessed 04 April 2016.
} 
best interests. According to Zlenko, developing a strategic partnership with Russia and the United States would be the "key guarantee of our [Ukraine's] security."904

With the United States, once in office Kuchma's tendency to align with this regional great power as part of his great power bridging strategy was also almost immediately seen. In 1996, Kuchma entered Ukraine into a strategic partnership with the United States through the establishment of the Kuchma-Gore Commission. This bilateral arrangement served as a foundational mechanism by which Kiev's alignment with Washington would develop across various lines of operation including trade, investment, and national security. The high relevance of the Kuchma-Gore commission to the Ukrainian president was made clear when he stated how, "the strategic axis "Washington-Kiev" has become a significant factor of global peace and stability." ${ }^{905}$ Kuchma's emphasis on the centrality of this bilateral arrangement was two-fold. First, Kuchma believed an alignment with the U.S. via this commission could help him acquire external funding to help the country's struggling economy. Second, an improving economy would then translate into political capital, which would help him to be re-elected in 1999.

Kuchma's support for NATO is another facet of his tendency to align with the United States. For example, Ukraine was the first CIS state to join the alliance's PFP program in 1994. Beginning in 1996, Kuchma fully supported U.S.-led military activities in the Balkans authorizing the deployment of Ukrainian military forces for NATO operations in Bosnia and Kosovo. In 1997, Kiev then signed NATO's Charter on a Distinctive Partnership, which subsequently facilitated the opening of a NATO Liaison Office in Kiev in $1999 .{ }^{906}$ In 2002,

\footnotetext{
${ }^{904}$ Zlenko, Anatolii. 2001. "Ukrainian Foreign Affairs Minister Anatoliy Zlenko on Changes in Foreign Political Course.” Kiyevskiye Vedomosti, 29 January 2001.

${ }^{905}$ Kuchma, Leonid. 1998. "President Kuchma and Vice President Gore Open 2nd Plenary Session of Ukraine-US Binational Commission." Embassy of Ukraine to the United States of America, 23 July 1998. http://www.brama. com/ukraine-embassy/pre0723.html. Accessed 20 December 2016.

${ }^{906}$ North Atlantic Treaty Organization. 2002. "NATO and Ukraine: Distinctive Partners." NATO Update, 09 July 2002. https://www.nato.int/ docu/update/2002/07-july/e0709a1.htm. Accessed 19 December 2016.
} 
Kiev's alignment with the United States continued along a positive trajectory when Kuchma announced his intention for Ukraine to join NATO leading to the establishment of the NATOUkraine Action Plan. By 2004, Kiev had signed the Ukraine-NATO Memorandums on Host Nation Support and Strategic Airlift. The memorandum on Host Nation Support established protocols for the conduct of joint military exercises in Ukraine, while the Strategic Airlift memo detailed how NATO would be able to use the Ukrainian Air Force's transport planes for operations in Afghanistan. ${ }^{907}$ In 2003, Kuchma then supported U.S.-led military operations in Iraq by approving the deployment of approximately 2,000 soldiers for various missions in the theater of operations. ${ }^{908}$

Viktor Yushchenko. From 2005-2009, President Yushchenko maintained an accommodative foreign policy orientation with the United States seeking develop a strong political, economic, and military alignment with Washington. Concurrently, the Ukrainian president took on a more confrontational orientation with Russia owing to Moscow's continued meddling in the country's internal affairs. Domestic politics, in terms of government fragmentation and issue polarization were important shape agents, but not decisive factors constraining Yushchenko's ability to translate his ideas about a strategic alignment with the United States and its European allies into action.

For his first year in office, government fragmentation remained generally low for Yushchenko since his presidential powers were based on the 1996 constitution. However, in the political wake of the 'Orange Revolution' that brought Yushchenko to power, the 2004 constitutional amendments, which went into effect in 2006 changed Ukraine's form of government to a

\footnotetext{
${ }^{907}$ Socor, Vladmir. 2004. "NATO Summit Takes Stock of Ukraine’s Performance.” Eurasia Daily Monitor 1 (45). https://jamestown.org/program/nato-summit-takes-stock-of-ukraines-performance/. Accessed 19 December 2016. ${ }^{908}$ Carney 2012, 116.
} 
parliamentary-presidential republic. Under this system, President Yushchenko was still the commander-in-chief and the lead actor charged with developing the state's foreign policies; however, some power was transferred to the Rada and the prime minister. Specifically, the prime minister was given the authority to make government appointments, less the foreign and defense ministers, which still needed Rada approval. ${ }^{909}$

Issue polarization over Yushchenko's ideas on an alignment with the United States was moderate during his first two years in office. Beginning in 2006, there was a notable uptick in domestic political opposition to the Ukrainian president and his 'Our Ukraine' party on a myriad of domestic and foreign policy issues. As a result, Yushchenko's party was forced to enter into a coalition with his former political rival, Viktor Yanukovych. Following the 2006 parliamentary elections, Yanukovych's 'Party of Regions' won 30 percent of the vote giving the opposition 186 seats in the legislature. Yulia Tymoshenko's bloc came in second with 129 seats and Yushchenko's 'Our Ukraine' a distant third with 81 seats. ${ }^{910}$ This was significant because it forced Yushchenko to band together with Yanukovych, who would become prime minister and who would also seek to constrain the president's ideas about a positive bandwagoning alignment with the United States.

Despite higher levels of government fragmentation and issue polarization, Yushchenko's political acumen and ability to make full use of his presidential powers allowed him to bring to fruition some of his ideas about a strategic alignment with the United States. A hallmark example of Yushchenko's alignment with the United States occurred in 2005 when the Ukrainian president visited Washington D.C. where he was granted a rare privilege to address a joint

\footnotetext{
${ }^{909}$ Karatnycky, Adrian. 2005. “Ukraine's Orange Revolution.” Foreign Affairs 84 (2), 42.

${ }^{910}$ Ukraine-Parliamentary Elections, Final Report. 2006. Organization for Security and Cooperation in Europe, Office for Democratic Institutions and Human Rights. http://www.osce.org/odihr/elections/ukraine/19595. Accessed 05 April 2017, 24.
} 
session of Congress. Prior to this time, the only other former Soviet state leader to address Congress was Boris Yeltsin in 1992. ${ }^{911}$ During this singular event, President Yushchenko also signed a joint statement with President Bush on establishing a new strategic partnership with the United States. Formalized in 2008 as the U.S.-Ukraine Charter on Strategic Partnership, this agreement sought to expand security cooperation between both countries with the long-term goal of Ukraine's accession into NATO. ${ }^{912}$

President Yushchenko also pursued a strong alignment with the United States in the economic arena by consistently touting his commitment to open market principles and integrating Ukraine's economy into the global economy. His efforts paid off when beginning in 2006, the U.S. government began providing higher levels of political and economic support. From 2005 through 2007, U.S. assistance to Ukraine for its accession to the WTO included the allocation of technical advisors, \$50 million for economic reform programs, and the repeal of 1974 JacksonVanik amendment. Enhancing these activities, President Yushchenko opened six public information centers across Ukraine to help inform the public on his aspirations to join the WTO as well as other Euro-Atlantic organizations such as the EU and NATO. ${ }^{913}$ Separately, in April 2008 Ukraine signed the Trade and Investment Cooperation Agreement with the United States. This agreement created a bilateral Trade and Investment Council, which authorized economic

\footnotetext{
911 Joint Meeting \& Joint Session Addresses Before Congress by Foreign Leaders \& Dignitaries. 2017. United States House of Representatives-History, Art, and Archives. http://history.house.gov/Institution/Foreign-Leaders/JointSessions/. Accessed 05 March 2017.

${ }_{912}$ United States-Ukraine Charter on Strategic Partnership. 2008. United States Department of State-Bureau of European and Eurasian Affairs. https://www.state.gov/p/eur/rls/or/142231.htm. Accessed 14 January 2017.

${ }^{913}$ Country Assessments and Performance Measures-Ukraine. 2007. United States Department of State-Bureau of European and Eurasian Affairs. https://www.state.gov/p/eur/rls/rpt/92794.htm. Accessed 14 January 2017. Country Assessments and Performance Measures-Ukraine. 2006. United States Department of State-Bureau of European and Eurasian Affairs. https://www.state.gov/p/eur/rls/rpt/63181.htm. Accessed 14 January 2017; Country Assessments and Performance Measures-Ukraine. 2005. United States Department of State-Bureau of European and Eurasian Affairs. https://www.state.gov/p/eur/rls/rpt/55799.htm. Accessed 14 January 2017.
} 
officials to discuss ways of bolstering economic ties between both countries. ${ }^{914}$ Taken together, these efforts significantly helped Yushchenko to realize his goal of WTO membership in 2008.

Although opposed by Yanukovych and his Party of Regions, Yushchenko was able to strengthen Ukraine's alignment with the United States via NATO. The most significant step forward for Yushchenko occurred in April 2005 when during the NATO-Ukraine Commission meeting in Vilnius, alliance leaders invited Kiev to begin an Intensified Dialogue on Membership. The Intensive Dialogue program is a pivotal precursor step prior to the issuance of a MAP. In February 2006, during a meeting in Brussels, the Ukrainian president told NATO officials his country was ready for a MAP, proceeding to establish an interagency commission, which would oversee the country's accession into the alliance. ${ }^{915}$ President Yushchenko's continued commitment to align Ukraine with the United States and produced positive results when President Bush signed into law the 2007 NATO Freedom Consolidation Act, which provided Ukraine with $\$ 30$ million of U.S. military assistance from 2008-2012. ${ }^{916}$

Viktor Yanukovych. From 2010 through the end of his presidency, Viktor Yanukovych exhibited an accommodative foreign policy orientation with the Russian Federation, which framed his positive bandwagoning alignment with Moscow. Even prior to his election, Yanukovych signaled his intentions to domestic and international audiences about how one of his first actions, if elected president, would be to re-establish Ukraine's strategic partnership with

\footnotetext{
914 International Trade Administration. 2017. "Ukraine-Trade Agreements." United States Department of Commerce. https://www.export.gov/article?id=Ukraine-Trade-Agreements. Accessed 15 January 2017.

${ }^{915}$ Interagency Commission to be set up for Ukraine's Ascendance to NATO. Ukrainian Government Web Portal, 03 March 2006. http://www.kmu.gov.ua/control/en/publish/article?art_id=31466745\&cat_id=244315200. Accessed 14 January 2017.

916 Albania, Croatia, Georgia, and Macedonia were also included in this act. See NATO Freedom Consolidation Act. 2007. U.S. Senate Report 110-34, 09 March 2007. U.S. Government Publishing Office. https://www.gpo.gov/ fdsys/pkg/CRPT-110srpt34/html/CRPT-110srpt34.htm. Accessed 14 January 2017.
} 
Russia. ${ }^{917}$ With the United States however, the Ukrainian president's orientation was best understood as cordial. For Yanukovych, good relations with America was important; however, he firmly believed Washington's meddling in Ukraine's internal affairs was the primary catalyst for the 2004 Orange Revolution. As a result, Yanukovych sought to maintain routine interstate activities with the United States in order to stave off any social and political instability that could threaten his hold on power. ${ }^{918}$

Yanukovych's ability to enact his ideas about a strong alignment with Russia were partially enabled by low levels of government fragmentation, which was brought into being by his own hand. After being elected president, Yanukovych appointed a commission to review the legality of the 2004 constitutional amendments that relegated some of the president's power to parliament. The country's constitutional court subsequently found the 2004 amendments illegal and proceeded to return those powers to Yanukovych, thus moving the country back to a presidential system of governance. ${ }^{919}$ Specifically, the court's ruling gave Yanukovych strong executive powers over the cabinet and the legislature empowering him to make government appointments and take foreign policy actions independent of other branches of the government.

President Yanukovych's presidency was also marked by increasing levels of issue polarization over his foreign policy actions to solidify Ukraine's alignment with Russia. During the period 2010-2012, issue polarization was moderate as leading political figures such as Yulia Tymoshenko and various opposition parties (e.g. Our Ukraine, United Opposition, etc.) resisted

\footnotetext{
${ }^{917}$ Yanukovych, Viktor. 2009. "No Hope for Better Relations with Russia Under Current Leadership Yanukovych." Interfax, 11 August 2009.

918 Osborn, Andrew. 2010. "Viktor Yanukovych Says West has Nothing to Fear from Ukraine." The Telegraph, 15 February 2010. http://www.telegraph.co.uk/news/worldnews/europe/ukraine/7236642/Yanukovych-says-West-hasnothing-to-fear-from-Ukraine.html. Accessed 07 July 2016.

${ }^{919}$ Tolksdorf, Dominik. 2010. "The Constitutional Process in Ukraine." United States Institute for Peace, Peace Brief, 22 May 2014. https://www.usip.org/publications/2014/05/constitutional-process-ukraine. Accessed 07 July 2016.
} 
Yanukovych's Russian orientation. For example, political leaders from the 'Our Ukraine' party strongly opposed Yanukovych's renunciation of Ukraine's goal to join NATO and the introduction of a bill formalizing this proposal. According to one official from the 'Our Ukraine' party, "those who are campaigning against NATO are allies of terrorists, pirates and illegal regimes that possess weapons of mass destruction and engage in nuclear blackmail against those who NATO is acting." $" 920$

Despite these political challenges to his alignment strategy, President Yanukovych was able to check this opposition by aligning his Party of Regions with the Communist Party and the Lytvyn Bloc. Through the use of divide-and-rule tactics, Yanukovych kept the opposition at odds with one another, thereby curtailing the effectiveness of their actions to counter his foreign policies. Additionally, President Yanukovych used political threats and bribery to either remove oppositionists or change their minds about aligning the state with Russia. For example, following his election Yanukovych's administration initiated a series of criminal investigations resulting in the incarceration of the president's major political rivals. Political figures incarcerated for abusing government funds and misusing their authority included former interior minister Yuriy Lutsenko and former Prime Minister Yulia Tymoshenko. ${ }^{921}$

Taken together, these actions allowed Yanukovych to more easily translate his ideas about an alignment with Russia into action up until 2013. After his decision to take the Kremlin's economic aid package in lieu of an economic association with the EU, political oppositionists in the Rada were able to unify and block Yanukovych's alignment with Russia. The strength of

\footnotetext{
920 "Our Ukraine Accuses Yanukovych of Complicity with Terrorists for Rejecting NATO Integration.” 2010. Kyiv Post, 02 June 2010. https://www.kyivpost.com/article/content/ukraine-politics/our-ukraine-accuses-yanukovych-ofcomplicity-with-68428.html. Accessed 03 June 2017.

${ }^{921}$ Polityuk, Pavel. 2012. "Ally of Ukraine's Tymoshenko Jailed for 4 years." Reuters, 27 February 2012. https://in.reuters.com/article/ukraine-lutsenko/ally-of-ukraines-tymoshenko-jailed-for-4-years-idINDEE81Q0JO2 0120227. Accessed 03 June 2017.
} 
their unity was bolstered with the backing of popular support from Ukrainians across the western and central parts of the country. Clearly, domestic political opposition and issue polarization was an important factor in bringing about Yanukovych's removal from power; however, it was not decisive. In the proceeding paragraphs, I detail the significant events associated with Yanukovych's positive bandwagoning with Russia up until his fall from power.

Yanukovych's tendency to align with Russia over the United States and its allies in Western Europe was most visible in his leadership actions on military, economic, and socio-political issues. One of his first actions to align with Russia occurred in April 2010 when Yanukovych signed an agreement to extend Moscow's lease for the Russian Navy's Black Sea Fleet in Sevastopol until 2042. In exchange for Yanukovych's commitment to foster a stronger alignment with Russia, President Medvedev announced Moscow would lower the price of Russian natural gas to Ukraine by 30 percent bringing the cost down to approximately $\$ 230$ per 1,000 cubic meters. ${ }^{922}$ This act alone indicated that when given a choice between aligning with Russia or any other regional great power or collective (e.g. the EU), Yanukovych preferred to place Ukraine in Russia’s orbit.

In another sign of Ukraine's military alignment with Moscow, Yanukovych authorized the country's armed forces to partake in the Russian-led 'Union Shield' exercises albeit at a lowlevel of participation. ${ }^{923}$ Interestingly however, in concert with these actions, Yanukovych still allowed U.S. military forces to exercise in Ukraine; however, this was done under a new law that prevented Kiev from joining NATO. Introduced by President Yanukovych as a bill in April 2010, by July parliament had made it a law that Ukraine would be henceforth defined as a

\footnotetext{
${ }^{922}$ Harding, Luke. 2010a. "Ukraine Extends Lease for Russia's Black Sea Fleet.” The Guardian, 21 April 2010. https://www.theguardian.com/world/2010/apr/21/ukraine-black-sea-fleet-russia. Accessed 12 January 2017. ${ }^{923}$ McDermott, Roger. 2011. "Russia and Belarus Prepare Union Shield 2011.” Eurasia Daily Monitor 8 (167). https://jamestown.org/program/russia-and-belarus-prepare-union-shield-2011/. Accessed 12 January 2017.
} 
militarily non-aligned country. ${ }^{924}$ In essence, this law helped Yanukovych squelch issue polarization brought on by political elites, who advocated for Ukraine's accession into the U.S.led NATO alliance.

A series of socio-political events also demonstrated how President Yanukovych was able to translate his verbal pronouncements about an alignment with Russia into action. In this area, Yanukovych was quick to articulate conciliatory words about Russia and the country's importance for all Ukrainians. For example, in April 2010 during a speech in front of the OSCE's parliamentary assembly, Yanukovych brought the government's position about Stalin's artificial famine on Soviet Ukraine in line with Moscow's view that such actions should not be categorized as genocide. According to Yanukovych, "recognizing the Holodomor as an act of genocide, we think, will be incorrect, and unjust. It was a tragedy, a common tragedy of the states that made up the united Soviet Union."925 Yanukovych's remarks stand in marked contrast to former President Yushchenko's position on this topic, which was designed to signal international audiences of his desire to align the state with Russia.

In the field of economics, Viktor Yanukovych was able to foster an alignment with Russia by quickly concluding a series of new security and economic agreements with Moscow. For example, in May 2010 during a visit by Russian President Dimitry Medvedev to Ukraine, Yanukovych signed agreements on intelligence sharing, border demarcation, as well as interbank and science and technical cooperation. ${ }^{926}$ Beyond these agreements, Yanukovych's meeting

\footnotetext{
924 Ukraine's Parliament Votes to Abandon NATO Ambitions. BBC News Online, 03 June 2010. http://www. bbc.com/news/10229626. Accessed 12 January 2017.

${ }^{925}$ Kupfer, Matthew and Thomas De Waal. 2014. "Crying Genocide: Use and Abuse of Political Rhetoric in Russia and Ukraine.” Carnegie Endowment for International Peace, 28 July 2014. Accessed 14 January 2017.

${ }^{926}$ Dyomkin, Denis and Yuri Kulikov. 2010. "Russia's Medvedev Cozies up to Ukraine with Visit." Reuters, 17 May 2010. https://www.reuters.com/article/us-russia-ukraine/russias-medvedev-cozies-up-to-ukraine-with-visitidUSTRE64G4TT20100517. Accessed 14 January 2017.
} 
with Medvedev also helped frame his alignment with Russia, given this was the seventh time both presidents had met in approximately three months. ${ }^{927}$

Perhaps the most prevalent indicator of Yanukovych's positive bandwagoning with the Russian Federation occurred in late 2013 when the Ukrainian president opted to take a Russian economic assistance package in lieu of continuing the state's efforts to integrate into the EU. Specifically, Yanukovych accepted the Kremlin's offer of a \$15 billion bailout for Ukraine’s debt and a significant cut in the price Kiev would pay for Russian natural gas from $\$ 400$ to $\$ 268$ per 1,000 cubic meters. ${ }^{928}$ For Yanukovych, his decision to align with Russia by accepting Moscow's financial package was driven by his ideas that pursuing an accommodative foreign policy relationship with Russia would return him and the state maximum benefits. Additionally, eschewing the EU partnership agreement would mean Yanukovych was free to continue his semi-authoritarian methods of governance as a way to stay in power. Finally, by aligning with Kremlin elites, who tended to use similar semi-authoritarian methods of governance, Yanukovych could quickly acquire the necessary economic and political backing to bolster Ukraine's struggling economy and his ability to stay in power.

Viktor Yanukovych's decision to accept Moscow's economic package became his Waterloo. Following the announcement of his decision to not sign the EU agreement in November 2013, issue polarization in the ruling government skyrocketed as Ukrainians took to the streets in a series of large-scale and frequently violent demonstrations against Yanukovych's actions. Yanukovych's attempts to control the situation using force did little to temper the volatile

\footnotetext{
${ }^{927}$ Matuszak, Slawomir. 2010. "Medvedev in Kyiv - No Breakthrough in Economic Negotiations. Centre for Eastern Studies, 19 May 2010. https://www.osw.waw.pl/en/publikacje/analyses/2010-05-19/medvedev-kyiv-nobreakthrough-economic-negotiations. Accessed 12 January 2017.

${ }_{928}$ Korsunskaya, Darya and Timothy Heritage. 2013. "Russian Bailout Wins Ukraine Economic Respite but Deepens Political Rift.” Reuters, 17 December 2013. http://www.reuters.com/article/us-ukraine/russian-bailoutwins-ukraine-economic-respite-but-deepens-political-rift-idUSBRE9BF11U20131217. Accessed 12 January 2017.
} 
situation as protests escalated through the end of January. By February 2014 parliament finally voted 380-0 to remove Yanukovych from office. ${ }^{929}$ The legislature then appointed interim ministers and political leaders in the run-up to presidential and parliamentary elections, which would witness a volte-face of the state's alignment trajectory.

Petro Poroshenko. From 2014 to 2015 Petro Poroshenko exhibited an accommodative foreign policy orientation with the United States. This same accommodative orientation also conveyed to major European powers such as France, Great Britain, and the United Kingdom. With the Russian Federation, Poroshenko clearly exhibited a confrontational orientation owing to Moscow's annexation of Crimea and the Kremlin's ongoing support for separatist in Donetsk and Luhansk. ${ }^{930}$ His accommodative orientation with Washington and a confrontational one toward Moscow would become a basis for his positive bandwagoning alignment with the United States.

For the two years under examination, domestic politics was an important factor, but not necessarily the most critical element in Poroshenko's alignment with the United States. Two points support this assertion. First, in the days prior to Yanukovych's removal from office, parliament voted to restore the 2004 constitution as part of an agreement to reestablish political and social order in the government and throughout country. Although rejected by Yanukovych during his final days in office, President Poroshenko's alignment actions were framed by the 2004 constitution. ${ }^{931}$ Under Article 106, the president retained a significant amount of power. In

\footnotetext{
${ }^{929}$ Booth, William. 2014. "Ukraine's Parliament Votes to Oust President." Washington Post Online, 22 February 2014. https://www.washingtonpost.com/world/europe/ukraines-yanukovych-missing-as-protesters-take-control-ofpresidential-residence-in-kiev/2014/02/22/802f7c6c-9bd2-11e3-ad71-e03637a299c0_story.html?utm_term=. b509dfb3294b. Accessed 22 January 2017.

${ }^{930}$ Interview on file with author.

931 "Press Release of the Permanent Mission of Ukraine to the UN on Latest Events in the State." 2014. Ministry of Foreign Affairs Ukraine, 24 February 2014. http://mfa.gov.ua/en/news-feeds/foreign-offices-news/18355povidomlennya-dlya-presi-postijnogo-predstavnictva-ukrajini-pri-oon-u-zvjazku-z-ostannimi-podijami-u-derzhavianglijsykoju-movoju. Accessed 22 January 2017.
} 
his duties as a foreign policy executive, Poroshenko was the commander-in-chief, who had the authority to appoint the ministers of defense and foreign affairs. The president was also the state's lead agent in international relations responsible for negotiations, concluding treaties, and administering the foreign political activity of Ukraine. The Rada was the lead organization responsible for developing the principles of foreign policy as stipulated in Article 85. ${ }^{932}$

President Poroshenko's ability to transform his words into action were enabled by lower levels of issue polarization on the country's alignment with the United States and Western Europe. A contributing factor to these low levels of issue polarization over the state's alignment was derived, in part, from the outcome of the October 2014 parliamentary election. Here, many of the political parties acquiring seats in the Rada were already predisposed towards an alignment with the United States and Western Europe. This allowed President Poroshenko to more easily establish a coalition government consisting of the Poroshenko Block (133 seats), the People's Front (81 seats), the Fatherland Party (19 seats), the Self Reliance Party (33 seats), and the Radical Party (22 seats). The extent to which Poroshenko's ideas were in synch with the parliamentary coalition were reflected in Arseniy Yatsenyuk's (leader of the People's Front) comments prior to his appointment as prime minister. Speaking to U.S. Vice-President Joe Biden, Yatsenyuk stated,

Mr. Vice President, between our two countries there is an agreement about strategic partnership. And this agreement is not only on the paper. This agreement is in action. The goal of this agreement is the development of free democratic and stable Ukrainian society and government. The goal of this agreement and objective of it is our joint work and cooperation in providing stability and peace on the continent. The goal of this agreement is to support the strategic relations between the United States and Ukraine..$^{933}$

\footnotetext{
${ }^{932}$ Constitution of Ukraine. 2014. European Commission for Democracy Through Law (Venice Commission), 19; 26-27.

${ }^{933}$ Yatsenyuk, Arseniy. 2014. "Remarks to the Press by Vice President Joe Biden and Ukrainian Prime Minister Arseniy Yatsenyuk." The White House of President Barrack Obama, 22 April 2014. https://obamawhitehouse. archives.gov/ the-press-office/2014/04/22/remarks-press-vice-president-joe-biden-and-ukrainian-prime-ministerarse. Accessed 13 May 2017.
} 
After becoming prime minister, Yatsenyuk's ideas about a Western alignment were made visible in his appointment of a former U.S. State Department officer as Ukraine's finance minister and former Georgian President Mikheil Saakashvili as the Governor of Odessa. These moves were meant to signal to international and domestic audiences of the new government's intent of aligning Ukraine with the United States and Western Europe. Finally, the communist party failed to acquire any seats in parliament, while representatives from Party of Regions formed an 'Opposition Bloc' receiving only 29 seats.

Poroshenko's strategic alignment with the United States was made visible in his level of material cooperation with Washington across three lines of operation: political, military, and economic. The first indicator affirming Poroshenko's foreign policy orientation with the United States was seen in the political sphere and his proclivity to view the country's security based on the actions of Washington. According to Poroshenko, "if we have the support of the United States and other countries to protect Ukraine in case of a Russian invasion, then Russia will not dare to cross this line." ${ }^{934}$ To achieve this long-term goal, President Poroshenko introduced a legislative amendment in 2014 to overturn the law designating Ukraine a neutral country. Parliament overwhelmingly passed Poroshenko's proposal with 303 'yes' votes thereby paving the way for the country's future accession into Euro-Atlantic economic and security structures. ${ }^{935}$ Relatedly, Poroshenko also fostered a political alignment with the United States with the number of diplomatic visits to America. For the two years under examination, Poroshenko and leading

\footnotetext{
934 Poroshenko, Petro. 2014d. "Ukraine: Presidential Hopeful Poroshenko Warns of Terrorist Rebels, Stresses Importance of Election.” Bild, 28 April 2014.

935 Ukraine Votes to Abandon Neutrality, Set Sights on NATO. 2014. Radio Free Europe / Radio Liberty, 23 December 2014. https://www.rferl.org/a/ukraine-parliament-abandons-neutrality/26758725.html. Accessed 21 April 2017.
} 
political figures from Ukraine made 233 visits to the United States as compared to 122 to the Russian Federation. ${ }^{936}$

President Poroshenko also introduced several new military initiatives as part of his positive bandwagoning alignment with the United States. First, in March 2014 Poroshenko made a direct request for U.S. military assistance, which resulted in a decision by Washington to allocate over $\$ 50$ million in non-lethal aid to Ukraine. ${ }^{937}$ Second, in June 2014 Poroshenko welcomed a team of U.S. military and defense advisors to Ukraine for an in-depth assessment of the status of the country's armed forces and the material requirements of each branch of service. ${ }^{938}$ The expansion of Ukraine's military exercise regimen with the United States outside NATO channels was a second key indicator of Poroshenko's alignment with Washington. Beginning in 2015, Poroshenko approved “Operation Fearless Guardian,” a bilateral peacekeeping command post exercise with U.S. military forces in Lviv. According to Poroshenko,

It is completely natural that strategic partnership between Ukraine and United States acquires new meanings and quantitative parameters. It is shown at various levels - from Presidents to soldiers. It is the first Ukrainian-American event of such level, which indicates the transition of bilateral military cooperation to a new practical dimension. ${ }^{939}$

Beyond political and military affairs, Poroshenko sought out an economic alignment with the United States; however, for this line of operation, such an effort took a backseat to his efforts to establish strong economic relations with the EU. The central importance of Poroshenko's

\footnotetext{
936 Author's analysis.

937 Payne, Sebastian. 2014. "Ukraine to get \$53 million in 'non-lethal' Aid from the United States.” Washington Post, 18 September 2014. https://www.washingtonpost.com/politics/ukraine-to-get-53-million-in-non-lethal-aidfrom-the-united-states/2014/09/18/c2c19c28-3f4b-11e4-b0ea 8141703bbf6f_story.html?utm_term=. $87512 \mathrm{f} 68 \mathrm{f} 655$. Accessed 17 January 2017.

938 Vinch, Chuck. 2014. "U.S. Sending Advisors, Gear to Ukraine.” Military Times, 05 June 2014. https://www. usatoday.com/story/news/nation/2014/06/05/us-sending-advisers-gear-to-ukraine-/10046845/. Accessed 14 January 2017.

939 Poroshenko, Petro. 2015. "President Launched Ukrainian-American Military Training "Fearless Guardian 2015." Ministry of Defense of Ukraine, 20 April 2015. http://www.mil.gov.ua/en/news/2015/04/20/presidentlaunched-ukrainian-american-military-training-fearless-guardian---2015"-a-new-face-of-ukrainian-army-is-beingformed-here-today/. Accessed 17 January 2017.
} 
economic alignment with the EU was almost immediately demonstrated when he signed an EU

Association Agreement in June 2014. This agreement was perhaps the single most important economic event for Ukraine since its independence. According to one area expert,

The association agreement can be a game-changer for Ukraine. It includes a deep and comprehensive free trade arrangement (DCFTA) that will open much of the European market to Ukrainian exports. Implementation of the agreement will not only bring Ukraine's trade and customs rules into conformity with EU standards, it will help the country draw closer to EU democratic norms and "Europeanize" other Ukrainian regulatory regimes. ${ }^{940}$

So, what is the significance here? In marked contrast to Viktor Yanukovych, Poroshenko firmly believed the EU Agreement represented a key political and economic enabler to move the country out of Russia's geopolitical orbit and into the West where leading countries such as Germany, Great Britain, and the United States could serve as a bastion of support.

Although the preceding examples help demonstrate Poroshenko's inclination to positively bandwagon with the United States, one cannot discount Washington's enabling actions during this time. With Moscow's brazen actions in Crimea and the Donbass, the Obama administration's attempted 'reset' with Russia was officially squelched. For Washington, Russia's military aggression in Georgia in 2008 and Ukraine in 2014 represented a threat to regional stability in Europe that if left unchecked could encourage future hostile actions from Moscow. To counter the Kremlin's moves, economic sanctions and the building-up of Ukraine's military capabilities and economic capacity became an important interest for the United States. To realize its goals in the region, from 2013 to 2015 the United States committed over $\$ 867$ million in foreign assistance to Ukraine. This financial backing helped Poroshenko and his ruling government promote democratic reforms, foster economic growth, and bolster civil society. ${ }^{941}$

\footnotetext{
940 Pifer, Steven. 2014. "Poroshenko Signs EU-Ukraine Association Agreement.” The Brookings Institution, 27 June 2014. https://www.brookings.edu/blog/up-front/2014/06/27/poroshenko-signs-eu-ukraine-association-agreement/. Accessed 21 January 2017.

941 Author's analysis. See Foreign Aid Explorer. Economic Analysis Data Services. United States Agency for International Development. https://explorer.usaid.gov. Accessed 02 February 2017.
} 
Although U.S. political leaders may have taken an increased interest in supporting Kiev, ultimately it was Poroshenko, who decided the manner in which this support would be employed in Ukraine.

In concert with Poroshenko's accommodative foreign policy orientation with the United States, the Ukrainian president assumed a more confrontational approach with Russia. For example, in 2014 Poroshenko prohibited Ukrainian defense companies from cooperating with Russia, despite the negative impact such a decision would have on the country's economy. According to one estimate, Poroshenko's decision reduced Ukrainian-produced military exports to Russia by as much as 70 percent equating to over $\$ 15$ billion across all contracts. ${ }^{942}$ In light of this and other similar events, Poroshenko continued to engage in routine state-level activities with Moscow, which almost exclusively focused on finding a peaceful resolution to the conflict in the Donbass. For example, in late 2014 and early 2015 President Poroshenko, with backing from France and Germany, signed two ceasefires (Minsk I and Minsk II) leading to a cessation of hostilities that would ultimately create a frozen conflict in the east.

The preceding analysis on the relationship between Ukrainian presidential foreign policy orientations and the state's alignment trajectory as conditioned by domestic politics yields several conclusions. First, Ukrainian presidents believed a strategy grounded in cooperation with external states was the optimal approach to achieve their respective foreign policy goals. Second, all four presidents displayed the full range of foreign policy orientations. Here, Presidents Yushchenko and Poroshenko exhibited an accommodative foreign policy orientation with the United States, which was correlated with a positive bandwagoning alignment with Washington.

\footnotetext{
${ }^{942}$ Weir, Fred. 2014. "Why Ukraine's Freeze on Arms Sales to Russia will Hurt Kiev." The Christian Science Monitor, 17 June 2014. https://www.csmonitor.com/World/Europe/2014/0617/Why-Ukraine-s-freeze-on-armssales-to-Russia-will-hurt-Kiev-too. Accessed 20 January 2017
} 
President Yanukovych exhibited an accommodative foreign policy orientation with Russia, which was associated with his positive bandwagoning alignment with Moscow. Meanwhile Leonid Kuchma's pragmatism was followed by his effort to implement a great power bridging strategy. Finally, the relevance of domestic politics was mixed. Although each president operated under different levels of government fragmentation and issue polarization, they were still able to bring to fruition some of their ideas about great power bridging or positive bandwagoning with the United States and/or Russia.

\section{Conclusion}

This chapter examined the relationship between a president's instrumental beliefs and the state's alignment trajectories with the United States and Russia from 1995-2015. The output from Profiler Plus reveals all 12 presidents believed a cooperative strategy was the best approach to realize their foreign policy goals. While this finding orients us to each president's ideas about strategy, they do not necessarily tell how those beliefs may have applied to specific state actors. Through a qualitative analysis, a majority of presidents under examination exhibited a pragmatic foreign policy orientation and a great power bridging alignment. This was the case with Heydar Aliyev, Ilham Aliyev, Eduard Shevardnadze, Giorgi Margvelashvili (2013), Petru Lucinschi, Vladimir Voronin (after 2003), and Leonid Kuchma.

Presidents who had an accommodative orientation with the United States routinely followed a positive bandwagoning alignment with this regional great power. Mikheil Saakashvili, Giorgi Margvelashvili (after 2013), Nicolae Timofti, Viktor Yushchenko, and Petro Poroshenko fell into this category. In concert with this accommodative orientation, these presidents also exhibited a confrontational orientation towards Moscow, less President Timofti, who attempted to not poke the 'bear' in the eye by explaining his country's aspirations to join the EU did not represent a 
threat to Russia. Vladimir Voronin (before 2003) and Viktor Yanukovych had an accommodative foreign policy orientation vis-à-vis Moscow, which was associated with a positive bandwagoning alignment this regional great power.

The role of domestic politics and its conditioning of a president's ability to translate his alignment preferences into policy action was an important factor, but not necessarily a decisive one. Of the seven presidents with a pragmatic orientation, all of them were able to see to fruition some of their ideas about great power bridging under different combinations of government fragmentation and issue polarization. Presidents who followed a positive bandwagoning alignment with either the United States or Russia were also able to bring to affect material actions in line with their alignment preferences despite differing levels of government fragmentation and issue polarization.

With only a few exceptions_-Vladimir Voronin after the Kozak Memorandum and Viktor Yanukovych after the 2013 Russian economic deal— this study concludes domestic politics was an important factor, but not necessarily a decisive one with respect to the ability of a president to realize his alignment preferences. Several key points support this conclusion. First, even though a head of state may face moderate or high levels of government fragmentation and/or issue polarization, one cannot discount a president's strategic leadership skills and his/her ability to build a supporting coalition across the state's bureaucratic organizations. For example, Leonid Kuchma, Petru Lucinschi, and Eduard Shevardnadze had the necessary political acumen and consensus building skills to minimize the impacts from government fragmentation and issue polarization over their alignment preferences. The appointment of key political figures in key government positions also minimized the impact from domestic politics. 
Second, in some cases, domestic politics became an enabler of the president's alignment agenda. In Georgia and Ukraine, parliamentary elections brought to power like-minded political figures, who supported Mikheil Saakashvili and Petro Poroshenko's positive bandwagoning with the United States. Third, in some instances presidents used coercive measures, bribery, or their executive powers to overcome domestic political opposition on their alignment preferences. This was especially true in Azerbaijan where one cannot discount the semi-authoritarian nature of the ruling government and the ability of Heydar and Ilham Aliyev to use the state's security services to minimize political fragmentation and issue polarization.

There were two instances where issue polarization took on a higher level of importance. First in Moldova after Moscow attempted to force President Voronin to sign the Kozak Memorandum, MPs in parliament united against any political settlement that yielded too much power to Tiraspol and undermined the government's attempts to reestablish territorial sovereignty. Second, in Ukraine issue polarization over Viktor Yanukovych's positive bandwagoning with Russia spiked after the Ukrainian president decided not to sign the EU Association Agreement opting to take an economic assistance package from the Kremlin. Beyond domestic political opposition, the ensuing civil backlash and the "Maidan" revolution contributed to Yanukovych's removal from power. To recap, domestic politics is certainly an important factor in the state's foreign policy processes; however, this consideration remains secondary to a president's ideas about the state's alignment and his ability to generate favorable foreign policy outcomes in line with those ideas. 


\section{Chapter Eight: Conclusion}

\section{The Puzzle}

The empirical puzzle driving this research endeavor centered on explaining why former Soviet states have pursued different strategic alignments with the Russian Federation since the end of the Cold War. In some instances, ruling governments in Armenia, Belarus, Kazakhstan, Kyrgyzstan, and Tajikistan have formalized their alignment with Moscow by becoming an alliance member in the Russian-led CSTO or the EEU. Meanwhile, other countries such as Estonia, Latvia, and Lithuania have formalized their alignment with the West becoming a member of the U.S.-led NATO alliance or the EU. With the post-Soviet space becoming an arena of strategic competition between Russia and the West, discerning the key factors affecting the alignment trajectories of countries along Russia’s geographical periphery can add to our cumulative knowledge on this political phenomenon and improve U.S. foreign policy.

A survey of the IR literature revealed that the dominant alignment theories, to date, have not been able to consistently explain small state alignment with many scholars focusing their analyses on the great powers or incorrectly categorizing alignment and alliance as one in the same. On one hand, balance of power theories, which posit secondary states should align with weaker powers fall short given how the Baltics have entered into an alliance with the most powerful country in the world, the United States. In line with William Wohlforth and his conclusions on post-Soviet alignment, this study also finds balance of power theory, “...is of little utility in explaining much of the variation in local responses to Russia."943 Separately, Stephen Walt's balance of threat theory also fails to hold water in the post-Soviet space. For example, in

\footnotetext{
943 Wohlforth, William C. 2004. "Revisiting Balance of Power Theory in Central Eurasia.” In T.V. Paul, James J. Wirtz, and Michel Fortmann (eds.) Balance of Power: Theory and Practice in the 21st Century. Stanford: Stanford University Press, 232.
} 
Georgia, political elites consistently regarded Russia as the most threatening regional great power; however, rather than kowtowing to Moscow, ruling governments have sought out alignments with the United States, despite being denied accession into NATO. At issue is Walt's overemphasis on material factors and his under specified concept of 'aggressive intentions' that prevented a more robust explanation of small state alignment.

Looking beyond Walt's balance of threat theory, this study took a leader-centric approach as a new way to conceptualize small state alignment in the post-Soviet space. In marked contrast to those who have attempted to categorize a political leader's alignment tendencies as pro-West or pro-Russian, this study conceptualizes the dependent variable (alignment) in two ways: positive bandwagoning and great power bridging. Positive bandwagoning occurs when lead actors in the state's foreign policy executive prefer and are able to implement foreign policies that produce higher levels of political/diplomatic, economic, and/or military cooperation with one regional great power over another. Alternatively, great power bridging occurs when political leader preferences and foreign policy actions are, on average, equal with two or more regional great powers.

The independent variables for this study took their cue from Margaret Hermann and her colleagues in a study, which finds "who leads matters." With these words in mind, this study posited the ideas and beliefs of political leaders, more so than the balance of power or threat, are the key factors shaping a ruling government's alignment with different regional great powers. Using aspects of social identity theory and self-categorization theory, it was argued political elite ideas about the state's identity and external state-based threats, as well as his/her accompanying foreign policy orientation, as conditioned by domestic politics, are the primary variables 
independently shaping Azerbaijan, Georgia, Moldova and Ukraine's alignment trajectory from 1995-2015.

\section{Major Empirical Findings}

In Chapters Five, Six, and Seven, multiple methods were used to examine the relationship between a president's ideas about the state's identity, threat perceptions, and foreign policy orientation as conditioned by domestic politics. The concept of domestic politics was operationalized in terms of government fragmentation and issue polarization. This research endeavor revealed a series of overarching conclusions and specific findings.

This study identified two overarching conclusions. First, a president's ideas about state identity, his threat perceptions, and foreign policy orientation, as conditioned by domestic politics, more so than the balance of power or threat, played an important role in shaping his alignment preferences and foreign policy actions with the United States and Russia in the postCold War era. This is not to say systemic and other domestic-level factors were unimportant. On the contrary, conditions in the systemic and domestic environment were relevant to the extent that they shaped a political leader's ideas and belief systems and ultimately their strategic choices. Following Suny, this dissertation found that...

[Small] states act on the basis of their perceived interests, but conceptions of the kind of state (e.g. empire, nation-state) its historical purposes, and its operative belief systems, as well as the discursive universe in which it operates, are all fundamental to construction of those interest. ${ }^{944}$

Second, a majority of presidents in Azerbaijan, Georgia, Moldova, and Ukraine preferred great power bridging. Presidents pursing this alignment included Heydar Aliyev, Ilham Aliyev, Eduard Shevardnadze, Giorgi Margvelashvili (2013), Petru Lucinschi, Vladimir Voronin (after

\footnotetext{
${ }^{944}$ Suny, Ronald Grigor. 2007. "Living in the Hood: Russia, Empire, and Old and New Neighbors." In Robert Legvold (ed.) Russian Foreign Policy in the 21st Century \& the Shadow of the Past. New York: Colombia University Press, 35.
} 
2003), and Leonid Kuchma. The second most preferred alignment was positive bandwagoning with the United States. Mikheil Saakashvili, Giorgi Margvelashvili (2014-2015), Nicolae Timofti, Viktor Yushchenko, and Petro Poroshenko fell into this category. The least preferred alignment option was positive bandwagoning with Russia. Only Viktor Yanukovych and Vladimir Voronin (2001-2003) followed this alignment course.

There was also little variation in each president's alignment trajectory with the exception of two presidents. First, Vladimir Voronin initially pursued a positive bandwagoning alignment with Russia from 2001-2003, but then transitioned to great power bridging following the Kozak Memorandum debacle. Second, Giorgi Margvelashvili initially followed a great power bridging alignment as a way to reestablish the country's territorial integrity during his first year in office. By 2014, Russian obstinacy on this issue reinforced his ideas about the merits of a positive bandwagoning with the United States, even if accession to NATO was not in the cards.

This dissertation also identified several key findings based on an investigation into the relationship between each of the independent variables and the dependent variable. In Chapter Five, this study uncovered three key findings in an examination of the relationship between a president's ideas about the state's identity and his alignment preferences. First, each of the 12 presidents from Azerbaijan, Georgia, Moldova, and Ukraine displayed a unique array of different political, cultural, ideological, and economic conceptions of their state's identity. Second, the verbal discourse of six of the 12 presidents indicated they primary viewed the state as independent, which was subsequently associated with a preference for great power bridging. These presidents included Azeri Presidents Heydar and Ilham Aliyev, Georgian President Eduard Shevardnadze, Moldovan Presidents Petru Lucinschi and Vladimir Voronin (after 2003), and Ukrainian President Leonid Kuchma. Third, Georgia’s Mikheil Saakashvili and Giorgi 
Margvelashvili, Moldova's Nicolae Timofti and Ukraine's Viktor Yushchenko and Petro Poroshenko primarily conceptualized the state as European-Western, free, and democratic. These narratives were associated with a preference for positive bandwagoning with the United States. Only two instances of positive bandwagoning alignment with Russia was uncovered. The first was in Moldova under Vladimir Voronin from 2001-2002. During this time the Moldovan president primarily viewed the state as Eastern and Eurasian. Second, in Ukraine Viktor Yanukovych viewed the state as European, Eastern, and Eurasian.

In Chapter Six, this study conducted a multi-stage examination on the relationship between a president's threat perceptions and his accompanying alignment preferences with the United States and Russia. The first step in this investigation involved a by-country operational code analysis of Azeri, Georgian, Moldovan, and Ukrainian presidents. Unlike other studies that simply use qualitative techniques to assess a political leader's belief system, Profiler Plus-a computerized content analysis software program-allowed for an unbiased assessment of each president's operational code. This step established a by-country baseline of how each political leader viewed world politics, political conflict, and the nature of the international system. These findings then served as a point of reference a qualitative analysis of each president's threat perceptions and their alignment preferences with the United States and/or Russia.

This multi-stage analysis produced several important findings. First, based on a quantitative analysis of each president's master philosophical beliefs (P-1), all 12 presidents viewed the political universe in friendly terms. In Azerbaijan, Heydar and Ilham Aliyev viewed the political universe as definitely friendly. In Georgia, Presidents Shevardnadze and Margvelashvili viewed the international system as definitely friendly, while Mikheil Saakashvili regarded world politics as somewhat friendly. In Moldova, Presidents Lucinschi and Timofti believed the nature of the 
international system was definitely friendly; however, Vladimir Voronin retained a somewhat friendly view of the political universe. Finally, in Ukraine, Leonid Kuchma and Viktor Yushchenko viewed the political universe as somewhat friendly, while Viktor Yanukovych regarded the international system as definitely friendly. President Poroshenko's operational code score indicated the Ukrainian president had mixed beliefs viewing world politics as the least friendly as compared to his predecessors.

Second, all of the presidents from Azerbaijan, Georgia, Moldova, and Ukraine viewed Russia as the primary external threat; however, each political leader maintained differing perceptions about the nature (political/diplomatic, economic, and/or military) and intensity of the Russian threat. With respect to intensity, eight of the twelve presidents (Heydar and Ilham Aliyev, Petru Lucinschi, Vladimir Voronin (after 2003), Eduard Shevardnadze, Giorgi Margvelashvili, and Leonid Kuchma) perceived Russia as a moderate threat, believing some form of military or economic conflict was somewhat likely. Four presidents, Georgian President Mikheil Saakashvili, Moldovan President Nicolae Timofti, and Ukrainian Presidents Viktor Yushchenko and Petro Poroshenko perceived Russia as a high threat, believing some form of military and/or economic conflict was very likely during his time in office. Moldovan President Vladimir Voronin (before 2003) and Ukraine's Viktor Yanukovych were the only presidents to view Russia as a low threat, believing some form of military or economic conflict was very unlikely. All presidents viewed the United States as a low threat.

Third, using the ICEWS output from Chapter Five, a qualitative analysis of each president's verbal pronouncements identified three different relationships. Those presidents with a moderate threat perception of Russia tended to prefer a great power bridging alignment. Next, those presidents with a high threat perception of Russia gravitated toward a positive bandwagoning 
preference with the United States. Finally, when a president had a low threat perception of Russia, he preferred a positive bandwagoning alignment with Moscow.

Fourth, there was minimal variation in president's threat perceptions and his accompanying alignment preferences less two instances. In Moldova, President Vladimir Voronin initially viewed the threat from Russia as low, which was associated with a preference for a positive bandwagoning alignment with Moscow. Voronin's threat perceptions of Russia increased from low to moderate following an attempt by the Kremlin to force the Moldovan president to sign the Kozak Memorandum. Afterwards, Voronin preferred great power bridging with both the United States and Russia. Separately, Giorgi Margvelashvili initially perceived Russia as a moderately high threat believing a tenuous political and economic alignment with Moscow could restore Georgia's territorial integrity. When Moscow refused to compromise on South Ossetia and Abkhazia, Margvelashvili's threat perceptions of Russia spiked moving him from a preference for great power bridging to positive bandwagoning with the United States.

The fifth finding from this chapter centers on methodology where statistical tests designed to identify similarities and differences in each president's master philosophical beliefs do not necessarily convey to their alignment preferences. For example, ANOVA and Tukey's HSD tests found Leonid Kuchma and Viktor Yushchenko were the most similar in their philosophical beliefs; however, a qualitative analysis revealed the former preferred great power bridging and the latter positive bandwagoning with the United States. In Moldova and Georgia, statistical tests indicated Presidents Lucinschi and Timofti and Presidents Shevardnadze and Margvelashvili exhibited the most similar beliefs, but qualitative analyses revealed Lucinschi and Shevardnadze preferred great power bridging whereas Timofti and Margvelashvili gravitated toward a positive bandwagoning alignment with the United States. These findings serve as a reminder to 
academics and practitioners on how using multiple methods in any research effort can potentially yield a more comprehensive understanding of small state alignment.

In Chapter Seven, multiple methods were again employed as part of a multi-step investigation that examined the relationship between a president's foreign policy orientation and his accompanying alignment tendencies with the United States and Russia. The first step in this effort focused on a by-country operational code analysis of the master instrumental beliefs (I-1) of all 12 presidents. Just like in Chapter 6, an analysis of the output from Profiler Plus established a baseline for each president's beliefs about the optimal ways to realize their foreign policy objectives. From this check, ANOVA and Tukey's HSD tests were applied to assess the similarities and differences between a president's master instrumental beliefs within each country. Next, these findings were then used as an analytical touchstone in a qualitative analysis of each president's foreign policy orientation (accommodative, confrontational, or pragmatic) vis-à-vis the U.S. or Russia and how government fragmentation and issue polarization constrained or enable the state's material cooperation with both regional great powers.

Given the preceding, five key findings were uncovered. First, an analysis of the output from Profiler Plus indicated all 12 presidents believed a cooperative strategy was the best approach to realize their foreign policy goals. Ten of the 12 presidents (Heydar and Ilham Aliyev, Eduard Shevardnadze, Mikheil Saakashvilli, Giorgi Margvelashvili, Petru Lucinschi, Vladimir Voronin, Nicolae Timofti, Leonid Kuchma, and Viktor Yushchenko) 'definitely’ believed a cooperative strategy with other state actors was the best approach to achieve their goals. In Ukraine, Viktor Yanukovych believed a 'very' cooperative strategy was necessary, while Petro Poroshenko believed a somewhat cooperative strategy could achieve his political goals. 
Second, ANOVA and Tukey's HSD tests provided some increased specificity as to which presidents within each country were the most similar in their beliefs about strategy. In Georgia, Presidents Shevardnadze and Margvelashvili had the most similar beliefs while in Moldova there were no statistically significant differences in the instrumental beliefs of Presidents Lucinschi, Voronin, and Timofti. Finally, in Ukraine Viktor Yushchenko and Petro Poroshenko were the most similar in their master instrumental beliefs about strategy and the tactics with other states in the international system. As will be detailed below, just because two presidents are the most similar in their instrumental beliefs, does not mean they will follow the same alignment strategy.

Third, the results of a qualitative analysis revealed a majority of presidents exhibited a pragmatic foreign policy orientation and an associated great power bridging alignment with the United States and Russia. The pragmatic-great power bridging relationship was associated with Heydar Aliyev, Ilham Aliyev, Eduard Shevardnadze, Giorgi Margvelashvili (before 2014), Petru Lucinschi, Vladimir Voronin (after 2003), and Leonid Kuchma. Separately, Georgian Presidents Giorgi Margvelashvili (2014-2015) and Mikheil Saakashvili, Moldovan President Nicolae Timofti, and Ukrainian presidents Viktor Yushchenko and Petro Poroshenko displayed a confrontational orientation with Moscow. At the same time, these presidents exhibited an accommodative orientation with Washington, which was associated with a positive bandwagoning alignment with the United States. Finally, Vladimir Voronin (before 2003) and Viktor Yanukovych demonstrated an accommodative foreign policy orientation with Moscow, which was related to a positive bandwagoning alignment with Russia.

Fourth, an examination of the relevance of domestic politics as a constraint or enabler on the state's alignment returned mixed results. On one hand, pragmatic presidents were able to pursue a great power bridging alignment despite differing levels of government fragmentation and issue 
polarization within each government. For example, in Azerbaijan Heydar and Ilham Aliyev operated under low levels of government fragmentation and issue polarization owing to the semiauthoritarian nature of the government. In Moldova and Ukraine, the political acumen of Vladimir Voronin and Leonid Kuchma helped minimize issue polarization over an alignment with the United States and Russia. Separately, low levels of government fragmentation and issue polarization served as an enabler for Georgian President Saakashvili's positive bandwagoning alignment with the United States. Taken together, this study finds domestic politics is an important factor but not necessarily a decisive one in alignment politics. The preceding finding on domestic politics is in line with a conclusion put forward by Robert Putnam in the late 1980s. To quote Putnam...

Domestic politics and international relations are often somehow entangled, but our theories have not yet sorted out the puzzling tangle. It is fruitless to debate whether domestic politics really determine international relations, or the reverse. The answer to that question is clearly "Both, sometimes." 945

Fifth, the use of multiple methods provided a more holistic understanding of small state alignment. While there is high value in conducting an operational code analysis of each president's instrumental beliefs, the results of the econometric tests identifying which presidents are the most similar in their beliefs about strategy should not be taken at face value when attempting to understand a ruling government's alignment with a regional great power. For example, a Tukey's HSD test indicated there were no statistically significant differences in the belief systems of Moldovan presidents; however, a qualitative analysis indicated Presidents Lucinschi and Voronin followed a great power bridging alignment, while President Timofti opted for a positive bandwagoning alignment with the United States.

\footnotetext{
945 Putnam, Robert D. 1988. "Diplomacy and Domestic Politics: the Logic of Two-level Games." International Organization 42 (3), 427.
} 


\section{State Identity, Threat Perceptions, Foreign Policy Orientation and Alignment}

Chapters Five through Seven independently examined the relationship between the three independent variables (state identity, threat perceptions, and foreign policy orientation as conditioned by domestic politics) and the dependent variable (alignment). Chapter 5 focused on the relationship between a president's ideas about the state's identity and his alignment preferences with the United States and Russia. Chapter 6 concentrated on a president's threat perceptions and his alignment preferences. Chapter 7 then examined the relationships between a political leader's foreign policy orientation and the state's alignment strategy as conditioned by domestic politics. Each of these independent research endeavors produced a set of findings specific to the variables under consideration.

With these findings in mind and recalling the model from Chapter 1 (Figure 1 - Small State Alignment), what has not yet been examined is how potentially the three independent variables may indirectly influence the dependent variable and how each of the explanatory variables may influence one another. Beginning with a president's ideas about the state's identity, a variable sequencing was posited whereby when a president's primary conceptions about the state's identity coincide with a regional great power, it is possible this political leader may be more apt to view this target state as a low threat. Barnett and Suny do well to help us understand the potential relationship between identity and threat perceptions.

Threat is a matter of perceptions... [which] depends on how identities and interests are constructed... "National histories" may be investigated, not so much to discover the "real" story behind the Serb-Albanian conflict in Kosovo or the Armenian-Azerbaijani hostility in Karabakh - as if one side's claims could convincingly outweigh the others - but rather how to assess particular conceptualizations of nationhood contribute to notions of national interest and threats to national security. ${ }^{946}$

Continuing in the variable sequence, it is also plausible that when a president perceives a

${ }^{946}$ Suny 1999/2000, 141; 147. 
regional great power as a low threat, he may then exhibit an accommodative foreign policy orientation and a tendency for positive bandwagoning with the target state. Simultaneously, when a president's ideas about the state's identity are not as similar with a particular regional great power, it is possible he may view this state as more of a threat. As his/her threat perceptions rise, one can expect to see a pragmatic orientation and great power bridging. In some cases, when a president's threat perceptions become high, he may even adopt a confrontational foreign policy orientation with a regional great power. This may then spur a president to prefer a positive bandwagoning alignment with a different regional great power. In the paragraphs below, a comparison of the findings for each independent variable is made to establish a foundation for future research.

From Chapter Five, Georgian Presidents Mikheil Saakashvili and Giorgi Margvelashvili (after 2013), Moldovan President Nicolae Timofti, and Ukrainian Presidents Viktor Yushchenko and Petro Poroshenko primarily conceptualized the state's identity as Western and/or one based on democracy or freedom. The findings from Chapters Six and Seven revealed these presidents also perceived Russia as a high threat—less President Margvelashvili during the first several months in office - and gravitated towards a confrontational foreign policy orientation with Moscow and a more accommodative one with Washington and its European allies. These findings were correlated with a president's tendency to exhibit an accommodative foreign policy orientation with the U.S. and a positive bandwagoning alignment with this regional great power.

Next, the findings from Chapter 5 revealed Azeri presidents Heydar and Ilham Aliyev, Georgian President Eduard Shevardnadze, Moldovan Presidents Petru Lucinschi and Vladimir Voronin (after 2003), and Ukrainian President Leonid Kuchma primarily viewed the state as independent. These presidents also tended to perceive Russia as a moderate threat as outlined in 
Chapter 6. From Chapter 7, these presidents displayed a pragmatic foreign policy orientation, which was associated with a great power bridging strategy. Finally, in Chapter 5 this study found Ukraine's Viktor Yanukovych and Vladimir Voronin (before 2004) primarily viewed the state in Eastern and Eurasian terms with the latter also giving emphasis to communist ideals. As detailed in Chapter 6, both presidents regarded Russia as a low threat, which was correlated with an accommodative foreign policy orientation. While never outright displaying a confrontational orientation with the United States, Voronin during his early years in office and Yanukovych preferred and implemented a positive bandwagoning alignment with Russia.

In summary, although future research is certainly in order, a comparison of the findings from each of the substantive chapters of this dissertation appear to validate the existence of a potential relationship between the independent variables. As expected by SIT/SCT, a shared sense of state identity decreases threat perceptions spurring an accommodative foreign policy orientation leading to positive bandwagoning behavior. However, when state identities diverge, threat perceptions of a particular regional great power increased leading first to a pragmatic orientation and, in some cases, a confrontational one. Pragmatic presidents followed a great power bridging alignment while those with a confrontational orientation towards a target regional power followed a positive bandwagoning alignment with a different regional great power.

\section{Implications for Theory and Methods}

The findings in this dissertation point to several important implications for theorizing about small state alignment and the accompanying methods to examine this political phenomenon. The first theoretical implication is that small state alignment cannot simply be explained by focusing on one independent variable. As was demonstrated in this study, there is no strong empirical evidence to support a conclusion that a president's ideas about the state's identity more so than 
his/her threat perceptions of external states or foreign policy orientation have a strong causal relationship on the state's alignment trajectory. To the extent possible, various statistical methods and qualitative analyses did establish a series of associations between each of the independent variables and the dependent variable. A key takeaway here is that simply focusing on one variable to explain small state alignment is folly because multiple factors can exert varying levels of direct or indirect influence.

A second theoretical implication centers on variable sequencing. In examining the three explanatory variables in this study, one can discern a basic temporal sequence where a president's ideas about the state's identity and threat perceptions precede his/her foreign policy orientation. Specifically, an argument can be made that a president enters into office with a preestablished set of ideas about the state's identity and the major state-based external threats. Once in office, these cognitive factors, while being influenced by changes in the strategic environment, become shape agents for his/her ideas about strategy and how best to move the state forward by aligning with one or more great powers. This conclusion and the preceding one mirror Timothy Colton's research on post-Communist voting in Russia. In his work, Colton finds there are multiple factors directly and indirectly influencing the decision-making process of Russian citizens during an election. Additionally, an individual's background and social characteristics precede his/her assessments of their environment before making a choice. ${ }^{947}$

With respect to methodology, the findings from this study demonstrate the utility of using multiple methods to understand small state alignment in the post-Soviet space and its potential application to other political phenomena. As was previously shown, large-n data sets and econometric analyses can provide us a baseline understanding of a president's ideas about the

${ }^{947}$ Colton 2000, 22-25. 
state's identity and his/her general alignment tendencies or his/her beliefs about the nature of the political universe and optimal strategies. However, qualitative techniques are required to provide a more holistic understanding of these relationships. For example, in Ukraine statistical findings indicated Presidents Leonid Kuchma and Viktor Yushchenko were the most similar in their philosophical beliefs; however, a qualitative analysis revealed they preferred to follow two different alignment strategies.

\section{Implications for U.S. Policy}

The implosion of the Soviet Union over twenty-seven years ago brought an end to a decadeslong rivalry between the United States and Soviet Union. While the early 1990s may have seen a warming of relations between Moscow and Washington, by 1995 a new round of strategic competition was underway with each regional super power vying for influence in the 14 newlyindependent states. For some academics and policy analysts, Russia and the West are now engaged in a new Cold War with NATO and the EU continuing its eastward expansion and Russia responding with military force in Georgia in 2008 and Ukraine in 2014. As argued by the highly renowned political scientist Robert Legvold,

... the new Cold War began the moment we [the West] went over the cliff, and that happened with the Ukraine crisis. I trace this qualitative shift to be a result of what happened in Ukraine, with the Russian annexation of Crimea and Russia's direct support for separatism in the Donbas. Going over the cliff did not happen suddenly though, it happened as a result of a series of steps that cover most of the post-Cold War period. I see it as a phased process, in which no one, including the leadership of Washington, Moscow and Berlin recognized the phases we were in. ${ }^{948}$

With tensions between Washington and Moscow at a new all-time high, the empirical findings from this dissertation could assist U.S. intelligence analysts, strategists, and policymakers in several important ways. First, this study highlights the potential usefulness of employing an

\footnotetext{
${ }^{948}$ Levgold, Robert. 2015. "Robert Legvold on the New Cold War.” The World Post, 24 September 2015. https:// www.huffingtonpost.com/samuel-ramani/robert-legvold-on-the-new_b_8514120.html. Accessed 02 December 2017.
} 
operational code analysis to understand a political leader's belief system. As demonstrated in the preceding chapters, while a president's operational code can by no means predict a foreign leader's actions, this analytical tool can be used as an econometric point of reference from which to focus a more nuanced qualitative assessment about a president's foreign policy tendencies. Second, this dissertation indirectly reinforces the necessity for the U.S. Intelligence Community to conduct an in-depth leadership profile of foreign political leaders in Azerbaijan, Georgia, Moldova and Ukraine, particularly those who may become president or a member of the state's foreign policy executive. Policymakers can then use these leadership profiles to better understand and interact with foreign leaders and develop a viable set of foreign policies to advance U.S. interests in the region.

Third, this research project elucidates the complexity of interstate relations and how even the smallest of states can still have a voice in world politics, particularly when they are of high interest to different regional great powers. From one perspective, it can be argued "small powers can and do initiate policies which evoke all manner of reactions from other nations. Small powers are sought after, and they seek; they may act to enhance peace, or they may promote conflict and chaos. They may be overawed, overpowered, or simply dominated, but they cannot be ignored." ${ }^{\prime 49}$ The takeaway for Washington political elites is that in the $21^{\text {st }}$ Century, political leaders in the borderlands of Russia have an independent voice, which may allow them some degree of strategic maneuverability and influence on the world stage. Furthermore, when one factors in Russia's geographical proximity and historical ties with these countries, discerning the alignment tendencies of Azerbaijan, Georgia, Moldova, and Ukraine becomes a very challenging endeavor. Elizabeth Sherwood-Randall provides egocentric U.S. policymakers with some sage

\footnotetext{
${ }^{949}$ Milsten, Donald. 1969. "Small Powers-A Struggle for Survival.” Journal of Conflict Resolution 13 (3), 388.
} 
advice about the necessity to seriously consider the perspectives of Russia and those in each of the newly-independent states in the formulation of U.S. foreign policies for Southeastern Europe and the South Caucasus. In her words...

To understand the complex relationships between and among the United States, Russia and the new states, it is useful to think of a post-Soviet triangle. The United States, Russia and the group of new states each occupies one of the three points on the conceptual triangle. In this configuration, we cannot and should not think of any one of the three sides of the triangle in isolation from the other two..$^{950}$

Next, this dissertation reminds strategists and policymaker alike of how non-material factors may be equally, if not more important than material considerations in shaping the actions of small states in the international arena. By giving increased emphasis to the ideas and beliefs of the leading actors in the state's foreign policy executive, U.S. policymakers can begin to see how simple balance of power or threat calculations do not necessarily translate into predictable state behavior. For example, despite Russia’s invasion of Georgia in 2008 and Ukraine in 2014 as well as Moscow's continued backing of Armenia, Azeri President Ilham Aliyev remains committed to great power bridging. Despite NATO's refusal to offer Ukraine and Georgia a guaranteed path to membership, Presidents Margvelashvili and Poroshenko continue to follow a positive bandwagoning alignment with the United States. The key point here is that while material factors are important, it is the ideas of the presidents that likely matter more.

Similarly, U.S. intelligence analysts can do well by heeding the call to focus more on ideational factors and their impact on the alignment tendencies of leading political elites. Here, analysts can potentially improve their ability to warn U.S. policymakers of potential changes in the alignment trajectories of countries along Russia’s border. By scrutinizing the foreign policy speeches of rising political figures, analysts can provide timely analysis about the rise of the next

\footnotetext{
${ }^{950}$ Elizabeth Sherwood-Randall, 2000. "Memorandum for the President." In Robert B. Zoellick and Philip D. Zelikow (eds.) America and Russia: Memos to a President. New York: W.W. Norton \& Company, 159.
} 
Viktor Yanukovych or Vladimir Voronin. This information can subsequently help the current administration to craft pro-active policies that promote U.S. national interests.

Finally, with this study's focus on threat perceptions and state identity, intelligence professionals can potentially acquire new insights into the creation and longevity of modern-day security alliances and regional economic unions. For example, this study can be used as a springboard to further investigate the relationship between identity politics and national security matters. This study and subsequent similar endeavors may then be able to provide intelligence officials critical information that allow them to better support the strategy formulation process at the highest levels of the U.S. government.

\section{Future Research}

In the preceding chapters, this dissertation demonstrated how ideational factors can play an important role in shaping the alignment trajectories of former Soviet states. The findings from this study have added to our cumulative knowledge on small state alignment; however, there remains ample opportunity for additional research on this topic. First, the application of the analytical framework in this dissertation to countries in Central Asia may yield additional insights about the generalizability of the conclusions found in Azerbaijan, Georgia, Moldova, and Ukraine. Recalling the rigorous case selection process from Chapter Four, investigating the state identity narratives, threat perceptions, and foreign policy orientation of Uzbek president Islam Karimov may yield insight into his alignment trajectory with the United States and Russia over the course of his presidency.

Future research could also expand the operationalization of the dependent variable (alignment). Rather than just using ICEWS event data on a president's level of verbal cooperation and confrontation, expanding the data set to include material cooperation and 
confrontation can provide a more detailed analysis of the alignment tendencies of Azeri, Georgian, Moldovan, and Ukrainian presidents with Russia and the United States. Such an effort would require the collection of new event data and a subsequent automated or manual assignment of a value on the cooperation-conflict continuum (+10 to -10) in line with the Goldstein scale used in the WEIS dataset. Of note, manually assigning an event's intensity may carry varying levels of risk. Specifically, event selection bias and a subjective assessment of an event's intensity could skew the research findings.

Third, future research could more closely examine each of the president's ideas about the state's identity, threat perceptions, and foreign policy orientations. This study took a broad-brush approach by detailing a president's beliefs system on an annual basis, which returned some generally consistent findings on the relationships between the independent and dependent variables. As such, a deep dive on a single case with measurements on a monthly or quarterly basis could provide a better assessment of a president's ideas and the state's alignment with different regional great powers. Furthermore, employing other quantitative techniques like OLS regression could help discern statistically significant relationship between different variables.

Next, in the preceding section of this chapter, an analytical comparison of the findings from an examination of each of the three independent variables and the dependent variable was undertaken. This comparison was done in order to gauge how potentially the three explanatory variables may sequentially influence one another. This comparison should serve as a point of departure for future research on the relationship between a president's ideas about the state's identity and his/her threat perceptions of different regional great powers. As part of this effort, future studies could use role theory to frame an in-depth analysis of the alignment tendencies of ruling governments in the post-Soviet space. 
Congruently, a separate research effort could be undertaken to examine how a political leader's threat perceptions may shape his/her ideas about strategy and what the state foreign policies actually are with different regional great powers. Recalling Harvey Starr, sometimes a political leader's threat perceptions do not consistently reflect the foreign policies of the state. In Starr's work, he found this situation existed during the Cold War when Henry Kissinger was one of the leading figures crafting U.S. foreign policies with the Soviet Union and China. According to Starr, “...Kissinger’s images are not congruent with American foreign-policy behavior. Although Kissinger was the dominant foreign-policy decision maker during the period under investigation, his words and the evaluative assertions they contained—did not simply and directly reflect American behavior toward the Soviet Union and China." ${ }^{951}$

Finally, the role of public opinion as a driver of a president's state identity narratives deserves a closer examination. Because most political leaders want to stay in power as long as possible, ruling elites are highly sensitive to public opinion. Given this reality, incorporating public opinion as another variable could yield additional insight into the alignment tendencies of the lead actors in the state's foreign policy executive. This is particularly true with foreign policy elites, who may sometimes say something to gauge the reaction from other states. In other cases, politicians will tailor their messages to a particular audience. For example, in speeches to domestic constituents, politicians may exaggerate the threat from a particular foreign country but when speaking at an international venue may then temper their remarks.

\footnotetext{
${ }^{951}$ Starr, Harvey. 1984. Henry Kissinger: Perceptions of International Politics. Lexington: University Press of Kentucky, 142.
} 


\section{APPENDIX A - Scenario-Based Surveys ${ }^{952}$}

Scenario Overview:

Scenario 1 - Similar State Identity; Favorable Military Balance; Democratic Government Scenario 2 - Similar State Identity; Unfavorable Military Balance; Democratic Government Scenario 3 - Dissimilar State Identity; Favorable Military Balance; Authoritarian Government Scenario 4 - Dissimilar State Identity; Unfavorable Military Balance; Authoritarian Government

Scenario Instructions:

As part of my dissertation research, I am interested in understanding how you would personally respond to a hypothetical scenario from the field of international relations. In this scenario, you will be asked to play the role of a senior national security advisor to the president of the country on a long-standing unresolved foreign policy issue with a neighboring country. You will be presented with a particular situation and asked how you would respond if the president asked for your input on the options being discussed. Please take the time to carefully read the scenario and think about how you would respond to the survey questions if confronted with the situation.

\section{Scenario 1 Narrative}

You are the chief national security advisor for your country's president, who was elected six months ago. In the national election, he received $53 \%$ of the popular vote while the leading opposition candidate received $46 \%$ of the vote. The election also triggered a change in control of the legislature as your political party took control of the upper house by a three-vote margin. The political opposition controls the lower house by a ten-vote margin. Your country has a long history of peaceful and fair democratic elections.

Your job is to advise the president on all security and foreign policy matters. The most pressing foreign policy that the new president wants to resolve centers on a long-standing border dispute with your country's southern neighbor over ownership of a 950-square mile stretch of land. This territory includes a very fertile agricultural region and a mountainous region with large mining operations. A sparsely populated area centuries ago, it is now home to over 500,000 people. In 1913, both countries agreed to have King Alfonso XIII of Spain (1886-1931) resolve the dispute. When the King ruled in favor of your country, your southern neighbor rejected the decision and refused to give up its portion of the territory. In response, your country's army occupied the remaining half of the disputed territory. Although there have been numerous rounds of diplomatic negotiations to resolve this dispute, an enduring settlement remains elusive.

At the time of the 1913 decision, both countries had armed forces of approximately 30,000 troops, the majority of which were stationed along the disputed territory. Since that time, the size of your country's population and military has experienced tremendous growth as compared to your southern neighbor. Currently, there are a total of 300,000 active duty troops and 500,000 reservists in your country's armed forces. Your country's military also possesses the most modern equipment and weapon platforms. The army has 500 main battle tanks, 250 artillery pieces, and 1,000 armored personnel carriers (APCs) and infantry fighting vehicles (IFVs). The

\footnotetext{
${ }^{952}$ Full credit for the four scenarios used in this study goes to David Rousseau, who used eight scenarios in his study. See Rousseau 2006. In using these four scenarios at the Army War College, I made several modifications to the descriptions of each country's military forces in order to provide increased clarity for the respondents.
} 
air force has 300 combat aircraft, while the navy has ten frigates, six corvettes and four submarines. Your southern neighbor's military is half the size with older generation equipment and weapons. The army has 150,000 active duty troops and 250,000 reservists. Their army has 250 older main battle tanks, 125 artillery pieces, and 500 APCs and IFVs. The air force has 150 combat aircraft while the navy possesses five frigates, three corvettes, and only two submarines. Your country's level of readiness is high while your southern neighbor's is low.

During the Cold War, your southern neighbor was ruled by military leaders in an authoritarian government. After the demise of the Soviet Union, democracy flourished in the south with the civilians taking full control over the military and political leaders coming to power under free and fair elections in every national election. National political leaders in the south have also publically described their country in the same way political leaders have characterized your country. That is, Northern and Southern political leaders alike frequently espouse the same state identity narratives such as Western, independent, democratic, modernizing, and liberal. The next Parliamentary elections are scheduled for May 2018 and the next presidential elections are scheduled for May 2020.

\section{Scenario 2 Narrative}

You are the chief national security advisor for your country's president, who was elected six months ago. In the national election, he received $53 \%$ of the popular vote while the leading opposition candidate received $46 \%$ of the vote. The election also triggered a change in control of the legislature as your political party took control of the upper house by a three-vote margin. The political opposition controls the lower house by a ten-vote margin. Your country has a long history of peaceful and fair democratic elections.

Your job is to advise the president on all security and foreign policy matters. The most pressing foreign policy that the new president wants to resolve centers on a long-standing border dispute with your country's southern neighbor over ownership of a 950-square mile stretch of land. This territory includes a very fertile agricultural region and a mountainous region with large mining operations. A sparsely populated area centuries ago, it is now home to over 500,000 people. In 1913, both countries agreed to have King Alfonso XIII of Spain (1886-1931) resolve the dispute. When the King ruled in favor of your country, your southern neighbor rejected the decision and refused to give up its portion of the territory. In response, your country's army occupied the remaining half of the disputed territory. Although there have been numerous rounds of diplomatic negotiations to resolve this dispute, an enduring settlement remains elusive.

At the time of the 1913 decision, both countries had armed forces of approximately 30,000 troops, the majority of which were stationed along the disputed territory. Since that time, the size of your southern neighbor's population and military has experienced tremendous growth as compared to your country. Currently, your southern neighbor has a total of 300,000 active duty troops and 500,000 reservists in the armed forces. Your neighbor's military also possesses the most modern equipment and weapon platforms. The army has 500 main battle tanks, 250 artillery pieces, and 1,000 armored personnel carriers (APCs) and infantry fighting vehicles (IFVs). The air force has 300 combat aircraft, while the navy has ten frigates, six corvettes and four submarines. Your country's military is half the size with older generation equipment and 
weapons. The army has 150,000 active duty troops and 250,000 reservists. Your country's army has 250 older main battle tanks, 125 artillery pieces, and 500 APCs and IFVs. The air force has 150 combat aircraft while the navy possesses five frigates, three corvettes, and only two submarines. Your country's level of readiness is low while your southern neighbor's is high.

During the Cold War, your southern neighbor was ruled by military leaders in an authoritarian government. After the demise of the Soviet Union, democracy flourished in the south with the civilians taking full control over the military and political leaders coming to power under free and fair elections in every national election. National political leaders in the south have also publically described their country in the same way political leaders have characterized your country. That is, Northern and Southern political leaders alike frequently espouse the same state identity narratives such as Western, independent, democratic, modernizing, and liberal. The next Parliamentary elections are scheduled for May 2018 and the next presidential elections are scheduled for May 2020.

\section{$\underline{\text { Scenario } 3 \text { Narrative }}$}

You are the chief national security advisor for your country's president, who was elected six months ago. In the national election, he received $53 \%$ of the popular vote while the leading opposition candidate received $46 \%$ of the vote. The election also triggered a change in control of the legislature as your political party took control of the upper house by a three-vote margin. The political opposition controls the lower house by a ten-vote margin. Your country has a long history of peaceful and fair democratic elections.

Your job is to advise the president on all security and foreign policy matters. The most pressing foreign policy that the new president wants to resolve centers on a long-standing border dispute with your country's southern neighbor over ownership of a 950-square mile stretch of land. This territory includes a very fertile agricultural region and a mountainous region with large mining operations. A sparsely populated area centuries ago, it is now home to over 500,000 people. In 1913, both countries agreed to have King Alfonso XIII of Spain (1886-1931) resolve the dispute. When the King ruled in favor of your country, your southern neighbor rejected the decision and refused to give up its portion of the territory. In response, your country's army occupied the remaining half of the disputed territory. Although there have been numerous rounds of diplomatic negotiations to resolve this dispute, an enduring settlement remains elusive.

At the time of the 1913 decision, both countries had armed forces of approximately 30,000 troops, the majority of which were stationed along the disputed territory. Since that time, the size of your country's population and military has experienced tremendous growth as compared to your southern neighbor. Currently, there are a total of 300,000 active duty troops and 500,000 reservists in your country's armed forces. Your country's military also possesses the most modern equipment and weapon platforms. The army has 500 main battle tanks, 250 artillery pieces, and 1,000 armored personnel carriers (APCs) and infantry fighting vehicles (IFVs). The air force has 300 combat aircraft, while the navy has ten frigates, six corvettes and four submarines. Your southern neighbor's military is half the size with older generation equipment and weapons. The army has 150,000 active duty troops and 250,000 reservists. Their army has 250 older main battle tanks, 125 artillery pieces, and 500 APCs and IFVs. The air force has 150 
combat aircraft while the navy possesses five frigates, three corvettes, and only two submarines. Your country's level of readiness is high while your southern neighbor's is low.

During the Cold War, military dictators ruled over the people in the country to your south. After the demise of the Soviet Union, although a small group of reformers attempted to transition the country to a democracy hardliners were able to maintain the upper hand. As a result, democracy failed to flourish thus allowing former military elites to establish an authoritarian system of government (autocracy). National elections are held every five years, but they are neither fair nor open. While political leaders in your country have consistently espoused state identity narratives such as Western-liberal, independent, and democratic, political leaders in the south use words such as a "managed democracy," a "market-socialist" republic, and an aspiring great power in their public characterizations of the state's identity.

\section{$\underline{\text { Scenario } 4 \text { Narrative }}$}

You are the chief national security advisor for your country's president, who was elected six months ago. In the national election, he received $53 \%$ of the popular vote while the leading opposition candidate received $46 \%$ of the vote. The election also triggered a change in control of the legislature as your political party took control of the upper house by a three-vote margin. The political opposition controls the lower house by a ten-vote margin. Your country has a long history of peaceful and fair democratic elections.

Your job is to advise the president on all security and foreign policy matters. The most pressing foreign policy that the new president wants to resolve centers on a long-standing border dispute with your country's southern neighbor over ownership of a 950-square mile stretch of land. This territory includes a very fertile agricultural region and a mountainous region with large mining operations. A sparsely populated area centuries ago, it is now home to over 500,000 people. In 1913, both countries agreed to have King Alfonso XIII of Spain (1886-1931) resolve the dispute. When the King ruled in favor of your country, your southern neighbor rejected the decision and refused to give up its portion of the territory. In response, your country's army occupied the remaining half of the disputed territory. Although there have been numerous rounds of diplomatic negotiations to resolve this dispute, an enduring settlement remains elusive.

At the time of the 1913 decision, both countries had armed forces of approximately 30,000 troops, the majority of which were stationed along the disputed territory. Since that time, the size of your southern neighbor's population and military has experienced tremendous growth as compared to your country. Currently, your southern neighbor has a total of 300,000 active duty troops and 500,000 reservists in the armed forces. Your neighbor's military also possesses the most modern equipment and weapon platforms. The army has 500 main battle tanks, 250 artillery pieces, and 1,000 armored personnel carriers (APCs) and infantry fighting vehicles (IFVs). The air force has 300 combat aircraft, while the navy has ten frigates, six corvettes and four submarines. Your country's military is half the size with older generation equipment and weapons. The army has 150,000 active duty troops and 250,000 reservists. Your country's army has 250 older main battle tanks, 125 artillery pieces, and 500 APCs and IFVs. The air force has 150 combat aircraft while the navy possesses five frigates, three corvettes, and only two submarines. Your country's level of readiness is low while your southern neighbor's is high. 
During the Cold War, military dictators ruled over the people in the country to your south. After the demise of the Soviet Union, although a small group of reformers attempted to transition the country to a democracy hardliners were able to maintain the upper hand. As a result, democracy failed to flourish thus allowing former military elites to establish an authoritarian system of government (autocracy). National elections are held every five years, but they are neither fair nor open. While political leaders in your country have consistently espoused state identity narratives such as Western-liberal, European, independent, and democratic, political leaders in the south use words such as a "managed democracy," a "market-socialist" republic, and an aspiring great power in their public characterizations of the state's identity.

Post Scenario Survey: [Questions 2-3 are Manipulation Checks]

1. At the Army War College, you are a

[ ] U.S. Military Officer

[ ] International Officer

[ ] Federal Civilian Employee

[ ] U.S. Government Contractor

2. In the scenario you just read, your southern neighbor is a
[ ] autocracy
[ ] democracy
[ ] theocracy
[ ] not sure

3. In the scenario, which country has a larger army, air force, and navy?

[ ] your country

[ ] your southern neighbor

[ ] not sure

4. Please respond to the following statement: "If my southern neighbor refuses to resolve the dispute through diplomatic negotiation, my country should use its military forces to take back the land."

[ ] Strongly Agree

[ ] Somewhat Agree

[ ] Neither Agree Nor Disagree

[ ] Somewhat Disagree

[ ] Strongly Disagree

[ ] Not Sure

5. In one sentence, why do you support or oppose the FIRST use of military force?

[text box: code rationale as either realist, institutionalist, norms, mixed, other, or not sure]

6. Suppose another advisor in the administration suggests secretly funneling military arms, equipment, supplies, and training to opposition groups in the disputed territory. If you could be virtually guaranteed (i.e., $99 \%$ chance) that information about this secret program would not be 
leaked to the either the legislature or the public at large, would you support the FIRST use of clandestine military assistance to opposition groups as a way to retake the territory?

[ ] Strongly Support First Use of Clandestine Military Assistance

[ ] Somewhat Support First Use of Clandestine Military Assistance

[ ] Neutral

[ ] Somewhat Oppose First Use of Clandestine Military Assistance

[ ] Strongly Oppose First Use of Clandestine Military Assistance

[ ] Not Sure

7. In one sentence, why do you support or oppose the FIRST use of Clandestine Military Assistance?

[text box: code rationale as either realist, institutionalist, norms, mixed, other, or not sure]

8. Now let's alter the situation. Suppose your southern neighbor was the first to use military force, such as seizing a border outpost with ground troops or bombing border positions with aircraft. Should your country respond with military force?

[ ] Definitely Respond with Military Force

[ ] Probably Respond with Military Force

[ ] Neutral

[ ] Probably NOT Respond with Military Force

[ ] Definitely NOT Respond with Military Force

[ ] Not Sure

9. Suppose your southern neighbor was the first to use military force AND the leadership of your political opposition at home called for a military response. Would you be more or less likely to respond with military force after the opposition party's demand?

[ ] Much More Likely to Respond with Military Force

[ ] Somewhat More Likely to Respond with Military Force

[ ] About the Same

[ ] Somewhat Less Likely to Respond Military Force

[ ] Much Less Likely to Respond with Military Force

[ ] Not Sure

10. Suppose your southern neighbor was the first to use military force AND the United Nations Security Council condemned the attack and authorized your country to use "all means appropriate for defending the territory." Would you be more or less likely to respond with military force after United Nations approval?

[ ] Much More Likely to Respond with Force

[ ] Somewhat More Likely to Respond with Force

[ ] About the Same

[ ] Somewhat Less Likely to Respond Force

[ ] Much Less Likely to Respond with Force

[ ] Not Sure

11. In general, do you think democracies or autocracies are more likely to be the FIRST to use military force to resolve an international dispute? 
[ ] Democracies are MUCH more likely to use force

[ ] Democracies are SOMEWHAT more likely to use force

[ ] No Difference

[ ] Autocracies are SOMEWHAT more likely to use force

[ ] Autocracies are MUCH more likely to use force

[ ] Not Sure

12. In one sentence, if you believe democracies are less (or more) likely to use force, why might this be the case?

[text box: code rationale as either realist, institutionalist, norms, mixed, other, or not sure] 


\section{APPENDIX B - Interview Questions}

NOTE: As part of my data collection effort for my dissertation, I will conduct a series of semistructured interviews with area specialists, foreign government officials, and policy analysts. If needed, I am prepared to provide interviewees amplifying details on the definitions of key concepts used in this study.

1. (Primary) In this study, state identity is defined as the public articulation of a ruling group's ideas about the country's purpose in international affairs. From your perspective, what are the dominant state identities (e.g. democratic, European, Western, liberal, modernizing, independent, Slavic, etc.) espoused by each ruling group in Ukraine (or Georgia, Azerbaijan, and Moldova) since the end of the Cold War? Why do think these are the dominant state identities?

1a. (Secondary) During the tenure of each ruling group, to what extent did state identity narratives vary, if at all? If there was variation, can you describe the nature of this change and its underlying causes?

1b. (Secondary) In each ruling group, which political figure(s) (e.g. president, prime minister, foreign minister, defense minister, etc.) do you believe were the most influential in developing the country's state identity narratives?

2. (Primary) Which foreign country (or countries) did each ruling group perceive to be the primary national security threat?

2a. (Secondary) How would you describe the nature of this national security threat? Was it military (armed attack; the provision of arms or money to other state/non-state actors, etc.), economic (sanctions, trade embargoes, cut in energy supplies, etc.), political (coercive diplomacy, UN voting, etc.), or informational (propaganda, disinformation campaign, cyberattacks, etc.) or a combination of the four?

3. (Primary) How would you best categorize the intensity of each ruling group's threat perceptions of the country identified as the primary external threat? Would you say those threat perceptions were high, moderate, or low? High-the ruling group perceive some form of military and/or economic conflict is very likely during their time in office; moderate-political leaders perceive some form of military or economic conflict is somewhat likely; or low-political leaders perceive some form of military or economic conflict is very unlikely. Please provide a brief explanation for your ranking.

3a. (Secondary) Did the ruling group's threat perceptions remain stable or vary while in office? If there was variation, can you describe the nature of this change and its causes?

4. (Primary) In those countries identified as the primary external national security threat, what were the dominant state identities espoused by each ruling group from 1991 to present?

5. (Primary) To what extent do you believe dissimilar state identities between countries may influence political leader threat perceptions? Would you say they are not at all influential, slightly influential, somewhat influential, very influential, or extremely influential? 
6. (Primary) In this study, a political leader's foreign policy orientation is defined as his/her basic beliefs about the nature of international affairs and political conflict as they relate to other countries and their respective state's national priorities. To what extent do you believe a political leader's threat perceptions influence his/her general foreign policy orientation towards Russia, and the United States? Would you say they are not at all influential, slightly influential, somewhat influential, very influential, or extremely influential?

7. (Primary) How would you best categorize the foreign policy orientation of the key political leaders in each of Ukraine's (or Georgia, Azerbaijan, Moldova) ruling groups towards Russia, the United States, and Western European powers? Would you characterize their foreign policy orientation as accommodative, pragmatic, confrontational, or something else? In this study, an accommodative, pragmatic, or confrontational foreign policy orientation are defined as follows:

Accommodative - A ruling group with an accommodative foreign policy orientation does not regard a regional great power as fundamentally hostile or directly threatening to the state's national security. Accommodative ruling groups tend to see a wide array of important strategic issues in the international system that requires constructive engagement and cooperation in order to find mutually beneficial resolutions.

Pragmatic - A ruling group with a pragmatic foreign policy orientation perceives a regional great power to be a potential national security threat; however, this threat is manageable and does not require immediate consideration. Pragmatic ruling groups generally maintain restrained foreign policies vis-à-vis a regional great power since this country is viewed as having limited goals that are frequently materially constrained thus making it difficult to exert excessive, consistent pressure. While confrontation is still possible, because this regional great power does not pose an immediate threat, pragmatic leaders have time to exercise diplomacy and engage in bargaining and mutually beneficial cooperation.

Confrontational - A ruling group with a confrontational foreign policy orientation perceives a regional great power to be inherently dangerous where strategic interactions represent a zero-sum game. Ruling groups with a confrontational foreign policy orientation believe a particular regional great power has unlimited objectives with access to adequate material resources, political support, and public backing to realize those goals. This regional great power represents an unambiguous and immediate threat to the state's national security and territorial sovereignty.

8. (Primary) For the purposes of this study, alignment is defined as a formal or informal set of expectations about defense, economic, and diplomatic cooperation between a small state and one or more regional great powers that political leaders believe will enhance the country's national security and allow them to remain in power. When thinking about each ruling group's foreign policy decision-making process to align with a particular regional power(s), how important (not at all important, low importance, slightly important, neutral, moderately important, very important, or extremely important) are the following factors? Please provide a brief explanation for your ranking of each factor?
a. Public opinion.
b. Political leader beliefs and perceptions.
c. Domestic political opposition to the ruling government's foreign policies. 
d. The regional balance of power with Russia.

8a. (Secondary) Beyond public opinion, political leader beliefs, etc., are there any other domestic and/or international factors you believe are important drivers moving a small state to align with a particular regional great power? How important (not at all important, low importance, slightly important, neutral, moderately important, very important, or extremely important) are those factors? Please provide a brief explanation for your ranking of each factor.

8b. (Secondary) What are the key domestic or international factors driving these political leaders to align with a particular regional power?

8c. (Secondary) What are the key domestic or international factors driving these political leaders to align against a particular regional power?

9. (Primary) How would you describe the priority (not a priority, low priority, medium priority, high priority, essential) assigned by each ruling group to align with the United States, Russia, or major powers in Western Europe?

9a. (Secondary) In those instances where equal priority was assigned to aligning with different regional powers, why do you think that occurred?

10. (Primary) From your perspective, how successful was each ruling group in implementing various foreign policies to align with a preferred regional great power? Would you say they were quite unsuccessful, somewhat unsuccessful, somewhat successful, or quite successful?

10a. (Secondary) In those instances where a ruling government was either quite or somewhat unsuccessful in advancing foreign policies to align with a regional great power, what were the primary obstacles preventing the realization of this foreign policy goal?

10b. (Secondary) In those instances where a ruling government was either quite or somewhat successful in advancing foreign policies to align with a regional great power, what were the primary enablers facilitating the realization of this foreign policy goal? 


\section{APPENDIX C - The Relevancy of Ideational Factors}

How important are the ideas and beliefs of political leaders in the development and execution of the state's foreign policies? Are they more important than other domestic and systemic-level variables? Recognizing the limits of this study and how time and space do not allow for the presentation of all the major arguments supporting one domestic and/or systemic-level variable over another, this study considers the potential relevancy of public opinion, domestic politics, and the balance of military power as three factors shaping the foreign policies of post-Soviet states. In the proceeding paragraphs, a brief discussion of the potential relevance of these alternative variables are examined. This is followed by an empirical probe that concludes ideational factors should be given increased emphasis in explaining foreign policy outcomes.

Public Opinion. Although there is a mountain of scholarly articles on public opinion and foreign policy in the United States and other developed countries, the literature covering public opinion in the post-Soviet space is not as robust owing to perhaps a lack of data availability, low academic interest, or how many of these countries have only recently gained their independence. Additionally, the scholarly literature returns mixed results with some scholars finding public opinion matters little, while others concluding it is a relevant factor in the foreign policy decision making process.

Several scholars confirm the validity of the Almond-Lipmann consensus in their analysis of the post-Soviet space. For example, Robert Dorff finds mixed support in Hungary, Czech Republic, and Poland during 1997 for NATO accession even though the ruling governments in each country were aggressively pursuing a Western foreign policy course. Using polling data from 1997, Dorf notes how many citizens were more concerned about domestic economic 
issues. ${ }^{953}$ Several years later, Chudowsky and Kuzio found similar trends in Ukraine concluding Ukrainian public opinion is of little relevance to foreign policy issues. ${ }^{954}$ For most of the 1990 s, the authors also find the Ukrainian public is generally passive and atomized across various foreign policy issues thereby reducing its impact on political elite decisions.

Other scholars have concluded that public opinion in the post-Soviet space is a relevant factor in foreign policy elite decision making. For example, Nathaniel Copsey, using archival public opinion data and focus groups, concludes that the business communities in Poland and Ukraine exert considerable influence on the foreign policy decision making process in both states. ${ }^{955}$ Like Copsey, Martin Muller finds public opinion matters in Georgia as well. Using regression analysis and data derived from a 2009 national representative survey $(n=1,886)$, Muller concludes that, in line with the ruling government's foreign policy trajectory, there is high public support for accession into NATO and the EU. Interestingly, Muller uncovers a divergence where, unlike the Saakashvili government, there is broad public support for improved foreign policy relations with Moscow. As Muller notes, many citizens believe a prolonged antagonistic relationship with Russia is detrimental to the country's long-term stability. ${ }^{956}$

Domestic Politics. Domestic politics is a second key factor that carries a potential high relevance in the state's foreign policy processes. The IR literature on the relationship between domestic politics and the state's foreign policies is legion. Highlighting the breadth and depth of this body of literature, James Fearon found that between 1987 and 1996, over 30 percent $(\mathrm{n}=193)$

\footnotetext{
${ }^{953}$ Dorff, Robert. 1998. "Public Opinion and NATO Enlargement." In Stephen Blank (ed.) NATO After Enlargement: New Challenges, New Missions, New Forces. Carlisle, PA: U.S. Army War College, Strategic Studies Institute, 10-18.

${ }^{954}$ Chudowsky, Victor and Taras Kuzio. 2003. "Does public opinion matter in Ukraine? The case of Foreign Policy." Communist and Post-Communist Studies 36, 287.

${ }^{955}$ Copsey, Nathaniel. 2011. Public Opinion and Making of Foreign Policy in the "New Europe"- A Comparative Study of Poland and Ukraine. Burlington Vermont: Ashgate Publishing Company, 3.

${ }^{956}$ Muller, Martin. 2011. "Public Opinion Toward the European Union in Georgia." Post-Soviet Affairs 27 (1), 8384.
} 
of articles in International Organization used domestic-political variables to explain various political outcomes. ${ }^{957}$ Two examples help use to understand the potential relevance of domestic politics. First, in his book Myths of Empire: Domestic Politics and International Ambitions, Jack Snyder argues foreign policies (e.g. a decision to go to war) are derived from "the justification for the policies of domestic political coalitions formed among groups having parochial interests in imperial expansion, military preparations, or economic autarky. These groups, which included leading figures in the country's economic sectors and state bureaucracies, log rolled their various imperialist or military interests, using arguments about security through expansion to justify their self-serving policies in terms of a broader public interest in national survival. ${ }^{958}$ It from these points one can begin to better understand the foreign policies of Britain during the Crimean War (1853-1856), Imperial Germany's decisions during World War I, and Imperial Japan's actions in the run-up to World War II.

Second, Robert Putnam also provides insight into how domestic politics can affect the state's actions on the world stage. For Putnam, political leaders play a two-level game. On the international stage (Level I), the chief executive (e.g. president or prime minister), is constrained in his/her actions by a plethora of domestic actors (Level II), with their own interests and capacity to exert influence on the chief negotiator in terms of what will or will not come to

\footnotetext{
${ }^{957}$ Fearon, James D. 1998. "Domestic Politics, Foreign Policy, and Theories of International Relations." Annual Review of Political Science 1 (1), 289. For example, on interstate war see Bueno de Mesquita, Bruce, and David Lalman. 1992. War and Reason. New Haven, CT: Yale University and Levy, Jack S. 1988. "Domestic Politics and War." Journal of Interdisciplinary History 18 (4); on compliance and international cooperation see Downs, George W., and David M. Rocke. 1995. Optimal Imperfection? Domestic Uncertainty and Institutions in International Relations. Princeton, NJ: Princeton University Press; on territorial disputes see Huth, Paul. 2009. Standing your Ground: Territorial Disputes and International Conflict. University of Michigan Press; on trade policy see Milner, Helen. 1997. Resisting Protectionism. Princeton, NJ: Princeton University; on government fragmentation see Hagan, Joe D. 1994. "Domestic Political Regime Change and Foreign Policy Restructuring: A Framework for Comparative Analysis." In Jerel A. Rosati, Joe D. Hagan, and Martin W. Sampson (eds.) Foreign Policy Restructuring: How Governments Respond to Global Change. Columbia, SC: University of South Carolina Press.

${ }^{958}$ Snyder, Jack. 1991. Myths of Empire: Domestic Politics and International Ambition. Ithaca, NY: Cornell University Press, 2.
} 
fruition during international negotiations. These domestic actors include special interest groups, big business, a state's bureaucracy, and electorate, who all want to protect or advance their interests by pressuring the government to enact policies favorable to their respective position..$^{959}$ For example, while President Bill Clinton signed the Kyoto Protocol in 1997, the Senate failed to ratify the agreement due to the interests and strong influence of large companies, which expressed concern over the exorbitant costs to comply with the agreement. ${ }^{960}$

Balance of Military Power. Beyond public opinion and domestic politics, conditions and events in the international system can influence a state's foreign policies. The necessity to give precedence to a systemic approach is derived, in part, from Waltz and his criticisms of reductionism. According to Waltz, a reductionist approach seeks to explain state behavior by analyzing the plethora of domestic factors internal to the state that are in line with what he calls first- and second-image explanations. ${ }^{961}$ Waltz sees a reductionist approach as extremely problematic arguing, "it is not possible to understand world politics simply by looking inside of states... every time we think that we see something different or new, we will have to designate another unit-level 'variable' for its cause... leading to the infinite proliferation of variables." 962

It is from this shortfall, realists attempt to explain state actions by taking a systemic approach that is based on two key assumptions. First, systemic, and not domestic-level factors best explain small state foreign policies. The underlying logic here is that regional great powers, owing to their respective military and/or economic capabilities, worry less about survival and are therefore

\footnotetext{
${ }_{959}$ Putnam 1988, 436-437.

${ }^{960}$ Hovi, Jon, Detlef F. Sprinz, and Guri Bang. 2012. "Why the United States did not become a Party to the Kyoto Protocol: German, Norwegian, and US perspectives." European Journal of International Relations 18 (1).

${ }^{961}$ See Waltz, Kenneth N. 1959. Man, the State, and War. New York: Columbia University Press. For example, a first-image explanation may center on the behavior of men. As such, wars result from selfishness, from misdirected aggressive impulses, and from stupidity. A second-image explanation may be derived from conditions inside the state such its economic structure.

962 Waltz 1979, 65.
} 
more susceptible to domestic influences as they relate to foreign policy choices. On the contrary, unlike the great powers, small states are continuously worried about their survival in an anarchic, self-help system and will base their foreign policy decisions on material factors, specifically the balance of military power, from a would-be adversarial state. ${ }^{963}$ This study's selection of the balance of military power as the most important systemic variable takes its cue from John Mearsheimer. In developing his theory of offensive realism, a state's military forces, particularly its land forces are the most important, "because they are the principal instrument for conquering and controlling territory—-the paramount political objective in a world of territorial states."

An Empirical Probe. In an effort to tease out the level of importance of a political leader's ideas and beliefs, public opinion, domestic politics, and the balance of military power in the foreign policy calculations of the presidents in Azerbaijan, Georgia, Moldova, and Ukraine this study interviewed over 25 area specialists and regional experts. The question asked of these individuals were as follows: Lots of factors can affect a country's foreign policies and its tendency to align with a regional great power. On a scale of 1 to 7 (1 - extremely important; 2 very important; 3 - moderately important; 4 - neutral; 5 - slightly important; 6 - low importance; 7 - not at all important), when thinking about the presidency of [insert Azerbaijani, Georgian, Moldovan or Ukrainian president's name], how important do you assess the following factors were in their foreign policy decision-making: public opinion, the beliefs and perceptions of the president, domestic political opposition to the ruling government's foreign policies, and the regional balance of power with Russia? A summary of the respondent's professional assessments

\footnotetext{
${ }^{963}$ See Handel 1990, 3; Skidmore, David. 1994. "Explaining States Responses to International Change: The Structural Sources of Foreign Policy Rigidity and Change." In Jerel A. Rosati, Joe D. Hagan, Martin W. Sampson III, (eds.) Foreign Policy Restructuring: How Governments Respond to Global Change. Columbia, SC: University of South Carolina Press, 50-56; and Waltz 1979, 194-195.

${ }^{964}$ Mearsheimer 2001, 43.
} 
reveals that on average a president's ideas and beliefs were very important. Domestic political opposition and public opinion were moderately important with the regional balance of power regarded as slightly important.

In addition to interviews with area specialists, a scenario-based experiment helped discern the extent to which identity matters in the foreign policy calculations of political elites. For this empirical probe, a scenario-based experiment was given to senior military and civilian leaders from the United States and 80 foreign countries, who were assigned to the U.S. Army War College in 2017. ${ }^{965}$ Specifically, four different hypothetical scenarios were randomly disseminated to approximately 1,000 senior U.S. and foreign civilian and military officers using Survey Monkey with a response rate of 35 percent $(n=350)$. The four scenarios involve two neighboring countries at odds with one another over a territorial dispute. The questions in the survey measured three dichotomous dimensions: state identity as either similar or dissimilar, balance of military power as favorable or unfavorable, and government type as democratic or authoritarian. The two primary hypotheses for this experiment were:

\section{H1: A favorable balance of military power increases an individual's willingness to use armed force.}

H2: Similar state identities reduces an individual's willingness to use armed force.

The results from the table below support, by the thinnest of margins, realist claims that a favorable balance of military power increases an actor's proclivity to use armed force. When one state has a 2 to 1 military advantage over another country, only eight percent of the respondents either somewhat agreed or strongly agreed that the state should use armed force first if a neighboring country refuses to resolve a dispute through diplomacy. This finding is only slightly

\footnotetext{
965 This effort replicates the work of Dr. David Rousseau, who conducted a similar experiment with undergraduate students at the University of Pennsylvania using eight scenario-based surveys. I would also like to specifically thank Dr. Rousseau for his kind assistance with my research effort. Dr. Rousseau provided me with analytical insight and copies of all eight of his scenarios that he used in his experiment at Penn.
} 
higher than the two percent of the respondents, who either somewhat agreed or strongly agreed that military force should be a first option even when the country is at a military disadvantage. This finding indicates other factors may be exerting an influence on an individual's strategic calculations. ${ }^{966}$

Table 6: Support for "First Use" of Armed Force by the Balance of Power

\begin{tabular}{|l|c|c|c}
\hline & $\begin{array}{c}\text { Weak Military } \\
\text { Position (n=160) }\end{array}$ & $\begin{array}{c}\text { Strong Military } \\
\text { Position }(\mathbf{n}=\mathbf{1 6 3})\end{array}$ & $\begin{array}{c}\text { Totals } \\
(\mathbf{n}=\mathbf{3 2 3})\end{array}$ \\
\hline Support & $2 \%$ & $8 \%$ & $5 \%$ \\
\hline Do Not Support & $98 \%$ & $92 \%$ & $95 \%$ \\
\hline Totals & $100 \%$ & $100 \%$ & $100 \%$ \\
\hline
\end{tabular}

When considering the identity of the state as articulated by ruling political leaders, the results in the table below also minimally support constructivist claims that similar identities reduce an individual's willingness to use armed force. When political leaders in a neighboring country espouse a similar state identity narrative, 96 percent of the respondents believe that armed force should not be used first as compared to 94 percent when state identities diverge. According to one respondent, "regional relationships with fellow democracies are valued greater than whether we have dominion over a small plot of disputed territory" while another noted how, "Democracies don't go to war with each other; we negotiate and resolve our differences."967 Although it appears similar state identities are also a potential factor affecting an individual's willingness to use armed force, more empirical support is required to strengthen this argument.

\footnotetext{
${ }^{966}$ Respondents were asked the following question: "If my southern neighbor refuses to resolve the dispute through diplomatic negotiation, my country should use military force FIRST to take back the land."

${ }^{967}$ Survey responses on file with the author.
} 
Table 32: Support for "First Use" of Armed Force by Opponent's State Identity

\begin{tabular}{|l|c|c|c|}
\hline & $\begin{array}{c}\text { Similar State Identity } \\
(\mathbf{n = 1 5 6 )}\end{array}$ & $\begin{array}{c}\text { Dissimilar State Identity } \\
(\mathbf{n = 1 6 7 )}\end{array}$ & $\begin{array}{c}\text { Totals } \\
(\mathbf{n}=\mathbf{3 2 3})\end{array}$ \\
\hline Support & $4 \%$ & $6 \%$ & $5 \%$ \\
\hline Do Not Support & $96 \%$ & $94 \%$ & $95 \%$ \\
\hline Totals & $100 \%$ & $100 \%$ & $100 \%$ \\
\hline
\end{tabular}

In order to better understand the potential relevance of identity on a political leader's foreign policy decision-making, Army War College participants were also asked to provide a response about providing clandestine military assistance to opposition groups in the neighboring country. ${ }^{968}$ In the table below, the constructivist argument that identity is an important variable in international relations gains strength. Specifically, 82 percent of senior leaders were less willing to use clandestine military assistance when state identities converged as compared to those with dissimilar state identities, which came in at 73 percent. Commentary from respondents help to provide a sharper qualitative edge to this finding. One respondent stated, "Fraught with risk not the least of which is compromising the integrity of the system we espouse" while another noted, "I oppose it... [because] the southern country is a Western democracy." 969

Table 33: Support for "First Use" of Clandestine Assistance by Opponent's State

\begin{tabular}{|l|c|c|c|}
\hline & $\begin{array}{c}\text { Similar State Identity } \\
(\mathbf{n}=\mathbf{1 5 8})\end{array}$ & $\begin{array}{c}\text { Dissimilar State Identity } \\
(\mathbf{n}=\mathbf{1 6 1 )}\end{array}$ & $\begin{array}{c}\text { Totals } \\
(\mathbf{n}=\mathbf{3 1 9})\end{array}$ \\
\hline Support & $18 \%$ & $27 \%$ & $23 \%$ \\
\hline Do Not Support & $82 \%$ & $73 \%$ & $77 \%$ \\
\hline Totals & $100 \%$ & $100 \%$ & $100 \%$ \\
\hline
\end{tabular}

\footnotetext{
${ }^{968}$ Respondents were asked the following question: "Suppose another advisor in the administration suggests secretly funneling military arms, equipment, supplies, and training to opposition groups in the disputed territory. If you could be virtually guaranteed (i.e., $99 \%$ chance) that information about this secret program would not be leaked to either the legislature or the public at large, would you support the FIRST use of clandestine military assistance to opposition groups as a way to retake the territory?"

${ }^{969}$ Survey responses on file with the author.
} 
The relevance of the military balance of power is also brought into clearer perspective when applied to the provision of clandestine military assistance. In the table below, individuals were willing to provide lethal aid to opposition groups in the neighboring country at a much higher rate (94 percent) when their country has a marked military advantage. When the balance of military power favored the adversary, 78 percent of the respondents believed this course of action was optimal. Given the preceding analyses, an argument can be made that both material and ideational factors should be considered important factors influencing an individual's actions in international relations.

Table 34: Support for "First Use" of Clandestine Assistance by the Balance of Power

\begin{tabular}{|l|c|c|c}
\hline & $\begin{array}{c}\text { Weak Military } \\
\text { Position (n=160) }\end{array}$ & $\begin{array}{c}\text { Strong Military } \\
\text { Position (n=163) }\end{array}$ & $\begin{array}{c}\text { Totals } \\
(\mathbf{n = 3 1 3})\end{array}$ \\
\hline Support & $78 \%$ & $94 \%$ & $87 \%$ \\
\hline Do Not Support & $22 \%$ & $6 \%$ & $13 \%$ \\
\hline Totals & $100 \%$ & $100 \%$ & $100 \%$ \\
\hline
\end{tabular}

The preceding analyses serve to guide this study's focus on three ideational variables: a political leader's ideas about the state's identity, his/her threat perceptions, and accompanying foreign policy orientation as conditioned by domestic politics. As a reminder, this research project acknowledges how small state alignment with a regional great power or set of regional great powers is a complex political phenomenon where multiple variables can and will exert varying levels of influence on the strategic calculus of political leaders charged with determining the state's foreign policies. 


\section{Bibliography}

Abarinov, Vladimir and Vitalii Tretiakov. 1992. "The Union Left Russia With a Poor Foreign Policy Legacy.” Nevavisimaia Gazeta, 01 April 1992. In Current Digest of the PostSoviet Press (CDPDP) 44 (3).

Abrams, Dominic, and Michael A. Hogg. 1988. Social Identifications: A Social Psychology of Intergroup Relations and Group Processes. London: Routledge.

Aliyev, Heydar. 1993. "Speech of Heydar Aliyev, Chairman of the Supreme Soviet of the Republic of Azerbaijan, at the meeting of the Parliament - June 15, 1993." Heydar Aliyev Heritage International Online Library. http://lib.aliyev-heritage.org/en/3857190.html.

Aliyev, Heydar. 1994. "Speech of the President of Azerbaijan Heydar Aliyev at 49th session of the UN General Assembly - New York, September 29, 1994." Heydar Aliyev Heritage International Online Library. http://lib.aliyev-heritage.org/en/7119983.html.

Aliyev, Heydar. 1994a. "Speech of the President of the Republic of Azerbaijan Heydar Aliyev at the meeting of the Heads of states and governments of the OSCE member-countries in Budapest. December 6, 1994.” Heydar Aliyev Heritage International Online Library http://lib.aliyev-heritage.org/en/2003842.html.

Aliyev, Heydar. 1995. “Aliyev on Ties with U.S., Pipeline Route, Karabakh. Azerbaycan Televiziyasi, 23 October 1995.

Aliyev, Heydar. 1995a. “Aliyev Sees 'Possible' Agreement on Karabakh.” Die Zeit, 26 May 1995.

Aliyev, Heydar. 1995b. "Speech of the Azerbaijani President Heydar Aliyev at the Ceremony of Signature Documents on Giving a share of Azerbaijan at the International Oil Consortium to Exxon.” Heydar Aliyev Heritage International Online Library, 19 April 1995. http://lib.aliyev-heritage.org/en/19981.html.

Aliyev, Heydar. 1995c. "Speech of the President of the Republic of Azerbaijan Heydar Aliyev at the 60th anniversary of the prominent Azerbaijani writer and cinematograph Magsud Ibrahimbeyov, May 14, 1995.” Heydar Aliyev Heritage International Online Library. http://lib.aliyev-heritage.org/en/2908961.html.

Aliyev, Heydar. 1996. “Aliyev Complains to U.S. Envoy About Congress Resolution.” Turan, 14 June 1996.

Aliyev, Heydar. 1996a. “Aliyev on Domestic, International Issues.” Sobesednik, 01 July 1996.

Aliyev, Heydar. 1996b. "Moscow Paper Interviews President Aliyev.” Pravda Pyat, 21 August 1996. 
Aliyev, Heydar. 1996c. "Statement of Heydar Aliyev after Signing of the Agreement on Commercial-economic, Scientific-technical and Cultural Cooperation between the Republics of Azerbaijan and Tatarstan.” Heydar Aliyev Library, 21 November 1996. http://lib.aliyev-heritage.org/en/7854107.html.

Aliyev, Heydar. 1997. "Yeltsin, Aliyev Comment on Friendship Treaty." Mayak Radio Network, 03 July 1997.

Aliyev, Heydar. 1998. "Interview of the President of Azerbaijan Heydar Aliyev to the Reporter of the Japanese Newspaper." Heydar Aliyev Heritage International Online Library, 27 February 1998. http://lib.aliyev-heritage.org/en/562426.html.

Aliyev, Heydar. 1998a. "Speech of the Azerbaijani President Heydar Aliyev in his Inauguration Ceremony - October 18, 1998.” Heydar Aliyev Heritage International Online Library. http://lib.aliyevheritage.org/en/7958721. html.

Aliyev, Heydar. 1999. “Aliyev Sees 'Negative Aspects' in Azeri-Russian Ties.” ANS Television Network, 17 December 1999.

Aliyev, Heydar. 2000. "Azerbaijani President Confident of Improved Relations with Russia." Moscow Mayak Radio, 15 June 2000.

Aliyev, Heydar. 2001. "Speech of President of the Republic of Azerbaijan Heydar Aliyev at the I Congress of the World Azerbaijanis - Baku, 10 November 2001." Heydar Aliyev Heritage International Online Library. http://lib.aliyev-heritage.org/en/2428604.html

Aliyev, Heydar. 2001a. "Statement of the Azerbaijan President Heydar Aliyev in Connection with the Act of Terrorism Occurred in the United States of America on September 11, 2001.” Heydar Aliyev Library, 11 September 2001. http://lib.aliyevheritage.org/en/ 2735953.html.

Aliyev, Heydar. 2002. "Address of Heydar Aliyev, the President of the Republic of Azerbaijan to the World Azerbaijanis on the occasion of the Day of Solidarity - Baku, December 26, 2002.” Heydar Aliyev Heritage International Online Library. http://lib.aliyevheritage.org/ en/3750555.html.

Aliyev, Heydar. 2002a. "Azerbaijani President Pleased with Visit to Moscow." Azerbaijani TV 1, 27 January 2002.

Aliyev, Heydar. 2003. "From the conversation of the Azerbaijani President Heydar Aliyev with Bruce Jackson, Director of the Project on Transition of Democracies, Co-chairman of the Committee on NATO. Heydar Aliyev Library, 18 April 2003. http://lib.aliyevheritage. org/en/9085432.html.

Aliyev, Heydar. 2017. “Azerbaijan-U.S. Economic Relations.” Heydar Aliyev Library. http://lib.aliyev-heritage.org/en/showmap.html. 
Aliyev, Ilham. 2003. “Azeri President, US Defense Secretary Discuss Military Ties.” Azerbaijani TV 1, 03 December 2003.

Aliyev, Ilham. 2003a. "Ilham Aliyev: Policy Innovations? No Way! Azerbaijani President-Elect on his Father, Himself, and Opposition." Rossiyskaya Gazeta, 21 October 2003.

Aliyev, Ilham. 2004. "Azerbaijan: President Praises Relations with Russia Ahead of Visit." RIANovsti, 02 February 2004.

Aliyev, Ilham. 2004a. “Azerbaijan's Aliyev Interviewed on Relations with France, Russia, U.S. Le Figaro, 23 January 2004.

Aliyev, Ilham. 2004b. "Azeri President Quizzed on Russia's Caucasus Policy, Karabakh, NATO, EU.” Izvestiya, 04 February 2004.

Aliyev, Ilham. 2004c. "President Ilham Aliyev spoke in the sitting of spring session of PACE." President of Azerbaijan Speech Archive. http://archive.president.az/articles.php?item_ id $=20070813045408862 \&$ sec $\_i d=11$.

Aliyev, Ilham. 2004d. "Russia: Azerbaijani President Plans to Increase Bilateral Trade, Military Cooperation." Itar-Tass, 07 February 2004.

Aliyev, Ilham. 2004e. "Speech of Azerbaijani President Ilham Aliyev at meeting at the Columbia University in New York." President of Azerbaijan Website, 24 September 2004. http://archive.president.az/articles.php?item_id=20070813060710459\&sec_id=11.

Aliyev, Ilham. 2004f. "Speech of President of Azerbaijan Ilham Aliyev at the first AzerbaijanRussia Economic Forum.” President of Azerbaijan Website, 07 April 2004. http://archive. president.az/articles.php?item_id=2007 0813043859856\&sec_id=11.

Aliyev, Ilham. 2005. "Interview of President of Azerbaijan Republic to Great Britain." Sky News, 16 August 2005. http://archive.president.az/articles.php?item_id=20070810064109248 \&sec_id=14.

Aliyev, Ilham. 2006. "Azerbaijan Is Accustomed to Relying Only on Its Own Resources and Therefore Does Not Join Coalitions." Security Index 1-81 (13). http://www.pircenter. org/media/content/files/0/13413248491.pdf.

Aliyev, Ilham. 2006a. "Inauguration of the Heydar Aliyev Baku-Tbilisi-Ceyhan Main Export Oil Pipeline." President of Azerbaijan Website, 13 July 2006. http://archive.president.az/ articles.php?item_id=200708130 54416242\&sec_id=11.

Aliyev, Ilham. 2006b. "Speech of Azeri President Ilham Aliyev at the Washington the 6th Business and Investment Conference." President of Azerbaijan Website, 27 April 2006. http://archive.president.az/articles.php? item_id=20070813062030377\&sec_id=11. 
Aliyev, Ilham. 2007. "National Security Concept of the Republic of Azerbaijan." The President of the Republic of Azerbaijan, 23 May 2007. https://www.files.ethz.ch/isn/154917/ Azerbaijan2007.pdf.

Aliyev, Ilham. 2008. "Statements for Media Representatives by President Ilham Aliyev and Prime Minister of Turkey Recep Tayyip Erdogan.” President of Azerbaijan Website, 20 August 2008. http://archive.president.az/articles.php?item_id=20080903105812573 \&sec_id=70.

Aliyev, Ilham. 2009. “Azerbaijan Considers Nabucco Gas Pipeline Project as Commercial.” ItarTass, 26 January 2009.

Aliyev, Ilham. 2012. "Meeting with President of Azerbaijan Ilham Aliyev." President of Russia Website, 23 January 2012. http://en.kremlin.ru/catalog/persons/192/events/14347.

Aliyev, Ilham. 2012a. Cited in Sultanova, Shahla. 2012. "Azerbaijan Brings in the Big Guns." Transitions Online, 12 July 2012. http://www.tol.org/client/article/23254-azerbaijanmilitary-spending.html.

Aliyev, Ilham. 2013. "Speech by President Ilham Aliyev at the opening of the Azerbaijan-USA forum "Vision for the Future" in Baku." President of Azerbaijan Website, 29 May 2013. http://en.president.az/articles/8311.

Aliyev, Ilham. 2014. "Speech by Ilham Aliyev at the 4th Summit of the Heads of State of Caspian Littoral States." President of Azerbaijan Website, 29 September 2014. http://en.president.az/articles/13039.

Altstadt, Audrey L. 2003. "Azerbaijan and Aliyev: A Long History and an Uncertain Future." Problems of Post-Communism 50 (5).

Andersen, Benedict. 1991. Imagined Communities: Reflections on the Origin and Spread of Nationalism. New York: Verso.

Antidze, Margarita. 2007. "Russia Closes Last Military Base in Georgia." Reuters, 13 November 2007. https://www.reuters.com/article/us-georgia-russia-bases/russia-closes-last-militarybase-in-georgia-idUSL1387605220071113.

Antidze, Margarita. 2014. "Georgian President Challenges PM to Affirm pro-Western Course." Reuters, 14 November 2014. https://www.reuters.com/article/uk-georgia-governmentpresident/georgian-president-challenges-pm-to-affirm-pro-western-course idUKKCNOIY1HH20141114.

Areshidze, Irakly. 2002. "Helping Georgia?” Perspective 7 (4). http://www.bu.edu/iscip/vol12/ areshidze.html. 
Armstrong, Adrienne. 1981. "The Political Consequences of Economic Dependence." The Journal of Conflict Resolution 25 (3).

Art, Robert J. 2004. “Europe Hedges Its Security Bets.” In T. V. Paul, James J. Wirtz, and Michel Fortmann (eds.) Balance of Power: Theory and Practice in the 21st Century. Stanford University Press.

Art, Robert J., Stephen G. Brooks, William C. Wohlforth, Keir A. Lieber and Gerard Alexander. 2006. "Correspondence: Striking the Balance." International Security 30 (3).

Association for Participatory Democracy. 2009. Parliamentary Elections in Moldova, 29 July 2009. http://www.e-democracy.md/en/elections/parliamentary/20092/results/.

"Azerbaijan Cancels Military Exercise with the United States." 2010. Radio Free Europe/Radio Liberty, 20 April 2010. https://www.rferl.org/a/Azerbaijan_Cancels_Military_Exercises _With_United_States/ 2019023.html.

“Azerbaijan Links CIS Integration to Karabakh Conflict." 1997. Radio Free Europe/Radio Liberty Newsline 1 (148), October 1997. http://www.hri.org/news/balkans/rferl/1997/9710-29.rferl.html\#02.

Azita, Amjadi, Philip Schuler, Hiroaki Kuwahara, and Susanne Quadros. 2016. World Integrated Trade Solutions User Manual 2.01, World Bank.

Bachman, Jessica and Denis Dyomkin. 2010. "UPDATE 2-Russia buys Azeri gas to keep EU market -analysts." Reuters, 03 September 2010. http://uk.reuters.com/article/russiaazerbaijan-gas/update-2-russia-buys-azeri-gas-to-keep-eu-market-analystsidUKLDE6820GJ20100903.

Baldwin, David A. 1997. "The Concept of Security.” Review of International Studies 23 (1).

Baldwin, David A. 2016. Power and International Relations: A Conceptual Approach. Princeton: Princeton University Press.

Baleanu, Virgil George. 2000. "In the Shadow of Russia: Romania's Relations with Moldova and Ukraine." Conflict Studies Research Centre. Royal Military Academy Sandhurst.

Bandow, Doug. 2014. "Ukraine Wants to Join NATO and Fight Russia: U.S. Must Say No and Make Alliance an Issue of Security, Not Charity." CATO Institute, 26 December 2014. https://www.cato.org/publications/commentary/ ukraine-wants-join-nato-fight-russia-usmust-say-no-make-alliance-issue.

Barnett Michael N. 1996. "Identity and Alliances in the Middle East." In Peter Katzenstein, (ed.) The Culture of National Security: Norms and Identity in World Politics. New York: Columbia University Press. 
Barnett, Michael N. and Jack S. Levy. 1991. "Domestic Sources of Alliances and Alignments: The Case of Egypt, 1962 - 1973." International Organization 45 (3).

Beer, Francis A. (ed.). 1970. Alliances: Latent War Communities in the Contemporary World. New York: Holt, Rinehart and Winston Publishers.

Beres, Louis René. 1972. "Bipolarity, Multipolarity, and the Reliability of Alliance Commitments." The Western Political Quarterly 25 (4).

Bergsmann, Stefan. 2001. "The Concept of Military Alliance.” In Erich Reiter and Heinz Gärtner (eds.) Small States and Alliances. Physica-Verlag.

Bierstedt, Robert. 1950. “An Analysis of Social Power.” American Sociological Review 15 (6).

Bingham, Hiram. 1914. "Should We Abandon the Monroe Doctrine?” In Hubbard Blakeslee, George, Granville Stanley Hall, Harry Elmer Barnes (eds.), The Journal of International Relations, Volume 4. Worcester, MA: Clark University.

Birch, Sarah. 1995. “The Ukrainian Parliamentary and Presidential Elections of 1994.” Electoral Studies 14 (1).

Birch, Sarah. 2000. Elections and Democratization in Ukraine. New York: MacMillan Press.

Black, David, Jeff Chinn, Robert Herman and Charlotte Watson. 2005. "Moldova Democracy and Government Assessment." United States Agency for International Development, December 2005.

Blair, Betty. 1999. "Looking Back on the Century, Personally and Professionally." Azerbaijan International 7 (4).

Booth, Ken. 1987. “Alliances.” In John Baylis et al. (eds.) Contemporary Strategy I. New York: Holmes \& Meier.

Booth, William. 2014. "Ukraine's Parliament Votes to Oust President." Washington Post Online, 22 February 2014. https://www.washingtonpost.com/world/europe/ukraines-yanukovychmissing-as-protesters-take-control-of-presidential-residence-inkiev/2014/02/22/802f7c6c9bd2-11e3-ad71e03637a299c0_story.html?utm_term=.b509dfb3294b.

Brawley, Mark. 2004. "The Political Economy of Balance of Power Theory." In T. V. Paul, James J. Wirtz, and Michel Fortmann (eds.) Balance of Power: Theory and Practice in the 21st Century. Stanford University Press.

Bremner, Charles. 2008. "Vladimir Putin Threat to Hang Georgian President 'by balls." The Guardian, 15 November 2008. http://www.theaustralian.com.au/archive/news/putinthreat-to-hang-leader-by-balls/news-story/fbf5f998da1deaf583419ad8392d4c53. 
Brewer, Marilynn B., and Rupert J. Brown. 1998. Intergroup Relations. McGraw-Hill.

Brooks, Stephen G. 1997. “Dueling Realisms.” International Organization 51 (3).

Brooks, Stephen G., and William C. Wohlforth. 2005. "Hard Times for Soft Balancing." International Security 30 (1).

Brooks, Stephen G. and William C. Wohlforth. 2008. World Out of Balance: International Relations and the Challenge of American Primacy. Princeton University Press.

Brooks, Stephen G., and William C. Wohlforth. 2011. "Assessing the Balance." Cambridge Review of International Affairs 24 (2).

Brown, Neville. 1989. "Climate, Ecology and International Security.” Survival 31 (6).

Bruni, Frank. 2001. "France and Germany Caution Bush on U.S. Missile Defense Plan." New York Times, 14 June 2001. http://www.nytimes.com/2001/06/14/world/14PREX.html? pagewanted=all. 14 June 2001 .

Bryant, Nick. 2014. "Ukraine's Yanukovych asked for troops, Russia tells UN." BBC, 04 March 2014. http://www.bbc.com/news/world-europe-26427848.

Buckley, Neil. 2013. "Georgian Wine to Flow as Russia Lifts Ban." Financial Times, 04 February 2013. https://www.ft.com/content/13269432-6ee9-11e2-9ded-00144feab49a.

Bueno de Mesquita, Bruce, and David Lalman. 1992. War and Reason. New Haven, CT: Yale University.

Bueno de Mesquita, Bruce. 2002. "Domestic Politics and International Relations." International Studies Quarterly 46 (1).

Bueno de Mesquita, Bruce. 2003. 'Neorealism's Logic and Evidence: When Is a Theory Falsified?" In John A. Vasquez and Colin Elman (eds.), Realism and the Balancing of Power: A New Debate. Saddle River, NJ: Prentice Hall.

Bull, Hedley. 1977. The Anarchical Society: A Study of Order in World Politics. London and Basingstoke: Macmillan.

Bush, George H.W. 1991. "Address Before a Joint Session of the Congress on the State of the Union, 29 January 1991.” The American Presidency Project. http://www.presidency. ucsb.edu/ws/?pid=19253.

Buzan, Barry and Thomas Dietz. 1999. "The European Union.” Survival 41 (1). 
Buzan, Barry. 1993. "Rethinking System and Structure.” In Barry Buzan, Charles Jones, and Richard Little (eds.) The Logic of Anarchy: Neorealism to Structural Realism. New York: Columbia University Press.

Buzan, Barry. 2004. The United States and the Great Powers: World Politics in The TwentyFirst Century. Cambridge: Polity Press.

Byman, Daniel L. and Kenneth M. Pollack. 2001. "Let Us Now Praise Great Men: Bringing the Statesman Back In.” International Security 25 (4).

Calus, Kamil. 2014. "Russian Sanctions against Moldova. Minor effects, Major Potential." Centre for Eastern Studies, 11 November 2014. https://www.osw.waw.pl/en/ publikacje/osw-commentary/2014-11-06/russian-sanctions-against-moldova-minoreffects-major-potential.

Campbell, David. 1992. Writing Security: United States Foreign Policy and the Politics of Identity. University of Minnesota Press.

Cantir, Cristian and Ryan Kennedy. 2014. "Balancing on the Shoulders of Giants: Moldova's Foreign Policy toward Russia and the European Union.” Foreign Policy Analysis 11 (4).

Carley, Kathleen. 1993. "Coding Choices for Textual Analysis: A Comparison of Content Analysis and Map Analysis.” Sociological Methodology 23.

Carney, Stephen A. 2012. Allied Participation in Operation Iraqi Freedom. Government Printing Office.

Central Intelligence Agency. 1988. "Unrest in the Caucasus and the Challenge of Nationalism." Declassified Research Paper, Director of Intelligence, August 1988.

Central Intelligence Agency. 1990. "Georgia: Independence Drive Accelerating." Directorate of Intelligence, 24 April 1990.

Cenusa, Denis, Michael Emerson, Tamara Kovziridse and Veronika Movchan. 2014. "Russia's Punitive Trade Policy Measures Towards Ukraine, Moldova and Georgia." CEPS Working Document No. 400.

Chalmers, Malcolm. 1990. "Beyond the Alliance System.” World Policy Journal 7 (2).

Charter of the Collective Security Treaty Organization. 2002. President of Russia Website. http://en.kremlin.ru/supplement/3506/.

Checkel, Jeffrey T. 1999. "Norms, Institutions, and National Identity in Contemporary Europe." International Studies Quarterly 43 (1). 
Cherniavskiy, Stanislav. 2010. "Russia and Azerbaijan: the Special Features and Main Vectors of Interstate Cooperation in the Post-Soviet Period." The Caucasus \& Globalization 4 (12).

Chidley, Colleen. 2014. "Towards a Framework of Alignment in International Relations." Politikon: South African Journal of Political Studies 41 (1).

Chivers, C.J. 2006. "Explosions in Southern Russia Sever Gas Lines to Georgia.” The New York Times, 23 January 2006. http://www.nytimes.com/2006/01/23/world/europe/explosionsin-southern-russia-sever-gas-lines-to-georgia.html.

Christensen, Thomas J., and Jack Snyder. 1990. "Chain Gangs and Passed Bucks: Predicting Alliance Patterns in Multipolarity.” International Organization 44 (2).

Chudowsky, Victor and Taras Kuzio. 2003. "Does public opinion matter in Ukraine? The case of Foreign Policy.” Communist and Post-Communist Studies 36.

Chun, Chae-Sung. 2000. "Theoretical Approaches to Alliance: Implications on the ROK-US Alliance." Journal of International and Area Studies 7 (2).

Churchill, Winston S. 1948. The Second World War: Volume I - The Gathering Storm. Boston: Houghton Mifflin.

CIS Legislation. 1999. "The Agreement Between the Government of the Russian Federation and the Government of Georgia on Avoidance of Double Taxation." http://cis-legislation. com/document.fwx?rgn=6650.

“CIS Summit Ends; 'Not a Single Document' Signed." 1997. Basapress, 23 October 1997.

Clark, Ian. 1989. The Hierarchy of States: Reform and Resistance in the International Order. New York: Cambridge University Press.

Claude, Inis L. 1989. "The Balance of Power Revisited." Review of International Studies 15 (2).

Clausewitz, Carl von. 1989. On War. Michael Howard and Peter Paret (eds). Princeton: Princeton University Press.

Clinton, William Jefferson. 1994. "Remarks Welcoming President Leonid Kuchma of Ukraine." The American Presidency Project-William J. Clinton, 22 November 1994. http://www. presidency.ucsb.edu/ws/index.php?pid= 49506 .

Clinton, William J. 1997. Public Papers of the Presidents of the United States: William J. Clinton, 1997. Best Books On. 
Coalson, Robert. 2009. "Russia's Message to Ukraine Echoes Across Former Soviet Union." Radio Free Europe/Radio Liberty, 12 August 2009. https://www.rferl.org/a/Russias_ Message_To_Ukraine_Echoes_Across_Former_Soviet_Union/1798413.html.

Cobden, Richard. [1903] 1969. The Political Writings of Richard Cobden. F. W. Chesson, ed. London: T. Fisher Unwin. 1903. Library of Economics and Liberty [Online]. http://www. econlib.org/library/YPDBooks/Cobden/ cbdPW6.html.

Cohen, Ariel. 2006. "The Dragon Looks West: China and the Shanghai Cooperation Organization." The Heritage Foundation, Lecture \#961 on Asia, Russia and Eurasia, Shanghai Cooperation Organization, 03 August 2001.” http://www.heritage.org/research /lecture/the-dragon-looks-west-china-and-the-shanghai-cooperation-organization.

Cohen, Raymond. 1979. Threat Perception in International Crisis. Madison: University of Wisconsin Press.

Collier, David. 1998. "Comparative Method in the 1990s." Newsletter of the American Political Science Association Organized Section in Comparative Politics 9 (1).

Collin, Matthew. 2006. “Azeris Warn Russia on Gas Prices.” BBC News, 24 December 2006. http://news. bbc.co.uk/2/hi/europe/6207257.stm.

Collin, Mathew. 2007. “Azeri Radar Eyed for U.S. Shield.” BBC News, 18 June 2007. http:// news.bbc.co.uk/2/hi/europe/6764079.stm.

Colton, Timothy J. 2000. Transitional Citizens: Voters and What Influences Them in the New Russia. Harvard University Press.

Constitution of Ukraine. 2014. European Commission for Democracy Through Law (Venice Commission).

Copeland, Eale C. 2000. Origins of Major War. Ithaca: Cornell University Press.

Coppedge, Michael. 1999. "Thickening Thin Concepts and Theories: Combining large N and Small N in Comparative Politics." Comparative Politics 31 (4).

Copsey, Nathaniel. 2011. Public Opinion and Making of Foreign Policy in the "New Europe"- A Comparative Study of Poland and Ukraine. Burlington Vermont: Ashgate Publishing Company.

Cornell, Svante E. 2011. Azerbaijan Since Independence. Routledge.

Costello, M. 1978. “Eastern Mediterranean Security.” Editorial Research Reports 1978 (Vol. II). Washington, DC: CQ Press. http://library.cqpress.com/cqresearcher/cqresrre1978070700. 
Country Assessments and Performance Measures-Ukraine. 2005. United States Department of State-Bureau of European and Eurasian Affairs. https://www.state.gov/p/eur/rls/rpt/ 55799.htm.

Country Assessments and Performance Measures-Ukraine. 2006. United States Department of State-Bureau of European and Eurasian Affairs. https://www.state.gov/p/eur/rls/rpt/ 63181.htm.

Country Assessments and Performance Measures-Ukraine. 2007. United States Department of State-Bureau of European and Eurasian Affairs. https://www.state.gov/p/eur/rls/rpt/ 92794.htm.

Cronin, Bruce. 1998/1999. "From Balance to Community: Transnational Identity and Political Integration.” Security Studies 8 (2/3).

Crowther, William and Helen Fedor. 1995. Belarus and Moldova Country Studies. Washington D.C.: Government Printing Office.

Crowther, William. 1997. "The Politics of Democratization in Postcommunist Moldova." In Dawisha, Karen, and Bruce Parrott (eds.) Democratic Changes and Authoritarian Reactions in Russia, Ukraine, Belarus and Moldova Vol. 3. Cambridge University Press.

Crowther, William. 2007. "Moldova, Transnistria and the PCRM's Turn to the West." East European Quarterly 41 (3).

Czerewacz-Filipowicz, Katarzyna, and Agnieszka Konopelko. 2016. Regional Integration Processes in the Commonwealth of Independent States: Economic and Political Factors. Springer.

D'Anieri, Paul J. 2007. Understanding Ukrainian Politics: Power, Politics, and Institutional Design. New York: ME Sharpe.

D'Orazio, Vito. 2012. “Advancing Measurement of Foreign Policy Similarity.” APSA 2012 Annual Meeting Paper.

Danileyan, Emil. 2002. "U.S. Scraps Arms Ban on Armenia, Azerbaijan. Radio Free Europe/Radio Liberty, 29 March 2002. https://www.azatutyun.am/a/1567641.html.

Daniloff, Ruth. 1995. "Oil and Blood in the Caucasus." The Washington Post, 01 October 1995. https://www. washingtonpost.com/archive/opinions/1995/10/01/oil-and-blood-in-thecaucasus/a7855658-019c-4f5e-b2e2-75b1413cb152/?utm_term=.10d55814af64.

David, Stephen R. 1991. Choosing Sides: Alignment and Realignment in the Third World. Baltimore: The Johns Hopkins University Press.

De Santis, Hugh. 1991. “The Graying of NATO.” Washington Quarterly 14 (4). 
Declaration to Complement the Charter on a Distinctive Partnership. 2009. NATO, 21 August 2009. https://www.nato.int/cps/ ua/natohq/official_texts_57045.htm.

Demidetskiy, Valeriy. 1998. "Moldovan President Expresses Support for 'Centrists'.” Itar-Tass, 20 March 1998.

Demidetsky, Valery. 2002. "Moldova Willing to join Eurasian Economic Community.” ItarTass, 09 October 2002.

Deutsch, Karl W. 1968. The Analysis of International Relations. Vol. 12. Englewood Cliffs, NJ: Prentice-Hall.

Deutsch, Karl W., et al. 1957. Political Community and the North Atlantic Area. Princeton: Princeton University Press.

Deutsch, Karl. W. and J. David Singer. 1964. "Multipolar Power Systems and International Stability." World Politics 16 (3).

Dix, Holger. 2011. "Republic of Moldova at the End of an Election Marathon?” KAS International Reports, 2011. http://www.kas.de/wf/doc/kas_21875-544-230.pdf?110209122237.

Dmitri Trenin Dmitri. 2014. "The Ukraine Crisis and the Resumption of Great-Power Rivalry." Carnegie Moscow Center 9 (7).

Dorff, Robert. 1998. "Public Opinion and NATO Enlargement." In Stephen Blank (ed.) NATO After Enlargement: New Challenges, New Missions, New Forces. Carlisle, PA: U.S. Army War College, Strategic Studies Institute.

Downs, George W., and David M. Rocke. 1995. Optimal Imperfection? Domestic Uncertainty and Institutions in International Relations. Princeton, NJ: Princeton University Press.

Dreher, Axel, Peter Nunnenkamp, and Rainer Thiele. 2008. "Does U.S. Aid Buy U.N. General Assembly Votes? A Disaggregated Analysis.” Public Choice 136.

Duffield, John S. 1999. "Political Culture and State Behavior: Why Germany Confounds Neorealism.” International Organization 53 (4).

Dyomkin, Denis and Yuri Kulikov. 2010. "Russia's Medvedev Cozies up to Ukraine with Visit." Reuters, 17 May 2010. https://www.reuters.com/article/us-russia-ukraine/russiasmedvedev-cozies-up-to-ukraine-with-visit-idUSTRE64G4TT20100517.

Dzhindzhikhashvili, Misha. 2006. "Russia Recalls Ambassador.” The Washington Post, 29 September 2006. http://www.washingtonpost.com/wpdyn/content/article/2006/09/28/ AR2006092800658.html. 
Eagly, Alice H., and Shelly Chaiken. 1998. “Attitude Structure and Function.” In Daniel T. Gilbert, Susan T. and Gardner Lindzey (Eds) The Handbook of Social Psychology, Vols. 1-2, 4th ed. New York: McGraw-Hill.

Ehin, Piret and Eiki Berg. 2009. "Incompatible Identities? Baltic-Russian Relations and the EU as an Arena for Identity Conflict." In Eiki Berg and Piret Ehin (eds.) Identity and Foreign Policy: Baltic-Russian Relations and European Integration. Burlington, VT: Ashgate Publishing.

Ekedahl, Carolyn and Melvin A. Goodman. 2010. Wars of Eduard Shevardnadze. Penn State Press.

Elizabeth Sherwood-Randall, 2000. "Memorandum for the President." In Robert B. Zoellick and Philip D. Zelikow (eds.) America and Russia: Memos to a President. New York: W.W. Norton \& Company.

Elman, Miriam Fendius. 1995. "The Foreign Policies of Small States: Challenging Neorealism in its Own Backyard," British Journal of Political Science 25 (2).

Embassy of the Republic of Moldova to the United States and Mexico. 2015. Diplomatic Relations-Visits. http://www.sua.mfa.md/diplomatic-relations-en/.

Ereli, Adam. 2003. "Press Statement, Presidential Election in Azerbaijan." U.S. Department of State, 21 October 2003. https://2001-2009.state.gov/r/pa/prs/ps/2003/25502.htm.

Ergun, Ayca. 2005. "Democratization from Below: The Role of Civil Society in Azerbaijan." In Ayes Gunta-Ayata, Ayca Ergun, and Isil Celimli (eds.) Black Sea Politics: Political Culture and Civil Society in an Unstable Region. London: IB Tauris.

European Union. 2016. “Security and Defense.” http://www.eeas.europa.eu/csdp/index_en.htm.

“European Integration Remains Moldovan Priority.” Basapress, 28 August 2000.

Executive Office of the President. 2007. "United States and Georgia Sign Trade and Investment Framework Agreement." Office of the United States Trade Representative, June 2007. https://ustr.gov/about-us/policy-offices/press-office/pressreleases/archives/2007/june/ united-states-and-georgia-sign-trade-and-inv.

Fearon, James D. 1998. "Domestic Politics, Foreign Policy, and Theories of International Relations." Annual Review of Political Science 1 (1).

Fedder, Edwin H. 1968. “The Concept of Alliance.” International Studies Quarterly 12 (1).

Federal Department of Foreign Affairs. 2016. "Protocols and Visits." https://www.eda. admin.ch/eda/en/home/fdfa/diplomacy/protocol-and-visits.html. 
Feng, Huiyun. 2006. "Crisis Deferred: An Operational Code Analysis of Chinese Leaders Across the Strait." In Mark Schafer and Stephen Walker (eds.) Beliefs and Leadership in World Politics: Methods and Applications of Operational Code Analysis. New York: Palgrave Macmillan.

Fiefer, Gregory. 2002. "Caspian: Russia, Azerbaijan Sign Agreement on Sea Boundaries.” Radio Free Europe/Radio Liberty, 24 September 2002. https://www.rferl.org/a/1100881.html.

Finnemore, Martha, and Kathryn Sikkink. 2001. "Taking Stock: The Constructivist Research Program in International Relations and Comparative Politics." Annual Review of Political Science 4 (1).

Foreign Aid Explorer. 2017. Economic Analysis Data Services. United States Agency for International Development. https://explorer.usaid.gov.

Fortmann, Michel, T. V. Paul, and James J. Wirtz. 2004. "Conclusions: Balance of Power at the Turn of the New Century.” In T. V. Paul, James J. Wirtz, and Michel Fortmann (eds.) Balance of Power: Theory and Practice in the 21st Century. Stanford University Press.

Fox, Annette Baker. 1959. The Power of Small States: Diplomacy in World War II. University of Chicago Press.

Franke, Anja, Andrea Gawrich, and Gurban Alakbarov. 2009. "Kazakhstan and Azerbaijan as Post-Soviet Rentier States: Resource Incomes and Autocracy as a Double 'Curse' in postSoviet regimes.” Europe-Asia Studies 61 (1).

Freedman, Robert. 1998. "Primakov and the Middle East." The State of Russian Foreign Policy and U.S. Policy Toward Russia. The Heritage Lectures, no. 607. http://s3.amazonaws. com/thf_media/1998/pdf/hl607.pdf.

Freedom House. 1999. "Ukraine.” Freedom in the World 1999. https://freedomhouse.org/report/ freedom-world/1999/ukraine.

Freedom House. 2006. "Georgia.” Freedom in the World 2006. https://freedomhouse.org/report/ freedom-world/2006/georgia.

Freedom House. 2009. “Ukraine.” Freedom in the World 1998-2003. https://freedomhouse.org/ report/freedom-world/2009/ukraine.

Freedom House. 2015. “Azerbaijan.” Freedom in the World 2015. https://freedomhouse.org/ report/freedom-world/2015/azerbaijan.

Freedom House. 2015. "Georgia.” Freedom in the World 2015. https://freedomhouse.org/report/ freedom-world/2015/georgia. 
Freedom House. 2017. “Azerbaijan.” Freedom in the World 1998-2003. https://freedomhouse. org/country/azerbaijan.

Fukuyama, Francis. 1989. “The End of History?” The National Interest 16.

Fuller, Liz. 1998. "1998 In Review: Little Progress in Caucasus Conflicts." Radio Free Europe / Radio Liberty, 09 December 1998. https://www.rferl.org/a/1090161.html.

Gaddis, John Lewis. 1982. Strategies of Containment: A Critical Appraisal of Postwar American National Security Policy. Oxford University Press.

Gelb, Bernard. 2007. "Russian Natural Gas: Regional Dependence." Congressional Research Service, 05 January 2007. http://www.dtic.mil/dtic/tr/fulltext/u2/a460847.pdf.

George, Alexander L., and Andrew Bennett. 2005. Case Studies and Theory Development in The Social Sciences. MIT Press.

George, Alexander. 1969. "The 'Operational Code': A Neglected Approach to the Study of Political Leaders and Decision-making." International Studies Quarterly 13 (2).

George, Alexander. 1979. "The Causal Nexus between Cognitive Beliefs and Decision-Making Behavior: The 'Operational Code' Belief System.” In Lawrence S. Falkowski (ed.) Psychological Models of International Politics. Boulder, CO: Westview Press.

Georgia Country Commercial Guide. 2017. "Georgia, 2 Bilateral Investment Agreements. Export.gov, 19 July 2017. https://www.export.gov/article?id=Georgia-2-BilateralInvestment-Agreement.

“Georgia: Shevardnadze Says Exercises Reflect 'High Level of Cooperation' with NATO.” 2002. Tbilisi Georgian Radio 1, 17 June 2002.

Georgia's New National Security Concept. 2011. Civil.ge, 23 December 2011. http://civil.ge/ eng/article. php?id=24299.

Gerner, Deborah J., et al. 2002. "Conflict and mediation event observations (CAMEO): A New Event Data Framework for the Analysis of Foreign Policy Interactions." International Studies Association, New Orleans.

Geybullayeva, Arzu. 2015. “Azerbaijan: Striking a Balance between Russia and the West.” In Anahit Shirinyan and Louisa Slavkova (eds), Unrewarding Crossroads? The Black Sea Region amidst the European Union and Russia. Sofia Platform.

Gibler, Douglas M. 2008. International Military Alliances, 1648-2008. CQ Press.

Gibler, Douglas M. and Meredith Reid Sarkees. 2004. "Measuring Alliances: The Correlates of War Formal Interstate Alliance Dataset, 1816-2000.” Journal of Peace Research 41 (2). 
Giddens, Anthony. 1991. Modernity and Self-identity: Self and Society in the Late Modern Age. Stanford University Press.

Gilpin, Robert W. 1981. War and Change in World Politics. Cambridge: Cambridge University Press.

Goldstein Joshua S. 1992. “A Conflict-Cooperation Scale for WEIS Events Data.” Journal of Conflict Resolution 36 (2).

Goldstein, Judith, and Robert Owen Keohane, eds. 1993. Ideas and Foreign Policy: Beliefs, Institutions, and Political Change. Cornell University Press.

Gombos, Catalin and Dragos C. Mateescu. 2012. "Moldova's Political Self and the Energy Conundrum in the Context of the European Neighborhood Policy." Central European Journal of International and Security Studies 6.

Gotsadze, Elene. 2014. "Georgia in International Peacekeeping Missions.” Information Center on NATO and EU. http://eu-nato.gov.ge/sites/default/files/ENGLISH.pdf.

Government of Ukraine. 1990. "Declaration of State Sovereignty of Ukraine.” Verkhovna Rada of the Ukrainian SSR, 16 July 1990. http://static.rada.gov.ua/site/postanova_eng/ Declaration_of_State_Sovereignty_of_Ukraine_rev1.htm.

Gowa, Joanne. 2011. “The Democratic Peace After the Cold War.” Economics \& Politics 23 (2).

Gowing, Margaret, and Lorna Arnold. 1974. Independence and Deterrence. Britain and Atomic Energy, 1945-1952. Volume I. Policy Making. Palgrave Macmillan.

Gribincea, Mihai. "Russian Troops in Transnistria - a Threat to the Security of the Republic of Moldova. Moldova.org. "http://www.moldova.org/en/russian-troops-in-transnistria-athreat-to-the-security-of-the-republic-of-moldova-20998-eng/.

Grieco, Joseph M. 1988. "Anarchy and the Limits of Cooperation: A Realist Critique of the Newest Liberal Institutionalism.” International Organization 42 (3).

Grieco, Joseph M. 2007. "Structural Realism and the Problem of Polarity and War." In Felix Berenskoetter and M. J. Williams (eds), Power in World Politics. New York: Routledge.

Grove, Thomas. 2013. "Russia starts delivering \$1 billion Arms Package to Azerbaijan." Reuters, 18 June 2013. https://www.reuters.com/article/us-russia-azerbaijan-arms/russiastarts-delivering-1-billion-arms-package-to-azerbaijan-idUSBRE95H0KM20130618.

Grytsenko, Anatolii. 1999. “Ukraine's Defense Sector in Transition: Impacts on Foreign and Security Policy”. In Kurt R. Spillman, Andreas Wenger, and Derek Muller (eds.) Between Russia and the West: Foreign and Security Policy of Independent Ukraine. Bern: Peter Lang. 
Grytsenko, Oksana. 2013. "Yanukovych Confirms Refusal to Sign Deal with EU." Kyiv Post, 26 November 2013. http://www.kyivpost.com/content/politics/yanukovych-confirmsrefusal-to-sign-deal-with-eu-332493.html.

Gulick, Edward V. 1955. Europe's Classical Balance of Power. Ithaca, NY: Cornell University Press.

Gupta, Amit. 2006. The Second Bush Presidency: Global Perspectives. Pearson Education India.

Gutterman, Steve. 1994. “Azerbaijan Parliament Ratifies Oil Deal.” UPI, 15 November 1994. https://www.upi.com/Archives/1994/11/15/Azerbaijan-parliament-ratifies-oildeal/2509784875600/.

Guzzini, Stefano. 2006. "From (Alleged) Unipolarity to the Decline of Multilateralism? A Power-theoretical Critique." In Edward Newman, Ramesh Thakur and John Tirman (eds), Multilateralism Under Challenge? Power, International Order, and Structural Change. New York: United Nations University Press.

Gvalia, Giorgi, David Siroky, Bidzina Lebanidze and Zurab Iashvili. 2011. Political Elites, Ideas and Foreign Policy: Explaining and Understanding the International Behavior of Small States in the Former Soviet Union. Tbilisi: Ilia State University.

Gvalia, Giorgi, David Siroky, Bidzina Lebanidze and Zurab Iashvili. 2013. "Thinking Outside the Bloc: Explaining the Foreign Policies of Small States.” Security Studies 22 (1).

Haas, de Marcel. 2011. "Russia’s Military Reform: Victory After 20 Years of Failure.” Netherlands Institute of International Relations, Clingendael Paper No. 5.

Haas, Ernst B. 1953. “The Balance of Power: Prescription, Concept, or Propaganda?” World Politics 55 (4).

Hagan, Joe D. 1987. "Regimes, Political Oppositions, and the Comparative Analysis of Foreign Policy." In New Directions in the Study of Foreign Policy. Boston: Allen and Unwin.

Hagan, Joe D. 1989. "Domestic Political Regime Changes in Third World Voting Realignments and the United Nations, 1946 -84.” International Organization 43 (3).

Hagan, Joe D. 1994. "Domestic Political Regime Change and Foreign Policy Restructuring: A Framework for Comparative Analysis." In Jerel A. Rosati, Joe D. Hagan, and Martin W. Sampson (eds.) Foreign Policy Restructuring: How Governments Respond to Global Change. Columbia, SC: University of South Carolina Press.

Hagan, Joe D. 2015. "Coalition Politics and Foreign Policy Decision Making in Anocratic Regimes." Paper prepared for Presentation at the Annual Meeting of the British International Studies Association, Edinburgh, UK; June 17-19, 2016. 
Hall, Rodney Bruce. 1998/1999. "Territorial and National Sovereigns: Sovereign Identity and Consequences for Security Policy." Security Studies 8 (2/3).

Hallward-Driemeier, Mary. 2003. "Do Bilateral Investment Treaties Attract Foreign Direct Investment? Only a Bit and They Could Bite.” World Bank Policy Research Working Paper 3121.

Handel, Michael. 1990. Weak States in the International System. London: Frank Cass Publishers.

Harding, Luke. 2007. "State of Emergency in Georgia as Street Protests Turn Violent." The Guardian, 17 October 2007. https://www.theguardian.com/world/2007/nov/08/ russia.georgia.

Harding, Luke 2010. "Viktor Yanukovych Promises Ukraine will Embrace Russia.” The Guardian, 05 March 2010. https://www.theguardian.com/world/2010/mar/05/ukrainerussia-relations-viktor-yanukovych.

Harding, Luke. 2010a. "Ukraine Extends Lease for Russia's Black Sea Fleet." The Guardian, 21 April 2010. https://www.theguardian.com/world/2010/apr/21/ukraine-black-sea-fleetrussia.

Harding, Luke. 2014. "Georgia Angered by Russia-Abkhaz Military Agreement.” The Guardian, 25 November 2014. https://www.theguardian.com/world /2014/nov/25/georgia-russiaabkhazia-military-agreement-putin.

Hassner, Pierre. 1990. "Europe Beyond Partition and Unity: Disintegration or Reconstitution?" International Affairs 66 (3).

Haugaard, Mark. 2010. “Power: A ‘Family Resemblance’ Concept.” European Journal of Cultural Studies 13 (4).

Havarky, R. H. 1989. Bases Abroad: The Global Foreign Military Presence. Oxford: Oxford University Press.

He, Kai. 2012. "Undermining Adversaries: Unipolarity, Threat Perception, and Negative Balancing Strategies after the Cold War." Security Studies 21 (2).

Hemmer, Christopher and Peter J. Katzenstein. 2002. "Why is There No NATO in Asia? Collective Identity, Regionalism, and the Origins of Multilateralism." International Organization 56 (3).

Henderson, Simon. 2001. "The Gulf Cooperation Council Defense Pact: An Exercise in Ambiguity." The Washington Institute, 16 January 2001. http://www.washingtoninstitute. org/policy-analysis/view/the-gulf-cooperation-council-defense-pact-an-exercise-inambiguity. 
Heradstveit, Daniel. 2001. "Local Elites Meet Foreign Corporations: The Examples of Iran and Azerbaijan.” Norwegian Institute of International Affairs Working Paper 617 (June).

Herbert, Rudolph. 2009. "Interview with Moldovan Prime Minister Vlad Filat.” Euronews, 08 August 2009. http://www.euronews.com/2009/10/07/interview-moldovan-primeminister-vlad-filat.

Hermann, Margaret G., Charles F. Hermann and Joe. D. Hagan. 1987. "How Decision Units Shape Foreign Policy Behavior.” In Charles F. Hermann, Charles W. Kegley, Jr. and James N. Rosenau (eds.) New Directions in the Study of Foreign Policy. London: Allen \& Unwin.

Hermann, Margaret G., Thomas Preston, Baghat Korany, and Timothy M. Shaw. 2001. "Who Leads Matters: The Effects of Powerful Individuals." International Studies Review 3 (2).

Herrmann, Richard K. 1985. Perceptions and Behavior in Soviet Foreign Policy. Pittsburgh, PA: University of Pittsburgh Press.

Herrmann, Richard K. and Michael P. Fischerkeller. 1995. "Beyond the Enemy Image and Spiral Model: Cognitive-Strategic Research After the Cold War." International Organization 49 (3).

Herrmann, Richard K., James F. Voss, Tonya Y. E. Schooler, and Joseph Ciarrochi. 1997. "Images in International Relations: An Experimental Test of Cognitive Schemata." International Studies Quarterly 41 (3).

Herszenhorn, David. 2012. "Russia to Close Radar Station in Azerbaijan." New York Times, 11 December 2012. "http://www.nytimes.com/2012/12/12/ world/europe/russia-to-shutdown-radar-station-in-azerbaijan.html.

Hill, Fiona and Pamela Jewett. 1994. "Intervention in the Internal Affairs of the Former Soviet Republics and the Implications for United States Policy Towards Russia.” Harvard University, John F. Kennedy School of Government. https://www.brookings.edu/wpcontent/uploads/2016/06/Back-in-the-USSR-1994.pdf.

Hirschman, Albert O. 1961, "Ideologies of Economic Development in Latin America" In Albert O. Hirschman (ed.) Latin American Issues. New York: Twentieth Century Fund.

Hoffmann, Erik Peter and Frederic J. Fleron, eds. 1971. The Conduct of Soviet Foreign Policy. Transaction Publishers.

Hoffmann, Stanley N. 1959. "International Relations: The Long Road to Theory." World Politics $11(3)$. 
Hogg, Michael A. 1996. Intragroup Processes, Group Structure, and Social Identity. In Robinson, William (ed.), Social Groups and Identities: Developing the Legacy of Henri Tajfel. Oxford: Butterworth-Heinemann.

Hogg, Michael A. and Deborah I. Terry. 2000. "Social Identity and Self-Categorization Processes in Organizational Contexts." Academy of Management Review 25 (1).

Hogg, Michael A., Deborah J. Terry, and Katherine M. White. 1995. “A Tale of Two Theories: A Critical Comparison of Identity Theory with Social Identity Theory." Social Psychology Quarterly 58 (4).

Holsti, Kalevi. J. 1970. National Role Conceptions in the Study of Foreign Policy. International Studies Quarterly 14 (3).

Holsti, Ole R., P. Terrance Hoffman and John D. Sullivan (eds.). 1973. Unity and Disintegration in International Alliances. Lanham, MD: University Press of America.

Honorary Consulate of Moldova in India. 2016. "Foreign Relations: Republic of Moldova." http://www.consulateofmoldova.in/foreign-relations.html.

Horowitz, Shale. 2003. "War After Communism: Effects on Political and Economic Reform in the Former Soviet Union and Yugoslavia.” Journal of Peace Research 40 (1).

Houston-Baku Sister City Association. 2017. https://houstonbaku.org.

Hovi, Jon, Detlef F. Sprinz, and Guri Bang. 2012. "Why the United States did not become a Party to the Kyoto Protocol: German, Norwegian, and US perspectives." European Journal of International Relations 18 (1).

Hrycak Jarostaw. 2000. Historia Ukrainy 1772-1999. The Birth of a Modern Nation. Institute of Central and Eastern Europe. Lublin. http://shron.chtyvo.org.ua/Hrytsak_Yaroslav/ Historia_Ukrainy_17721999_Narodziny_nowoczesnego_narodu_pol.pdf.

Human Rights House. 2004. “Azerbaijani Leaders Sentenced to Long Prison Terms.” http:// humanrightshouse.org/Articles/6171.html.

Human Rights Watch. 2017. “Azerbaijan-Reports.” https://www.hrw.org/publications?country\% $5 \mathrm{~B} 0 \% 5 \mathrm{D}=9583$.

Huntington, Samuel P. 1991. "Democracy's Third Wave.” Journal of Democracy 2 (2).

Huth, Paul. 2009. Standing your Ground: Territorial Disputes and International Conflict. University of Michigan Press.

Ibrahimov, Rovshan. 2014. "U.S.-Azerbaijan Relations: A View from Baku." Rethink Institute, 14 October 2014. 
Iglesias, Julien Danero. 2013. “Constructing National History in Political Discourse: Coherence and Contradiction (Moldova, 2001-2009).” Nationalities Papers 41 (5).

Ikenberry, G. John, Michael Mastanduno, and William C. Wohlforth. 2009. "Unipolarity, State Behavior, and Systemic Consequences." World Politics 61 (1).

Ikenberry, G. John. 1998. "Institutions, Strategic Restraint, and the Persistence of American Postwar Order.” International Security 23 (3).

Integrated Conflict Early Warning System (ICEWS). 2016. Harvard Dataverse. https://dataverse. harvard.edu.

Interagency Commission to be set up for Ukraine's Ascendance to NATO. Ukrainian Government Web Portal, 03 March 2006. http://www.kmu.gov.ua/control/en/ publish/article?art_id=31466745\&cat_id=244315200.

International Monetary Fund Staff Country Report. 2002. "Republic of Moldova: 2002 Article IV Consultation, First Review Under the Three-Year Arrangement Under the Poverty Reduction and Growth Facility and Request for Waiver of Performance Criteria." International Monetary Fund.

International Trade Administration. 2017. "Ukraine-Trade Agreements." United States Department of Commerce. https://www.export.gov/article?id=Ukraine-TradeAgreements.

Ismayilov, Ravshon. 2008. "Kosovo and Karabakh: How Azerbaijan Sees the Connection." Eurasianet, 28 March 2008. https://reliefweb.int/report/azerbaijan/kosovo-and-karabakhhow-azerbaijan-sees-connection.

Istanbul Document 1999. 2000. Organization for Security Cooperation in Europe. http://www. osce.org/mc/ 39569?download=true.

Iwański, Tadeusz. 2016. "Ukraine: Successful Diversification of Gas Supply." The Centre for Eastern Studies (OSW), 03 February 2016. https://www.osw.waw.pl/en/publikacje/ analyses/2016-02-03/ukraine-successful-diversification-gas-supply.

Jackson, Robert 2000. The Global Covenant. Human Conduct in a World of States. Oxford: Oxford University Press.

Jakniunaite, Dovile. 2009. "Neighborhood Politics of Baltic States: Between the EU and Russia." In Eiki Berg and Piret Ehin (eds.) Identity and Foreign Policy: Baltic-Russian Relations and European Integration. Burlington, VT: Ashgate Publishing.

James Roaf et. al. 2014. "25 Years of Transition Post-Communist Europe and the IMF." The International Monetary Fund, Washington D.C. https://www.imf.org/external/ pubs/ft/reo/2014/eur/eng/pdf/erei_sr_102414.pdf. 
Jarvenpaa, Pauli. 2016. "NATO’s Truly Enhanced Partnership Program.” International Centre for Defense and Security, July 2016. https://www.icds.ee/fileadmin/media/icds.ee/failid/ Pauli_Jarvenpaa_NATO_s_Truly_Enhanced_Partnership.pdf.

Jervis, Robert. 1976. Perceptions and Misperceptions in International Politics. Princeton: Princeton University Press.

Jervis, Robert. 1997. System Effects: Complexity in Political and Social Life. Princeton: Princeton University Press.

Joffe, Josef. 2001. “Who's afraid of Mr. Big?” The National Interest 64 (Summer 2001).

Joffe, Josef. 2002. "Defying History and Theory: The United States as the Last Remaining Superpower." In G. John Ikenberry (ed.) America Unrivaled: The Future of the Balance of Power. Ithaca, NY: Cornell University Press.

Johnson, Allan G. 1995. The Blackwell Dictionary of Sociology. Cambridge: Blackwell Reference.

Joint Meeting \& Joint Session Addresses Before Congress by Foreign Leaders \& Dignitaries. 2017. United States House of Representatives-History, Art, and Archives. http://history.house.gov/Institution/Foreign-Leaders/Joint-Sessions/.

Jones, Seth G. 2006. The Rise of Europe: Great Power Politics and Security Cooperation. Cambridge: Cambridge University Press.

Kagan, Donald. 1995. On the Origins of War and the Preservation of the Peace. New York: Doubleday.

Kakachia, Kornely and Salome Minesashvili. 2015. "Identity Politics: Exploring Georgian Foreign Policy Behavior.” Journal of Eurasian Studies 6 (2).

Kaplan, Morton A. 1957. System and Process in International Politics. New York: John Wiley \& Sons, Inc.

Karatnycky, Adrian. 2005. "Ukraine's Orange Revolution.” Foreign Affairs 84 (2).

Karmanu, Yaras. 2006. "Russia Ending Ban on Moldovan Products." The Associated Press, 28 November 2006. http://www.washingtonpost.com/wp-dyn/content/article/2006/11/28/ AR2006112801119.html.

Kassimeris, Christos. 2009. “The Foreign Policy of Small Powers.” International Politics 46 (1).

Katchanovski, Ivan. 2006. Cleft Countries: Regional Political Divisions and Cultures in PostSoviet Ukraine and Moldova. Vol. 33. Columbia University Press. 
Kazimova, Arifa. 2011. “Azerbaijan Joins Ranks of Non-Aligned Movement.” Radio Free

Europe/Radio Liberty, 25 May 2011. https://www.rferl.org/a/azerbaijan_join _nonaligned_movement/24200776.html.

Kelly, Michael. 2013. "Ukraine Just Made A 'Civilization Defining' Decision — And It Picked Russia Over the West.” Business Insider, 21 November 2013. http://www.businessinsider.com/ukraine-wont-sign-eu-agreement-2013-11.

Kennedy, Paul. 1982. The Rise of the Anglo-German Naval Rivalry, 1860 - 1914. London: Allen \& Unwin.

Kennedy, Paul. 1987. The Rise and Fall of the Great Powers: Economic Change and Military Conflict from 1500 to 2000. New York: Random House.

Keohane, Robert O. 1969. "Lilliputians' Dilemmas: Small States in International Politics.” International Organization 23 (2).

Keohane, Robert O. 1989. International Institutions and State Power: Essays in International Relations Theory. Boulder, Colorado: Westview Press.

Keohane, Robert O. 1993. "The Diplomacy of Structural Change: Multilateral Institutions and State Strategies." In Helga Haftendorn and Christian Tuschhoff (eds.) America and Europe in an Era of Change. Boulder, CO: Westview Press.

Keohane, Robert O. 2012. "Twenty Years of Institutional Liberalism." International Relations $26(2)$.

Khanna, Parag. 2008. The Second World: Empires and Influence in the New Global Order. New York: Random House.

Kim, Soo Yeon and Bruce Russett. 1996. "The New Politics of Voting Alignments and United Nations General Assembly.” International Organization 50 (4).

Kirkpatrick, Ambassador Jeane J. 1985. "Introductory Statement." In Report to Congress on Voting Practices in the United Nations, 20 May 1985. Washington: United States Department of State.

Kissinger, Henry. 2011. White House Years. Simon and Schuster.

Klare, Michael T. 1984. "Soviet Arms Transfers to the Third World." Bulletin of the Atomic Scientists 40 (5).

Klympush-Tsintsadzen, Ivanna. 2017. "U.S.-Ukraine Relations in the Context of Euro-Atlantic Security." Small Group Event at the Center for Strategic and International Studies (CSIS), 11 September 2017. 
Knorr, Klaus. 1970. Military Power and Potential. Lexington: D.C. Heath.

Kornely, Kakachia, and Cecire Michael. 2013. "Georgian Foreign Policy: The Quest for Sustainable Security.” Tbilisi, GA: Konrad-Adenauer-Stiftung.

Korsunskaya, Darya and Timothy Heritage. 2013. "Russian Bailout Wins Ukraine Economic Respite but Deepens Political Rift.” Reuters, 17 December 2013. http://www.reuters.com/ article/us-ukraine/russian-bailout-wins-ukraine-economic-respite-but-deepens-politicalrift-idUSBRE9BF11U20131217.

Kozhokin, Evgeny. 1996. "Chapter 5: Georgia-Abkhazia.” In Jeremy R. Azrael and Emil A. Payin (eds.) US and Russian Policymaking with Respect to the Use of Force. Rand Corporation. https://www.rand.org/pubs/conf_proceedings/CF129/CF-129chapter5.html.

Kozyrev, Andrei. 1995. Cited in Valentina Starova, "Kozyrev: Russia Remains 'Great Power."” UPI, 27 February 1995. http://www.upi.com/Archives/1995/02/27/Kozyrev-Russiaremains-Great-Power/1490793861200/.

Kramer, Andrew and Ellen Berry. 2008. "Russia, In Accordance with Georgia, Set Withdrawal." The New York Times, 12 August 2008. http://www.nytimes.com/2008/08/13/world/ europe/13georgia.html?mtrref=www.google.com\&gwh=6337FB545276FA5EB97C9CF4 4CDA0F2D\&gwt=pay.

Krasner, Stephen D. 1993. "Power, Polarity, and the Challenge of Disintegration." In Helga Haftendorn and Christian Tuschhoff, (eds.) America and Europe in an Era of Change. Boulder, CO: Westview Press.

Krawciw, Nicholas. 2016. "Ukrainian Perspectives on National Security and Ukrainian Military Doctrine." In Bruce Parrot (ed.) State Building and Military Power in Russia and the New States of Eurasia 5. Routledge.

Krieger, Joel, ed. 2013. The Oxford Companion to Comparative Politics. Vol. 2. Oxford University Press.

Kucera, Joshua. 2011. “Azerbaijan Makes Big Helicopter Buy.” Euarasia.net, 03 March 2011. http://www. eurasianet.org/node/62995.

Kuchma, Leonid. “Kuchma on Threat from Russian Nationalism.” Financial Times, 25 November 1995.

Kuchma, Leonid. 1995. "Kuchma Interviewed on CIS, Russia, Parliament's Stance.” Zerkalo Nedeli, 14 October 1995.

Kuchma, Leonid. 1995a. "President Kuchma Independence Day Speech.” Kiev Radio, 24 August 1995. 
Kuchma, Leonid. 1996. “Kuchma Discusses 'Road to Europe'.” Kiyevskiye Novosti, 06 December 1996.

Kuchma, Leonid. 1996a. "Kuchma Interview on State of Nation." Krymskaya Gazeta, 17 August 1996.

Kuchma, Leonid. 1996b. "Kuchma Interviewed on Poland, NATO, Russia.” Zycie Warszawy, 25 June 1996.

Kuchma, Leonid. 1996c. "Kuchma 8 Oct Speech to Spanish Legislature." Uryadovyy Courier, 10 October 1996.

Kuchma, Leonid. 1997. “Kuchma Addresses II Forum of Ukrainians.” Uryadovyy Kuryer, 23 August 1997.

Kuchma, Leonid. 1997a. "Kuchma on State of Mutual Relations." Svobodnaya Gruziya, 28 October 1997.

Kuchma, Leonid. 1998. "President Kuchma and Vice President Gore Open 2nd Plenary Session of Ukraine-US Binational Commission." Embassy of Ukraine to the United States of America, 23 July 1998. http://www.brama. com/ukraine-embassy/pre0723.html.

Kuchma, Leonid. 1998a. "Ukraine's Kuchma Hails Ties with Russia." Radio Ukraine World Service, 07 March 1998.

Kuchma, Leonid. 1998b. "Kuchma's Speech at Moscow University." UT-1 Television Network, 28 February 1998.

Kuchma, Leonid. 1998d. "Ukrainian President Addresses Foreign Diplomats." UT-1 Television Network, 27 January 1998.

Kuchma, Leonid. 2000. "Ukraine: Kuchma to Envoys on Foreign Policy.” Uryadovvy Kuryer, 20 January 2000.

Kuchma, Leonid. 2001. "President Kuchma Sums up Ukraine-EU Summit." UT-1 Television Network, 11 September 2001.

Kuchma, Leonid. 2002. "Ukrainian President Discusses NATO Bid, Relations with Russia." Hospodarske Noviny Online, 07 June 2002.

Kuchma, Leonid. 2002a. "Ukrainian President on Mideast Peace, Ties with Iraq, Iran, Russia, Europe." Beirut Al-Nahar Online, 23 April 2002.

Kuchma, Leonid. 2002b. "Kuchma Delivers State of the Nation Address." Ukrainian Radio 1, 18 June 2002. 
Kuchma, Leonid. 2004. "Ukrainian President Pledges to Hold Fair Election.” Itar-Tass, 20 April 2004.

Kuchma, Leonid. 2004a. "Ukrainian President: US Partnership of Strategic Importance.” ItarTass, 20 April 2004.

Kupchan, Charles A. 2002. "Hollow Hegemony or Stable Multipolarity?” In G. John Ikenberry (ed.) America Unrivaled: The Future of the Balance of Power. Ithaca, NY: Cornell University Press.

Kupfer, Matthew and Thomas De Waal. 2014. "Crying Genocide: Use and Abuse of Political Rhetoric in Russia and Ukraine." Carnegie Endowment for International Peace, 28 July 2014. http://carnegieendowment.org /2014/07/28/crying-genocide-use-and-abuse-ofpolitical-rhetoric-in-russia-and-ukraine-pub-56265.

Kuzio, Taras. 1996. "Kravchuk to Kuchma: The Ukrainian Presidential Elections of 1994.” The Journal of Communist Studies and Transition Politics 12 (2).

Kuzio, Taras. 2002. "In Wake of Kuchma Snub, Whither Relations with NATO?” The Ukrainian Weekly 45 (70). http://www.ukrweekly.com/old/archive/2002/450204.shtml.

Kuzio, Taras. 2003. "Ukraine's Relations with the West: Disinterest, Partnership, Disillusionment." European Security 12 (2).

Kuzio, Taras. 2005. "From Kuchma to Yushchenko Ukraine's 2004 Presidential Elections and the Orange Revolution." Problems of Post-Communism 52 (2).

Kuzio, Taras. 2005. "Russian Policy Toward Ukraine During Elections.” Demokratizatsiya, 13 (4).

Kuzio, Taras. 2011. "Ukrainian Politicians Put the Squeeze on Civil Society." Radio Free Europe/Radio Liberty, 18 May 2011. https://www.rferl.org/a/ukrainian_politicians_puts_ the_squeeze_on_civil_society/24178777.html.

Labs, Eric J. 1992. “Do Weak States Bandwagon?” Security Studies 1 (3).

Lachowski, Zdzislaw. 2007. Foreign Military Bases in Eurasia. Stockholm International Peace Research Institute. SIPRI Policy Paper 18.

Lamarque, Kevin. 2014. "Ukraine President Secures Military Aid but not Weapons." Newsweek, 18 September 2014. http://www.newsweek.com/ukraine-president-secures-us-militaryaid-not-weapons-271624.

Lansford, Tom. 2012. 9/11 and the Wars in Afghanistan and Iraq: A Chronology and Reference Guide. ABC-CLIO. 
Lansford, Tom. 2012a. Political Handbook of the World 2012. Sage.

Lansford, Tom. 2017. “Georgia.” Political Handbook of the World 2016-2017. Sage.

Larson, Deborah W. 1985. Origins of Containment: A Psychological Explanation. Princeton: Princeton University Press.

Larson, Deborah W. 1991. "Bandwagoning Images in American Foreign Policy: Myth or Reality." In Robert Jervis and Jack Levy (eds.) Dominoes and Bandwagons: Strategic Beliefs and Great Power Competition in the Eurasian Rimland. New York: Oxford University Press.

Larson, Deborah Welch, and Alexei Shevchenko. 2003. "Shortcut to Greatness: The New Thinking and the Revolution in Soviet Foreign Policy.” International Organization 57 (1).

Lavrov, Sergey. 2013. "Speech by the Russian Foreign Minister, Sergey Lavrov.” The Ministry of Foreign Affairs of the Russian Federation.http://www.mid.ru/en/press_service/minister _ speeches /-/asset_publisher/7OvQR5KJWVmR/content/id/85330.

Layne, Christopher. 1993. "The Unipolar Illusion: Why New Great Powers Will Rise." International Security 17 (4).

Layne, Christopher. 2006. "The Unipolar Illusion Revisited: The Coming End of the United States' Unipolar Moment.” International Security 31 (2).

Leeds, Brett Ashley, Jeffrey M. Ritter, Sara McLaughlin Mitchell, and Andrew G. Long. 2002. Alliance Treaty Obligations and Provisions, 1815-1944. International Interactions 28. http://atop.rice.edu.

Leeds, Brett Ashley. 2005. Alliance Treaty and Obligations (ATOP) Codebook. Rice University.

Legal Information Institute (LII). 2016. "Bilateral Investment Treaty.” Cornell Law School. https://www.law.cornell.edu/wex/bilateral_investment_treaty.

Leites, Nathan C. 1951. The Operational Code of the Politburo. New York: McGraw Hill.

Lemke, Douglas. 2004. "Great Powers in the Post-Cold War World: A Power Transition Perspective.” In T. V. Paul, James J. Wirtz, and Michel Fortmann (eds.) Balance of Power: Theory and Practice in the 21 st Century. Stanford University Press.

Levgold, Robert. 2015. "Robert Legvold on the New Cold War." The World Post, 24 September 2015. https:// www.huffingtonpost.com/samuel-ramani/robert-legvold-on-thenew_b_8514120.html. 
Levy, Jack S. 1983. "Misperception and the Causes of War: Theoretical Linkages and Analytical Problems." World Politics 36 (1).

Levy, Jack S. 1985. "The Polarity of the System and International Stability: An Empirical Analysis." In Alan Ned Sabrosky (ed.) Polarity and War: The Changing Structure of International Conflict. Boulder \& London: Westview Press.

Levy, Jack S. 1988. "Domestic Politics and War.” Journal of Interdisciplinary History 18 (4).

Levy, Jack S. 1989. "The Causes of War: A Review of Theories and Evidence." In Philip E. Tetlock, Jo L. Husbands, Robert Jervis, Paul C. Stern, and Charles Tilly (eds.), Behavior, Society, and Nuclear War, Vol. 1. New York: Oxford University Press.

Levy, Jack S. and William R. Thompson. 2005. "Hegemonic Threats and Great Power Balancing in Europe, 1495 - 2000." Security Studies 14 (1).

Levy, Jack S. and William R. Thompson. 2010. "Balancing at Sea: Do States Ally Against the Leading Global Power?” International Security 35 (1).

Library of Congress. 2007. "Country Profile-Turkmenistan.” https://www.loc.gov/rr/frd/cs/ profiles/Turkmenistan-new.pdf.

Lieber, Keir A. and Gerard Alexander. 2005. "Waiting for Balancing: Why the World is Not Pushing Back." International Security 30 (1).

Light, Margot, John Lowenhardt, and Stephen White. 2003. "Russia and the Dual Expansion of Europe." In Gabriel Gorodestky (ed.) Russia between East and West: Russian Foreign Policy on the Threshold of the Twenty-First Century. London: Frank Cass.

Lijphart, Arend. 1963. "The Analysis of Bloc Voting in the General Assembly: A Critique and a Proposal." American Political Science Review 57 (4).

Lilia. 2010. Lonely Power: Why Russia has Failed to Become the West and the West is Weary of Russia. Washington D.C.: Carnegie Endowment for International Peace.

Lippmann, Walter. 1943. U.S. Foreign Policy: Shield of the Republic. Boston: Little Brown.

Liska, George. 1962. Nations in Alliance: The Limits of Interdependence. Baltimore: Johns Hopkins University Press.

Lobell, Steven E., Norrin M. Ripsman, and Jeffrey W. Taliaferro. 2009. Neoclassical Realism, the State, and Foreign Policy. Cambridge: Cambridge University Press.

Lord, Kristin M. and William B. Taylor. 2016. "Tunisia and Ukraine: Linchpins of U.S. Interests.” United States Institute of Peace. https://www.usip.org/publications/2016/02/ tunisia-and-ukraine-linchpins-us-interests. 
Lovett, Robert. 1948. "Minutes of the Third Meeting of the Washington Exploratory Talks on Security, July 7, 1948." Foreign Relations of The United States, 1948, Western Europe, Volume III. Office of the Historian, U.S. Department of State. https://history.state.gov/ historicaldocuments/frus 1948v03/d114.

Lucinschi, Petru. 1996. "New President Lucinschi Interviewed." Moscow NTV, 03 December 1996.

Lucinschi, Petru. 1997. "Lucinschi Reaffirms Independence, Sovereignty, Neutrality." Itar-Tass, 15 January 1997.

Lucinschi, Petru. 1997a. "Lucinschi on Dniester Issues, GUUAM.” Interfax, 18 November 1999.

Lucinschi, Petru. 1997b. “Lucinschi Says `No Problem' With Russian Troop Presence.” ItarTass, 25 February 1997.

Lucinschi, Petru. 1997c. "Moldova Ready to Work with NATO on 'Conflict Prevention.'” Infotag, 09 July 1997.

Lucinschi, Petru. 1997d. “New President Delivers Inaugural Speech.” Infotag, 15 January 1997.

Lucinschi, Petru. 1997e. "President on Ties with Ukraine, Dniester." Holos Ukrayiny, 12 March 1997.

Lucinschi, Petru. 1998. "Moldovan President Urges 'European Patriotism' as Ideal." Moscow Interfax, 04 December 1998.

Lucinschi, Petru. 1998a. "Speech of the President of Moldova Petru Lucinschi at the UN General Assembly." United Nations General Assembly Speech, September 29, 1998. http://www.un.org/ga/search/view_doc.asp?symbol=A/53/PV.14.

Lucinschi, Petru. 1999. "Lucinschi on Dniester Issues, GUUAM.” Interfax, 18 November 1999.

Lucinschi, Petru. 1999a. "Lucinschi: Moldova Pro-European, Not Pro-Western.” Itar-Tass, 27 April 1999.

Lucinschi, Petru. 1999b. "Moldova: President Says to Attend Sarajevo Summit.” Interfax, 27 July 1999.

Lucinschi, Petru. 1999c. "Moldovan President Views Bilateral Relations, Tasks." Nepszabadsag, 30 August 1999.

Lucinschi, Petru. 2000. "News Conference on the Results of the Russian-Moldovan Talks." President of Russia Website, June 17, 2000. http://en.kremlin.ru/events/president/ transcripts/24217. 
Lynch, Marc. 1998. "Abandoning Iraq: Jordan's Alliances and the Politics of State Identity." Security Studies 8 (2-3)

MacFarquar, Neil. 2014. "Gazprom Cuts Natural Gas Supply to Ukraine. New York Times, 16 June 2014. https://www.nytimes.com/2014/06/17/world/europe/russia-gazpromincreases-pressure-on-ukraine-in-gas-dispute.html?mtrref=www.google.com\&gwh=2941 BAE7F435A6321A9B9B9055FDD5B6\&gwt=pay\&assetType=nyt_now.

Magaloni, Beatriz. 2006. Voting for Autocracy: Hegemonic Party Survival and its Demise in Mexico. Cambridge: Cambridge University Press.

Magocsi, Paul Robert. 2002. Roots of Ukrainian Nationalism. University of Toronto Press.

Mandelbaum, Michael. 1988. The Fate of Nations: The Search for National Security in the Nineteenth and Twentieth Centuries. Cambridge: Cambridge University Press.

Mankoff, Jeffrey. 2009. Russian Foreign Policy: The Return of Great Power Politics. New York: Rowman and Littlefield.

Mansfield, Edward D. 1988. “The Distribution of Wars Over Time.” World Politics 41 (1).

Mansfield, Edward D., and Jack Snyder. 1995. "Democratization and the Danger of War." International Security 20 (1).

Manstead, Antony and Miles Hewstone. 1996. The Blackwell Encyclopedia of Social Psychology. Blackwell Publishers, 1996. http://www.blackwellreference.com/public/ tocnode?id=g9780631202899_chunk_g978063120289921_ss1-6\#citation.

Maoz, Zeev and Bruce Russett. 1993. "Normative and Structural Causes of Democratic Peace, 1946-1986." American Political Science Review 87 (3).

Marcus, Jonathan. 2014. "Ukraine: The Military Balance of Power." BBC News Online, 03 March 2014. http://www.bbc.com/news/ world-europe-26421703.

Margvelashvili, Giorgio. 2013. "President Margvelashvili's Inauguration Speech.” Civil Georgia, 17 November 2013. http://www.civil.ge/eng/article.php?id=26693.

Margvelashvili, Giorgio. 2013a. "After Initialing the EU Association Agreement "Euronews" Talked to the President of Georgia." Official Website of the President of Georgia, 29 November 2013. https://www.president.gov.ge/en-US/pressamsakhuri/interviuebi/

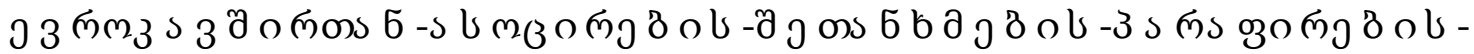
g. aspx.

Margvelashvili, Giorgi. 2014. "President: Russia Poses No Immediate Threat to Georgia." Agende.ge, 22 April 2014. http://agenda.ge/news/12671/eng. 
Margvelashvili, Giorgi. 2014a. "The Processes that are Developed in this area by Russian Federation are not Leading to Further Partnership Between Nations." Official Website of the President of Georgia. https://37.46.105. 69/en/PressOffice/News?p=9178\&i=3.

Margvelashvili, Giorgi. 2014b. "The State of the Nation Address." Official Website of the President of Georgia, 21 February 2014. http://civil.ge/eng/article.php?id=26971\& search $=$ president $\% 20$ state $\% 20$ of\%20nation\%20address.

Margvelashvili, Giorgio. 2014c. "Toasts Offered by the Presidents of Georgia and Poland at The Official Dinner." Official Website of the President of Georgia, 02 April 2014. https://www.president.gov.ge/en-US/pressamsakhuri/siakhleebi/The-toasts-offered-bythe-Presidents-of-Georgi-(1).aspx.

Margvelashvili, Giorgi. 2015. "2015 Annual Report of the President of Georgia.” Official Website of the President of Georgia. https://www.president.gov.ge/enUS/prezidenti/cliuri-mokhseneba/2015-clis-saparlamento-mokhseneba.aspx.

Margvelashvili, Giorgi. 2015a. "A Conversation with Giorgi Margvelashvili.” Council of Foreign Relations, 29 September 2015. https://www.cfr.org/event/conversation-giorgimargvelashvili.

Marin-Bosch, Miguel. 1987. "How Nations Vote in the General Assembly of the United Nations." International Organization 41 (4).

Marshall, Monty G. Ted Robert Gurr, and Keith Jaggers. 2017. Polity IV Project: Political Regime Characteristics and Transitions, 1800-2016. http://www.systemicpeace. org/inscr/p4manualv2016.pdf.

Mastanduno, Michael. 1997. "Preserving the Unipolar Moment: Realist Theories and U.S. Grand Strategy after the Cold War." International Security 21 (4).

Matarykin, Vitaliy. 2004. “Ukrainian President: US Partnership of Strategic Importance.” ItarTass, 20 April 2004.

Matsumura, Masahiro. 2008. "The Japanese State Identity as a Grand Strategic Imperative." Working Paper for the 2006-2007 Visiting Fellows Program at the Brookings Institution's Center for Northeast Asian Policy Studies (CNAPS). The Brookings Institution Center for Northeast Asian Policy Studies, Washington D.C.

Matuszak, Slawomir. 2010. "Medvedev in Kyiv - No Breakthrough in Economic Negotiations. Centre for Eastern Studies, 19 May 2010. https://www.osw.waw.pl/en/publikacje/ analyses/2010-05-19/medvedev-kyiv-no-breakthrough-economic-negotiations.

MAXQDA, software for qualitative data analysis, 1989-2018, VERBI Software - Consult Sozialforschung GmbH, Berlin, Germany. 
McDermott, Roger. 2011. "Russia and Belarus Prepare Union Shield 2011.” Eurasia Daily Monitor 8 (167). https://jamestown.org/program/russia-and-belarus-prepare-union-shield2011/.

McGowan, Patrick J., and Robert M. Rood. 1975. "Alliance Behavior in Balance of Power Systems: Applying a Poisson Model to Nineteenth-Century Europe." American Political Science Review 69 (3).

McGuire, William J., et al. 1978. "Salience of Ethnicity in the Spontaneous Self-Concept as a Function of One's Ethnic Distinctiveness in the Social Environment." Journal of Personality and Social Psychology 36 (5).

Mearsheimer, John J. 1990. "Back to the Future: Instability in Europe After the Cold War." International Security 15(1).

Mearsheimer, John J. 2001. "The Future of the American Pacifier.” Foreign Affairs 80 (5).

Mearsheimer, John J. 2014. The Tragedy of Great Power Politics. New York and London: W. W. Norton \& Company.

Mearsheimer, John J. and Stephen M. Walt. 2013. "Leaving Theory Behind: Why Simplistic Hypothesis Testing is Bad for International Relations." European Journal of International Relations 19 (3).

Mel, Mary. 2010. United States Protocol: The Guide to Official Diplomatic Etiquette. Rowman $\&$ Littlefield Publishers.

Menkiszak, Marek, Rafał Sadowski, and Piotr Żochowski. 2014. "The Russian Military Intervention in Eastern Ukraine. The Centre for Eastern Studies (OSW), 03 September 2014. https://www.osw.waw.pl/en/publikacje/ analyses/2014-09-03/russian-militaryintervention-eastern-ukraine.

Migdal, Joe S. 1988. Strong Societies and Weak States: State-Society Relations and State Capabilities in the Third World. Princeton: Princeton University Press.

Mihalisko Kathleen. 1995. "Yeltsin's CIS Decree: An Instrument for Regaining Russia's Superpower Status." The Jamestown Foundation, 06 October 1995. https://jamestown. org/program/yeltsins-cis-decree-an-instrument-for-regaining-russias-superpower-status/.

Miller, Eric A. 2006. To Balance or Not to Balance: Alignment Theory and Commonwealth of Independent States. Ashgate Publishing Limited.

Miller, Eric A., and Arkady Toritsyn. 2005. "Bringing the Leader Back In: Internal Threats and Alignment Theory in the Commonwealth of Independent States." Security Studies 14 (2).

Miller, Steven E. and Dmitri Trenin (eds.). 2004. The Russian Military: Power and Policy. Cambridge: MIT Press. 
Milner, Helen. 1997. Resisting Protectionism. Princeton, NJ: Princeton University.

Milsten, Donald. 1969. "Small Powers-A Struggle for Survival." Journal of Conflict Resolution $13(3)$.

Minzarari, Dumitru. 2012. "Russian Military Developments in Transnistria Worry Moldovan Officials.” Eurasia Daily Monitor 9 (195), 26 October 2012. https://jamestown.org/ program/russian-military-developments-in-transnistria-worry-moldovan-officials/.

Modelski, George, 1963. "The Study of Alliances; a Review.” The Journal of Conflict Resolution 7 (4).

Moldova Sets Record in Ratifying EU Agreement. 2014. Euractiv, 02 July 2014. http://www. euractiv.com/ section/europe-s-east/news/moldova-sets-record-in-ratifying-euassociation-agreement/.

"Moldovan Troops to Participate in International Peacekeeping Mission in Kosovo." 2013. Government of the Republic of Moldova. http://www.gov.md/en/content/moldovantroops-participate-international-peacekeeping-mission-kosovo.

Moldovan Leader Requests US Role in Dniester Settlement. 2000. Basapress, 09 March 2000.

Moon, Bruce E. 1985. "Consensus or Compliance? Foreign Policy Change and External Dependence." International Organization 39 (2).

Morgenthau, Hans J. 1946. Scientific Man vs. Power Politics. Chicago: The University of Chicago Press.

Morgenthau, Hans J. 1959. "Alliances in Theory and Practice.” In Arnold Wolfers (ed.) Alliance Policy in the Cold War. Baltimore: Johns Hopkins University Press.

Morgenthau, Hans J. 1962. The Decline of Democratic Politics. Chicago: The University of Chicago.

Morgenthau, Hans J. 1967. Politics Among Nations. 4 ed. New York: Knopf.

Morrow, James D. 1991. "Alliances and Asymmetry: An Alternative to the Capability Aggregation Model of Alliances." American Journal of Political Science 35 (4).

Morton, Jeffrey S. and Harvey Star. 2001. "Uncertainty, Change, and War: Power Fluctuations and War in the Modern Elite Power System." Journal of Peace Research 38 (1).

Mowle, Thomas S. and David H. Sacko. 2007. The Unipolar World: An Unbalanced Future. Palgrave Macmillan. 
Mroz, John Edwin, and Oleksandr Pavliuk. 1996. "Ukraine: Europe's Linchpin.” Foreign Affairs $75(3)$.

Muller, Martin. 2011. "Public Opinion Toward the European Union in Georgia." Post-Soviet Affairs 27 (1).

Muravschi, Alexandro, Ivan Cernioglo, Sergiu Botezatu, Patricia Orlowitz, and Dorin Dumbraveanu. "Moldova Case Study - The National Land Program." Regional Workshop in Land Issues in Central and Eastern Europe and the CIS, 03-06 April 2002. http://pdf.usaid.gov/pdf_docs/PBAAD027.pdf.

Murinson, Alexander. 2009. Turkey's Entente with Israel and Azerbaijan: State Identity and Security in the Middle East and Caucasus. Routledge.

Myers, Steve Lee. 2006. "Russia Severs Transportation Links with Georgia." The New York Times, 03 October 2006. http://www.nytimes.com/2006/10/03/world/europe/03russia. html?mtrref=www. google.com\&gwh=E755F9C82F0F7E9AA5332FE311041760\& gwt=pay.

Nabers, Dirk. 2009. "Filling the Void of Meaning: Identity Construction in US Foreign Policy after September 11, 2001.” Foreign Policy Analysis 5 (2).

Name Redacted. 2004. "Ukraine: Background and U.S. Policy." Congressional Research Service, 27 February 2004.

Narizny, Kevin. 2003. "Both Guns and Butter, or Neither: Class Interests in the Political Economy of Rearmament.” American Political Science Review 97 (2).

NATO Freedom Consolidation Act. 2007. U.S. Senate Report 110-34, 09 March 2007. U.S. Government Publishing Office. https://www.gpo.gov/fdsys/pkg/CRPT-110srpt34/ html/CRPT-110srpt34.htm.

NATO-Georgia Joint Training and Evaluation Center. 2015. NATO Fact Sheet. https://www. nato.int/ nato_static_f12014/assets/pdf/pdf_topics/20150827_150827-jtec-georgia.pdf.

"NATO: No MAP for Georgia or Ukraine, But Alliance Vows Membership." Radio Free Europe/Radio Liberty, 03 April 2008. https://www.rferl.org/a/1079726.html.

Neumann Iver B. 1999. Uses of the Other: The East in European Identity Formation. Minneapolis: University of Minnesota Press.

Newnham, Randall. 2011. “Oil, Carrots, and Sticks: Russia's Energy Resources as a Foreign Policy Tool." Journal of Eurasian Studies 2 (2).

Newnham, Randall. 2015. "Georgia on My Mind? Russian Sanctions and the End of the "Rose Revolution."” Journal of Eurasian Studies 6 (2). 
Nichol, Jim, Steven Woehrel, and Barbara Gelb. 2006. "Russia's Cutoff of Natural Gas to Ukraine: Context and Implications." Congressional Research Service, 15 February 2006. https://pdfs.semanticscholar.org/edde/8d92a 925c6fe040a76f3cb97ad7c226a7ccb.pdf.

Nichol, Jim. 2003. "Armenia, Azerbaijan, and Georgia: Political Developments and Implications for U.S. Interests.” Congressional Research Service, 27 June 2003.

Nichol, Jim. 2004. “Azerbaijan: Current Developments and U.S. Interests.” Congressional Research Service, 10 May 2004. https://www.justice.gov/sites/default/files/pages/ attachments/2015/10/14/crs-reports_azerbaijan-current-developments.pdf.

Nichol, Jim. 2005. "Armenia, Azerbaijan, and Georgia: Political Developments and Implications for U.S. Interests.” Congressional Research Service, 05 May 2015, 15. https://digital. library.unt.edu/ark:/67531/metacrs6897/m1/1/high_res_d/IB95024_2005May12.pdf.

Nichol, Jim. 2006. “Armenia, Azerbaijan, and Georgia: Political Developments and Implications for U.S. Interests.” Congressional Research Service, 09 May 2006. http://www.au.af. mil/au/awc/awcgate/crs/ib95024.pdf.

Nicol, Jim. 2009. "Azerbaijan: Current Developments and U.S. Interests.” Congressional Research Service. Washington D.C., 10 May 2004. https:/www.justice.gov/sites/ default/files/pages/attachments/2015/10/14/crs-reports_azerbaijan-currentdevelopments.pdf.

Nohlen, Dieter, and Philip Stöver. 2010. Elections in Europe: A Data Handbook. Baden-Baden, Nomos.

Norberg, Johan. 2015. Training to Fight: Russia's Major Military Exercises 2011-2014. Swedish Ministry of Defense.

North Atlantic Treaty Organization. 2002. "NATO and Ukraine: Distinctive Partners.” NATO Update, 09 July 2002. https://www.nato.int/ docu/update/2002/07-july/e0709a1.htm.

North Atlantic Treaty Organization. 2015. "NATO Published Defense Expenditures Data for 2014 and Estimates for 2015.” 22 June 2015. http://www.nato.int/nato_static_fl2014/ assets/pdf/pdf_2015_06/20150622_PR_CP_2015_093-v2.pdf.

North Atlantic Treaty Organization. 2017. "Individual Partnership Action Plans, 09 June 2017.” https://www.nato.int/cps/en/natohq/topics_49290.htm.

North Atlantic Treaty Organization. 2017. "Relations with Moldova.” NATO Topics, 08 December 2017. https://www.nato.int/cps/ic/natohq/topics_49727.htm.

Nygren, Bertil. 2007. The Rebuilding of Greater Russia: Putin's Foreign Policy Towards the CIS Countries. Vol. 4. Routledge. 
Ó Beacháin, Donnacha, and Frederik Coene. 2014. "Go West: Georgia's European Identity and its Role in Domestic Politics and Foreign Policy Objectives." Nationalities Papers 42 (6).

Office for Democratic Institutions and Human Rights. 2001. "Republic of Moldova:

Parliamentary Elections, 25 February 2001 (Final Report). Organization for Security and Cooperation in Europe, 03 April 2001. http://www.e-democracy.md/files/elections/ parliamentary2001/final-report-osce-elections-2001-en.pdf.

Olearychyk, Roman. 2008. "Yushchenko Stands Firm on Foreign Policy." Financial Times Online, 04 September 2008. https://www.ft.com/content/e88c17ce-7aaf-11dd-adbe$000077 \mathrm{~b} 07658$.

Olszafski, Tadeusz Andrzej. 2001. "Ukraine and Russia: Mutual Relations and the Conditions that Determine Them." Central European Studies. https://core.ac.uk/download/pdf/ 11871235.pdf.

Organization for Security and Cooperation in Europe. 1994. "The Transdniestrian Conflict in Moldova: Origins and Main Issues." Vienna, 10 June 1994, CSCE Conflict Prevention Centre.

Organski, A. F. K. and Jacek Kugler. 1980. The War Ledger. Chicago: The University of Chicago Press.

Osborn, Andrew. 2010. "Viktor Yanukovych says West has Nothing to Fear From Ukraine." The Telegraph, 15 February 2010. http://www.telegraph.co.uk/news/worldnews/europe/ ukraine/7236642/Yanukovych-says-West-has-nothing-to-fear-from-Ukraine.html.

Osgood, Robert. 1968. Alliances in American Foreign Policy. Baltimore: The Johns Hopkins Press.

Ottaway, Mariana S. 2003. Democracy Challenged: The Rise of Semi Authoritarianism. Washington, D.C.: Carnegie Endowment for International Peace.

"Our Ukraine Accuses Yanukovych of Complicity with Terrorists for Rejecting NATO Integration.” 2010. Kyiv Post, 02 June 2010. https://www.kyivpost.com/article/content/ ukraine-politics/our-ukraine-accuses-yanukovych-of-complicity-with-68428.html.

Pape, Robert A. 2005. "Soft Balancing against the United States." International Security 30 (1).

Parliament of Georgia. 2004. "The Constitution of Georgia.” http://www.parliament.ge/ files/68_1944_95119 0_CONSTIT_27_12.06.pdf.

Parliament of Georgia. 2010. "The Constitution of Georgia." http://www.parliament.ge/ uploads/other/28/ 28803.pdf. 
Patrikarakos, David. 2014. “A Billionaire Goes Begging." Politico, 03 June 2014. https://www. politico.com/ magazine/story/2014/06/obama-ukraine-poroshenko-107383.

Paul, Thaza V. 2005. "Soft Balancing in an Age of U.S. Primacy," International Security 30 (1).

Payne, Sebastian. 2014. "Ukraine to get \$53 million in 'non-lethal' Aid from the United States." Washington Post, 18 September 2014. https://www.washingtonpost.com/politics/ ukraine-to-get-53-million-in-non-lethal-aid-from-the-united-states/2014/09/18/c2c19c283f4b-11e4-b0ea 8141703bbf6f_story.html?utm_term=. 87512f68f655.

Perina, Rudolf, William Hill, Ceslav Ciobanu, Craig Dunkerley, and Charles King. 2002. "The 1999 OSCE Istanbul Summit Decisions on Moldova and Georgia: Prospects for Implementation.” Woodrow Wilson International Center for Scholars, December 2002. https://www.wilsoncenter.org/sites/default/files/op284 _1999_osce_instanbul_summit_conference_2002.pdf.

Peterson, J. E. 2009. "Foreign Military Presence and its Role in Reinforcing Regional Security: A Double-Edged Sword." In Arabian Gulf Security: Internal and External Challenges. The Emirates Center for Strategic Study and Research, Dubai.

Peuch, Jean-Christophe. 2006. "Georgia: Parliament Votes Russian Troops Out of South Ossetia." Radio Free Europe/Radio Liberty, 15 February 2006. https://www.rferl.org/ a/1065805.html.

Peuch, Jean-Christopher. 2002. "Russia/Azerbaijan: Radar Deal: Win-Win Situation or Fool's Bargain?” Radio Free Europe/Radio Liberty, 29 January 2002. https://www.rferl.org/ a/1098628.html.

Pierre, Andrew J. 2014. The Global Politics of Arms Sales. Princeton: Princeton University Press.

Pifer, Stephen. 2011. "Can Ukraine Join Europe as Yanukovych Moves Away from EU Values?" The Brookings Institution, 28 January 2011.

Pifer, Steven. 2014. "Poroshenko Signs EU-Ukraine Association Agreement." The Brookings Institution, 27 June 2014. https://www.brookings.edu/blog/up-front/2014/06/27/ poroshenko-signs-eu-ukraine-association-agreement/.

Pifer, Steven. 2016. "Pay Attention, America: Russia Is Upgrading its Military." The Brookings Institution, 05 February 2016. http://www.brookings.edu/research/opinions/2016/02/05russian-military-modernization-us-response-pifer.

Pipes, Richard. 1997. “Is Russia Still an Enemy?” Foreign Affairs (76) 5. 
Poindexter, John M. 1986. “Covert Action Finding Regarding Iran.” The White House. The National Security Archives. http://nsarchive.gwu.edu/NSAEBB/NSAEBB210/15Reagan\%20Finding\%201-17-86\%20(IC\%2002181).pdf.

Polity IV Country Report. 2010. “Ukraine.” http://www.systemicpeace.org/polity/Ukraine 2010.pdf.

Polityuk, Pavel. 2012. “Ally of Ukraine's Tymoshenko Jailed for 4 years.” Reuters, 27 February 2012. https://in.reuters.com/article/ukraine-lutsenko/ally-of-ukraines-tymoshenko-jailedfor-4-years-idINDEE81Q0JO20120227.

Poroshenko, Petro. 2014. "First Interview with Klitschco and Poroshenko." Bild, 29 May 2014. http://www.bild.de/politik/ausland/petro-poroschenko/first-interview-with-klitschko-andporoshenko-36172502.bild.html.

Poroshenko, Petro. 2014a. "Full Text of Poroshenko's Speech to Joint Session of US Congress." Kyiv Post, 19 September 2014. https://www.kyivpost.com/article/content/war-againstukraine/full-text-of-poroshenkos-speech-to-joint-session-of-us-congress-365182.html.

Poroshenko, Petro. 2014b. “Ukraine President Poroshenko's Inauguration Speech: No Compromise with Donesk and Lugansk." Global Research, 08 June 2014. https:/ /www.globalresearch.ca/ukraine-president-poroshenkos-inauguration-speech-nocompromise-with-donesk-and-lugansk/5386120.

Poroshenko, Petro. 2014c. "Ukraine: Poroshenko Urges Germany To Boycott Russian Gas, Rejects 'Oligarch' Epithet.” Bild, 02 April 2014.

Poroshenko, Petro. 2014d. "Ukraine: Presidential Hopeful Poroshenko Warns of Terrorist Rebels, Stresses Importance of Election.” Bild, 28 April 2014.

Poroshenko, Petro. 2014e. Cited in Amanpour, Christiane. 2014. "Interview with Petro Poroshenko, President of Ukraine." CNN, 26 June 2014. http://edition.cnn.com/ TRANSCRIPTS/1406/26/ampr.01.html.

Poroshenko, Petro. 2014f. In Weymouth, Lally. "Interview with Ukrainian Presidential Candidate Petro Poroshenko.” Washington Post, 25 April 2014. https://www. washingtonpost.com/opinions/interview-with-ukrainian-presidential-candidate-petroporoshenko/2014/04/25/74c73a48-cbbd-11e3-93eb-6c0037dde2ad_story.html.

Poroshenko, Petro. 2015. "President Launched Ukrainian-American Military Training "Fearless Guardian - 2015." Ministry of Defense of Ukraine, 20 April 2015. http:/www.mil.gov. ua/en/news/2015/04/20/president-launched-ukrainian-american-military-training-fearlessguardian---2015"-a-new-face-of-ukrainian-army-is-being-formed-here-today/. 
Poroshenko, Petro. 2015a. "Speech by President of Ukraine Petro Poroshenko at the session of the National Security and Defense Council of Ukraine." President of Ukraine Website, 22 September 2015. http://www. president.gov.ua/en/news/vistup-prezidenta-ukrayinipoporoshenka-na-zasidanniradi-na-36007.

Posen, Barry R. 2004. "ESDP and the Structure of World Power." International Spectator 2 (9).

Post, Jerrold M. 2004. Leaders and Their Followers in a Dangerous World: The Psychology of Political Behavior. Ithaca: Cornell University Press.

Pouliot, Vincent. 2010. International Security in Practice: the Politics of NATO-Russia Diplomacy. Vol. 113. Cambridge University Press.

Poushter, Jacob and Dorothy Manevich. "Globally, People Point to ISIS and Climate Change as Leading Security Threats." The Pew Research Center, 01 August 2017. http://www. pewglobal.org/2017/08/01/ globally-people-point-to-isis-and-climate-change-as-leadingsecurity-threats/.

“Presidents Yeltsin, Lucinschi Signs Agreements.” RIA Novosti, 02 September 1999.

"Press Release of the Permanent Mission of Ukraine to the UN on Latest Events in the State." 2014. Ministry of Foreign Affairs Ukraine, 24 February 2014. http://mfa.gov.ua/en/newsfeeds/foreign-offices-news/18355-povidomlennya-dlya-presi-postijnogo-predstavnictvaukrajini-pri-oon-u-zvjazku-z-ostannimi-podijami-u-derzhavi-anglijsykoju-movoju.

Pressman, Jeremy. 2004. “If Not Balancing, What?” Discussion Paper 2004-02. Belfer Center for Science and International Affairs, Harvard University.

Prizel, Ilya. 1998. National Identity and Foreign Policy: Nationalism and Leadership in Poland Russia and Ukraine. Cambridge: Cambridge University Press.

Putin, Vladimir. 2007. "Putin's Prepared Remarks at 43rd Munich Conference on Security Policy." The Washington Post, 12 February 2007. http://www.washingtonpost.com/wpdyn/content/article/2007/02/12/AR2007021200555.html.

Putin, Vladimir. 2008. Cited in "Putin Threatens Ukraine Over NATO." The Washington Post, 13 February 2008. http://www.washingtonpost.com/wpdyn/content/article/2008/02/12/AR2008021201658.html.

Putnam, Robert D. 1988. "Diplomacy and Domestic Politics: the Logic of Two-level Games." International Organization 42 (3).

Quinlan, Paul D. 2002. “Moldova under Lucinschi.” Demokratizatsiya 10 (1).

Ragin, Charles C. 1998. "The Logic of Qualitative Comparative Analysis." International Review of Social History 43 (S6). 
Ragin, Charles C. 2014. The Comparative Method: Moving Beyond Qualitative and Quantitative Strategies. University of California Press.

Rai, Kul B. 1980. "Foreign Aid in the U.N. General Assembly, 1967 - 1976." Journal of Peace Research 3 (17).

Rayfield, Donald. 2013. Edge of Empires: A History of Georgia. Reaktion Books.

Reber, Arthur S. 1995. The Penguin Dictionary of Psychology. New York: Penguin Press.

Regan, Ronald. 1983. “'Evil Empire' Speech, 08 March 1983.” The Miller Center, University of Virginia. http://millercenter.org/president/ speeches/speech-3409.

Rejali, Darius. 2007. Torture and Democracy. Princeton: Princeton University Press.

Republic of Moldova-Parliamentary Elections 25 February 2001, Final Report. 2001. Organization for Security and Cooperation in Europe, Office for Democratic Institutions and Human Rights. http://www.osce.org/odihr/ elections/moldova/14837?download=true.

Republic of Moldova, Early Parliamentary Elections, 28 November 2010. 2011. Organization for Security and Cooperation in Europe. SCE/ODIHR Election Observation Mission Final Report, 26 January 2010. http://www.osce.org/odihr/75118?download=true.

Republic of Moldova. 2006. "Constitution of the Republic of Moldova." ConstituteProject.org. https://www.constituteproject.org/constitution/Moldova_2006.pdf?lang=en.

Republic of Philippines. 2016. Official Gazette. http://www.gov.ph/diplomaticrelations/differentiating-visits/.

Reuters Staff. 2008. "Georgian Parliament Votes to Quit CIS.” Reuters, 14 August 2008. https://www.reuters.com/article/us-georgia-ossetia-cis/georgian-parliament-votes-to-quitcis-idUSLE26086620080814.

Rhodes, Matthew. 2004. “Central Europe and Iraq: Balance, Bandwagon, or Bridge?” Orbis 48 (3).

Richardson, Neil R., and Charles W. Kegley. 1980. Trade Dependence and Foreign Policy Compliance. International Studies Quarterly 24 (2).

Richter, James. 1996. "Russian Foreign Policy and the Politics of National Identity." In Celeste A. Wallander (ed.) The Sources of Russian Foreign Policy After the Cold War. Boulder, CO: Westview.

Ripsman, Norrin M. 2002. Peacemaking by Democracies: The Effect of State Autonomy on the Post-World War Settlements. University Park, PA: Penn State Press. 
Rittel, Horst WJ, and Melvin M. Webber. 1973. "Dilemmas in a General Theory of Planning." Policy Sciences 4 (2).

Robakidze, Ana. 2014. "Margvelashvili Decides PM will Sign Association Agreement with the EU.” The Messenger Online, 28 April 2014. http://www.messenger.com.ge/issues/ 3124_may_28_2014/3124_ani.html.

Robison, Sam. 2006. “George W. Bush and the Vulcans: Leader-advisor relations and America's response to the 9/11 attacks." In Mark Schafer and Stephen Walker (eds.) Beliefs and Leadership in World Politics: Methods and Applications of Operational Code Analysis. New York: Palgrave Macmillan.

Roper, Steven D. 2008. "From Semi-Presidentialism to Parliamentarism: Regime Change and Presidential Power in Moldova.” Europe-Asia Studies 60 (1).

Rosati, Jerel A. 1987. The Carter Administration's Quest for Global Community: Beliefs and their Impact on Behavior. University of South Carolina Press.

Rosca, Iurie. 1997. “Opposition Leader: President Plays into Russia's Hands.” Infotag, 14 October 1997.

Rose, Gideon. 1998. "Neoclassical Realism and Theories of Foreign Policy.” World Politics 51 (1).

Rosecrance, Richard N. 1963. Action and Reaction in World Politics. Boston: Little, Brown and Company.

Rothstein, Robert L. 1968. Alliances and Small Powers. New York: Columbia University Press.

Rousseau, David L. 2006. Identifying Threats and Threatening Identities: The Social Construction of Realism and Liberalism. Stanford University Press.

Rovshan Ismayilov. 2005. “Azerbaijan's Parliamentary Election: When is an Independent Candidate Truly Independent?” Eurasianet.org, 30 October 2005. http://www. eurasianet.org/departments/ insight/articles/eav103105a.shtml.

Rukhadze, Vasili. 2012. "Is Georgia's New Government Shifting the Country's Geopolitical Course Toward Russia?” Eurasia Daily Monitor 9 (208). https://jamestown.org/program /is-georgias-new-government-shifting-the-countrys-geopolitical-course-toward-russia/.

Rukhadze, Vasili. 2013. "New Georgian Presidential Administration: New Foreign Policy?" Eurasia Daily Monitor 10 (209). https://jamestown.org/program/new-georgianpresidential-administration-new-foreign-policy/. 
Rukhadze, Vasili. 2015. "The Conflict Between the President and the Prime Minister Continues to Dominate the Georgian Political Landscape." Eurasia Daily Monitor 12 (15). https://jamestown.org/program/the-conflict-between-the-president-and-the-primeminister-continues-to-dominate-the-georgian-political-landscape/.

Rumelili, Bahar. 2004. "Constructing Identity and Relating to Difference: Understanding the EU's Mode of Differentiation." Review of International Studies 30 (1).

Russett, Bruce and Harvey Starr. 2010. World Politics: The Menu for Choice 9th edition. Boston: Cengage Learning.

Russett, Bruce M. 1965. Trends in World Politics. New York: Macmillan.

"Russia, Moldova and Trans-Dniester have adopted a joint declaration aimed at continuing efforts to settle the Trans-Dniester conflict." President of Russia Website, 08 March 2009. http://en.kremlin.ru/events/president/ news/44819.

Saakashvili, Mikheil. 2004. "Belgian Daily Interviews Georgia's Saakashvili on Relations with Russia, US.” Le Soir, 08 April 2004.

Saakashvili, Mikheil. 2004a. "President Saakashvili's Inauguration Speech." Civil Georgia Online, 25 January 2004. http://www.civil.ge/eng/article.php?id=26694.

Saakashvili, Mikheil. 2004b. "Speech Delivered by Mikheil Saakashvili at John Hopkins University." The President of Georgia Speeches and Statements, 04 February 2004. http://www.saakashviliarchive. info/en/PressOffice/News/SpeechesAndStatements?p= $2779 \& \mathrm{i}=1$.

Saakashvili, Mikheil. 2005. “Georgian TV: Saakashvili Bestows First 'St George's Order' Award to US President.” Rustavi-2 Television, 10 May 2005.

Saakashvili, Mikheil. 2005a. National Security Concept of Georgia. Parliament of Georgia. http://www. parliament.ge/files/292_880_927746_concept_en.pdf.

Saakashvili, Mikheil. 2006. “Georgia 'cannot be broken' Saakashvili tells Russia” Rustavi-2 Television, 04 October 2006.

Saakashvili, Mikheil. 2009. "Georgia Finalizes Withdraw from CIS.” Radio Free Europe/Radio Liberty, 18 August 2009. https://www.rferl.org/a/Georgia_Finalizes_Withdrawal_From_ CIS/1802284.html.

Saakashvili, Mikheil. 2009a. "President of Georgia, Mikheil Saakashvili held a conference regarding the signing of Charter between Georgia and the United States." President of Georgia Website, 11 January 2009. http://www. saakashviliarchive.info/en/PressOffice/ News/SpeechesAndStatements?p=2204\&i=1. 
Saakashvili, Mikheil. 2012. "UNM Holds Series of Day-Long Rallies.” Civil Georgia Online, 08 September 2012. http://www.civil.ge/eng/article.php?id=25193\&search=.

Saakashvili, Mikheil. 2012a. National Security Concept of Georgia. Parliament of Georgia. https://mod. gov.ge/assets/up-modul/uploads/pdf/NSC-ENG.pdf.

Safaryan, Stepan. 2014. Cited in Gevorgyan, Tigran. 2014. "Yerevan Angry at Russian Arms Sales to Baku." Institute for War and Peace Reporting. https://iwpr.net/globalvoices/yerevan-angry-russian-arms-sales-baku.

Salmore, Barbara G. and Stephen A. Salmore. 1978. "Political Regimes and Foreign Policy." In Why Nations Act. Beverly Hills: Sage.

Sandler, Todd, and Justin George. 2016. "Military Expenditure Trends For 1960-2014 and What They Reveal." Global Policy 7 (2).

Sartori, Giovanni. 1970. "Concept Misformation in Comparative Politics.” American Political Science Review 64 (4).

Saul, Heather. 2015. "Putin Signs Deal Calling for Almost Complete Integration of South Ossetia into Russia - on Anniversary of Crimea Annexation.” The Independent Online, 19 March 2015. http://www. independent.co.uk/news/world/europe/putin-signs-dealcalling-for-almost-complete-integration-of-south-ossetia-into-russia-on-anniversary10120690.html.

Schafer, Mark, and Stephen Walker, eds. 2006. Beliefs and Leadership in World Politics: Methods and Applications of Operational Code Analysis. Palgrave Macmillan.

Schmemann, Serge. 1992. "A Day's Work in Georgia: Shevardnadze Dodges a Coup and Ends a War.” New York Times, 25 June 1992. http://www.nytimes.com/1992/06/25/world/aday-s-work-in-georgia-shevardnadze-dodges-a-coup-and-ends-a-war.html?mcubz=1 .

Schmidt, Brian C, 2005. “Competing Realist Conceptions of Power.” Millennium: Journal of International Studies 33 (3).

Schrodt, Phillip A. and Omar Yilmaz. 2007. CAMEO Conflict and Mediation Event Observations Codebook. Lawrence: University of Kansas.

Schweller, Randall L. 1993. "Tripolarity and the Second World War.” International Studies Quarterly 37 (1).

Schweller, Randall L. 1994. "Bandwagoning for Profit: Bringing the Revisionist State Back In." International Security 19 (1).

Schweller, Randall L. 1997. "New Realist Research on Alliances: Refining, Not Refuting, Waltz's Balancing Proposition.” American Political Science Review 91 (4). 
Schweller, Randall L. 1998. Deadly Imbalances: Tripolarity and Hitler's Strategy of World Conquest. Columbia University Press.

Schweller, Randall L. 1999. "Realism and the Present Great Power System: Growth and Positional Conflict Over Scarce Resources.” In Kapstein, Ethan B. and Michael Mastanduno (eds.) Unipolar Politics: Realism and State Strategies after the Cold War. Columbia University Press.

Schweller, Randall L. 2010. Unanswered Threats: Political Constraints on the Balance of Power: Political Constraints on the Balance of Power. Princeton University Press.

Schweller, Randall L., and David Priess. 1997. "A Tale of Two Realisms: Expanding the Institutions Debate." Mershon International Studies Review 41 (1).

Schweller, Randall L. and Xiaoyu Pu. 2011. "After Unipolarity: China's Visions of International Order in an Era of US Decline.” International Security 36 (1).

Scott, James C. 1990. Domination and the Arts of Resistance: Hidden Transcripts. New Haven, Conn.: Yale University Press.

Sens, Allen Gregory. 1994. The Security of Small States in Post-Cold War Europe: A New Research Agenda. Institute of International Relations, University of British Columbia. September 2001.

Shaverdashvili, Shorena. 2015. "Spurned by the West, Georgians Look to Russia Despite Past Quarrels.” Washington Post, 04 July 2015.

Shevardnadze, Eduard. 1995. "Shevardnadze Calls Break with Russia 'Mistake."” Die Tageszeitung, 03 November 1995.

Shevardnadze, Eduard. 1995a. "Shevardnadze Delivers Inauguration Speech." First Program Television Network, 26 November 1995.

Shevardnadze, Eduard. 1995b. "Weekly Interview with President Shevardnadze." Tbilisi Radio Tbilisi Network, 05 June 1995.

Shevardnadze, Eduard. 1997. "Shevardnadze Discusses Latest Developments." Radio Tbilisi Network, 07 July 1997.

Shevardnadze, Eduard. 1998. "Georgia's Shevardnadze on Abkhaz Conflict." Radio Tbilisi Network, 25 May 1998.

Shevardnadze, Eduard. 1998a. "Shevardnadze Gives Weekly Interview." Radio Tbilisi Network, 04 May 1998. 
Shevardnadze, Eduard. 1998b. "Shevardnadze: Russia Planned Recent Attack." Frankfurter Rundschau, 14 March 1998.

Shevardnadze, Eduard. 1999. "Shevardnadze on Abkhaz 'Disaster,' US Ties." Radio Tbilisi Network, 27 September 1999.

Shevardnadze, Eduard. 1999a. "Shevardnadze on Elections, Thanks US." Radio Tbilisi Network, 12 July 1999.

Shevardnadze, Eduard. 1999b. "Shevardnadze on NATO, GUUAM Issues." Moscow Vremya, 07 May 1999.

Shevardnadze, Eduard. 2000. "Georgia and the World: A Strategy for the Future." http://www.bits.de. NRANEU/ docs/CFE/Georgia Strategy.pdf.

Shevardnadze, Eduard. 2000a. "Reelected Shevardnadze Promises 'State Pragmatism."' Kommersant, 11 April 2000.

Shevardnadze, Eduard. 2001. "Georgia: Shevardnadze Says Relations with US Entering New Phase.” Tbilisi Georgian Radio 1, 08 October 2001.

Shevardnadze, Eduard. 2001a. "Georgia's Shevardnadze Cited on NATO Membership." Le Figaro, 27 June 2001.

Shevardnadze, Eduard. 2002. "Statement by President of Georgia Eduard Shevardnadze at the EAPC Summit.” NATO, 22 November 2002. https://www.nato.int/docu/speech/2002/ s021122h.htm.

Shevardnadze, Eduard. 2003. "Georgia: Shevardnadze Comments on St Petersburg Meeting During Interview.” Tbilisi Georgian Radio 1, 02 June 2003.

Shevardnadze, Eduard. 2003a. "President Shevardnadze Focuses Weekly Interview on Georgian Energy Sector Problems.” Georgian Radio 1, 04 August 2003.

Singer, J. David. 1958. "Threat-perception and the Armament-tension Dilemma." Journal of Conflict Resolution 2 (1).

Skidmore, David. 1994. "Explaining States Responses to International Change: The Structural Sources of Foreign Policy Rigidity and Change." In Jerel A. Rosati, Joe D. Hagan, Martin W. Sampson III, eds., Foreign Policy Restructuring: How Governments Respond to Global Change. Columbia, SC: University of South Carolina Press.

Skvortova, Alla. 2003. "Country Report Moldova." In Iris Kempe (ed.) Prospects and Risks Beyond EU Enlargement. Eastern Europe: Challenges of a Pan-European Policy. Wiesbaden, Germany: Trade Media. 
Slider, Darrell. 1991. “The Politics of Georgia's Independence.” Problems of Communism 40 (6).

Smith, Diane L. 1998. "Breaking Away from the Bear.” U.S. Army War College Strategic Studies Institute.

Smith, M.A. 2000. "Russian Foreign Policy 2000: The Near Abroad." Conflict Studies Research Centre. Royal Military Academy Sandhurst.

Smith, Roger. 2010. "Russia Extends Lease on Military Base in Armenia through 2044." Defense News, 21 August 2010. http://defensenews-updates.blogspot.sg/2010/08/dtnnews-russia-extends-lease-on.html.

Snyder, Glenn H. 1990. “Alliance Theory: A Neorealist First Cut.” Journal of International Affairs 44 (1).

Snyder, Glenn H. 1997. Alliance Politics. Ithaca, N.Y.: Cornell University Press.

Snyder, Jack. 1991. Myths of Empire: Domestic Politics and International Ambition. Ithaca, NY: Cornell University Press.

Snyder, Jack. 1991. Myths of Empire: Domestic Politics and International Ambition. Ithaca, NY: Cornell University Press.

Socor, Vladmir. 2004. "NATO Summit Takes Stock of Ukraine's Performance." Eurasia Daily Monitor 1 (45). https://jamestown.org/program/nato-summit-takes-stock-of-ukrainesperformance/.

Socor, Vladmir. 2007. “Is Moldova's President Dropping the European Banner?" Eurasia Daily Monitor, 4 (127). https://jamestown.org/program/is-moldovas-president-dropping-theeuropean-banner/.

Soldak, Katya. 2014. "Georgian President Margvelashvili Condemns Russian Aggression, Says Georgia Looks to The West." Forbes, 08 October 2014. https://www.forbes.com/sites/ katyasoldak/2014/10/08/georgian-president-margvelashvili-condemns-russianaggression-says-georgia-looks-to-the-west/2/\#6f1b5fe14447.

Sorensen, George. 2008. "The Case for Combining Material Forces and Ideas in the Study of IR.” European Journal of International Relations 14 (1).

Sorokin, Gerald L. 1994. "Arms, Alliances, and Security Tradeoffs in Enduring Rivalries." International Studies Quarterly 8 (3).

Sotnikov, Vladimir. 2014. "The Kremlin Shores up its Influence along Caspian Sea." Russia Direct, 14 October 2014. http://www.russia-direct.org/analysis/kremlin-shores-itsinfluence-along-caspian-sea. 
Sprūds, Andrei. 2009. "Entrapment in the Discourse of Danger? Latvian-Russian Interaction in the Context of European Integration." In Eiki Berg and Perit Ehin (eds.) Identity and Foreign Policy: Baltic-Russian Relations and European Integration. New York: Ashgate Publishing.

Stein, Janice. 2013. “Threat Perception in International Relations.” In Leonie Huddy, David O. Sears, and Jack S. Levy (eds.) The Oxford Handbook of Political Psychology, 2nd edition. Oxford: Oxford University Press.

Stein, Matthew. 2015. "Compendium of Central Asian Military and Security Activity." Foreign Military Studies Office (FMSO), Fort Leavenworth, KS.

Stevenson, David. 1996. Armaments and the Coming of War: Europe 1904 - 1914. New York: Oxford University Press.

Stiftung, Bertelsmann. 2003. "Moldova Country Report." Bertelsmann Transformation Index 2003-Towards Democracy and Market Economy. Gütersloh, Germany: Bertelsmann Stiftung.

Stockholm International Peace Research Institute (SIPRI). 2016. "Sources and Methods." https://www.sipri.org/databases/armsindustry/sources-and-methods.

Stolberg, Alan G. 2012. "Crafting National Interests in the 21st Century." In J. Boone Bartholomees (ed.) The U.S. Army War College Guide to National Security Issues, Vol. II: National Security Policy and Strategy, 5th edition. Carlisle Barracks, PA: Strategic Studies Institute.

Stoltenberg, Jens. 2016. "Press Point by NATO Secretary General Jens Stoltenberg Following the Aegis Ashore Operationalisation Ceremony." North Atlantic Treaty Organization, 12 May 2016. http://www.nato.int/cps/en/natohq/opinions_130698.htm.

Strassler, Richard B., ed. 1996. The Landmark Thucydides: A Comprehensive Guide to the Peloponnesian War. New York: The Free Press.

“Strategic Partners Russia and Azerbaijan." President of Russia Website, 03 July 2008. http://en.kremlin.ru/ events/president/news/651.

Suedfeld, Peter, Karen Guttieri, and Philip E. Tetlock. 2003. "Assessing Integrative Complexity at a Distance: Archival Analyses of Thinking and Decision Making." In Jerrold M. Post (ed.) The Psychological Assessment of Political Leaders: With Profiles of Saddam Hussein and Bill Clinton. Ann Arbor, MI: University of Michigan Press.

Sultanova, Shahla. 2014. "Challenging the Aliyev Regime: Political Opposition in Azerbaijan." Demokratizatsiya 22 (1).

Suny, Ronald G. 1996. Armenia, Azerbaijan, and Georgia. Diane Publishing. 
Suny, Ronald Grigor. 2007. "Living in the Hood: Russia, Empire, and Old and New Neighbors." In Robert Legvold (ed.) Russian Foreign Policy in the 21st Century \& the Shadow of the Past. New York: Colombia University Press.

Sushko, Oleksandr. 2010. "Yanukovych Kills Ukraine’s Bid for NATO.” Christian Science Monitor, 06 April 2010. https://www.csmonitor.com/World/Europe/2010/0406/ Yanukovich-kills-Ukraine-s-bid-to-join-NATO.

Swietochowski, Tadeusz. 1995. Russia and Azerbaijan: A Borderland in Transition. New York: Columbia University Press.

Szeptycki, Andrzej. 2015. "Independent Ukraine.” In Klaus Bachmann and Igor Lyubashenk (eds.) The Maidan Uprising, Separatism and Foreign Intervention: Ukraine's Complex Transition. Frankfurt: Peter Lang.

Taghiyeva, Gulia. 2000. "Liberal Democracy in Transitional Azerbaijan: Challenges and Prospects.” In Calder, Gideon, Garrett, Edward and Jess Shannon Liberalism and Social Justice: International Perspectives. Aldershot, England: Ashgate.

Tajfel, Henri and John C. Turner. 1979. "An Integrative Theory of Intergroup Conflict.” In William Austin, and Stephen Worchel (eds.) The Social Psychology of Intergroup Relations. Monterey, CA: Brooks/Cole.

Tajfel, Henri. 1978. Social Categorization, Social Identity, and Social Comparison. In Henry Tajfel (ed.) Differentiation Between Social Groups: Studies in the Social Psychology of Intergroup Relations. London: Academic Press.

Tajfel, Henri. 1981. Human Groups and Social categories: Studies in Social Psychology. Cambridge: Cambridge University Press.

Talbott, Strobe. 1990. "America Abroad: Defusing the German Bomb.” Time, 2 July 1990. http://content.time.com/time/magazine/article/0,9171,970497, 00.html.

Tannenwald, Nina. 2005. "Ideas and Explanation: Advancing the Theoretical Agenda." Journal of Cold War Studies 7 (2).

Tannenwald, Nina. 2007. The Nuclear Taboo: The United States and the Non-use of Nuclear Weapons Since 1945. Vol. 87. Cambridge University Press.

Tansey, Oisin. 2007. "Process Tracing and Elite Interviewing: A Case for non-Probability Sampling." PS: Political Science and Politics 40 (4).

Tarnoff, Curt. 2002. "US Assistance to the Former Soviet Union, 1991-2001: A History of Administration and Congressional Action." Congressional Research Service, 15 January 2002. 
Tarnoff, Curt. 2007. "US Assistance to the Former Soviet Union." Congressional Information Service, Library of Congress.

Taylor, Alan John Percivale. 1954. The Struggle for Mastery in Europe, 1848-1918. Oxford University Press.

Te-Yu. 1999. "US Foreign Aid and UN Voting: An Analysis of Important Issues." International Studies Quarterly 43 (1).

Telhami, Shibley and Michael N. Barnett. 2002. Identity and Foreign Policy in the Middle East. Ithaca, NY: Cornell University Press.

Tertrais, Bruno. 2004. "The Changing Nature of Military Alliances.” The Washington Quarterly 27 (2).

Teune, Henry and Sig Synnestvedt. 1965. "Measuring International Alignment.” Orbis 9 (1).

The Jamestown Foundation. 1999. "Russian-Armenian Air Defense System Inaugurated.” The Jamestown Foundation Monitor 5 (74).

The Jamestown Foundation. 2001. "Russian Military Hands Over Vaziani Base to Georgia." The Jamestown Foundation Monitor, 03 July 2001. https://jamestown.org/program/russianmilitary-hands-over-vaziani-base-to-georgia/.

The Ministry of Finance for the Republic of Azerbaijan. 2012. "The 3rd meeting of the Azerbaijan - USA Intergovernmental Commission on Economic Cooperation. http://www.maliyye.gov.az/en/node/1323.

Thomas, Timothy L., and John Shull. 1999. "Russian National Interests and the Caspian Sea." Journal of International Affairs 4 (4).

Tilley, Virginia. 2012. “The Ethnic State.” In Cris E. Toffolo (ed.) Emancipating Cultural Pluralism. New York: SUNY Press.

Timofti, Nicolae. 2012. "Moldova's New President Outlines Priorities." Publika TV, 16 March 2012.

Timofti, Nicolae. 2012a. "Moldovan Leader Calls for Broad Autonomy for Rebel Region." Infotag, 23 July 2012.

Timofti, Nicolae. 2012b. "Moldovan President Congratulates Obama on Reelection.” Presidency of Republic of Moldova, 07 November 2012. http://www.infotag.md/news-en/598186/.

Timofti, Nicolae. 2012c. "Timofti Interviewed on Moldova's Relations With EU, Russia, Poland." Radio Chisinau, 01 December 2012. 
Timofti, Nicolae. 2013. "Nicolae Timofti." Presidency of Republic of Moldova, 04 December 2013. http://www.presedinte.md/eng/presa/nicolae-timofti-avem-nevoie-de-o-participareputernica-a-statelor-unite-in-asigurarea-securitatii-in-regiune.

Timofti, Nicolae. 2013a. "President Nicolae Timofti Delivers Speech on National Day of Romania." Presidency of the Republic of Moldova Website, 01 December 2013. http://www.presedinte.md/eng/comunicate-de-presa/nicolae-timofti-speram-sa-devenimct-maicurnd-parte-a-spatiului-european.

Timofti, Nicolae. 2013b. "Russia's Actions Represent an Unfriendly Act." President of Moldova Website. http:// www.presedinte.md/eng/comunicate-de-presa/nicolae-timofti-actiunilerusiei-reprezinta-un-act-neprietenesc.

Timofti, Nicolae. 2014. "Association Agreement with European Union is Absolute Priority of Present Government, Moldovan President Says." President of Moldova Website, 26 June 2014. http://www.presedinte.md/ eng/comunicate-de-presa/presedintele-nicolae-timoftia-facut-o-declaratie-de-presa-cu-ocazia-semnarii-acordului-de-asociere-cu-uniuneaeuropeana.

Timofti, Nicolae. 2014a. "Moldovan Leader Comments on Ties with NATO, Dniester, Russian Embargo.” Infotag, 01 April 2014.

Timofti, Nicolae. 2014b. "National Army Receives Military Equipment from US Government." Official Website of the President of Moldova, 12 November 2014. http://www. presedinte.md/eng/presa/presedintele-nicolae-timofti-a-participat-la-ceremonia-dedonare-a-unui-lot-de-tehnica-militara-din-partea-guvernului-sua-catre-armata-nationala.

Timofti, Nicolae. 2014c. "President Nicolae Timofti Attends Events Dedicated to Europe Day." President of Moldova Website, 10 May 2014. http://www.presedinte.md/eng/comunicatede-presa/nicolae-timofti-republica-moldova-a-pasit-ireversibil-pe-calea-integrariieuropene.

Timofti, Nicolae. 2014d. "President Nicolae Timofti Conveyed a Message on the Occasion of the 20th anniversary of Moldova's Constitution Adoption. Presidency of the Republic of Moldova Website, 29 July 2014. http://www. presedinte.md/eng/discursuri/mesajulpresedintelui-nicolae-timofti-cu-prilejul-celeide-a-20-a-aniversari-a-adoptariiconstitutiei-republicii-moldova.

Timofti, Nicolae. 2015. "Moldovan Leader Comments on Ties with NATO, Dniester, Russian Embargo." Infotag, 01 April 2015.

Timofti, Nicolae. 2015a. "Moldovan President Urges Change of Constitution, Criticizes Visits of Russian Officials in Gagauzia.” Teleradio-Moldova Online, 16 March 2015. 
Timofti, Nicolae. 2015b. "Speech delivered by President Nicolae Timofti at the Reception Offered to the Representatives of Diplomatic Missions Accredited in Chisinau." President of Moldova Website, 30 January 2015. http://www.presedinte.md/eng/ discursuri/discursul-rostit-de-presedintele-nicolae-timofti-la-receptia-oferita-pentrumembrii-corpului-diplomatic-acreditati-la-chisinau.

Timofti, Nicolae. 2015c. "Moldova Says Participation in Peacekeeping Missions not in Breach of Neutrality.” Infotag, 14 December 2015.

Tolksdorf, Dominik. 2010. "The Constitutional Process in Ukraine.” United States Institute for Peace, Peace Brief, 22 May 2014. https://www.usip.org/publications/2014/05/ constitutional-process-ukraine.

Tomiuc, Eugen. 2001. "Moldova: Moscow and Chisinau Initial Bilateral Agreement." Radio Free Europe / Radio Liberty, 06 November 2001. https://www.rferl.org/a/1097905.html.

Tsygankov, Andrei. 2001. Pathways After Empire: National Identity and Foreign Economic Policy in the Post-Soviet World. Rowman \& Littlefield Publishers.

Tsygankov, Andrei. 2006. Russia's Foreign Policy: Change and Continuity in National Identity. Rawman \& Littlefield Publishers.

Tsygankov, Andrei. 2007. Review of To Balance or Not to Balance: Alignment Theory and the Commonwealth of Independent States by Eric A. Miller. Slavic Review 66 (2).

Turkish Daily News. 2003. Cited Murinson, Alexander. 2009. Turkey's Entente with Israel and Azerbaijan: State Identity and Security in the Middle East and Caucasus. Routledge.

Turner, John C., Michael A. Hogg, Penelope J. Oaks, Stephen D. Reicher, and Margaret Wetherell. 1987. Rediscovering the Social Group: A Self-Categorization Theory. Oxford, UK: Blackwell.

Ukraine Votes to Abandon Neutrality, Set Sights On NATO. 2014. Radio Free Europe / Radio Liberty, 23 December 2014. https://www.rferl.org/a/ukraine-parliament-abandonsneutrality/26758725.html.

Ukraine-Parliamentary Elections, Final Report. 2002. Organization for Security and Cooperation in Europe, Office for Democratic Institutions and Human Rights. http://www.osce.org/ odihr/elections/ukraine/14947? download=true.

Ukraine-Parliamentary Elections, Final Report. 2006. Organization for Security and Cooperation in Europe, Office for Democratic Institutions and Human Rights. http://www.osce.org/ odihr/elections/ukraine/19595.

Ukraine's Parliament Votes to Abandon NATO Ambitions. BBC News Online, 03 June 2010. http://www. bbc.com/news/10229626. 
Ulam, Adam B. 1959. "Soviet Ideology and Soviet Foreign Policy.” World Politics 11 (2).

United Nations Bibliographic Information System (UNBIS). 2016. United Nations Dag Hammarskjold Library. http://unbisnet.un.org.

United Nations Conference on Trade and Development. 2017. "Georgia Bilateral Investment Treaties." http://investmentpolicyhub.unctad.org/IIA/CountryBits/77.

United Nations. 2007. "Bilateral Investment Treaties 1995-2006: Trends in Investment Rulemaking." United Nations Conference on Trade and Development. Geneva, February 2007.

“U.S. Army War College Key Strategic Issues List, 2012-2013.” 2012. U.S. Army Strategic Studies Institute, U.S. Army War College, Carlisle Barracks, PA. http://www.dtic.mil/ $\mathrm{dtic/tr/fulltext/u2/a565538.pdf.}$

United States Census Bureau. 2017. "Trade in Goods with Georgia.” https://www.census.gov/ foreign-trade/balance/c4633.html\#1996.

United States Department of Defense. 1997. "Exercise Cooperative Nugget '97 Scheduled." DoD News, 12 June 1997. http://archive.defense.gov/news/newsarticle.aspx?id=41045.

"United States State Department Reports 'Goof' on Azerbaijan.” 2000. Eurasia Daily Monitor 6 (144). https://jamestown.org/program/u-s-state-department-report-goofs-on-azerbaijan/.

United States Department of State. 1997. "Azerbaijan Country Report on Human Rights Practices for 1996." Bureau of Democracy, Human Rights, and Labor, January 30, 1997. https://reliefweb.int/report/azerbaijan/ azerbaijan-country-report-human-rights-practices1996.

United States Department of State. 2009. "United States-Georgia Charter on Strategic Partnership." Bureau of European and Eurasian Affairs, 09 January 2009. https://www.state.gov/p/eur/rls/or/121029.htm.

United States Department of State. 2017. "U.S. State Department Country Reports on Human Rights Practices - Azerbaijan." Bureau of Democracy, Human Rights, and Labor. https://www.state.gov/j/ drl/rls/hrrpt/.

United States Energy Information Administration (USEIA). 2016. "U.S. Imports from Azerbaijan of Crude Oil and Petroleum Products." https://www.eia.gov/dnav/pet/hist/ LeafHandler.ashx?n=PET\&s=MTTIM_NUS-NAJ_1\&f=M.

United States-Ukraine Charter on Strategic Partnership. 2008. United States Department of State-Bureau of European and Eurasian Affairs. https://www.state.gov/p/eur/rls/or/ 142231.htm. 
Valasjek, Tomas. 2000. "Military Cooperation between Georgia, Ukraine, Uzbekistan, Azerbaijan, and Moldova in the GUUAM Framework." Belfer Center, Harvard Kennedy School for Science and Technology, Policy Brief-Caspian Studies Program, 30 November 2000. http://www.belfercenter.org/publication/military-cooperation-betweengeorgia-ukraine-uzbekistan-azerbaijan-and-moldova-guuam.

Valiyev, Anar. 2011. "Azerbaijan-Russia Relations After the Five-Day War: Friendship, Enmity, Or Pragmatism?” Turkish Policy Quarterly 10 (3).

Vashakmadze, Mindia. 2005. "Foreign Forces in Georgia: Status, Legitimacy, Prospects.” In Eden Cole and Phillip Fluri (eds.) From Revolution to Reform: Georgia's Struggle with Democratic Institution Building and Security Sector Reform. Vienna: GKS.

Vasquez, John A., and Colin Elman, eds. 2003. Realism and the Balancing of Power: A New Debate. Saddle River, NJ: Prentice Hall.

Vasquez, John. 1995. "Why Do Neighbors Fight? Proximity, Interaction, or Territoriality." Journal of Peace Research 32 (3).

Verdine, Hubert. 1999. Cited in Layne, Christopher. "What's Built Up Must Come Down." Washington Post, 04 November 1999. http://www.washingtonpost.com/wpsrv/WPcap/1999-11/14/017r-111499-idx.html.

Vernon, Will. 2014. "Ukraine Rebels Hold Referendums in Donetsk and Luhansk." BBC, 11 May 2014. http://www.bbc.com/news/world-europe-27360146.

Vick, Karl. 2003. "Iranians Assert Right to Nuclear Weapons.” Washington Post, 11 March 2003. https://www.washingtonpost.com/archive/politics/2003/03/11/iranians-assert-rightto-nuclear-weapons/2f8cd96d-29ca-4765-bbef-6e08c53d5dc9/.

Vinch, Chuck. 2014. "U.S. Sending Advisors, Gear to Ukraine.” Military Times, 05 June 2014. https://www.usatoday.com/story/news/nation/2014/06/05/us-sending-advisers-gear-toukraine-/10046845/.

"Vladimir Putin Held Talks with Ukrainian President Viktor Yushchenko and Hosted a Meeting of the Russian-Ukrainian Intergovernmental Commission." President of Russia Website, 12 February 2008. http://en.kremlin.ru/events/president/news/43796.

Voronin, Vladimir. 2001. "Moldovan Leader Addresses Nation on Independence Day." Moldova TV, 27 August 2001.

Voronin, Vladimir. 2001a. "Moldovan President Looks with Interest at Russia-Belarus Union." Itar-Tass, 17 April 2001.

Voronin, Vladimir. 2001b. "Moldovan President Urges Pragmatic Foreign Policy in Inaugural Speech.” Basapress, 07 April 2001. 
Voronin, Vladimir. 2001c. "Excerpts from the Transcript of a Joint Press Conference with President Vladimir Voronin of Moldova." President of Russia Website, 19 November 2001. http://en.kremlin.ru/events/president/ transcripts/21405.

Voronin, Vladimir. 2001d. Moldovan President on Relations with Russia, Romania, Dniester Region Situation." Rossiyskaya Gazeta, 09 June 2001.

Voronin, Vladimir. 2002. "Moldovan President Interviewed on Visit to US, Bilateral Relations." Nezavisimaya, 13 December 2002.

Voronin, Vladimir. 2002a. "President Voronin: Partnership with Russia necessary for Moldova's Prosperity.” Itar-Tass, 19 November 2002.

Voronin, Vladimir. 2002b. "Moldovan President Laments Country's Role within GUUAM." Interfax, 22 Jul 2002.

Voronin, Vladimir. 2002c. "President Voronin: Partnership with Russia necessary for Moldova's Prosperity.” Itar-Tass, 19 November 2002.

Voronin, Vladimir. 2002d. "Moldovan President Hopes for Better Ties with US.” Itar-Tass 30 December 2002.

Voronin, Vladimir. 2003. "Moldova: Voronin says Transdnestria Needs Peacekeepers for Transitional Period." Interfax, 21 November 2003.

Voronin, Vladimir. 2003a. "Moldovan Leader Pleased with Ties with Neighboring Countries." Infotag, 30 July 2003.

Voronin, Vladimir. 2003b. "Moldovan President Reiterates EU Bid in Independence Day Speech." Infotag, 28 August 2003.

Voronin, Vladimir. 2003c. "Moldovan President Sums Up Work in 2003." Moldova TV, 29 December 2003.

Voronin, Vladimir. 2003d. "Opening speech by Vladimir Voronin, President of the Republic of Moldova." Council of Europe, 06 November 2003. http://www.coe.int/T/e/Com/files/ CM_chair-sessions/session/Nov-2003/disc_voronin.asp.

Voronin, Vladimir. 2003e. "Voronin Says Russia 'Essential' to Dniester Settlement. Itar-Tass 30 October 2003.

Voronin, Vladimir. 2004. "Moldovan Leader Says Relations with Russia Improved Despite No Dniester Solution." Infotag, 07 July 2004.

Voronin, Vladimir. 2004a. "Moldovan President Calls Russian Military Presence 'Humiliating."” Interfax 11 December 2004. 
Voronin, Vladimir. 2004b. "Moldovan President Congratulates George W. Bush on Winning Election.” Basapress, 04 November 2004.

Voronin, Vladimir. 2005. "Moldovan President Refutes Reports of Deteriorating Relations with Russia.” Infotag, 13 April 2005.

Voronin, Vladimir. 2005a. "Opening Statements by Secretary General, Jaap de Hoop Scheffer and H.E. Mr. Vladimir Voronin, President of Moldova.” NATO Online Library, 07 June 2005. https:// www.nato.int/docu/speech/2005/s050607b.htm.

Voronin, Vladimir. 2005b. "Speech of Vladimir Voronin." European Union Parliament, 08 June 2005. http://www.europarl.europa.eu/meetdocs/2004_2009/documents/fd/dmd20050621_ 08/dmd20050621_08en.pdf.

Voronin, Vladimir. 2005c. "Moldovan President Says Russia Remains Strategic Partner.” ItarTass, 08 May 2005.

Voronin, Vladimir. 2006. "President of Moldova Discusses Perceived Deterioration of Relations Between Moldova and Russia.” Nezavisimaya Gazeta, 07 April 2006.

Voronin, Vladimir. 2006a. "Moldovan President Says No Plans to Leave CIS Group.” Itar-Tass, 21 July 2006.

Voronin, Vladimir. 2007. "Moldovan President Calls for Pragmatism in Relations with Russia." Itar-Tass, 05 April 2007.

Voronin, Vladimir. 2007a. "Moldova Targets for Consistent Integration Into EU." Itar-Tass, 19 June 2017. Accessed 12 August 2017.

Voronin, Vladimir. 2009. "Moldovan President Comments on Political Crisis, ties with Romania, Russia." Ekho Moskvy Online, 24 May 2009.

Voronin, Vladimir. 2009a. "Voronin Thanks Russia For Support Of Moldovan Statehood." ItarTass, 21 June 2009.

Walker, Shaun. 2013. "Vladimir Putin offers Ukraine financial incentives to stick with Russia." The Guardian. 18 December 2013. http://www.theguardian.com/world /2013/dec/17/ukraine-russia-leaders-talks-kremlin-loan-deal.

Walker, Stephen G. (ed.). 1987. Role Theory and Foreign Policy Analysis. Durham: Duke University Press.

Walker, Stephen G., Mark Schafer and Michael D. Young. 1998. "Systematic Procedures for Operational Code Analysis: Measuring and Modeling Jimmy Carter's Operational Code.” International Studies Quarterly 42. 
Wallander, Celeste A., and Robert O. Keohane. 2002. "Risk, Threat, and Security Institutions." In Robert O. Keohane (ed.), Power and Governance in a Partially Globalized World. New York: Routledge.

Walsh, Nick Paton. 2006. "First Wine, Now Russia Bans Georgian Water.” The Guardian, 05 May 2006. https://www.theguardian.com/world/2006/may/06/russia.nickpatonwalsh.

Walt, Stephen M. 1987. The Origins of Alliances. Ithaca, NY: Cornell University Press.

Walt, Stephen M. 1991. “The Renaissance of Security Studies.” International Studies Quarterly 35 (2).

Walt, Stephen M. 1993. “Alliance.” In Joel Krieger et al. (eds.). The Oxford Companion to Politics of the World. New York: Oxford University Press.

Walt, Stephen M. 2005. Taming American Power: The Global Response to U.S. Primacy. New York: W. W. Norton.

Walt, Stephen M. 2006. Taming American Power: The Global Response to U.S. Primacy. New York: W. W. Norton.

Walt, Stephen M. 2009. “Alliances in a Unipolar World.” World Politics 61 (1).

Waltz, Kenneth N. 1959. Man, the State, and War. New York: Columbia University Press.

Waltz, Kenneth N. 1979. Theory of International Politics. New York: Columbia University Press.

Waltz, Kenneth N. 1997. "Evaluating Theories.” American Political Science Review 91 (4).

Waltz, Kenneth N. 2000. "Structural Realism After the Cold War.” International Security 25 (1).

Wang, Te-Yu. 1999. "US Foreign Aid and UN Voting: An Analysis of Important Issues.” International Studies Quarterly 43 (1).

Wang, Yuan-Kang. 2006. "China’s Grand Strategy and U.S. Primacy: Is China Balancing American Power?" The Brookings Institution-Center for Northeast Asian Policy Studies. http://www.brookings.edu/fp/cnaps/papers/wang2006.pdf.

Ward, Michael Don. 1982. Research Gaps in Alliance Dynamics Vol. 19. Graduate School of International Studies. University of Denver.

Wasserman, Aryeb. 1995. In Yaacov Ro'i (ed.) Muslim Eurasia: Conflicting Legacies. Portland: Frank Cass. 
Waterfield, Bruno. 2009. "Russia Resumes Gas Flow to Ukraine and Europe." The Telegraph, 20 January 2009. http://www.telegraph.co.uk/news/worldnews/europe/russia/4293979/ Russia-resumes-gas-flow-to-Ukraine-and-Europe.html.

Way, Lucan. 2002. "Pluralism by Default in Moldova.” Journal of Democracy 13 (4).

Webber, Mark. 1996. The International Politics of Russia and the Successor States. Manchester: Manchester University Press.

Webber, Mark. 1997. CIS Integration Trends: Russia \& the Former Soviet South. Brookings Institution Press.

Weiner, Robert. 2004. "The Foreign Policy of the Voronin Administration." Demokratizatsiya 12 (4).

Weir, Fred. 2014. "Why Ukraine's Freeze on Arms Sales to Russia will Hurt Kiev." The Christian Science Monitor, 17 June 2014. https://www.csmonitor.com/World/Europe/ 2014/0617/Why-Ukraine-s-freeze-on-arms-sales-to-Russia-will-hurt-Kiev-too.

Weldes, Jutta. 1996. “Constructing National Interests.” European Journal of International Relations 2 (3).

Welzel, Christian and Ronald Inglehart. 2008. "The Role of Ordinary People in Democratization.” Journal of Democracy 19 (1).

Wendt 1992. "Anarchy is What States Make of It: The Social Construction of Power Politics." International Organization 46 (2).

Wendt, Alexander. 1999. The Social Theory of International Politics. New York: Cambridge University Press.

Wight, Martin. 2002. Power Politics. A\&C Black.

Wilkins, Thomas S. 2012. “'Alignment', not 'Alliance'-the Shifting Paradigm of International Security Cooperation: Toward a Conceptual Taxonomy of Alignment." Review of International Studies 38 (1).

Wirtz, and Michel Fortmann (eds.). 2004. Balance of Power: Theory and Practice in the 21st Century. Stanford: Stanford University Press.

Woehrel, Stephen. 2004. "Moldova: Background and U.S. Policy." Congressional Research Service, 17 December 2004.

Woehrel, Stephen. 2009. "Moldova: Background and U.S. Policy.” Congressional Research Service, 14 April 2009. 
Woehrel, Stephen. 2012. "Ukraine: Current Issues and U.S. Policy.” Congressional Research Service, 12 January 2012. https://digital.library.unt.edu/ark:/67531/metadc84058/m1/1/ high_res_d/RL33460_2012Jan04.pdf.

Woehrel, Stephen. 2014. "Moldova: Background and U.S. Policy.” Congressional Research Service, 23 April 2014.

Wohlforth William C. 1993. The Elusive Balance: Power and Perceptions During the Cold War. New York: Cornell University Press.

Wohlforth, William C. 1999. "The Stability of a Unipolar World." International Security 24 (1).

Wohlforth, William C. 2004. "Revisiting Balance of Power Theory in Central Eurasia." In T.V. Paul, James J. Wirtz, and Michel Fortmann (eds.) Balance of Power: Theory and Practice in the 21st Century. Stanford: Stanford University Press.

Wolczuk, Kataryna. 2001. The Moulding of Ukraine: The Constitutional Politics of State Formation. Central European University Press.

Wolfers, Arnold. 1952. "National Security as an Ambiguous Symbol.” Political Science Quarterly 67 (4).

Woodman, Stewart. 1997. "Beyond Armageddon? The Shape of Conflict in the Twenty-First Century.” In D. Roy (ed.), The New Security Agenda in the Asia-Pacific Region. London: Macmillan.

World Bank. 2016. World Integrated Trade Solution (WITS). http://wits.worldbank.org/about_ wits.html.

World Bank. 2017. World Development Indicators, Azerbaijan. http://databank.worldbank.org/ data/reports.aspx ?source=2\&type=metadata \&series=NY.GDP. MKTP.CD.

Woronowycz, Roman. 1997. "Ukrainian, Russian PMs Sign Pact on Black Sea Fleet.” The Ukrainian Weekly 22 (65), 01 June 1997. http://www.ukrweekly.com/old/archive/ 1997/229701.shtml.

Wróbel, Jacek. 2004. "The European Union and Moldova.” Center for European Studies 13. Harvard University.

Yanukovych, Viktor. 2008. Cited in Kuzio, Taras. 2009. "Strident, Ambiguous and Duplicitous: Ukraine and the 2008 Russia-Georgia War." Demokratizatsiya 17 (4).

Yanukovych, Viktor. 2009. "No Hope for Better Relations with Russia Under Current Leadership - Yanukovych.” Interfax, 11 August 2009. 
Yanukovych, Viktor. 2010. "Beginning of Meeting with President of Ukraine Viktor Yanukovych.” President of Russia Website, 05 March 2010. http://en.kremlin. ru/events/president/transcripts/7040.

Yanukovych, Viktor. 2010a. "News Conference Following Russian-Ukrainian Summit Talks." President of Russia Website, 17 May 2010. http://en.kremlin.ru/events/president/ transcripts/7781.

Yanukovych, Viktor. 2010b. "President Victor Yanukovych's Inaugural Speech in Parliament." Kyiv Post, 25 February 2010. https://www.kyivpost.com/article/content/ukrainepolitics/president-victor-yanukovychs-feb-25-inaugural-spee-60475.html.

Yanukovych, Viktor. 2010c. "Ukraine's Yanukovich pledges to work for EU Integration." Euractiv, 02 March 2010. https://www.euractiv.com/section/europe-s-east/news/ukraines-yanukovich-pledges-to-work-for-eu-integration/.

Yanukovych, Viktor. 2010d. "Yanukovych Aware of Threat of Ukrainian Economy's Absorption by Russia." Interfax, 09 October 2010.

Yanukovych, Viktor. 2010e. 'Yanukovych Says Ukraine Turned 'New Page,' West Has 'Nothing to Fear.'” Telegraph, 15 February 2010. http://www.telegraph.co.uk/news/ worldnews/europe/ukraine/7236642/Yanukovych-says-West-has-nothing-to-fear-fromUkraine.html.

Yanukovych, Viktor. 2013. "Annual Address of the President of Ukraine to the Ukrainian Parliament." Embassy of Ukraine to the United Kingdom of Great Britain and Northern Ireland, 12 June 2013. http://mfa.gov.ua/en/news-feeds/foreign-offices-news/13010shhorichne-poslannya-prezidentaukrajini-viktora-janukovicha-do-verkhovnoji-radiukrajini.

Yanukovych, Viktor. 2013a. "President Yankovych Press Conference." Sputnik News, 19 December 2013. http://sputniknews.com/voiceofrussia/news/2013_12_19/Ukrainesuspends-talks-with-EU-to-clarify-free-trade-area-terms-Yanukovych-4159/.

Yatsenyuk, Arseniy. 2014. "Remarks to the Press by Vice President Joe Biden and Ukrainian Prime Minister Arseniy Yatsenyuk." The White House of President Barrack Obama, 22 April 2014. https://obamawhitehouse.archives.gov/ the-press-office/2014/04/22/remarkspress-vice-president-joe-biden-and-ukrainian-prime-minister-arse.

Yee, Albert. 1996. “The Causal Effect of Ideas on Policies.” International Organization 50 (1).

Yeltsin, Boris. 1992. Cited in Ambrosio, Thomas. 2006. "The Geopolitics of Demographic Decay: HIV/AIDS and Russia's Great-Power Status.” Post-Soviet Affairs 22 (1).

Yeltsin, Boris. 1997. "1997 Year in Review.” The Ukrainian Weekly 52 (65). http://www. ukrweekly.com/old/archive/1997/529706.shtml. 
Young, Erika G. 2014. "The Diplomatic Protocol of the Republic.” Ministry of Foreign Affairs of Italy. http://www.esteri.it/mae/cerimoniale/cerimoniale/pdf/3.\%20cerimoniale\% 20diplomatico\%202.0\%20-\%20versione\% 20in\%20inglese\%20(marzo\%202014).pdf.

Yushchenko, Viktor. 2005. "Address of the President Viktor Yushchenko at the Parliamentary Assembly of the Council of Europe." Council of Europe, 25 January 2005. http:// assembly.coe.int/Sessions/2005/Speeches/Yuschenko_250105_E.htm

Yushchenko, Viktor. 2005a. "Inaugural address by President Viktor Yushchenko." The Ukrainian Weekly 5 (73). http://www.ukrweekly.com/old/archive/2005/050523.shtml.

Yushchenko, Viktor. 2005b. "Opening Statement by Viktor Yushchenko at the meeting of the NATO-Ukraine Council.” NATO, 22 February 2005. http://www.nato.int/docu/ speech/2005/s050222e.htm.

Yushchenko, Viktor. 2005c. "Remarks by Ukrainian President Viktor Yushchenko to the U.S. Chamber of Commerce.” U.S. Chamber of Commerce Washington, D.C., 04 April 2005. http://www.usubc.org/AUR/ aur465.php.

Yushchenko, Viktor. 2005d. "Ukraine Makes Its Place as Democratic State.” Ukrinform, 10 December 2009. https://www.ukrinform.net/rubric-other_news/888303ukraine_ makes_its_place_as_democratic_state__president_yushchenko_175322.html.

Yushchenko, Viktor. 2005e. "Ukraine's Yushchenko Addresses Joint Session of U.S. Congress." U.S. Department of State, 06 April 2005. http://iipdigital.usembassy.gov/st/english/ texttrans/2005/04/200504061638281cjsamoht0. 3202631.html\#axzz41g7IIUAg.

Yushchenko, Viktor. 2006. "Address of Ukrainian President Viktor Yushchenko to the Students of the College of Europe, 12 May 2006." College of Europe. Natolin, Poland.

Yushchenko, Viktor. 2008. "Yushchenko: Kyiv Does Not Support Recognition of South Ossetia, Abkhazia." Interfax, 27 August 2008.

Zakaria, Fareed. 1992. "Realism and Domestic Politics: A Review Essay." International Security 17 (1).

Zemin, Jiang. 2001. "Russia and China Sign 'Friendship' Pact.” New York Times, . http://www.nytimes.com /2001/07/17/world/russia-and-china-sign-friendshippact.html?pagewanted $=$ all.

Zlenko, Anatolii. 2001. "Ukrainian Foreign Affairs Minister Anatoliy Zlenko on Changes in Foreign Political Course.” Kiyevskiye Vedomosti, 29 January 2001. 